\author{
UNIVERSIDAD DE SALAMANCA \\ PROGRAMA DE DOCTORADO \\ LÓGICA Y FILOSOFÍA DE LA CIENCIA
}

\title{
LA INCORPORACIÓN DEL DARWINISMO \\ EN LA CULTURA CÍVICA DE OCCIDENTE Y ORIENTE. \\ UN ESTUDIO COMPARADO DE ESPAÑA Y COREA DEL SUR
}

TESIS DOCTORAL

OONEE KOH

DIRECTOR

MIGUEL ÁNGEL QUINTANILLA FISAC 

A mis padres, por su cariño y apoyo.

부모님께 

Agradecimiento

A mi director de tesis, Miguel Ángel Quintanilla Fisac, A todos los miembros del instituto eCyT, especialmente Esther y Pilar, A los profesores de Lógica y Filosofía de la Ciencia, A mis amigas, Rosario e Irene, Y a mis compañeros del doctorado, Les agradezco por todo. 사랑하는 나의 가족, 믿어주셔서 고맙습니다. 곧 만나요. 

Índice

Introducción

PARTE I. El Encuentro del Darwinismo y la Sociedad en España y Corea del Sur

Capítulo 1. El Darwinismo en la Filosofía Occidental y Oriental .................................... 25

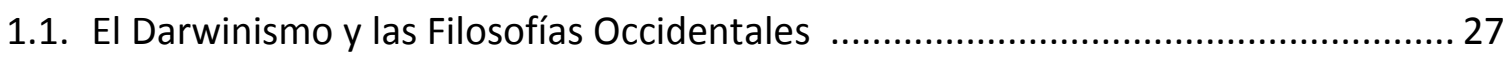

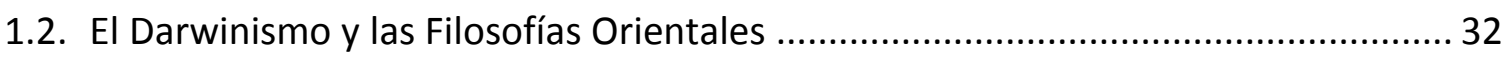

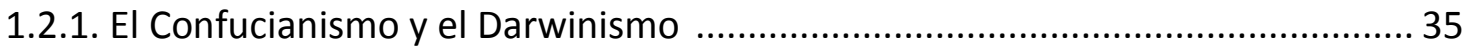

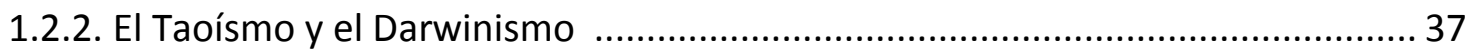

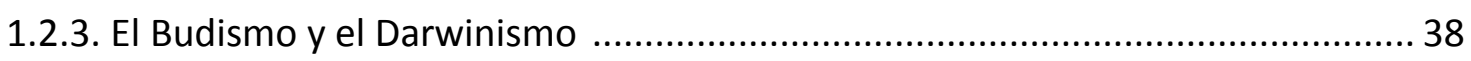

Capítulo 2. La Transmisión y la Recepción del Darwinismo. España y Corea del Sur ........ 43

2.1. El Encuentro entre el Darwinismo y la Sociedad Española ................................... 45

2.2. El Encuentro entre el Darwinismo y la Sociedad Coreana ...................................... 52

Capítulo 3. El Darwinismo Actual. España, Corea del Sur y Sus Religiosidades ...............61 61

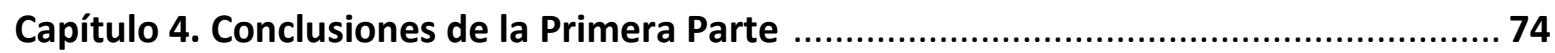

PARTE II. La incorporación del Darwinismo en España y Corea del Sur. Análisis de textos divulgativos

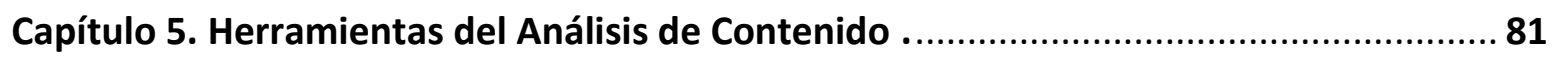

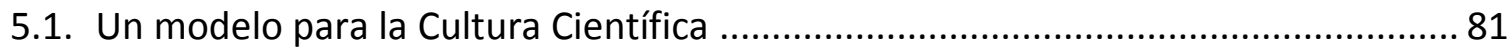

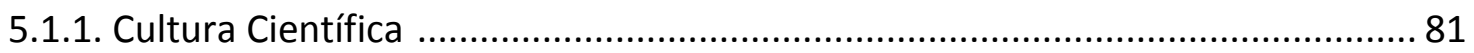

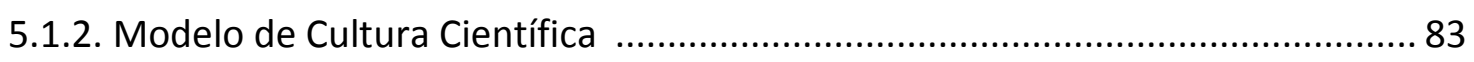

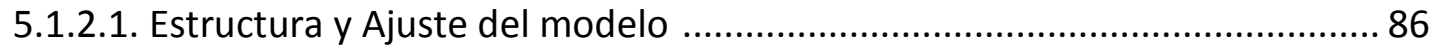


5.1.2.2. Proceso de la Codificación y la Revisión 89

5.2. Análisis por características de Texto. Libro de Texto y Artículos Periodísticos ....... 91

5.2.1. Análisis de Contenido. Libros de Texto ............................................................. 91

5.2.2. Análisis de contenido. Artículos Periodísticos ................................................. 94

Capítulo 6. El Darwinismo en Libros de Texto de España y Corea del Sur ......................... 96

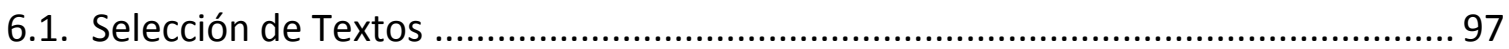

6.2. Darwinismo en el Currículo Escolar de España y Corea del Sur ............................ 101

6.3. Darwinismo en Libros de Texto. ¿Cómo aparece la Cultura Científica de España y

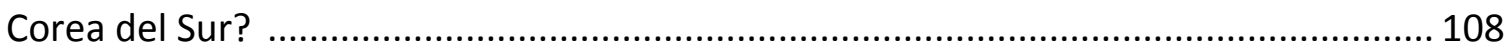

6.4. Darwinismo en Libros de Texto. ¿Cómo enseñan en las aulas de España y Corea del

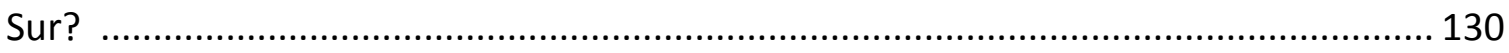

6.4.1. Los Científicos Principales: Darwin y Wallace ............................................. 131

6.4.2. Antes de Darwin. Historia de la Ciencia ........................................................ 136

6.4.3. Después de Darwin. Desarrollo del Darwinismo ............................................... 143

6.4.4. Definición, Pruebas y Ejemplos de la Evolución ............................................... 147

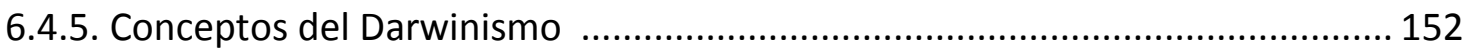

6.5. Libros Antiguos de Texto: la Evolución de los Contenidos sobre el Darwinismo en

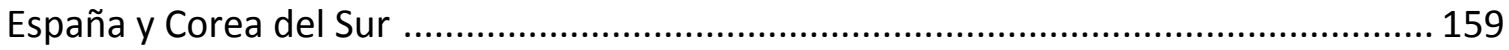

6.5.1. La Evolución del Darwinismo en Libros de Texto de España (los años 40-90. Siglo $\mathrm{XX})$

6.5.2. La evolución del Darwinismo en Libros de Texto de Corea del Sur (los años 40-

90. Siglo XX) 165

Capítulo 7. El Darwinismo en la Prensa de España y Corea del Sur

7.1. Selección de Textos

7.2. Darwinismo en la Prensa. ¿Cómo aparece la Cultura Científica de España y Corea del Sur? 175

7.3. Darwinismo en la Prensa. ¿Cómo y Qué trasmiten los medios de comunicación de

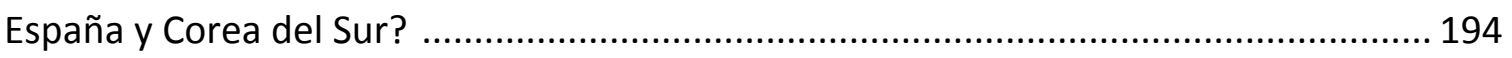

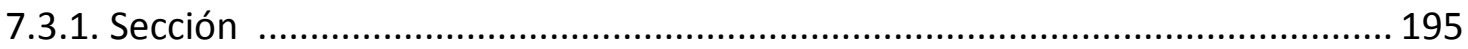

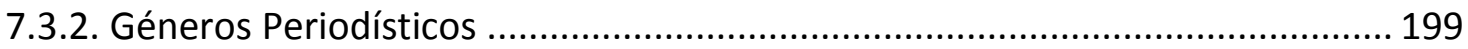


7.3.3. Autoría 203

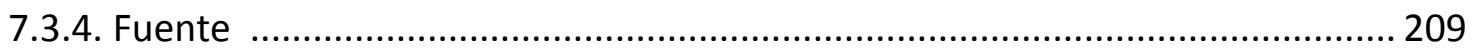

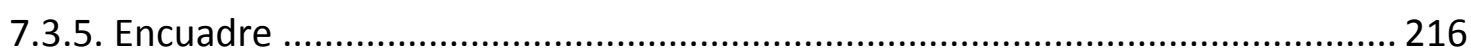

7.3.6. Temas. Novedades Científicas e Ideas Religiosas .......................................... 226

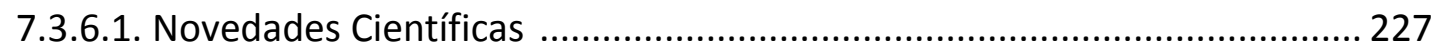

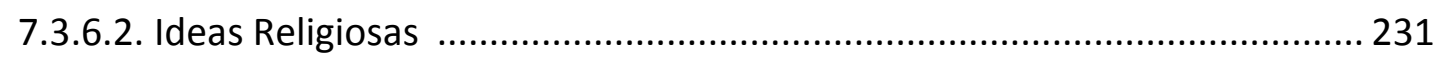

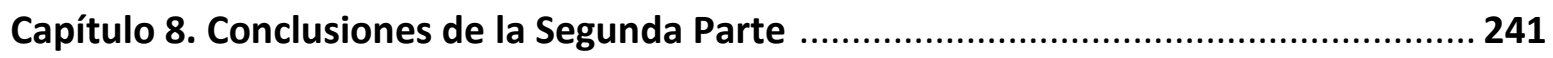

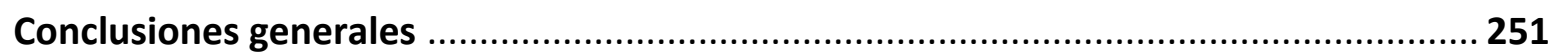

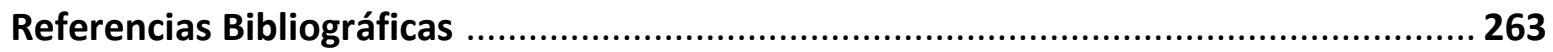

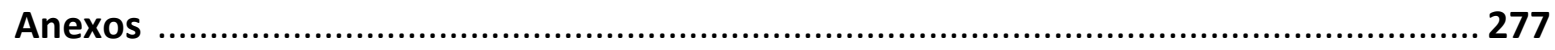

Anexo I. Lista de materiales del análisis de contenido (España y Corea del Sur) .......... 279

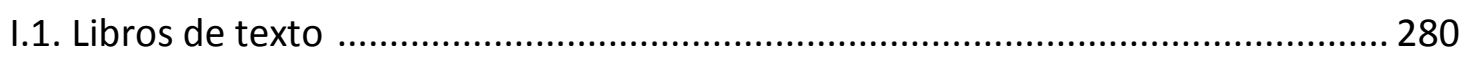

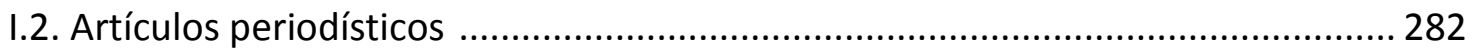

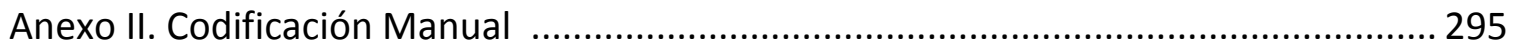

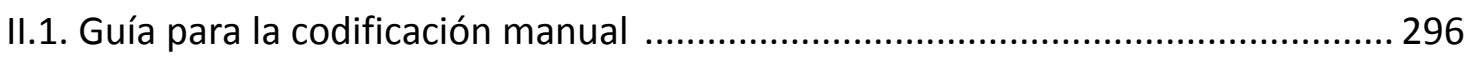

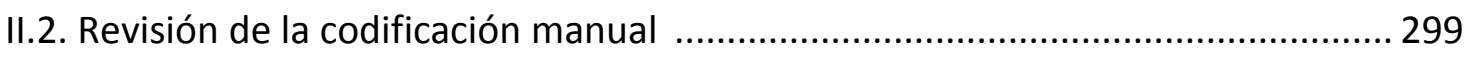




\section{Introducción}

It is curious how nationality influences opinion; a week hardly passes without my hearing of some naturalist in Germany who supports my views, and often puts an exaggerated value on my works; whilst in France I have not heard of a single zoologist, except $M$. Gaudry (and he only partially), who supports my views. But I must have a good many readers as my books are translated, and I must hope, notwithstanding your strictures, that I may influence some embryo naturalists in France. - Charles Robert Darwin, 28 de mayo de 1870.

Ciertas teorías científicas han cambiado la historia intelectual del ser humano. Es más, hubo teorías que presentaron una nueva manera de pensar y ver el mundo, por lo que las denominamos "teorías revolucionarias". Normalmente no son aceptables al principio y provocan escándalos y críticas, pero poco a poco se difunden y las influencias se hacen más grandes en el mundo académico, y finalmente generan una transición de pensamientos.

No debe olvidarse que esta historia intelectual es un concepto que sólo se consideraba en Europa, o sea en Occidente, apenas hace dos o tres siglos. Entonces, ¿qué habría pasado si la misma teoría fuera publicada en otra parte del mundo donde la nueva teoría no era tan impactante o revolucionaria?

La teoría de la evolución de Darwin cambió la visión occidental de la vida. Muchas controversias surgieron en los primeros días porque la teoría tenía diversos contenidos en conflicto con la visión de la vida preexistente. ¿La teoría tenía tantos puntos polémicos en Oriente $^{1}$ también? Sería significativo estudiarlo y comparar con el aspecto occidental.

\footnotetext{
${ }^{1}$ En este estudio, reducimos el significado de 'Oriente' a China, Corea (del Sur y Norte), Japón, Taiwan y
} 
El darwinismo, que explica la diversidad de todos los seres vivos en la Tierra, nació en Occidente y se extendió a Oriente, y hoy es la teoría clave y básica de la biología moderna globalmente. Se puede presuponer que el proceso y el resultado de la incorporación del darwinismo en cada sociedad difieran por varios factores sociales.

Como el propio Darwin sentía, la reacción a la misma teoría de la evolución era muy diferente entre los estudiosos alemanes y franceses. ¿Cuál fue su causa? Es el punto al que prestamos atención y queremos abordarlo a través de una comparación más global, entre Oriente y Occidente.

Hasta ahora, la incorporación del darwinismo ha sido estudiada extensamente por país. Y la comparación entre países también se ha llevado a cabo activamente. (Glick y Shaffer, 2014; Engels y Glick, 2006; Glick, et al., 1999; Numbers y Stenhouse, 1999; Glick, 1974). Estos estudios tienden a centrarse en las comparaciones dentro de un continente (Europa) o una zona lingüística (de inglés o español). En cambio, los estudios comparativos sobre los países asiáticos no son suficientes y especialmente es difícil encontrar estudios específicos que comparen Oriente y Occidente.

Por lo tanto, en esta tesis examinamos el papel de los factores culturales en el proceso de la incorporación del darwinismo y su resultado (situación actual) comparando Occidente y Oriente. Para concretar la investigación, seleccionamos un país de Occidente y otro de Oriente y realizamos un estudio comparativo.

España y Corea del Sur pueden ser una elección acertada para esta comparativa. Aunque pertenecen a diferentes culturas, otras variables pueden ser reducidas porque tienen factores similares de la sociedad. Así que compararemos la sociedad española y la surcoreana.

Comenzaremos con el trasfondo filosófico de ambas sociedades, examinaremos el proceso de aceptar el darwinismo desde el momento de la llegada por primera vez, y luego averiguaremos cómo está incorporado actualmente el darwinismo en las dos sociedades. Luego, realizaremos un análisis de contenido de libros de texto y artículos de periódicos

Vietnam que genéricamente son llamados los países del área cultural de carácter chino. 
para averiguar cómo el darwinismo se está transmitiendo al público en los dos países hoy en día.

El camino del argumento del presente estudio es como sigue:

- Comparar la visión de los seres vivos de Occidente y Oriente con la del darwinismo e investigar la compatibilidad entre ellas.

- Averiguar el proceso de la transmisión del darwinismo a la sociedad española y la coreana y la influencia de la cultura y la situación socio-política de la época.

- Investigar los aspectos actuales de la incorporación del darwinismo en las dos sociedades. Explorar la religiosidad de las dos sociedades y su influencia en la incorporación del darwinismo.

- Recopilar aquellos textos divulgativos destacados en la actualidad y con los que el público puede acercarse al darwinismo, libros de texto y artículos periodísticos. Analizar los contenidos de los dos países e inferir diferencia y semejanza entre ellos.

A. Aplicar a los textos seleccionados el modelo teórico de Cultura Científica (Quintanilla, et al., 2011). Clasificar en Cultura Científica Intrínseca y Cultura Científica Extrínseca.

B. Para enriquecer el resultado de A, analizar adicionalmente contenidos y formas de los textos en detalle según el carácter de texto y encontrar diferencia y semejanza entre los dos países.

- Concluir sintetizando la investigación teórica y empírica y obtener una nueva perspectiva de la incorporación del darwinismo en la cultura cívica en Occidente y Oriente.

Es una estructura sintética que nos permite ver los aspectos de la incorporación del darwinismo en ambas sociedades a través de la investigación, que cubre desde la época del primer encuentro hasta la actualidad. 
Este estudio se divide en dos partes; La primera de ellas es la parte teórica de la incorporación del darwinismo en España y Corea del Sur que cubre argumentos filosóficos, históricos y sociológicos. La segunda es la parte empírica del análisis de texto divulgativo del darwinismo. El esquema se muestra en gráfico 1.
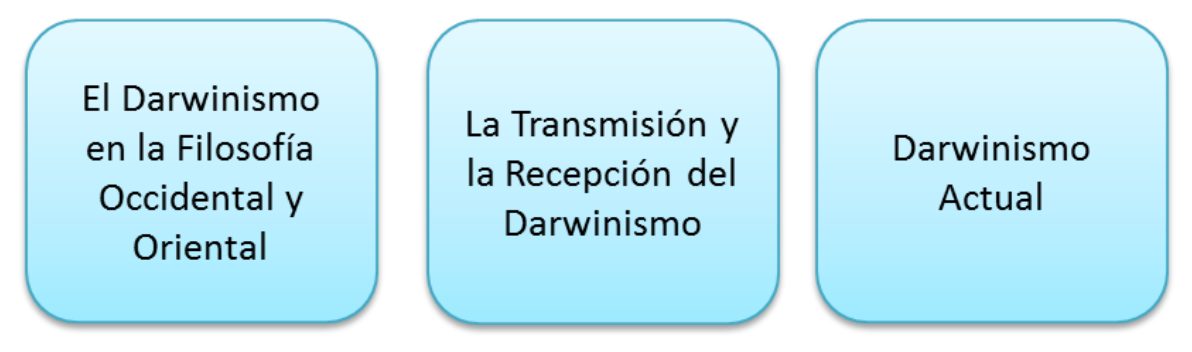

Darwinismo en Libros de Texto

Darwinismo en Artículos Periodísticos

Gráfico 1. Esquema del estudio. Parte teórica (azul claro) y empírica (borde naranja)

El índice de este estudio sigue el gráfico 1, más si el mismo esquema se divide en dos partes por época, se podría señalar en color tal y como indica el gráfico 2.

Los primeros dos cuadrados corresponden al trasfondo de las dos sociedades, mientras que los tres siguientes pertenecen a la actualidad:
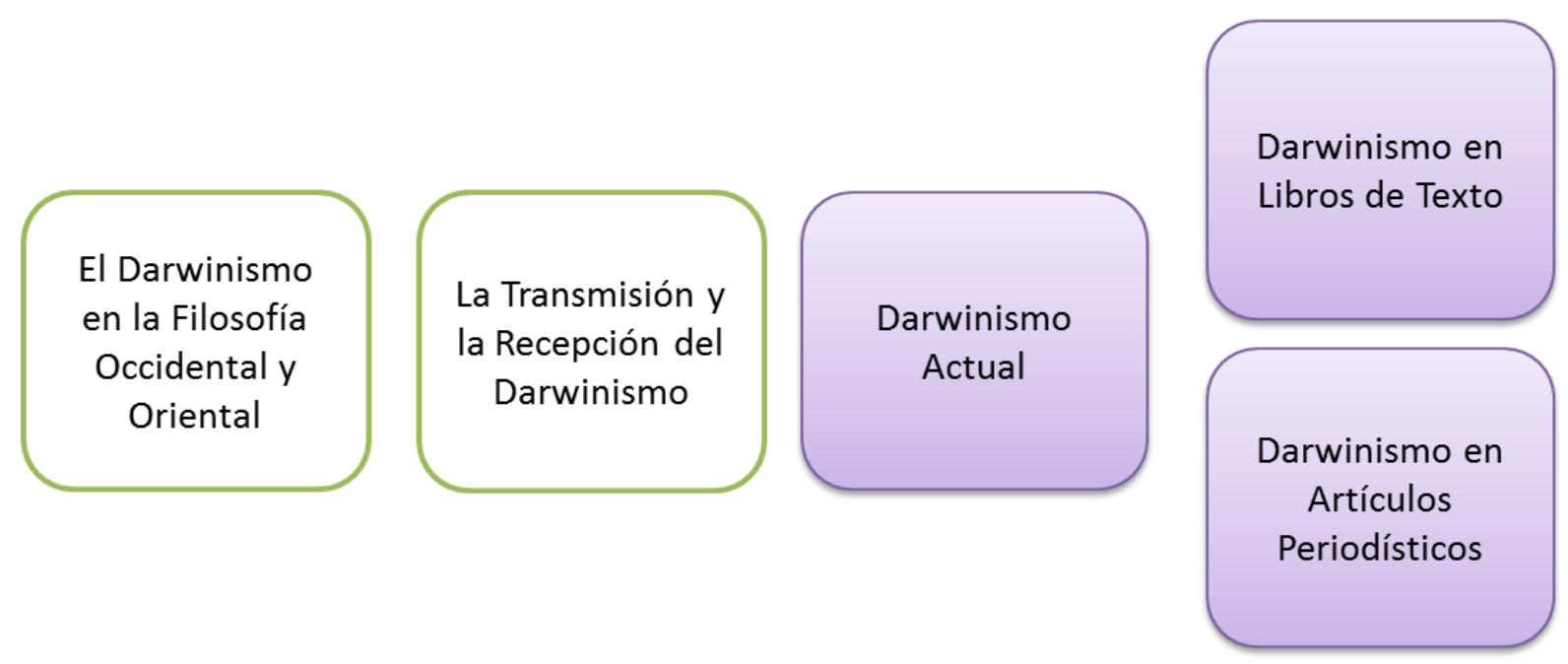

Gráfico 2. Esquema del estudio. Parte filosófico-histórica (borde verde) y parte actual (violeta) 


\section{El Darwinismo}

En este estudio hacemos referencia al evolucionismo de Charles R. Darwin (1809-1882) como 'darwinismo'. Aun cuando las teorías que Darwin propuso se han reforzado y modificado por estudios posteriores, todavía la teoría biológica de la evolución se denomina así. Después de la época del neodarwinismo ${ }^{2}$ y de la síntesis evolutiva ${ }^{3}$ recuperó su nombre 'darwinismo', porque las ideas primarias de Darwin siguen siendo el fundamento definitivo del evolucionismo.

Adoptamos la definición del 'darwinismo' del prominente biólogo Ernst Mayr, que es uno de los fundadores de la síntesis evolutiva.

"Después de 1859, es decir, durante la primera revolución darwiniana, el darwinismo significó para casi todo el mundo una explicación del mundo viviente mediante causa naturales. Como veremos, durante y después de la síntesis evolutiva, el término darwinismo significó de forma unánimemente reconocida el cambio evolutivo adaptativo bajo la influencia de la selección natural, designando la evolución variacional frente a la transformacional." (Mayr, 1992: 118)

Mayr define el darwinismo en dos épocas. En la primera el término tenía un significado más filosófico que biológico porque era una teoría que explica todos los seres vivos sin un agente intencional. En la primera mitad del siglo XX, se confirmó la definición biológica del darwinismo con la teoría sintética de la evolución. Según la síntesis, es la teoría de la evolución adaptativa por la variación de los seres y la selección natural. Esta definición se acepta ampliamente en la biología moderna y es la clave del evolucionismo que se difunde hoy en día al público a través de las aulas escolares y de los medios de comunicación.

\footnotetext{
${ }^{2}$ El neodarwinismo: "Teoría de la evolución desarrollada por August Weismann a finales del siglo XIX consistente en un darwinismo sin la herencia de caracteres adquiridos y con un fuerte énfasis en la selección natural." (Mayr, 1992:183)

${ }^{3}$ Síntesis evolutiva: “Paradigma darwiniano modificado parcialmente que incluye la refutación de la evolución transformacional, el saltacionismo y la ortogénesis, al tiempo que subraya fuertemente el papel de la selección natural, la adaptación y el estudio de la diversidad (el origen de las especies y de los taxones superiores)." (Mayr, 1992:186)
} 
Por lo tanto, en este estudio el darwinismo es filosóficamente "una explicación del mundo viviente mediante causas naturales" y biológicamente "el cambio evolutivo adaptativo bajo la influencia de la selección natural". A partir de estas definiciones, investigaremos aspectos de la incorporación del darwinismo en Occidente y Oriente, especialmente España y Corea del Sur.

\section{España y Corea del Sur}

Para observar la influencia de la cultura (más concretamente, en la comunicación e incorporación del darwinismo), es preferible elegir sociedades representativas de los dos mundos, y que por ello porten con cultura visiblemente diferente. La sociedad española en Europa (Occidente) y la sociedad surcoreana en Asía (Oriente), pueden ser modelos adecuados porque, aunque tienen culturas distintas, no hay gran diferencia en el resto de los indicadores sociales. 


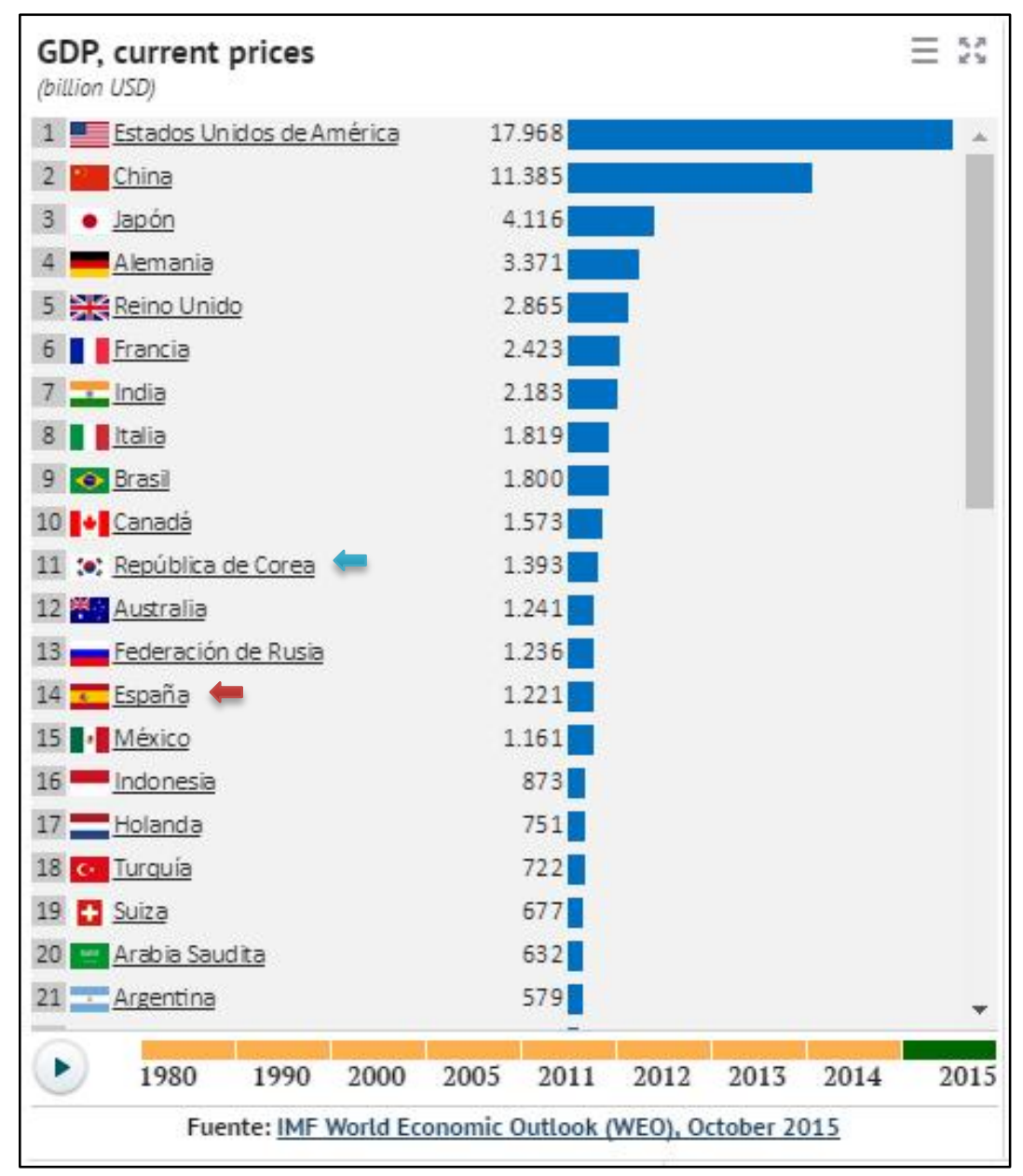

Ilustración 1. PIB (nominal) ranking 2015 (fuente: IMF (2015) citado en Knoema, 2016)

Por ejemplo, el PIB (nominal) del año 2015 sitúa a España en el puesto 14ㅇy y a Corea del Sur en el puesto $11^{\circ}$ del mundo. En el ranking del PIB PPA, España se encuentra en 16 y Corea del Sur en 13으 puesto. Podríamos afirmar que el tamaño de las economías de Corea del Sur y de España es relativamente similar.

Entre las poblaciones de los dos países, tampoco se da una gran diferencia. España cuenta con 46 millones de habitantes mientras que Corea del Sur, tiene 50 millones. 


\section{Countries in the world by population (2016)}

This list includes both countries and dependent territories. Data based on the latest United Nations Population Division estimates. Click on the name of the country or dependency for current estimates (live population clock), historical data, and projected figures.

See also: World Population

\begin{tabular}{|c|c|c|c|c|c|c|c|c|c|c|c|}
\hline$\#^{*}$ & Country (or dependency) & $\begin{array}{c}\text { Population } \\
(2016)\end{array}$ & $\begin{array}{l}\text { Yearly } \\
\text { Change }\end{array}$ & $\begin{array}{c}\text { Net } \\
\text { Change }\end{array}$ & $\begin{array}{l}\text { Density } \\
\left(\mathrm{P} / \mathrm{Km}^{2}\right)\end{array}$ & $\begin{array}{l}\text { Area } \\
\left(\mathrm{Km}^{2}\right)\end{array}$ & $\begin{array}{l}\text { Migrants } \\
\text { (net) }\end{array}$ & $\begin{array}{l}\text { Search: } \\
\text { Fert. } \\
\text { Rate }\end{array}$ & $\begin{array}{l}\text { Med. } \\
\text { Age }\end{array}$ & $\begin{array}{l}\text { Urban } \\
\text { Pop \% }\end{array}$ & $\begin{array}{l}\text { World } \\
\text { Share }\end{array}$ \\
\hline 2 & India & $1,326,801,576$ & $1.2 \%$ & $15,751,049$ & 446 & $2,972,892$ & $-519,644$ & 2.48 & 27 & $32.4 \%$ & $17.9 \%$ \\
\hline 3 & U.S. & $324,118,787$ & $0.73 \%$ & $2,345,156$ & 35 & $9,155,898$ & $1,001,577$ & 1.89 & 38 & $82.7 \%$ & $4.4 \%$ \\
\hline 27 & South Korea & $50,503,933$ & $0.42 \%$ & 210,494 & 519 & 97,235 & 60,000 & 1.26 & 41 & $81.7 \%$ & $0.7 \%$ \\
\hline 28 & Colombia & $48,654,392$ & $0.88 \%$ & 425,688 & 44 & $1,108,301$ & $-29,000$ & 1.93 & 30 & $79 \%$ & $0.7 \%$ \\
\hline 29 & Kenya & $47,251,449$ & $2.61 \%$ & $1,201,147$ & 83 & 569,295 & $-10,000$ & 4.44 & 19 & $26.4 \%$ & $0.6 \%$ \\
\hline 30 & Spain & $46,064,604$ & $-0.12 \%$ & $-57,095$ & 92 & 498,535 & $-118,614$ & 1.32 & 43 & $82 \%$ & $0.6 \%$ \\
\hline
\end{tabular}

Ilustración 2. Países en el mundo por población de 2016 (fuente: Worldmeters, 2016)

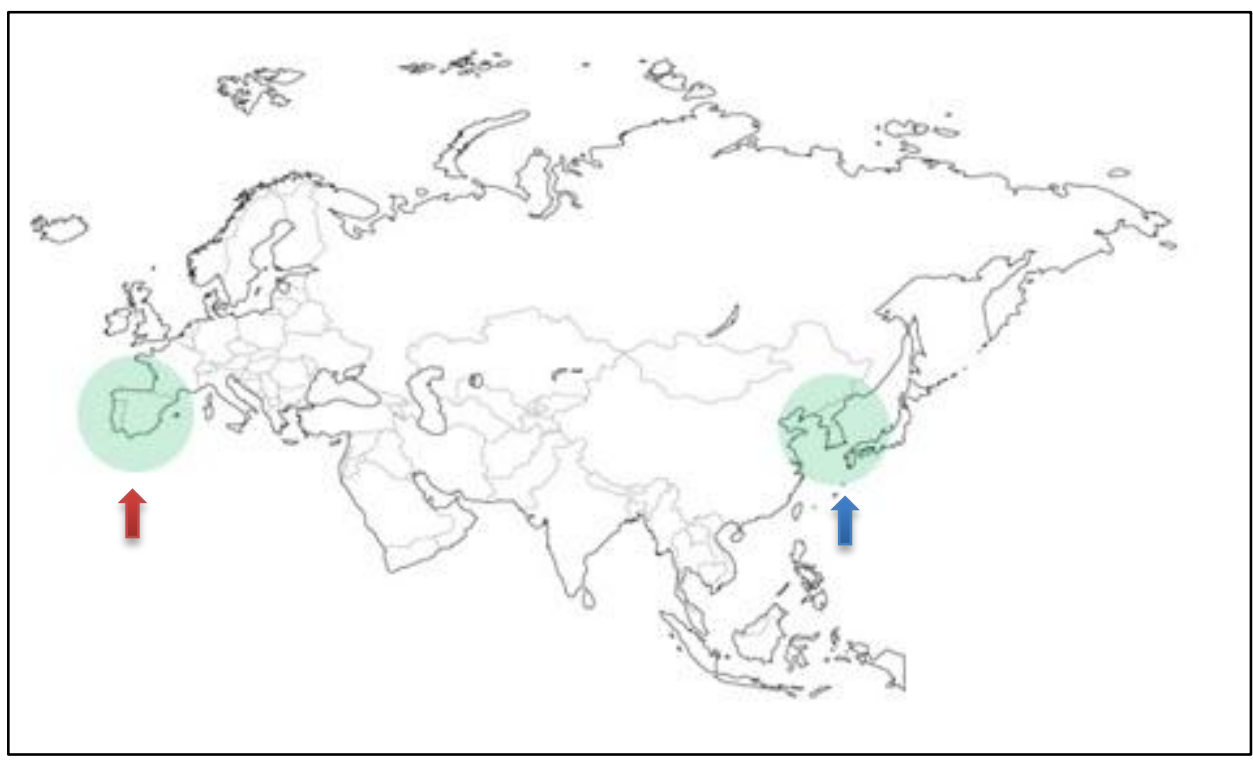

Ilustración 3. Posición geográfica de España y Corea del Sur en el continente Euro-Asiático

Además, los dos países tienen posiciones geográficas similares (son países peninsulares al oeste y al este extremo del continente) y llegaron a ser países democráticos después de sufrir guerras y dictaduras militares a mediados del siglo XX. Por eso, podremos reducir variables por la estructura de la sociedad y el tamaño de la economía, lo que nos permitiría desarrollar un estudio comparado significativo. 
La parte I de esta tesis trata de la incorporación del darwinismo en España y Corea del Sur desde los puntos de vista filosófico, histórico y social ${ }^{4}$.

De esta forma, la primera parte comienza con el capítulo 1 que contempla el trasfondo filosófico de las culturas occidental y oriental y compara la visión de la vida en el darwinismo con la de Occidente y Oriente. Como se ha mencionado antes, el darwinismo tenía puntos polémicos ya que no encajaba bien en la cosmovisión occidental de la época. Después de revisar este aspecto, se presenta la cosmovisión oriental comparando con el darwinismo y se examina la compatibilidad entre ellos.

En el capítulo 2, se examinan la transmisión y la apropiación del darwinismo en España y Corea $^{5}$. Habría reacciones diferentes del darwinismo cuando se introdujo por primera vez en los dos países. España está cerca de Inglaterra donde nació el darwinismo, pero Corea es un país geográficamente muy lejano. Además, en ese momento cada país vivía en una cultura relativamente independiente, y el ambiente político y social en el que vivían también era muy diferente. Por eso, se explora cómo afectaron estos aspectos en la incorporación del darwinismo.

El capítulo 3 indaga cómo el darwinismo está incorporado en la sociedad española y surcoreana de la actualidad. Hoy en día, la religión es el último oponente del darwinismo. Este es el motivo de que se explore la religiosidad de las dos sociedades y su influencia en la incorporación del darwinismo examinando factores sociales y encuestas externas.

El capítulo 4 es conclusiones parciales de la primera parte.

A partir del capítulo 5, empieza la parte II que realiza los análisis empíricos.

\footnotetext{
${ }^{4}$ Algunos de los contenidos de la Introducción y la Parte I están basados en el artículo de la autora (KOH, O. E. (2013) El encuentro entre el darwinismo y la sociedad. Un estudio comparado de España y Corea del Sur. ArtefaCToS, 6 (1), pp. 81-107.). Los argumentos del artículo están incluidos en este estudio, debido a que el artículo fue la ponencia para presentar el progreso de esta Tesis Doctoral en el encuentro de doctorado.

${ }^{5}$ En esta tesis, cuando menciona 'Corea', si es antes de la división (1945) se refiere a la península coreana (Antiguo Chosŏn: Corea del Sur y Corea del Norte). Si es después de 1945, siempre se refieren a 'Corea del Sur'.
} 
Para la investigación empírica sobre la incorporación del darwinismo en Corea del Sur y España, se examinan textos didácticos (libros de texto) y periodísticos (artículos de prensa) que son los dos canales principales que transmiten el darwinismo al público directamente (Marcos, 2010: 179; Godin y Gingras, 2000: 50; The Royal Society, 1985: 8).

Estos textos serían el resultado del proceso de la incorporación, ya que la teoría de Darwin lleva bastante tiempo) desde que se transmitió a ambos países (más de 150 años en España y 100 años en Corea. Se puede ver la situación actual de la incorporación del darwinismo mediante estos análisis de contenido.

El capítulo 5 explica la metodología para aplicar el análisis de contenido. El modelo primario que se utilizará es el modelo de Cultura Científica. El modelo representa una herramienta que clasifica el texto si está incorporado en el sistema científico (cultura científica intrínseca) o no incorporado pero relacionado con la ciencia (cultura científica extrínseca). En el capítulo se presenta el modelo y el proceso de la codificación mediante el programa Atlas.ti.

En el resultado de la codificación, si la diferencia entre España y Corea del Sur es notoria en el mismo género de texto, se podría afirmar que las proporciones de cultura científica intrínseca y extrínseca dependen del país. En cambio, si la diferencia entre los países no es tan destacada pero los resultados de texto didáctico y periodístico son bastante diferentes, se podría anotar que el objetivo del texto es más decisivo que la cultura incorporada en el texto.

Después de completar este análisis, se aplica otro marco de análisis para investigar cómo y qué transmitir más finamente según el género de texto. En el caso de los libros de texto, se realiza un análisis detallado de los contenidos que se enseñan. En el caso de los artículos periodísticos, se analiza según criterios para el género (Quintanilla, et al., 2005). Si alguna diferencia entre los dos países se destaca, se la examina con más detalle.

El capítulo 6 presenta el análisis de contenidos del darwinismo en libros de texto mediante la metodología del capítulo 5. Este estudio trata la teoría de la evolución de Darwin que aparece plenamente por primera vez en el currículo de décimo curso de educación pública en ambos países. Cuatro libros de diferentes editoriales de España (del cuarto curso de 
E.S.O.) y cuatro de Corea del Sur (del primer curso de Bachillerato) se han seleccionado. También se han añadido dos libros de 12 curso coreanos para balancear los contenidos entre los dos países, porque en los libros de 10 curso las ediciones españolas con mucho más detalle que las coreanas. Los 10 libros seleccionados estaban en vigor en 2013.

Primeramente se realiza el análisis con el modelo de Cultura Científica. Se puede presuponer que los libros de texto tengan la mayor parte de la información de cultura científica intrínseca debido a la naturaleza del texto.

Luego se explora cómo enseñar el darwinismo en el aula. Se podría encontrar alguna diferencia cultural en la forma de enseñar la misma teoría. Puede ser significativo a qué parte da la importancia, a qué se refiere brevemente, o qué se menciona o no.

El capítulo 7 presenta el análisis de contenidos del darwinismo en artículos periodísticos mediante la metodología del capítulo 5. El País y El Mundo de España y Hankyoreh y Joongang de Corea del Sur han sido elegidos considerando el tamaño y el ámbito político. Se examina cómo tratan el darwinismo los cuatro periódicos nacionales. En particular, los artículos de 2009 han sido seleccionados porque el año fue el bicentenario del nacimiento de Darwin. Y para ver la influencia del año especial, los de 2008 y 2010 también se han incluidos. En definitiva, se analiza un total de 612 artículos periodísticos relacionados con el darwinismo de los tres años.

A los artículos de prensa también se aplica el modelo de Cultura Científica. Se puede suponer que los artículos de periódicos tengan más información de cultura científica extrínseca que los textos didácticos.

Con el fin de analizar más a fondo, se clasifica adicionalmente los artículos mediante varios criterios, como pueden ser los siguientes: autoría, sección, género periodístico, encuadre y fuente. Además, se compara la presencia de algunos temas que revelan diferencias entre los dos países.

El capítulo 8 presenta conclusiones parciales de la parte II, que se dedica a los análisis empíricos de textos divulgativos del darwinismo de España y de Corea del Sur. 
Al sintetizar la primera y la segunda parte en las conclusiones generales, se podrá ver los aspectos de la incorporación del darwinismo en España y Corea del Sur, que pertenecen en las culturas diferentes, desde una perspectiva bastante amplia. Además, se podrá saber cómo afectan factores culturales a la apropiación del darwinismo en la sociedad moderna, especialmente la española y la surcoreana. 
PARTE I

EL ENCUENTRO ENTRE EL DARWINISMO Y LA SOCIEDAD

EN ESPAÑA Y COREA DEL SUR 


\section{Capítulo 1. El Darwinismo en la Filosofía Occidental y Oriental}

El darwinismo se encontró con temas tradicionales de la filosofía debido a que propuso una nueva visión de los seres vivos. Es considerado como una teoría científica que creó una grieta en la visión occidental tradicional del mundo. La grieta se ramificó y la teoría se convirtió en una nueva cosmovisión intelectual (González, 2009: 4).

Una visión del mundo (cosmovisión) es "una colección coherente de conceptos y teoremas que deben permitirnos construir una imagen global del mundo $y$, de esta manera, comprender tantos elementos de nuestra experiencia como sea posible" (Aerts, et al., 2007: 8). Los pensamientos tradicionales de una región, aunque no estén incorporados visiblemente en alguna disciplina académica, de cualquier modo se convierten en una de las raíces de su cultura y afectan en cómo la gente ve el mundo.

La filosofía y la cosmovisión están estrechamente relacionadas y la filosofía está incorporada profundamente a la cultura de la sociedad. Según Clément Vidal (2008: 3), "Hablar de "una filosofía" en su sentido más amplio se refiere en realidad a una cosmovisión." La visión del mundo procede de la filosofía, y viceversa.

Podemos hacer hipótesis que el trasfondo filosófico o cultural de un receptor puede influir en su incorporación de teorías científicas. Examinaremos la visión del mundo de Oriente y Occidente para estudiar la incorporación del darwinismo.

Científicos y filósofos han investigado implicaciones filosóficas del darwinismo en profundidad y la mayoría de los estudios se han basado en la filosofía que dominaba el mundo occidental.

En este capítulo, añadiremos una perspectiva oriental hacia al darwinismo y compararemos con la de occidental. No es un estudio sobre las propias filosofías o la historia de las ideas evolucionistas, sino que tratamos las filosofías para averiguar las cosmovisiones de los dos países que pueden influir en la incorporación del darwinismo. Por eso, nos concentramos a las filosofías dominantes de Occidente y Oriente como la raíz de la visión del mundo. 
La filosofía occidental en este estudio es los pensamientos de origen europeo que son descendentes de la tradición griega y la cristiana y ahora forman el trasfondo filosófico de la sociedad española.

La filosofía oriental es la raíz de la cosmovisión de Asia Oriental que proviene de la tradición del confucianismo, el taoísmo y el budismo, y actualmente es el trasfondo filosófico de la sociedad surcoreana.

La filosofía de Asia tiene una gran variedad dependiendo de la región como Oriente Medio, Asia del Sur, Asia del Este, etc. Es difícil incluir todas las ramas de la filosofía bajo un término. Por eso, aquí solamente llamamos a la filosofía de Asia del Este (Asia Oriental) como la filosofía oriental, porque es la filosofía incorporada en Corea.

Entre Oriente Medio y Asia del Este había intercambios culturales pero su influencia mutua era más práctica que filosófica. Oriente Medio tenía una relación más estrecha con Occidente que con Asia oriental, sus pensamientos y religiones se expandieron al oeste y fueron una de las raíces de religiones occidentales.

En cambio, Asia del Este aceptó el budismo de Asia del Sur activamente. El budismo de India se naturalizó después de llegar a Asia oriental, se combinó con la filosofía autóctona y produjo la filosofía y la cultura peculiar de cada país de la zona.

En Corea del Sur, la filosofía oriental incluye académicamente las filosofías autóctonas de la zona cultural y el budismo adaptado en el país (Park, 2007: 54). Las filosofías antiguas de origen chino como el confucianismo y el taoísmo se combinaron el budismo que llegó desde India. Aun cuando las filosofías coreanas tienen sus propias ramas y pensamientos originales, comparten con las filosofías chinas la "raíz" y el "tronco" del árbol de pensamientos.

Hoy día en Corea del Sur el confucianismo y el taoísmo prácticamente no son religiones practicantes en sentido actual, sino que se quedan como una cultura tradicional o ideología. Por eso, en este estudio los términos del confucianismo y el taoísmo incluyen sus pensamientos, éticas y filosofías, no solamente su religiosidad. 
Un individuo crece en un grupo (o en una sociedad) particular e inevitablemente se ve influido por el 'habitus' del grupo al que pertenece. A pesar de que todas las personas tienen biológicamente el mismo proceso de la percepción, difieren en pensar dependiendo su cultura (Nisbett, 2003:14). Es posible que la cosmovisión tradicional de Corea no afecte definitivamente a los jóvenes coreanos en la actualidad que crecen bajo la educación moderna y de estilo occidental. Sin embargo, el habitus de la sociedad influye en la percepción sobre nuevas informaciones de un individuo a pesar de que se pueda reconocer o no (Kim, 2016: 38-39; Bourdieu, 1991: 53-56). Es decir, el trasfondo filosófico de la sociedad en la que el individuo se desenvolvió puede afectar a la apropiación de las teorías científicas.

Por consiguiente, para comparar la incorporación del darwinismo en los dos países, empezamos desde el trasfondo filosófico de las dos culturas que generan sus visiones del mundo y de los seres vivos. Después de repasar las implicaciones filosóficas del darwinismo en la filosofía occidental que ya se han estudiado con suficiencia, las investigaremos a través de la filosofía oriental.

\subsection{El Darwinismo y las Filosofías Occidentales}

La teoría de la evolución de Charles Darwin apareció en la época victoriana del Reino Unido bajo la tradición de la filosofía occidental. Es cierto que Darwin realizó una ingente labor con su estudio de toda la vida, pero su teoría no nació solamente por su propio esfuerzo. Estudios previos o contemporáneos del campo filosófico, sociológico y científico ofrecieron inspiraciones al naturalista británico para formar sus ideas como una teoría científica (González, 2009: 16-17; Mayr, 1992: 17-22; Ruse, 1988: 14). No es casual que A. R. Wallace, que creó una teoría muy similar a la de Darwin en la misma época, también fuera británico. 
La evolución no era una idea original de Darwin. La idea de que los organismos cambian ya existía desde el mundo antiguo helénico. Anaximadro de Mileto, Heráclito de Éfeso y Empédocles de Acragante fueron precursores de ideas naturalistas sobre los seres vivos. Sus argumentos incluyeron varios conceptos de la evolución biológica como el origen natural de los seres, trasformación, generación sucesiva y cambio continuo (Claramonte, 2010: 23; Russell, 1972: 45;). Hasta la Edad Media no se descartaba la idea evolucionista en el mundo intelectual de Occidente aunque siempre fue idea minoritaria y no la investigaron mucho. En la Edad Media la idea se quedó al margen, ya que teólogos cristianos se atribuyeron los conocimientos. Después de pasar la época negra de la idea evolucionista, regresaron los intentos filosóficos de explicar la vida de modo racional y natural a partir del siglo XVII (Kim y Choi, 2010: 303; Ayala, 2007: 44; Lee, 2002: 14).

En la época de Darwin, el concepto de evolución no era en absoluto extraño entre los naturalistas británicos, debido a que ya existían muchas pruebas a favor del cambio de los seres vivos. Coleccionar fósiles se convirtió en una afición de caballeros (Im y Choi, 2010: 28). A pesar del interés intelectual, no se sabía 'cómo' y 'por qué' ocurre este cambio concretamente. Hubo intentos de explicarlo a través de algunas teorías preexistentes pero no fueron suficientes.

El primer científico que presentó una teoría de la evolución científicamente organizada fue el naturalista francés Jean-Baptiste Lamarck. Su teoría se llama transformismo, lamarckismo o teoría de uso y desuso. Según la cual, los seres vivos tienen una fuerza interna hacia la perfección, modifican sus órganos bajo la influencia del ambiente y transmiten los caracteres adquiridos a su descendencia (Lamarck, 1809). Su teoría implicaba que el ser humano es la especie más desarrollada (o evolucionada) y los seres vivos 'progresan' de organismos inferiores a los superiores. Era una idea bastante común en la época en los ambientes intelectuales. Lamarck pensó en que los seres 'mejoran' con el tiempo por la energía interna y el ser humano está en la cumbre de la evolución. Era una teoría bastante 'metafísica' y 'finalista' (González, 2009: 6; Ayala, 2007: 45). A pesar de tener defectos, la teoría del Lamarck se trataba durante muchos años como una de las teorías más persuasivas sobre el mundo viviente. 
En el año 1859, cincuenta años después de la teoría de Lamarck, Charles Darwin presentó su bien estructurada teoría de la evolución a través del libro «El origen de las especies» que consta de ejemplos abundantes y explicaciones detalladas. A pesar de que no fue la primera persona que presentó el concepto de evolución, con mecanismo científico comprobable y las pruebas suficientes que mostró, la evolución se convirtió en un concepto revolucionario en el mundo intelectual (Ayala, 2007: 50; Mayr, 2004: 112).

La teoría de Darwin se quedó en conflicto con ciertas ideologías dominantes de la época. El concepto básico del darwinismo era la evolución variacional. "Era fundamentalmente diferente de los conceptos transformacionales y saltacionales ${ }^{6}$ de evolución que habían sido propuestos anteriormente" (Mayr, 1992: 109). En el sentido evolutivo, los animales siguen variando y ramificando, y entre especies existen seres intermedios. Estos seres son semejantes a especies cercanas, así que a veces pueden relacionarse con sus vecinos, y su descendencia es capaz de reproducirse también (Dawkins, 2009: 42-43; Mayr, 1992: 3334). Es decir, no existe la esencia de una especie porque los seres vivos cambian generación tras generación, tampoco existían paredes insuperables entre las especies porque aparecen los seres intermedios fértiles. Es lo contrario al esencialismo filosófico y al fijismo biológico. El darwinismo muestra la continuidad entre las especies, y según la teoría, no existe la esencia de especies, porque los seres vivos están cambiando (Kim y Choi, 2010: 304; Dawkins, 2009: 39; Lee, 2002: 17-18; Mayr, 1992: 53-55; Grasa, 1987: 6668).

Según Darwin, la evolución de los seres vivos se produce en dos etapas, que son la variación de los seres y la selección. Darwin presentó el mecanismo de la segunda etapa, la selección 'natural', pero no sabía exactamente cómo ocurre la variación. Gracias al desarrollo de la genética se descubrieron los mecanismos de las variaciones en detalle: el papel del azar en el proceso evolutivo fue comprobado (Mayr, 2004: 121-122). La importancia del azar en el darwinismo era ajena a la física de la época. Según el fiscalismo, que dominaba el mundo científico del momento, la predicción científica no era sólo una

\footnotetext{
6 "Saltación: En la teoría evolutiva, la afirmación de que los nuevos tipos de organismos se originan por la aparición repentina de un individuo nuevo único que se convierte en el progenitor de este nuevo tipo de organismo." (Mayr, 1992: 185)
} 
posibilidad sino que era la auténtica prueba de la validez de las teorías. Eran deterministas estrictos. Sin embargo, los procesos evolutivos que Darwin propuso implicaban un considerable componente de azar, que es una característica del indeterminismo (Lee, 2002: 19; Mayr, 1992: 16).

Por otra parte, la selección 'natural' se realiza sin un agente intencional. El ser humano a menudo selecciona plantas y animales por su interés, pero el proceso evolutivo en el mundo natural es diferente. La naturaleza no tiene voluntad de seleccionar ni de producir mutaciones. Es decir, los seres vivos no se seleccionan por alguna voluntad o intención, sino naturalmente: "Darwin trata de explicar el diseño de los organismos, su complejidad, diversidad y maravillosos ingenios como resultado de procesos naturales." (Ayala, 2007: 51) La teoría excluye la voluntad en el proceso de la evolución de los seres vivos. Algunas palabras que se usan en el darwinismo como 'selección', 'lucha' y 'adaptación' tienen matices de voluntad en el lenguaje cotidiano, pero en la teoría de Darwin no los contienen.

Darwin fue la primera persona que explicó el mecanismo de todos los fenómenos orgánicos sin intervención intencionada, es decir, sin agente intencional (Ayala, 2007: 5053; Mayr, 2004: 114-115). Es uno de los logros más destacados del científico británico. El propio Darwin nunca negó a un ser trascendental ni Dios, simplemente presentó ejemplos que no se puede explicar con el creacionismo pero se pueden interpretar bien con su teoría de la selección natural, para demostrar su teoría ${ }^{7}$ (Darwin, 1859: 459-484). Sin embargo, es cierto que no es necesario incluir ningún agente trascendental en el argumento. El darwinismo explica el mundo vivo entero sin creador ni sujeto final de la voluntad. La teoría no presupone el sitio definitivo del Dios Creador como agente final de todos los argumentos del mundo.

\footnotetext{
${ }^{7}$ Por ejemplo, "Such cases as the presence of peculiar species of bats on oceanic islands and the absence of all other terrestrial mammals are facts utterly inexplicable on the theory of independent acts of creation." (Darwin, 1859: 473), "It must be admitted that these facts receive no explanation on the theory of creation." (Darwin, 1859: 474), "On the view of each organism with all its separate parts having been specially created, how utterly inexplicable is it that organs bearing the plain stamp of inutility, such as the teeth in the embryonic calf or the shrivelled wings under the soldered wing-covers of many beetles, should so frequently occur." (Darwin, 1859: 475), etc.
} 
Por consiguiente, la teoría tampoco coincidía con el finalismo tradicional. La creencia de que el mundo ha de tener un propósito era un pensamiento muy extendido en Occidente. Según esta premisa, cualquier cambio en este mundo es debido a causas finales que hacen moverse al objeto o fenómeno particular hacia un fin último. Un fin significa algo direccional y también puede implicar voluntad para conducir a él. Si negamos el propósito del mundo, resulta que se pierde el papel de Dios como la causa final de todo (Lee, 2010: 19-20; Mayr, 1992: 63-78).

Miles de años hacía ya que los occidentales pensaban que un ser supremo había creado la naturaleza. La doctrina sobre la creación parecía plausible porque los seres vivos tenían muchos órganos complejos e ingeniosos. También creían que el ser humano dominaba la naturaleza, ya que el Dios Creador le había dado directamente el poder de manejarla. Sin embargo, el darwinismo explica la naturaleza sin Dios, además, el concepto de 'origen común' rebaja la especificidad del ser humano. Darwin propuso una forma de árbol para mostrar la relación entre los seres vivos, en vez de la 'scala naturae'. En su 'árbol de la vida', todos los seres vivos son varias ramas que se extienden desde un antepasado común y el ser humano es sólo una de las ramas actualmente vivas (Mayr, 2001:22).

Llegando a este punto de vista, es natural que el darwinismo haga frente a las doctrinas religiosas. Se podría afirmar que el darwinismo era una teoría que tenía consecuencias materialistas (Agazzi, 2009: 44) y abrió la puerta de la 'ciencia secular' como argumentó Ernst Mayr (2004: 114-115). Aparte de los propósitos de Darwin, el desarrollo de la teoría evolutiva ha sacudido las pretensiones de la religión (Dupré, 2006: 98).

Como hemos observado hasta ahora, el darwinismo tenía varias implicaciones que no coincidían bien con los pensamientos tradicionales de la filosofía europea de la época. Por eso, surgían a menudo debates sociales y científicos, interpretaciones equivocadas e incluso el rechazo absoluto. 


\subsection{El Darwinismo y Las Filosofías Orientales}

El darwinismo nació durante la época transicional de la filosofía occidental e influyó en la propia transición. Actualmente se trata como uno de los pensamientos más revolucionarios de la historia intelectual del mundo occidental. ¿La teoría fue tan impactante en el mundo oriental de aquel entonces también? Ahora averiguaremos las implicaciones filosóficas del darwinismo a través de la tradición de la filosofía oriental.

La filosofía oriental difiere en la forma de pensar y de los intereses intelectuales de la perspectiva occidental. Las dos filosofías, que procedieron de antigua China y Grecia respectivamente, tienen maneras distintas de especular y la visión diferente del mundo. Las estructuras de las sociedades que se fundaron en su trasfondo filosófico, también son diferentes (Song, 2012: 358; Park, 2007: 51; Nisbett, 2003: 14; Gernet, 1982: 417; Northrop, 1946: 312).

Cuando Darwin presenta su teoría, es decir, hasta la mitad del siglo XIX, Occidente y Oriente todavía no tenían intercambio libre entre ellos por lo que habían desarrollado sus propios pensamientos respectivamente.

Antes de la época moderna que solamente vivían del nomadismo, la agricultura y el comercio local, fuera en Oriente u Occidente, pensaron que el mundo y la civilización en los que vivían era el centro de todo el mundo y el exterior de su mundo se consideró como bárbaros. (Song, 2012: 400)

La cultura occidental entró a Oriente poco a poco, a partir del cristianismo en el siglo XVII y el XVIII. El intercambio de las filosofías nunca fue igualado sino que casi unilateralmente la occidental se transmitió a Oriente. En la primera época, los misioneros que llegaron a China tuvieron muchas dificultades de traducir la doctrina cristiana en chino. Por la diferencia de las estructuras ideológicas y lingüísticas, traducir los pensamientos occidentales y difundir al pueblo chino fueron misiones complicadas (Park, 2007:62; Gernet, 1982: 416-418). 
Sin embargo, al pensamiento naturalista del darwinismo no le hacía falta sufrir esa dificultad en el encuentro con el pueblo asiático. Según Joseph Needham (1977: 250), que introdujo a Occidente la historia de la ciencia y la tecnología de China, los chinos "nunca creyeron en la inmutabilidad de las especies" y "nunca concibieron una creación especial", por lo tanto, "no había razón para creer que diferentes géneros de seres vivos no pudieran transmutarse fácilmente, si se les daba tiempo suficiente". En contraste con Occidente, que también tenía pensamientos naturalistas pero nunca los tenía como la filosofía dominante hasta la época darwiniana, Oriente los tenía como su visión principal del mundo.

La cosmovisión que comparten las tres filosofías principales de Oriente (el confucianismo, el taoísmo y el budismo) es el pensamiento de que el ser humano es una parte de la gran armonía y todos los seres están conectados dentro de un universo orgánico. El darwinismo explica que todos seres vivos están relacionados porque originaron de un árbol de la vida, se generaron interactuando y han coexistido en la Tierra hasta ahora. A través de la filosofía que idea el mundo como un organismo, la filosofía del darwinismo es inteligible (Song, 2012: 384; Hong, 2010: 278). Aun cuando los pensamientos dominantes de Occidente y los pensamientos tradicionales de Oriente, que se enfrentaron en aquellos tiempos en China, eran inconmensurables (Song, 2012: 384), pero la cosmovisión del darwinismo era compatible y conmensurable con los pensamientos orientales.

Si comparamos los pensamientos sobre los seres vivos de los dos mundos, la visión oriental es mucho más 'eco-céntrica' que la de Occidente, que es antropocéntrica:

En Oriente, piensan que el ser humano es una parte de todos los seres naturales y ocupa solo un eslabón del todo. En cambio, en Occidente el concepto del ser humano como el centro del universo e hijo de Dios es fundamental en su cosmovisión. (Park, 2007: 72-73)

Los pensamientos sobre el 'Tao (도(道))' están situados en el fundamento de la filosofía oriental. El confucianismo y el taoísmo lo llaman 'Tao' y el budismo tiene un concepto correspondiente y lo llama 'Dharma'. La palabra 'Tao' literalmente significa 'el camino' en chino y filosóficamente tiene implicaciones de 'el camino de la naturaleza' o 'el camino del cielo' como principio del mundo. El 'Tao' es la única existencia metafísica en el mundo 
antiguo de China y el orden natural que promueve todos los cambios del mundo (Park, 2007: 66; Han, 2001: 90; Gernet, 1982: 422).

El concepto 'Tao' era el principio o el mecanismo del movimiento universal y el 'Tiān (천(天)): cielo' como la realidad verdadera y la fuente de moral. A veces los conceptos tenían características de una creencia religiosa, pero nunca llegaron a ser una religión potente, generalmente sólo funcionaban como una metáfora de la naturaleza. Influían en las gentes, en general, pero normalmente quedaban en el nivel de animismo respecto a la creencia. Es difícil encontrar monoteísmo a lo largo de la historia de Oriente, aunque tampoco tenía tradiciones materialistas.

En Occidente, era frecuente el concepto de que todos los seres vivos tienen su esencia respectivamente y mantienen su forma desde siempre. En cambio, en Oriente pensaban que todos los seres cambian excepto algunos conceptos principales como 'Tao' y 'Tiān'. Según el filósofo chino Liang Shuming (1921: 112, citado en Gernet, 1982: 421-422), "los chinos nunca cuestionaron alguna esencia fija e inmutable, (...) Todos los pensamientos fundamentales que provienen de la metafísica tradicional china argumentan la armonía y el cambio, no la esencia inmutable."

Por otra parte, en la historia de las ideas de Oriente, no existía un ser supremo personal significativo. No se suponía un ser trascendental como el Creador del mundo o la causa final que está fuera del universo (Han, 2001: 85). El padre del taoísmo Lăož (노자(老子)) dice en su libro más importante del taoísmo, «Taodéjīng (도덕경(道德經))》, "la naturaleza es una corriente que camina sin intención ni intervención y no podemos controlarla (Lǎož̀ , citado en Kim y Choi, 2010: 327)".

En la filosofía oriental, la palabra que se refiere a todos los seres (orgánicos e inorgánicos) de la naturaleza, 'Wànwù (만물(萬物))' es un concepto muy esencial. Solía designar a los seres sin distinguir al ser humano del resto. En el taoísmo, todos los seres (Wànwù) son iguales desde el nacimiento porque proceden del mismo 'Tao' (Kim y Choi, 2010: 339; Cho, 
1992: 40). En el budismo, el concepto de 'Pratītyasamutpāda'8 (explicaremos en 1.2.3) que se basan en la generación interactiva y la corriente sin cesar del mundo muestra el pensamiento similar (Woo H, 2010:137). La vinculación entre los seres es uno de los arquetipos principales de las disciplinas tradicionales asiáticas (Song, 2012: 378; Kim y Choi, 2010: 340).

En Oriente, la jerarquía filosófica entre los seres vivos no era tan clara en comparación a la de Occidente. No había un ser supremo que pudiera dar el poder al hombre para gobernar el mundo, así que el ser humano era sólo una parte de la naturaleza que vive bajo la corriente natural y el cuerpo del ser humano era tratado como un universo pequeño (Lee, 2010: 190; Kim y Choi, 2010: 344; Han, 2001: 103-104).

Ahora exploramos los caracteres compatibles del confucianismo, el taoísmo y el budismo respectivamente con las implicaciones filosóficas del darwinismo.

\subsubsection{El Confucianismo y el Darwinismo}

Entre los pensamientos orientales que surgieron en la zona cultural de Asia del Este centrada en China, lo más influyente en la política, la ética y la cultura de Oriente era el confucianismo. Se instaló como el principal sistema moral del mundo oriental (Nisbett, 2003: 6).

El libro en el que podemos detectar más claramente la visión del mundo del confucianismo es el «l Ching» (역경(易經) o 주역(周易)) (Fuxi, et al., siglo XI a.C aprox.). Es uno de tres clásicos del confucianismo y es un libro que describe los principios de cambio del mundo. El taoísmo también se basa en este libro.

El propio título significa «el libro de cambios (mutaciones)». Podemos resumir sus principios con estas frases: "El mundo cambia incesantemente. Es el principio del cambio. Todas las cosas (Wànwù) cambian excepto el principio. La verdad es simple y fácil." (Kim y

\footnotetext{
${ }^{8}$ Pratītyasamutpāda (연기설): “Todos los acontecimientos psicológicos y físicos son por la relación de ocurrencia condicional." (Ahn, et al., 2010: 297)
} 
Choi, 2010: 343). La luz se hace sombra y la sombra se hace luz, el día se hace noche y la noche se hace día, las estaciones se cambian ordenadamente. Todos los seres nacen, envejecen, enferman y se mueren. El concepto principal del libro es la generación sin cesar y según lo cual el 'Tao' es un término genérico que cubre todos los cambios del universo (Han, 2001: 90; Kim, 1992: 6-7).

Otra característica destacada de la cosmovisión confuciana es la visión orgánica, que piensa el universo como un organismo en el que ocurren la generación y la desaparición de continuo. Según la visión del mundo, la naturaleza es 'el gran universo' y una persona es 'un pequeño universo' que principalmente tiene la misma estructura con el grande, así todos los seres vivos son relacionados entre sí. En esta visión orgánica no necesita un agente exterior del mundo, porque el propio universo es orgánico y vive por sí mismo (Song, 2012: 377-379; Han, 2001: 104).

En el siglo XII en la Dinastía Song en China apareció una escuela sintética de varias ramas de la filosofía oriental, el neoconfucianismo. Luego la escuela fue de suma importancia en el mundo oriental, especialmente en la Dinastía Chosŏn (1392-1897). Su base era el confucianismo y se aceptaron pensamientos budistas y taoístas para ampliar y mejorar sus argumentos filosóficos. El confucianismo tenía el carácter fuerte de la ética, pero el neoconfucianismo aportaba el carácter de la metafísica y una actitud naturalista. Prestaba más atención al cosmos y a la naturaleza por la influencia del budismo (Needham, 1977: 252).

En la Corea de la Dinastía Chosŏn, que era plenamente neoconfuciana, la igualdad y la desigualdad entre el ser humano y los otros animales fue uno de los temas más importantes en los debates de los intelectuales, especialmente en el siglo XVII y XVIII. (Lee, 2014: 214; Kim, 1995: 388-389; Yoon, 1986: 313). Los debates duraron más de un siglo y eso significa que el tema fue realmente 'polémico' para los neoconfucianistas. Podemos imaginar que es imposible en Occidente antropocéntrico. 


\subsubsection{El Taoísmo y el Darwinismo}

El confucianismo fue el fundamento principal de la cultura patriarcal de las sociedades asiáticas adoptando incluso como una filosofía política. En cambio, el taoísmo tenía carácter de filosofía más naturalista y daba importancia a la generosidad y la armonía en la sociedad.

El concepto principal del taoísmo es 'Wuwei (무위(無爲))', que significa un estado sin cosas ni asuntos artificiales. No indica el no hacer nada, sino que es una actitud de esquivar comportamientos intencionados a la fuerza. El taoísmo explica que el tao verdadero existe en un lugar transcendente de la intención humana y se lo puede conocer por la intuición. El principio del taoísmo es evitar la intención humana y volver a la naturaleza o el estado natural. Lógicamente no son pensamientos finalistas ya que evitan intenciones, por eso en el taoísmo no existe ningún agente que tiene voluntad. Vivir naturalmente dentro de la gran corriente del universo es su filosofía fundamental.

El 'cambio' también es uno de los conceptos principales del taoísmo. Según uno de los dos fundadores del taoísmo Zhuāngzǐ (citado en Kim, 1992: 6), "La naturaleza no se para ni un momento y entra a una fase nueva de improviso, por eso todos los seres del mundo cambia continuamente." Todos los seres cambian, lo cual es el 'Tao'.

El 'Wànwù (todos los seres)' es insustancial porque cambia desde 'nada' hasta 'existencia' y vuelve otra vez a 'nada' reiteradamente por el principio del mundo, el 'Tao', el cual es el propio proceso de la generación y el cambio. Sin embargo, "el 'Tao' no puede comportarse como otros seres independientes, pero es la energía fundamental para generar, criar, completar y extinguir todos los seres, porque es de 'Wuwei (sin intencionalidad)'," (Song, 2012: 372)

El 'Wànwù (todos los seres) proviene del mismo Tao, por eso no hay jerarquía entre los seres. Este concepto aparece más a menudo en la literatura taoísta. En la disciplina tampoco hay gran diferencia conceptual entre el ser humano y los animales (Song, 2012: 378; Kim y Choi, 2010: 339; Song, 1994: 310). Según el taoísmo, en este universo enorme todos los seres vivos tienen relación entre ellos, por eso no hace falta poner el ser humano 
en el centro del mundo, debido a que todos los conocimientos son relativos dependiendo del sujeto de la percepción (Song, 2012: 364, 1994: 345-346).

\subsubsection{El Budismo y el Darwinismo}

A diferencia del confucianismo y el taoísmo, el budismo nació en India y se extendió al este. Generalmente el budismo se conoce como la religión más compatible con las ciencias modernas. La teoría de Darwin tiene bastantes similitudes con el budismo. Algunos investigadores suponían que Darwin habría conocido los pensamientos budistas (Choe, 2010: 84-86; Ekman, 2008: 150).

La filosofía central del budismo es Pratītyasamutpāda, que puede combinarse con los métodos científicos o al menos no se choca con ellos. (Woo H, 2010: 137; Ahn, 2010: 31; Choe, 2010: 112). Según la doctrina, en todos los fenómenos, su causa y su resultado intercambian la influencia y cambian de continuo. La literatura budista Āgama dice, "Éste existe, por eso aquél existe. Éste aparece, por eso aquél aparece. Si no existe éste, tampoco existe aquél y si desaparece éste, aquél también desaparece." (Āgama citado en Woo H, 2010: 181) Este pensamiento de la generación interactiva y circulación de los seres pueden ser compatibles con la filosofía del darwinismo, que los seres vivos evolucionan dentro del ambiente y los seres cercanos (Woo H, 2010: 137).

Por otra parte, el budismo tampoco reconoce la intervención de un ser trascendente en la naturaleza ni incluye pensamientos finalistas. En vez de la causa final, el budismo tiene el concepto 'Karma (업(業) $)^{9}$ que puede explicar todos los cambios en la naturaleza sin finalidad ni fuerza trascendental (Woo H, 2010: 156; Ahn, 2010: 32).

Por otra parte, los conceptos budistas como el 'Anātman (무아(無我): no-yo, carencia de ego), ${ }^{10}$ y 'Shuniata (공(空): vacío) ${ }^{11}$ se pueden entender con el nihilismo que la ciencia

\footnotetext{
${ }^{9}$ Karma (업): “Es comportamiento ético. Se considera como la causa de dolores. En el proceso de la reencarnación el Karma forma condiciones físicas y sociales que el individuo va a recibir." (Ahn, et al., 2010: 297)

${ }^{10}$ Anātman (무아): “Los cincos agregados (que son componentes de una persona: físico, sentimiento,
} 
materialista como el darwinismo puede provocar. Los seres viven en un mundo sin fin ni Dios y su existencia es solamente un conjunto temporal de las energías naturales. Por lo tanto, no es muy significativo distinguir el ser humano de los animales (Ahn, 2010, 31; Choe, 2010: 113; Park, 2007: 223;). Podemos ver este pensamiento también en el concepto budista bastante conocido en Occidente, la reencarnación. El concepto muestra que no existe la distinción tajante entre el ser humano y los animales (Lee, 2010: 222).

Por supuesto, el budismo no es totalmente concordante con el darwinismo. El darwinismo implica el materialismo, pero el budismo pone énfasis en la disciplina mental. Sin embargo, "a pesar de que la ciencia y el budismo tienen conflictos superficiales, en el nivel metafísico se coinciden", por eso "son compatibles (Park, 2007: 227)."

Elaboramos tablas en dos maneras para que vean de un vistazo la compatibilidad de las filosofías orientales con el darwinismo.

\begin{tabular}{|c|c|c|c|}
\hline & Confucianismo & Taoísmo & Budismo \\
\hline $\begin{array}{l}\text { Fundador (Personaje } \\
\text { importante) }\end{array}$ & Kǒngzǐ y Mèngzǐ & Lǎozǐ y Zhuāngzǐ & Buda \\
\hline $\begin{array}{l}\text { Época (aprox.) y lugar de } \\
\text { origen }\end{array}$ & Siglo V a.C., China & Siglo V a.C., China & Siglo VI a.C., India \\
\hline $\begin{array}{l}\text { Pensamientos } \\
\text { compatibles con el } \\
\text { darwinismo }\end{array}$ & $\begin{array}{l}\text {-Todos los seres } \\
\text { cambian. } \\
\text {-Todos los seres } \\
\text { están relacionados. } \\
\text { - En el universo no } \\
\text { se paran la } \\
\text { generación y la } \\
\text { desaparición de los } \\
\text { seres vivos. }\end{array}$ & $\begin{array}{l}\text { - Todos los seres } \\
\text { cambian. } \\
\text {-Esquivar la } \\
\text { intencionalidad } \\
\text { humana. } \\
\text { - El ser humano es } \\
\text { una parte de la } \\
\text { armonía del mundo. } \\
\text { - Todos los seres } \\
\text { provienen del mismo } \\
\text { tao, por eso son } \\
\text { iguales. }\end{array}$ & $\begin{array}{l}\text {-Todos los seres son } \\
\text { formas temporales } \\
\text { en la corriente del } \\
\text { universo. } \\
\text {-Todos los seres } \\
\text { vivos están } \\
\text { vinculados entre } \\
\text { ellos. } \\
\text {-Todas las cosas son } \\
\text { transitorias. } \\
\text { - La naturaleza sin } \\
\text { ser supremo. }\end{array}$ \\
\hline
\end{tabular}

Tabla 1.1. Resumen. La compatibilidad entre las filosofías orientales y el darwinismo

pensamiento, comportamiento y percepción) nunca identifican con el ego (yo, ātman). Anātman se considera como la doctrina más peculiar del budismo en épocas posteriores." (Ahn, et al., 2010: 296-297)

${ }^{11}$ Shuniata (공): “En el budismo Mahāyāna (Gran Vehículo), todos los seres fenomenales NO tienen su esencia (naturaleza) fija." (Ahn, et al., 2010: 294) 


\begin{tabular}{|l|l|l|l|}
\hline & Darwinismo & Cosmovisión Occidental & Cosmovisión Oriental \\
\hline $\begin{array}{l}\text { ¿Las especies } \\
\text { cambian? }\end{array}$ & $\begin{array}{l}\text { Sí, cambian } \\
\text { gradualmente. }\end{array}$ & $\begin{array}{l}\text { No, cada una tiene su } \\
\text { esencia y es firme. }\end{array}$ & $\begin{array}{l}\text { Sí, todos los seres } \\
\text { cambian continuamente. }\end{array}$ \\
\hline $\begin{array}{l}\text { ¿Existe un ser } \\
\text { supremo en el } \\
\text { mundo? }\end{array}$ & $\begin{array}{l}\text { No, el mundo vivo } \\
\text { sin agente } \\
\text { intencional. }\end{array}$ & $\begin{array}{l}\text { Si, el mundo bajo el Dios } \\
\text { Creador. }\end{array}$ & $\begin{array}{l}\text { No, el mundo armónico } \\
\text { sin agente intencional. }\end{array}$ \\
\hline $\begin{array}{l}\text { ¿El mundo es } \\
\text { finalista? }\end{array}$ & $\begin{array}{l}\text { No, el azar interviene } \\
\text { en el proceso de la } \\
\text { evolución. }\end{array}$ & Sí, existe la causa final. & $\begin{array}{l}\text { No, el mundo sin } \\
\text { finalidad ni dirección. }\end{array}$ \\
\hline $\begin{array}{l}\text { ¿El ser humano } \\
\text { es superior que } \\
\text { otros seres } \\
\text { vivos? }\end{array}$ & $\begin{array}{l}\text { No, es una rama del } \\
\text { árbol de la vida. }\end{array}$ & $\begin{array}{l}\text { Sí, es el rey de la } \\
\text { Creación. }\end{array}$ & $\begin{array}{l}\text { No, es una parte de la } \\
\text { gran armonía del mundo. }\end{array}$ \\
\hline
\end{tabular}

Tabla 1.2. Resumen. Cosmovisión del Darwinismo, Occidente y Oriente
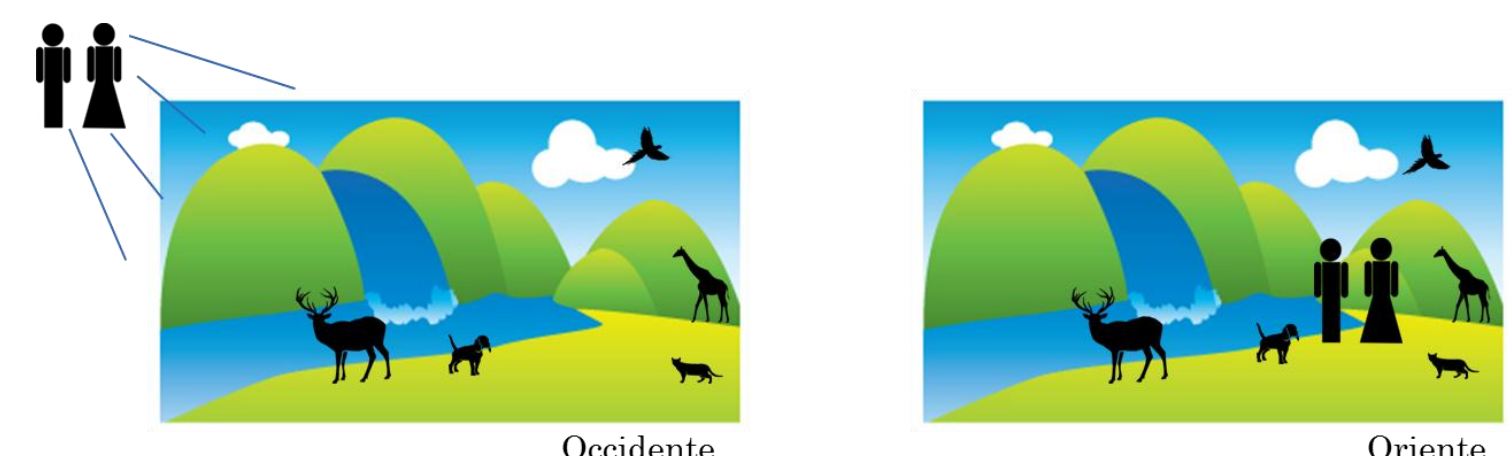

Gráfico 1.1. Cosmovisión tradicional de Occidente y Oriente

Intentamos mostrar la diferencia de las visiones del mundo de Occidente y Oriente en un dibujo (gráfico 1.1). La filosofía occidental prestaba atención a la razón humana como peculiaridad del ser humano; por otro lado, objetivó la naturaleza. El ser humano miraba por abajo otros seres vivos. En cambio, el ser humano en la filosofía oriental estaba formando parte de la gran armonía de la naturaleza (Song, 2012, 400-413; Park, 2007: 5176; Gernet, 1982: 432). Es decir, como la naturaleza y el ser humano no estaban separados conceptualmente, no era común la actitud de investigar la naturaleza como un objeto. A través del gráfico, podemos reconocer fácilmente que la cosmovisión oriental es más parecida al mundo viviente que explicó Darwin y que luego fue comprobado científicamente. 
En definitiva, la filosofía oriental presupone el cambio continuo de todos los seres. No presenta un ser trascendente ni causa final. Además, todos los seres son igualados relativamente incluso el ser humano y el mundo no es finalista ni determinista. No es extraño que Erich Fromm (1970: 80) diga, "paradójicamente, los pensamientos religiosos de Oriente resultan ser más afines a los pensamientos racionales de Occidente que los pensamientos religiosos occidentales en sí."

Hasta el momento nos hemos referido de la compatibilidad entre el darwinismo y la filosofía oriental, para averiguar la influencia de la cosmovisión tradicional de Oriente en la incorporación del darwinismo. Por supuesto, cabe señalar que la cosmovisión no se concuerda con exactitud con la postura del darwinismo. La filosofía materialista no está muy visible en la historia de los pensamientos orientales, a pesar de que algunos eruditos como Wang Chhung del siglo I la presentaron (Needham, 1977: 254). Por otra parte, el dualismo de mente-cuerpo es una de las doctrina principales del budismo. El confucianismo y el taoísmo igualmente tratan la mente aparte. Por lo tanto, difieren del darwinismo, que se puede clasificar como una teoría materialista monista. Además, la filosofía oriental no tenía rama científica que pudiera compararse en detalle con el darwinismo.

La filosofía occidental también contaba con las ideas evolucionistas que explicaban los fenómenos biológicos naturalmente. En la Edad Media perdieron su corriente pero después de pasar la época de la revolución científica (y llegando a la era darwiniana) resurgieron y se convirtieron en una de las raíces del darwinismo. Sin embargo, las ideas no llegaron a ser la cosmovisión universal de Occidente hasta el siglo XIX.

En el siglo de Darwin, los fenómenos de vida se convirtieron en tema principal del mundo académico de Occidente, que acumuló estudios sobre los seres vivos. "La época victoriana que Darwin trabajó era muy religiosa pero a la vez se estaba secularizando rápidamente la sociedad (Hong, 2010: 259)" En la época ya se maduró la filosofía naturalista y se desarrolló bastante la geología. Especialmente los estudios de Charles Lyell influyeron mucho a Darwin. Además, se presentaron algunos conceptos importantes de la evolución como el cambio de los seres, antepasado común, competencia, aislamiento, catastrofismo 
y transformismo a través de los estudios de Buffon, Erasmus Darwin, Cuvier, Lamarck, etc. Por otra parte, Darwin se inspiró en Malthus y tomó el concepto de 'lucha', aprendió la metodología científica de Herschel y Whewell (González, 2009: 42; Mayr, 1992: 23). La teoría de Darwin se gestó en un huerto fértil que estaba preparado para resolver "el misterio de los misterios ${ }^{12}$."

En la misma época, en Oriente, pensaban en una manera diferente y todavía no se distinguieron teorías científicas desde las doctrinas o las ideologías. Además, no se desarrollaron la ciencia moderna ni la industria del estilo occidental. Por lo tanto, es natural que fuera difícil nacer una teoría como el darwinismo en el mundo oriental de entonces.

Si lo pensamos en otra manera, como Oriente ya tenía una filosofía bastante adecuada para percibir el mundo de los seres vivos, no tomaba mucha atención a las pruebas de los 'cambios de las especies' que descubrieron Darwin y otros naturalistas occidentales. A lo mejor, fue porque ya sabían que 'todos los seres cambian'. Es decir, no hacía falta buscar una nueva teoría que explica mejor el mundo, debido a que a través de su filosofía los fenómenos naturales se podían dar explicaciones convincentes.

A pesar de todo, es muy interesante y merece atención que la filosofía oriental tenga puntos de contacto con el darwinismo, que se presentó en el otro lado del mundo miles de años después. Aun cuando sus colegas cercanos Huxley y Hooker aprendieron alguna parte, al parecer, el propio Darwin nunca conoció personalmente los pensamientos orientales, pero presentó una teoría bastante compatible con ellos (Choe, 2010:85-86).

Lo que argumentamos en este capítulo es que la cosmovisión de la filosofía oriental no se contrapone a la del darwinismo sino que es compatible con ella, y por ello es poco probable que el trasfondo filosófico de Oriente fuera un obstáculo para la incorporación del darwinismo para los coreanos.

\footnotetext{
${ }^{12}$ Es originalmente expresión del astrónomo inglés, John Herschel, en su carta para Charles Lyell para hablar elogiando de su uniformismo. Charles Darwin mencionó la expresión en el prefacio de El origen de las especies. (Darwin, 1859:23)
} 


\section{Capítulo 2. La Transmisión y la Recepción del Darwinismo. España y Corea del Sur}

Cuando el público encuentra una nueva teoría científica, suponemos que la situación socio-política de la sociedad influye a su percepción y la reacción sobre la nueva información como su trasfondo filosófico. Por consiguiente, es necesario investigar el proceso de la transmisión y la apropiación en el contexto socio-histórico en la época de entrada del darwinismo en las dos sociedades, la española y la coreana.

Elaboramos una tabla cronológica de la historia resumida de la teoría de la evolución, con una comparativa entre España y Corea del Sur: desde el año 1859 (en el que se publicó el libro «El Origen de las Especies») hasta ahora.

\begin{tabular}{|c|c|c|c|}
\hline Años & Teoría de la evolución & $\begin{array}{l}\text { Contexto socio-político } \\
\text { de España }\end{array}$ & $\begin{array}{l}\text { Contexto socio-político } \\
\text { de Corea } \\
\text { (1945-actual: Corea del Sur) }\end{array}$ \\
\hline $\begin{array}{l}1859 \\
-1900\end{array}$ & $\begin{array}{l}1859 \text { On the origin of species } \\
1871 \text { The descent of man } \\
1885 \text { Neodarwinismo } \\
\text { (Weismann) } \\
1900 \text { Redescubrimiento de leyes } \\
\text { de Mendel }\end{array}$ & $\begin{array}{l}\text { 1868-1873 Sexenio democrático } \\
\text { 1873-1874 Primera República } \\
\text { 1874-1931 Restauración } \\
\text { Borbónica } \\
\text { (1877 El origen de las especies)* }\end{array}$ & $\begin{array}{l}\text { 1392-1897 Dinastía Chosŏn } \\
\text { 1897-1910 Imperio de Corea }\end{array}$ \\
\hline $\begin{array}{l}1901 \\
-1950\end{array}$ & $\begin{array}{l}\text { 1920s-40s Teoría sintética de la } \\
\text { evolución } \\
\text { (genética, citología, sistemática, } \\
\text { botánica y paleontología) }\end{array}$ & $\begin{array}{l}\text { 1874-1931 Restauración } \\
\text { Borbónica } \\
\text { 1923-1930 Dictadura de Primo } \\
\text { de Rivera } \\
\text { 1931-1936 Segunda República } \\
\text { 1936-1939 Guerra Civil Española } \\
\text { 1940-1975 Dictadura Militar (F. } \\
\text { Franco) }\end{array}$ & $\begin{array}{l}\text { 1910-1945 Ocupación de Japón } \\
\text { 1919-1948 Gobierno provisional } \\
\text { de la República de Corea } \\
1945 \text { Recuperación de la } \\
\text { Soberanía (Fin de la II Guerra } \\
\text { Mundial) y División en Corea del } \\
\text { Sur y Norte } \\
\text { 1945-1948 Gobierno Militar } \\
\text { Estadounidense } \\
\text { 1948-1960 Primera República } \\
\text { Presidencialista } \\
\text { 1950-1953 Guerra de Corea }\end{array}$ \\
\hline $\begin{array}{l}1951 \\
\text {-actual }\end{array}$ & $\begin{array}{l}1953 \text { Descubrimiento de Doble } \\
\text { Hélice (Desarrollo de la genética } \\
\text { molecular) } \\
1968 \text { Teoría neutralista } \\
1972 \text { Equilibrio Puntuado }\end{array}$ & $\begin{array}{l}\text { 1940-1975 Dictadura Militar (F. } \\
\text { Franco) } \\
\text { 1975-actual Monarquía } \\
\text { parlamentaria } \\
1978 \text { Democratización }\end{array}$ & $\begin{array}{l}\text { 1950-1953 Guerra de Corea } \\
\text { (1958 On the origin of species } \\
\text { (종의 기원))* } \\
\text { 1960-1961 Segunda República } \\
\text { 1961-1979 Dictadura Militar } \\
\text { (C.H. Park) } \\
\text { 1980-1987 2a Dictadura Militar } \\
\text { (D.H. Chun) } \\
\text { 1987-actual República } \\
\text { Presidencialista (Sufragio directo) }\end{array}$ \\
\hline
\end{tabular}

Tabla 2.1. Tabla cronológica. Teoría de la evolución, España y Corea (Mayr, 1992: 155; Grasa, 1987: 14-28) 
Lo que se debe tener en cuenta es el año en el que se publicó «El Origen de las Especies» en su idioma local. En el caso de España, en el año 1877 se publicó por primera vez, fue 18 años después de la publicación original en Inglaterra. Antes del año se publicaron algunas partes, pero la versión íntegra no se había publicado. Es por ello más tardía que la publicación en castellano de «El Origen del Hombre» (1876). En la época, aun cuando ya contaron con la versión castellana, los españoles leyeron más la versión francesa, ya que el francés se consideraba el idioma para discusiones académicas (Hull, 1974: 390). En el caso del Corea, tardó casi cien años en publicarse «El Origen de las Especies» en coreano, en el año 1958. Principalmente es porque la historia coreana de la primera mitad del siglo XX fue muy complicada. Además, no era tan urgente la traducción del libro en coreano porque la mayoría de los intelectuales coreanos de la época podían entender las literaturas en chino y japonés ${ }^{13}$.

Por otra parte, ha de recordarse que entre la historia del siglo XX de España y Corea del Sur se da una situación parecida. La primera mitad del siglo XX el mundo estaba en plena confusión por las Guerras Mundiales y el auge del imperialismo y los dos países también estaban bajo su influencia. Luego España sufrió la Guerra Civil de cuatro años y luego hasta el año 1975 tuvo el gobierno militar de 35 años. En el caso de Corea del Sur, la Guerra de Corea estalló en 1950 y duró tres años. Antes de superar la devastación de la Guerra el general Chung-hee Park armó un golpe de estado, formó una dictadura y duró hasta que se asesinó en 1979. Sin embargo, otra vez recurrió un golpe de estado, la dictadura siguiente de Chun duró hasta el año 1987.

Observaremos las primeras apropiaciones del darwinismo, considerando las experiencias comunes como pueden ser las guerras, las dictaduras o la democratización de los dos países, en su contexto socio-político y las vías de la trasmisión de la teoría.

\footnotetext{
${ }^{13}$ En Japón, se publicaron las versiones japonesas de «The Descent of Man» de Charles Darwin en el 1874, «Lectures on Origin of Species» de Thomas H. Huxley en el 1879 y "On the Origin of Species» de Darwin en el 1896. (Lee, 1992: 124; Yang, 2008: 92). En China, en el año 1896 Yan Fu tradujo «Evolution and Ethics» de Huxley. En el 1903, el cuarto capítulo de «On the Origin of Species» se tradujo en China, y en el 1919 el libro entero de «On the Origin of Species» se publicó (Yang, 2008: 92).
} 


\subsection{El Encuentro entre el Darwinismo y la Sociedad Española}

En España, la entidad más influyente en la primera recepción del darwinismo fue la Iglesia Católica. Y los asuntos socio-políticos más impactantes fueron el Sexenio Revolucionario (1868-1874) y la dictadura de Franco. La Iglesia y las fuerzas políticas conservadoras trataron el darwinismo como una oposición ideológica. Cada vez que tomaron el poder político intentaron suprimir la difusión del darwinismo.

En la época de Darwin, el sector neo-católico estaba ganando más fuerza política, la educación y los ambientes intelectuales sufrían una fuerte censura oficial (Núñez, 1997: 31). La ciencia se quedaba al margen y casi nunca se mencionaba a Charles Darwin en la comunidad científica. Las primeras menciones sobre la evolución normalmente fueron críticas y sátiras (Glick, 1974: 307).

Gracias a la revolución democrática que ocurrió en el año 1868, se permitió la libertad de pensamiento y surgió un cambio total en el campo académico español. La teoría llamaba la atención de los intelectuales, se convirtió como uno de los pensamientos centrales de la época y aumentaron estudios favorables al darwinismo. La revolución también influyó en el ámbito de la educación: se abolió la censura y se establecieron los departamentos de fisiología e histología en universidades. Naturalmente, eso sí, en cuanto al darwinismo surgieron discusiones activas y productivas.

Antes del Sexenio, no se introdujeron directamente las obras de Darwin en España, pero se tradujo en castellano un estudio del geólogo Charles Lyell que explicó parcialmente la investigación de Darwin. La idea de la evolución llegó en España por la vía de la geología porque era una disciplina que interesaba entonces. En un primer momento la teoría de Darwin se quedaba en la disciplina entre los expertos. Como hemos mencionado antes, el darwinismo empezó a difundirse más ampliamente gracias a la libertad intelectual por la Revolución democrática (Núñez, 1997: 32). En el año 1872 del gobierno democrático, se tradujo parcialmente «El Origen de las Especies» dos veces desde la versión original y la versión francesa de Royer (Brumme, 2013: 3). Si consideramos la distancia geográfica entre Inglaterra y España, tardó mucho tiempo en publicarse en castellano. 
Sin embargo, la democracia solamente duró seis años y acabó con la Restauración borbónica. La Iglesia Católica tomó el poder de nuevo y anunció nuevos decretos como represalias, que prohibieron difundir los conocimientos en contra de la monarquía y la fe católica. Había discusiones para la difusión del darwinismo, pero desaparecieron a causa de la censura y el reproche de la Iglesia. Sin embargo, la idea de la evolución ya se había difundido ampliamente en la comunidad científica (Blázquez, 2013: 23; Pelayo, 1996: 276278; Glick, 1974: 307-308).

La educación fue la sección más influida por la Restauración Borbónica. Por la inclusión del darwinismo al libro de texto, también ocurrieron opiniones contrarias. (Puelles y Hernandez, 2009: 72-78) Sin embargo, el campo académico mantenía el interés sobre el darwinismo con cautela. En el año 1876, J. M. Bartrina tradujo «El origen del hombre y la selección en relación al sexo» y añadió comentarios franceses. Y El año siguiente (1877), E. Godinez tradujo de forma íntegra la obra de «El Origen de las especies» (Gomis y Josa, 2009: 50-59).

A continuación, simplificamos las vías de la transmisión del darwinismo desde su cuna, Inglaterra, hasta España (Gráfico 2.1.).

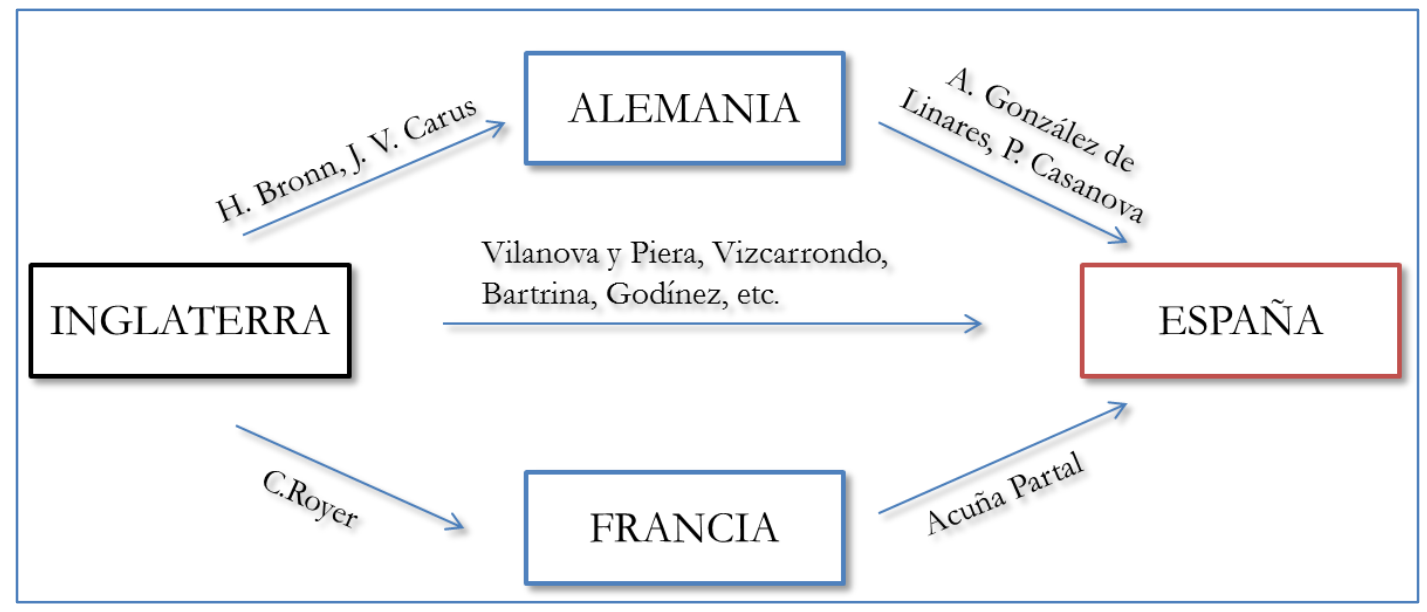

Gráfico 2.1. Vías de la transmisión del darwinismo a España en la segunda mitad del siglo XIX. Con los primeros traductores (Gomis y Josa, 2009: 50-59; Pelayo, 2009b: 27-30; Glick, 1974: 307-313) 


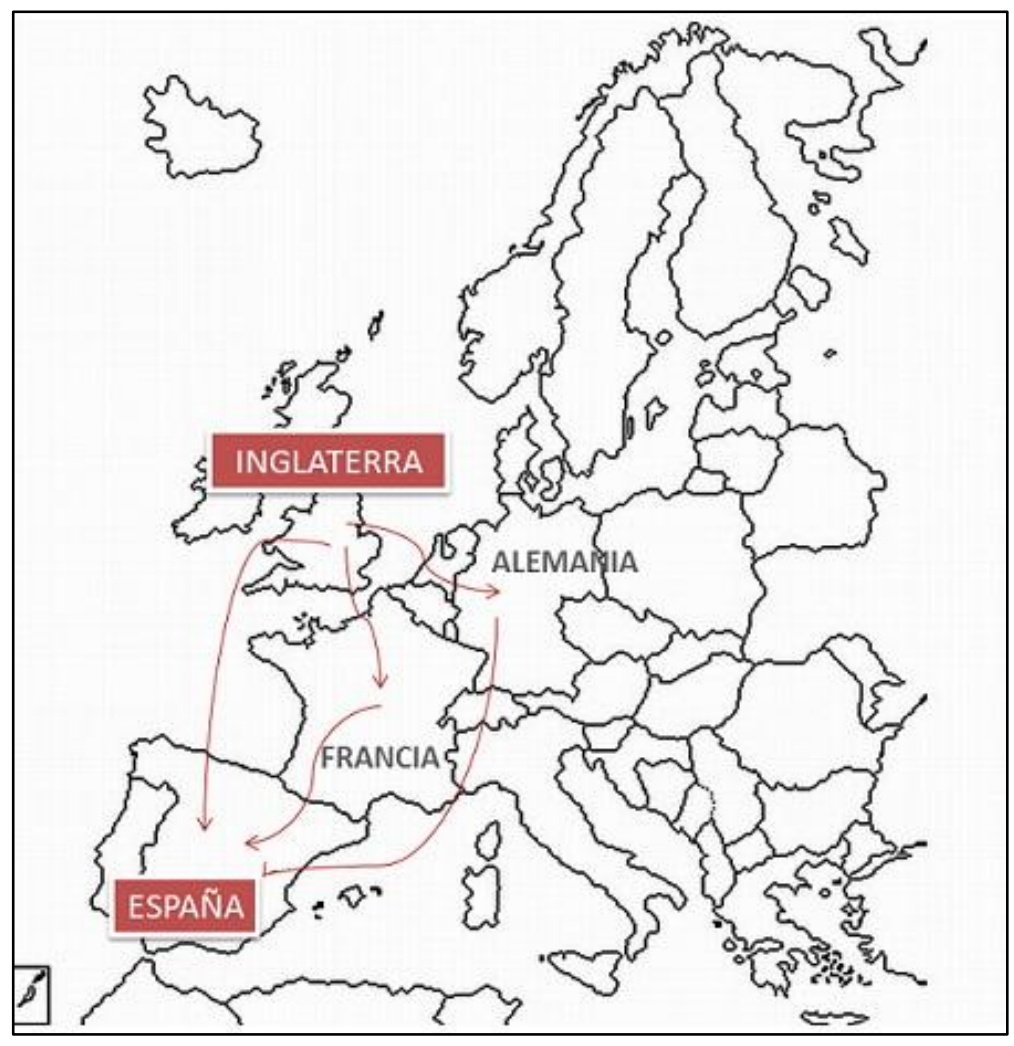

Gráfico 2.2. Vías de transmisión del darwinismo desde su origen, Inglaterra hasta España (Durante la segunda mitad del s. XIX y la primera mitad del XX)

Conforme a su posición geográfica, España recibió la teoría de Darwin directamente desde Inglaterra y también vía Francia y Alemania. En esos días las culturas científicas de Francia y Alemania influyeron en el ambiente académico de España.

Desde Francia se transmitió el transformismo de Lamarck. Se tradujeron varios libros franceses sobre el pensamiento y algunos científicos notables de España realizaron sus estudios en Francia (Pelayo, 2009a: 105). La primera traductora de «El Origen de las especies» en francés, C. Royer añadió su punto de vista progresista de la evolución en la traducción arbitrariamente y luego debatió con el propio Darwin al respecto. Sin embargo, muchos científicos españoles leyeron la versión francesa de Royer y además salió una traducción castellana del libro desde la versión de Royer, no de Darwin (Pelayo, 2009b: 28). La influencia de Alemania también fue notable. La teoría de la evolución entró a España no como la idea puramente darwiniana, sino que ya estaba influida por Spencer y los naturalistas alemanes. Los filósofos y naturalistas españoles krausistas de España 
aceptaron el darwinismo de una forma casi similar de la filosofía naturalista alemana. Se difundieron las obras de Büchner, Vogt, Haeckel en el ambiente académico de España. Especialmente, se aceptó bien a Haeckel: su pensamiento, que insistía en la extensión de la teoría de la evolución hasta fuera del mundo viviente, se conectaba de forma natural con la teoría de Spencer (Simó, 2004: 199; Núñez, 1997: 33;).

Como es bien conocido, el filósofo y economista inglés H. Spencer aplica el mecanismo de la evolución 'la selección natural' en instituciones humanas. Es una ideología que proviene de la analogía de la sociedad a la naturaleza. Spencer acuñó el término 'supervivencia del más apto' en su libro antes de que Darwin presentara su teoría. La idea de Spencer implicó el 'progreso' y 'desarrollo' de las sociedades (Woo N, 2011: 137; Sandín, 2000: 8). Su teoría tuvo un impacto considerable en la academia y la sociedad de la época. Muchos de los estudiosos españoles que fueron influidos por Spencer porque tenían una gran influencia en los evolucionistas alemanes.

Al mismo tiempo, el evolucionismo teísta surgió en los debates dentro y fuera de la comunidad científica como una versión ecléctica entre el catolicismo y el darwinismo. La idea fue diseñada para la compatibilidad con la fe católica, por eso tomarla fue mejor que rechazar totalmente la evolución con muchas pruebas (Pelayo, 2009b: 29; Simó, 2004: 210).

A pesar de la censura después de la Restauración de la monarquía, no se apagó el interés sobre el darwinismo de la comunidad científica. En el año 1878 tuvo lugar una conferencia bastante grande sobre la evolución y en ella se presentó un buen número de ponentes. Algunos apreciaron los logros de Darwin y otros consideraron la compatibilidad entre el darwinismo y la religión, también habían estudios que criticaron el darwinismo desde el punto de vista religioso (Glick, 1974: 325-326)

Gran parte de la comunidad científica de España aceptó el darwinismo en versión limitada o mitigada. Muchos científicos dejaron el origen de la vida y la evolución de la humanidad a la creación de Dios. Aun cuando admitieron la evolución, se difundieron "otras teorías 
evolucionistas no darwinistas, como la ortogénesis ${ }^{14}$, el neolamarckismo ${ }^{15}$, el mutacionismo ${ }^{16}$ y teorías vitalistas." (Pelayo, 2009a: 104). Además, se tenía una mayor preferencia por la teoría de Haeckel ${ }^{17}$ respecto a la de Darwin; sus obras, que incluyeron "la extensión del modelo darwiniano a las ciencias sociales" (Glick, 1974: 312), se difundieron y se convirtieron en libros de texto de muchos evolucionistas españoles (Simó, 2004: 207; Núñez, 1997: 33; Glick, 1974: 311-312).

En 1909, el centenario de su nacimiento de Darwin, tuvo lugar un acto de homenaje al naturalista británico por un grupo de estudiantes de medicina en Valencia y Lorca y se publicó un volumen conmemorativo. En el acto surgieron varios argumentos sobre las ideas de Darwin desde la difusión hasta el rechazo, pero la mayoría de ellos no era científicamente profunda. (Blázquez, 2013: 24; Pelayo, 2009a: 104).

En el acto conmemorativo, asistió Miguel de Unamuno, rector de la Universidad de Salamanca por entonces, a pesar de la polémica intensa en prensa. En el discurso de homenaje que dio en el acto mostró sus pensamientos que aplicaban la evolución no solo a los seres vivos, sino a las sociedades y materiales también como Spencer y Teilhard de Chardin ${ }^{18}$ (Blázquez, 2007: 260). Unamuno concibió sus ideas evolucionistas aprendiendo

\footnotetext{
14 “Ortogénesis: La evolución de estirpes filéticas siguiendo un curso lineal predeterminado y no a través de la selección natural." (Mayr, 1992: 183), "fuerza interna que encauzaba el progreso evolutivo en una dirección determinada" (Pelayo, 2009a: 103)

${ }^{15}$ El neolamarckismo: "Teorías evolucionistas cuyo mecanismo principal es la herencia de caracteres adquiridos. Los neolamarckistas insistieron en que la inducción ambiental directo provoca las variaciones de los seres vivos, no el azar. Surgió como un oponente fuerte del 'neodarwinismo ("teoría de la evolución desarrollada por August Weismann a finales del siglo XIX consistente en un darwinismo sin la herencia de caracteres adquiridos y con un fuerte énfasis en la selección natural” (Mayr, 1992:183))'." (Lee, 2001: 146)

${ }^{16}$ El mutacionismo es teorías de la evolución en las que la mutación es el mecanismo principal de la evolución de los seres vivos frente a la selección natural.
}

${ }^{17}$ Ernst Haeckel (1834-1919). Naturalista alemán que difundió el darwinismo en Alemania. Evolucionista progresista. Materialista y monista. Tenía idea de mejorar la sociedad mediante la selección. Propuso la teoría de recapitulación. ("recapitulación: El recorrido de un organismo individual durante su desarrollo (ontogenia) a lo largo de las mismas etapas de desarrollo que siguieron sus antepasados durante la filogenia“ (Mayr, 1992: 185)

\footnotetext{
${ }^{18}$ Teilhard de Chardin (1881-1955): Religioso (jesuita), filósofo y paleontólogo francés. Fue evolucionista universal que insistía en que no solo la vida, sino la material y el pensamiento también evolucionan. (Blázquez, 2009: 61)
} 
a Hegel y Spencer en sus años universitarios y luego tradujo varios libros de Spencer. A pesar de que Unamuno valoró a Darwin filosóficamente, para el escritor español la evolución era universal y no solamente biológica. Además, es progreso desde lo inferior hasta lo superior y el ser humano seguía siendo el centro en la naturaleza. (Blázquez, 2013: 24; Núñez, 1997: 35; Glick, 1974: 318; París, 1968: 166).

José Ortega y Gasset aceptó los pensamientos darwinistas y lamarckistas en su primera etapa; luego cambió su postura y se hizo anti-darwinista para afirmar: "hay que borrar al darwinismo de la serie de teorías científicas" (Blázquez, 2007: 28) y defendió el vitalismo. "Con posterioridad abandonaría el vitalismo y tantearía orientaciones mutacionistas y saltacionistas" (Pelayo, 2009a: 105). Benavides (1988) explicó la trayectoria de los pensamientos evolucionistas de Ortega y Gesset.

(...) después de una primera etapa de escarceos con el darwinismo, con la teoría de los tropismos ${ }^{19}$ y con un lamarckismo vulgar, a partir de 1914 asume plenamente el vitalismo de J. von Uexküll, hasta aproximadamente 1929, (...) se liberta de la seducción del vitalismo, (...). Mientras tanto, la teoría de las mutaciones mantendrá intacta su vigencia en toda la obra del pensador, determinado en buena medida su concepción de la historia y sellando su lenguaje. (Benavides, 1988: 25)

Como podemos ver a través de los ejemplos de Unamuno y Ortega y Gasset, en el primer tercio del siglo XX en España se dieron varias posturas, desde el anti-evolucionismo hasta el evolucionismo darwinista. Clérigos con formación biológica y naturalistas difundieron pensamientos no darwinianos sobre el mundo natural. Había divulgadores que aceptaron el evolucionismo pero defendieron el mutacionismo o transformismo en vez del darwinismo. Muchos biólogos eran partidarios de la evolución, pero no tuvieron lugar muchos proyectos sobre ella (Pelayo, 2009a: 110-111).

El personaje más importante de la época en el campo darwiniano de España era Antonio de Zulueta, el director del Museo Nacional de Ciencias Naturales de entonces. Contribuyó a la divulgación del darwinismo traduciendo obras de Darwin y de otros evolucionistas e

\footnotetext{
${ }^{19}$ El tropismo: "movimiento propio de los organismos determinado por el estímulo de agentes físicos o químicos." (Benavides, 1988: 30)
} 
introdujo conceptos fundamentales del campo en España. Además trabajó con científicos estadounidenses que estaban participando en la síntesis moderna de la evolución (Blázquez, 2013: 25; Pelayo, 2009a: 109).

La guerra civil y la dictadura de Franco produjeron un cambio definitivo en la divulgación de la evolución. Especialmente el darwinismo y el neodarwinismo ${ }^{20}$ quedaron marginados en la educación excepto en el ámbito universitario, debido a que fueron acusados como pensamientos materialistas y ateístas. Muchos investigadores se exiliaron, Zulueta quedó en España y presentó sólo una obra sobre el darwinismo en las dos primeras décadas de la dictadura (Blázquez, 2013: 25-26).

El pensamiento más influyente en cuanto al evolucionismo en la comunidad científica española de los años cincuenta y sesenta: fue el del jesuita y paleontólogo francés Teilhard de Chardin: que trató de sintetizar la ciencia y la religión. Según él, "el ser humano era uno de los últimos tramos de un proceso evolutivo ascendente y cuya evolución espiritual proseguía hasta llegar a la convergencia con Dios o "punto omega»." (Blázquez, 2009: 61). Sus estudios (y otros estudios jesuitas franceses) fueron traducidos al español a finales de los años 50 y el paleontólogo español M. Crusafont fue su divulgador más activo. Muchos estudiosos españoles fueron influenciados por ellos y aceptaron el evolucionismo finalista y teísta.

En la segunda mitad de la dictadura, la censura se debilitó y el darwinismo comenzó a difundirse de nuevo. El centenario de «El origen de las especies» también fue uno de los motivos de la difusión. Desde entonces en la comunidad científica empezó a coexistir el evolucionismo finalista y el darwinismo (Blázquez, 2009: 61-62; Pelayo, 2009b: 32).

En los setenta el darwinismo volvió a la enseñanza secundaria y en los ochenta, con el centenario de la muerte de Darwin, proliferaron artículos e investigaciones y su teoría ya no era tan polémica (Blázquez, 2013: 28; Pelayo, 2009b: 32).

\footnotetext{
${ }^{20}$ El neodarwinismo: "Teoría de la evolución desarrollada por August Weismann a finales del siglo XIX consistente en un darwinismo sin la herencia de caracteres adquiridos y con un fuerte énfasis en la selección natural." (Mayr, 1992:183)
} 
En resumen, al principio España aceptó la idea de la evolución por versiones moderadas para esquivar la polémica social. Especialmente con la postura teísta del evolucionismo, pretendía la compatibilidad con el dogma católico. Surgieron diversas maneras combinadas con los pensamientos tradicionales de Occidente para entender la idea de la evolución sin mucho problema. El darwinismo fue excluido en el libro de texto y las investigaciones universitarias sobre la teoría, durante los regímenes pro-católicos, casi desaparecieron también. A pesar de los esfuerzos de la Iglesia Católica, el darwinismo se difundió cada vez más en la comunidad científica y se hizo un tema importante en los ambientes intelectuales de España.

Sin duda, a lo largo de la historia del encuentro entre el darwinismo y la sociedad española, el oponente más fuerte de la teoría siempre fue la Iglesia Católica y su contexto. Como hemos indagado en el capítulo I, la cosmovisión tradicional de Occidente tiene diversos puntos incompatibles con el darwinismo. La fe católica, que provino de los pensamientos occidentales, y su entidad física, la Iglesia Católica, también tenían dificultad de aceptar la nueva idea de Darwin que explicó el mundo sin mencionar a su Dios.

\subsection{El Encuentro entre el Darwinismo y la Sociedad Coreana}

La transmisión del darwinismo a Corea es muy distinta a la de España. Corea está geográficamente muy alejada de Inglaterra y cuando el darwinismo surgió, el reino de Chosŏn (antiguo nombre de Corea) estaba en un estado de aislamiento internacional.

Hasta mediado del siglo XIX, Asia de Este vivió en un mundo independiente y peculiar teniendo China como su centro cultural. En ese momento las potencias occidentales, como Gran Bretaña, Francia, Alemania y EE.UU. empezaron a pegarse a la zona asiática para obtener concesiones. China fue derrotada en las Guerras de Opio (1839-1842 y 18561860) por Gran Bretaña y abrió sus puertos. Aun cuando no perdió su soberanía totalmente porque era un país enorme, sufrió invasiones de las potencias occidentales 
repetidamente desde entonces. En cambio, Japón adoptó una actitud diferente que voluntariamente abrió su puerta, aceptó la cultura occidental y finalmente concibió las ambiciones imperialistas.

La apertura de Corea fue realizada por Japón en 1876 forzosamente, y con ella también comenzó a entrar las culturas occidentales a toda escala. Así, a finales del siglo XIX, los pensamientos occidentales llegaron a Corea. Durante unos diez años se introdujo de forma simultánea desde Aristóteles a los pensamientos más recientes de la época. El darwinismo tardó unos años en llegar a Corea, pero una vez transmitido, empezó a influir en los ambientes intelectuales del país.

Las ideas de la evolución entraron a Corea fueron casi exclusivamente del darwinismo social o el evolucionismo social ${ }^{21}$. Es decir, fue una explicación general de la competencia entre los países de la época como si fuera una teoría política. (Woo N, 1999: 28). El evolucionismo social introducido en el Oriente fue de Spencer que enfatizó el "progreso" en general. (Yang, 2013: 74-75) Fue diferente de la idea darwiniana que demostró el papel de azar en el proceso de la evolución. Para Spencer, la evolución es desarrollo progresivo, pero para Darwin, es cambio por variaciones al azar. Además, según la teoría de Darwin la selección ocurre en la población de una especie, pero en la teoría spenceriana la unidad puede variar por la fase de desarrollo de las sociedades (Woo N, 2011: 137). Por consiguiente, su evolucionismo social podía ser la base de diversas ideologías para explicar fenómenos sociales dependiendo de la interpretación. Por supuesto, se aceptó en Asia de Este como el significado literal de la "supervivencia del más apto" que explicaba las competencias extremas entre los países de la zona en la época.

A finales del siglo XIX el imperio japonés quería utilizar la península coreana como un "puente" para invadir el continente. $\mathrm{Y}$ otras potencias de Occidente también querían obtener concesiones del país. La Corea de entonces (Chosŏn) ya tenía bastantes problemas internos y la dinastía no fue capaz de aguantar todas las amenazas externas. No sólo los intelectuales sino que todo el pueblo sentían ya el peligro nacional e

\footnotetext{
${ }^{21}$ En esta tesis, no distinguimos entre el darwinismo social y el evolucionismo social.
} 
intentaban formar planes para superar la crisis. En ese momento crítico, el darwinismo se introdujo a la península.

Como ya hemos mencionado, el primer pensamiento evolucionista que llegó a la península coreana no fue tan darwiniana o biológica, sino más próximo a Spencer. Spencer aplicó el concepto de la evolución o el desarrollo en las sociedades humanas y en el mundo orgánico (Woo N, 2011: 137) y mostró una actitud optimista que si dejamos la sociedad naturalmente, mejoraría (Yang, 2013: 77). Sin embargo irónicamente el evolucionismo social se convirtió en justificaciones del imperialismo, la eugenesia, el racismo y de otros fines políticos mayormente negativos.

De todas maneras, estos pensamientos sociológicos se aceptaron como un lema ideológico en la Corea del entonces, debido a que el país estaba frente a una gran corriente del imperialismo. Según la teoría, los fuertes ganan y los débiles pierden (Lee, 1992: 124) así que la única esperanza de sobrevivir era ser un país fuerte.

Fue natural que los ambientes intelectuales de Oriente entendieran el darwinismo como una ideología global aunque se explicase con lenguaje biológico, debido a que la teoría era bastante persuasiva y no tan contradictoria desde el punto de vista oriental en el aspecto ideológico (Lee, 1992: 125-126) y todavía no se distinguían los conocimientos científicos claramente desde todos los pensamientos. Enfrente de las amenazas de potencias internacionales, intelectuales influyentes aceptaron el darwinismo social y lo difundieron para ilustrar al público y proteger el país (Park, 1982: 145-146).

Corea no podía recibir el darwinismo directamente porque no tenía relaciones directas con los países por la política de aislamiento. La teoría llegó parcialmente vía China, Japón o Estados Unidos, indirectamente vía Alemania también. El darwinismo no fue la única teoría occidental que viajó mucho para llegar a Corea, sino casi todos los pensamientos occidentales pasaron algunos 'filtros' hasta entrar a la península coreana.

A pesar de que el país tenía sus propios motivos de modernización y se produjeron las insurrecciones del pueblo contra el sistema feudal, los esfuerzos no dieron fruto por las invasiones externas y resultó que el país se quedó en modo pasivo durante toda la época de la modernización. Por lo tanto, pensamos que la expresión de que la modernidad de 
Corea es una "modernidad traducida" (Kim, 2010: 56) es precisa. No había muchos coreanos que entendían idiomas occidentales, ya que el país no aceptó los extranjeros ni permitió que salieran los coreanos al extranjero durante muchos años. Por eso, la mayoría de la literatura occidental que se publicó en coreano fue traducida desde versión china o japonesa. Lógicamente pasar dos veces el proceso de la traducción puede afectar al contenido. Además, la doble traducción significa que los coreanos pueden tener la versión coreana solamente de los libros elegidos por los chinos y los japoneses. Los coreanos no tenían ni siquiera la oportunidad de elegir pensamientos occidentales para el pueblo coreano. Fue lógico que la entrada de los pensamientos occidentales dependiera de los círculos académicos de China y Japón (Kim, 2010: 56). Por lo tanto, los aspectos de la aceptación en estos países influyeron en la incorporación del darwinismo en Corea considerablemente.

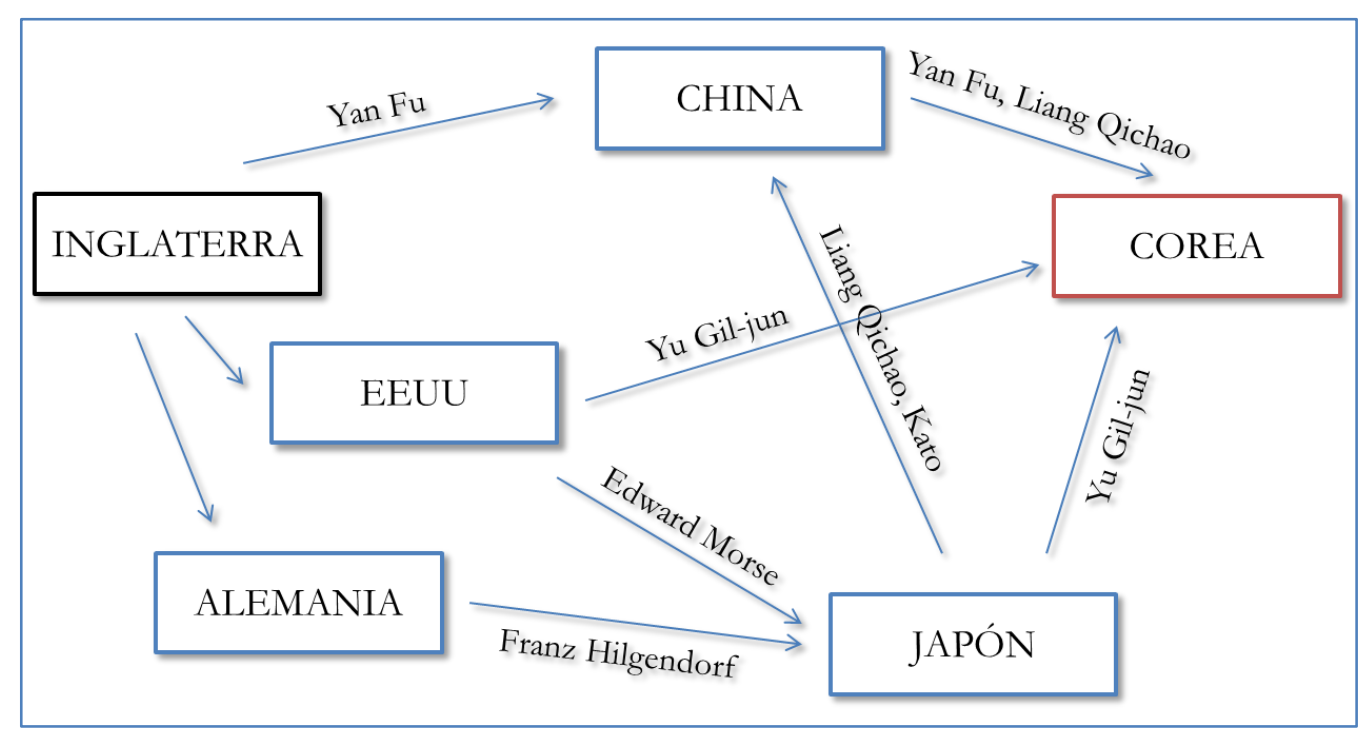

Gráfico 2.3. Vías de la transmisión del darwinismo a Corea a finales del siglo XIX y a principio del Siglo XX. Con los traductores y los divulgadores (Woo N, 2011, 2010; Lee, 1992; Park, 1982) 


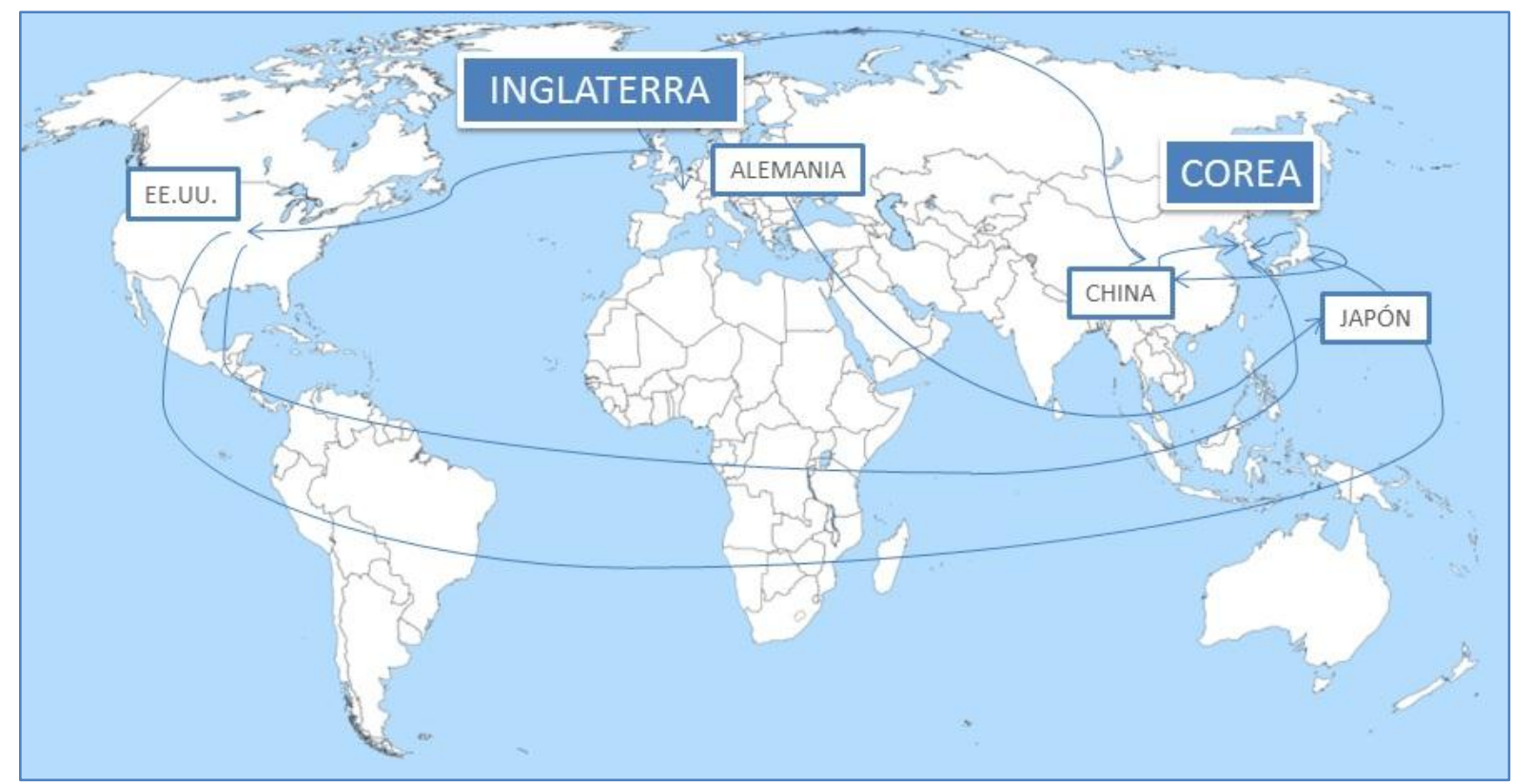

Gráfico 2.4. Vías de transmisión del darwinismo desde su origen, Inglaterra hasta Corea (Durante la segunda mitad del s. XIX y la primera mitad del XX)

La idea de Darwin llegó a Corea en la década de 1880 a través de los intelectuales que estudiaban en Japón. El Japón de la era Meiji es el primer país asiático que recibió el darwinismo, debido a que aceptaba la cultura occidental más activamente que China y Corea. En Japón, después de que el zoólogo estadounidense E. S. Morse diese lecturas en la universidad de Tokio en 1877, las teorías de la evolución de Darwin se aceptaron como un hecho (Lee, 1992: 123). La teoría se recibió sin debates señalados, debido a que la sociedad japonesa de aquel entonces no tenía una filosofía ni un dogma religioso opuesto al darwinismo. Aceptó el darwinismo como teoría biológica y sociológica a la vez, pero el darwinismo social llamó la atención más intensamente. Era una teoría adecuada de su situación política que se estaba dirigiendo al imperialismo y al totalitarismo.

China también estaba sufriendo un momento crítico por el imperio japonés y otras potencias de Occidente que intentaban aprovecharse de este país. En la época, hubo dos estudiosos importantes en la entrada del darwinismo a China: Yan Fu y Liang Qichao.

Yan Fu fue a estudiar a Inglaterra en 1877 y vivió allá más de dos años y medio. Después de volver a China se dedicó a disciplinar a las fuerzas navales y en los años noventa empezó a traducir libros notables del mundo occidental. En 1896, tradujo el libro de T. H. Huxley, «Evolution and ethics», añadió sus propios comentarios en cada capítulo y publicó 
el libro «Tiānyănlùn (천연론(天演論))》. Inventó varias palabras para explicar el darwinismo porque había muchos conceptos que en Oriente no existían hasta entonces. En sus comentarios para los textos de Huxley hay huellas de los pensamientos de Spencer ya que Yan Fu estaba absorbido en sus lecturas (Yang, 2008: 55-69). Yan puso énfasis en la cosmovisión occidental progresista introduciendo los pensamientos de Spencer a la academia china. El valor occidental que quería difundir en China es 'progreso constante' y 'progreso orientado hacia el futuro'. (Yang, 2013: 79)

Liang Qichao fue un estudioso más comprometido y difundió al público chino los pensamientos de la evolución social (Yang, 2013: 82). Se exilió por motivos políticos en Japón y aceptó el pensamiento del sociólogo anglo-Irlandés Benjamin Kidd que la supervivencia de la sociedad como un organismo es más importante que el interés de individuos. Después de volver a China, Liang insistió en el enriquecimiento del país y la fortaleza del ejército para enfrentarse a Occidente (Yang, 2013: 84; Park, 1992: 142).

La influencia de los ambientes intelectuales de China era importante en Corea de entonces, porque el chino era el idioma académico y los intelectuales coreanos entendían sus literaturas sin traducción. Las obras de Yan y Liang se extendieron en Corea. Sus argumentos sociológicos parecían persuasivos en Corea ya que Corea era un país más pequeño y débil y estaba cerca del imperio japonés que ambicionaba invadir el continente.

El intelectual coreano Yu Gil-Jun publicó el artículo 'La Teoría de Competencia' en el año 1882 después de volver de Japón, también era un artículo sociológico. Luego Yu fue a Estados Unidos y estudió bajo la dirección del profesor Morse que introdujo el darwinismo en Japón. A Yu también le interesaba el darwinismo social y lo admitió, pero respetó más el confucianismo (Woo N, 2010: 176-182).

Antes de la apertura, Corea tenía su biología original basada en la agricultura y la medicina. La biología europea entró en la educación en la época del Imperio Coreano (1897-1910). Sin embargo, durante la época de ocupación por Japón (1910-1945), los japoneses monopolizaron la educación en la península coreana y ninguna universidad en Corea tenía departamento de biología. El imperio Japonés no permitió a los coreanos el derecho de estudiar la ciencia y la tecnología porque quería que la economía de Corea dependiera de 
Japón. Por lo tanto, los intelectuales coreanos de entonces no podían tener conocimientos básicos de la biología europea y fue imposible debatir entre ellos sobre la teoría científicamente, así que la aceptación era inevitablemente pasiva. El evolucionismo social llamó más su atención con la situación socio-política (Kim, 2010: 253-254; Park, 1982: 145).

El darwinismo social era una teoría irónica en la situación socio-política del país. La teoría podía ser el motor de los movimientos de independencia contra Japón, pero a la vez, la misma teoría podía justificar el imperialismo. Por eso, algunas personas favorables al darwinismo social, que insistían en fortalecer Corea contra Japón y otras potencias occidentales, después de la pérdida de la soberanía por el Imperio Japonés, traicionaron a Corea y obedecieron a Japón, como si la ocupación de Japón fuera la ley de naturaleza.

El darwinismo tardó aproximadamente entre treinta y cuarenta años en llegar a Corea, durante este período, la situación internacional cambió brutalmente. El reino que ya se había mantenido quinientos años y estaba debilitado visiblemente. El imperio Japonés trataba de invadir a Corea aprovechando la situación, consiguió abrir su puerta y finalmente en el año 1910 logró anexionar la península coreana. Hasta la derrota de la Segunda Guerra Mundial Japón ocupó Corea y oprimió al pueblo coreano.

Aun cuando entraron libros en chino y en japonés sobre la evolución, la mayoría de los coreanos no podía entenderlos. A pesar de que los japoneses enseñaron japonés en la escuela popular, los coreanos seguían usando el coreano. Por eso, los coreanos no podían aprender la idea de la evolución directamente con las obras originales, sino a través de los comentarios de algunos intelectuales normalmente favorables del darwinismo social. Como hemos mencionado, sus explicaciones del darwinismo hacia el público eran más sociológicas que científicas y no era de Darwin, sino de Spencer.

Además, el imperio japonés restringió la libertad de prensa, publicación, reunión y asociación de los coreanos y expurgó libros activamente dependiendo del caso. Por lo tanto, publicar libros en coreano era muy complicado y arriesgado. Muchos coreanos publicaron libros en coreano en el extranjero, la mayoría de ellos tenía mensajes de resistencia a Japón e independencia. No consideraron el darwinismo como un tema tan 
urgente para publicar a pesar de las dificultades, aunque la teoría nunca estuvo en la lista de censura.

Por eso tardó casi un siglo en publicarse en Corea los libros originales de Darwin. Después de terminar la ocupación de Japón y la guerra de Corea (1950-1953), finalmente en el año 1958 se publicó la primera versión coreana de «El origen de las especies».

La teoría de Darwin que se introdujo en Corea con los aspectos sociales dejó huellas en la sociedad, su sentido puramente biológico no se valoró y sólo se aceptó pasivamente. El país no tuvo oportunidades de modernizar el campo intelectual y la educación por su propia mano porque Corea sufrió una época extremadamente caótica en la primera mitad del siglo XX. Experiencias tan intensas como la pérdida de la soberanía, el período de la ocupación de Japón, la segunda guerra mundial, la recuperación de la soberanía, la división territorial y la guerra de Corea, cubrieron todo el país.

En 1945, Corea del Sur construyo por primera vez su sistema de la enseñanza escolar moderna independientemente. El evolucionismo se incluyó en el libro de Biología en ese momento y nunca ha sido eliminado hasta ahora, pasando por siete reformas del programa educativo (Cho, 2007: 28-52).

Después de los tres años de la guerra, que paralizó toda la función del país, la ideología anti-comunista cubrió la sociedad surcoreana fuertemente. El dictador Chung-hee Park (estancia 1961-1979), que obtuvo el poder por un golpe de Estado militar, que implementó la política anticomunista con mucha fuerza, censuró y prohibió bastantes libros para fortalecer su poder. La mayoría de los libros prohibidos eran de sociología, como socialismo, comunismo y postnacionalismo. El materialismo, especialmente de Marx, fue censurado estrictamente. Sin embargo, el darwinismo no estaba en la lista de censura porque en Corea la teoría no fue considerada como una teoría materialista, sino que representaba solamente la competencia en la naturaleza y la sociedad.

La dictadura de Park hizo todos los esfuerzos posibles para desarrollar la industria surcoreana. Fomentó la ciencia y la tecnología y ayudó económicamente en el ámbito del campo. Sin embargo, enfocó solamente a las técnicas prácticas no a las ciencias básicas, no se ocupó del entendimiento público de la ciencia y de la tecnología. Todo el país estaba 
centrado en el desarrollo económico. El ambiente conspiró con las huellas del darwinismo social que quedaban en la comunidad y la competencia se convirtió en una doctrina de la sociedad.

En esta atmósfera, era difícil que los científicos se concentraran en las ciencias naturales, debido a que sus estudios no podían generar beneficio económico a corto plazo. La situación del campo científico no ha mejorado mucho hasta ahora. El zoólogo y el divulgador más destacado del darwinismo en el país, J. C. Choe (2010: 87-88; 2012: 7), anotaba que Corea del Sur es un "país subdesarrollado en cuanto a Darwin".

La primera recepción del darwinismo en Corea fue realizada casi exclusivamente en forma de lo social. Los divulgadores del darwinismo de entonces entendieron la evolución como un progreso y así difundieron (Woo N, 2010: 137-138). Por consiguiente, podemos imaginar que el darwinismo social ya incorporado en los ambientes intelectuales de Corea también influyera en la apropiación del darwinismo biológico. La confusión del público entre la evolución y el progreso no es un mal entendimiento peculiar de Corea, pero se destaca más en el país que los otros en este contexto.

Cuando el darwinismo entró en Corea no surgieron debates sociales ni científicos, debido a que sus implicaciones filosóficas eran compatibles con el trasfondo filosófico del país, y también porque en la época Corea aceptó todos los conocimientos simultánea y pasivamente por la situación socio-política. No existieron los ambientes intelectuales que podrían descubrir el significado científico de la teoría y discutirlo porque aún no se había formado una comunidad científica en sentido moderno. Los propios conceptos de la 'ciencia' y la 'teoría científica' también se estaban definiendo por primera vez en la sociedad. Además, el darwinismo no dañaba la filosofía de ningún grupo específico, por eso tampoco provocó debates sociales. Es decir, en Corea no existió un grupo como la Iglesia del Occidente que tiene motivo de luchar contra el darwinismo para defender su filosofía. 


\section{Capítulo 3. El Darwinismo Actual. España, Corea del Sur y Sus Religiosidades}

Hoy en día, se extinguieron casi todos los debates científicos sobre el propio darwinismo. Discutir sobre los principios de la teoría de Darwin ya no tiene sentido alguno en el campo científico, debido a que la teoría ya fue comprobada mediante incontables evidencias. Además, se convirtió como una de las leyes de la Naturaleza, porque si se cumplen los requisitos, ocurre la evolución por selección natural inevitablemente. (Choe, 2010: 90-94) Por consiguiente, la mayoría de las opiniones contrarias al darwinismo en la actualidad poseen un origen religioso.

Cuando llegó el darwinismo a España, el factor más influyente de la sociedad en su primer encuentro eran pensamientos religiosos e ideológicos, como ya hemos observado en el capítulo II. La teoría fue acusada como materialista y ateísta, que desafiaba a la religión. Sin embargo, hoy día en España no surgen debates sociales ni científicos destacados en cuanto al propio darwinismo. Aunque la cultura española sigue teniendo un ambiente católico, no hay un movimiento organizado contra el darwinismo en la sociedad. Podemos afirmar que ya se pasó la "época llena de polémica, exaltaciones, demonización, censura o indiferencia" (Blázquez, 2013: 28) del darwinismo en España, por eso ya no se oyen muchas voces contra la teoría en la sociedad.

En el caso de Corea, el darwinismo se transmitió en la época crítica en la que la soberanía del país estaba en peligro por la situación internacional. No había conflicto destacado con su trasfondo filosófico y religioso, y el concepto de 'lucha por supervivencia' se usaba como una metáfora para interpretar la situación socio-política del país. Es decir, el factor social de la sociedad coreana fue definitivo en su aceptación primaria de la teoría.

Corea del Sur también sufrió guerra y dictaduras como España, pero en el país asiático el darwinismo nunca ha sido censurado. Recientemente han surgido pequeños conflictos entre el darwinismo y la fe. Sin embargo, se debe tener en cuenta que la religión que tiene problemas con la teoría no pertenece a la tradición coreana, sino que es una religión occidental e importada, el cristianismo, especialmente, el protestantismo. 
El catolicismo llegó a la península coreana en el siglo XVII - XVIII y se lo llamó 'conocimientos occidentales'. La dinastía de aquel entonces persiguió a los primeros cristianos porque pensaba que sus pensamientos dañarían a la mentalidad confuciana. Más tarde cuando abrió la puerta del país, dejó de perseguirlos debido a las reclamaciones de los países occidentales (Kim, 2015: 35-37).

En España, el catolicismo es una tradición del país desde hace mucho tiempo y no se puede separar de la cultura española. La religión era uno de los símbolos de la 'premodernidad' en el mundo occidental. Sin embargo, en Corea el cristianismo obtuvo la imagen 'moderna' irónicamente porque entró al país en la edad contemporánea y era totalmente nuevo para los coreanos.

En la primera mitad del siglo $\mathrm{XX}$, muchos misioneros católicos y protestantes entraron a Corea. Crearon hospitales, iglesias y colegios de estilo occidental y ofrecieron ayuda material y mental al pueblo cuando los coreanos vivían en una condición muy difícil por la invasión de Japón y la Guerra de Corea. Por la situación extrema, el cristianismo se difundió rápida y exitosamente en el país. La mayoría de los misioneros protestantes era de los Estados Unidos.

Con el fin de la Segunda Guerra Mundial, los EE. UU y la Unión Soviética dividieron Corea a dos partes y los Estados Unidos establecieron un régimen militar de tres años (1945-1948) en Corea del Sur. Durante estos años los estadounidenses nombraron a los políticos coreanos pro-estadounidenses y protestantes para puestos importantes de Corea del Sur. Hasta ahora, el protestantismo coreano está influyendo como un grupo potente de ultraderechistas y pro-estadounidenses en la política, la economía, la prensa del país. Ellos se convirtieron como fuerzas de defensa del gobierno estadounidense que intervenía constantemente en los asuntos internos del país para no perder un mirador cercano o una torre de control hacia el mundo comunista durante la época de la Guerra Fría. (Kim, 2015: 151-155)

A pesar de que el propio dictador militar Chung-hee Park que gobernó Corea del Sur durante 17 años (1962-1979) no era protestante, fortaleció su dictadura gracias a los apoyos de poderosos protestantes de Corea del Sur y el gobierno estadounidense que 
aprobó su dictadura tácitamente. Después de la división y la Guerra, en el sur de la península coreana se armaron dos golpes de estado (en el año 1961 y el 1980) y en consecuencia las dos dictaduras militares (1962-1979 y 1980-1987) duraron en suma 24 años. Mientras sacerdotes católicos coreanos apoyaban al movimiento para la democratización contra las dictaduras, las iglesias protestantes siempre seguían el poder político. La orientación política de la Iglesia Católica de Corea del Sur es diferente de la de la española, que tomó el protagonismo en la dictadura.

Cuando el darwinismo entró en Corea por primera vez, la teoría no era inaceptable para la sociedad coreana si consideramos su filosofía y cultura. Aun cuando el evolucionismo social tenía puntos desagradables para el pueblo coreano porque el país perdió la soberanía por la mano del imperialismo japonés, era difícil denegar ya que parecía persuasivo por la situación socio-política y era compatible con la cosmovisión confuciana que pensaba el mundo como un organismo. El darwinismo no se enfrentó con los pensamientos tradicionales. El catolicismo y el protestantismo de entonces aún se estaban adaptando en el país y no prestaron atención a la teoría.

En la primera época de la incorporación del darwinismo en España, entre la teoría y la Iglesia Católica surgieron debates; pero ahora ya forman parte del pasado. Sin embargo, en Corea del Sur, aunque es bastante parcial, el conflicto entre el protestantismo y el darwinismo es un asunto actual. Se podría anotar que es debido a la cultura peculiar de la iglesia protestante del país. Se sabe mundialmente que el literalismo bíblico y el fundamentalismo del protestantismo son características exclusivas del grupo estadounidense, pero el surcoreano es su gemelo.

Algunos protestantes fundaron 'Asociación Coreana para la Investigación de la Creación' (Korea Association of Creation Research (KACR)) en los años 80, reunieron centenares de personas y publicaron libros y revistas en cuanto al creacionismo como una teoría alternativa del darwinismo. Gracias a la expansión del protestantismo en el país en los años 80 y 90 , el movimiento se hizo más activo y empezaron a difundir el creacionismo al extranjero también. Así, Corea del Sur se convirtió el centro de la propaganda del creacionismo en Asia. (Numbers, 2009: 221-222) 
En el año 2009, el grupo estableció 'Sociedad para Revisar la Evolución en los Libros de Texto' (Society for Revise Evolution in Textbook (STR)). A pesar de que se portaba como no tuviera origen religioso, su meta final es eliminar la evolución o incluir la creación (o el diseño inteligente) en los libros de texto. En el año 2012, STR dirigió dos instancias al Ministerio de Educación que insisten en la revisión del contenido de la evolución. Su petición era eliminar el Archaeopteryx y el dibujo de la evolución de caballo, porque según ello "es posible que el Archaeopteryx no sea la especie intermedia de reptil y ave" y "la evolución de caballo no es tan lineal" como muestran los libros de texto. Asombrosamente, el Ministerio aceptó las instancias sin consulta con el campo biológico ni alguna consideración seria e informó a las editoriales que cambiasen los contenidos. La prensa coreana ni siquiera le prestó atención, pero Nature (Park, 2012a) y Time (Traywick, 2012) publicaron artículos sobre el asunto como "una victoria del creacionismo en Corea del Sur". A través de estos artículos periodísticos extranjero, por fin el Ministerio se enteró de la gravedad del asunto. El campo científico publicó un artículo de la refutación oficial (The Paleontological Society of Korea, 2012: 153-159) y el Ministerio finalmente canceló la revisión. Posteriormente el grupo STR dirigió más instancias, el Ministerio ya denegó inmediatamente porque "no se puede incluir contenidos de intención religiosa". (Lee, 2012; Mok y Song, 2012; Park, 2012a; Park, 2012b; Traywick, 2012)

El grupo de personas que intentaba modificar la evolución en los libros de texto no era muy grande ni potente, por eso no llamaría la atención hasta que dos medios occidentales informaron el asunto. Sin embargo, era un asunto bastante grave porque por poco consiguió su primera meta. La ocurrencia muestra la ignorancia, la indiferencia y la administración improvisada del Ministerio de Educación del país y la exclusividad del protestantismo surcoreano. Además, para la mayoría de los coreanos era un asunto totalmente indiferente.

A diferencia del protestantismo, la Iglesia Católica de Corea del Sur no declaró opinión oficial sobre el darwinismo y reconoce su compatibilidad con la fe católica como el Vaticano. Normalmente la Iglesia es moderada y calmosa y no muestra la exclusividad religiosa en el país. 
Según un sondeo del año 2006, el 74\% de los españoles piensa que el evolucionismo es un hecho (Miller, et al., 2006: 765-766). En la encuesta internacional conmemorativa de British Council en 2009, el $61 \%$ de los españoles responde que existen suficientes evidencias científicas a favor de la teoría de la evolución de Charles Darwin. El 38\% opina que en el proceso evolutivo de todos los seres vivos en la Tierra es un resultado de la selección natural, sin ninguna intervención de Dios (British Council, 2009: 1-4). Según el informe de Percepción Social de la Ciencia y la Tecnología 2014 (FECYT, 2015), el 83,7\% de los españoles entrevistadas opinaron que "los seres humanos provienen de especies animales anteriores". Mientras que el 69,5\% respondió que "los primeros humanos no vivieron al mismo tiempo que los dinosaurios" (FECYT, 2015: 333).

Por otra parte, según la encuesta de Corea del Sur en 2009 , el 62,2\% de los coreanos considera el evolucionismo como un hecho (Jung, et al., 2010: 18). En 2012, Gallup Korea realizó una encuesta en cuanto al movimiento de STR para revisar los contenidos sobre el evolucionismo en los libros de texto. Para la pregunta, “¿Ud. Piensa que el ser humano fue creado por Dios, o fue evolucionado de otra especie?" $45 \%$ de los coreanos piensa que "EI ser humano evolucionó desde otros seres vivos". Aumentó $16 \%$ en 10 años ( $29 \% \rightarrow 45 \%$.) "El ser humano fue creado por Dios" es defendido por un 32\%. (Gallup Korea, 2012: 2).

En cuanto a la pregunta “¿el ser humano proviene de otras especies anteriores?" en las encuestas recientes respectivamente, a pesar de la subida del porcentaje coreano en los últimos diez años, se destaca un contraste muy claro entre España y Corea del Sur. Un $83,7 \%$ de los españoles y un $45 \%$ de los coreanos la afirmaron.

Lo más interesante de la encuesta coreana de 2012 es la diferencia entre las respuestas por religión de la persona (Gallup Korea, 2012: 1-3). Hemos organizado una tabla desde el resultado de la encuesta.

\begin{tabular}{|l|c|c|c|}
\hline & $\begin{array}{c}\text { Creacionismo } \\
\text { "Dios creó el ser } \\
\text { humano" }\end{array}$ & $\begin{array}{c}\text { Evolucionismo } \\
\text { "El ser humano fue } \\
\text { evolucionado de otra } \\
\text { especie." }\end{array}$ & No contesta \\
\hline Protestante & $\mathbf{7 5 \%}$ & $14 \%$ & $11 \%$ \\
\hline
\end{tabular}




\begin{tabular}{|l|l|l|l|}
\hline Católica/o & $42 \%$ & $31 \%$ & $27 \%$ \\
\hline Budista & $16 \%$ & $46 \%$ & $37 \%$ \\
\hline No Creyente & $17 \%$ & $63 \%$ & $20 \%$ \\
\hline
\end{tabular}

Tabla 3.1. El Origen del Ser Humano. Respuestas de Surcoreanos (Gallup Korea, 2012: 2)

El 75\% de los protestantes surcoreanos cree en el creacionismo, en el caso de los católicos el porcentaje es del $42 \%$. La diferencia es bastante notoria. La proporción de creacionistas en los budistas (16\%) es muy similar con el porcentaje entre los no creyentes (17\%). Podemos anotar que el budismo, que es una religión oriental, no afecta visiblemente al pensamiento de sus creyentes sobre el origen del ser humano.

El porcentaje de evolucionistas entre los budistas (46\%) es bajo que lo de los no creyentes (63\%). El grupo que confía más el darwinismo es lo de 'No Creyente' (63\%) como es de esperar. Generalmente los católicos están en el medio de la distribución (Gallup Korea, 2012: 2).

Esta encuesta demuestra que la recepción personal del darwinismo de los coreanos depende de la religión del individuo, especialmente cuando la religión es occidental. Este resultado cobra coherencia con lo que plantado en el capítulo 1 , que los pensamientos orientales generalmente no impiden la apropiación positiva del darwinismo.

¿Qué diferencia existe entre las sociedades actuales de España y Corea del Sur en cuanto a la incorporación del darwinismo? Como hemos indicado con anterioridad, hoy día el factor más influyente en la apropiación del darwinismo es la religiosidad de la sociedad y del individuo. Por eso, observaremos las sociedades en este contexto para obtener una perspectiva al respecto.

La sociedad española es aparentemente religiosa en comparación a la surcoreana y su trasfondo católico en la cultura es bastante visible. En cambio, la sociedad moderna de Corea del Sur no muestra una inclinación religiosa oficialmente. A pesar de que la cultura confuciana todavía está presente en la sociedad, hoy en día el confucianismo no es una religión practicante, sino que se queda relegada a una filosofía tradicional.

A continuación, anotaremos cómo se trata la religión en las Constituciones Nacionales de los dos países. A pesar de que Corea estaba bajo de la influencia del Imperio Japonés y los 
Estados Unidos en la primera mitad del siglo XX, la Constitución de Corea del Sur es autónoma porque es descendiente de la Constitución del Gobierno Provisional de Corea (1919) que redactaron los propios coreanos que luchaban para la recuperación de la soberanía.

En la Constitución Española (1978), el artículo 16 se refiere a la religión y en la Constitución de Corea del Sur (1987), se contempla en el artículo 20.

\begin{tabular}{|c|c|}
\hline Constitución Española (1978), Artículo 16. & $\begin{array}{l}\text { 대한민국 헌법 (1987) 제 } 20 \text { 조 } \\
\text { (Constitución de República de Corea, Artículo } \\
\text { 20.) }\end{array}$ \\
\hline $\begin{array}{l}\text { 1. Se garantiza la libertad ideológica, } \\
\text { religiosa y de culto de los individuos y las } \\
\text { comunidades sin más limitación, en sus } \\
\text { manifestaciones, que la necesaria para el } \\
\text { mantenimiento del orden público protegido } \\
\text { por la ley. } \\
\text { 2. Nadie podrá ser obligado a declarar } \\
\text { sobre su ideología, religión o creencias. } \\
\text { 3. Ninguna confesión tendrá carácter } \\
\text { estatal. Los poderes públicos tendrán en } \\
\text { cuenta las creencias religiosas de la } \\
\text { sociedad española y mantendrán las } \\
\text { consiguientes relaciones de cooperación } \\
\text { con la Iglesia Católica y las demás } \\
\text { confesiones. }\end{array}$ & $\begin{array}{l}\text { - 모든 국민은 종교의 자유를 가진다. } \\
\text { (Todo ciudadano tiene la libertad } \\
\text { religiosa.) } \\
\text { - 국교는 인정되지 아니하며, 종교와 } \\
\text { 정치는 분리된다. } \\
\text { (No se reconoce religión oficial de la } \\
\text { Nación. La política y la religión están } \\
\text { separadas.) }\end{array}$ \\
\hline
\end{tabular}

Tabla 3.2. Religión en la Constitución de España y la Constitución de República de Corea (Corea del Sur)

Los dos países garantizan a sus ciudadanos la libertad religiosa y ningún país posee religión oficial o estatal. Sin embargo, podemos percibir la diferencia clara en los contenidos de las Constituciones. La Constitución Coreana declara la libertad religiosa y la separación entre la política y la religión con precisión. En cambio, la Constitución Española trata la libertad religiosa con la de ideológica y no incluye la declaración de 'la separación de la política y la religión'. Además, menciona la Iglesia Católica aparte y hace hincapié en la cooperación entre los poderes públicos y la Iglesia. La frase muestra el puesto especial de la Iglesia Católica en la sociedad española. Por esta razón, a pesar de que España no tiene religión estatal, constitucionalmente no es un país laico, sino religioso, especialmente católico. 
Por otra parte, el Estado Español entrega en 2015 y 2016 a la Iglesia Católica 13,2 millones de euro mensualmente (Europa Press, 2015). El Estado Surcoreano no entrega a ninguna entidad religiosa su presupuesto, excepto si se necesita para el mantenimiento del patrimonio cultural (Ministry of Strategy and Finance of Korea, 2015).

A través de los festivos nacionales de los dos países, también podemos detectar la diferencia evidente de la religiosidad de estas sociedades.

\begin{tabular}{|c|c|}
\hline $\begin{array}{l}\text { Festivos Nacionales de ESPANA } \\
\text { (12 DÍAS) }\end{array}$ & (11 DÍAS) \\
\hline $\begin{array}{l}\text { - Año Nuevo (1 de enero) } \\
\text { - } \quad \text { Epifanía del Señor (6 de enero) * } \\
\text { - } \text { ( } 25 \text { de julio), a elección de cada Comunidad } \\
\text { Autónoma * } \\
\text { - Viernes Santo * } \\
\text { - Jueves Santo * } \\
\text { - } \quad \text { Día del Trabajo (1 de mayo) } \\
\text { - Asunción de la Virgen (15 de agosto) * } \\
\text { - Todos los Santos (1 de noviembre) * } \\
\text { - Fiesta Nacional (12 de octubre) } \\
\text { - Día de la Constitución (6 de diciembre) } \\
\text { - Inmaculada Concepción (8 de diciembre) * } \\
\text { - Navidad (25 de diciembre) * }\end{array}$ & $\begin{array}{l}\text { - } \quad \text { Año Nuevo (1 de enero) } \\
\text { calendario lunar) } \\
\text { - } \text { Movimiento 1-Marzo (Aniversario del } \\
\text { movimiento para resistencia contra la } \\
\text { ocupación japonesa) } \\
\text { - } \quad \text { Cumpleaños de Buda (8 de abril en el } \\
\text { calendario lunar)* } \\
\text { - Día de los Niños (5 de mayo) } \\
\text { - Día de Liberación Nacional (15 de agosto) } \\
\text { - Chuseok (festival de la cosecha, } 15 \text { de } \\
\text { - } \text { agosto en el calendario lunar) } \\
\text { - de Antigua Corea, } 3 \text { de octubre) } \\
\text { - Hangeul-nal (día del alfabeto Coreano, } 9 \text { de } \\
\text { octubre) } \\
\text { Navidad (25 de diciembre) * }\end{array}$ \\
\hline *8 de los & $\begin{array}{l}\text { *1 de los } 11 \text { es budista y otro } 1 \text { es cristiano. Es } \\
\text { decir, } 2 \text { de los } 11 \text { son religiosos. }\end{array}$ \\
\hline
\end{tabular}

Tabla 3.3. Festivos nacionales de España y Corea del Sur (El País, 2015; Kyunghyang, 2015)

Entre los 12 festivos nacionales de España, 8 días son festivos católicos, excepto el Año Nuevo, Día del Trabajo, Fiesta Nacional y el Día de la Constitución. Es decir, el 67\% de los festivos nacionales son religiosos. En el caso de Corea del Sur, entre 11 días de los festivos nacionales, solamente dos (Nacimiento de Buda y Navidad) son religiosos. Parece equitativo porque las dos religiones más grandes (el budismo y el cristianismo) en Corea del Sur tienen un día respectivamente. Es el $18 \%$ de los festivos nacionales de Corea del Sur. 
La presencia de la asignatura de 'Religión' del sistema nacional de educación de España es también llamativa. A pesar de que es optativa, está en el plan de estudios para la enseñanza obligatoria del país. Además, la asignatura no cubre la diversidad de religiones, sino que transmite la doctrina católica casi exclusivamente. Últimamente se fortalece más los contenidos de la asignatura. En el plan nacional de estudio de Corea del Sur, por el contrario, la asignatura de 'Religión' no existe. Aunque hay algunos institutos privados que enseñan la religión de su fundación, pero no se reconoce como asignatura oficial.

Además en España, es natural que el Rey o el presidente del gobierno mencionen a Dios en los eventos públicos. Y cada domingo por la mañana una canal de televisión pública (La 2 de RTVE) emite misa católica a los ciudadanos españoles. Son asuntos casi inimaginables en Corea del Sur.

Hasta el momento, hemos observado que la sociedad española muestra una alta religiosidad en comparación a la surcoreana. Entonces, ¿cómo será la gente española y la coreana del sur al respecto? ¿Los españoles que crecieron en una sociedad más religiosa serán más religiosos que los coreanos en la sociedad bastante laica?

Observemos la distribución de los creyentes de España y Corea del Sur. Afortunadamente, podemos comparar los dos países gracias a las encuestas de preguntas muy similares que se llevaron a cabo en cada país.

Las encuestas que realizaron el Centro de Investigaciones Sociológicas (2016) de España y el Gallup Korea de Corea del Sur (2015) incluyeron preguntas sobre la religiosidad de la persona entrevistada. (Tabla 3.4)

\begin{tabular}{|c|c|}
\hline ESPAÑA (CIS, 2016) & $\begin{array}{c}\text { COREA DEL SUR } \\
\text { (Gallup Korea, 2015) }\end{array}$ \\
\hline $\begin{array}{l}\text { - Pregunta 26. Religiosidad de la } \\
\text { persona entrevistada } \\
\text { ¿Cómo se define Ud. en materia religiosa: } \\
\text { católico/a, creyente de otra religión, no } \\
\text { creyente o ateo/a? (\%) }\end{array}$ & $\begin{array}{l}\text { - 질문) 귀하는 현재 종교를 믿고 계십니까? } \\
\text { (믿는 종교가 있다면) 어느 종교를 } \\
\text { 믿으십니까? (\%) 불교, 천주교, 개신교, 기타 } \\
\text { 종교, 종교 없음 } \\
\text { (P. ¿Ud. tiene religión ahora? (Si tiene,) } \\
\text { ¿Cuál es su religión? (\%) el budismo, el } \\
\text { catolicismo, el protestantismo y otra } \\
\text { religión) }\end{array}$ \\
\hline
\end{tabular}

Tabla 3.4. Preguntas. Religiosidad de la gente española y la surcoreana (Gallup Korea, 2015: 3; CIS, 2016: 18) 
Las preguntas son bastantes similares para comparar los resultados. La encuesta española presentó como opciones de la respuesta, católico/a, creyente de otra religión, no creyente y ateo/a y la coreana presentó budista, protestante, católico/a, creyente de otra religión y no creyente.

Hemos realizado una tabla sintética de las repuestas de los dos países. (Tabla 3.5)

\begin{tabular}{|c|c|c|c|}
\hline \multicolumn{2}{|c|}{ ESPAÑA (abril 2016) } & \multicolumn{2}{|c|}{ COREA DEL SUR (2015) } \\
\hline $69,6 \%$ & \multicolumn{2}{|c|}{ Católico/a } & $7 \%$ \\
\hline \multirow{3}{*}{$2,8 \%$} & \multirow{3}{*}{ Creyente de otra religión } & Budista & $22 \%$ \\
\hline & & Protestante & $21 \%$ \\
\hline & & Creyente de otra religión & $0 \%$ \\
\hline $15,4 \%$ & No creyente & \multirow{2}{*}{ No creyente } & \multirow{2}{*}{$50 \%$} \\
\hline $9,5 \%$ & Ateo/a & & \\
\hline$(2.490)$ & \multicolumn{2}{|c|}{ Número de respuesta } & $(1.500)$ \\
\hline
\end{tabular}

Tabla 3.5. Respuestas. Religiosidad de la gente española y la surcoreana (Gallup Korea, 2015: 2; CIS, 2016: 18)

Si nos detenemos solamente esta tabla, parece que los españoles son más religiosos ya que $69,6 \%$ de los españoles respondió que es católico/a y si se añade los creyentes de otra religión, el porcentaje de creyentes en España se eleva hasta un 72,4\%. En el caso de Corea del Sur, solo el $50 \%$ de los coreanos son creyentes de alguna religión.

Sin embargo, si comparamos las repuestas de las siguientes preguntas, podemos interpretarlas de una manera diferente (Tabla 3.6).

\begin{tabular}{|l|l|}
\hline \multicolumn{1}{|c|}{ ESPAÑA (CIS, 2016) } & \multicolumn{1}{c|}{$\begin{array}{c}\text { COREA DEL SUR } \\
\text { (Gallup Korea, 2015) }\end{array}$} \\
\hline $\begin{array}{l}\text { • Sólo a quienes se definen en materia } \\
\text { religiosa como católicos/as o creyentes de }\end{array}$ & $\begin{array}{l}\text { (종교를 믿는 사람에게) 귀하는 요즘 } \\
\text { otra religión (1 ó 2 en P26) }\end{array}$ \\
$\begin{array}{l}\text { P26a. 됴회, 절 등에 얼마나 자 주 가십니까? } \\
\text { 단 결혼식, 장례식 등의 일로 방문한 것은 }\end{array}$ \\
$\begin{array}{l}\text { u otros oficios religiosos, sin contar las } \\
\text { ocasiones relacionadas con ceremonias de }\end{array}$ & (P. (Sólo a quienes tienen religión,) ¿Con \\
tipo social, por ejemplo, bodas, comuniones & qué frecuencia asiste Ud. a oficios \\
o funerales? & religiosos, sin contar bodas y funerales?) \\
\hline
\end{tabular}

Tabla 3.6. Preguntas. Frecuencia de la asistencia a oficios religiosos (Gallup Korea, 2015: 7; CIS, 2016: 19) 
La frecuencia de la asistencia a oficios religiosos es significativa porque podemos saber si la persona practica la religión de verdad o no, es decir, si la persona es creyente fiel o no. Es un barómetro importante, debido a que hay posibilidad que los creyentes que asisten al oficio religioso regularmente tengan más prejuicios que los que no le participan a menudo (Allport y Ross, 1967: 432).

Las respuestas de las preguntas se presentan en la siguiente tabla (Tabla 3.7).

\begin{tabular}{|c|c|c|}
\hline \multicolumn{2}{|c|}{ ESPAÑA (abril 2016) } & \multicolumn{2}{c|}{ COREA DEL SUR (2015) } \\
\hline $60,5 \%$ & Casi nunca & $36 \%$ \\
\hline $14,8 \%$ & Varias veces al año & \multirow{2}{*}{$18 \%$} \\
\hline $9,4 \%$ & Alguna vez al mes & \multirow{2}{*}{$44 \%$} \\
\hline $12,4 \%$ & Casi todos los domingos y festivos \\
\hline $1,7 \%$ & Varias veces a la semana & \\
\hline
\end{tabular}

Tabla 3.7. Respuestas. Frecuencia de la asistencia a oficios religiosos (Gallup Korea, 2015: 7; CIS, 2016: 19)

Según el resultado de la encuesta española, el 60,5\% de los creyentes casi nunca asiste a oficios religiosos. Hay un gran contraste con el resultado coreanos, que es solamente $2 \%$ de los creyentes.

El porcentaje de las respuestas "Voy a oficios religiosos una vez o más a la semana" es del $14,1 \%$ de los creyentes españoles y del $44 \%$ de los creyentes coreanos. Si consideramos la proporción de los creyentes, $10 \%$ de los españoles $(14,1 \%$ del $72,4 \%$ ) y $22 \%$ de los coreanos (44\% del $50 \%$ ) asisten una vez o más a la semana. Lo interesante es que $80 \%$ de los protestantes coreanos asiste una vez o más a la semana a su iglesia. Entre los católicos coreanos son $59 \%$. En cambio, solo $6 \%$ de los budistas asisten tan a menudo a sus oficios religiosos. (Gallup Korea, 2015:7)

Es decir, en España mucha gente se considera creyente, especialmente católico/a, pero no hay muchos que practiquen la religión sinceramente en la vida cotidiana. Los budistas coreanos son similares. Por el contrario, la mayoría de los protestantes coreanos (80\%) es creyente fiel que invierte bastante tiempo en su religión. Los católicos coreanos también son más activos que los españoles. El resultado muestra que las religiones de origen occidental se adaptaron bien en Corea del Sur, se establecieron exitosamente a través de la localización y sus creyentes las practican bastante. 
Especialmente el protestantismo surcoreano formó un grupo de presión bajo la influencia del evangelismo estadounidense y los anticomunista-ultraderechistas. Se destaca la exclusividad y la lealtad de los protestantes en la sociedad. Practican la doctrina y su visión del mundo en la vida cotidiana, y quieren predicar la fe a su alrededor. Últimamente intenta influir más a la política y a los asuntos sociales y provoca conflictos sociales. Estas características del protestantismo surcoreano causa resistencia para la gente de distinta fe y los no creyentes (Yoon y Yang, 2013: 256). No es casual que el protestantismo sea el único enemigo del darwinismo en Corea del Sur. Su exclusividad extrema, que insiste en que hasta el catolicismo es heterodoxo, espontáneamente llega a la defensa del creacionismo basándose en el literalismo bíblico.

Hemos observado la religiosidad de España y Corea del Sur, debido a la influencia que adquiere en la incorporación del darwinismo en una sociedad. Aun cuando la sociedad española es religiosa, la gente española es relativamente laica que no practica mucho la religión y solamente la tiene a modo de trasfondo cultural. En cambio, la sociedad surcoreana se formó laicamente, pero las gentes coreanos que poseen fe propia de una religión occidental, la practica bastante en su vida diaria y se impregna de la doctrina.

Si simplificamos este argumento, podemos afirmar que España muestra una 'sociedad religiosa y población laica' mientras que Corea del Sur tiene 'sociedad laica pero con gente religiosa'. Es solamente una comparación entre los dos países y el nivel de la religiosidad es relativa en ellos. No es una definición de la sociedad española y la surcoreana en general, sino que es únicamente una nueva perspectiva para entender mejor las sociedades para analizar su incorporación del darwinismo.

Entonces, ¿cómo podemos explicar la diferencia entre $83,7 \%$ (España) y $45 \%$ (Corea del Sur) en la aceptación del origen natural del ser humano?

La iglesia Católica en España está en su camino a la decadencia después de disfrutar de su prosperidad, pero el cristianismo en Corea es una religión relativamente nueva y tiene muchos creyentes practicantes hoy día. Pensamos que si una religión se ha establecido en el trasfondo cultural de una sociedad y ahora no está tan activa, pierde su influencia en la cosmovisión de cada miembro y en su aceptación del darwinismo. Por otra parte, si una 
persona es practicante de una religión cristiana, especialmente el protestantismo, su religión afecta mucho a su aceptación personal del darwinismo.

A pesar de que los pensamientos tradicionales de Corea son compatibles con el darwinismo, hoy en día la mayoría de los creyentes coreanos están influidos por su religión, no por su cultura tradicional. Igualmente, aunque los pensamientos tradicionales de España, específicamente las ideas católicas, son incompatibles con el darwinismo, la mayoría de los españoles actuales no están tan influidos por su cultura tradicional. 


\section{Capítulo 4. Conclusiones de la Primera Parte}

En esta parte I, investigamos cómo España y Corea han aceptado el darwinismo desde el punto de vista filosófico y sociológico. Se encontraron diferencias y semejanzas entre el darwinismo y la filosofía occidental y oriental. A continuación observamos cómo se transmitió el darwinismo desde su origen (Inglaterra), hasta España y Corea del Sur y cómo fue su primer encuentro. También indagamos en la religiosidad de los dos países para ver cómo afecta la religión, que es el último oponente del darwinismo, a la apropiación del darwinismo de los coreanos y españoles.

En el capítulo 1, comparamos las implicaciones del darwinismo con la filosofía occidental y oriental. No fue un análisis puramente filosófico, sino que la finalidad residía en examinar las visiones de la vida de Oriente y Occidente si son compatibles o no con el darwinismo.

¿Por qué el darwinismo fue tan revolucionario en Occidente? Según la cosmovisión que dominaba Occidente, el Dios Creador creó todos los seres vivos, las especies son fijas desde su creación hasta ahora, el ser humano es la especie favorita de Dios y todo el mundo se mueve por Providencia Divina. Sin embargo, el darwinismo explicó por la selección natural la variación y la especiación de todos los seres vivos sin mencionar a Dios y aplicó el azar en el proceso. Además, degradó el ser humano como una rama del árbol de vida. Por consiguiente, fue inevitable provocar polémicas en el ambiente intelectual de Occidente que se había fundido por la tradición griega y cristiana.

Sin embargo, el pensamiento 'revolucionario' de Darwin no fue tan sorprendente para el mundo oriental de entonces. Las ideas, en la teoría, no resultaron extrañas, debido a que el 'cambio' y la 'circulación' son conceptos principales de la filosofía oriental. Además, en la cosmovisión oriental no existe Creador. El parentesco evolutivo con otras especies tampoco fue tan desagradable, porque en el pensamiento oriental el ser humano no es dominador de la Tierra sino es un miembro de la gran armonía del universo como otros 
animales. En otras palabras, el pensamiento oriental era capaz de soportar casi plenamente el darwinismo.

Por supuesto, el confucianismo, el taoísmo y el budismo, que representan las ramas principales de la filosofía oriental, no concuerdan perfectamente con el darwinismo, ya que no son teorías científicamente estructuradas. Sin embargo, el darwinismo no causó ninguna disonancia importante con las ideas principales de estas filosofías, y no hubo temas polémicos filosóficos o religiosos especiales, ya que no había escuelas que serían golpeadas por la lógica del darwinismo.

En el capítulo 2, se examinaron la transmisión y la aceptación del darwinismo en España y Corea del sur. La aceptación inicial del darwinismo en España fue influenciada por los estudiosos franceses y alemanes y se encontró la oposición católica. También hubo discusiones académicas, pero carecían de investigación científica. Aunque el evolucionismo llamaba la atención del mundo intelectual, la teoría darwiniana de la evolución no era dominante, sino más bien el vitalismo, el evolucionismo finalista y teísta. La teoría de Darwin fue clasificada como materialista y ateísta. En la dictadura, fue censurada y retirada en los libros de texto. Las investigaciones darwinianas en las universidades se redujeron considerablemente y muchos investigadores fueron exiliados. A medida que la censura se soltó en la segunda mitad de la dictadura, la evolución de Darwin volvió al currículo de educación pública y a la universidad española.

En aquella época, Corea no estaba preparada para aceptar la evolución con una actitud científica. No existían investigadores dispuestos a estudiar el significado científico del darwinismo. Junto con la apertura del puerto, casi todo el conocimiento occidental entró al mismo tiempo a la península coreana. No existía una división académica moderna en Corea, y el concepto de 'sociedad' y 'ciencia' tampoco eran claros. Por lo tanto, la teoría fue aceptada como una teoría general más que como una teoría científica que sólo explica los seres vivos. Fue aceptada casi exclusivamente como teoría de la evolución social bajo la influencia de Japón y China. Debido a la política de aislamiento y al estatus colonial, no se pudo aceptar activamente las culturas occidentales, sino sólo a través de Japón y China. 
De ahí que surgieran debates sociales sobre el darwinismo pero que no se podía discutir científicamente.

Corea sufrió una dictadura al igual que España, pero el darwinismo en el plan de estudios nunca fue influido. El régimen de la dictadura intentó bloquear completamente las teorías socialistas como el materialismo, pero el darwinismo no estaba presente en la lista de censura. En ese momento el cristianismo coreano tampoco consideraba el darwinismo como una amenaza.

El capítulo 3 examina la relación entre la religión y la incorporación del darwinismo en ambos países. El último oponente del darwinismo hoy en día son las religiones, especialmente el protestantismo. Cuando el Darwinismo llegó por primera vez a España, surgieron debates religiosos, pero la era de la controversia ya pasó y en los últimos años no se ha encontrado algún ruido llamativo. En el caso de Corea, al principio de la introducción del darwinismo no había oposición desde el mundo religioso. Recientemente, hubo un intento de cambiar el contenido de la evolución del libro de texto en el protestantismo, debido a que la religión occidental que defiende el creacionismo literalmente ya está bien establecida en el país.

Un $83,7 \%$ de los españoles piensan que "el ser humano proviene de otros animales anteriores" (FECYT, 2015: 333), pero entre los coreanos solamente el 45\% piensa así (Gallup Korea, 2012: 2). Para examinar el motivo de la diferencia, investigamos la religiosidad que tienen las dos sociedades. La estructura de la sociedad y la religiosidad de sus miembros pueden influir en la aceptación del darwinismo.

España es una sociedad religiosa (católica) tal como se afirma en la Constitución, pero su religión ahora ya es algo cultural y la proporción de creyentes que la practican rutinariamente es muy baja. En otras palabras, la gente española no vive tan religiosamente. Por otra parte, Corea es una sociedad establecida en la Constitución totalmente laica pero muchos coreanos son creyentes fieles. Buena parte de los creyentes españoles no asiste a la iglesia, pero la mayoría de los creyentes coreanos de las religiones occidentales acude cada semana a su oficio religioso. 
Al resumir los distintos indicadores, España tiene una 'sociedad religiosa y gente laica' y Corea del Sur posee una 'sociedad laica y gente religiosa'. En este contexto, España muestra el porcentaje más alto de recepción y comprensión del darwinismo que Corea del Sur. Se puede ver que la incorporación del darwinismo por un individuo está más influida por su religión que por la tradición de la sociedad. Aun cuando el pensamiento tradicional coreano se traslapa con el darwinismo, los cristianos coreanos representan un porcentaje significativamente bajo de la incorporación de la evolución. El porcentaje de los españoles en la aceptación del darwinismo es considerablemente más alto que lo de Corea, a pesar de que el catolicismo posee varios puntos contrarios al darwinismo. La religión ya no influye mucho a la gente española, que es relativamente laica.

Cuando el darwinismo se transmitió a España y Corea, el mundo no se encontraba en un estado de comunicación fluida entre los países como ahora. Las teorías científicas fueron aceptadas por primera vez por los intelectuales de cada país y luego se extendió al público por su interpretación. En aquella época, España arrastraba una fuerte tradición católica y muchos estudiosos eran eclesiásticos. Era natural que el darwinismo se viera frente a la oposición filosófica y religiosa. Se comunica al público el darwinismo que interpretaban desde un punto de vista religioso. Por otra parte, Corea del Sur, bajo la influencia de Japón y China, aceptó el darwinismo a la vez con otras ideas occidentales. Debido a la influencia de ambos países y la situación socio-política, tenía que recibir el darwinismo social casi exclusivamente.

Hoy en día, Corea y España se han convertido en países de una dimensión similar tanto económica como socialmente. Los dos países están interactuando activamente con el mundo, llevando a cabo la educación con los estándares internacionales, y poseen medios avanzados y redes de comunicación. Pensamos que en esta situación la cultura tradicional de los dos países ya no alcanza una influencia notoria en la incorporación del concepto de la "evolución de la vida". Parece que ahora más depende de la visión personal como podemos observar el caso de Corea del Sur. La religión protestante tiene la influencia más decisiva a sus creyentes en la aceptación del darwinismo en el país. 
PARTE II

LA INCORPORACIÓN DEL DARWINISMO

EN ESPAÑA Y COREA DEL SUR.

ANÁLISIS DE TEXTOS DIVULGATIVOS 


\section{Capítulo 5. Herramientas del Análisis de Contenido}

La parte II examina la situación actual del darwinismo en la sociedad española y coreana, analizando libros de texto y artículos periodísticos que transmiten el darwinismo al público. Codificaremos los textos seleccionados en dos etapas. La base conceptual de este análisis empírico es el modelo de cultura científica (Quintanilla, 2010; Quintanilla, 2002). Después de analizar los textos mediante el modelo, que los clasifica por la inclusión de sistemas científicos y el tipo de contenido, añadiremos otros criterios para enriquecer el análisis e indagaremos en detalle cómo y qué enseñan los libros de texto, y cómo y qué transmiten los artículos periodísticos al público español y coreano.

\subsection{Un modelo para la Cultura Científica}

\subsubsection{Cultura Científica}

En este estudio se examina la incorporación del darwinismo en España y Corea del Sur. Investigamos el papel de la cultura en el proceso de la apropiación mediante la comparación de los dos países de diferentes culturas. En la Parte I, lo averiguamos desde el punto de vista filosófico, histórico y social. En la Parte II, analizaremos en detalle los textos del darwinismo que llega al público en ambos países.

Mosterín (1993: 32) define que, "Cultura es la información transmitida (entre animales de la misma especie) por aprendizaje social". La información que se transmite se puede clasificar en tres tipos, descriptiva (representacional), práctica (operacional) y valorativa. "La información descriptiva informa de cómo es el mundo, la valorativa informa sobre qué hacer, y la práctica, sobre cómo hacerlo." (Mosterín, 1993: 25-26)

Según la definición, la ciencia pertenece a la cultura y especialmente es "información generada por aprendizaje individual (descubrimiento, invención) y transmitida por aprendizaje social" (Mosterín, 1993: 111).

Godin y Gingras (2000: 53) también anotan que "la ciencia y la tecnología son desde el 
principio definidas como parte de la cultura". Según los citados autores, la cultura científica y tecnológica es "la expresión de todos los modos a través de los cuales los individuos y la sociedad se apropian de la ciencia y la tecnología." (Godin y Gingras, 2000: 44).

Quintanilla (2010), por su parte, pone énfasis en la distinción entre la ciencia y la cultura científica. Hay dos principios que debemos tener en cuenta: "La ciencia es siempre una parte de la cultura de una sociedad." y "No toda la cultura científica de una sociedad es parte de la ciencia." (Quintanilla, 2010: 33) La cultura científica a veces se refiere solamente a la cultura de la comunidad científica o como "sinónimo de ciencia popular" (Quintanilla, 2010: 34). La cultura científica en la que nos concentraremos en este estudio es un punto de vista que puede combinar estos dos conceptos.

La cultura científica es aquella parte de la cultura de un grupo social que consiste en información relacionada y compatible con la actividad científica. Se pueden distinguir dos tipos de componentes en la cultura científica: la ciencia propiamente dicha, por una parte, y el resto de la información, representacional, práctica o valorativa que forma parte de la cultura general del grupo, y tiene que ver con la ciencia aunque no forme parte de la actividad científica como tal. (Quintanilla, 2010: 35)

Esta definición de la cultura científica es compatible con la de Godin y Gingras (2000: 44) y también incluye la cultura dentro de la comunidad científica. Es un punto de vista que permite apreciar el sistema científico y su contexto social junto y separado. Por consiguiente, es más adecuado para esta tesis que analiza y compara textos de las dos sociedades de culturas distintas.

En resumen, la cultura se concibe como información transmitida por aprendizaje social y existirían tres tipos: la representacional, la práctica y la valorativa. (Mientras que la ciencia es un subconcepto de la cultura y pertenece a ella). La ciencia tiene su propio sistema que produce actividades científicas. Si la información está incorporada en el sistema científico, la consideramos cultura científica intrínseca y se puede clasificar como la representacional, práctica y valorativa. Si la información está relacionada con la ciencia pero no está incorporada en el sistema científico, la denominamos cultura científica extrínseca y también se puede clasificar en tres tipos de la información (Groves, et al, 2015: 4; Montañés, 2010: 218; Quintanilla, 2002: 24-30; Mosterín, 1993: 25-32). 


\subsubsection{Modelo de Cultura Científica (MCC)}

El objetivo de analizar el texto de la difusión de la ciencia es observar cómo la "ciencia" se expresa en dicho texto. De ahí se podrá encontrar la cultura científica de la sociedad que produjo el texto. Por eso, será importante distinguir entre la información de la misma ciencia: el conocimiento, el método y el valor del propio sistema científico, y la información científica en sentido más amplio, y clasificar los tipos de informaciones. El modelo de cultura científica realiza este proceso (Groves, et al., 2015: Quintanilla, 2002: 15). Se hace posible analizar textos relacionados con la ciencia mediante un análisis por códigos cualitativos según la clasificación de texto que hemos recordado en el apartado anterior (5.1.1). Este modelo es útil como método principal en el análisis de contenido relacionado con la ciencia. Ya se ha utilizado como metodología en varios proyectos y ha demostrado su eficacia (Groves, et al., 2015; Escobar, et al., 2014; Quintanilla, et al., 2011; Orellana, 2007).

Quintanilla (2002) expresa la estructura conceptual del modelo como el diagrama que sigue:

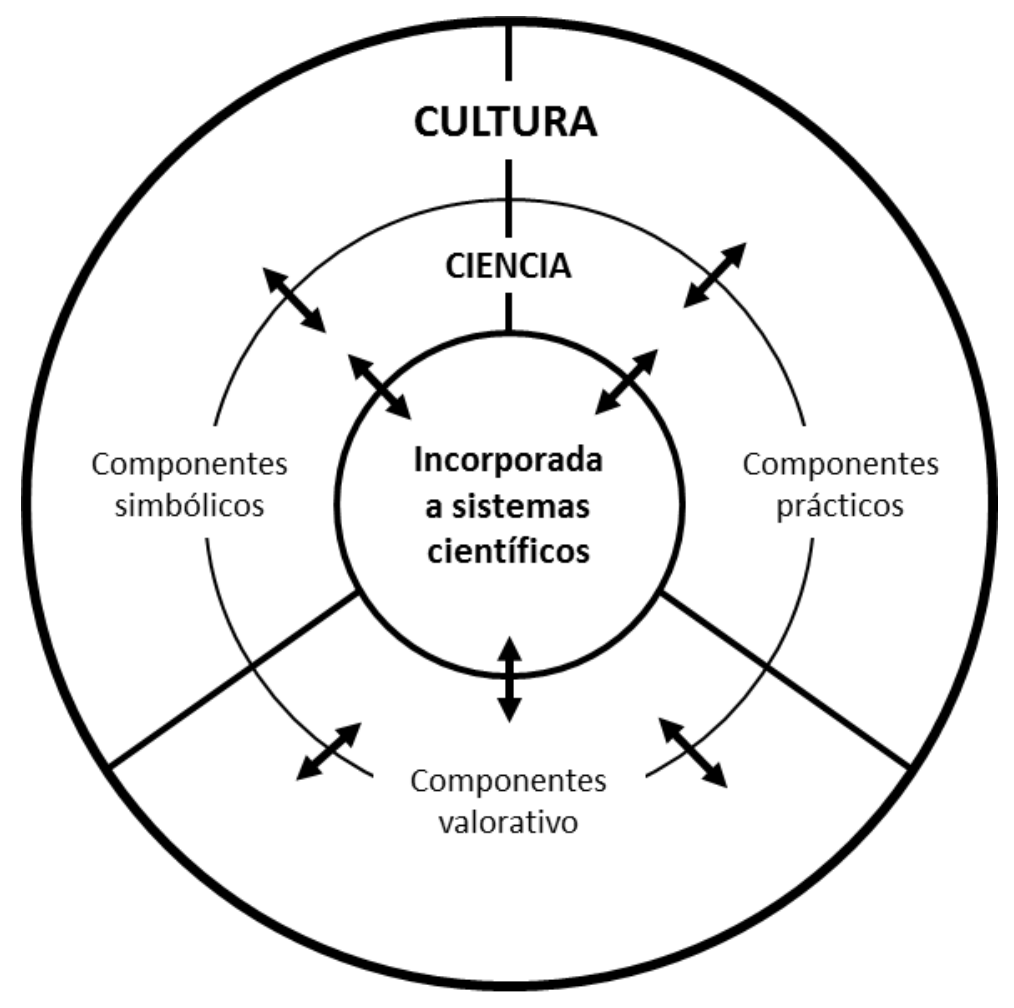

Diagrama 5.1. Componente de la cultura científica (fuente: Quintanilla, 2002: 30) 
El círculo céntrico en el diagrama 5.1 expresa la cultura científica en sentido estricto, que incluye "las creencias, reglas de actuación y valores científicos propiamente dichos". El círculo siguiente con línea fina expresa la cultura científica en sentido lato, que incluye "las creencias, reglas de comportamiento y valoraciones referidas a la ciencia y compatibles con ella pero que no forman parte de la ciencia" (Quintanilla, 2010: 35). El primer círculo lo llamamos cultura científica intrínseca y el segundo, cultura científica extrínseca (Quintanilla, 2010: 35; Montañés, 2010: 218; Quintanilla, 2002: 24). Fuera de este segundo círculo estará la información cultural que no pertenece a la cultura científica. Todas las informaciones culturales se pueden clasificar entre la Información representacional, práctica y valorativa. Cada texto se puede colocar en algún lugar en este diagrama y por supuesto también puede estar entre áreas ${ }^{22}$.

Hoy en día, no es exagerado reconocer que teorías básicas como el darwinismo son compartidas en todo el mundo. Se puede afirmar que los países abiertos al intercambio intelectual - países que no censuran conocimientos - comparten un enorme sistema científico. Generalmente los nuevos estudios científicos son verificados y compartidos dentro de este sistema universal, aunque puede haber diferencias entre países. Corea del Sur y España pertenecen a este sistema científico mundial. El porcentaje de informaciones dentro de este sistema mostrará la naturaleza de los textos científicos que investigamos en esta tesis.

Si consideramos dos modelos principales de la comprensión pública de la ciencia como el modelo de déficit ${ }^{23}$ y el modelo contextual ${ }^{24}$ (Montañés, 2010: 188; Gross, 1994: 3), la

\footnotetext{
22 Las explicaciones detalladas sobre cada área se dan en el capítulo 1 de ANEXO II: Codificación Manual.

23 Modelo de déficit: "el público padece una carencia de conocimientos científicos por causa de especialización de la ciencia y de la rápidez de su avance, de modo que el comunicador debe suplir ese déficit." (Marcos, 2010: 179). El público es pasivo en este modelo. "el conocimiento científico además de ser descrito como consolidado y definitivo, se concibe como un flujo unidireccional que va desde la comunidad científica, pasando por la prensa, hasta los ciudadanos." (Montañés, 2010: 193)

24 Modelo contextual: según el modelo, "la relación ciencia-público" influye en la comprensión de la ciencia del público. "la comprensión del público vincula con la interpretación de relaciones sociales, con opiniones sobre la veracidad de las fuentes de conocimiento, y con la negociación de identidades sociales." (Montañés, 2010: 199). La base del modelo es "la interacción entre la ciencia y el público" (Gross, 1994: 6). Contextos sociales y culturales afectan a la comunicación de la ciencia.
} 
información intrínseca está más cerca de 'trasmitir informaciones para enseñar' (modelo de déficit), mientras que la información extrínseca está relacionada con el contexto cultural del sistema científico de la sociedad (el modelo contextual).

Libros de texto y artículos periodísticos que investigamos en este estudio se pueden explicar a través del primer modelo y del segundo, respectivamente. Se puede presuponer que los libros de texto tengan una gran cantidad de informaciones de cultura científica intrínseca porque el objetivo de los libros es enseñar. Por otra parte, el objetivo de artículos periodísticos es no solo enseñar conocimientos científicos. A menudo se refiere a la ciencia en otro contexto social no propiamente científico. Por lo tanto, se puede esperar que la proporción de la cultura científica intrínseca de los artículos periodísticos sea inferior a la de los libros de texto.

Averiguaremos si existe alguna diferencia en la proporción de cultura científica intrínseca y extrínseca entre Corea del Sur y España en mismo tipo de texto. Si la diferencia entre los dos países es grande, podemos interpretar que los dos países tienen diferentes actitudes hacia la comunicación científica. Por el contrario, si no hay una gran diferencia, se puede concluir que las diferencias culturales no alcanzan una gran influencia en la actitud básica de la comunicación científica hoy en día.

En el modelo de cultura científica (en adelante MCC) con dos modalidades (cultura científica intrínseca y cultura científica extrínseca), se adoptan en cada modalidad tres subcategorías de tipos de la información (representacional, operacional y valorativa). Esto permite observar qué tipo de información incluyen los textos sobre el darwinismo de España y Corea del Sur.

MCC es un modelo cualitativo y cuantitativo para análisis de contenido, pero no clasifica el tema de los textos en detalle, sino su tipo y su característica; por ello se necesita un análisis complementario dependiendo del tema de estudio. Al analizar extensamente el contenido de la ciencia y la tecnología, este modelo por sí solo conducirá a resultados significativos. Sin embargo, dado que este estudio trata solamente con una teoría específica, el darwinismo, MCC por sí solo no puede proporcionar resultados específicos para la teoría peculiar. Por lo tanto, analizaremos las características de los contenidos utilizando MCC como herramienta 
del primer análisis y añadiremos otros criterios para averiguarlos más en detalle.

\subsubsection{Estructura y Ajuste del modelo}

El modelo original fue concebido como un modelo que abarca la ciencia, la tecnología y su ámbito empresarial (Quintanilla, et al., 2011), pero en esta tesis se refiere sólo al darwinismo, un tema específico de la ciencia pura. Por consiguiente, reduciremos solo a un código de la tecnología (TECNO) ya que no es necesario tener varios códigos. Las imágenes acompañadas con los textos se han clasificado entre la imagen intrínseca y extrínseca según el contexto (CINT_IM y CEXT_IM). Además, a veces podemos encontrar informaciones que no pertenecen a la cultura científica, para estos casos añadimos nuevo código 'no cultura científica (NoCC)'. Las imágenes acompañadas con texto de TECNO o NoCC, también se han codificado aparte (TECNO_IM y NoCC_IM).

La tabla siguiente (Tabla 5.1.) muestra todos los códigos de MCC que utilizamos en la codificación para este estudio:

\begin{tabular}{|c|c|c|c|}
\hline MCC & Tipo de información & Contenidos & CÓDIGO \\
\hline \multirow{4}{*}{$\begin{array}{c}\text { CULTURA } \\
\text { CIENTÍFICA } \\
\text { INTRÍNSECA }\end{array}$} & Representaciones & $\begin{array}{l}\text { Conocimientos } \\
\text { Información científica }\end{array}$ & CINTR \\
\hline & Prácticas/Operacionales & $\begin{array}{l}\text { Reglas del método científico } \\
\text { Hábitos científicos }\end{array}$ & CINTOP \\
\hline & Valores & $\begin{array}{l}\text { Valores científico: objetividad, } \\
\text { universalidad, verdad, precisión }\end{array}$ & CINTVA \\
\hline & Imágenes & $\begin{array}{l}\text { Datos visuales asociados con } \\
\text { texto intrínseco }\end{array}$ & CINT_IM \\
\hline \multirow{4}{*}{$\begin{array}{c}\text { CULTURA } \\
\text { CIENTÍFICA } \\
\text { EXTRÍNSECA }\end{array}$} & Representaciones & Imágenes de la ciencia & CEXTR \\
\hline & Prácticas/Operacionales & $\begin{array}{l}\text { Interés por la ciencia } \\
\text { Normas de comportamiento } \\
\text { (Moral, jurídico, etc.) } \\
\text { Relacionadas con la ciencia }\end{array}$ & CEXTOP \\
\hline & Valores & $\begin{array}{l}\text { Valoraciones y actitudes ante la } \\
\text { ciencia }\end{array}$ & CEXTVA \\
\hline & Imágenes & $\begin{array}{l}\text { Datos visuales asociados con } \\
\text { texto extrínseco }\end{array}$ & CEXT_IM \\
\hline \multirow{2}{*}{$\begin{array}{c}\text { CULTURA } \\
\text { TECNOLÓGICA }\end{array}$} & Informaciones Tecnológica & Informaciones Tecnológica & TECNO \\
\hline & Imágenes & $\begin{array}{l}\text { Datos visuales asociados con } \\
\text { texto tecnológico }\end{array}$ & TECNO_IM \\
\hline NO CULTURA & Informaciones & Informaciones & NoCC \\
\hline
\end{tabular}




\begin{tabular}{|l|l|l|l|}
\hline \multirow{2}{*}{ CIENTÍFICA } & no científica ni tecnológica & no científica ni tecnológica & \\
\cline { 2 - 4 } & Imágenes & $\begin{array}{l}\text { Datos visuales asociados con } \\
\text { texto no científico ni tecnológico }\end{array}$ & NoCC_IM \\
\hline
\end{tabular}

Tabla 5.1. Códigos aplicados al análisis del modelo de Cultura Científica (MCC) (Fuente: Quintanilla, et al, 2011: anexo I- 5)

La unidad de codificación es párrafo (libro de texto) y artículo (periódico). Examinaremos la proporción entre el contenido propiamente científico (intrínseco) y el contenido relacionado con la ciencia (extrínseco), y el porcentaje de los tres tipos de la información (representacional, operacional y valorativa) mediante el modelo de cultura científica (MCC). A través de la comparación de los resultados de la codificación entre los dos países, podremos encontrar una nueva perspectiva sobre la cultura científica en los textos del darwinismo.

La codificación se verificó mediante revisiones cruzadas. A través de este proceso, se crearon y revisaron criterios suplementarios requeridos en el proceso de codificación concreta para cada texto (libro de texto y prensa). Los siguientes son criterios de codificación agregados durante el proceso de revisión:

(1) Codificación de libros de texto (Unidad de codificación: párrafo)

- Si el párrafo trata de la historia de la ciencia (por ejemplo, "Darwin presentó su teoría de la evolución en 1859), se codifica como CINTR. Pero si también explica procesos de "hacer ciencia" (“Darwin observó muchos animales en el archipiélago Galápagos y coleccionó varios especímenes"), se codifica como CINTOP.

- Si el párrafo explica reacciones de la sociedad sobre la ciencia que se basan en normas o reglas por aquél entonces, se codifican como CEXTOP.

- Actividades y autoevaluaciones

$\checkmark$ Si la actividad hace recordar algún contenido ya presentado en el mismo capítulo (o libro), se codifica como CINTR

$\checkmark$ Si la actividad hace experimentar, pensar o reflexionar sobre el tema, se codifica como CINTOP.

(2) Codificación de artículos periodísticos (Unidad de codificación: artículo) 
- Un artículo periodístico puede tener más de un código. En general, se codifican por el tema principal del artículo, pero si la parte del darwinismo en él incluye otro código, se lo codifican también (porque esta tesis se centra en la teoría).

- Hay varios artículos cuyo tema no es ciencia, pero se refiere a Darwin o su teoría. En este caso, se codifican por el tema general del artículo (NoCC) y por la parte del darwinismo a la vez. Así se puede analizar cómo aparece el darwinismo en artículos no científicos.

- Dar noticia sobre exposiciones o actividades científicas divulgativas se codifica como CEXTOP.

- Si el artículo no solo presenta resultado de una investigación, sino también explica el proceso de "llegar al resultado (hacer ciencia)", se codifican como CINTR (resultado, conocimiento) y CINTOP (proceso, regla).

La codificación se ha realizado en la versión 6.2. de Atlas.ti, que es herramienta de análisis cualitativos de datos. Las siguientes imágenes muestran pantallas de la codificación:

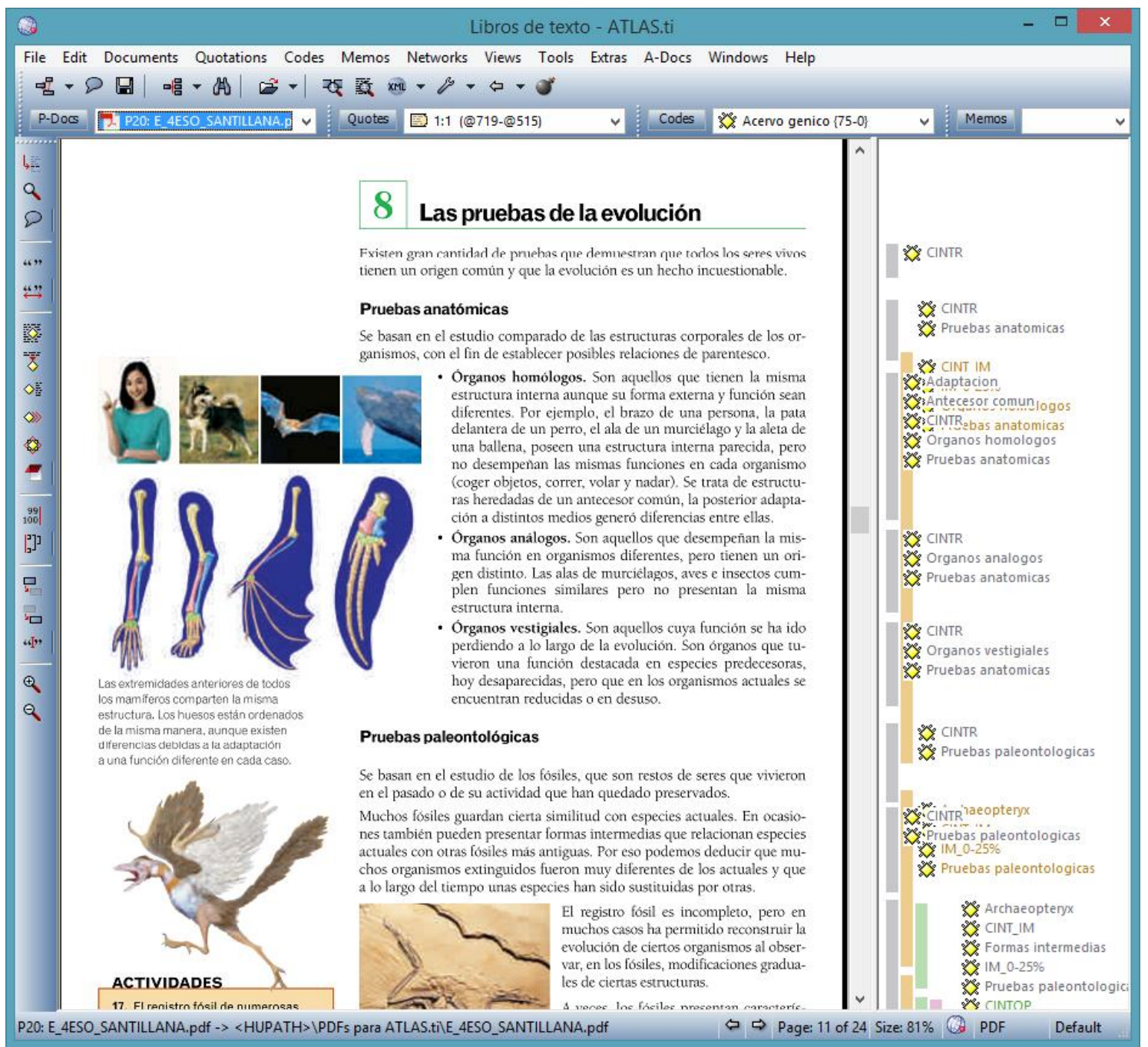

Ilustración 5.1. Captura de pantalla de Atlas.ti. Codificación de los contenidos. Libros de texto 


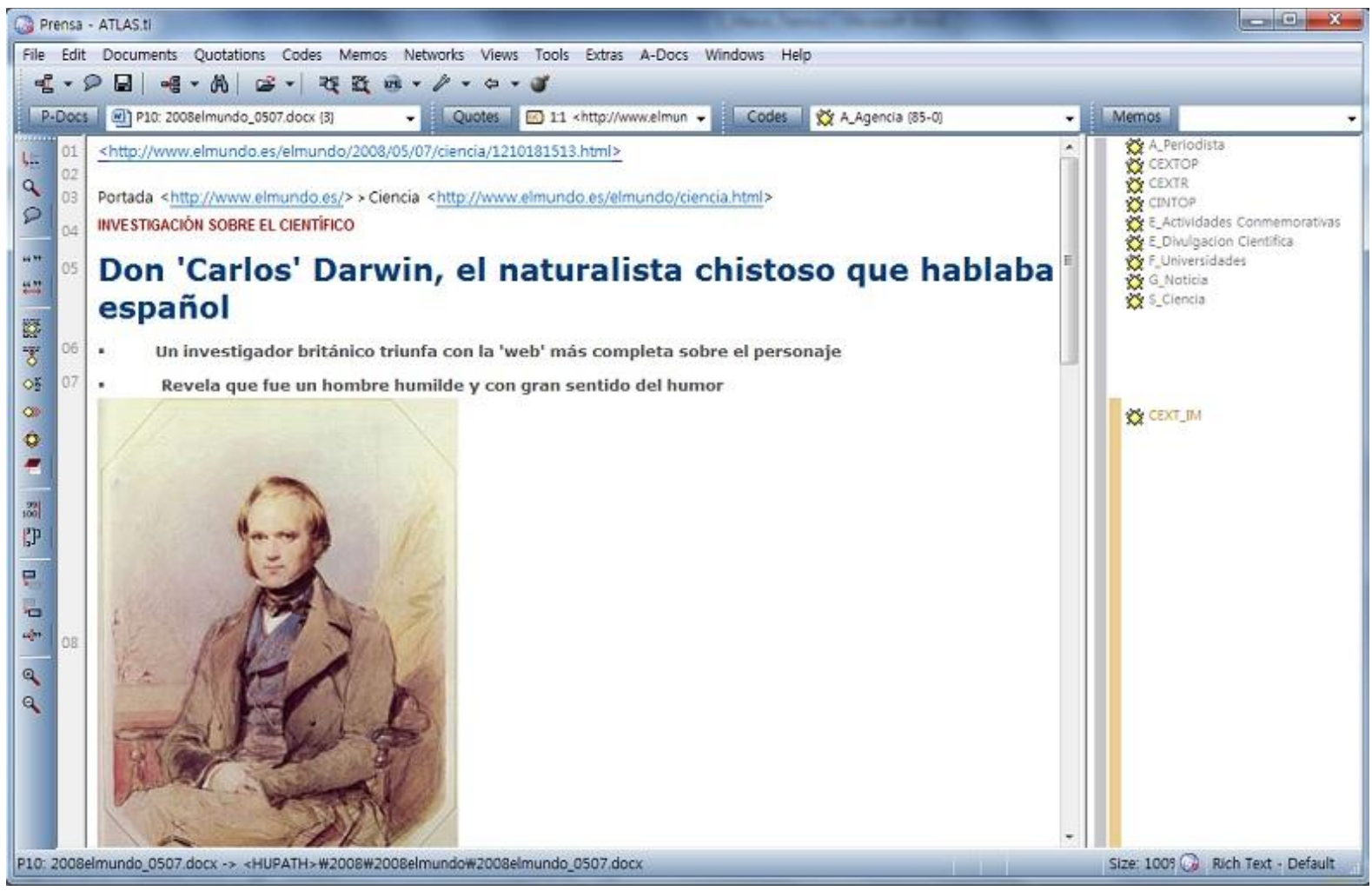

Ilustración 5.2. Captura de pantalla de Atlas.ti. Codificación de los contenidos. Prensa

\subsubsection{Proceso de la Codificación y la Revisión}

Se han codificado manualmente en Atlas.ti todos los textos seleccionados según los criterios de MCC (explicación en 5.1.2.1 y Anexo II). El proceso principal de la codificación es: Leer cada unidad y decidir en qué subcategoría se puede colocar; luego, marcar el código correspondiente en el párrafo (libro de texto) o artículo (periódico).

Después de la codificación, realizamos la comprobación cruzada con el segundo codificador para aumentar la fiabilidad. Codificadora A (Autora de esta tesis) y B (Segunda codificadora) tienen más de un año de experiencia de la codificación en MCC. A través de la revisión, se han establecido criterios complementarios (se han presentado en 5.1.2.1) sobre detalles no considerados antes. Revisamos y recodificamos los datos para obtener resultados finales. 


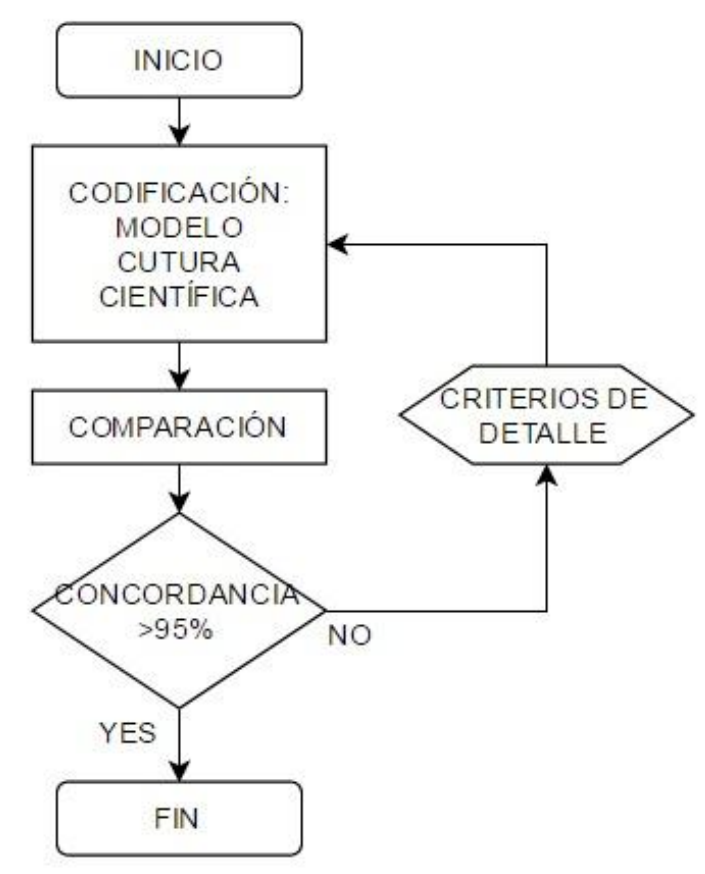

Diagrama 5.2. Diagrama de flujo. Revisión de la codificación

El Proceso de Revisión de Codificación se desarrolló en el siguiente orden (A: codificador 1 y B: codificador 2):

(1) A codifica todo el texto.

(2) B codifica $10 \%$ del texto aleatoriamente seleccionado. (En el caso de esta tesis, el $20 \%$ del texto en español se han seleccionado porque el texto coreano no se puede revisar).

(3) A y B comparan sus codificaciones del texto (2).

(4) Calcular la proporción de concordancia entre la codificación de A y B. La unidad no coincidida en su codificación pasa por una discusión. La primera concordancia se clasifica como 'concordancia 1' y si llegan a un acuerdo después de la discusión entre A y B, es 'acuerdo'. Calcular el valor de 'concordancia 2' agregando el valor de 'acuerdo' al valor de 'concordancia 1'.

(5) Si se proponen nuevos criterios en el proceso de llegar al acuerdo, se agrega a criterio complementario de MCC (apuntado en 5.1.2.1).

(6) Si la 'concordancia 1 ' es más de $80 \%$ y la 'concordancia 2 ' es más de $95 \%$, se acaba la revisión.

(7) Si no, A codifica de nuevo todo el texto (textos españoles y coreanos) considerando los nuevos criterios añadidos. 
(8) Para comprobar el resultado de la segunda codificación, se selecciona $5 \%$ del texto aleatoriamente. El $10 \%$ de la primera revisión no se repiten. B codifica el $5 \%$ y compara con el resultado de $A$.

(9) Si la 'concordancia 1 ' es más de $80 \%$ y la 'concordancia 2 ' es más de $95 \%$, se acaba la revisión. Finalizar la revisión y calcular los resultados de las estadísticas. Revisión de codificación y cálculo de resultados completados.

\begin{tabular}{|c|c|c|c|c|c|c|c|}
\hline \multicolumn{3}{|c|}{ 1a REVISIÓN: 10\% de los textos } & \multicolumn{3}{c|}{ 2a REVISIÓN: otro 5\% de los textos } \\
\hline LIBRO DE TEXTO & \multicolumn{2}{c|}{ PRENSA } & \multicolumn{2}{c|}{ LIBRO DE TEXTO } & \multicolumn{3}{c|}{ PRENSA } \\
\hline 1a CONC. & 2 a CONC. & 1a CONC. & 2a CONC. & 1a CONC. & 2a CONC. & 1a CONC. & 2a CONC. \\
\hline $77,74 \%$ & $98,52 \%$ & $73 \%$ & $95 \%$ & $93,55 \%$ & $100 \%$ & $83,90 \%$ & $97,32 \%$ \\
\hline
\end{tabular}

Tabla 5.2. Resultado de revisiones (CONC: concordancia entre dos codificadoras.)

Tabla 5.2 muestra el resultado la revisión. Se obtuvo la concordancia suficiente en la segunda revisión, de modo que se terminó la codificación y se analizaron los resultados. (Más información sobre la revisión está disponible en el Anexo II.)

\subsection{Análisis por características de texto. Libros de texto y artículos periodísticos}

Como se ha mencionado anteriormente, el MCC es un modelo que clasifica los textos por tipos de textos y la inclusión de sistemas científicos y no es para temas específicos en la ciencia. Dado que esta tesis solamente trata con el darwinismo, se necesita un análisis más concreto que permite ver y comparar las informaciones darwinianas en los dos países. Por lo tanto, se realiza un análisis detallado que depende de las características del texto. Libros de texto y artículos periodísticos tienen características muy diferentes, por lo que el análisis adicional les aplicó criterios diferentes.

\subsubsection{Análisis de Contenido. Libros de Texto}

Para analizar cómo enseñar el darwinismo, hemos localizado la parte del darwinismo en los libros de texto de ciencias. Dado que el análisis de MCC muestra la proporción entre la cultura científica intrínseca y extrínseca, esta vez, decidimos examinar qué y cómo enseñar 
el darwinismo en aulas escolares concretamente.

El darwinismo consiste en varias sub-teorías y es una teoría amplia que incluye una variedad de conceptos. Por lo tanto, tratamos de clasificar y resumir todos los conceptos en los libros de texto para ver lo que comparten. También utilizamos el programa Atlas.ti para clasificar los textos. Las grandes categorías son:

A. CIENTÍfICOS PRINCIPALES: Presencia y manera de presentar a Darwin y Wallace que publicaron juntos el darwinismo.

B. ANTES DE DARWIN: Explicaciones anteriores sobre los seres vivos al darwinismo.

C. DESPUÉS DE DARWIN: Estudios posterior a Darwin sobre la evolución.

D. DEFINICIÓN DE LA EVOLUCIÓN: ¿Cómo definen la evolución?

E. PRUEBAS DE LA EVOLUCIÓN: ¿QQué pruebas de la evolución incluyen?

F. IDEAS PRINCIPALES DEL DARWINISMO: ¿Cómo explica los conceptos principales del darwinismo?

G. CONCEPTOS BÁSICOS DEL DARWINISMO: Conceptos que están incluidos en más de 5 libros.

H. CONCEPTOS AVANZADOS DEL DARWINISMO: Conceptos que están incluidos en menos de 5 libros.

I. EJEMPLOS PARA EXPLICAR LA EVOLUCIÓN: ¿Qué ejemplos de la evolución incluyen?

El camino de análisis de contenido de libros de texto por dos etapas es el siguiente:

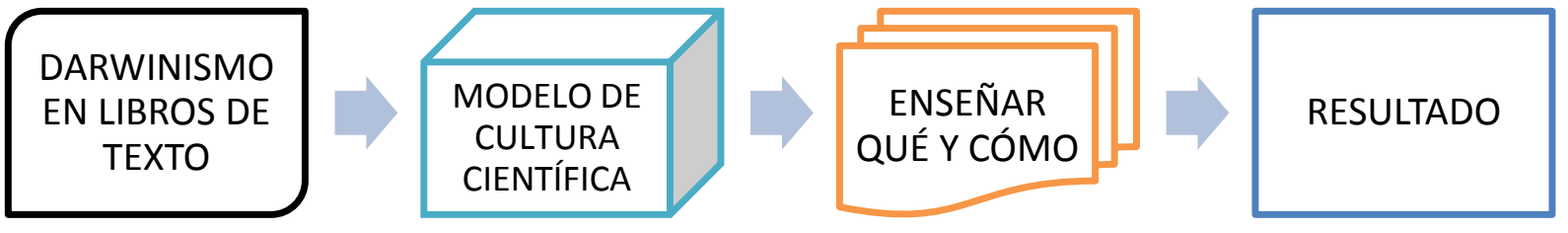

Diagrama 5.3. Proceso del análisis. Libros de texto (Capítulo 6).

Los códigos de detalle de las categorías son los siguientes:

\begin{tabular}{|l|l|l|l|l|}
\hline $\begin{array}{l}\text { CIENTÍFICOS } \\
\text { PRINCIPALES }\end{array}$ & ANTES DE DARWIN & \multicolumn{2}{|l|}{ DESPUÉS DE DARWIN } & $\begin{array}{l}\text { DEFINICIÓN DE LA } \\
\text { EVOLUCIÓN }\end{array}$ \\
\hline -Charles Darwin & -Aristóteles & -Dawkins & -Economía & - \\
\hline
\end{tabular}




\begin{tabular}{|c|c|c|c|c|}
\hline $\begin{array}{l}\text {-Alfred Russel } \\
\text { Wallace }\end{array}$ & $\begin{array}{l}\text {-Buffon } \\
\text {-Cuvier } \\
\text {-Erasmus Darwin } \\
\text {-Spencer } \\
\text {-Lamarck } \\
\text {-Linné } \\
\text {-Lyell } \\
\text {-Malthus } \\
\text {-Catastrofismo } \\
\text {-Creacionismo } \\
\text {-Fijismo } \\
\text {-Transformismo }\end{array}$ & $\begin{array}{l}\text {-De Vries } \\
\text {-Dobzhansky } \\
\text {-Eimer } \\
\text {-Gould\&Eldredge } \\
\text {-Grant } \\
\text {-Henning } \\
\text {-Marx } \\
\text {-Kimura } \\
\text {-Lotsy } \\
\text {-Pauling } \\
\text {-Romanes } \\
\text {-Smith } \\
\text {-Van Valen } \\
\text {-Wagner } \\
\text {-Weisman }\end{array}$ & $\begin{array}{l}\text { evolucionista } \\
\text {-Neodarwinismo } \\
\text {-Psicología } \\
\text { evolutiva } \\
\text {-Saltacionismo } \\
\text {-Sociobiología } \\
\text {-Teoría del } \\
\text { equilibrio puntuado } \\
\text {-Teoria neutralista } \\
\text {-Teoría sintética de } \\
\text { la evolución }\end{array}$ & \\
\hline $\begin{array}{l}\text { PRUEBAS DE LA } \\
\text { EVOLUCIÓN }\end{array}$ & $\begin{array}{l}\text { IDEAS PRINCIPALES } \\
\text { DEL DARWINISMO }\end{array}$ & $\begin{array}{l}\text { CONCEPTOS } \\
\text { BÁSICOS DEL } \\
\text { DARWINISMO } \\
\end{array}$ & $\begin{array}{l}\text { CONCEPTOS } \\
\text { AVANZADOS DEL } \\
\text { DARWINISMO }\end{array}$ & $\begin{array}{l}\text { EJEMPLOS PARA } \\
\text { EXPLICAR LA } \\
\text { EVOLUCIÓN }\end{array}$ \\
\hline $\begin{array}{l}\text {-Pruebas } \\
\text { anatómicas } \\
\text {-Pruebas } \\
\text { biogeográficas } \\
\text {-Pruebas de } \\
\text { adaptación } \\
\text {-Pruebas } \\
\text { embriológicas } \\
\text {-Pruebas en el ser } \\
\text { humano } \\
\text {-Pruebas } \\
\text { genéticas } \\
\text {-Pruebas } \\
\text { paleontológicas }\end{array}$ & $\begin{array}{l}\text {-Antepasado } \\
\text { común } \\
\text {-Especiación } \\
\text {-Gradualismo } \\
\text {-Selección natural }\end{array}$ & $\begin{array}{l}\text {-Acervo genético } \\
\text {-Acumulación de } \\
\text { variaciones } \\
\text {-Adaptación } \\
\text {-Aislamiento } \\
\text { geográfico } \\
\text {-Aislamiento } \\
\text { reproductivo } \\
\text {-Alelo } \\
\text {-Árbol genealógico } \\
\text {-Azar } \\
\text {-Biodiversidad } \\
\text {-Extinción } \\
\text {-Lucha por la } \\
\text { supervivencia } \\
\text {-Mutación } \\
\text {-Órganos análogos } \\
\text {-Órganos } \\
\text { homólogos } \\
\text {-Órganos } \\
\text { Vestigiales } \\
\text {-Parentesco } \\
\text { evolutivo } \\
\text {-Población (grupo) } \\
\text {-Reproducción } \\
\text { sexual } \\
\text {-Selección artificial } \\
\text {-Supervivencia del } \\
\text { más apto } \\
\text {-Variación } \\
\end{array}$ & $\begin{array}{l}\text {-Coevolución } \\
\text {-Cuellos de botella } \\
\text {-Deriva genética } \\
\text {-Efecto fundador } \\
\text {-Equilibrio } \\
\text { Hardy-Weinberg } \\
\text {-Especiación } \\
\text { alopátrica } \\
\text {-Especiación } \\
\text { simpátrica } \\
\text {-Evolución } \\
\text { convergente } \\
\text {-Fenotipo } \\
\text {-Flujo genético } \\
\text {-Fósiles vivientes } \\
\text {-Genes homeóticos } \\
\text {-Macroevolución } \\
\text {-Microevolución } \\
\text {-Mimetismo } \\
\text {-Nicho (ecológico) } \\
\text {-Presión de } \\
\text { selección } \\
\text {-Radicación } \\
\text { adaptiva } \\
\text {-Selección sexual }\end{array}$ & $\begin{array}{l}\text {-Anemia } \\
\text { falciforme } \\
\text {-Archaeopteryx } \\
\text {-Embriones de } \\
\text { vertebrados } \\
\text {-Evolución de } \\
\text { amonites } \\
\text {-Evolución de } \\
\text { ballena } \\
\text {-Evolución de } \\
\text { caballo } \\
\text {-Evolución } \\
\text { humana } \\
\text {-Jirafa de Darwin } \\
\text {-Jirafa de Lamarck } \\
\text {-Órganos } \\
\text { análogos } \\
\text {-Órganos } \\
\text { homólogos } \\
\text {-Órganos } \\
\text { vestigiales } \\
\text {-Pinzones de } \\
\text { Galápagos } \\
\text {-Polilla de abedul } \\
\text {-La resistencia a } \\
\text { los antibióticos o } \\
\text { a los insecticidas }\end{array}$ \\
\hline
\end{tabular}

Tabla 5.3. Subcategorías de los criterios. Libros de texto

Después de analizar libros actuales de texto, también localizamos el darwinismo en antiguos libros de texto de los años 40 a los años 90 en España y Corea del Sur para ver el cambio del contenido con el tiempo. 


\subsubsection{Análisis de Contenido. Artículos Periodísticos}

Al analizar los artículos periodísticos que incluyen el darwinismo, se necesitan normas apropiadas a las características de los textos de prensa. Libros de texto enseñan la teoría darwiniana en sí y profesores de la biología y biólogos son sus autores. Todo el texto tiene el concepto darwiniano como su tema principal, su formato es similar y su objetivo es trasmitir conocimientos. Por lo tanto, se han analizado por contenidos detallados del darwinismo. Sin embargo, los artículos periodísticos se han seleccionado si incluyen una mención de concepto darwiniano. Por eso el tema principal del artículo no siempre es el darwinismo ni la ciencia, y el contexto de la mención es variado. Se necesitan criterios detallados para analizar las diversas características de los artículos periodísticos.

Hemos traído diversos criterios para artículos periodísticos a partir de un estudio que investigó diez años de artículos de noticias sobre biotecnología en España, «La biotecnología española: Impacto económico, evolución y perspectivas» (Quintanilla, et al., 2005). En el caso que nos ocupa, cada artículo ha sido categorizado por los seis criterios que se enumeran a continuación, mientras que cada uno de ellos puede incluir más de un código de dichas categorías.
A. SECCIÓN DEL PERIÓDICO.
B. GÉNERO PERIODÍSTICO.
C. AUTORÍA.
D. ENCUADRE DEL TEXTO.
E. FUENTES DE INFORMACIÓN.
F. TEMA.

El camino de análisis de contenido de artículos periodísticos por dos etapas es el siguiente:
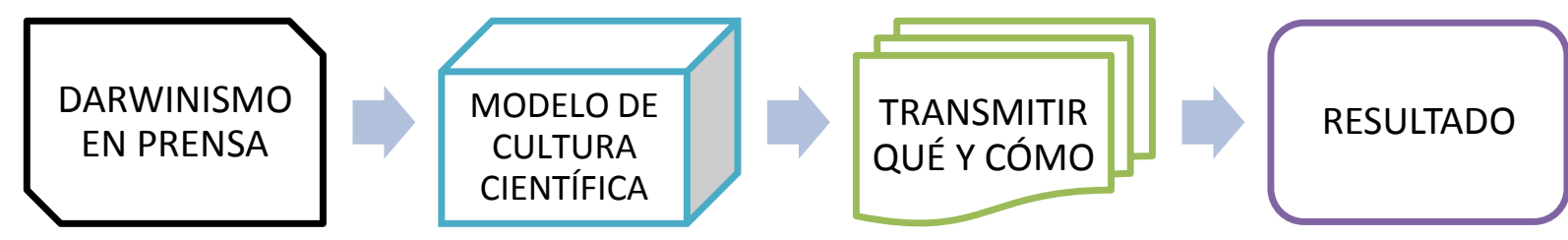
Diagrama 5.4. Proceso del análisis. Artículos Periodísticos (Capítulo 7).

Mientras que los códigos de detalle de las categorías son los siguientes:

\begin{tabular}{|l|l|l|}
\hline SECCIÓN & GÉNERO PERIODÍSTICO & AUTORÍA \\
\hline -Ciencia & -Artículo & -Agencia \\
-Cultura & -Columna & -Científico \\
-Economía & -Entrevista & -Columnista \\
-Internacional & -Nota breve & -Redacción \\
-Opinión & -Noticia & -Periodista \\
-Regional & -Reportaje & \\
-Salud & -Reseña & \\
-Sociedad & & \\
-Tecnología & & \\
-Otra & & TEMA \\
\hline ENCUADRE & FUENTE & -Novedad Científica \\
\hline -Actividades Conmemorativas & -Centros e Institutos de investigación & -Ideas Religiosas \\
-Darwinismo en la Sociedad & -Entidades gubernamentales & \\
-Divulgación Científica & -Entidades Religiosas & \\
-Política Científica & -Empresa & \\
-Menciones Simples & - Museos & \\
& - Publicaciones & \\
\hline
\end{tabular}

Tabla 5.4. Subcategorías de los criterios. Artículos Periodísticos.

Los análisis de contenido sobre los textos del darwinismo de la educación y la prensa mediante los criterios que hemos visto hasta ahora nos permitirán una nueva perspectiva sobre la incorporación del darwinismo en España y Corea del Sur. 


\section{Capítulo 6. Darwinismo en Libros de Texto de España y Corea del Sur}

En este capítulo, investigaremos los contenidos didácticos sobre el darwinismo de España y Corea del Sur para averiguar cómo aparece la cultura científica de los dos países en sus libros de texto.

En primer lugar, analizaremos los contenidos a través del modelo de Cultura Científica (MCC en adelante) (Quintanilla, 2012), a los que ya nos referimos en el capítulo anterior, para detectar la distribución de informaciones intrínsecas y extrínsecas del sistema científico. Dentro de esa clasificación, también pensaremos si el contenido es representacional, práctico o valorativo.

En segundo lugar, para analizar qué y cómo enseñar el darwinismo en las aulas concretamente, contamos los conceptos del darwinismo. Las nociones principales de la teoría han sido inferidas según los currículos escolares de España y Corea del Sur, "National Standard of Science Education" de EE.UU. "The national curriculum in England" de Inglaterra y los criterios de Ernst Mayr. Clasificamos y contamos todos los conceptos posibles para detectar la diferencia y la semejanza entre los dos países. Para no perder ningún concepto aunque sea solamente una mención, lo hemos incluido.

Después del análisis de los libros actuales, se investigan libros antiguos de los dos países. Mirando el cambio de los contenidos con el tiempo, podemos detectar la influencia de la situación socio-política de cada país en la enseñanza de la teoría.

La comparación comienza con los años cuarenta del siglo XX, debido a que Corea formó su primer sistema educativo moderno en el año 1945 en el que se recuperó la soberanía desde el imperio japonés. Antes de la recuperación, en la península coreana no existió la asignatura «Biología» en sentido occidental. Podremos descubrir la influencia o la independencia de la situación socio-política española y la surcoreana en los contenidos sobre el darwinismo en los libros de texto. 


\subsection{Selección de Textos}

En el décimo curso escolar se enseñan por primera vez el evolucionismo biológico con su mecanismo en una asignatura científica en los dos países. Es el cuarto curso de Educación Secundaria Obligatoria (ESO) de España y el primero de Bachillerato (no obligatorio) de Corea del Sur. Ambos países empiezan la enseñanza primaria con los niños de 6 ó 7 años.

En España, en el curso el darwinismo se transmite en la asignatura de «Biología y Geología». Es una asignatura optativa y no todos los estudiantes la estudian. En Corea del Sur, la asignatura obligatoria de «Ciencias» incluye el darwinismo. Tampoco llega a toda la población porque el bachillerato no forma parte de la educación obligatoria del país. El porcentaje de entrada al bachillerato es más de 93\% (Statistics Korea, 2014).

Han sido elegidas cuatro editoriales por país. ANAYA (2008), EDELVIVES (2010), SANTILLANA (2008) y SM (2009) son de España, y CHUNJAE (2011a), KUMSUNG (2011), SANGSANG (2011) y THE TEXT (2011) son de Corea del Sur. En el curso 2013-14 en España, se utilizan los libros de texto de "Biología y Geología» que se publicaron en 2008-2010. En Corea del Sur, en el curso 2013 y 2014, se mantienen los libros de «Ciencias» del año 2011. Han sido elegidos para el análisis, porque son los libros más recientes y están en vigor en 2013.

La asignatura "Ciencias» de Corea del Sur es una introducción de todas las disciplinas científicas (Física, Química, Biología y Ciencias de la Tierra) de bachillerato. Por eso, presenta contenidos más elementales en comparación a las asignaturas de España del mismo curso, «Biología y Geología» o «Física y Química». Los estudiantes coreanos aprenden durante el segundo y tercer curso del bachillerato las asignaturas siguientes y avanzadas, como «Física I, ||», «Química I, ||», «Biología I, ||» o «Ciencias de la Tierra I, ||», dependiendo de su elección.

Si nos detenemos en los contenidos del darwinismo en los libros de texto del décimo curso, los de España son mucho más detallados que los de Corea. Los contenidos de Corea, son sólo una parte del libro que cubre las ciencias y el darwinismo se presenta muy brevemente. Así que si analizamos solamente los contenidos del décimo curso, será difícil obtener un resultado significativo sobre la enseñanza de los dos países. Por este motivo, incluimos dos 
libros más de "Biología II » (12o curso) de BISANG (3B) y CHUNJAE (3B). "Biología II» tiene un nivel similar con los libros de 4을 ESO de España o un poco más avanzado. Por la diferencia del programa escolar, ampliamos la selección de textos.

En total, han sido seleccionados cuatro libros de España de 4ㅇ de E.S.O «Biología y Geología» y cuatro libros de Corea del Sur de 10 de Bachillerato "Ciencias» y dos libros de Corea del Sur de 3 o curso de Bachillerato «Biología II».

Los textos del darwinismo se seleccionan por el índice y sus contenidos. Siguiendo la definición del darwinismo que hemos indicado en el capítulo de la Introducción, se escoge la totalidad de la parte que se refiere a la evolución de los seres vivos. Sin embargo, hay algunos contenidos que suelen aparecer con la evolución pero no son del propio darwinismo. Por ejemplo,

- El origen de la vida (el primer organismo en la Tierra, Hipótesis de Pasteur y Oparin, etc.)

- La clasificación de los seres vivos (de Linneo)

- Leyes de Mendel y Reproducción (Genética)

- Edades geológicas, etc.

Es cierto que estos contenidos tienen relación con la evolución de los seres vivos, pero se tratan aparte en los libros y existe una distancia a los propósitos de este estudio, así que han sido descartados.

Por otra parte, como el catastrofismo, el lamarckismo, el equilibro puntuado, etc., hay contenidos que explicaban el cambio de los seres vivos con el tiempo antes o después de Darwin. Estos contenidos no pertenecen al darwinismo pero están relacionados con él en el contexto de la historia de la ciencia, así que se incluyen en los textos seleccionados.

En la tabla, se puede ver los títulos de capítulos y subcapítulos seleccionados.

\begin{tabular}{|c|c|c|}
\hline \multirow{2}{*}{ País } & \multirow{2}{*}{ Editorial } & Capítulo \\
\cline { 3 - 3 } & & Subcapítulos \\
\hline España & ANAYA (4E) & Unidad5. La evolución de los seres vivos \\
\hline
\end{tabular}




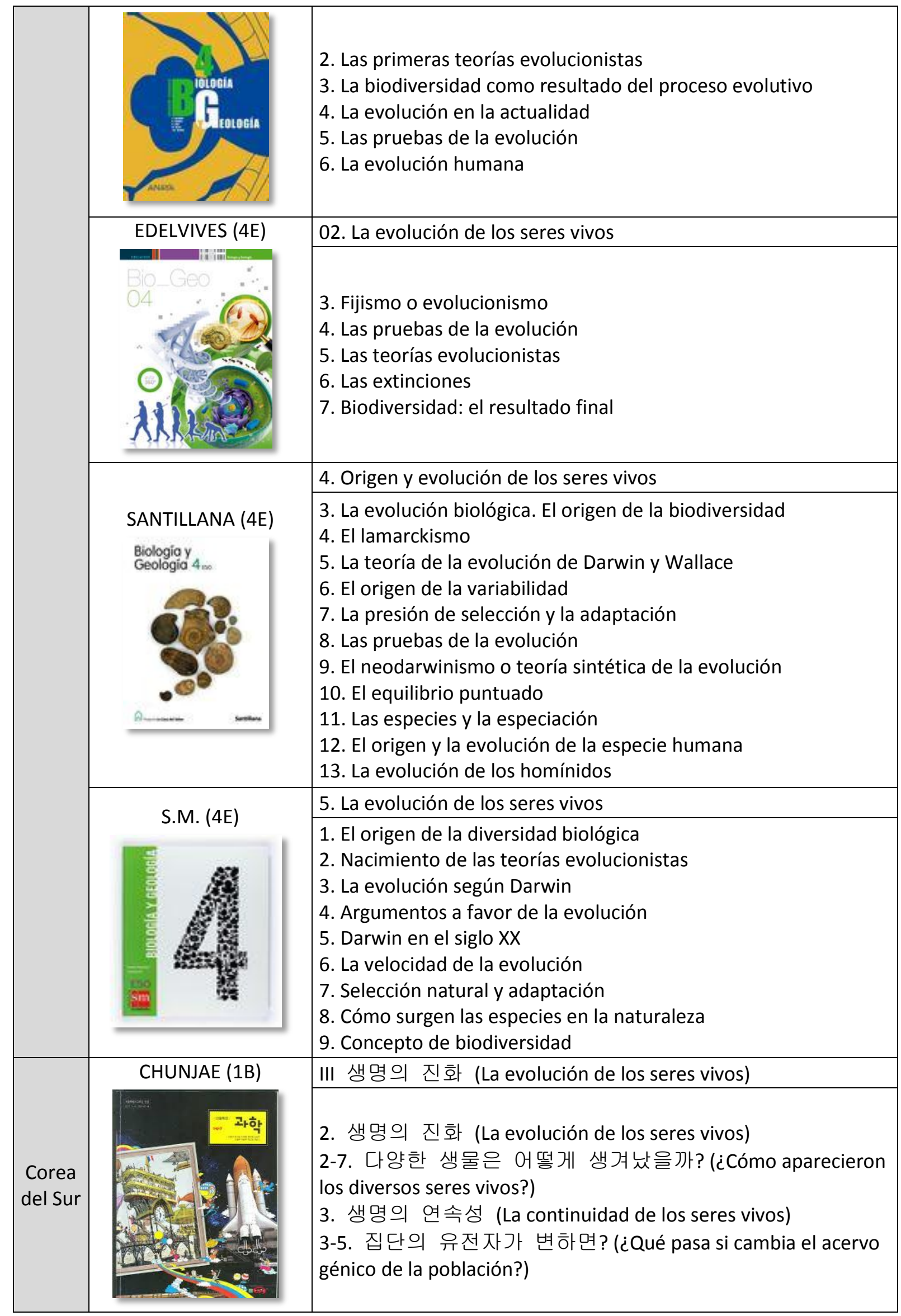




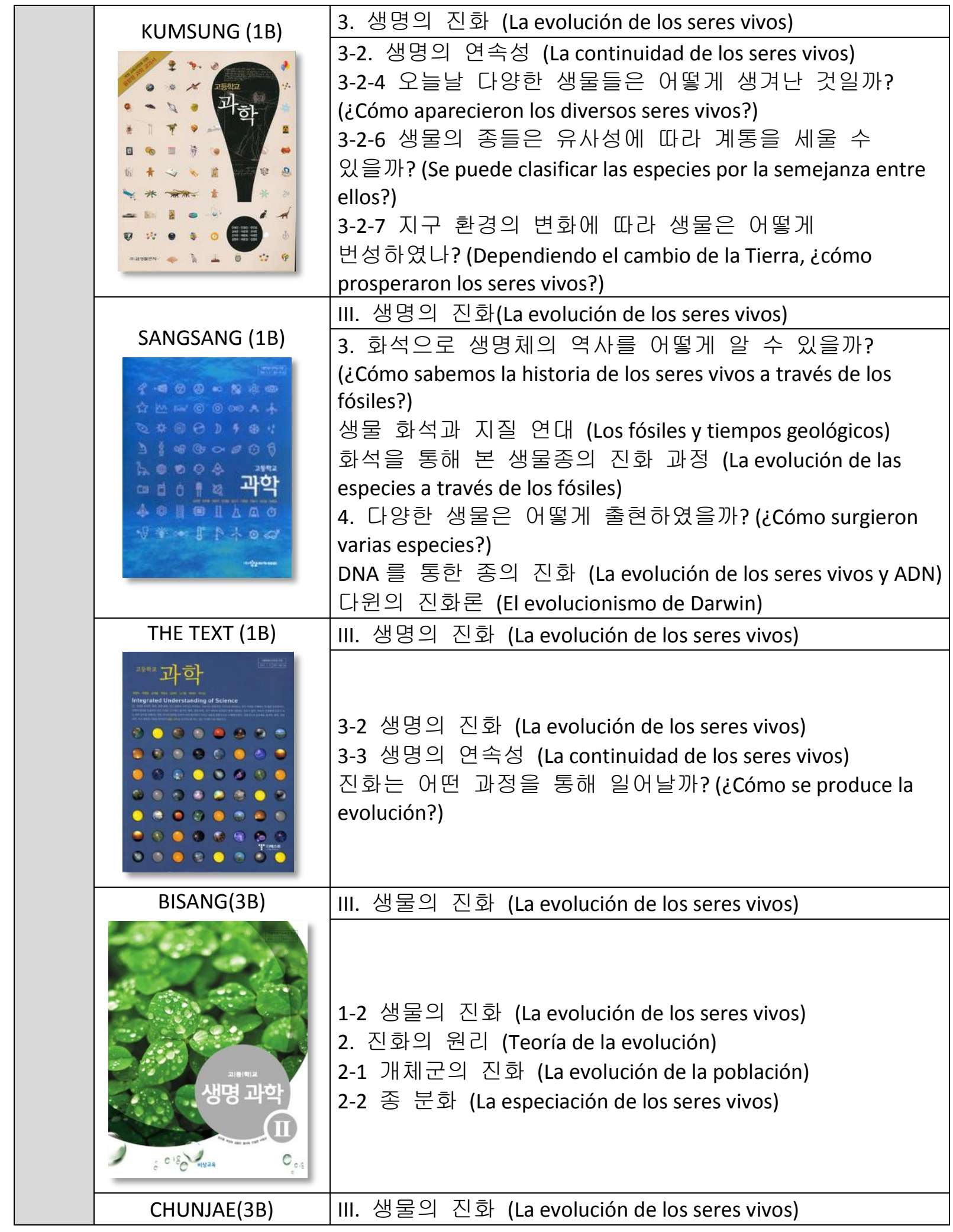




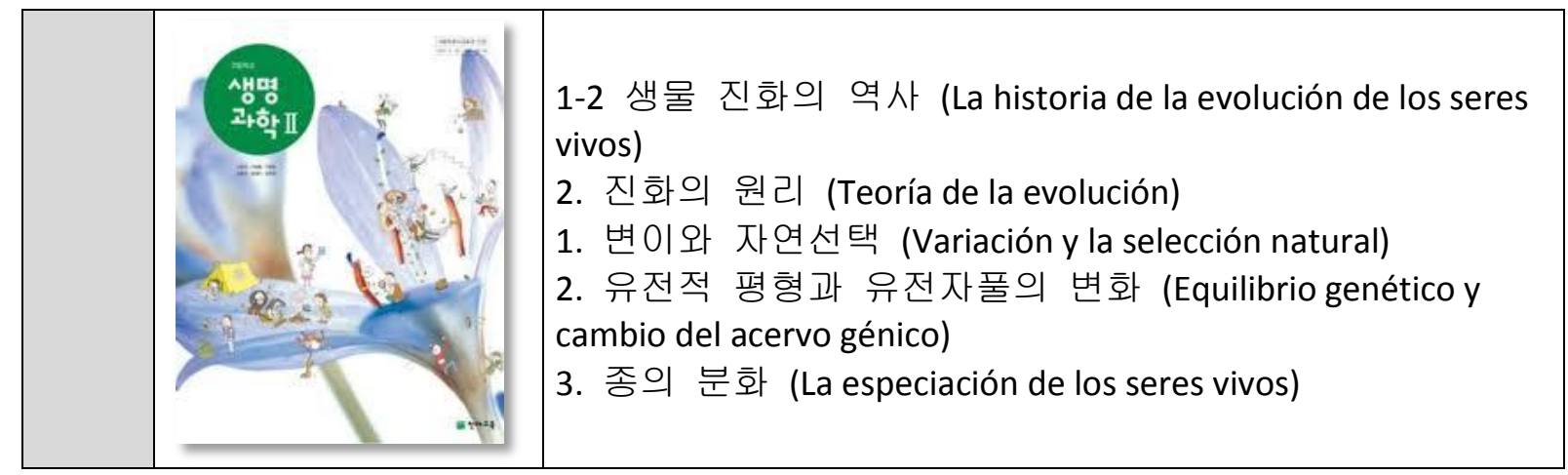

Tabla 6.1. Los títulos de capítulos y subcapítulos seleccionados para el análisis

En este estudio, para facilitar la distinción, llamaremos los libros de texto seleccionados por su editorial, en vez de los nombres de autores. Por consiguiente, haremos referencia a los cuatros libros editados en España como: ANAYA, EDELVIVES, SANTILLANA y SM en mayúsculas. Estos cuatros son para el mismo curso académico, el décimo curso (4으 de ESO), así que omitiremos el curso si no es necesario. Entre los libros coreanos, CHUNJAE (1B), KUMSUNG (1B), SANGSANG (1B) y THE TEXT (1B) son para el décimo curso (1ㅇ de Bachillerato) y BISANG (3B) y otro libro de CHUNJAE (3B) son para el duodécimo (3o de Bachillerato).

Cuando se citan los contenidos en los libros de texto directamente, en el final del párrafo, indicaremos así: (PAÍS_EDITORIAL (CURSO): página)

\subsection{Darwinismo en el Currículo Escolar de España y Corea del Sur}

Antes de empezar el análisis de los contenidos, consultaremos brevemente los currículos escolares en los que incluyen el darwinismo. Presentamos la introducción de las asignaturas (Biología y Geología de España, Ciencias y Biología II de Corea del Sur) y los contenidos imprescindibles en las asignaturas. Añadimos los contenidos de EE. UU e Inglaterra para comparar con España y Corea del Sur.

\section{España}


La ley actual de Educación en el año 2014, LOE (Ley Orgánica de Educación), no incluye los contenidos imprescindibles de cada asignatura. Por eso, encontramos la presentación de la asignatura «Biología y Geología» y los contenido sobre el darwinismo en DECRETO 52/2007 en la comunidad de Castilla y León (Consejería de Educación Castilla y León, 2007)

\section{Currículo de Castilla y León}

En lo referente a Biología y Geología, se aborda con detalle la dinámica terrestre, partiendo de un tema dedicado a la historia de la Tierra y haciendo énfasis en el paradigma de la tectónica global, que se trata exhaustivamente. Se profundiza en aspectos de citología, herencia y genética humana y evolución de los seres vivos a lo largo del bloque La vida en el planeta. Finalmente, se incluye un bloque de contenidos dedicado al estudio de la ecología y el medio ambiente, en el que se aborda además el estudio de los ecosistemas de nuestra Comunidad. (Consejería de Educación Castilla y León, 2007: 7)

Los libros de texto españoles que se han seleccionado para esta tesis pertenecen a la LOE.

La nueva ley de Educación, LOMCE (Ley Orgánica para la Mejora de la Calidad Educativa) explica la asignatura Biología y Geología para el cuarto curso de ESO:

\section{Boletín Oficial del Estado}

Finalmente, en el cuarto curso de la ESO, se inicia al alumnado en las grandes teorías que han permitido el desarrollo más actual de esta ciencia: la tectónica de placas, la teoría celular y la teoría de la evolución, para finalizar con el estudio de los ecosistemas, las relaciones tróficas entre los distintos niveles y la interacción de los organismos entre ellos y con el medio, así como su repercusión en la dinámica y evolución de dichos ecosistemas. (Ministerio de Educación, Cultura y Deporte de España, 2015: 205)

Ahora veamos los contenidos concretos sobre el darwinismo en los planes de estudio de España.

DECRETO 52/2007, de 17 de mayo, por el que se establece el currículo de la Educación Secundaria Obligatoria en la Comunidad de Castilla y León. Suplemento al N. 99 (pp. 15-16)

Bloque 3. La vida en el planeta.

Origen y evolución de los seres vivos. 


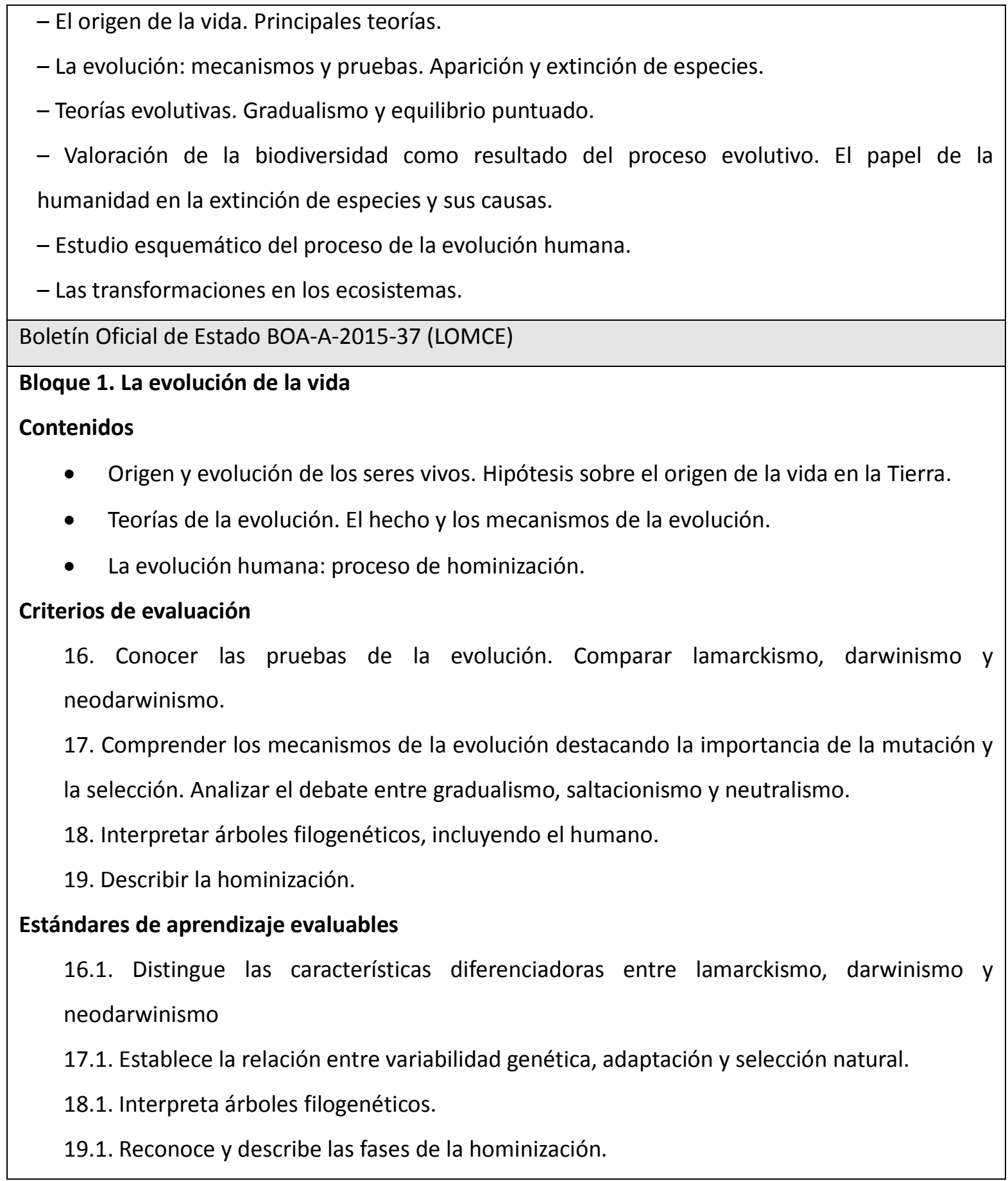

Tabla 6.2. Darwinismo en currículo escolar de España (Consejería de Educación Castilla y León, 2007: 15-16; Ministerio de Educación, Cultura y Deporte de España, 2015: 211)

No se destaca gran diferencia entre los dos planes en los contenidos, solamente en el nuevo se los han categorizado por propósito. Comienza con el origen de la vida y presenta el mecanismo y las pruebas de la evolución. Además, se refiere a la historia de la ciencia (teorías anteriores y posteriores a Darwin). Tratan el equilibrio puntuado de la misma manera que el gradualismo. 


\section{Corea del Sur}

Ahora vamos a observar el plan de estudios de Corea del Sur. Como se ha mencionado anteriormente, la asignatura 'Ciencias' del primer curso de bachillerato es una asignatura obligatoria y básica para que tomen los alumnos una visión general de todas las asignaturas de ciencias. El plan de estudio explica la asignatura del mismo modo.

'Ciencias' es una asignatura para que tengan los estudiantes conocimientos mínimos de Ciencias como miembro de la sociedad democrática. [...]

En la asignatura de 'Ciencias', los conceptos principales de Física, Química, Biología y Ciencias de la Tierra se fusionan de manera natural con un equilibrio adecuado. A pesar de que sea un concepto difícil, si se necesita para que entiendan los estudiantes sintéticamente la naturaleza y animar su interés por la ciencia, se puede incluir en la asignatura 'Ciencias' en un nivel adecuado. (Ministerio de Educación, Ciencia y Tecnología de Corea del Sur, 2011: 58)

Podemos detectar que la idea más importante es la 'fusión' y 'equilibrio'. Parecen propósitos buenos pero son ambiguos. La meta de esta asignatura es conocer la corriente general de las disciplinas científicas del bachillerato como se ha mencionado en la última frase, por este motivo se controla el grado de dificultad.

A continuación, recordemos la presentación de la asignatura optativa Biología II.

'Biología II' es una asignatura para crear la capacidad de resolver problemas sobre los fenómenos de la vida aplicando conceptos biológicas y diversos métodos de investigación. Los contenidos de 'Biología II' son la célula y el metabolismo, los genes y biotecnología y la evolución de los seres vivos. (Ministerio de Educación, Ciencia y Tecnología de Corea del Sur, 2011: 115)

Ahora veamos los contenidos concretos sobre el darwinismo en los planes de estudio de Corea del Sur.

Currículo de Ciencias. Declaración 2011-361, número 9, Ministerio de Educación, Ciencia y Tecnología (교육과학기술부 고시 제 2011-361호[별책 9] 과학과 교육과정)

Ciencias (1을 de Bachillerato) 
(3) Evolución de los seres vivos

3. Relacionar fósiles de seres vivos con épocas geológicas y explicar el proceso de la evolución de los seres vivos a través del cambio de fósiles. Y razonar el medio ambiente que los seres antiguos tenían.

4. Distinguir procarionte, eucarionte, seres unicelulares y policelulares y explicar los principios del evolucionismo.

5. Entender la continuidad de los seres vivos por tener mismos códigos genéticos.

6. Explicar el proceso de la herencia y la evolución a través de la transmisión y variación de los genes.

[Actividades]

1. Investigar y discutir sobre la influencia del Darwinismo en la ciencia y la sociedad.

2. Investigar y discutir sobre la causa de gran extinción y cambios posteriores.

Biología II (3ㅇ de Bachillerato)

(2) Principios de la evolución

1. Explicar la evolución a través de la competencia y la selección natural entre las variaciones dentro de una población.

2. Explicar la evolución a través del equilibrio génico y el cambio del acervo génico de la población.

3. Entender el proceso de la especiación.

[Actividades]

1. Estudiar el equilibrio de Hardy-Weinberg y experimentarlo.

2. Buscar un caso del cambio del acervo génico.

Tabla 6.3. Darwinismo en currículo escolar de Corea del Sur (Ministerio de Educación, Ciencia y Tecnología de Corea del Sur, 2011: 61-62, 115)

En el plan de estudio de Corea del Sur, no aparecen claramente la historia de las teorías sobre los seres vivos, las pruebas de la evolución ni su mecanismo. Sin embargo, se anota la importancia del proceso de la evolución e informaciones genéticas. En vez de la propia teoría y sus principios, parece que aplicaciones o avances prácticas de la teoría toman el protagonismo. Imaginamos que esté relacionada la cultura que respeta más las disciplinas prácticas.

La actividad 1 de 'Ciencias' es muy interesante. El plan reconoce la influencia del darwinismo en la ciencia y la sociedad e incluye el tema para que investiguen y discutan entre 
estudiantes y profesores.

\section{Estados Unidos e Inglaterra}

Ya hemos observado el darwinismo en los planes de estudio de España y Corea del Sur. Ahora, queremos comparar los contenidos con los de otros países que pueden ser un ejemplo en el ambiente biológico. Se han seleccionado EE. UU e Inglaterra ya que el aquél prácticamente lidera la ciencia mundial y el éste es el origen de la teoría.

Ahora analicemos los contenidos concretos sobre el darwinismo en los planes de estudio de Estados Unidos e Inglaterra.

National Science Education Standards (1996)

BIOLOGICAL EVOLUTION

- Species evolve over time. Evolution is the consequence of the interactions of (1) the potential for a species to increase its numbers, (2) the genetic variability of offspring due to mutation and recombination of genes, (3) a finite supply of the resources required for life and (4) the ensuing selection by the environment of those offspring better able to survive and leave offspring.

- The great diversity of organisms is the result of more than 3.5 billion years of evolution that has filled every available niche with life forms.

- Natural selection and its evolutionary consequences provide a scientific explanation for the fossil record of ancient life forms, as well as for the striking molecular similarities observed among the diverse species of living organisms.

- The millions of different species of plants, animals, and microorganisms that live on earth today are related by descent from common ancestors.

- Biological classifications are based on how organisms are related. Organisms are classified into a hierarchy of groups and subgroups based on similarities which reflect their evolutionary relationships. Species is the most fundamental unit of classification.

Tabla 6.4. Darwinismo en 'National Science Education Standards' de EE.UU. (National Research Council of USA, 1996:185)

The national curriculum in England - Key stages 3 and 4 framework document (2014) 
KEY STAGE 3 (AGE 11-14) BIOLOGY p.62

\section{Genetics and evolution}

- the variation between individuals within a species being continuous or discontinuous, to include measurement and graphical representation of variation

- the variation between species and between individuals of the same species means some organisms compete more successfully, which can drive natural selection

- changes in the environment may leave individuals within a species, and some entire species, less well adapted to compete successfully and reproduce, which in turn may lead to extinction

- the importance of maintaining biodiversity and the use of gene banks to preserve hereditary material.

\section{KEY STAGE 4, BIOLOGY (AGE 14-16) p.74}

\section{Evolution, inheritance and variation}

- genetic variation in populations of a species

- the process of natural selection leading to evolution

- the evidence for evolution

- developments in biology affecting classification

- the importance of selective breeding of plants and animals in agriculture

- the uses of modern biotechnology including gene technology; some of the practical and ethical considerations of modern biotechnology.

Tabla 6.5. Darwinismo en 'The national curriculum in England'. (Department of Education of England, 2014: 62, 74)

El estándar nacional de Estados Unidos y el 'key stage 3' del currículo nacional de Inglaterra son más explicativos que los otros planes e incluyen contenidos concretos. En cambio, los contenidos de 'key stage 4' de Inglaterra son mucho más sencillos y claros. Resumimos los currículos sobre el darwinismo de los cuatro países en una tabla por sus palabras clave.

\begin{tabular}{|l|c|c|c|c|}
\hline & ESPAÑA & COREA S. & EE.UU. & INGLATERRA \\
\hline Acervo génico & & $\mathrm{V}$ & & \\
\hline Adaptación & $\mathrm{v}$ & & & $\mathrm{v}$ \\
\hline Antepasado Común & $\mathrm{v}$ & $\mathrm{v}$ & $\mathrm{v}$ & \\
\hline Biodiversidad & $\mathrm{v}$ & & $\mathrm{v}$ & $\mathrm{v}$ \\
\hline Biotecnología & & & & $\mathrm{v}$ \\
\hline Evolución Humana & $\mathrm{v}$ & & & \\
\hline Extinción & $\mathrm{v}$ & $\mathrm{v}$ & & $\mathrm{v}$ \\
\hline
\end{tabular}




\begin{tabular}{|l|c|c|c|c|}
\hline Otras teorías evolucionistas & $\mathrm{V}$ & & & \\
\hline Principios del darwinismo & & $\mathrm{V}$ & & \\
\hline Proceso de la evolución & $\mathrm{V}$ & $\mathrm{V}$ & $\mathrm{V}$ & $\mathrm{V}$ \\
\hline Pruebas de la evolución & $\mathrm{V}$ & & & $\mathrm{V}$ \\
\hline Selección Natural & $\mathrm{V}$ & $\mathrm{V}$ & $\mathrm{V}$ & $\mathrm{V}$ \\
\hline Variación & $\mathrm{V}$ & $\mathrm{V}$ & $\mathrm{V}$ & $\mathrm{V}$ \\
\hline Variación genética & $\mathrm{V}$ & $\mathrm{V}$ & $\mathrm{V}$ & $\mathrm{V}$ \\
\hline
\end{tabular}

Tabla 6.6. Presencia de palabras clave en los planes de estudio

Los contenidos del darwinismo en los planes de estudio no son tan distintos, pero podemos ver algunas palabras que se presentaron en sus planes como la clave del contenido. España y Inglaterra incluyen "pruebas de la evolución" pero Estados Unidos y Corea del Sur no lo tienen escrito en sus planes. Solo España menciona "Evolución humana” y Corea del Sur es el único país que incluye "acervo génico" en su plan de estudio. Corea del Sur dedica una buena parte del plan a Genética, especialmente en la asignatura avanzada Biología II, e Inglaterra también la menciona pero no tanto como Corea.

6.3. Darwinismo en Libro de Texto. ¿Cómo aparece la Cultura Científica de España y Corea del Sur?

En el capítulo 5, se ha presentado MCC para analizar los contenidos. La unidad de la codificación es párrafo. Ilustraciones y tablas también se consideran como un párrafo. El número total de párrafos en los contenidos seleccionados es 2286.

Vamos a ver el resultado general de la codificación.

\begin{tabular}{|c|c|c|c|c|c|c|c|c|}
\hline \multirow{12}{*}{$\begin{array}{c}\text { TOTAL } \\
\text { PARRAFOS }\end{array}$} & \multirow[t]{12}{*}{2286} & \multirow[t]{8}{*}{ CIENCIA } & \multirow[t]{8}{*}{2340} & \multirow[t]{4}{*}{ INTRINSECA } & \multirow{2}{*}{\begin{tabular}{l|} 
TEXTO \\
IMAGEN \\
\end{tabular}} & \multirow{2}{*}{$\begin{array}{r}1665 \\
490\end{array}$} & \multirow{2}{*}{\begin{tabular}{l|} 
CINTR \\
CINTOP
\end{tabular}} & \multirow{2}{*}{$\begin{array}{r}1278 \\
378\end{array}$} \\
\hline & & & & & & & & \\
\hline & & & & & & & CINTVA & 9 \\
\hline & & & & & & & CINT_IM & 490 \\
\hline & & & & \multirow[t]{4}{*}{ EXTRINSECA } & TEXTO & 164 & CEXTR & 83 \\
\hline & & & & & IMAGEN & 21 & CEXTOP & 59 \\
\hline & & & & & & & CEXTVA & 22 \\
\hline & & & & & & & CEXT_IM & 21 \\
\hline & & \multirow[t]{2}{*}{ TECNOLOGIA } & \multirow[t]{2}{*}{16} & TECNO & TEXTO & 16 & & \\
\hline & & & & TECNO_IM & IMAGEN & 0 & & \\
\hline & & \multirow{2}{*}{$\begin{array}{c}\text { NO C. } \\
\text { CIENTÍFICA }\end{array}$} & \multirow[t]{2}{*}{9} & NOCC & TEXTO & 9 & & \\
\hline & & & & NOCC_IM & IMAGEN & 0 & & \\
\hline
\end{tabular}




\begin{tabular}{|l|l|c|lc|}
\hline & $\begin{array}{c}\text { TOTAL } \\
\text { CÓDIGOS }\end{array}$ & 2365 \\
\hline
\end{tabular}

Tabla 6.7. Sumario de las categorías de la codificación manual MCC

La tabla muestra la distribución de los códigos en los dos países. La siguiente tabla presenta el resultado de los contenidos españoles.

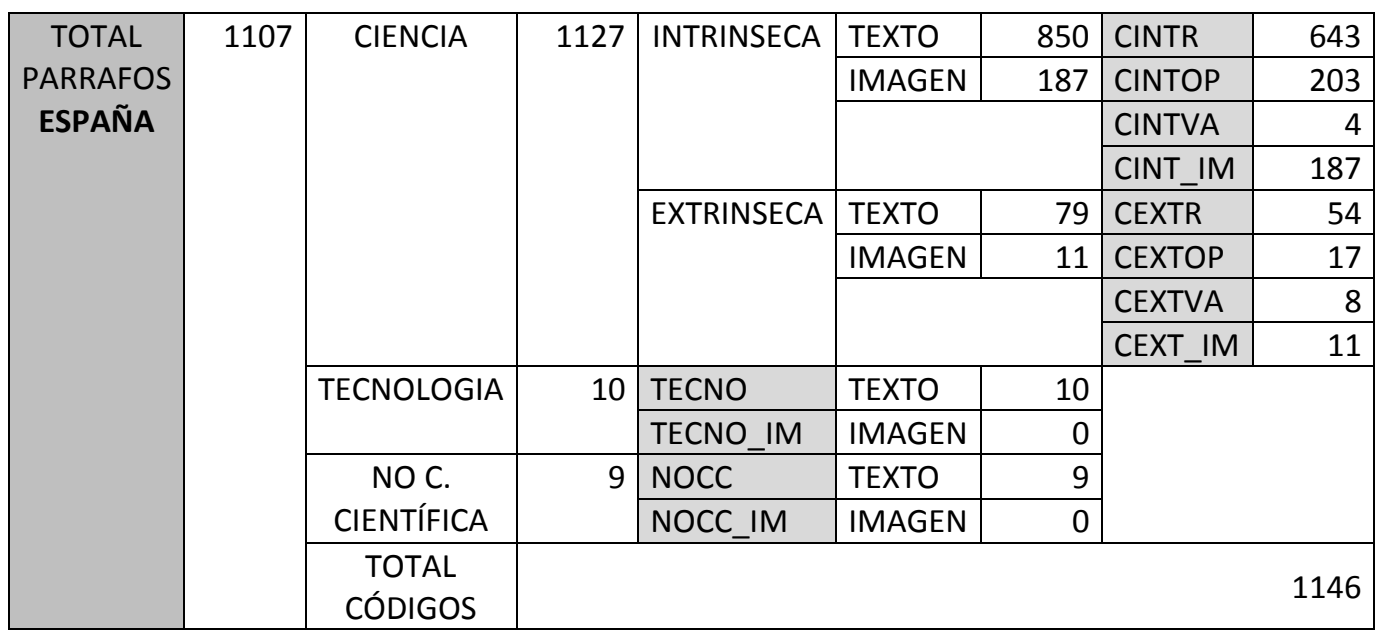

Tabla 6.8. Sumario de las categorías de la codificación manual MCC (ESPAÑA)

La siguiente tabla presenta el resultado de los contenidos surcoreanos.

\begin{tabular}{|c|c|c|c|c|c|c|c|c|}
\hline \multirow{12}{*}{$\begin{array}{c}\text { TOTAL } \\
\text { PARRAFOS } \\
\text { COREA S. }\end{array}$} & \multirow[t]{12}{*}{1179} & \multirow[t]{7}{*}{ CIENCIA } & \multirow[t]{7}{*}{1213} & \multirow[t]{3}{*}{ INTRINSECA } & $\begin{array}{l}\text { TEXTO } \\
\text { IMAGEN }\end{array}$ & $\begin{array}{l}815 \\
303\end{array}$ & $\begin{array}{l}\text { CINTR } \\
\text { CINTOP }\end{array}$ & $\begin{array}{l}635 \\
175\end{array}$ \\
\hline & & & & & & CINTVA & 5 \\
\hline & & & & & & & CINT_IM & 303 \\
\hline & & & & \multirow[t]{4}{*}{ EXTRINSECA } & TEXTO & 85 & CEXTR & 29 \\
\hline & & & & & IMAGEN & 10 & CEXTOP & 42 \\
\hline & & & & & & & CEXTVA & 14 \\
\hline & & & & & & & CEXT_IM & 10 \\
\hline & & \multirow[t]{2}{*}{ TECNOLOGIA } & \multirow[t]{2}{*}{6} & TECNO & TEXTO & 6 & & \\
\hline & & & & TECNO_IM & IMAGEN & 0 & & \\
\hline & & \multirow{2}{*}{$\begin{array}{c}\text { NO C. } \\
\text { CIENTÍFICA }\end{array}$} & \multirow[t]{2}{*}{0} & NOCC & TEXTO & 0 & & \\
\hline & & & & NOCC_IM & IMAGEN & 0 & & \\
\hline & & $\begin{array}{c}\text { TOTAL } \\
\text { CÓDIGOS }\end{array}$ & & & & & & 1219 \\
\hline
\end{tabular}

Tabla 6.9. Sumario de las categorías de la codificación manual MCC (COREA)

Los contenidos seleccionados de España ofrecen 1107 códigos y los coreanos generan 1179. Los detalles específicos de los códigos de estas tres tablas se describirán de forma gradual. La siguiente tabla muestra el resultado de la codificación de los párrafos de textos excepto imágenes.

\begin{tabular}{|l|l|l|} 
4을O (ESP) & 1ㅇachillerato (KOR) & 3ㅇ B (KOR) \\
\hline
\end{tabular}




\begin{tabular}{|l|r|r|r|r|r|r|r|r|r|r|}
\hline & AN & \multicolumn{1}{|c|}{ ED } & \multicolumn{1}{c|}{ SA } & \multicolumn{1}{l|}{ SM } & \multicolumn{1}{c|}{ CJ } & \multicolumn{1}{c|}{ KS } & \multicolumn{1}{c|}{ SS } & \multicolumn{1}{c|}{ TT } & BS & CJ3 \\
\hline CINTR & 167 & 166 & 183 & 127 & 58 & 50 & 62 & 77 & 226 & 162 \\
\hline CINTOP & 44 & 57 & 37 & 65 & 27 & 14 & 13 & 18 & 60 & 43 \\
\hline CINTVA & 1 & 2 & 0 & 1 & 2 & 1 & 0 & 1 & 1 & 0 \\
\hline CEXTR & 7 & 21 & 14 & 12 & 4 & 2 & 3 & 9 & 9 & 2 \\
\hline CEXTOP & 1 & 6 & 6 & 4 & 10 & 6 & 13 & 4 & 8 & 1 \\
\hline CEXTVA & 0 & 4 & 4 & 0 & 8 & 2 & 1 & 2 & 1 & 0 \\
\hline TECNO & 6 & 2 & 2 & 0 & 0 & 0 & 0 & 2 & 4 & 0 \\
\hline NoCC & 2 & 6 & 0 & 1 & 0 & 0 & 0 & 0 & 0 & 0 \\
\hline № pp. & 222 & 248 & 239 & 202 & 97 & 71 & 91 & 110 & 301 & 196 \\
\hline
\end{tabular}

Tabla 6.10. Resultados de la codificación de los párrafos textual en libros de texto

Podemos observar la extensión de los contenidos a través de los números totales de párrafos de textos. En Corea del Sur, el darwinismo ocupa menos espacios en los libros del primer curso de Bachillerato que los del tercer curso. Los dos libros de Biología II de Corea y los cuatro libros de Biología y Geología de España dedican al darwinismo más textos.

\begin{tabular}{|l|r|r|}
\hline & ESPAÑA & COREA \\
\hline CINTR & 643 & 635 \\
\hline CINTOP & 203 & 175 \\
\hline CINTVA & 4 & 5 \\
\hline CEXTR & 54 & 29 \\
\hline CEXTOP & 17 & 42 \\
\hline CEXTVA & 8 & 14 \\
\hline TECNO & 10 & 6 \\
\hline NoCC & 9 & 0 \\
\hline № pp. & 911 & 866 \\
\hline
\end{tabular}

Tabla 6.11. Los códigos de MCC. Por país

Para comparar España y Corea, sumamos los datos por país y obtenemos la tabla 6.10. Convertimos los datos a porcentaje y expresamos como gráfico. 


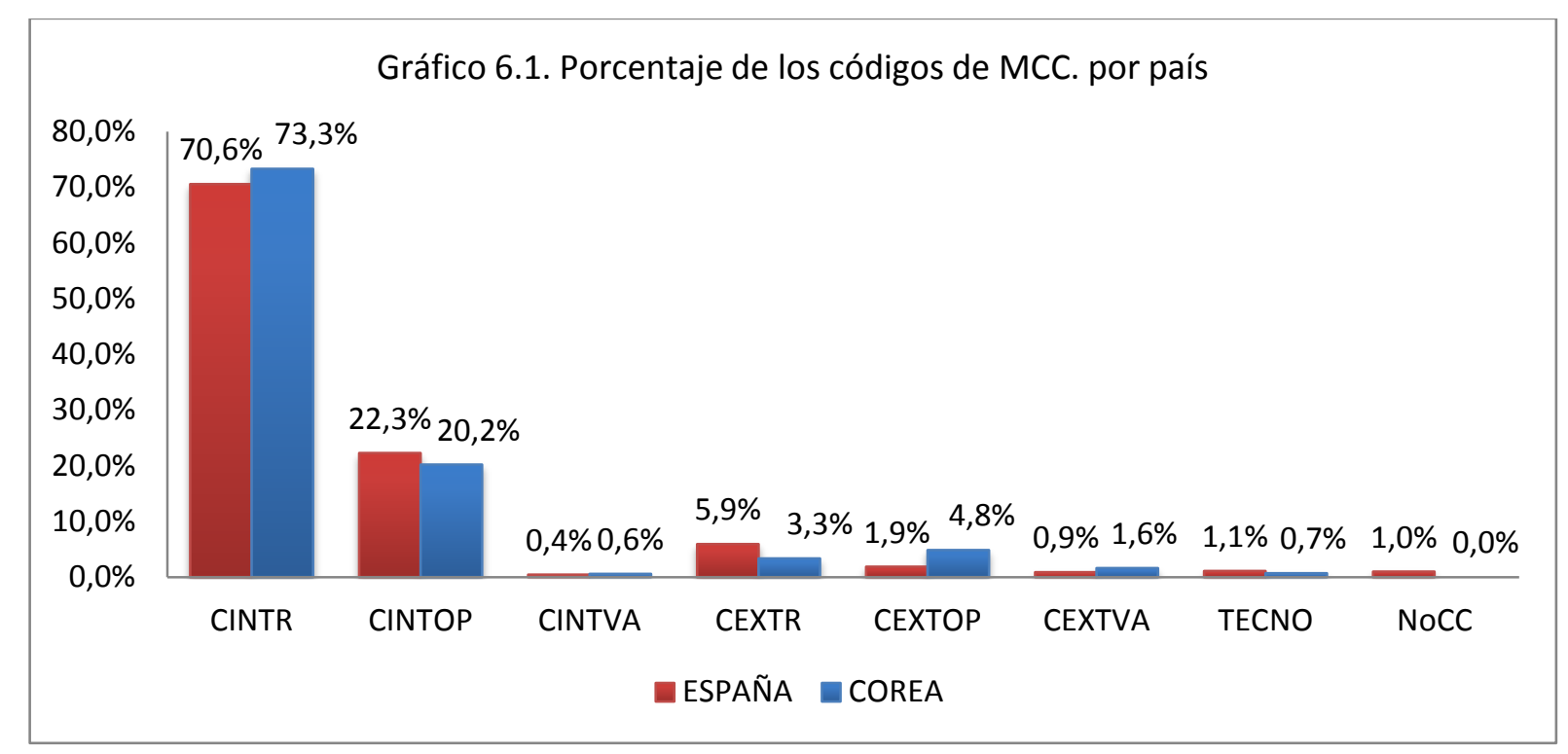

En este gráfico no podemos encontrar gran contraste entre España y Corea del Sur. No se detecta gran diferencia a través de MCC entre los contenidos sobre el darwinismo en libros de texto de los dos países, aunque los dos países son muy lejanos uno a otro y tienen culturas considerablemente diferentes.

Es natural que la mayoría de los contenidos sea intrínseca, porque los contenidos se seleccionaron por la teoría científica, 'el evolucionismo de Darwin' y son textos didácticos.

\begin{tabular}{|l|r|r|}
\hline & ESPAÑA & \multicolumn{1}{|c|}{ COREA } \\
\hline INTRÍNSECO & 850 & 815 \\
\hline EXTRÍNSECO & 79 & 85 \\
\hline TECNO & 10 & 6 \\
\hline NoCC & 9 & 0 \\
\hline № pp. & 911 & 866 \\
\hline
\end{tabular}

Tabla 6.12. Las categorías de MCC. Por país

Podemos ver en la tabla 6.11 el alto porcentaje de las informaciones intrínsecas en los contenidos. Convertimos los datos a porcentaje y expresamos como gráfico. 


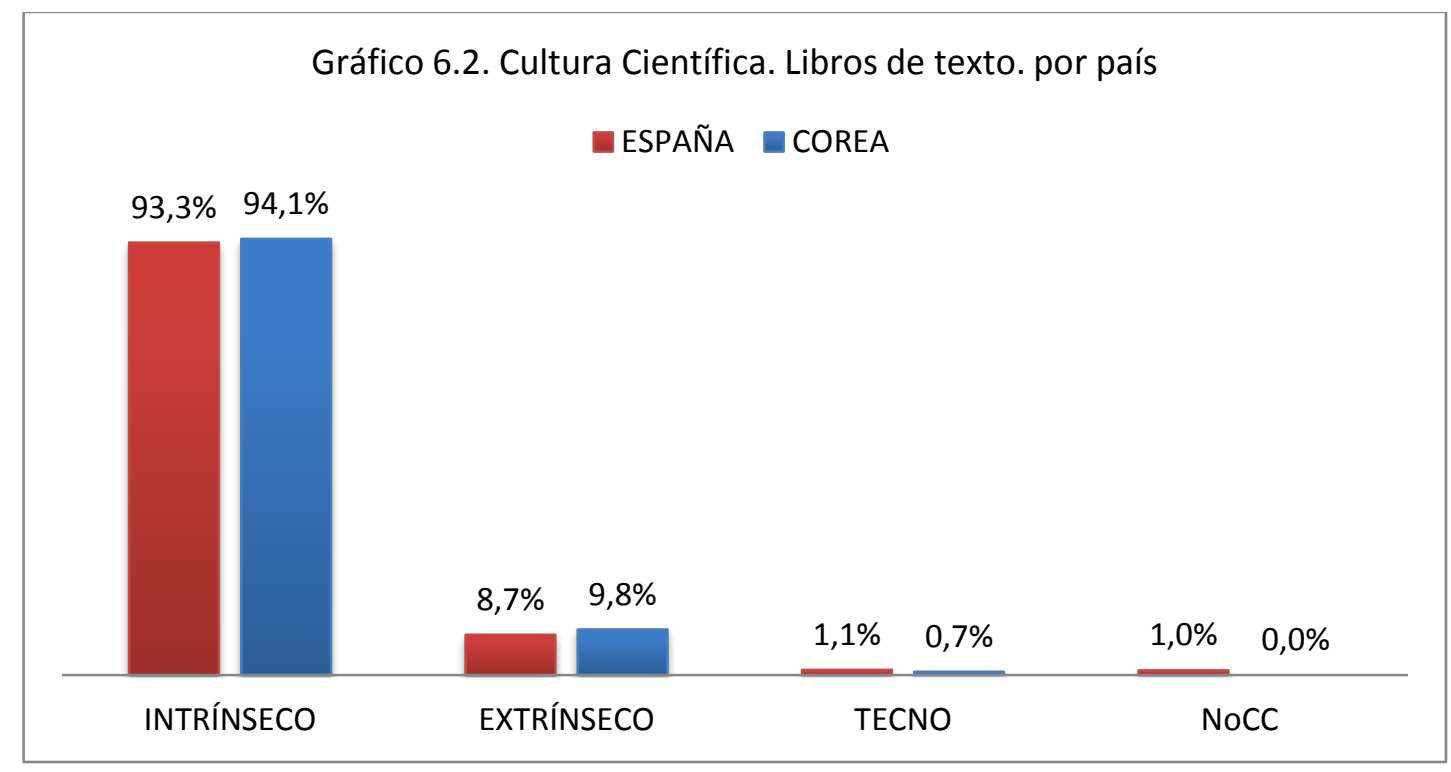

En cada categoría, los dos países poseen porcentajes similares. La distribución de las informaciones didácticas no varía mucho en los dos países que investigamos.

Ahora vamos a ver ejemplos concretos de cada código e intentaremos detectar algunos factores culturales en ellos. Las informaciones intrínsecas transmiten conocimientos científicos y las extrínsecas implican más aspectos sociales. Por lo tanto, suponemos que en las extrínsecas podemos detectar algún carácter de la sociedad y en las intrínsecas podemos percibir qué y cómo transmitir.

\section{Informaciones de Cultura Científica Intrínseca}

Como podemos observar en el gráfico 6.2, 93,3\% de los contenidos españoles es informaciones intrínsecas. El porcentaje de Corea del Sur es $94,1 \%$ y muy similar con lo de España. Los altos porcentajes de la cultura intrínseca son por el carácter del texto, ya que su propósito es muy claro, que es enseñar el darwinismo. Como hemos mencionado, la información intrínseca se puede clasificar entre la representacional, la operacional y la valorativa. 


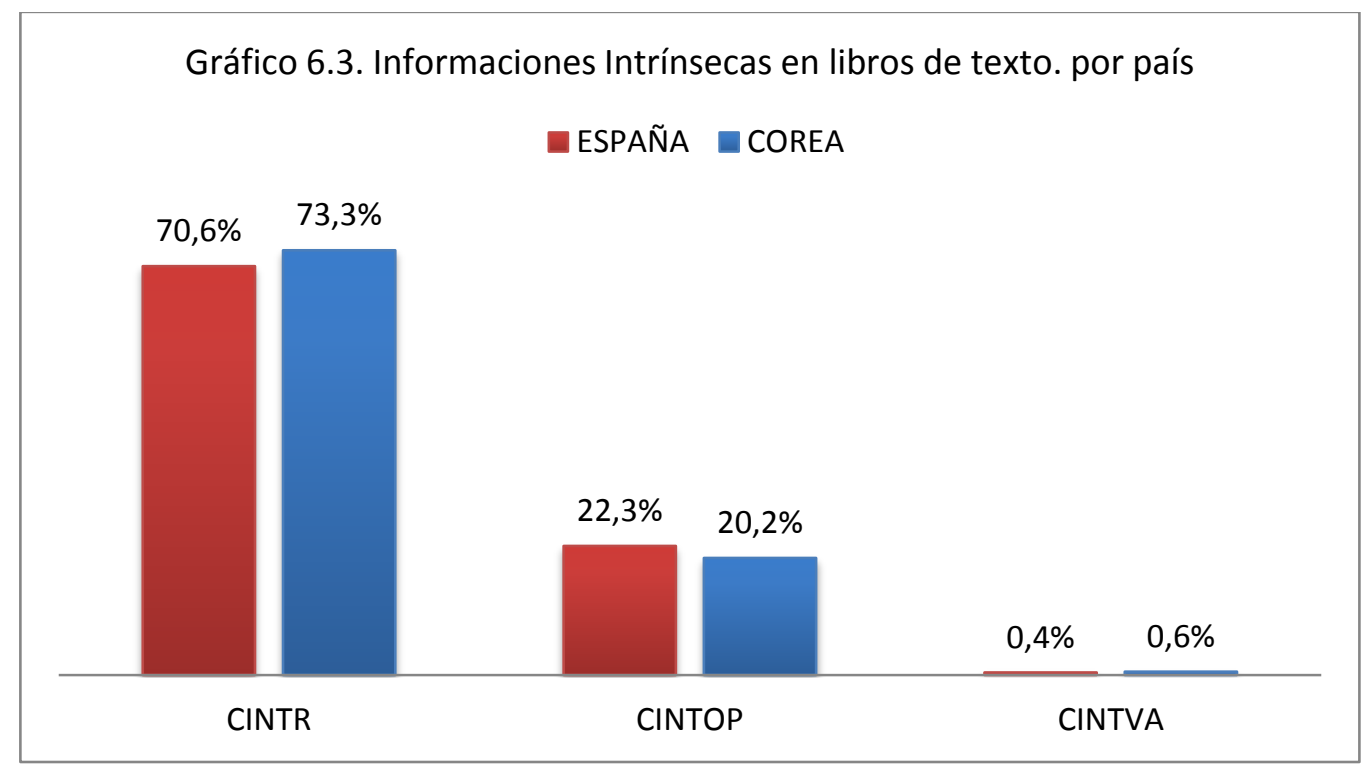

Las proporciones en el gráfico 6.3 son por todos los párrafos de textos. El código que ocupa La información que ocupa la mayor proporción es de Cultura científica intrínseca representacional (CINTR). Los párrafos que explican la teoría como los siguientes.

진화에 의해 새로운 종이 생성되어 지구에는 수많은 생물종이 나타나게 되었고, 오 늘날 지구에 생존하는 것으로 밝혀진 생물종 수만도 약 170 만 종에 이른다. 이런 다 양한 생물은 현재도 진화하고 있어 먼훗날의 생물종은 현재와는 다른 모습으로 될 것이다. [Gracias a la evolución, en la Tierra han surgido numerosas especies, los seres actuales llega a unos 1.700 mil especies hoy en día. Estas varias especies siguen evolucionando aun ahora, los seres futuros tendrán figuras diferentes de las actuales.] (COREA_CHUNJAE (1B): 198)

지구에 최초의 생명체가 출현한 순간부터 오늘날까지 너무 많은 시간이 흘렀기 때문 에 초기 생명체의 흔적을 찾는 것은 매우 어렵다. 하지만 진화는 지금도 진행되고 있으며 다양한 진화의 증거가 발견되고 있다. 현재까지 발견된 진화의 증거에는 어 떤 것이 있는지 알아보자. [Como hace muchísimo tiempo que surgió el primer ser vivo en la Tierra, es muy difícil hallar huellas de los seres iniciales. Sin embargo, la evolución sigue actuando y se están descubriendo sus varias evidencias. Vamos a ver las evidencias halladas hasta ahora.] (COREA_BISANG (3B): 226)

Los distintos animales domésticos proceden siempre de una única especie salvaje original. La selección artificial hace que los animales domésticos estén peor adaptados a las condiciones ambientales que los salvajes, por lo que estos animales estarían desfavorecidos en un ambiente natural. (ESPAÑA_ANAYA (4E): 93) 
La evolución ha originado la enorme diversidad de especies que hay en nuestro planeta. Todas ellas provienen de otras ya existentes. Así mismo, las especies actuales darán lugar a otras distintas en el futuro. (ESPAÑA_SANTILLANA (4E): 76)

En cuanto al darwinismo hay pocos aspectos sobre los que se pueden realizar experimentos en el aula, ya que la evolución es un proceso muy lento para observar en corto plazo. Por lo tanto, en los contenidos de los libros de texto, no podemos detectar muchas informaciones operacionales. Una de las pocas opciones es ensayar mecanismos de la evolución con algunos sustitutivos. Los libros de 'Ciencias (1B)' de Corea que no incluyen ningún experimento. Los dos libros avanzados de Corea incluyen un experimento simple con las canicas sobre el fenómeno del "cuello de botella" para explicar el principio de la deriva genética. Son ejemplos de información operacional de la cultura científica intrínseca. Veamos ejemplos de Cultura Científica Intrínseca Operacional (CINTOP):

병 속의 구슬 색깔은 집단을 이루는 개체의 형질을 나타낸 것이고, 좁은 병목은 환경의 급격한 변화를 의미한다. 병목을 통과하기 전의 기존집단과 통과한 후 살아남은 집단의 구슬 색깔의 비율은 어떻게 다른가? [El color de las canicas significa un carácter de cada individuo del grupo y el cuello de botella representa el cambio repentino del medio. ¿Cómo varia la tasa de los colores antes y después de pasar el cuello de botella?] (COREA_BISANG (3B), p. 292)

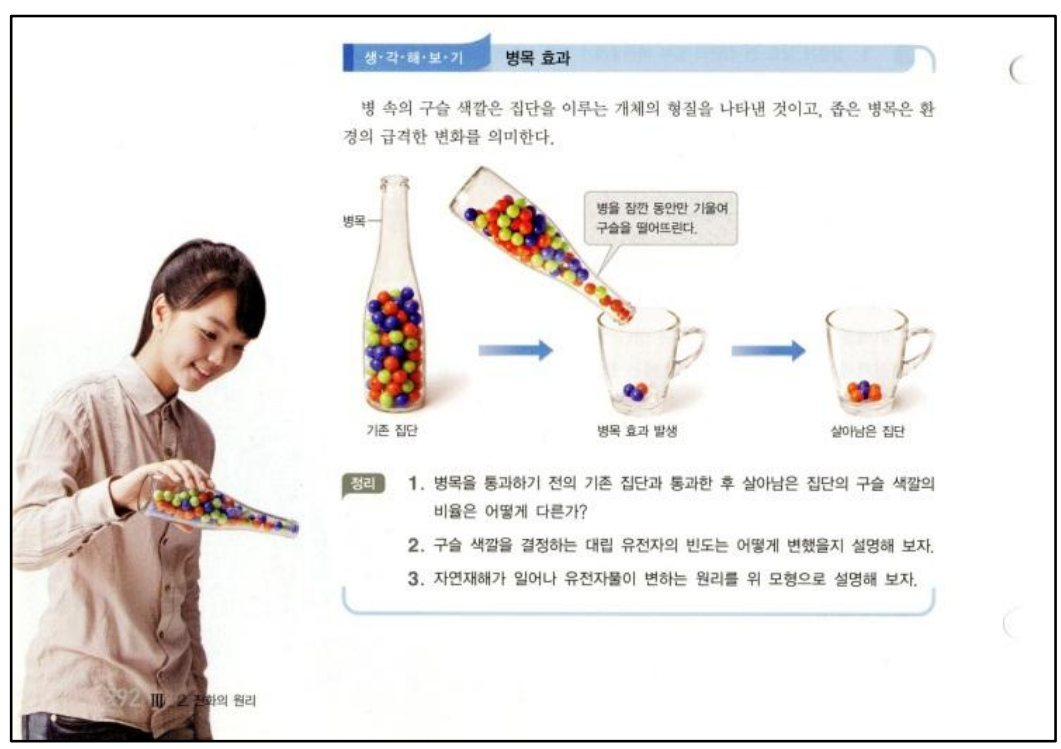

Ilustración 6.1. Experimento sobre 'Efecto de Cuello de Botella' (COREA_BISANG (3B): 292)

비커에 대립 유전자를 가정한 빨간색 구슬 60 개와 파란색 구슬 40 개를 넣고 잘 섞은 
후 목이 좁은 플라스틱 병에 함께 넣는다. 병을 비커에 1 회 털었을 때 빠저 나온 구슬의 수와 10 회 털었을 때 빠져 나온 구슬의 수를 세고, 빠져 나온 구슬의 빈도를 각각 계산한다. [Ponemos en un vaso sesenta canicas rojas y cuarenta azules que simbolizan un alelo, mezclamos bien y los ponemos en una botella plástica del cuello estrecho. Contamos las canicas salidas después de inclinar la botella una vez y diez veces y calculamos cada tasa de las canicas salidas.] (COREA_CHUNJAE (3B): 240)

Entre los libros españoles, SM incluye un experimento en el final del capítulo de la evolución. Es un experimento simple para entender el principio de la selección natural.

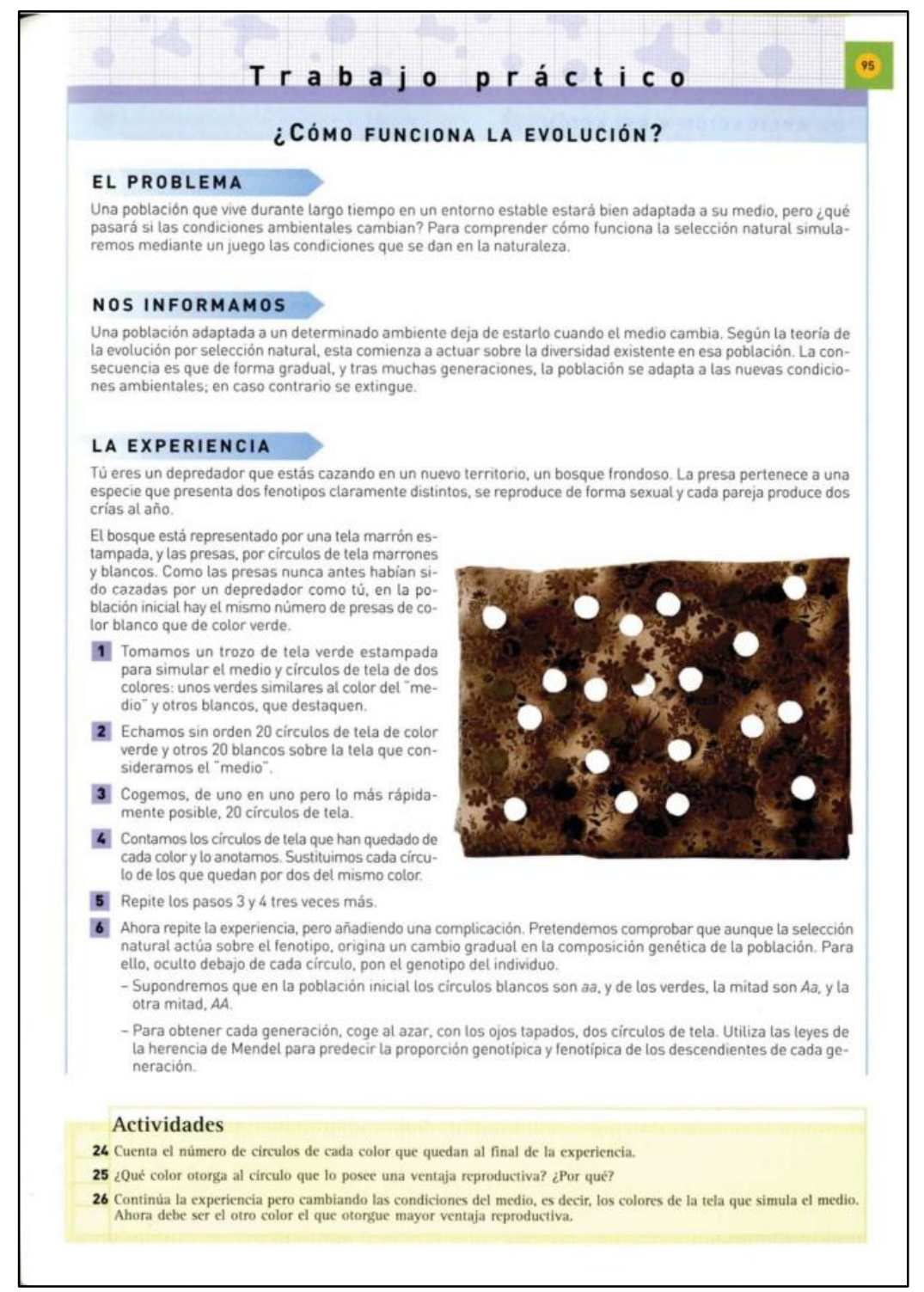

Ilustración 6.2. Experimento sobre el proceso de la selección natural (ESPAÑA_SM (4E): 95)

Tomamos un trozo de tela verde estampada para simular el medio y círculos de tela de dos 
colores: unos verdes similares al color del "medio" y otros blancos, que destaquen. Echamos sin orden 20 círculos de tela de color verde y otros 20 blancos sobre la tela que consideramos el "medio". (ESPAÑA_SM (4E): 95)

Además de los experimentos, si el texto explica el proceso de 'hacer ciencia' (es decir, el 'método científico'), también se codifica como CINTOP.

Terminada la expedición, Darwin trabajó durante años organizado todos los tatos y notas que había recogido durante el viaje y comenzó a elaborar su revolucionaria teoría. (ESPAÑA_SANTILLANA (4E):73)

그는 남미 에콰도르의 서쪽 $650 \mathrm{~km}$ 떨어진 갈라파고스 군도에서 각 섬마다 핀치들의 모양에 조금씩 차이가 있으며, 이들이 다른 먹이를 먹고 사는 것을 관찰하였다. [(Darwin) Observó en el archipiélago Galápagos, que está 650 kilómetros de distancia desde Ecuador en Sudamérica, los pinzones tenían apariencias diferentes y comían alimentos distintos dependiendo de la isla en la que viven.](COREA_KUMSUNG (1B): 180)

1831년 다윈은 비글호를 타고 5년간 항해하면서 세계 각지의 생물상과 화석을 관찰 하였다. 그는 조사 지역마다 독특한 생물이 살고 있으며 같은 종에 속하는 생물이라 도 개체 사이에 변이가 존재한다는 사실을 발견하였다. [En el año 1831, Darwin empezó a viajar en el barco Beagle. Durante los 5 años del viaje, observó faunas, floras y fósiles del mundo. Descubrió que cada zona tiene sus seres vivos peculiares y entre los individuos que pertenecen en una misma especie también existen variaciones.] (COREA_CHUNJAE (3B): 236)

Normalmente los capítulos de los libros de texto de las disciplinas científicas llevan actividades o autoevaluación en su final para ayudar a los alumnos que piensen científicamente. A través de estas actividades, los alumnos pueden aprender métodos científicos y reglas y normas de la ciencia, por eso también son intrínseca operacional (CINTOP).

사람은 현재 먹이 사슬의 최종 위치에 존재하면서 지구를 지배하고 있다. 그렇다면 진화의 관점에서 사람은 다른 종에 비해 가장 우월한 종으로 볼 수 있을까? 우월한 능력과 생존 가능성에 대하여 생각해 보고, 진화란 무엇인지 토론해 보자. [El ser humano ejerce el dominio sobre la Tierra como el último consumidor de la cadena alimenticia. Entonces, desde el punto de vista evolucionista, ¿el ser humano es la especie más superior del mundo? Pensemos la capacidad superior y la posibilidad de supervivencia y discutamos qué es 
la evolución.] (COREA_THETEXT (1B):223)

생물 대멸종 원인에 대한 다음 두 가지 가설의 근거를 조사해 보고, 과학적 타당성 에 대해 토론해 보자. 가설1: 중생대 말에 커다란 운석 또는 혜성이나 소행성 등이 지구에 떨어져 생물 대멸종이 일어났다. 가설2: 생물 대멸종의 주요 원인은 지구의 기후가 크게 변했기 때문이다. [Investiguemos los fundamentos de las dos hipótesis sobre la extinción masiva y discutamos su validez científica. Hipótesis 1: Al final la era mesozoica un meteorito grande, una cometa o una planeta menor se cayó a la Tierra y provocó la extinción masiva. Hipótesis 2: La causa principal de la extinción masiva es el clima de la Tierra cambió bruscamente.](COREA_SANGSANG (1B):162)

Busca información sobre otros casos de mimetismo diferentes a los tratados en el texto y redacta un informe. (ESPAÑA_ANAYA (4E): 109)

Define especie. ¿Crees que el orangután y el chimpancé pertenecen a la misma especie? Argumenta tu respuesta. (ESPAÑA_EDELVIVES (4E): 53)

Los dos países no incluyeron muchas informaciones intrínsecas valorativas (CINTVA). España solo tiene 4 párrafos $(0,4 \%)$ y Corea 5 párrafos $(0,5 \%)$. Veamos ejemplos del código.

진화에 관해 다윈이 뛰어난 이론을 제시하고 맣은 연구를 한 것은 사실이지만, 평생 세계의 오지를 다니며 현장 생물학자로 산 월리스의 공적 역시 다윈의 업적과 함께 높이 평가되고 기억되어야 할 것이다. [Es cierto que Darwin propuso la teoría extraordinaria y realizó muchos estudios, pero también se debe apreciar y recordar el estudio de Wallace que vivió toda la vida como biólogo en campo natural observando en rincones del mundo.] (COREA_CHUNJAE (1B): 224)

Las islas Galápagos ofrecieron a Darwin un espectáculo de valor incalculable para el futuro. (ESPAÑA_EDELVIVES (4E): 49)

La cultura científica intrínseca ocupa más del 93\% en los dos países, debido a que los contenidos se dirigen a enseñar el darwinismo dentro del sistema educativo. En los tres códigos de la cultura intrínseca (CINTR, CINTOP y CINVA), no se detecta mucha diferencia entre España y Corea del Sur. 


\section{Informaciones de Cultura Científica Extrínseca}

Entre los contenidos seleccionados de libros de texto para este estudio, las informaciones de Cultura Científica Extrínseca son 8,3\% de los contenidos españoles y 9,4\% de los coreanos.

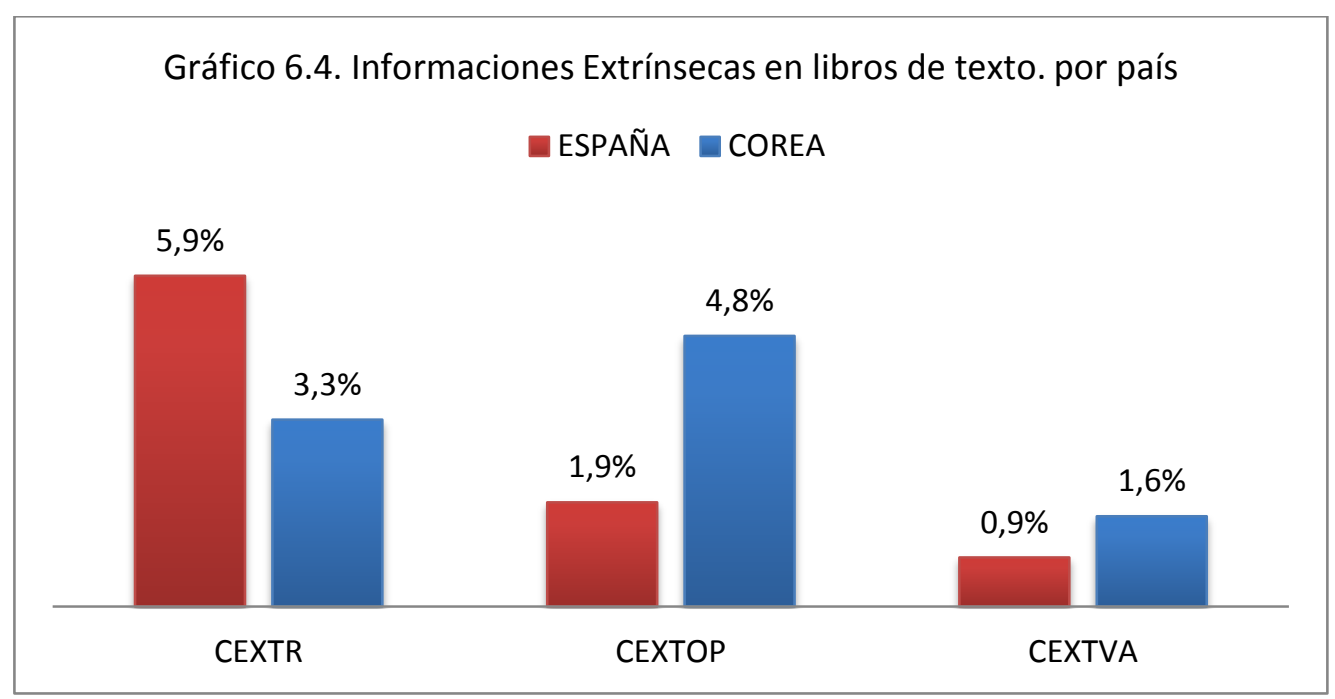

Las informaciones de Cultura Científica Extrínseca no llegan al 10\% en los dos países ya que los contenidos seleccionados son de libros de texto, por lo tanto los autores deben seguir el plan nacional (o regional) en redactar.

CEXTR, Cultura Científica Extrínseca Representacional ocupa el 5,7\% de los contenidos españoles y el 3,2\% de los coreanos. En los párrafos codificados por este componente podemos ver las imágenes hacia la ciencia de la sociedad.

En la Antigüedad se mezclaba ideas mitológicas y religiosas para ofrecer una explicación al origen y la diversidad de los seres vivos que existen en la Tierra. (ESPAÑA_EDELVIVES (4E): 42)

"La Biblia nos habla del origen del universo y sus componentes, no con el propósito de enunciar un tratado científico, sino en orden a establecer las relaciones apropiadas del hombre con Dios y con el universo.". Juan XXIII, 1961. (ESPAÑA_SM (4E): 82)

책이 출간된 후 그의 진화론은 대토론을 거쳐서 학자들 사이에서는 판정승을 거두었으나 사회 전체의 통념을 바꾸기까지는 상당한 기간이 걸렸으며 오늘날에도 그의 이론을 믿지 않는 사람들이 상당수 있다. [Después la publicación del libro, su teoría de la evolución sufrió un debate enorme y logró la victoria por puntos en el campo académico, pero tardó mucho tiempo en cambiar la idea común de la sociedad. Hoy en día todavía hay 
gente que no cree su teoría. ] (COREA_KUMSUNG (1B):180)

공상 과학 영화나 소설을 보면 지구의 종말을 다루는 내용이 많이 나온다. '투모로우 (2004)라는 영화에서는 급격한 지구 온난화로 북극의 빙하가 녹가 바닷물의 순환이 약해지면서 북미 대륙 전체가 빙하로 뒤덮이다는 내용이 나온다. [El fin del mundo es uno de los temas más frecuentes en las películas y las novelas de la ciencia ficción. En la película 'El día de mañana', el continente entero de la América del Norte cubre por el glaciar, porque el calentamiento global deshiela el glaciar del Polo Norte y no circula bien el agua del mar.] (COREA_THETEXT (1B):202)

Corea del Sur tiene 4,6\% de CEXTOP, Cultura Científica Extrínseca Operacional. Mientras que España alcanza una cifra menor, un 1,8\%. Los párrafos que muestran normas o reglas de comportamiento de la época o el interés en la ciencia (Quintanilla, 2006:6).

El libro ocasionó tal polémica, que los 1.250 ejemplares de la primera edición se agotaron en pocas horas. (ESPAÑA_SANTILLANA (4E):73)

다윈의 진화론이 정치, 경제, 사회, 문화, 철학 등 다른 학문 분야에 영향을 끼친 구체적인 사례를 찾아 조사해보고 토론해 보자. [Investiguemos y discutamos los casos específicos que el darwinismo influyo en otras disciplinas como la política, la economía, la sociología, la cultura y la filosofía.](COREA_CHUNJAE (1B): 201)

"종의 기원" 출간 당시 영국 사회를 지배하던 것은 종교 개혁 결과 성립된 교회인 국교회였는데, 국교회에서는 모든 만물이 신에 의해 창조되었다고 보았으며, 처음 모습 그대로 변하지 앟았다고 하였다. 이 때문에 다윈의 진화론은 당시 종교계에 큰 반발을 가져왔다. 또한 다윈의 진화론은 부자연스러운 독점과 특권을 타파하려는 개혁적인 중간 계급의 사회적,정치적 논리로도 이용되었다. [La iglesia anglicana, que se construyó por la Reforma, dominaba a la sociedad británica cuando Darwin publicó el libro “El origen de las especies". Según la iglesia, Dios creó todos los seres y ellos mantienen su forma sin cambio hasta ahora. Por ello, la comunidad religiosa desechó el evolucionismo de Darwin. Además, su teoría se utilizó como lógica de la clase media reformista que quería destruir privilegios y monopolizaciones.] (COREA_SANGSANG (1B):175)

A través de las informaciones de Cultura Científica Extrínseca Valorativa, CEXTVA, podemos saber evaluaciones y actitudes hacia el darwinismo en las dos sociedades. 
CHUNJAE (1B) tiene más párrafos de CEXTVA que otros libros. Ya hemos visto en el plan de estudio de Corea (Tabla 6.3.) la actividad 1 de la asignatura 'Ciencias' que recomienda que "investiguen y discuten sobre la influencia del Darwinismo en la ciencia y la sociedad." (Ministerio de Educación, Ciencia y Tecnología de Corea del Sur, 2011: 62) y solamente CHUNJAE (1B) incluyó la actividad del plan nacional de estudio. La ilustración siguiente es la imagen de la página.

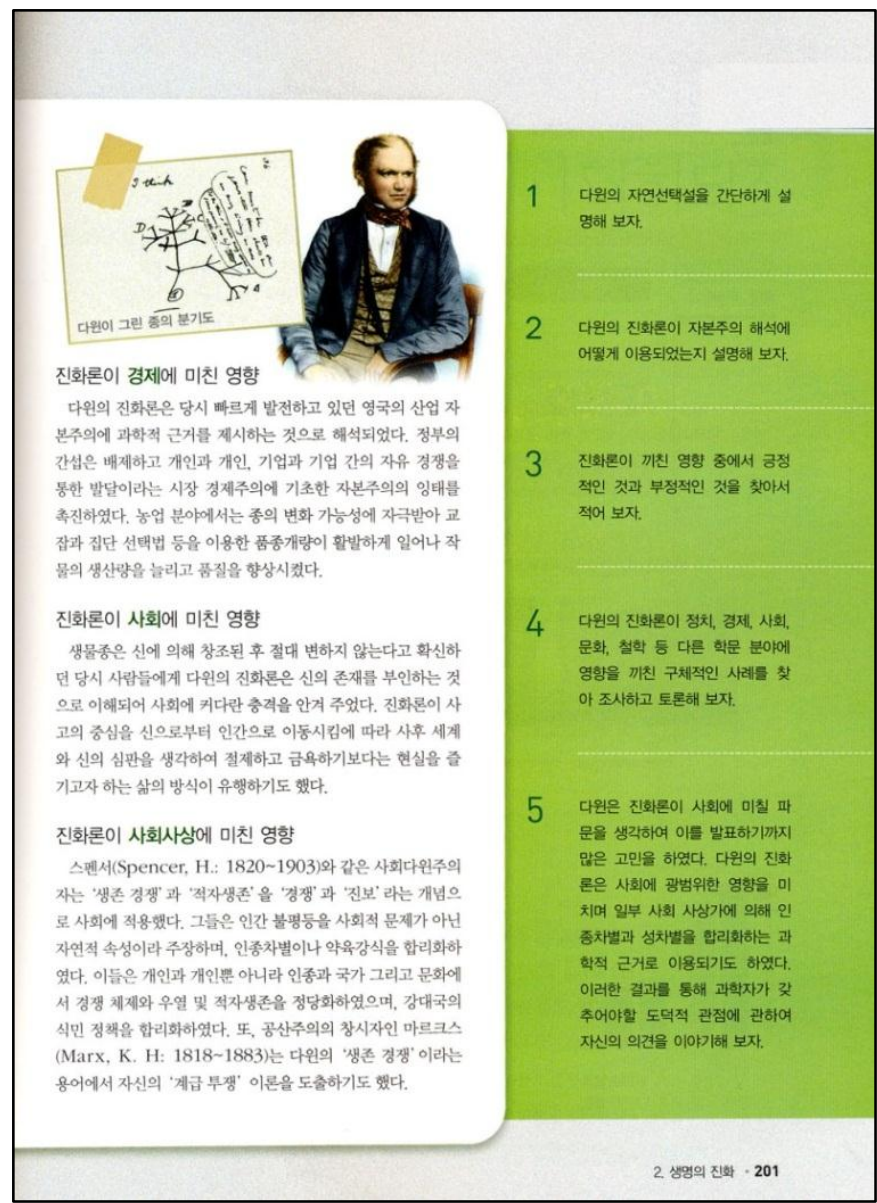

Ilustración 6.3. El darwinismo y la sociedad (COREA_CHUNJAE (1B): 201)

다윈의 진화론은 과학분 아니라 철학이나 경제에 이르기가지 사회의 여러 분야에
영향을 미쳤다. 진화론이 인류 문명에 끼친 영향에는 어떤 것이 있을까? [El evolucionismo de Darwin influyo en varias áreas de la sociedad, no solo en la ciencia sino en la filosofía y la economía también. ¿Cómo afectó el darwinismo a la cultura humana?] (COREA_CHUNJAE (1B): 200)

진화론이 끼친 영향 중에서 긍정적인 것과 부정적인 것을 찾아서 적어 보자. [Entre las influencias del evolucionismo, apuntamos las positivas y negativas.] (COREA_CHUNJAE (1B): 
Estos dos párrafos son actividades para que los alumnos piensen la influencia del darwinismo en la sociedad. Aunque en las frases no están incluidas valoraciones positivas ni negativas, ya piden las evaluaciones de los alumnos sobre la influencia del darwinismo. Además, la misma página acompaña con los párrafos siguientes que pueden provocar imágenes negativas sobre el darwinismo.

스펜서(Spencer, H. : 1820-1903)와 같은 사회다윈주의자는 '생존경쟁'과 '적자생존'을 '경쟁'과 '진보'라는 개념으로 사회에 적용했다. 그들은 인간 불평등을 사회적 문제가 아닌 자연적 속성이라 주장하며, 인종차별이나 약육강식을 합리화하였다. 이들은 개인과 개인뿐 아니라 인종과 국가 그리고 문화에서 경쟁 체제와 우열 및 적자생존을 정당화하였으며, 강대국의 식민 정책을 합리화하였다. [Los darwinistas sociales como H. Spencer (1820-1903) aplicaron 'lucha por supervivencia' y 'supervivencia de los más aptos' del darwinismo a la sociedad a través de los conceptos de 'competencia' y 'progreso'. Insistieron en que la desigualdad entre individuos del ser humano no era un problema social sino natural. Y racionalizaron la discriminación racial y la ley de la selva. Además, justificaron el sistema competitivo, superioridad e inferioridad y la supervivencia de los más aptos no solo entre los individuos, sino también entre las razas, los países y las culturas, e hicieron razonable el colonialismo de los países potentes.] (COREA_CHUNJAE (1B): 201.)

다윈은 진화론이 사회에 미칠 파문을 생각하여 이를 발표하기까지 많은 고민을 하였다. 다윈의 진화론은 사회에 광범위한 영향을 미치며 일부 사회 사상가에 의해 인종차별과 성차별을 합리화하는 과학적 근거로 이용되기도 하였다. 이러한 결과를 통해 과학자가 갖추어야 할 도덕적 관점에 관하여 자신의 의견을 이야기해 보자. [Antes de presentar su teoría, Darwin sabía que su pensamiento provocaría polémica social y se lo preocupaba seriamente. El darwinismo afectó ampliamente a la comunidad y algunos pensadores sociales lo utilizaron como una base científica para justificar el racismo y el sexismo. Con esta consecuencia, presenta tu opinión sobre la ética que los científicos deben tener.] (COREA_CHUNJAE (1B): 201)

Estos dos párrafos muestran los fenómenos sociales negativos que tenían relaciones directas e indirectas con el darwinismo social o biológico. A pesar de que ampliar la perspectiva hacia la relación entre la sociedad y la ciencia es muy recomendable, presentar los fenómenos sin 
explicar la situación socio-política de la época, solamente puede causar malas imágenes sobre el darwinismo.

A continuación, veamos los ejemplos españoles de CEXTVA.

Las ideas de Darwin (A) y Wallace (B) causaron una revolución social tan importante, que el mismo día en el que se publicó El origen de las especies se agotaron todos los ejemplares. (ESPAÑA_SANTILLANA (4E):78)

El siguiente titular se publicó en el diario El Mundo el 10 de mayo de 2007: «Dios contra Darwin; el museo del creacionismo explica "científicamente" que Dios creó el mundo en seis días." Debatid en clase sobre si es adecuado abrir un museo que explique la evolución desde un punto de vista creacionista. (ESPAÑA_EDELVIVES (4E): 59)

En el primer párrafo, SANTILLANA (4E: 78) explica que el darwinismo causó "una revolución social tan importante". Es interesante que no sea 'revolución científica' sino 'social'. En el segundo párrafo en EDELVIVES, se presenta una actividad para evaluar y discutir sobre el asunto polémico.

Es difícil encontrar los párrafos de Cultura Tecnológica, TECNO y No Cultura Científica, NoCC, debido a que los contenidos que se tratan en este capítulo son de libros de texto de Ciencias Naturales. Solo 10 párrafos españoles $(1,1 \%)$ y 6 coreanos $(0,7 \%)$ incluyen la cultura tecnológica. La mayoría de ellos es para recomendar algún enlace de página web o CD-ROM como un suplemento.

En tu CD-ROM: Puedes consultar la simulación titulada: Los cráneos de los homínidos. Tras su visionado, haz un resumen de lo que has observado. (ESPAÑA_ANAYA (4E): 104)

준비물: 인터넷 검색을 할 수 있는 컴퓨터, 필기구 [Materiales necesarios: Un ordenador con acceso a Internet, instrumentos de escritura] (COREA_THETEXT (1B):220)

No localizamos ningún párrafo coreano de No Cultura Científica, NoCC. España tiene solo 9 párrafos $(0,9 \%)$.

Imágenes 
A continuación, veremos el análisis de las imágenes en los libros de texto seleccionados. Una imagen se codifica por su contexto o texto asociado, debido a que los libros de texto incluyen las imágenes generalmente para ayudar la comprensión de los contenidos. Como los párrafos de textos, puede tener más de un código. Codificamos en cuatro categorías, Imagen de Cultura Intrínseca (CINT_IM), de Cultura Extrínseca (CEXT_IM), de Cultura Tecnológica (TECNO_IM) y de No Cultura Científica (NoCC_IM). No clasificamos en la representacional, la operacional y la valorativa, porque a menudo las imágenes no transmiten informaciones suficientes para aplicarlas.

\begin{tabular}{|c|c|c|c|c|c|c|c|c|c|c|}
\hline & \multicolumn{4}{|c|}{ 4으SO (ESP) } & \multicolumn{4}{|c|}{ 1ㅇachillerato (KOR) } & \multicolumn{2}{|c|}{$3 \circ \mathrm{B}(\mathrm{KOR})$} \\
\hline & AN & ED & SA & SM & CJ & KS & SS & TT & BS & $\mathrm{CJ} 2$ \\
\hline CINT_IM & 34 & 35 & 62 & 56 & 37 & 35 & 18 & 15 & 123 & 75 \\
\hline CEXT_IM & 1 & 5 & 4 & 1 & 2 & 0 & 3 & 1 & 4 & 0 \\
\hline TECNO_IM & 0 & 0 & 0 & 0 & 0 & 0 & 0 & 0 & 0 & 0 \\
\hline NoCC_IM & 0 & 0 & 0 & 0 & 0 & 0 & 0 & 0 & 0 & 0 \\
\hline № imágenes & 34 & 40 & 65 & 57 & 39 & 35 & 21 & 16 & 127 & 75 \\
\hline
\end{tabular}

Tabla 6.13. Resultados de la codificación de las imágenes en libros de texto

\begin{tabular}{|l|r|r|}
\hline & ESPAÑA & \multicolumn{1}{|c|}{ COREA } \\
\hline CINT_IM & 187 & 303 \\
\hline CEXT_IM & 11 & 10 \\
\hline TECNO_IM & 0 & 0 \\
\hline NoCC_IM & 0 & 0 \\
\hline № imágenes & 196 & 313 \\
\hline
\end{tabular}

Tabla 6.14. Imágenes por categoría y por país

Convertimos los datos de la Tabla 6.14 a porcentaje y expresamos como gráfico. 


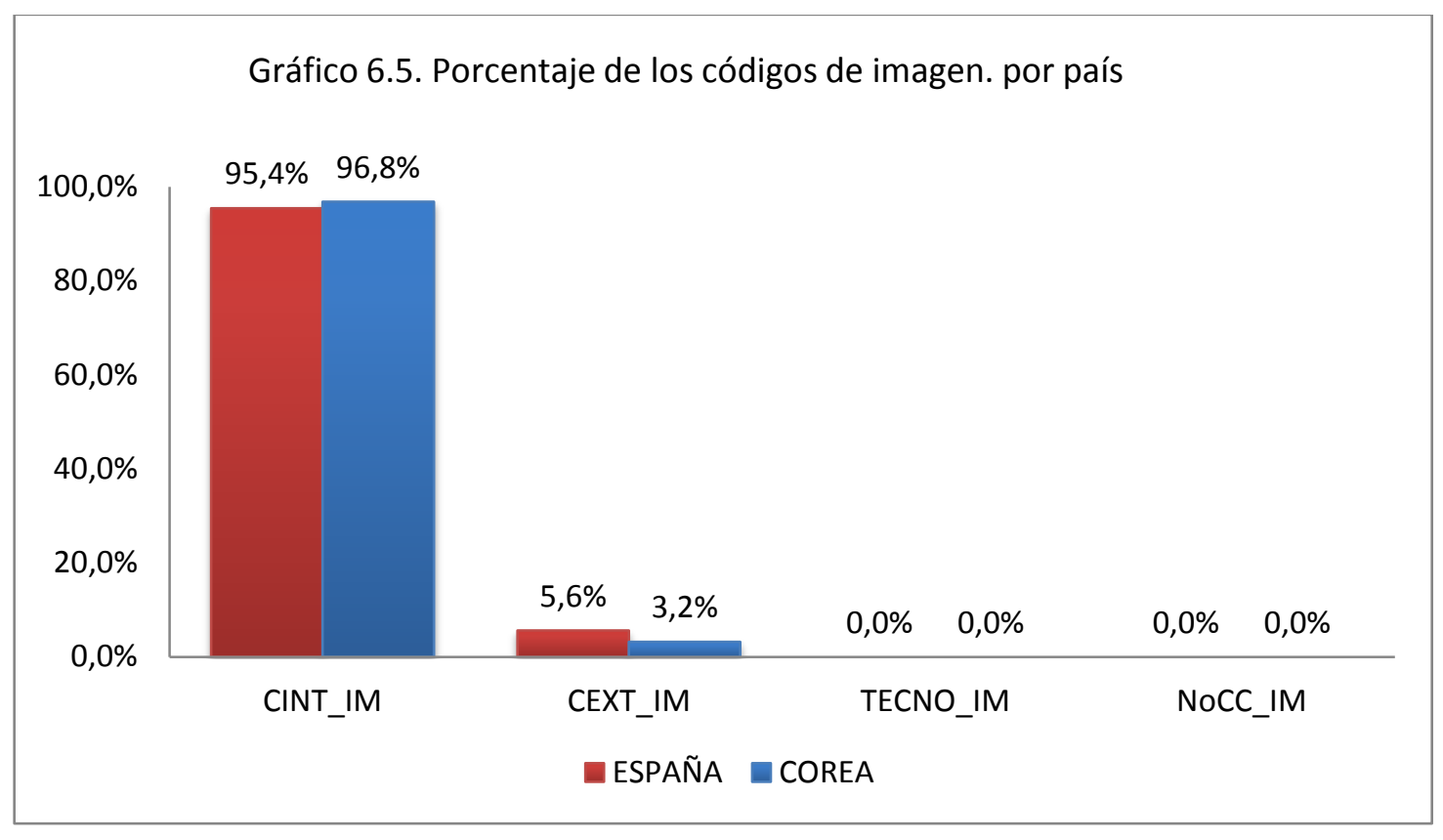

Más del 95\% de las imágenes en los dos países son de Cultura Científica Intrínseca (CINT_IM). Es decir, las imágenes estaban acompañadas con las informaciones intrínsecas de la ciencia. Las imágenes extrínsecas (CEXT_IM) fueron sólo una pequeña parte (España 5,6\%, Corea $3,2 \%)$.

Las imágenes intrínsecas para explicar el darwinismo son abundantes y entre las de los dos países podemos encontrar una cierta semejanza. Veamos algunos ejemplos.

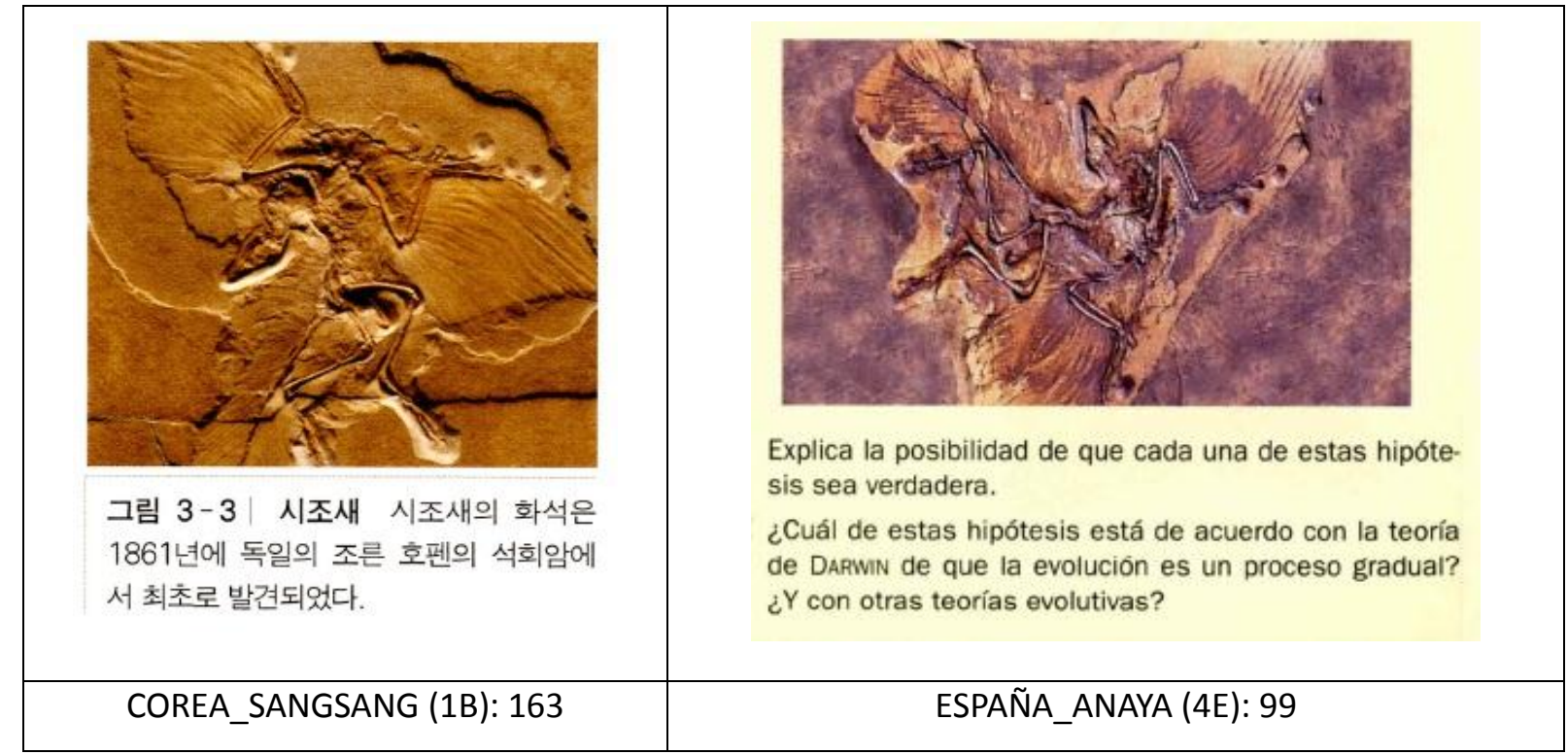

Ilustración 6.4. Imágenes de Cultura Científica Intrínseca (1). Archaeopteryx en SANGSANG (Corea del Sur) y ANAYA (España) 
En la tabla, podemos ver las imágenes de Archaeopteryx en los libros de España y Corea del Sur.

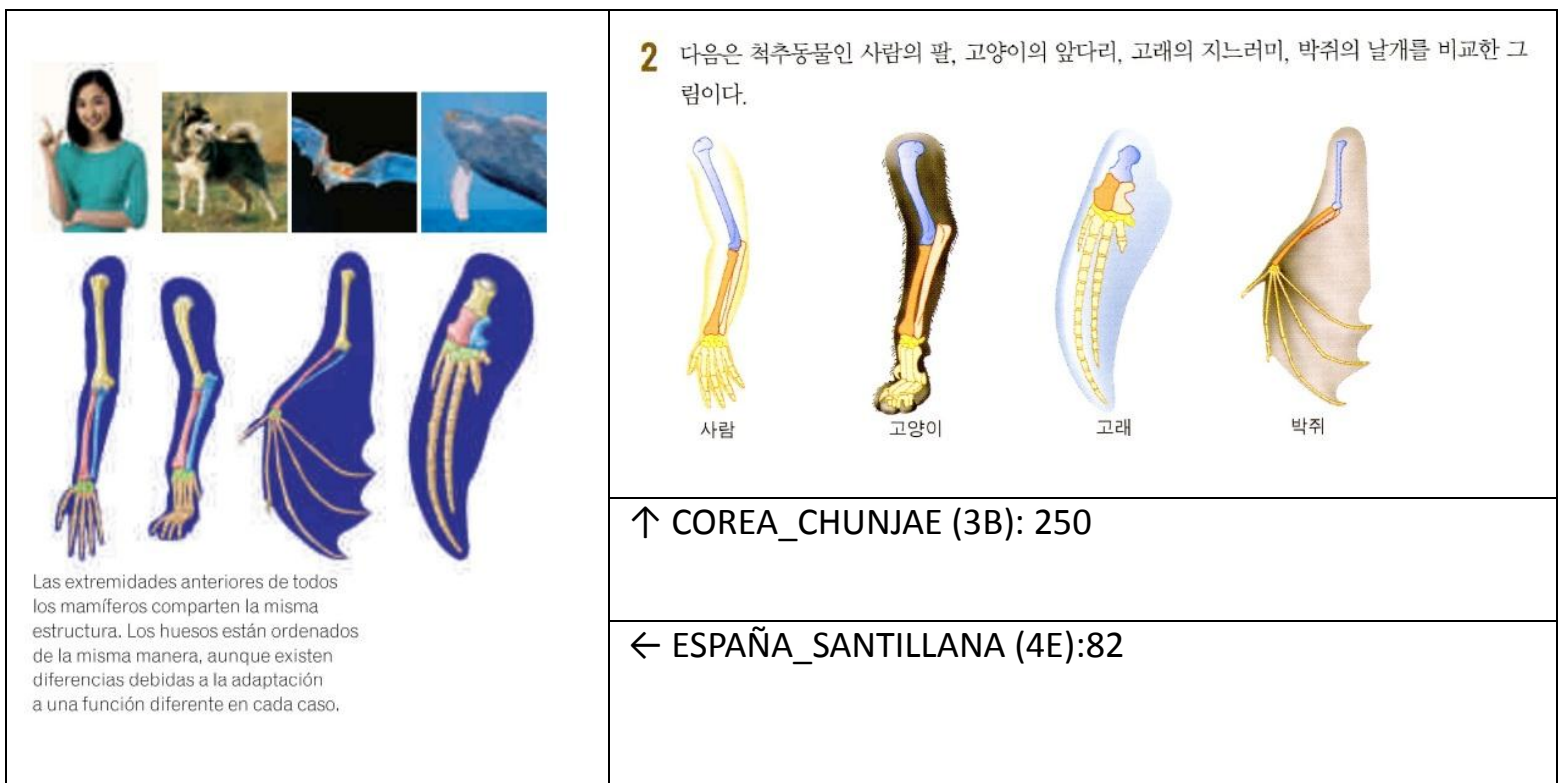

Ilustración 6.5. Imágenes de Cultura Científica Intrínseca (2). Órganos Homólogos en CHUNJAE (3B) (Corea del Sur) y SANTILLANA (España)

Estas imágenes son para explicar una de las pruebas de la evolución, los órganos homólogos. Son órganos de especies diferentes que tienen funciones y formas distintas pero sus estructura internas son semejantes. Si miramos las imágenes en detalle, podemos saber que son casi idénticas excepto el color.

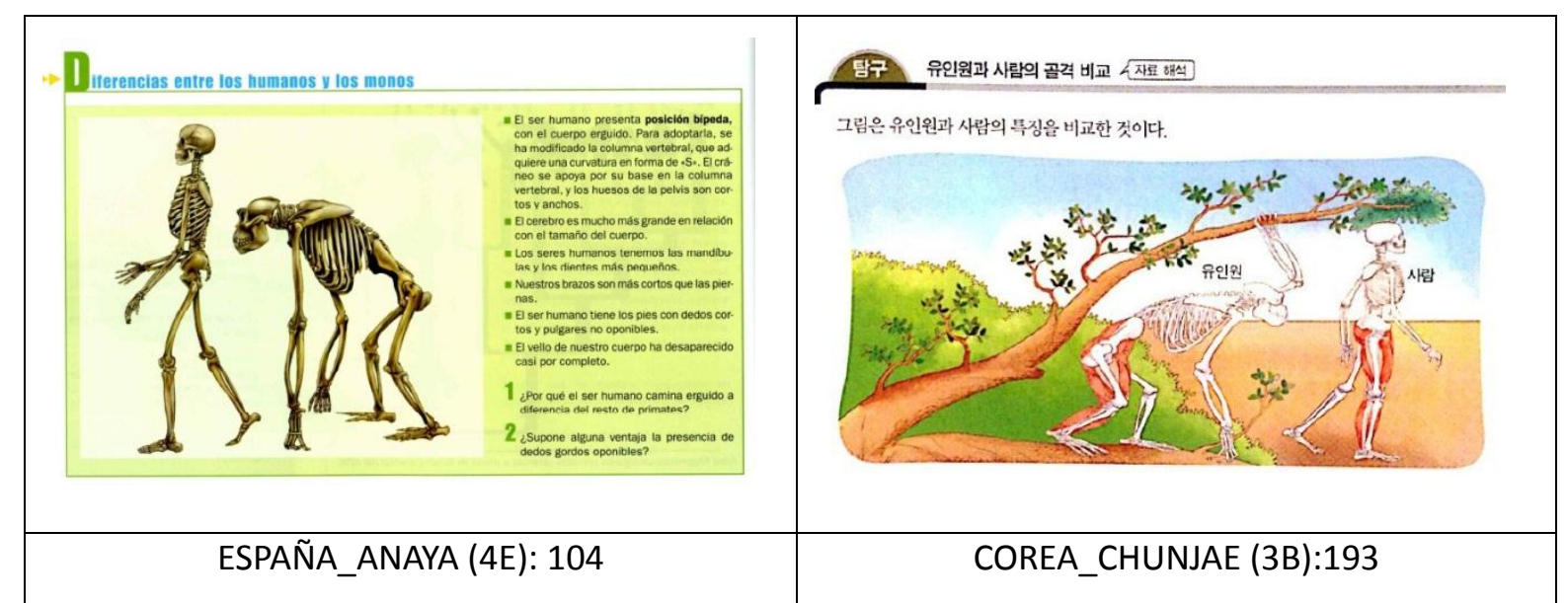

Ilustración 6.6. Imágenes de Cultura Científica Intrínseca (2). Bipedismo en ANAYA (España) y CHUNJAE (3B) (Corea del Sur)

Las dos imágenes en la llustración 6.6 también presentan la misma forma de visualizar el bipedismo. Además de estas imágenes que presentamos aquí, hay muchas imágenes semejantes entre los dos países, ya que están explicando la misma teoría. 
Ahora, vamos a ver ejemplos de las imágenes de Cultura Científica Extrínseca, CEXT_IM. La proporción de las imágenes extrínseca de la cultura científica es 5,6\% de España (11 imágenes) y 3,2\% de Corea del Sur (10 imágenes).

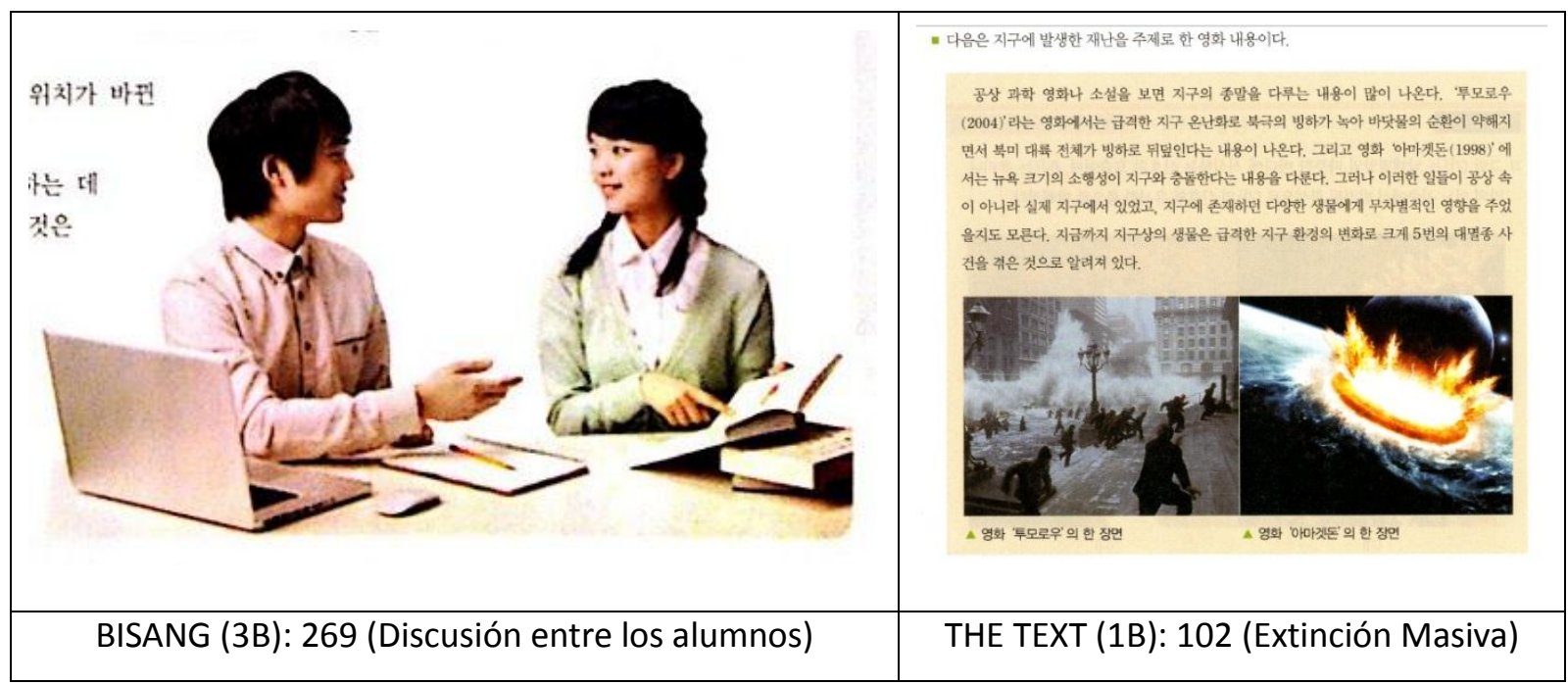

Ilustración 6.7. Imágenes de Cultura Científica Extrínseca de Corea del Sur

La Ilustración 6.7 muestra dos ejemplos de CEXT_IM en los libros coreanos. La primera imagen en BISANG (3B) es una foto que está acompañada con actividades de la investigación y expresa una discusión entre compañeros en la clase. THE TEXT (1B) incluyó dos escenas de las películas cuyo tema fue el fin de mundo para guiar una discusión sobre la extinción masiva.

Ahora veamos las imágenes de Cultura Científica Extrínseca de España. SM y EDELVIVES pusieron las obras de Miguel Ángel sobre la Creación explicando las teorías anteriores a Darwin. Aunque el fijismo que era una de las maneras de explicar los seres vivos antes del darwinismo y su raíz era el creacionismo, parece innecesario publicar las obras sobre la Creación Divina en los libros de texto de Biología. 


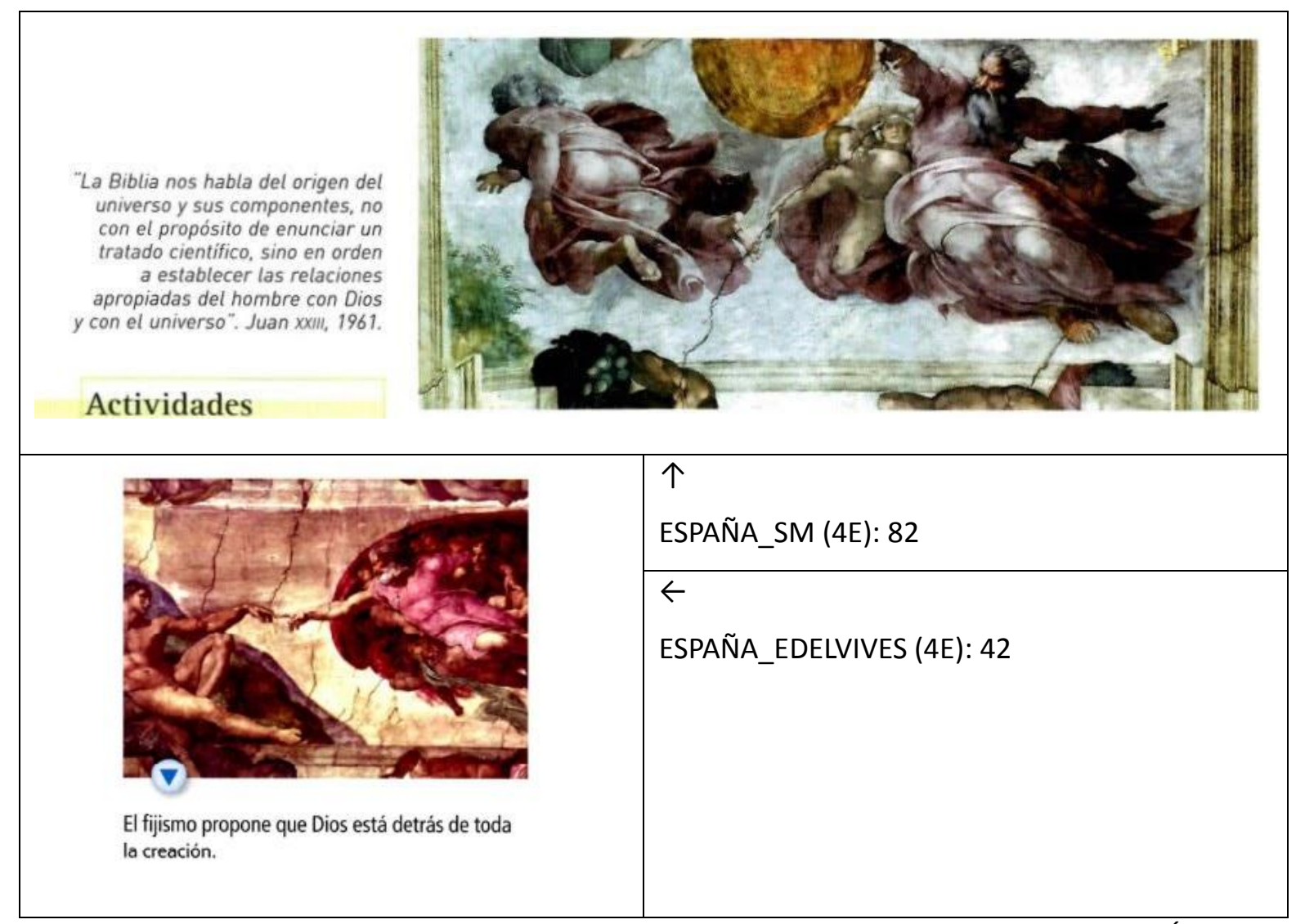

Ilustración 6.8. Imágenes de Cultura Científica Extrínseca de España. Las obras de Miguel Ángel para explicar el creacionismo y el fijismo (SM y EDELVIVES)

Por otra parte, codificando las imágenes también analizamos el porcentaje del tamaño de imagen que ocupan en la página.

\begin{tabular}{|l|r|r|r|r|r|r|r|r|r|r|}
\hline & \multicolumn{4}{|c|}{ 4ESO (ESP) } & \multicolumn{4}{|c|}{ 1을 } \\
\cline { 2 - 11 } & AN & ED & SA & SM & CJ & KS & \multicolumn{1}{c|}{ SS } & TT & \multicolumn{1}{c|}{ BS } & CJ2 \\
\hline IM_0-25\% & 25 & 37 & 59 & 53 & 28 & 17 & 11 & 9 & 93 & 54 \\
\hline IM_25-50\% & 6 & 2 & 4 & 1 & 7 & 6 & 5 & 4 & 26 & 16 \\
\hline IM_50-75\% & 2 & 1 & 1 & 0 & 3 & 8 & 2 & 2 & 5 & 2 \\
\hline IM_75-100\% & 1 & 0 & 1 & 3 & 1 & 4 & 3 & 1 & 3 & 3 \\
\hline № imágenes & 34 & 40 & 65 & 57 & 39 & 35 & 21 & 16 & 127 & 75 \\
\hline
\end{tabular}

Tabla 6.15. Tamaño de imágenes en la página

Sumamos los datos de la tabla 6.20 por país.

\begin{tabular}{|l|r|r|}
\hline & ESPAÑA & COREA \\
\hline IM_0-25\% & 174 & 212 \\
\hline IM_25-50\% & 13 & 64 \\
\hline IM_50-75\% & 4 & 22 \\
\hline IM_75-100\% & 5 & 15 \\
\hline № imágenes & 196 & 313 \\
\hline
\end{tabular}

Tabla 6.16. Tamaño de imágenes. por país 
Convertimos los datos de la tabla 6.16 a porcentaje y expresamos como gráfico.

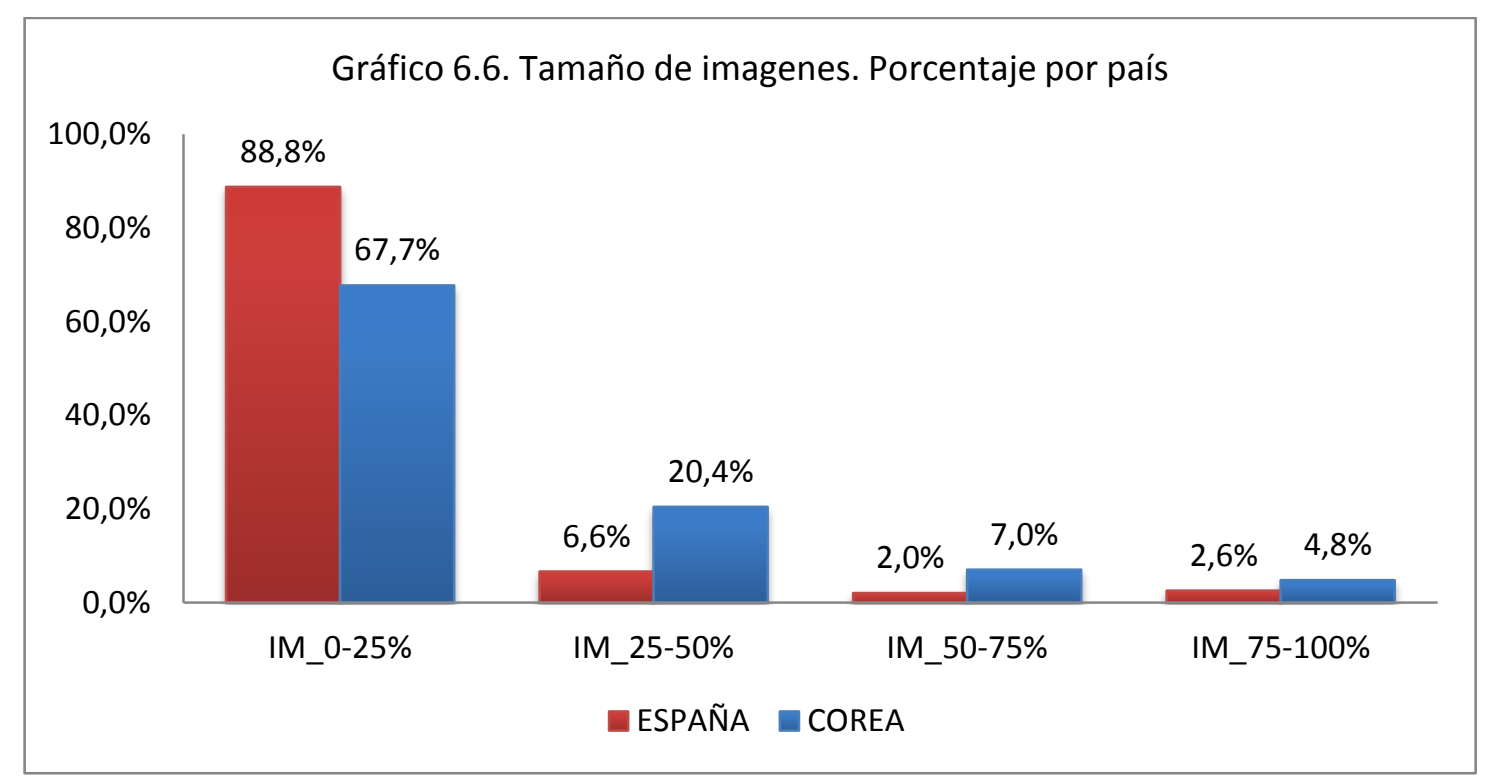

La mayoría de las imágenes utilizadas para explicar el darwinismo ocupa menos del $25 \%$ de la página. Las imágenes no tan grandes estaban en el lugar y el contexto adecuado para visualizar principios, ejemplos, pruebas de la evolución. En el caso de España, 88,8\% de las imágenes ocupa menos del $25 \%$ de la página.

En comparación a España, Corea del Sur puso más imágenes grandes. En los cuatros libros del primer curso de Bachillerato, $59 \%$ de las imágenes son más pequeñas que $25 \%$ de la página. Sin embargo, en los dos libros del tercer curso (Biología II de BISANG (3B) y CHUNJAE (3B)) $73 \%$ son pequeñas. Los libros básicos utilizan imágenes más grandes. Entre todo, 20,4\% de las imágenes coreanas ocupa el espacio entre $25 \%$ y $50 \%$ en la página.

Otro punto es el ratio entre el texto y la imagen para saber cuántas imágenes está acompañada por párrafo de textos.

\begin{tabular}{|l|r|r|}
\hline & ESPAÑA & \multicolumn{1}{|c|}{ COREA } \\
\hline TXT INT & 850 & 815 \\
\hline IMG INT & 187 & 303 \\
\hline TXT EXT & 79 & 85 \\
\hline IMG EXT & 11 & 10 \\
\hline
\end{tabular}

Tabla 6.17. Número de unidades. Cultura Científica Intrínseca y Extrínseca

\begin{tabular}{|l|r|r|}
\hline RATIO(IMG/TXT) & \multicolumn{1}{|c|}{ ESPAÑA } & \multicolumn{1}{c|}{ COREA } \\
\hline Informaciones Intrínsecas & 0,22 & 0,37 \\
\hline Informaciones Extrínsecas & 0,14 & 0,12 \\
\hline
\end{tabular}


Tabla 6.18. Ratio de imágenes por párrafo. Cultura Científica Intrínseca y Extrínseca

\begin{tabular}{|l|r|r|}
\hline & \multicolumn{1}{|c|}{ ESPAÑA } & \multicolumn{1}{|c|}{ COREA } \\
\hline TEXTO & 948 & 906 \\
\hline IMG & 196 & 313 \\
\hline RATIO & 0,21 & 0,35 \\
\hline
\end{tabular}

Tabla 6.19. Ratio de imágenes por párrafo. Por país

En el caso de España, un párrafo de textos de Cultura Científica Intrínseca acompaña con 0,22 imágenes y un párrafo de la Extrínseca lleva 0,14 imágenes. En los libros coreanos, un párrafo de Cultura Científica Intrínseca acompaña con 0,37 imágenes y lo de la Extrínseca viene con 0,12 imágenes.

Si lo calculamos por país, podemos saber que los libros de texto de Corea del Sur incluyen más imágenes que los de España para explicar el darwinismo. Un párrafo español se acompaña con 0,21 imágenes y un párrafo coreano con 0,35 imágenes, o sea, una imagen aparece por cada 4,8 párrafos de textos en España y por cada 2,9 párrafos en Corea del Sur.

A través del análisis de MCC, ya sabemos que los contenidos seleccionados en los libros de texto están orientados hacia la Cultura Científica Intrínseca. Como se trata de textos didácticos sobre una teoría científica, es un resultado natural.

Además, no se destaca gran contraste entre España y Corea con este modelo. Sus libros de texto cumplieron su propósito, 'enseñar el darwinismo a los alumnos'. Casi el $90 \%$ de los contenidos son intrínsecos de la Cultura Científica y solamente se añadieron un 10 \% de la Cultura Científica Extrínseca y la Cultura Tecnológica para complementar la explicación.

En el siguiente subcapítulo 6.4., investigaremos los contenidos más en detalle prestando la atención a qué y cómo enseñan los libros en cuanto al darwinismo se refiere. 
6.4. Darwinismo en Libro de Texto. ¿Cómo enseñan en las aulas escolares España y Corea del Sur?

En este subcapítulo, investigamos cómo y qué enseñan sobre el darwinismo los libros de texto de España y Corea del Sur. Analizamos los contenidos seleccionados los criterios siguientes:

- Los científicos principales: Darwin y Wallace

- Antes del Darwin: Historia de la Ciencia

- Después del Darwin: Desarrollo del darwinismo

- Definición, Pruebas y Ejemplos de la evolución

- Conceptos del darwinismo

En primer lugar, explicar el científico Charles Darwin y su proceso intelectual hasta la presentación de su teoría es muy importante para entender el darwinismo. Su vida y su trayectoria científica como el viaje de HMS Beagle es uno de los mejores ejemplos para mostrar a los alumnos qué es el 'hacer ciencia'. Además, en este sentido es interesante que su contemporáneo A. R. Wallace, que investigó en otra parte del mundo independientemente, llegara a la misma teoría, la evolución por selección natural. Por lo tanto, investigamos cómo y qué se habla de Darwin y Wallace en los libros de texto en los dos países.

En segundo lugar, encontraremos cómo describieron los libros sobre las teorías anteriores al darwinismo que explicaron los fenómenos de los seres vivos. Es examinar la historia de las teorías de la vida antes de Darwin, 'historia de la ciencia'. Podemos percibir la diferencia en los contenidos entre los dos países.

A continuación, compararemos las teorías posteriores al darwinismo en los libros de texto de España y Corea del Sur. El darwinismo se complementó con los estudios sucesivos gracias a los avances de la ciencia. Veremos la presencia y la importancia de las teorías.

Después de mirar la historia de las teorías de la vida, ya indagaremos cómo explicar el darwinismo. La evolución es un concepto importante y que puede ser difícil. ¿Cómo definen la evolución los libros de texto? Comparar la definición de la evolución de España y Corea del 
Sur puede exponer la visión general de los libros sobre el darwinismo. Además, los libros presentan las pruebas de que la evolución por selección natural es verdad. Miraremos también las pruebas y los ejemplos del darwinismo en los libros de texto.

Por último, terminaremos el análisis de los contenidos de los libros de texto averiguando qué conceptos del darwinismo están en los libros y cómo aparecen. Trajimos los conceptos (teorías) principales del darwinismo que Ernst Mayr (1992) presentó, que son la evolución, la selección natural, el antepasado común, la variación y el gradualismo (la velocidad de la evolución). Son conceptos principales y básicos del darwinismo así que los planes de Estudio de cuatro países que hemos recordado en el subcapítulo 6.2 los comparten. Además de ellos, analizaremos los conceptos más detallados para comparar los dos países. Así podemos cubrir todos los contenidos seleccionados en los libros de texto.

\subsubsection{Los Científicos Principales: Darwin y Wallace}

Como es bien conocido, Darwin presentó la teoría de la evolución por selección natural con A. R. Wallace, que es un científico también británico que realizó su estudio en Asia del sur. Los dos científicos fundaron la teoría independientemente, se comunicaron y se enteraron que sus estudios llegaron a una teoría casi idéntica. Por lo tanto presentaron junto la teoría, pero solo se sabe por Darwin y el propio Wallace la bautizó como darwinismo. El episodio puede ser un ejemplo de 'la contemporaneidad del pensamiento' y el 'hacer ciencia' en los libros de texto.

\begin{tabular}{|c|c|c|c|c|c|c|c|c|c|c|c|}
\hline \multicolumn{2}{|c|}{ Científicos principales } & \multicolumn{4}{|c|}{ 4을ㅇ (ESP) } & \multicolumn{4}{|c|}{ 1ㅇachillerato (KOR) } & \multicolumn{2}{|c|}{ 3ㅇ $\mathrm{B}$ (KOR) } \\
\hline Español & Coreano & AN & ED & SA & SM & CJ & KS & SS & TT & BS & $\mathrm{CJ3}$ \\
\hline Charles Darwin & 찰스 다윈 & $v$ & $v$ & V & $v$ & $v$ & v & $v$ & V & $\sqrt{ }$ & v \\
\hline Alfred Russel Wallace & A. R. 월리스 & - & $\mathrm{v}$ & $v$ & $\mathrm{v}$ & $\mathrm{v}$ & - & $\mathrm{v}$ & $\mathrm{v}$ & - & - \\
\hline
\end{tabular}

Tabla 6.20. Presencia de los científicos principales del darwinismo. Darwin y Wallace.

Naturalmente todos los libros explican a Darwin, pero cuatro libros no mencionaron a Wallace. Entre los cuatros libros españoles, tres libros excepto ANAYA incluyeron a Wallace y en los cuatros coreanos para el primer curso de bachillerato excepto KUMSUNG lo presentaron. Los dos libros avanzados de Corea del Sur (BISANG (3B) y CHUNJAE (3B)) no se 
refieren a Wallace y supondrían que ya se lo presentó en la asignatura anterior y obligatoria, Ciencias del 1 을 de bachillerato.

Ahora vemos Darwin y Wallace en los libros españoles. ANAYA es el único libro que no incluye una foto de Darwin entre todos los libro. Sin embargo, no se trata de un descuido porque en el capítulo no se encuentra ninguna imagen de un científico. El libro no explicó la vida de Darwin, solamente mencionó el viaje de Beagle.

EDELVIVES y SM se refieren incluso a la vida personal de Darwin. EDELVIVES presenta una tabla en la que están incluidos Darwin, Wallace y Malthus. Además, en la presentación corta sobre Darwin aparece su religiosidad como si fuera muy importante.

Charles Darwin (1809-1882) Este biólogo se considera, sin lugar a dudas, el científico más influyente en el desarrollo de las teorías evolucionistas, aunque comenzó su vida académica siento creacionista. Su aceptación del evolucionismo le supuso un conflicto interior debido a su religiosidad. (ESPAÑA_EDELVIVES (4E): 43)

Puede ser interesante su conflicto interior para entender la vida de Darwin, pero es difícil pensar que los libros de texto de Corea del Sur explique a Darwin en esta manera. SM y Edelvives son editoriales de origen católico y su religiosidad se nota en los contenidos que explican el darwinismo. Tradicionalmente, el sistema educativo en España no estaba libre de la influencia de la Iglesia Católica, y por lo tanto el color religioso aún sigue vivo en la cultura científica de España que se transmite en los libros de texto.

Por otro lado, no es aceptable en la cultura coreana que las editoriales religiosas publiquen libros de texto. Es difícil imaginar que algún contenido de una religión particular está presente en un libro de texto escrito por varios autores y publicado bajo la autorización oficial.

Como podemos ver en la llustración 6.4 , en la misma página está presente una foto de Lamarck y su tamaño es casi cuádruple de lo de Darwin. Lamarck también es un científico importante en la historia de las teorías de la vida, pero pensamos que la diferencia entre las dos fotos es exagerada. 


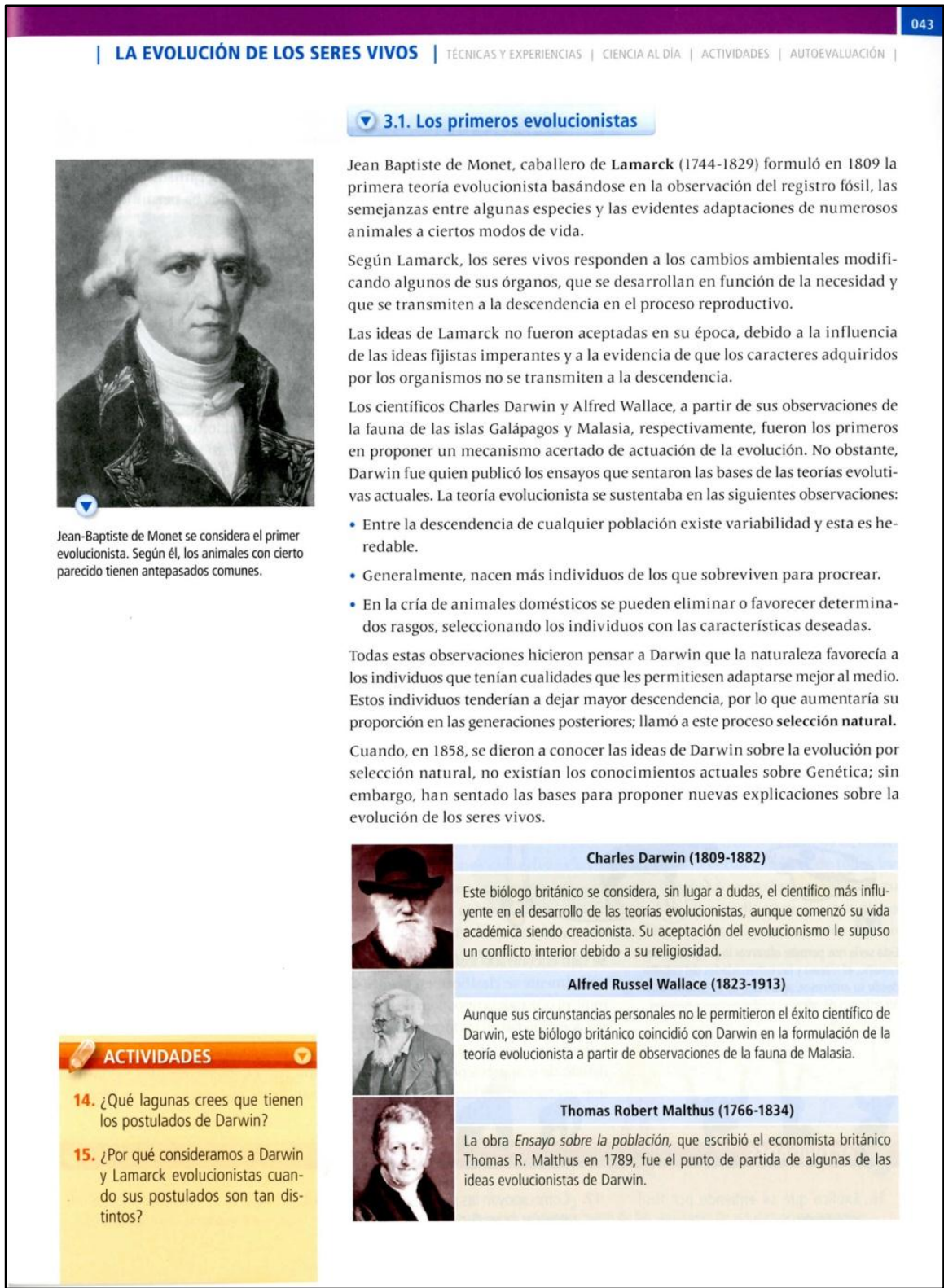

Ilustración 6.9. Fotos de Darwin, Wallace, Malthus y Lamarck (ESPAÑA_EDELVIVES (4E): 43)

SM presenta la vida de Darwin brevemente en el texto principal y también podemos advertir una mención religiosa.

La segunda gran teoría evolucionista del siglo XIX fue la de Charles Darwin (1809-1882). Hijo y nieto de médicos, Darwin comenzó también estudios de medicina, aunque pronto los abandonó. A los 22 años, indeciso sobre su futuro y a punto de iniciar una vida como clérigo anglicano, un hecho fortuito cambió su vida. (ESPAÑA_SM (4E): 84) 


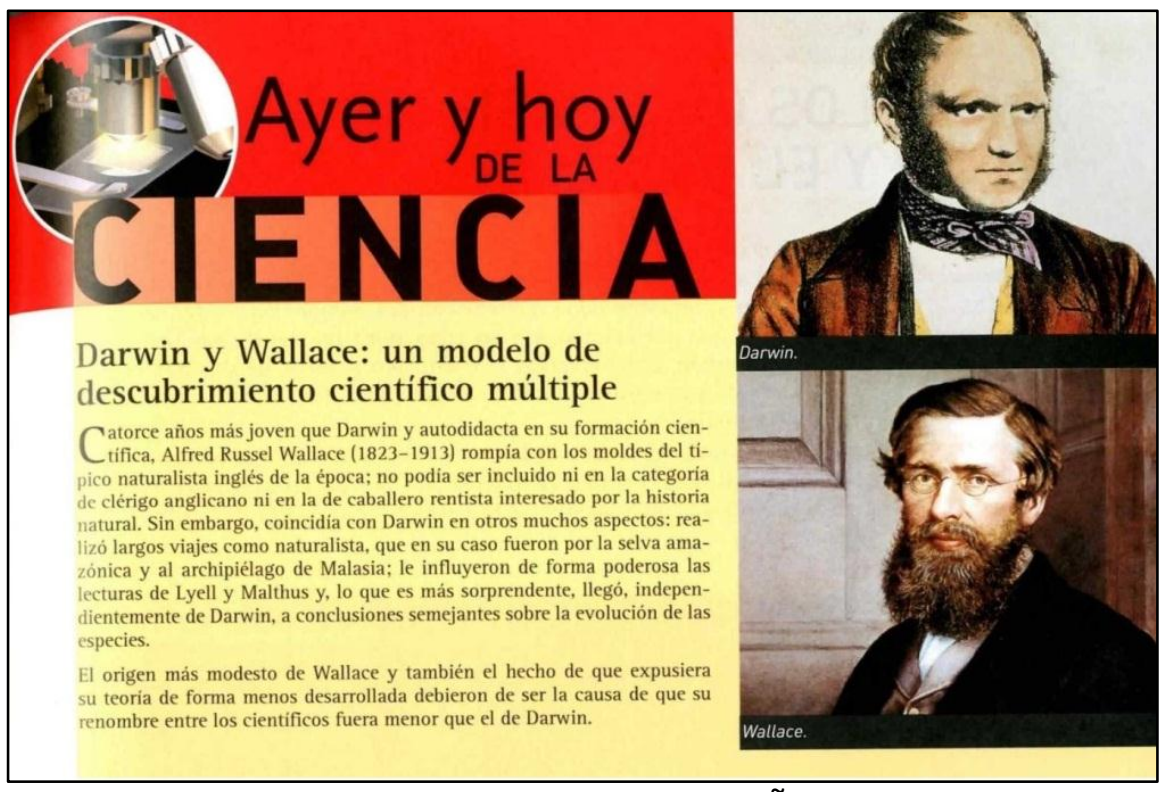

llustración 6.10. Darwin y Wallace (ESPAÑA_SM (4E): 99)

El libro incluye una sección especial en el final del capítulo para explicar el descubrimiento científico múltiple.

SANTILLANA es el único libro que escribe la teoría como 'la teoría de la evolución de Darwin y Wallace' y las fotografías también se publicaron lado a lado (Ilustración 6.11). Se percibe que el libro quería tratar a los dos científicos por igual. El viaje de Beagle es la única información adicional de Darwin. En este libro, también las fotos de Cuvier y Lamarck son más grandes que las de Darwin y Wallace.

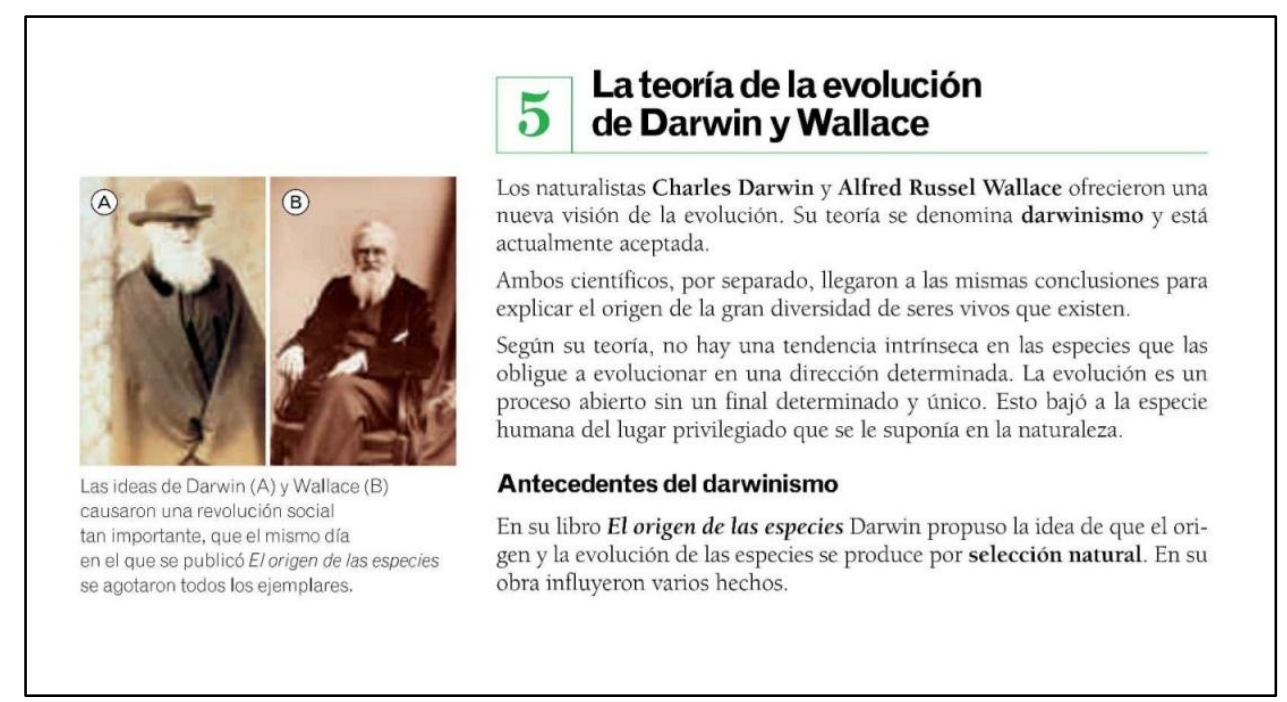

Ilustración 6.11. "La teoría de la evolución de Darwin y Wallace" (ESPAÑA_SANTILLANA (4E): 70) 
Ahora vamos a ver cómo presentan a Darwin los libros coreanos.

다윈(Darwin, C. R.: 1809-1882) 영국의 생물학자. 1859년 “종의 기원"을 저술하여 자연선 택설을 기초로 한 진화론을 수립하였다. [Darwin, C. R.: 1809-1882. Biólogo británico. En el año 1859, publicó “El Origen de las Especies" y fundó la teoría de la evolución por selección natural.] (COREA_BISANG (3B): 281)

찰스 로버트 다윈은 '종의 기원'에서 생물의 진화론을 발표하여 세상을 놀라게 했다. 그의 진화론은 생물학분만 아니라 철학 및 사회 과학에도 막대한 영향을 미쳤다. 그 는 1831년 12 월 27일 비글호의 박물학자로 약 5년 동안 탐사여행을 했다. [Charles Robert Darwin propuso la teoría de la evolución de los seres vivos en el libro "El Origen de las Especies" y asombró el mundo. Su teoría de la evolución influyo considerablemente no solo en la biología sino también en la filosofía y la sociología. ] (COREA_KUMSUNG (1B):180)

En los libros coreanos no podemos encontrar ningún contenido sobre su vida personal, como su religiosidad, ya que solo explican las actividades científicas relacionadas con la teoría. Los tres libros coreanos que mencionan a Wallace (CHUNJAE (1B), SANGSANG (1B) y THE TEXT (1B)) explican el proceso de la presentación de la teoría en detalle.

다윈이 진화론을 발표하게 된 결정적 계기를 제공한 것은 남미와 동남아시아를 항해 하며 생물을 관찰했던 월리스(Wallace, A. R. 1823 1913)의 편지였다. 월리스는 생물이 서로 다른 환경에 놓이게 되면 다른 종으로 변화한다는 사실을 발견하고 다윈에게 이 내용을 담은 편지를 보낸다. [Con motivo de una carta de Wallace (1823-1913), que estaba observando los seres vivos navegando por Sudamérica y Asia del Sureste, Darwin se decidió a presentar la teoría. Wallace descubrió que los seres vivos cambian si se ponen en ambientes distintos y envió su estudio a Darwin.] (COREA_CHUNJAE (1B): 224)

SANGSANG (1B) propone una actividad de reflexionar la contemporaneidad de pensamientos.

1858년 6월, 다윈은 말레이시아를 탐험하고 있던 영국의 생물학자 월리스 (Wallace, A. R. 1823 1913)로부터 1편의 논문을 전해받았다. 이 논문은 놀랍게도 생물 진화에 관한 다윈 자신의 견해와 비숫한 내용을 담고 있었다. (...) 다윈과 월리스의 경우처럼 두 명의 과학자가 비슷한 시기에 각각 같은 이론을 발표한다면 어떤 일이 생길지 이야 
기해보자. [En el junio del 1858, Darwin recibió un estudio que le envió Wallace (1823-1913) que exploraba Malasia. Sorprendentemente el estudio presentaba una idea muy similar a la de Darwin. (...) Discutamos qué va a ocurrir si dos científicos presentan la misma teoría independientemente en una misma época como el caso de Darwin y Wallace.] (COREA_SANGSANG (1B):175)

Este párrafo puede dar a los alumnos una oportunidad de pensar profundamente sobre 'hacer ciencia' y concretamente el proceso de elaborar teorías científicas y presentarlas.

\subsubsection{Antes de Darwin: Historia de la Ciencia}

A continuación, localizaremos la presencia de las teorías anteriores al darwinismo en los libros de texto de España y Corea del Sur.

\begin{tabular}{|c|c|c|c|c|c|c|c|c|c|c|c|}
\hline \multicolumn{2}{|c|}{$\begin{array}{c}\text { Científicos anteriores } \\
\text { o contemporáneos a Darwin }\end{array}$} & \multicolumn{4}{|c|}{ 4을ㅇ (ESP) } & \multicolumn{4}{|c|}{ 1ㅇachillerato (KOR) } & \multicolumn{2}{|c|}{ 3ㅇ B (KOR) } \\
\hline Español & Coreano & AN & ED & SA & SM & CJ & KS & SS & TT & BS & $\mathrm{CJ} 3$ \\
\hline Aristóteles & 아리스토텔레스 & - & $\mathrm{V}$ & - & - & - & - & - & - & - & - \\
\hline Buffon & 부폰 & - & - & - & - & - & - & - & - & $\mathrm{v}$ & - \\
\hline Cuvier & 쿠비에 & $\sqrt{ }$ & $\mathrm{V}$ & $\mathrm{V}$ & V & - & - & - & - & - & $\mathrm{V}$ \\
\hline Erasmus Darwin & 에라스무스 다윈 & - & $\mathrm{V}$ & - & - & - & - & - & - & $\mathrm{v}$ & - \\
\hline H. Spencer & H.스펜서 & - & - & - & - & $\mathrm{V}$ & - & - & - & - & - \\
\hline Lamarck & 라마르크 & $v$ & $\mathrm{~V}$ & $\mathrm{~V}$ & $\mathrm{v}$ & $\mathrm{v}$ & - & - & - & $\mathrm{v}$ & $v$ \\
\hline Linné & 린네 & $v$ & $v$ & $v$ & V & - & - & $\mathrm{V}$ & - & - & - \\
\hline Lyell & 라이엘 & - & - & $\mathrm{V}$ & V & - & - & - & $v$ & - & - \\
\hline Malthus & 맬서스 & - & $\mathrm{V}$ & $\mathrm{V}$ & V & - & - & $\mathrm{V}$ & $v$ & - & - \\
\hline
\end{tabular}

Tabla 6.21. Presencia de científicos anteriores o contemporáneos a Darwin

En la tabla 6.21, podemos observar la lista de los científicos anteriores o contemporáneos a Darwin en los libros de texto en España y Corea del Sur. Se detecta la diferencia en la tabla entre los dos países. Los libros coreanos no hablan mucho de los científicos anteriores y no hay ni un científico que esté incluido en todos los libros coreanos. Entre ellos, el más antiguo es Aristóteles en EDELVIVES.

Por otra parte, Spencer, Lyell y Malthus en la lista no son biólogos. Lyell y Malthus inspiraron 
a Darwin y Darwin inspiró a Spencer. Cuvier de catastrofismo ${ }^{25}$, Linné y Lamarck aparecen en todos los libros españoles.

\begin{tabular}{|l|l|c|c|c|c|c|c|c|c|c|c|c|}
\hline \multicolumn{2}{|c|}{$\begin{array}{c}\text { Teorías anteriores } \\
\text { al Darwinismo }\end{array}$} & \multicolumn{4}{c|}{ 4응 (ESP) } & \multicolumn{3}{c|}{ 10Bachillerato (KOR) } & \multicolumn{3}{c|}{ 3으 B (KOR) } \\
\hline \multicolumn{1}{|c|}{ Español } & \multicolumn{1}{|c|}{ Coreano } & AN & ED & SA & SM & CJ & KS & SS & TT & BS & CJ3 \\
\hline Catastrofismo & 격변설 (천 변지이설) & 2 & 2 & 3 & 1 & - & - & - & - & 1 & 1 \\
\hline Creacionismo & 창조론 & 3 & 4 & 3 & 7 & 1 & - & 1 & - & - & - \\
\hline Fijismo $^{26}$ & 종 고정주의 & 9 & 6 & 3 & 8 & 3 & - & 1 & - & 1 & 1 \\
\hline $\begin{array}{l}\text { Transformismo } \\
\text { (Lamarckismo) }\end{array}$ & 변형주의 (용불용설) & 9 & 16 & 12 & 10 & 1 & - & - & - & 2 & 1 \\
\hline
\end{tabular}

Tabla 6.22. Número de párrafos que explican las teorías anteriores al darwinismo

Las teorías de la tabla 6.28 son explicaciones del origen de los seres vivos y de la biodiversidad antes de que Darwin presentara sus teorías. Además de la presencia podemos ver la extensión del texto.

Los libros españoles tratan las teorías anteriores a Darwin como la historia de la ciencia. Los libros de texto coreanos carecen de descripciones de la historia de la ciencia antes de la teoría darwiniana, en comparación con los libros de texto españoles. Solo un libro de primer curso de bachillerato (CHUNJAE (1B)) presenta a Lamarck. En cambio, SANGSANG (1B) y THE TEXT (1B) no mencionan a Lamarck pero incluyen a Malthus y parece que acentúan el fondo social del nacimiento del darwinismo.

Los libros de texto coreanos generalmente no mencionan específicamente la teoría predarwiniana. En los libros de texto avanzados (BISANG (3B) y CHUNJAE (3B)), se explica brevemente, pero no se destaca su importancia. No prestan mucha atención al proceso del desarrollo de teorías científicas en comparación a los de España. No se ve algún esfuerzo por abordar la teoría evolutiva desde el punto de vista de la 'historia de la ciencia'.

Todos los textos de España que investigamos describen las teorías anteriores de Darwin por orden cronológico. Explican que el fijismo era la teoría admitida antes del evolucionismo con

\footnotetext{
${ }^{25}$ Catastrofismo: "Una teoría según la cual los sucesos catastróficos de la historia de la Tierra han producido la extinción parcial o total de la biota." (Mayr, 1992: 178)

26 Fijismo: "Las especies han permanecido inmuntables desde su creación." (BIOLOGÍA_GEOLOGÍA_4ESO_SANTILLANA_ESPAÑA: 76)
} 
apoyos religiosos y filosóficos. También introducen el catastrofismo de G. Cuvier que insistía en que por las catástrofes naturales, se extinguían unas especies y eran sustituidas por otras mediante creación divina. SM no menciona directamente el catastrofismo, pero se refiere a Cuvier e incluye su foto como uno de los fijistas. Luego, presentan el lamarckismo (transformismo) como la primera teoría científicamente organizada de la evolución.

Los cuatro textos de España explican el transformismo de Lamarck en detalle. En una página incluso más, describen la teoría a través del ejemplo de la longitud del cuello de las jirafas. Se refieren a que los principios de la teoría son la herencia de los caracteres adquiridos y la fuerza interna de los organismos para perfeccionarse. $Y$ también mencionan por qué fue rechazada. Entre los textos para primer curso de Bachillerato de Corea, sólo CHUNJAE (1B) menciona el transformismo brevemente. «Biología I|» lo describe más detalladamente, pero no en el texto principal sino en una sección separada con dibujos de jirafas. En el libro de BISANG explica el catastrofismo en relación con el transformismo mencionando la religión.

라마르크의 진화설에 반대하여 고생물학의 창시자인 퀴비에(Cuvier, B.: 1869 1832)는 천변지이설을 주장하기도 했다. (...) 이는 종교적인 생각을 지구의 역사에 적용시키려 했던 것으로, 과학의 발달을 크게 저해하였다. [Cuvier (1869 1832), que es el fundador de la paleontología, propuso el catastrofismo a la contra de la teoría evolucionista de Lamarck. (...) El pensamiento impidió considerablemente el desarrollo de la ciencia, porque era un intento de aplicar el pensamiento religioso a la historia de la Tierra.] (COREA_BISANG (3B): 284)

El párrafo muestra una actitud firme que la aplicación del pensamiento religioso a la ciencia es perjudicial. Resulta muy difícil detectar un contenido religioso en los libros de texto coreanos de Ciencias. Si encontramos algo, siempre está separado de la propia ciencia.

\section{Fijismo y Creacionismo}

La diferencia más importante entre España y Corea del Sur en los contenidos de las teorías anteriores es la presencia y la importancia del creacionismo y del fijismo. Los cuatros libros españoles hablan del creacionismo en relación con el fijismo.

Todos los textos de España mencionan el fijismo y el creacionismo. Los explican como un paso imprescindible para describir la maduración de las teorías evolucionistas. También 
describen que el fijismo estaba conectado con el creacionismo.

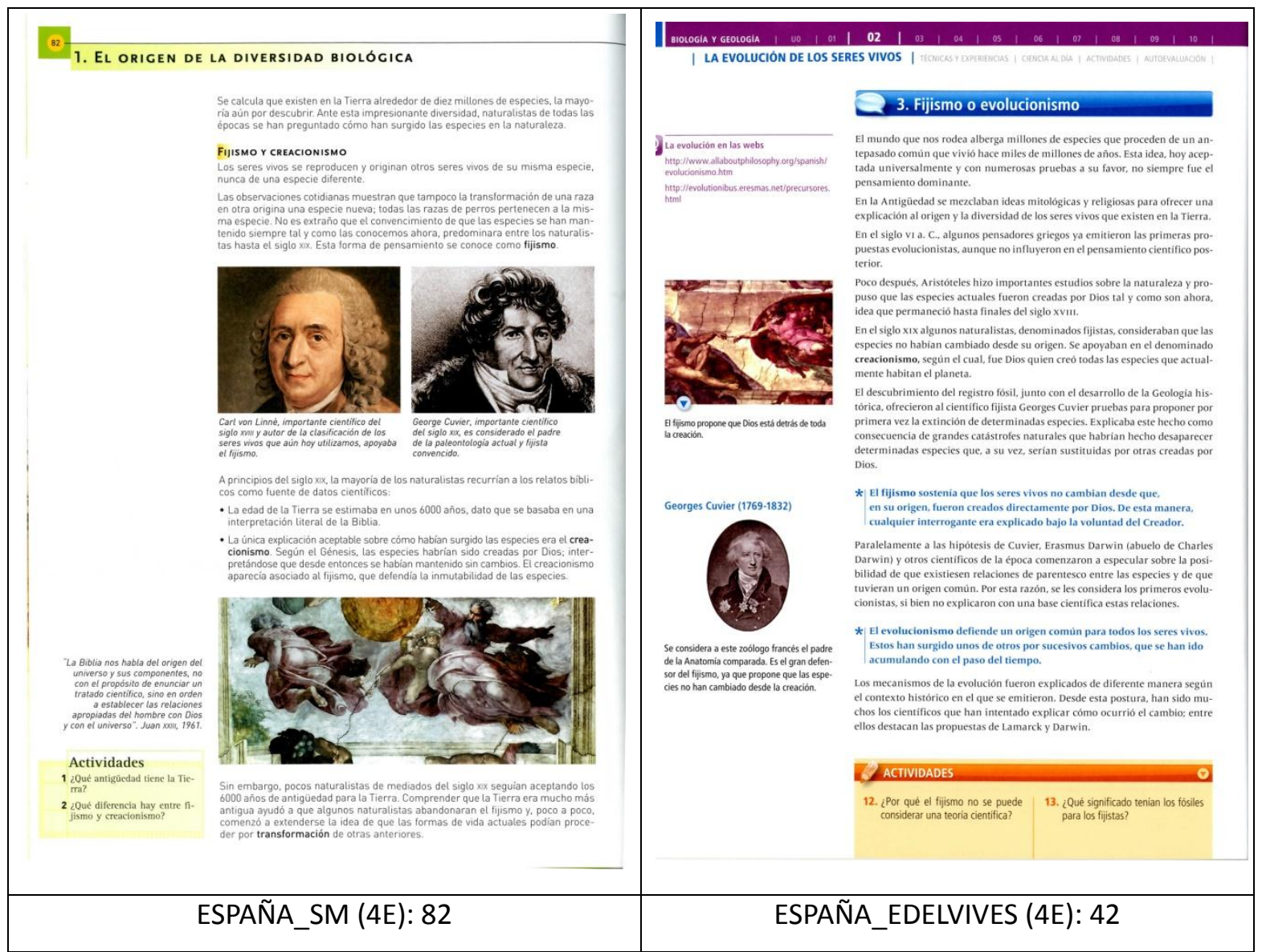

Ilustración 6.13 Dos libros españoles que explican el creacionismo acompañando con una obra de Miguel Ángel

EDELVIVES muestra la obra "La creación de Adán" de Miguel Ángel describiendo el creacionismo como una explicación anterior al darwinismo sobre los seres vivos. SM, que es una editorial de origen religioso, registra la obra "La Creación de los astros y las plantas" del mismo pintor y palabras del Papa Juan XXIII.

La Biblia nos habla del origen del universo y sus componentes, no con el propósito de enunciar un tratado científico, sino en orden a establecer las relaciones apropiadas del hombre con Dios y con el universo. - Juan XXIII (ESPAÑA_SM (4E):82)

Es inusual mencionar un discurso del Papa en relación con la teoría de la evolución en los libros de texto de biología. Pensamos que resulta cuestionable si es apropiado cargar estos contenidos en los libros de texto de biología. Además, el mismo libro menciona el Génesis 
para explicar el creacionismo.

A principios del siglo XIX, la mayoría de los naturalistas recurrían a los relatos bíblicos como fuente de datos científicos:

- La edad de la Tierra se estimaba en unos 6000 años, dato que se basaba en una interpretación literal de la Biblia.

- La única explicación aceptable sobre cómo habían surgido las especies era el creacionismo. Según el Génesis, las especies habrían sido creadas por Dios; interpretándose que desde entonces se habían mantenido sin cambios. El creacionismo aparecía asociado al fijismo, que defendía la inmutabilidad de las especies.

(ESPAÑA_SM (4E): 82)

A pesar de que podemos considerar que la intención principal de incluir estos contenidos en el libro era explicar la historia de las teorías de la vida, la explicación es demasiado detallada y religiosa. Mencionar la Biblia en el libro de texto de Biología es inaceptable en la cultura coreana.

ANAYA y EDELVIVES intentan explicar el creacionismo filosóficamente, no religiosamente. ANAYA muestra el pensamiento platónico y EDELVIVES menciona a Aristóteles.

Los creacionistas, que admitían que la existencia de diferencias entre los organismos solo se debía a imperfecciones en el ideal de una especie. (ESPAÑA_ANAYA (4E): 90)

Poco después, Aristóteles hizo importantes estudios sobre la naturaleza y propuso que las especies actuales fueron creadas por Dios tal y como son ahora, idea que permaneció hasta finales del siglo XVIII. (ESPAÑA_EDELVIVES (4E): 42)

Entre los libros coreanos, los dos libros de la editorial CHUNJAE (1B y 3B) mencionan el fijismo específicamente. Otros libros también lo mencionan pero muy brevemente. Los libros coreanos no traen el creacionismo para explicar el fijismo.

생물의 진화는 오랜 시간에 걸쳐 일어나기 때문에 진화를 직접 관찰하거나 증명하기 어렵다. 18 세기 초까지만 해도 사람들은 생물이 변하지 앟는다고 생각하였다. [Es difícil observar o demostrar la evolución directamente debido a que los seres vivos evolucionan por largo tiempo. Hasta el principio del siglo XVIII, se pensaban que los seres vivos no cambiaban.] 
(COREA_CHUNJAE (1B): 198)

18 세기까지 과학자들은 종의 불변성을 믿었으며, 종이 자연적인 원인에 의해 생겨난다고 생각하였다. 프랑스의 고생물학자 퀴비에(Cuvier, G.: 1769 1832)는 멸종의 이유를 천재지변이라고 생각하였고 종이 변화한다는 생각을 부인하였다. [Hasta el siglo $\mathrm{XVIII}$, los científicos creyeron en la estabilidad de las especies y pensaron que los seres surgirían espontáneamente. El paleontólogo francés G. Cuvier pensaban que la causa de la extinción era una catástrofe natural y negaba el pensamiento de que las especies cambiaban.] (COREA_CHUNJAE (3B): 236)

En cambio, los libros españoles explican claramente que el fijismo tiene relación estrecha con el creacionismo. La explicación sobre el fijismo es detallada como la historia de teoría sobre los seres vivos y el creacionismo también está presente con cierta importancia.

Antiguamente, se pensaba que las especies habian mantenido su aspecto sin cambiarlo desde su creación. (...) Los fijistas defendían que las especies eran inalterables y habían sido creadas para ocupar un lugar determinado en la naturaleza. (ESPAÑA_ANAYA (4E): 90)

El fijismo sostenía que los seres vivos no cambian desde que, en su origen, fueron creados directamente por Dios. De esta manera, cualquier interrogante era explicado bajo la voluntad del Creador. (ESPAÑA_EDELVIVES (4E): 42)

Fijismo. Las especies han permanecido inmutables desde su creación. En la actualidad, el fijismo no está cientificamente aceptado. (ESPAÑA_SANTILLANA (4E):76)

No es extraño que el convencimiento de que las especies se han mantenido siempre tal y como las conocemos ahora, predominara entre los naturalistas hasta el siglo XIX. Esta forma de pensamiento se conoce como fijismo. (ESPAÑA_SM (4E): 82)

Como podemos ver en la tabla 6.22, entre los textos de 1 을 curso de Bachillerato de Corea del Sur ningún libro menciona el catastrofismo, sólo dos libros (CHUNJAE (1B) y SANGSANG (1B)) se refieren al creacionismo y el fijismo.

Los textos de 3 ㅇ de Bachillerato «Biología II» explican el catastrofismo y el transformismo, pero el creacionismo no se menciona (BISANG (3B)) o sólo se refiere con unas palabras (CHUNJAE (3B)). Aunque los libros de texto hablan de las teorías anteriores a Darwin, no las tratan como contenidos importantes, sino que las explican en una sección posterior con el 
título 'historia del evolucionismo' (BISANG (3B)) o 'historia de las hipótesis evolucionistas' (CHUNJAE (3B)). Se podría decir que los autores consideran la historia de las teorías como conocimientos complementarios no principales. El fijismo o el creacionismo no están incluidos en ellas.

Los libros coreanos que mencionan el concepto de 'creación divina' son SANGSANG (1B) y CHUNJAE (1B), pero también sólo lo incluyen para explicar la situación cuando Darwin presentó su teoría. No explica el creacionismo, sólo describe que su teoría se oponía al concepto de la creación de Dios de la iglesia Anglicana.

"종의 기원" 출간 당시 영국 사회를 지배하던 것은 종교 개혁 결과 성립된 교회인 국교회였는데, 국교회에서는 모든 만물이 신에 의해 창조되었다고 보았으며, 처음 모습 그대로 변하지 않았다고 하였다. 이 때문에 다윈의 진화론은 당시 종교계에 큰 반발을 가져왔다. [La iglesia anglicana, que se construyó por la Reforma, dominaba a la sociedad británica cuando Darwin publicó el libro "El origen de las especies". Según la iglesia, Dios creó todos los seres y ellos mantienen su forma sin cambio hasta ahora. Por ello, la comunidad religiosa desechó el evolucionismo de Darwin.] (COREA_SANGSANG (1B):175)

생물종은 신에 의해 창조된 후 절대 변하지 앟는다고 확신하던 당시 사람들에게 다윈의 진화론은 신의 존재를 부인하는 것으로 이해되어 사회에 커다란 충격을 주었다. 진화론이 사고의 중심을 신으로부터 인간으로 이동시킴에 따라 사후 세계와 신의 심판을 생각하여 절제하고 금욕하기보다는 현실을 즐기고자 하는 삼의 방식이 유행하기도 했다. [La teoría de la evolución de Darwin fue muy impactante para la gente que creía que los seres vivos son inmutables desde su creación divina, debido a que su teoría, al parecer, niega la existencia de Dios. Como el evolucionismo traslada el centro de pensamiento de Dios al ser humano, se extendía la tendencia de disfrutar la vida en vez de moderarse preocupando el juicio de Dios y el otro mundo.] (COREA_CHUNJAE (1B): 201)

Solo estos dos párrafos mencionan el creacionismo en los seis libros de texto de Corea. El creacionismo aparece no como una teoría anterior al darwinismo desde el punto de vista histórico, sino para describir la situación social cuando Darwin presentó su teoría. Podemos saber que los libros de texto coreanos excluyen el creacionismo en relación con el darwinismo. 


\subsubsection{Después de Darwin. Desarrollo del Darwinismo.}

A continuación, veamos cómo los libros de texto describen los estudios posteriores a Darwin. Incluimos a la tabla siguiente todos los científicos y estudios que aparecen en los libros de texto de España y Corea del Sur.

\begin{tabular}{|c|c|c|c|c|c|c|c|c|c|c|c|}
\hline \multicolumn{2}{|c|}{$\begin{array}{c}\text { Científicos posteriores } \\
\text { a Darwin }\end{array}$} & \multicolumn{4}{|c|}{ 4통 (ESP) } & \multicolumn{4}{|c|}{ 1Bachillerato (KOR) } & \multicolumn{2}{|c|}{ 3ㅇ B (KOR) } \\
\hline Español & Coreano & AN & ED & SA & SM & $\mathrm{CJ}$ & KS & SS & TT & BS & $\mathrm{CJ} 3$ \\
\hline R. Dawkins & 도킨스 & - & - & - & - & - & - & - & - & $\mathrm{v}$ & - \\
\hline H. De Vries & 드 브리스 & - & - & - & - & - & - & - & - & $\mathrm{V}$ & $\mathrm{V}$ \\
\hline T. Dobzhansky & 도브잔스키 & $v$ & $\mathrm{~V}$ & - & - & - & - & - & - & - & $\sqrt{ }$ \\
\hline T. Eimer & 아이머 & - & - & - & - & - & - & - & - & $\mathrm{V}$ & - \\
\hline Gould\&Eldredge & 굴드\&엘드리지 & $\mathrm{V}$ & $\mathrm{V}$ & $\mathrm{V}$ & $\sqrt{ }$ & - & - & - & $\mathrm{V}$ & $\mathrm{V}$ & - \\
\hline Grant & 그랜트 & - & - & - & - & - & - & - & - & $\mathrm{V}$ & - \\
\hline Henning & 헤닝 & - & $\mathrm{V}$ & - & - & - & - & - & - & - & - \\
\hline K. Marx & 칼 마르크스 & - & - & - & - & $\mathrm{V}$ & - & - & - & - & - \\
\hline Kimura & 키무라 & - & - & - & - & - & - & - & $\mathrm{V}$ & - & - \\
\hline J.P. Lotsy & 로티 & - & - & - & - & - & - & - & - & $\mathrm{V}$ & - \\
\hline Pauling & 파울링 & $\mathrm{v}$ & - & - & - & - & - & - & - & - & - \\
\hline G. J. Romanes & 로마네스 & - & - & - & - & - & - & - & - & $\mathrm{V}$ & $\sqrt{ }$ \\
\hline Smith & 스미스 & $\mathrm{V}$ & - & - & - & - & - & - & - & - & - \\
\hline Van Valen & 반 발렌 & - & - & - & - & - & - & - & $\mathrm{V}$ & - & - \\
\hline M.F. Wagner & 바그너 & - & - & - & - & - & - & - & - & $\mathrm{V}$ & $\mathrm{V}$ \\
\hline A. Weismann & 바이스만 & - & - & - & - & - & - & - & - & $\mathrm{V}$ & $\mathrm{V}$ \\
\hline
\end{tabular}

Tabla 6.23. Presencia de científicos posteriores a Darwin

Los científicos que aparecen en más libros son S. J. Gould y N. Eldredge que presentaron el equilibrio puntuado ${ }^{27}$ (4 libros de España y 2 de Corea). El siguiente es Dobzhansky que es uno de los fundadores de la teoría sintética de la evolución ${ }^{28}$ ( 2 de España y 1 de Corea).

\footnotetext{
27 Equilibrio puntuado (puntualismo): “Teoría según la cual los sucesos evolutivos más importantes se producen durante cortos estallidos de especiación y una vez que las especies se han formado son relativamente estables, a veces durante periodos de tiempo muy largo. Conocida también como evolución especiacional." (Mayr, 1992: 184)

28 Teoría sintética de la evolución (Síntesis evolutiva, síntesis moderna): "Paradigma darwiniano modificado parcialmente que incluye la refutación de la evolución transformacional, el saltacionismo y la ortogénesis, al tiempo que subraya fuertemente el papel de la selección natural, la adaptación y el estudio de la diversidad (el origen de las especies y de los taxones superiores)." (Mayr, 1992: 186)
} 
Otros científicos están presentes en uno o dos libros.

SANTILLANA y SM solamente mencionan a Gould y Eldredge como científicos posteriores a Darwin. ANAYA tiene Dobzhansky, Pauling y Smith también, y EDELVIVES menciona a Dobzhansky y Henning.

CHUNJAE (1B) explica el darwinismo social críticamente y menciona a Karl Marx relacionando al darwinismo. KUMSUNG (1B) y SANGSANG (1B) no incluyen ningún científico posterior a Darwin. THE TEXT (1B) menciona a Kimura, Van Valen, Gould y Eldredge. No está muy claro por qué eligieron estos científicos entre muchos. Es cuestionable si pensamos la importancia de los estudios en el campo biológico.

Los dos libros de la asignatura avanzada de Biología II tienen más científicos posteriores relativamente. Especialmente el libro de BISANG es el libro que menciona más científicos entre diez libros que investigamos.

\begin{tabular}{|l|l|c|c|c|c|c|c|c|c|c|c|}
\hline $\begin{array}{c}\text { Teorías posteriores } \\
\text { al Darwinismo }\end{array}$ & \multicolumn{3}{c|}{ 4ESO (ESP) } & \multicolumn{3}{c|}{$\begin{array}{c}\text { 1Bachillerato } \\
\text { (KOR) }\end{array}$} & \multicolumn{2}{c|}{$\begin{array}{c}30 \\
\text { B } \\
\text { (KOR) }\end{array}$} \\
\hline \multicolumn{1}{|c|}{ Español } & \multicolumn{1}{|c|}{ Coreano } & AN & ED & SA & SM & CJ & KS & SS & TT & BS & CJ3 \\
\hline Economía evolucionista & 진화 경제 학 & - & - & - & - & 2 & - & - & - & 1 & - \\
\hline Neodarwinismo & 신다윈 주의 & 6 & 3 & 5 & - & - & - & - & - & - & - \\
\hline Psicología evolutiva & 진화 심리학 & - & - & - & - & - & - & - & - & 2 & - \\
\hline Sociobiología & 사회생물학 & - & - & - & - & - & - & - & - & 1 & - \\
\hline Teoría del equilibrio puntuado & 단 속평형설 & 5 & 4 & 9 & 2 & - & - & - & 2 & 8 & - \\
\hline Teoria neutralista & 중립진화 & - & - & - & - & - & - & - & 2 & - & - \\
\hline Teoría sintética de la evolución & 진화의 종합설 & 2 & 4 & 14 & 18 & - & - & - & 2 & 10 & 3 \\
\hline
\end{tabular}

Tabla 6.24. Número de párrafos que explican las teorías posteriores al darwinismo

Los cuatro libros de 4ㅇ de ESO de España introducen «la teoría sintética de la evolución» y «la teoría del equilibrio puntuado». SM no usa el término «neodarwinismo», pero los otros tres libros lo usan como sinónimo de la «teoría sintética de la evolución». Eso podría provocar una confusión de palabras. A lo largo de la historia de las teorías evolucionistas posteriores de Darwin, el término «neodarwinismo» ha aparecido dos veces. La primera fue cuando Weismann refutó la herencia de los caracteres adquiridos a finales del siglo XIX. La segunda es el significado que aparece en los libros de texto. En la década de los treinta y cuarenta del siglo XX, se sintetizaron las investigaciones de varios campos de la biología y a esta síntesis se la denominó "teoría sintética de la evolución» o "síntesis moderna de la evolución». La síntesis a veces se llama «neodarwinismo» también, pero es difícil distinguir 
de lo anterior. Uno de los científicos principales de la teoría sintética de la evolución, el ilustre biólogo E. Mayr dijo que a menudo la síntesis moderna se ha llamado como el neodarwinismo, pero es claramente incorrecto (Mayr, 2006: 168). Los libros de España los tratan como términos idénticos. Es posible que no sea necesario distinguir el neodarwinismo de la teoría sintética para los estudiantes generales, pero sería mejor denominar a las teorías más exactamente en los libros de texto.

Otra característica de los libros de España es incluir la «teoría del equilibrio puntuado» de S.J. Gould y N. Eldredge con una importancia similar a la «teoría sintética de la evolución». La teoría sintética de la evolución es una síntesis de los logros de genética, paleontología, bioquímica, ecología, etc., pero el equilibrio puntuado sólo argumenta sobre la velocidad de la evolución. Sin embargo, los libros de España los tratan como si fueran teorías del mismo nivel. El gradualismo de Darwin y los científicos de la teoría sintética no significa que la velocidad de la evolución sea uniforme, sino que el cambio es 'gradual' y por la acumulación de los cambios los organismos evolucionan. Por eso, hay opiniones significativas que dicen que el equilibrio puntuado no contiene ninguna idea peculiar y ha sido sobrevalorado (Dawkins, 1986; Dennett, 1995). Podríamos considerar también la influencia de la retórica de Gould que insistió en que la teoría sintética de la evolución ha perdido importancia por su propia teoría, la teoría del equilibrio puntuado (Gould, 1980). 


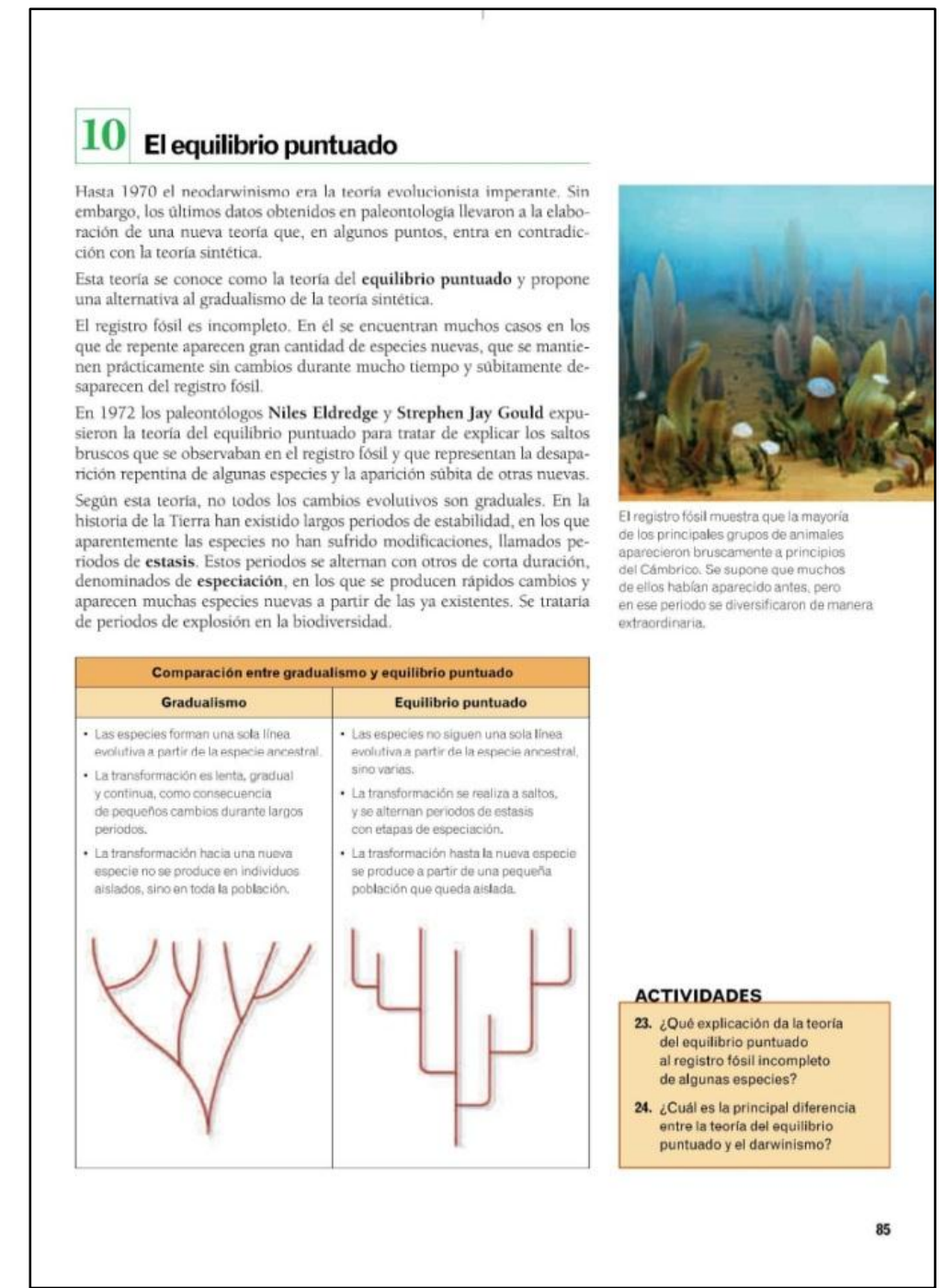

Ilustración 6.14. Equilibrio Puntuado (ESPAÑA_SANTILLANA (4E): 85)

Los libros de 10 curso de bachillerato de Corea del Sur no muestran las teorías posteriores a Darwin excepto THE TEXT (1B), que les dedica a las teorías una sección al fin del capítulo, con el título «las hipótesis evolucionistas contemporáneas». Se refiere a la síntesis moderna, la teoría neutralista y la teoría del equilibrio puntuado. Lo interesante es que el libro sólo menciona tres teorías y la teoría neutralista es una de ellas entre las numerosas teorías que surgieron después de Darwin.

Los libros de texto de «Biología II» de Corea, se refieren brevemente a varias teorías. Especialmente BISANG (3B) recuerda muchas teorías, pero sólo explica sus características y no describe sus papeles o sus estados en la historia de las teorías evolucionistas. Por 
ejemplo, la ortogénesis ${ }^{29}$ fue rechazada pero no lo menciona, como si fuera una teoría actualmente aceptada.

Como ya se ha anotado, los libros españoles describen comúnmente la teoría sintética de la evolución (o el neodarwinismo) y el equilibrio puntuado y no prestaron mucha atención a otras teorías. En cambio, los libros del primer curso de Corea no incluyen ningún estudio posterior excepto THE TEXT (1B). BISANG (3B) incluye diversos estudios.

\subsubsection{Definición, Pruebas y Ejemplos de la Evolución}

Entonces, ¿cómo explican los libros de texto la evolución? Entender el concepto de la evolución es un punto de partida para aprender la teoría. Es importante cómo los libros de texto definen la evolución. Hay varias maneras de definirla y a través de la definición elegida, podemos saber en qué parte ponen énfasis los libros de texto.

En primer lugar, veamos cómo los libros de texto españoles definen la evolución.

La evolución son los cambios graduales y lentos que se producen en las especies y que son el origen de nuevas especies. (ESPAÑA_ANAYA (4E):106)

La evolución biológica es el proceso de transformación de las especies a lo largo del tiempo. (ESPAÑA_SANTILLANA (4E):76)

Frente a las teorías fijistas, la idea central de las teorías evolucionistas es que las especies cambian a lo largo del tiempo. (ESPAÑA_SM (4E): 83)

El evolucionismo defiende un origen común para todos los seres vivos. Estos han surgido unos de otros por sucesivos cambios, que se han ido acumulando con el paso del tiempo. (ESPAÑA_EDELVIVES (4E): 42)

Los libros de texto de España adoptan la definición tradicional de la evolución. Entre las definiciones de los libros españoles, podemos encontrar comúnmente la palabra "cambio" ("transformaciones" en SANTILLANA), "especie" ("seres vivos" en EDELVIVES) y "tiempo"

${ }^{29}$ Ortogénesis: Véase la nota 10 en el subcapítulo 2.1. 
("gradual y lento" en ANAYA) como el núcleo de la definición. Con estas tres palabras, podemos resumir la definición como "el cambio de las especies con el paso del tiempo". Esta definición es la definición básica de la evolución que no ha cambiado mucho desde los días de Darwin hasta ahora.

Ahora vamos a ver las definiciones en los libros coreanos.

이처럼 생물이 오랜 세월 동안 여러 세대를 거치면서 환경에 적응하여 변화하는 현상을 진화라고 한다. [Como hemos visto, el fenómeno que los seres vivos cambian adaptando al medio ambiente con la generación, se llama la evolución.] (COREA_CHUNJAE (1B): 198)

집단 내에서 유전적 차이가 시간이 지남에 따라 쌓이게 되면 이전 세대와는 유전적으로 많이 달라저 몸의 구조나 기능 등에 차이를 보이는 새로운 종이 나타날 수 있는데, 이러한 현상을 진화라고 한다. [Si las diferencias genéticas ocurren con el tiempo en la población, los cambios genéticos pueden variar considerablemente de las generaciones anteriores para formar una nueva especie que difiere de la estructura del cuerpo o función. El fenómeno se llama la evolución.] (COREA_KUMSUNG (1B):174)

현대 생물학에서는 진화를 '생물 집단 속에서의 유전자풀이 세대가 지남에 따라 변화하는 것'으로 정의하고 있다. [La biología moderna define la evolución como 'el cambio del acervo génico ${ }^{30}$ en la población con la generación'.] (COREA_THETEXT (1B):217)

즉 진화적 변화는 한 개체의 변화가 아니라 개체군 내에서 새로운 유전자를 가진 개체의 비율이 변화하는 것을 말한다. [Es decir, el cambio evolutivo no significa el cambio en un individuo, sino que es el cambio de la proporción de los individuos, que tienen nuevos genes, en la población.] (COREA_CHUNJAE (1B): 237)

Como se percibe en los ejemplos, la mayoría de los libros de texto coreanos define la evolución en el nivel genético. Es una definición moderna a la que se aplica los estudios posteriores a Darwin. Los libros coreanos parecen haber subrayado la definición genética y

\footnotetext{
30 Acervo génico: “Todos los alelos que tiene los individuos de una población en un momento específico. Determina el carácter genético de la población. Es la colección de los genes que los miembros de la generación siguiente de la población van a tener. Y un individuo es un vehículo para transmitir los genes en el acervo génico a la generación siguiente." (BISANG: 286)
} 
más reciente, debido a la cultura de la sociedad coreana que valora la ciencia aplicada y la alta tecnología que la ciencia pura. Se revela indirectamente la tendencia del país a favorecer la biotecnología. En cambio, la definición española es genérica y meramente darwiniana que incluye el concepto principal de Darwin.

La definición coreana es más precisa hoy en día en el campo biológico, pero la definición española es más clara y fundamental para que los alumnos de 15 y 16 años entiendan el concepto principal de la evolución. Si los alumnos ya han entendido perfectamente la definición española, la definición coreana puede ayudarlos para que amplíen su perspectiva, pero si no, la definición genética puede resultar difícil y demasiado técnica.

Ahora veremos cómo los libros de texto están tratando con las pruebas de la evolución.

\begin{tabular}{|c|c|c|c|c|c|c|c|c|c|c|c|}
\hline \multicolumn{2}{|c|}{ Pruebas de la evolución } & \multicolumn{4}{|c|}{ 4으으 (ESP) } & \multicolumn{4}{|c|}{$\begin{array}{c}\text { 19Bachillerato } \\
\text { (KOR) }\end{array}$} & \multicolumn{2}{|c|}{$\begin{array}{l}30 \mathrm{~B} \\
\text { (KOR) }\end{array}$} \\
\hline Español & Coreano & AN & ED & SA & SM & $\mathrm{CJ}$ & KS & SS & TT & $\mathrm{BS}$ & $\mathrm{CJ} 3$ \\
\hline Pruebas anatómicas & 해부학적 증거 & 1 & 10 & 6 & 3 & 1 & 1 & - & 2 & 8 & 7 \\
\hline Pruebas biogeográficas & 생물지리학적 증거 & 9 & 6 & 3 & 4 & - & - & - & - & 4 & 4 \\
\hline Pruebas de adaptación & 적응 증거 & 2 & - & - & - & - & - & - & - & - & - \\
\hline Pruebas embriológicas & 발생학적 증거 & 3 & 8 & 4 & 4 & 2 & 1 & - & 1 & 3 & 7 \\
\hline $\begin{array}{l}\text { Pruebas en el ser } \\
\text { humano }\end{array}$ & 인체 증거 & - & 1 & - & - & 3 & - & - & - & 2 & - \\
\hline $\begin{array}{l}\text { Pruebas genéticas } \\
\text { (moleculares, } \\
\text { bioquímicas) }\end{array}$ & $\begin{array}{l}\text { 유전학적(분자생물학 } \\
\text { 적, 생화학적 증거) }\end{array}$ & 3 & 7 & 3 & 6 & 1 & 2 & 4 & 5 & 11 & 7 \\
\hline $\begin{array}{l}\text { Pruebas } \\
\text { paleontológicas }\end{array}$ & 고생물학적 증거 & 10 & 10 & 7 & 6 & 5 & 5 & 14 & 5 & 14 & 10 \\
\hline
\end{tabular}

Tabla 6.25. Número de párrafos de las pruebas de la evolución

Los cuatro libros de España y los dos libros del 3o curso (Biología II de BISANG (3B) y CHUNJAE (3B)) de Corea muestran las pruebas de la evolución ordenadamente. Describen las pruebas anatómicas, paleontológicas, biogeográficas, bioquímicas, embriológicas, etc. y hay poca diferencia entre ellos. Los ejemplos para explicar cada prueba también son similares.

Los libros españoles explican las pruebas de la evolución con método. Los cuatro libros dedican un subcapítulo para las pruebas de la evolución.

Existen gran cantidad de pruebas que demuestran que todos los seres vivos tienen un origen común y que la evolución es un hecho incuestionable. (ESPAÑA_SANTILLANA (4E):82) 
Actualmente, toda la comunidad científica acepta el mecanismo de la evolución biológica. El avance de la ciencia en los últimos años ha permitido recopilar pruebas que no dejan lugar a dudas sobre este hecho. (ESPAÑA_EDELVIVES (4E): 44)

ANAYA, EDELVIVES y SANTILLANA ponen al subcapítulo el título de "Las pruebas de la evolución" comúnmente. Sin embargo, la editorial de origen religioso SM le pone "Argumentos a favor de la evolución". Pensamos que 'argumento a favor' es una expresión bastante más moderada que 'prueba'. El libro nunca utiliza la palabra 'prueba' en las dos páginas del subcapítulo.

Los cuatro libros coreanos para el primer curso de bachillerato no ofrecen un subcapítulo ni apartado para explicar las pruebas de la evolución y tienden a centrarse sólo a las pruebas paleontológicas y genéticas. A los estudiantes que todavía no han tenido oportunidades de entender exactamente el concepto de la evolución, no se les explica por qué la evolución es un hecho científico, sino que presentan algo más difícil o técnico.

아주 오래 전에 있었던 생물의 진화를 설명하기 위해서는 화석 연구를 빼놓을 수 없
다. 화석이야말로 생물의 진화에 가장 기초적이고 직접적인 증거라고 할 수 있다. [Para explicar la evolución de los organismos que existían hace mucho tiempo, no se puede excluir la investigación de fósiles. Los fósiles son la prueba más básica y directa de la evolución de la vida.] (THE TEXT: 186)

다윈의 진화론은 화석에 의한 증거와 발생학적 증거로도 뒷받침되지만 더욱 구체적 인 증거는 현대 생물학에서 유전자 화석이라고 일컬어지는 유전 암호, 즉 현존하는 생물들의 유전 정보에서도 발견되며 (...) [La teoría darwiniana está apoyada por prueba de fósiles y prueba genética, pero también se encuentra prueba más concreta en la información genética de los seres actuales, código genético, que se conoce como fósil genético en la biología moderna.] (COREA_KUMSUNG (1B):180)

Como se puede ver en la tabla, hay explicaciones de las diversas pruebas, pero no prestan mucha atención a las pruebas básicas como las biogeográficas, las anatómicas y las embriológicas. Los libros coreanos explican la especiación a través del aislamiento geográfico, pero no la tratan como una prueba de la evolución. Es importante entender el concepto de la evolución y que sea un hecho, pero parece que los libros coreanos del primer curso de bachillerato no lo han considerado con cuidado. 
En cambio, los dos libros de Biología II (BISANG (3B) y CHUNJAE (3B)) dedican un subcapítulo a las pruebas de la evolución y las tratan con atención como los libros de texto de España.

Ahora veamos qué ejemplos utilizan los libros de texto para explicar el darwinismo.

\begin{tabular}{|c|c|c|c|c|c|c|c|c|c|c|c|}
\hline \multicolumn{2}{|c|}{$\begin{array}{c}\text { Ejemplos para explicar } \\
\text { la evolución }\end{array}$} & \multicolumn{4}{|c|}{4 으SO (ESP) } & \multicolumn{4}{|c|}{ 1ㅇachillerato (KOR) } & \multicolumn{2}{|c|}{ 3으 $\mathrm{B}(\mathrm{KOR})$} \\
\hline Español & Coreano & AN & ED & SA & SM & $\mathrm{CJ}$ & KS & SS & $\mathrm{TT}$ & BS & $\mathrm{CJ} 3$ \\
\hline Anemia falciforme & 겸상적혈구 빈혈 & - & - & - & - & - & - & - & - & - & 8 \\
\hline Archaeopteryx & 시조새 & 5 & - & 3 & - & - & 1 & 3 & 3 & 2 & 2 \\
\hline $\begin{array}{l}\text { Embriones de } \\
\text { vertebrados }\end{array}$ & 척추동물 배아 & 1 & 2 & 2 & 4 & - & - & - & - & - & 2 \\
\hline Evolución de amonites & 암모나이트 진화 & - & - & - & - & - & 3 & 2 & 2 & - & 1 \\
\hline Evolución de ballena & 고래 진화 & 1 & - & - & 1 & 1 & - & 2 & - & 2 & 2 \\
\hline Evolución de caballo & 말 진화 & 2 & 1 & - & - & - & - & 1 & - & 1 & - \\
\hline Evolución humana & 인간 진화 & 16 & 6 & 43 & 2 & 5 & 7 & 11 & 13 & 28 & 17 \\
\hline Jirafa de Darwin & 다윈의 기린 & 1 & 1 & 1 & - & 1 & 1 & - & - & 1 & 1 \\
\hline Jirafa de Lamarck & 라마르크의 기린 & 1 & 2 & 1 & 1 & - & - & - & - & 1 & 1 \\
\hline Órganos análogos & 상동기관 & 8 & 2 & 1 & - & - & - & - & - & 2 & 2 \\
\hline Órganos homólogos & 상사기관 & 9 & 3 & 2 & 3 & - & - & - & - & 2 & 3 \\
\hline Órganos vestigiales & 흔적(퇴화)기관 & - & 3 & 2 & - & - & - & - & - & 2 & 1 \\
\hline Pinzones de Galápagos & 갈라파고스 핀치 & 7 & 3 & 4 & 2 & - & - & - & - & 7 & 8 \\
\hline Polilla de abedul & 후추나방 & 3 & - & - & 8 & - & - & 3 & 3 & 3 & 1 \\
\hline $\begin{array}{l}\text { La resistencia a los } \\
\text { antibióticos } \\
\text { ó a los insecticidas }\end{array}$ & $\begin{array}{l}\text { 항생제, 살충제 } \\
\text { 내성 }\end{array}$ & 1 & 1 & - & 12 & - & - & 1 & 6 & 10 & 9 \\
\hline
\end{tabular}

Tabla 6.26. Ejemplos para explicar la evolución (número de párrafos)

El ejemplo de evolución que se ha tratado con mayor frecuencia en ambos países es la 'evolución humana'. Los libros de texto españoles han utilizado con una variedad de ejemplos para ilustrar la teoría evolutiva, pero los libros de texto coreanos del primer curso de bachillerato no prestan atención especial a la evolución humana. Los dos libros para el tercer curso incluyen diversos ejemplos como los libros españoles.

La 'jirafa de Darwin', el famoso ejemplo para explicar la evolución, apareció en tres libros en España y cuatro en Corea. La 'jirafa de Lamarck' fue publicada en los cuatro libros españoles y los dos de Biología II (BISANG (3B) y CHUNJAE (3B)) de Corea.

La 'similitud de los embriones de vertebrados' está incluida en los cuatro libros de España, pero entre los libros coreanos solo un libro de los seis, el de CHUNJAE (3B) lo ha incluido. 


\subsubsection{Conceptos del Darwinismo}

Según Ernst Mayr, el darwinismo está compuesto de cinco ideas principales, como evolución como tal, origen común, diversificación de las especies (especiación), gradualismo y selección natural (Mayr, 1992, 48-50). Podemos ver la presencia de las teorías en los libros de texto en la tabla siguiente excepto la evolución. Se contó sólo si se refería directamente al concepto. Generalmente los libros describen los componentes del darwinismo en detalle. Todos los libros que investigamos incluyen los conceptos sin excepción.

\begin{tabular}{|l|c|c|c|c|c|c|c|c|c|c|c|}
\hline \multicolumn{2}{|c|}{$\begin{array}{c}\text { Ideas principales } \\
\text { del Darwinismo (Ernst Mayr) }\end{array}$} & \multicolumn{4}{c|}{ 4응 (ESP) } & \multicolumn{3}{c|}{ 1으achillerato (KOR) } & \multicolumn{3}{c|}{ 3ㅇ B (KOR) } \\
\hline \multicolumn{1}{|c|}{ Español } & Coreano & AN & ED & SA & SM & CJ & KS & SS & TT & BS & CJ3 \\
\hline Antepasado común & 공통 조상 & 1 & 8 & 6 & 9 & 7 & 12 & 1 & 3 & 10 & 8 \\
\hline Especiación & 종분화 & 16 & 13 & 13 & 13 & 6 & 5 & 2 & 5 & 59 & 28 \\
\hline Gradualismo & 점진주의 & 6 & 6 & 6 & 11 & 1 & 2 & 1 & 4 & 10 & 1 \\
\hline Selección natural & 자연선택 & 16 & 10 & 18 & 21 & 7 & 13 & 4 & 9 & 35 & 23 \\
\hline
\end{tabular}

Tabla 6.27. Cuatro Ideas principales (excepto la propia 'evolución') del Darwinismo (Mayr, 1992), Número de párrafos

SANGSANG (1B) tienen menos párrafos al respecto. Los cuatro libros de España explican con detalle sobre la selección natural y la especiación dedicando más de diez párrafos. Entre los libros coreanos, el libro de BISANG (3B) los explica más minuciosamente. Excepto el de BISANG, los cinco libros de Corea tienen pocos párrafos que explican el gradualismo.

Ya veremos párrafos ejemplares de cada concepto, respectivamente.

i. Antepasado común

Los libros de texto de ambos países enfatizan que toda vida proviene de un antepasado común.

\footnotetext{
후대에 살고 있는 여러 생물의 조상은 계통수의 아래쪽 줄기에 그리고 이들을 공통조상이라고 한다. 이 공통 조상에서 진화되어 나온 생물은 나뭇가지 끝 부분에 그릳다. [Se dibuja en el tallo inferior del árbol filogenético el antecesor de varios seres vivos
} 
posteriores y se llama antepasado común. Los seres se originaron de este antecedente común, dibuja en los extremos de las ramas.] (COREA_CHUNJAE (1B): 156)

애 사람을 비롯한 모든 생명체들이 이렇게 동일한 유전 물질과 동일한 유전 암호를 사용하게 된 것일까? 그것은 바로 지구 상에 존재하는 모든 생명체들이 하나의 공통된 조상에서 시작되었기 때문이다. [¿Por qué todos los seres vivos incluido el ser humano tienen los mismos materiales y códigos genéticos? Es que todos ellos que existen en la Tierra se originaron de un antecesor común.] (COREA_KUMSUNG (1B):160)

오늘날 지구에 살고 있는 생물들은 약 37 억 년 전에 생존한 일종의 단세포 생물의 후손들이다. [Todos los seres orgánicos que viven en la Tierra actualmente, son descendencias de un ser unicelular que existió hace 3.700 millones años.] COREA_SANGSANG (1B):173)

Las especies con características semejantes han evolucionado a partir de un antepasado común. (ESPAÑA_ANAYA (4E): 92)

El estudio de la evolución nos permite afirmar que todos los seres vivos tenemos un origen común y compartimos la misma genética que los primeros seres vivos aparecidos hace 3800 m.a. (ESPAÑA_EDELVIVES (4E): 54)

Todos los seres vivos tienen un origen común. La diversidad biológica se ha originado a lo largo de millones de años de evolución. (ESPAÑA_SANTILLANA (4E):76)

El árbol filogenético y los códigos genéticos son importantes en los libros de texto coreanos para explicar el concepto del antepasado común. En comparación con ellos, la explicación de los libros españoles es más fácil y general.

ii. Especiación (diversificación de las especies)

Ahora vamos a leer párrafos ejemplares que describen la especiación.

오랜 시간에 걸쳐 일어나는 다양한 유전적 변이는 집단의 유전적 특성을 변화시켜 새로운 종을 탄생하게 하는 진화의 원동력이 된다. [Las diversas variaciones genéticas que ocurren durante un largo periodo de tiempo son motor de la evolución que provoca la especiación cambiando la característica genética del grupo.] (COREA_CHUNJAE (1B): 221) 
하나의 생물 종이 두 개 이상의 종으로 나뉘는 과정을 종 분화라고 한다. 종 분화가 일어나는 데 있어서 가장 중요한 과정은 한 집단의 유전자풀이 다른 집단의 유전자 풀과 격리되는 것이다. [El proceso de dividir una especie en dos o más especies se llama especiación. El paso más importante en la especiación es aislar el acervo génico de una población del acervo génico de la otra población.] (COREA_BISANG (3B): 296)

Los cambios evolutivos que afectan a los seres vivos son lentos, continuos y graduales, y culminan con la aparición de nuevas especies. (ESPAÑA_ANAYA (4E): 92)

Si el aislamiento se mantiene, las diferencias acumuladas pueden acabar por originar dos especies diferentes que no se reproducirán entre ellas aunque se encuentren juntas. (ESPAÑA_SM (4E): 92)

En estos ejemplos, se ve que los libros coreanos explican la especiación también desde el punto de vista genético más que los de España.

\section{iii. Gradualismo}

La velocidad de la evolución es uno de los temas que todavía quedan estudios por hacer en el darwinismo. Darwin (1859) explicó que es 'gradual' en su libro «El Origen de las Especies». Veamos ejemplos.

생물의 진화는 짮은 시간에 빠르게 일어나는 것이 아니라, 아주 오랜 시간에 걸쳐 천천히 일어난다. [La evolución de la vida no ocurre rápidamente en un corto período de tiempo, sino que ocurre lentamente durante un tiempo muy largo.] (COREA_KUMSUNG (1B):177) 환경에 적응하는 개체는 생존에 유리한 형질을 자손에게 전하고, 이것이 대를 거듭 하게 되면 가축이나 식물의 경우와 같이 선택된 형질이 점차 누적되어 결국에는 선 조와는 다른 형질을 가진 종으로 변해간다는 뜻이다. [Un individuo adaptado al medio ambiente trasmite su carácter genético ventajoso a su descendencia. Si se repite este proceso generación tras generación, los caracteres seleccionados se acumulan y finalmente la especie se convierte a otra nueva. ] (COREA_SANGSANG (1B): 174)

종 분화 속도는 생물 종에 따라 다르며, 동일한 생물 종이라 할지라도 집단을 둘러 싼 환경에 따라 그 속도가 매우 다양하다. [La velocidad de la especiación es diferente 
dependiendo de la especie. Incluso en la misma especie, su velocidad es muy diversa en función de las circunstancias que rodearon el grupo. ] (COREA_BISANG (3B): 302)

Los cambios evolutivos que afectan a los seres vivos son lentos, continuos y graduales, y culminan con la aparición de nuevas especies. (ESPAÑA_ANAYA (4E): 92)

Las especies cambian de forma lenta, continua y sin brusquedad. (ESPAÑA_EDELVIVES (4E):49)

De esta manera, poco a poco, de forma continua y gradual, las especies van cambiando. (ESPAÑA_SANTILLANA (4E):79)

Si las condiciones ambientales se mantienen, las variaciones favorables irán siendo más abundantes cada generación y las menos favorables irán desapareciendo. Así de forma continua y gradual, la especia cambia. (ESPAÑA_SM (4E): 85)

Los libros de texto españoles interpretan la velocidad de la evolución utilizando las palabras 'gradual', 'lenta' y 'continua'. En cambio, en Corea sólo BISANG (3B) se refiere directamente al 'gradualismo' acompañado con el 'equilibrio puntuado'. Otros libros coreanos no lo explican con detalle.

\section{iv. Selección natural}

Entonces, ¿cómo se ha explicado el núcleo del darwinismo, la 'selección natural'?

이처럼 환경에 불리한 것은 도태되고 유리한 것은 살아남아 유전자풀을 변화시키는 과정을 자연선택이라고 한다. [Como el ejemplo anterior, el proceso de cambiarse el acervo génico a través de la eliminación de los desfavorecidos y la supervivencia de los ventajosos.] (COREA_THETEXT (1B):218)

환경에 적응하기 유리한 형질을 가진 개체는 그렇지 못한 개체에 비해 생존율이 높 아 더 많은 자손을 남기므로 개체군 내에는 환경 적응에 유리한 형질의 빈도가 높아 진다. 다윈은 이러한 현상을 자연선택이라 하였고, 자연선택이 생물 진화의 주요 원 동력이라고 주장하였다. [En una población, sube la frecuencia de los caracteres ventajosos para adaptar al medio ambiente, debido a que un individuo con estos caracteres sobrevive más y tiene más descendencias. Darwin denominó este fenómeno la selección natural e insistió en que es el mecanismo principal de la evolución de los seres vivos.] (COREA_BISANG (3B): 282) 
La naturaleza es responsable de que los individuos mejor adaptados resulten favorecidos. Este proceso, denominado selección natural, hace que, a lo largo de sucesivas generaciones, las características más adecuadas sean más frecuentes y desaparezcan las menos ventajosas. (ESPAÑA_EDELVIVES (4E):49)

La selección natural actúa sobre las variaciones que se producen en los individuos. Si las condiciones del medio se mantienen sin cambios durante mucho tiempo, aquellos individuos con variaciones ventajosas que les confieran una mejor adaptación al medio, sobrevivirán más, se reproducirán más y transmitirán los cambios a la descendencia. (ESPAÑA_SANTILLANA (4E):79)

Generalmente los libros de ambos países interpretan la selección natural en manera similar, pero los libros coreanos ciertamente añaden la perspectiva genética, como el 'acervo génico'.

La diferencia más destacada entre España y Corea del Sur en los contenidos sobre los conceptos principales del darwinismo es el punto de vista genético. Los libros coreanos suelen explicar conceptos darwinianos a través de la interpretación genética, pero los libros españoles no lo muestran la tendencia.

A continuación, contamos todos los conceptos que se publicaron en los contenidos seleccionados excepto los conceptos principales que acabamos de ver. Los conceptos que fueron publicados en más de cinco libros entre los diez que investigamos se recogen en la tabla siguiente (tabla 6.28).

\begin{tabular}{|c|c|c|c|c|c|c|c|c|c|c|c|}
\hline \multicolumn{2}{|c|}{$\begin{array}{l}\text { Conceptos del Darwinismo } \\
\text { (más de } 5 \text { libros) }\end{array}$} & \multicolumn{4}{|c|}{ 4ESO (ESP) } & \multicolumn{4}{|c|}{ 19achillerato (KOR) } & \multicolumn{2}{|c|}{ 3ㅇ B (KOR) } \\
\hline Español & Coreano & AN & ED & SA & SM & $\mathrm{CJ}$ & KS & SS & $\pi$ & BS & $\mathrm{CJ} 3$ \\
\hline Acervo genético & 유전자풀 & - & - & - & - & 8 & 3 & 1 & 12 & 22 & 29 \\
\hline Acumulación de variaciones & 변이의 누적(축적) & 3 & 3 & 1 & 3 & 1 & 1 & 2 & 2 & 2 & 1 \\
\hline Adaptación & 적응 & 29 & 3 & 5 & 9 & 8 & 4 & 3 & 2 & 8 & 6 \\
\hline Aislamiento geográfico & 지리적 격리 & 14 & 7 & 9 & 12 & 2 & 3 & 2 & - & 28 & 17 \\
\hline Aislamiento reproductivo & 생식적 격리 & 4 & 7 & 2 & - & - & - & 1 & - & 35 & 14 \\
\hline Alelo & 대립유전자 & - & - & 2 & 5 & 6 & 2 & - & - & 39 & 19 \\
\hline $\begin{array}{l}\text { Árbol genealógico } \\
\text { (filogenético) }\end{array}$ & 계통수 & 3 & 11 & 2 & 3 & 4 & 5 & 1 & 1 & 13 & 7 \\
\hline Azar & 우연(무작위) & 2 & 3 & 3 & 2 & 1 & 3 & - & 5 & 7 & 2 \\
\hline Biodiversidad & 생물다양성 & 6 & 4 & 5 & 8 & 4 & 4 & 1 & 1 & 3 & 2 \\
\hline Extinción & 멸종 & 5 & 17 & 9 & 7 & 13 & 7 & - & 4 & 2 & 4 \\
\hline Lucha por la supervivencia & 생존경쟁 & 1 & 2 & 4 & 8 & 2 & 3 & 1 & 5 & 4 & 3 \\
\hline Mutación & 돌연변이 & 7 & 7 & 15 & 14 & 1 & 5 & 1 & 6 & 11 & 15 \\
\hline Órganos análogos & 상사기관 & 8 & 2 & 1 & - & - & - & - & - & 2 & 2 \\
\hline Órganos homólogos & 상동기관 & 9 & 3 & 2 & 3 & - & - & - & - & 2 & 3 \\
\hline
\end{tabular}




\begin{tabular}{|l|l|c|c|c|c|c|c|c|c|c|c|}
\hline Órganos Vestigiales & 퇴화(흔적)기관 & - & 3 & 2 & - & - & - & - & - & 2 & 1 \\
\hline Parentesco evolutivo & 진화적 친족관계 & 4 & 7 & 5 & 11 & 2 & 4 & 7 & 6 & 20 & 16 \\
\hline Población (grupo) & 개체군(집단) & 3 & 5 & 16 & 24 & 3 & 2 & 1 & 1 & 6 & 5 \\
\hline Reproducción sexual & 유성생식 & 1 & - & 6 & 3 & 1 & 1 & 1 & 3 & 2 & 1 \\
\hline Selección artificial & 인위선택 & 5 & 1 & 1 & 7 & 1 & 1 & 1 & 2 & - & 3 \\
\hline Supervivencia del más apto & 적자생존 & 6 & 5 & 4 & 12 & 8 & 5 & 2 & 5 & 5 & 9 \\
\hline Variación & 변이 & 10 & 11 & 13 & 27 & 8 & 10 & 2 & 4 & 15 & 14 \\
\hline
\end{tabular}

Tabla 6.28. Conceptos del darwinismo (más de 5 libros). Número de párrafos

Los conceptos de esta tabla son importantes para entender el darwinismo y podemos encontrar varios libros de texto en ambos países.

La diferencia más interesante entre los dos países es la de 'acervo genético (genetic pool)'. Todos los libros de texto coreanos que investigamos explican el acervo genético, pero ningún libro español lo mencionan.

Los libros de texto coreanos de 1ำ de bachillerato son más básicos que los de España y no incluyen órganos homólogos, análogos y vestigiales. Sin embargo, transmiten más conocimientos genéticos que los de España.

\begin{tabular}{|c|c|c|c|c|c|c|c|c|c|c|c|}
\hline \multicolumn{2}{|c|}{$\begin{array}{l}\text { Conceptos avanzados del darwinismo } \\
\text { (menos de } 5 \text { libros) }\end{array}$} & \multicolumn{4}{|c|}{ 4으으 (ESP) } & \multicolumn{4}{|c|}{ 1ㅇachillerato (KOR) } & \multicolumn{2}{|c|}{ 3ㅇ B (KOR) } \\
\hline Español & Coreano & AN & ED & SA & SM & $\mathrm{CJ}$ & KS & SS & $\mathrm{TT}$ & BS & $\mathrm{CJ} 3$ \\
\hline Coevolución & 공진화 & - & - & - & $\sqrt{ }$ & - & - & - & - & - & - \\
\hline Cuellos de botella & 병목현상 & - & - & - & - & - & - & - & - & $\mathrm{V}$ & $\mathrm{V}$ \\
\hline Deriva genética & 유전적 부동 & - & - & - & - & - & - & - & $\mathrm{V}$ & $\mathrm{V}$ & $\sqrt{ }$ \\
\hline Efecto fundador & 창시자 효과 & $\sqrt{ }$ & - & - & - & - & - & - & - & $\mathrm{V}$ & $\sqrt{ }$ \\
\hline $\begin{array}{l}\text { Equilibrio } \\
\text { Hardy-Weinberg }\end{array}$ & 하디-바인베르크 평형 & - & - & - & - & - & - & - & - & $\sqrt{ }$ & $v$ \\
\hline Especiación alopátrica & 이소적 종분화 & $\sqrt{ }$ & - & - & - & - & - & - & - & $\mathrm{V}$ & $\mathrm{V}$ \\
\hline Especiación simpátrica & 동소적 종분화 & $\sqrt{ }$ & - & - & - & - & - & - & - & $\mathrm{V}$ & $\sqrt{ }$ \\
\hline Evolución convergente & 수렴진화 & $\sqrt{ }$ & $\sqrt{ }$ & - & - & - & - & - & - & - & $\mathrm{V}$ \\
\hline Fenotipo & 표현형 & - & - & V & v & - & - & - & - & - & $\mathrm{V}$ \\
\hline Flujo genético & 유전자 흐름 & - & - & - & - & - & - & - & $\mathrm{V}$ & $\mathrm{V}$ & $\mathrm{V}$ \\
\hline Fósiles vivientes & 살아있는 화석 & - & - & - & $\sqrt{ }$ & - & - & - & $\mathrm{V}$ & - & - \\
\hline Genes homeóticos & 핵심조절유전자 & - & - & - & - & $\sqrt{ }$ & - & - & - & $\mathrm{V}$ & $\mathrm{V}$ \\
\hline Macroevolución & 대진화 & $\sqrt{ }$ & - & - & - & - & - & - & - & - & $\mathrm{V}$ \\
\hline Microevolución & 소진화 & $\sqrt{ }$ & - & - & - & - & - & - & - & - & $\mathrm{V}$ \\
\hline Mimetismo & 의태 & $\sqrt{ }$ & - & - & - & - & - & - & - & - & - \\
\hline Nicho (ecológico) & 생태적 지위 & $\sqrt{ }$ & $\sqrt{ }$ & - & - & - & - & - & - & - & - \\
\hline Presión de selección & 선택압 & - & - & $\sqrt{ }$ & - & - & - & - & - & - & - \\
\hline Radicación adaptiva & 적응 방산 & $\sqrt{ }$ & - & - & - & - & - & - & - & - & - \\
\hline Selección sexual & 성선택 & - & - & - & - & - & - & - & $\mathrm{V}$ & $\mathrm{V}$ & - \\
\hline
\end{tabular}

Tabla 6.29. Presencia de los conceptos avanzados del darwinismo (menos de 5 libros)

La tabla 6.29 muestra los conceptos que aparecen en cuatro libros o menos y normalmente 
son conceptos más avanzados.

Como es de esperar, entre los libros coreanos los de la asignatura avanzada (Biología II) incluyen más conceptos. KUMSUNG (1B) y SANGSANG (1B) no incluyen ningún concepto, THE TEXT (1B) tiene cuatro conceptos y CHUNJAE (1B) solamente tiene los 'genes homeóticos'.

ANAYA incluye más contenidos avanzados entre los libros de texto españoles. EDELVIVES y SANTILLANA tienen dos respectivamente, SM tiene tres conceptos.

Los libros de texto españoles organizan adecuadamente el contenido y lo comunican con claridad. Pensamos que explican con método el nacimiento del darwinismo, los principios de la teoría, las pruebas de la evolución, etc. En comparación con los libros coreanos, la diferencia más notoria es la presencia del creacionismo en los libros de Biología y Geología con tanta importancia como historia de la ciencia.

En general, los libros de texto coreanos prestan atención a los conocimientos genéticos. A pesar de que los libros del $1 \mathfrak{0}$ de bachillerato de Corea del Sur intentaron explicar el darwinismo fácilmente, parecen que no lo lograron. Según el plan nacional de estudio, la asignatura es una introducción de las ciencias e incluye conceptos difíciles en un nivel moderado $^{31}$. En consecuencia, los libros de Ciencias presentan conceptos difíciles sin explicación suficiente y no incluyen las pruebas de la evolución. Es dudable si los alumnos pueden entender el darwinismo correctamente con estos libros. Biólogos evolutivos coreanos muestran sus preocupaciones al respecto (Jung, et al, 2010: 27-28). Los dos libros de Biología II (BISANG (3B) y CHUNJAE (3B)) tienen estructuras similares a las de los libros de España pero incluyen más conocimientos genéticos.

\footnotetext{
31 "A pesar de que sea un concepto difícil, si se necesita para que entiendan los estudiantes sintéticamente la naturaleza y animar su interés por la ciencia, se puede incluir en la asignatura 'Ciencias' en un nivel adecuado." (Ministerio de Educación, Ciencia y Tecnología de Corea del Sur, 2011: 58)
} 
6.5. Libros Antiguos de Texto: la Evolución de los Contenidos sobre el Darwinismo en España y Corea del Sur

Este capítulo es un estudio complementario sobre el estudio de libros de texto actuales que se analizó anteriormente. Examinaremos los cambios del darwinismo en los libros de texto en ambos países durante un mismo período. Es importante investigar cómo este cambio se relaciona con la situación social en ambos países.

Corea del Sur formó su primer sistema educativo en el sentido moderno en 1945, por eso, compararemos los contenidos del darwinismo en libros de texto de España y Corea del Sur a partir de los años cuarenta hasta los años noventa del siglo XX.

Hemos conseguido 12 libros de Biología (o Ciencias Naturales) en España y 12 en Corea del Sur. Examinamos el índice, el índice onomástico, el índice analítico y los textos y seleccionamos el capítulo o el apartado que incluye la palabra 'evolución/evolucionismo' o 'Darwin (darwinismo, darwiniano/a y darwinista)'. Si el libro de texto no incluye la evolución, seleccionamos el capítulo o el apartado que explica 'el cambio de los seres vivos con el tiempo'.

Este análisis es una investigación parcial para obtener una perspectiva general, debido a que no fue posible conseguir muchos libros que se usaron durante casi 60 años en los dos países. Por lo tanto, aplicamos MCC solamente en manera sencilla para ver el porcentaje total de Cultura Científica Intrínseca y Extrínseca. Como se seleccionaron sólo uno o dos libros por década, no podemos garantizar su representatividad.

Sin embargo, pensamos que los contenidos seleccionados de libros de texto antiguos son suficientes para mirar cualitativamente el cambio con el tiempo de los contenidos darwinianos dependiendo de la situación socio-política de la sociedad.

Ahora veremos brevemente el análisis por MCC. Para la codificación, elegimos un libro por década (6 libros de España y 6 libros de Corea del Sur). Si hay varios libros en la década, seleccionamos uno mediano considerando su contenido y su extensión.

\begin{tabular}{|l|r|r|r|r|r|r|r|r|r|r|r|r|}
\hline & \multicolumn{4}{|c|}{ ESPAÑA } & \multicolumn{5}{c|}{ COREA DEL SUR } \\
\cline { 2 - 13 } & 1940 & 1958 & 1964 & 1975 & 1983 & 1995 & 1949 & 1956 & 1960 & 1974 & 1981 & 1995 \\
\hline CINTR & 49 & 13 & 170 & 81 & 180 & 235 & 104 & 77 & 51 & 46 & 65 & 143 \\
\hline
\end{tabular}




\begin{tabular}{|l|r|r|r|r|r|r|r|r|r|r|r|r|r|}
\hline CINTOP & 0 & 0 & 0 & 1 & 0 & 6 & 1 & 3 & 0 & 0 & 1 & 18 \\
\hline CINTVA & 0 & 0 & 2 & 3 & 0 & 1 & 7 & 3 & 0 & 0 & 0 & 0 \\
\hline CEXTR & 0 & 0 & 5 & 5 & 0 & 11 & 12 & 0 & 0 & 3 & 0 & 0 \\
\hline CEXTOP & 0 & 0 & 0 & 0 & 0 & 0 & 0 & 0 & 0 & 0 & 1 & 0 \\
\hline CEXTVA & 0 & 0 & 1 & 1 & 0 & 1 & 9 & 0 & 0 & 0 & 0 & 0 \\
\hline TECNO & 0 & 0 & 0 & 0 & 0 & 0 & 0 & 0 & 0 & 0 & 0 & 0 \\
\hline NoCC & 0 & 0 & 0 & 0 & 0 & 0 & 15 & 0 & 0 & 0 & 0 & 0 \\
\hline TOTAL & 49 & 13 & 178 & 91 & 180 & 254 & 148 & 83 & 51 & 49 & 67 & 161 \\
\hline
\end{tabular}

Tabla 6.30. Clasificación de los contenidos por MCC

Podemos ver en la tabla 6.30 el gran número de los párrafos de CINTR (Cultura Científica Intrínseca Representacional). A pesar de que es difícil decir categóricamente porque las muestras son pocas, no hay muchos párrafos de las informaciones operacionales de Cultura Científica Intrínseca y Extrínseca. Entre los libros españoles, el más moderno, el libro del 1995 tiene más contenidos no CINTR y entre los coreanos excepto el más antiguo, CINTR ocupa casi todos los párrafos.

Simplificamos la tabla por país y expresamos como el gráfico siguiente.

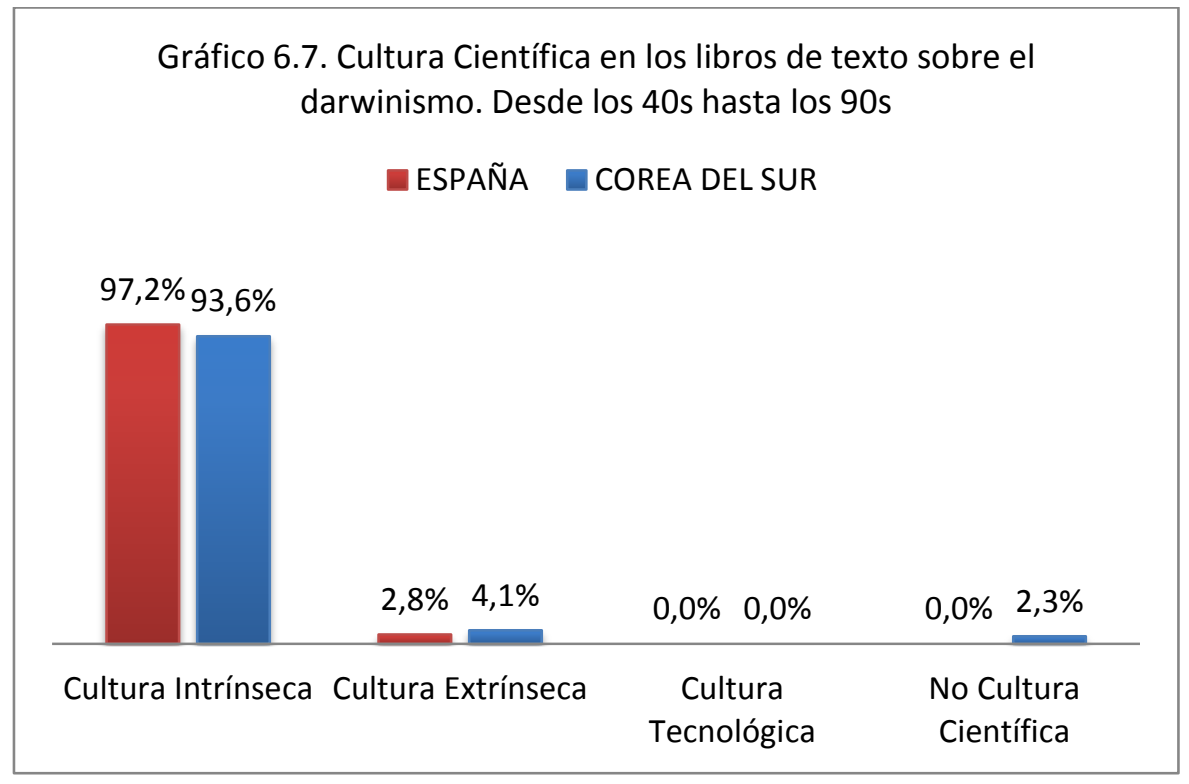

Los libros antiguos de los dos países poseen un porcentaje más alto de Cultura Científica Intrínseca que los actuales. Los libros de texto actuales de España tienen 93,3\% de Cultura Científica Intrínseca y los antiguos tienen 97,2\%. Los libros antiguos españoles incluyeron 3,9\% más de contenidos propiamente científicos. Los libros de texto actuales de Corea del Sur incluyen un $94,1 \%$ de Cultura Científica Intrínseca y los antiguos ofrecen un 93,6\%. Las 
proporciones son muy similares.

Ahora veremos el cambio de los contenidos sobre el darwinismo. Para comprobar si la situación socio-política de la sociedad, que hemos observado previamente en la parte I de esta tesis, influyó en los contenidos del darwinismo en los libros de texto, analizamos en todos los libros seleccionados si menciona la palabra 'evolución', el 'creacionismo', 'Darwin', 'Lamarck' y 'Mendel'. El creacionismo está incluido porque su presencia está relacionada con la censura de la dictadura. La presencia de Lamarck y Mendel es significativa si Darwin no está incluido, porque muestra la ausencia deliberada de Darwin.

6.5.1. La Evolución del Darwinismo en Libros de Texto de España (los años 40-90. Siglo XX)

Seleccionamos 12 libros de texto antiguos de España para ver la evolución de los contenidos sobre el darwinismo.

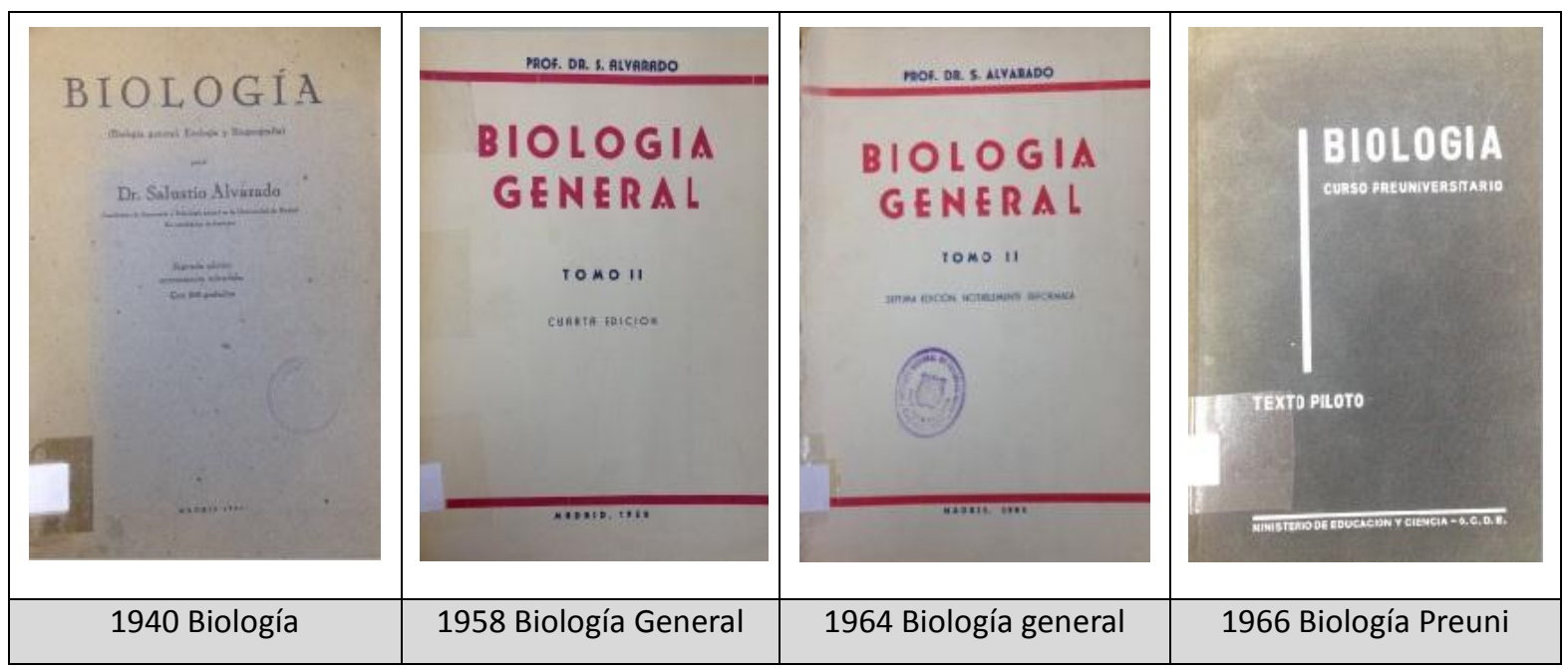




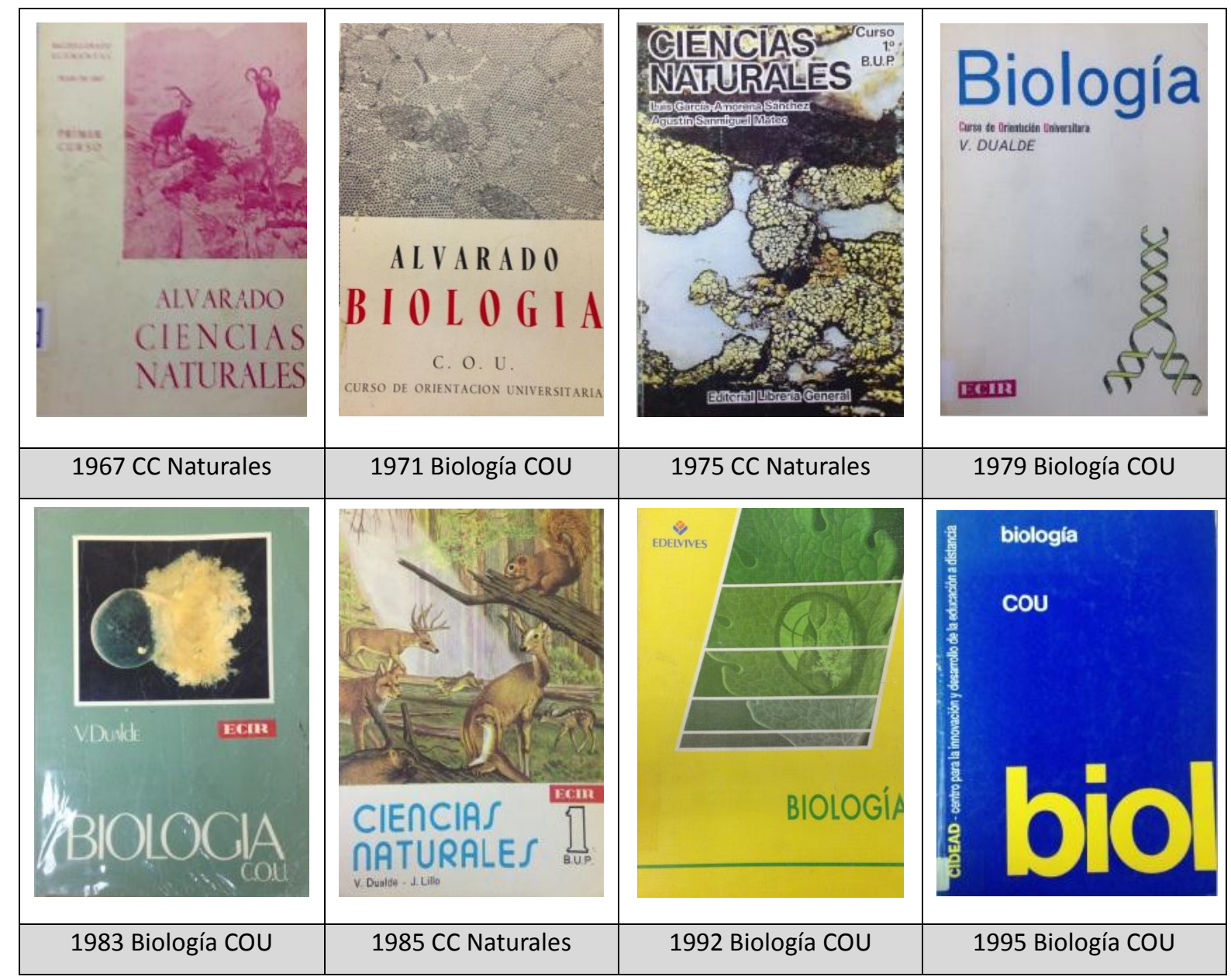

Tabla 6.31. Las portadas de los libros de texto antiguos de España

\begin{tabular}{|l|c|c|c|c|c|}
\hline \multicolumn{1}{|c|}{ ESPAÑA } & EVOLUCIÓN & CREACIONISMO & DARWIN & LAMARCK & MENDEL \\
\hline 1940 BIOLOGÍA & no & no & no & sí & sí \\
\hline 1958 BIOLOGÍA GENERAL & no & no & no & no & sí \\
\hline 1964 BIOLOGÍA GENERAL & sí & sí & sí & sí & sí \\
\hline 1966 BIOLOGÍA PREUNI & no & no & no & no & no \\
\hline 1967 CC NATURALES & no & no & no & no & no \\
\hline 1971 BIOLOGÍA COU & sí & sí & sí & sí & sí \\
\hline 1975 CC NATURALES & sí & sí & sí & sí & sí \\
\hline 1979 BIOLOGÍA COU & sí & no & sí & sí & sí \\
\hline 1983 BIOLOGÍA COU & sí & no & sí & sí & sí \\
\hline 1985 CC NATURALES & sí & no & sí & sí & sí \\
\hline 1992 BIOLOGÍA COU & sí & sí & sí & sí & sí \\
\hline 1995 BIOLOGÍA COU & sí & sí & sí & sí & sí \\
\hline
\end{tabular}

Tabla 6.32. La presencia de los contenidos principales del darwinismo en los libros de texto antiguo de España

En el libro que se publicó en 1940, explica el cambio de los seres vivos no con el concepto de 
la evolución, sino con la herencia. Se refiere a Lamarck, pero como el científico que propuso la teoría de la herencia de los caracteres adquiridos, no como el primer evolucionista que formó una teoría científicamente estructurada. $Y$ da mucha importancia a la teoría mendeliana, describe el mecanismo de la herencia con dibujos detallados. Sin mencionar Darwin, incluye varias teorías posteriores a él, por ejemplo, Weismann, que refutó la teoría de Lamarck y propuso la teoría de plasma germinal, y Morgan, que investigó la herencia de cromosoma. El concepto de mutación también está presente que no se sabía en la época de Darwin. Aunque no está en el libro la 'selección natural', pero para explicar el cambio de los seres se usa el concepto de 'selección'.

El libro se escribió más de 80 años después de la presentación del darwinismo. En la época, el valor del darwinismo ya fue reconocido mundialmente como la mejor teoría para explicar los seres vivos. Sin embargo, el libro de texto de 1940 de «Biología» explica la herencia y el cambio de los seres vivos sin mencionar a Darwin. Por ello, podemos saber que era una exclusión intencional. La iglesia católica y el gobierno militar de aquel entonces trataron el darwinismo como una teoría materialista y ateísta y no quería que se lo difundiera al público. Como no está incluido el 'problemático' Darwin en este libro, tampoco están presentes el creacionismo ni algún pensamiento religioso.

El libro «Biología general» del 1958 no es bastante diferente con el del 1940. Mendel posee más peso que antes y ocupa una buena parte del capítulo genética. La palabra 'evolución' está presente en este libro, pero no cobra exactamente el mismo significado que en el darwinismo, sino que se refiere al cambio de los cromosomas sexuales. Este libro tiene el mismo autor, Dr. S. Alvarado, que el libro de 1940 y el siguiente, de 1964, también fue escrito por él.

En el libro de 1964 el concepto de la evolución aparece manifiestamente. Se separó de las leyes genéticas y se hizo título de un capítulo. A la vez, la creación divina también apareció en el libro.

La evolución está presente en la cuarta parte del libro, "la evolución de los organismo" y la parte tiene dos capítulos, "las pruebas de la evolución” y “el mecanismo de la evolución”.

El capítulo 22, "las pruebas de la evolución" empieza con el argumento sobre fijismo y evolucionismo. Después de contar la historia del fijismo y presentar a Lamarck como el primer evolucionista que elaboró una teoría científica, viene el párrafo siguiente. 
La teoría evolucionista es la idea contraria a la teoría fijista, pero no se opone a la idea creacionista, que supone que la vida no pudo surgir en el mundo sin la intervención directa de la voluntad divina. La diferencia entre la doctrina fijista y la doctrina evolucionista estriba en que el fijismo postula la creación independiente de cada especie, mientras el evolucionismo queda satisfecho con admitir que Dios creó la asignatura viviente o una forma viviente primitiva dotada de la facultad de evolucionar para diversificarse cada vez más y originar los distintos grupos taxonómicos. (BIOLOGÍA GENERAL_ESPAÑA, 1964: 352)

Podemos decir que esta descripción no es científica, sino que proviene del trasfondo cultural o social. Cuando el concepto de la evolución no estaba incluido en la enseñanza, el creacionismo tampoco estaba. Con la aparición de la evolución, la idea religiosa también entra en escena. Pensamos que el autor escribió este párrafo para incluir el evolucionismo en el libro de texto, especialmente el darwinismo que ya había ganado el protagonismo en la biología. El contenido muestra la preocupación del autor y la actitud del 'evolucionismo teísta', ya que aún estaba bajo la dictadura a pesar de que la censura se estaba perdiendo con el tiempo.

Darwin aparece en el libro como el científico que presentó pruebas suficientes de la evolución. El libro incluyó varias pruebas presentadas en «El Origen de las Especies». Además, presentó el concepto de 'lucha por supervivencia' y la influencia de Malthus explicando el mecanismo de la evolución. También interpreta el desarrollo del darwinismo y el proceso de la combinación con la teoría de Mendel, es decir, dedicó bastante espacio a explicar el darwinismo que no estaba en los libros anteriores.

En la década de 1960, los libros de texto difieren en explicar la evolución y a Darwin. A finales de la dictadura, con la vuelta de Darwin a los libros de texto el creacionismo también apareció. El creacionismo no estaba incluido como una teoría de la vida anteriormente, sino que acompañó con el darwinismo como otra opción más tradicional.

La importancia del darwinismo aumentó en los años 70. Ya el evolucionismo y Darwin se instalaron como uno de los contenidos principales de la asignatura Biología y los logros de la genética empezaron a introducirse. 
El libro de «Biología COU» del 1971 también insistió en que la evolución no contrapone al creacionismo, pero desapareció la actitud del evolucionismo teísta. El libro del 1975 también dio una gran importancia al darwinismo y empezó a explicar el viaje de Beagle.

Pasando la Transición española, desapareció el creacionismo en los libros de texto de «Biología», en los años 90 volvió en el contexto distinto y sigue presente hasta ahora. En la época de la dictadura, la presencia del creacionismo era para insistir en la compatibilidad entre la fe y el darwinismo, pero después de los 90s, el creacionismo es una explicación anterior al darwinismo sobre la vida.

6.5.2. La Evolución del Darwinismo en Libros de Texto de Corea del Sur (los años 40-90. Siglo XX)

Seleccionamos 12 libros de texto antiguos de Corea del Sur para ver la evolución de los contenidos sobre el darwinismo.

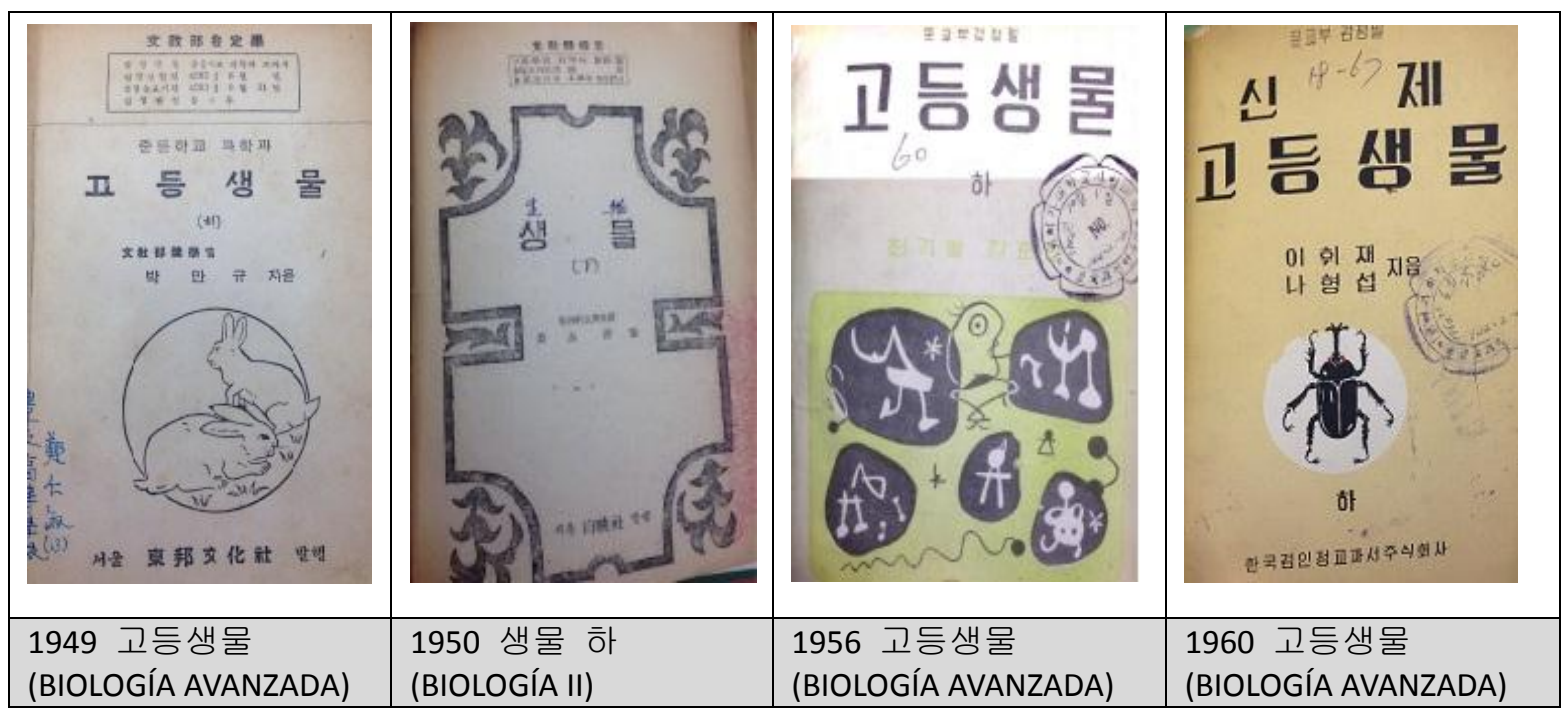




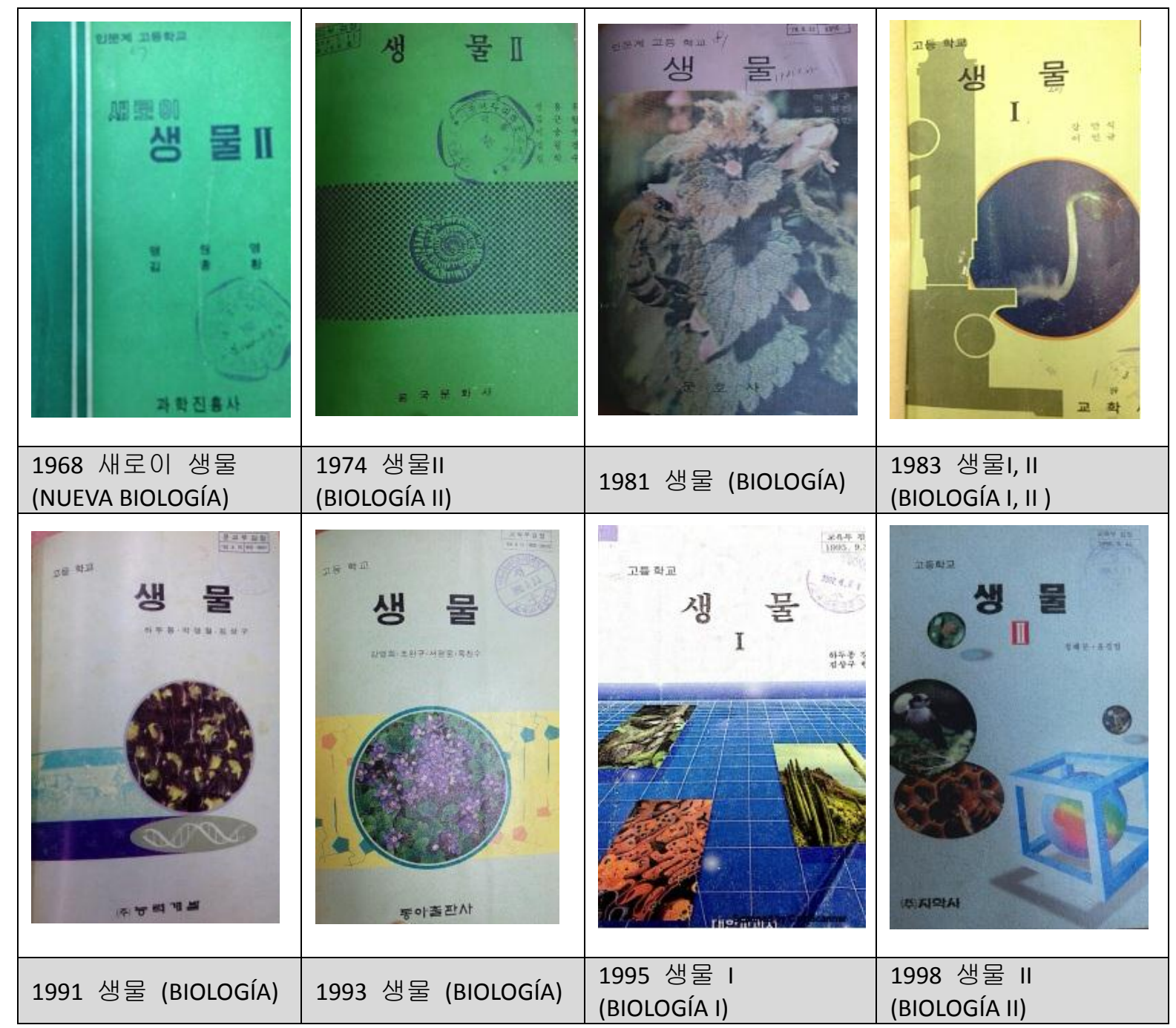

Tabla 6.33. Las portadas de los libros de texto antiguos de Corea del Sur

\begin{tabular}{|l|c|c|c|c|c|}
\hline \multicolumn{1}{|c|}{ COREA DEL SUR } & EVOLUCIÓN & CREACIONISMO & DARWIN & LAMARCK & MENDEL \\
\hline 1949 고등생물 (BIOLOGÍA AVANZADA) & sí & sí & sí & sí & sí \\
\hline 1950 생물 하 (BIOLOGÍA II) & sí & sí & sí & sí & sí \\
\hline 1956 고등생물 (BIOLOGÍA AVANZADA) & sí & no & sí & sí & sí \\
\hline 1960 고등생물 (BIOLOGíA AVANZADA) & sí & sí & sí & sí & sí \\
\hline 1968 새로이 생물 (NUEVA BIOLOGÍA) & sí & sí & sí & sí & sí \\
\hline 1974 생물 II (BIOLOGÍA II) & sí & no & sí & sí & sí \\
\hline 1981 생물 (BIOLOGÍA) & sí & no & sí & sí & sí \\
\hline 1983 생물 I, II (BIOLOGÍA I, II) & sí & no & sí & sí & sí \\
\hline 1991 생물 (BIOLOGÍA) & sí & no & sí & sí & sí \\
\hline 1993 생물 (BIOLOGÍA) & sí & no & sí & sí & sí \\
\hline 1995 생물 I (BIOLOGÍA I) & sí & no & sí & sí & sí \\
\hline 1998 생물 II (BIOLOGÍA II) & sí & no & sí & sí & sí \\
\hline
\end{tabular}

Tabla 6.34. La presencia de los contenidos principales del darwinismo en los libros de texto antiguo de Corea del Sur.

Entre los 12 libros de texto antiguos de Corea del Sur que se seleccionan, cuatro libros se 
publicaron durante las dictaduras militares (NUEVA BIOLOGÍA, 1968; BIOLOGÍA II, 1974; BIOLOGÍA, 1981; BIOLOGÍA I y II, 1983). Sin embargo, como hemos comentado en la parte I de este estudio, las dictaduras coreanas (El gobierno de Park (1961-1979) y de Chun (19801988)) no censuraron nunca el darwinismo, por eso no influyeron en los contenidos sobre el darwinismo en los libros de texto. Examinamos los cuatros libros $y$, confirmamos que no había diferencia observable.

El creacionismo está presente en cuatro libros coreanos y siempre como una explicación anterior al darwinismo, o sea, como historia de las teorías de la vida.

옛날 사람은 생물을 모두 신이 창조한 것이라고 믿었다. 저 유명한 생물학자 린네 (Linaeus, 1778)도 그 저서 "Sistema Naturae"에 생물이라는 것은 절대로 변하지 앟는다 는 것을 발표하였다. [Los antiguos creían que Dios creó todos los seres vivos. El eminente biólogo Linné (Linaeus, 1778) también presentó en su libro «Sistema Naturae» que los seres vivos nunca cambian.] (BIOLOGÍA AVANZADA_COREA, 1949: 148)

생명은 태초에 신이 창조하였고, 현재도 변함없다는 생각을 창조설이라고 한다. 이런 생각은 고대 그리이스 시대부터 중세기 암흑시대까지 계속하였다. 그림과 같이 개는 개에서 생기고, 말은 말에서 나온다. 그와 같이 종은 변하지 않는 것처럼 보인다. [EI creacionismo es el pensamiento que todos los seres vivos se crearon por Dios en el comienzo de todo y siguen sin cambio. Este pensamiento continuó desde los antiguos griegos hasta las edades oscuras de la Edad Media. Como podéis ver en la ilustración, los perros paren perros y los caballos paren caballos. Parecía que las especies no cambian.] (NUEVA BIOLOGÍA_COREA_1968:49)

Desde el principio, la compatibilidad entre el darwinismo y la fe cristiana no era algo para considerar en redacción de los libros de texto en Corea del Sur, sólo dependía de la presencia de la historia de la ciencia. Si está presente el creacionismo, siempre está acompañado con el fijismo. Llegando a los años 70, es difícil encontrar el creacionismo en los libros de texto de Biología.

Los libros de texto coreanos de la asignatura de Biología han tratado principalmente el concepto de evolución desde su primera versión en la década de 1940. Aunque la importancia varía a veces, siempre tienen a Lamarck, Mendel y Darwin y la evolución nunca 
ha sido eliminada.

Hasta ahora, hemos estudiado el darwinismo en los libros de texto de ciencia de España y Corea a través de MCC y los conceptos del darwinismo, también hemos visto los cambios de la teoría con el tiempo en libros antiguos de texto. Según el resultado del análisis con MCC, no hubo gran diferencia entre España y Corea del Sur en su proporción de la cultura científica intrínseca y extrínseca. Los contenidos de los libros de texto revelan algunas diferencias entre los dos países, que se pueden explicar por la influencia de su cultura respectivamente. En el análisis de los viejos libros de texto, se confirmó que el darwinismo en los libros de texto españoles fue influenciado por la censura, pero en los libros de texto coreanos siempre ha sido estable.

Los resultados de este capítulo se analizarán en detalle en el capítulo 8, que es la conclusión de esta parte, con el análisis de los artículos periodísticos en el capítulo que se presenta a continuación (capítulo 7). 


\section{Capítulo 7. El Darwinismo en Artículos Periodísticos de España y Corea del Sur}

En este capítulo reuniremos artículos periodísticos de ambos países que incluyen Darwin y la evolución darwiniana, y detectaremos en ellos la aceptación del darwinismo en los dos países a través de cómo los medios de comunicación de masas, especialmente los periódicos, comunican las teorías darwinianas.

En el campo de la divulgación científica, los medios de comunicación ocupan un papel decisivo. Los adultos que ya terminaron la educación obligatoria tienen pocas oportunidades de acercarse a los conocimientos científicos, por lo que los medios de comunicación representan una de las fuentes más importantes de la información científica para la sociedad. Si los contenidos de un asunto son interesantes para el público, se seleccionan y se convierten en un artículo periodístico (Gregory y Miller, 2001: 203). Los intereses del público dependen de los factores culturales. A través del análisis sobre el darwinismo en los medios de comunicación de los dos países, podríamos acercarnos a la influencia de la cultura en la divulgación de las teorías científicas.

Los objetivos del análisis de los artículos periodísticos son:

- Analizar los artículos periodísticos de 2009 (el bicentenario del nacimiento de Darwin), y un año antes y después (2008 y 2010) de España y Corea del Sur. Dos periódicos de cada país se han seleccionado (EL MUNDO y EL PAÍS de España. HANKYOREH y JOONGANG de Corea). 2009 ha sido elegido como punto de partida para detectar la repercusión de las actividades conmemorativas en la divulgación científica.

- Comparar la ratio entre la cultura científica intrínseca y la extrínseca y clasificar las informaciones representacionales, operacionales y valorativas a través del modelo de Cultura Científica, MCC (Quintanilla, 2012) para examinar la cultura científica en los artículos periodísticos en los dos países.

- Clasificar los artículos por autoría, encuadre, género periodístico, fuente, sección y temas (Quintanilla, et al., 2005) y comparar España y Corea del Sur para averiguar las 
características de los artículos periodísticos que incluyen el contenido darwiniano. Investigar quién escribe el artículo, de dónde viene el contenido y de qué habla en concreto para detecter si hay diferencias culturales. Especialmente, averiguaremos la presencia de las ideas religiosas que se oponen al darwinismo y de las novedades científicas que muestran el interés científico de la sociedad.

\subsection{Selección de Textos}

Para analizar cómo presentan el darwinismo los medios de comunicación en España y Corea del Sur, se han elegido dos periódicos nacionales de cada país. EL MUNDO y EL PAís de España, HANKYOREH y JOONGANG de Corea del Sur son los elegidos. Se ha considerado la ideología política de los periódicos. EL MUNDO y JOONGANG están en el espectro político centro-derechista. EL PAÍS y HANKYOREH son de centro-izquierda por lo general. Entre los periódicos de pago, EL PAÍS es el diario de más tirada en España (el promedio de tirada: 377.603 en julio de 2012/junio de 2013) y EL MUNDO es el segundo (267.151 en junioagosto de 2013). JOONGANG es el segundo de mayor tirada en Corea del Sur (1.292.428 en 2012) y HANKYOREH es el sexto (269.174 en 2012).

Debido a que el darwinismo es un conjunto de teorías ya comprobadas que se presentaron desde hace un siglo y medio, no es tan frecuente encontrar a Darwin o el darwinismo hoy en día en los medios de comunicación. Sin embargo, el año 2009 fue especial, porque fue el año del bicentenario del nacimiento de Darwin y además se cumplieron 150 años de la publicación de «El origen de las especies». El ambiente científico celebró diversas actividades conmemorativas como congresos, exposiciones, lecturas, etc. Así mismo, los medios de comunicación también prestaron mayor atención al darwinismo y al extraordinario científico, Charles Darwin.

Por lo tanto, analizando los artículos que mencionaron el darwinismo o a Darwin en 2009 de los periódicos elegidos, podríamos acercarnos a los aspectos de la presencia y la difusión del darwinismo en los medios de comunicación de los dos países. También se ha ampliado el 
análisis a 2008 y 2010, un año antes y después del año especial, para observar el efecto del año conmemorativo.

\section{Búsqueda, selección y descarga}

Se han coleccionado artículos que mencionan a Darwin o darwinismo en las versiones digitales de cada periódico. Las páginas web de los periódicos cuentan con un buscador de artículos por medio de palabras clave y la fecha de publicación.

Las palabras clave para la búsqueda han sido "Darwin (darwinismo)", "evolución (evolucionismo)", "selección natural", “antepasado (o antecesor) común" y "especiación". Estas palabras provienen de ideas generales como el fundador, la teoría y conceptos principales (Mayr, 1996). Dentro del marco darwiniano existen más conceptos específicos pero son muy técnicos y no se suelen relacionar con el propio darwinismo, así que delimitamos las palabras clave en conceptos más básicos y principales (Tabla 7.1 y 7.2). La fecha de publicación de los artículos seleccionados es entre 1 de enero de 2008 y 31 de diciembre de 2010.

Se ha repetido la búsqueda de artículos tres veces (fechas: Tabla 7.1 y 7.2 ) dando un margen temporal para reafirmar. Además, averiguamos de nuevo con motores de búsqueda como Google, Yahoo, Daum, o Naver.

De esta colección de artículos, se han descartado algunos textos que no se refieren a la evolución darwiniana, ya que palabras como 'evolución' y 'selección' se utilizan a menudo en un sentido distinto del darwinismo.

\begin{tabular}{|c|c|c|}
\hline \multirow[b]{2}{*}{ Selección de texto } & \multicolumn{2}{|c|}{ ESPAÑA } \\
\hline & $\begin{array}{r}\text { ELMUNDO } \\
\text { ELEMUN }\end{array}$ & $\begin{array}{c}\text { ELPAÍS } \\
\text { EL PATSS }\end{array}$ \\
\hline Palabras clave & \multicolumn{2}{|c|}{$\begin{array}{c}\text { Darwin (Darwinismo), } \\
\text { Evolución (Evolucionismo), } \\
\text { Selección natural, Antepasado común y Especiación }\end{array}$} \\
\hline \multirow{2}{*}{$\begin{array}{l}\text { Fecha de búsqueda, } \\
\text { selección y descarga }\end{array}$} & $15 / 08 / 2013$ & $16 / 08 / 2013$ \\
\hline & 09/09/2013 & $10 / 09 / 2013$ \\
\hline
\end{tabular}




\begin{tabular}{|c|l|c|}
\hline & \multicolumn{1}{|c|}{$15 / 06 / 2014$} & $14 / 06 / 2014$ \\
\hline Buscador & http://www.elmundo.es & http://elpais.com \\
\hline
\end{tabular}

Tabla 7.1. Selección de artículos periodísticos. España

\begin{tabular}{|c|c|c|}
\hline \multirow[b]{2}{*}{ Selección de texto } & \multicolumn{2}{|c|}{ COREA DEL SUR } \\
\hline & HANKYOREH & JOONGANG \\
\hline Palabras clave & \multicolumn{2}{|c|}{$\begin{array}{c}\text { 다윈 (다윈주의), } \\
\text { 진화 (진화론), 자연선택, } \\
\text { 공통조상, 종 분화 }\end{array}$} \\
\hline \multirow{3}{*}{$\begin{array}{l}\text { Fecha de búsqueda, } \\
\text { selección y descarga }\end{array}$} & $14 / 08 / 2013$ & $14 / 08 / 2013$ \\
\hline & $11 / 09 / 2013$ & $11 / 09 / 2013$ \\
\hline & $03 / 06 / 2014$ & 03/06/2014 \\
\hline Buscador & http://www.hani.co.kr & http://JOONGANG.joins.com \\
\hline
\end{tabular}

Tabla 7.2. Selección de artículos periodísticos. Corea del Sur

Se han descargado los artículos seleccionados en formato PDF o Word ( ${ }^{*}$.docx) con todos los materiales que incluyen y se han nombrado cada artículo como "añoperiódico_fecha.xxx (por ejemplo, 2008elmundo_0101.docx)" ${ }^{\prime 32}$. El siguiente paso es crear un archivo de Atlas.ti y incluir todos los artículos para analizar en una 'unidad hermenéutica ${ }^{33}$.

Cuando se citan literalmente contenidos que aparecen en los libros de texto, en el final del párrafo, indicaremos según este formato de cita: (autor, "título del artículo", dd/mm/aaaa(fecha de publicación), periódico).

\section{Número de Artículos}

El número total de artículos seleccionados en los tres años son 271 artículos españoles y 341 artículos surcoreanos.

\footnotetext{
32 La lista completa de los artículos seleccionados está disponible en ANEXO I: Lista de materiales del análisis de contenido.

${ }^{33}$ Es nombre de la unidad de proyecto en el programa Atlas.ti. versión 6.2.
} 


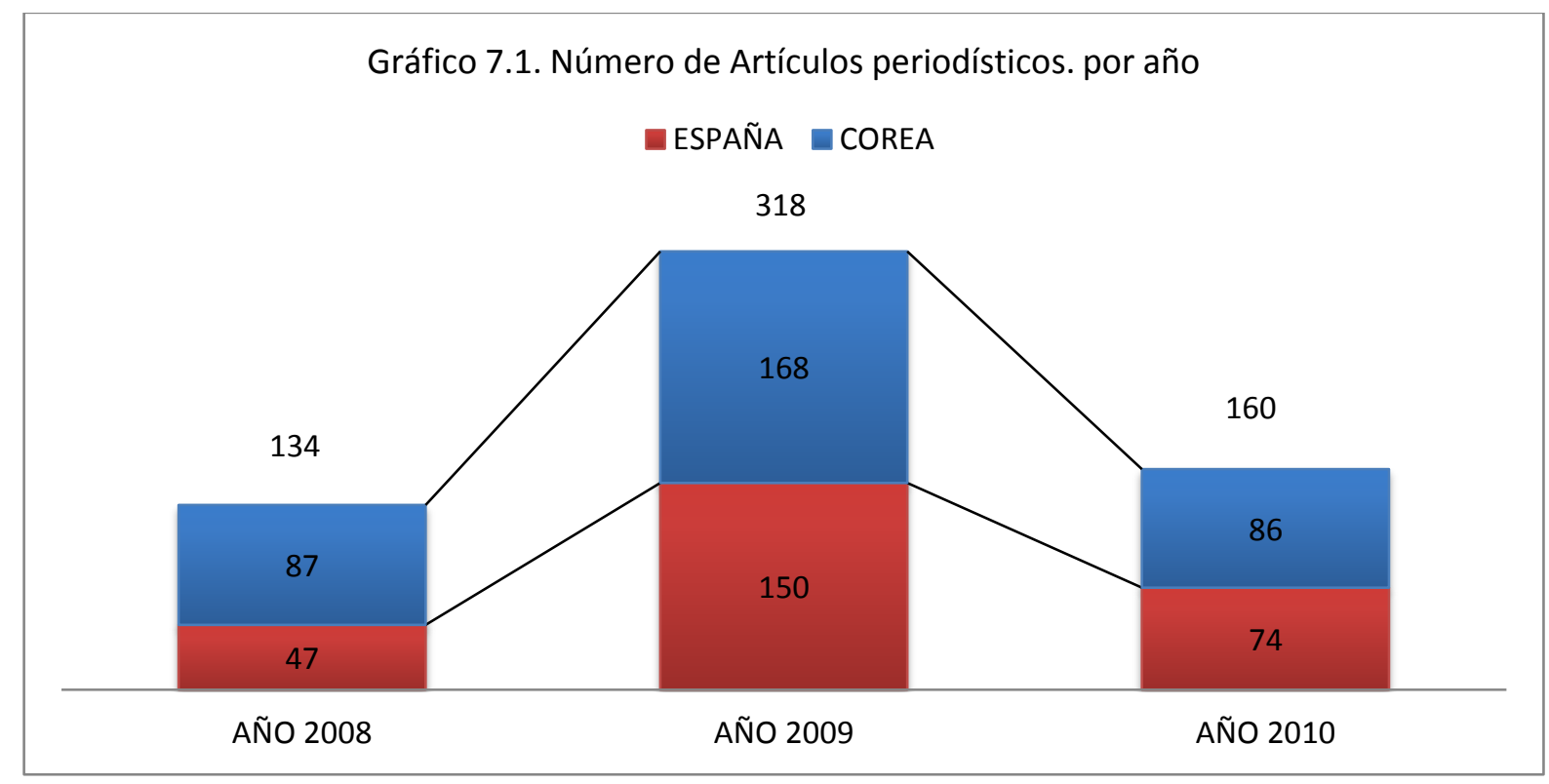

En 2008, un año antes del bicentenario, en Corea se menciona mucho más el darwinismo que en España. Corea tiene 87 artículos, mientras que España ofrece 47. En 2009 (el bicentenario) aumenta considerablemente el número de artículos en comparación a 2008. En España los artículos aumentan 219\% (47 $\rightarrow$ 150). En Corea del Sur aumentan 93\% (87 $\rightarrow$ 168).

Después del año conmemorativo, en 2010, el número de artículos coreanos (86) vuelve a lo normal y es casi igual en número que en 2008 (87). Significa que en Corea del Sur el aumento del número de artículos por el año especial de Darwin fue temporal y no afectó al año siguiente. Por el contrario, el número de artículos españoles en 2010 aumenta 57.4\% en comparación a 2008. Es decir, se puede considerar que el año conmemorativo estimuló el interés periodístico sobre el darwinismo y lo mantenía hasta el año siguiente. 


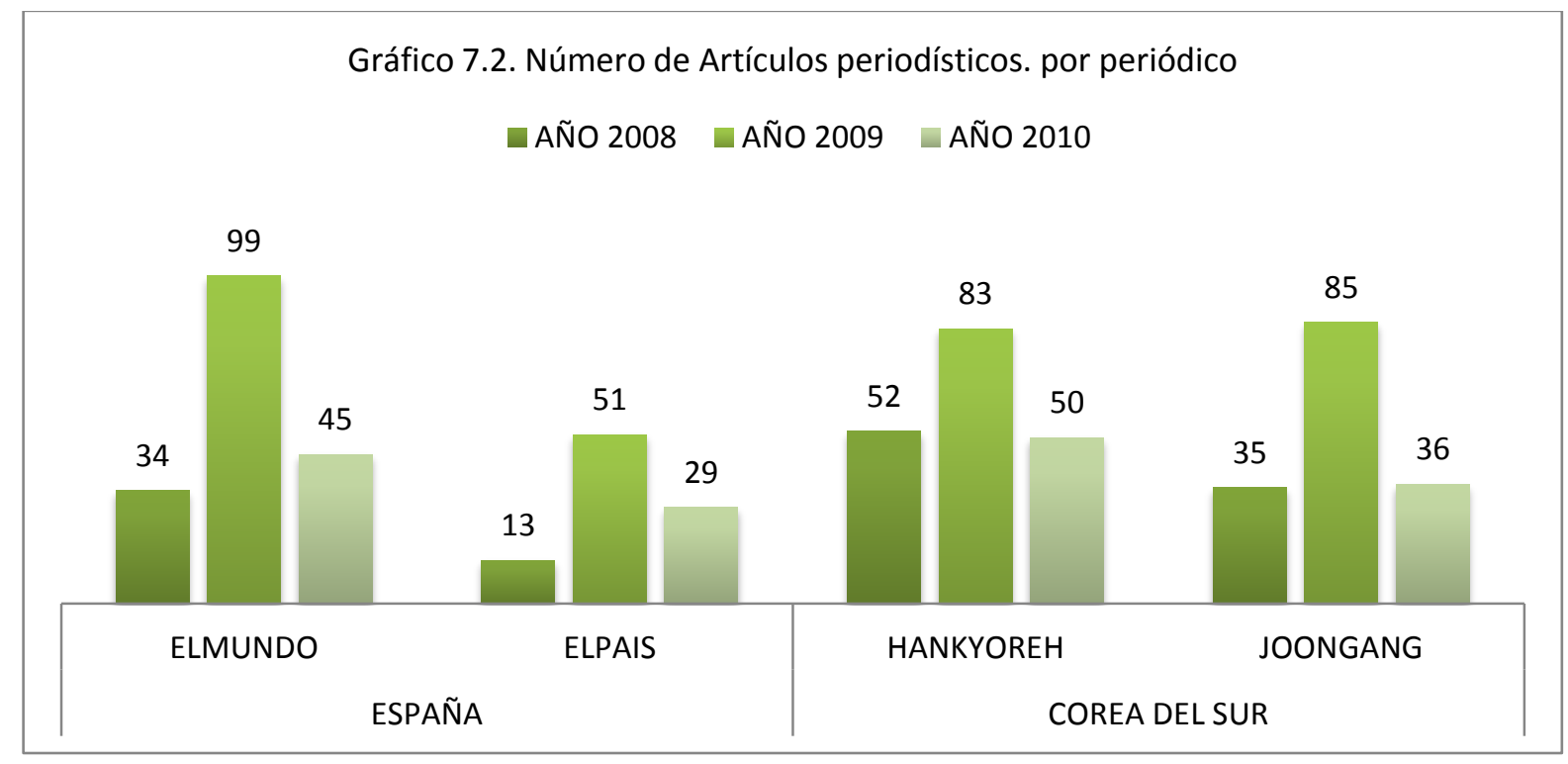

Si nos detenemos en el número de artículos por periódico y por año, la tendencia es la misma. En el caso de España, el número de artículos aumenta visiblemente en 2009. En 2010 disminuye pero se mantiene más alto que en 2008. En Corea del Sur, en 2009 aumenta el número de los artículos, sin embargo en 2010 disminuye por igual que 2008.

Otra cosa que llama la atención en el gráfico 7.2 es la diferencia entre los periódicos en el mismo país. Entro los dos periódicos españoles, EL MUNDO, que se considera como un periódico más conservador, publicó 178 artículos que mencionan el darwinismo durante los tres años y EL PAÍS de centro-izquierda publicó solo 93 artículos. La diferencia es de 85, una cifra llamativa. En cambio, entre los dos periódicos coreanos, el periódico derechista JOONGANG ofrece 159 artículos y el de centro-izquierda HANKYOREH genera 185. La diferencia es 26 y más pequeña que la de España, pero el periódico de izquierda publicó más artículos que el derechista. HANKYOREH publicó en 2009 un número similar a JOONGANG, pero los años normales (2008 y 2010) publicó más artículos del darwinismo que JOONGANG. 


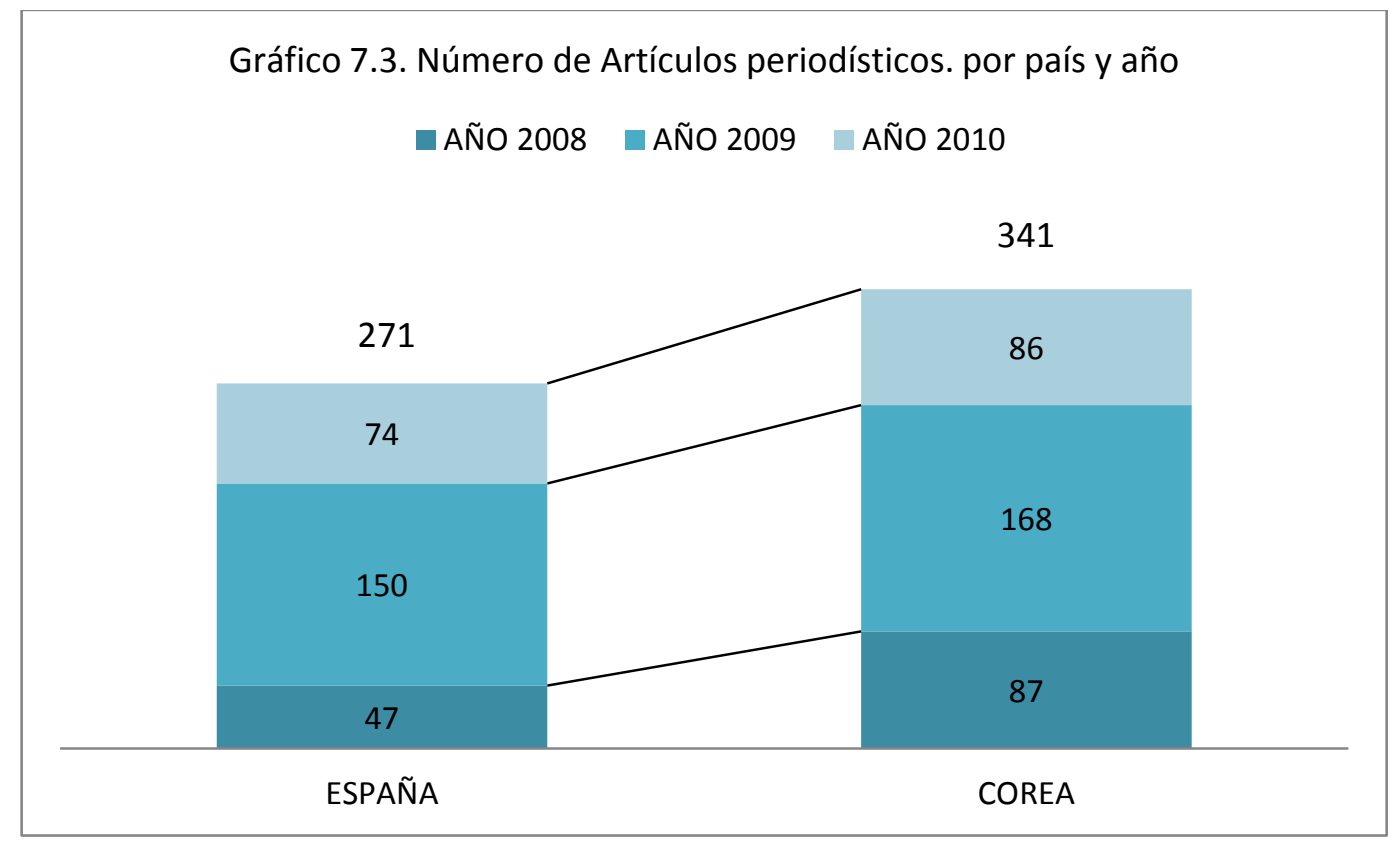

En los años previo y posterior al conmemorativo, Corea del Sur publicó más artículos periodísticos que incluyen contenidos darwinianos que España, aunque los periódicos españoles publicaron más en 2010 por la influencia que el año conmemorativo que 2008.

7.2. Darwinismo en la Prensa. ¿Cómo aparece la Cultura Científica de España y Corea del Sur?

En el capítulo 5, se ha presentado el modelo de Cultura Científica (MCC en adelante) para analizar los contenidos. Un artículo periodístico es la unidad de la codificación con MCC y puede tener varios códigos. El número total de artículos seleccionados es de 612 .

Hay varios artículos cuyo tema no es el darwinismo, ya que reunimos todos los artículos si menciona a Darwin, el darwinismo o algún concepto principal de la teoría una vez o más. A veces la teoría aparece como un concepto complementario para explicar otra idea científica o no científica. En estos casos, codificamos pensando el contexto general del artículo y a la vez cómo aparece el darwinismo.

Véase el resultado general de la codificación. 


\begin{tabular}{|c|c|c|c|c|c|c|c|c|}
\hline \multirow{13}{*}{$\begin{array}{c}\text { TOTAL } \\
\text { ARTÍCULOS }\end{array}$} & \multirow[t]{13}{*}{612} & \multirow[t]{8}{*}{ CIENCIA } & \multirow[t]{8}{*}{1110} & \multirow[t]{4}{*}{ INTRINSECA } & TEXTO & 280 & CINTR & 242 \\
\hline & & & & & IMAGEN & 212 & CINTOP & 18 \\
\hline & & & & & & CINTVA & 20 \\
\hline & & & & & & & CINT_IM & 212 \\
\hline & & & & \multirow[t]{4}{*}{ EXTRINSECA } & TEXTO & 403 & CEXTR & 238 \\
\hline & & & & & IMAGEN & 215 & CEXTOP & 97 \\
\hline & & & & & & & CEXTVA & 68 \\
\hline & & & & & & & CEXT_IM & 215 \\
\hline & & \multirow[t]{2}{*}{ TECNOLOGIA } & \multirow[t]{2}{*}{29} & TECNO & TEXTO & 17 & & \\
\hline & & & & TECNO_IM & IMAGEN & 12 & & \\
\hline & & \multirow{2}{*}{$\begin{array}{c}\text { NO C. } \\
\text { CIENTÍFICA }\end{array}$} & \multirow[t]{2}{*}{125} & NOCC & TEXTO & 71 & & \\
\hline & & & & NOCC_IM & IMAGEN & 54 & & \\
\hline & & $\begin{array}{c}\text { TOTAL } \\
\text { CÓDIGOS }\end{array}$ & & & & & & 1264 \\
\hline
\end{tabular}

Tabla 7.3. Sumario de las categorías de la codificación manual por MCC

La tabla 7.3 muestra la distribución de los códigos en los dos países. La siguiente tabla presenta el resultado de los contenidos españoles.

\begin{tabular}{|c|c|c|c|c|c|c|c|c|}
\hline \multirow{13}{*}{$\begin{array}{c}\text { TOTAL } \\
\text { ARTÍCULOS } \\
\text { ESPAÑA }\end{array}$} & \multirow[t]{13}{*}{271} & \multirow[t]{8}{*}{ CIENCIA } & \multirow[t]{8}{*}{485} & \multirow[t]{4}{*}{ INTRINSECA } & TEXTO & 121 & CINTR & 101 \\
\hline & & & & & IMAGEN & 92 & CINTOP & 12 \\
\hline & & & & & & CINTVA & 8 \\
\hline & & & & & & & CINT_IM & 92 \\
\hline & & & & \multirow[t]{4}{*}{ EXTRINSECA } & TEXTO & 188 & CEXTR & 80 \\
\hline & & & & & IMAGEN & 84 & CEXTOP & 74 \\
\hline & & & & & & & CEXTVA & 34 \\
\hline & & & & & & & CEXT_IM & 84 \\
\hline & & \multirow[t]{2}{*}{ TECNOLOGIA } & \multirow[t]{2}{*}{14} & TECNO & TEXTO & 11 & & \\
\hline & & & & TECNO_IM & IMAGEN & 3 & & \\
\hline & & \multirow{2}{*}{$\begin{array}{c}\text { NO C. } \\
\text { CIENTÍFICA }\end{array}$} & \multirow[t]{2}{*}{65} & NOCC & TEXTO & 40 & & \\
\hline & & & & NOCC_IM & IMAGEN & 25 & & \\
\hline & & $\begin{array}{c}\text { TOTAL } \\
\text { CÓDIGOS }\end{array}$ & & & & & & 564 \\
\hline
\end{tabular}

Tabla 7.4. Sumario de las categorías de la codificación manual por MCC. ESPAÑA

Los 271 artículos españoles seleccionados poseen 564 códigos.

La siguiente tabla presenta el resultado de los artículos surcoreanos.

\begin{tabular}{|c|c|c|c|c|c|c|c|c|}
\hline \multirow{6}{*}{$\begin{array}{c}\text { TOTAL } \\
\text { ARTÍCULOS } \\
\text { COREA S. }\end{array}$} & \multirow[t]{6}{*}{341} & \multirow[t]{6}{*}{ CIENCIA } & \multirow[t]{6}{*}{625} & \multirow[t]{4}{*}{ INTRINSECA } & TEXTO & 159 & CINTR & 141 \\
\hline & & & & & IMAGEN & 120 & CINTOP & 6 \\
\hline & & & & & & & CINTVA & 12 \\
\hline & & & & & & & CINT_IM & 120 \\
\hline & & & & \multirow[t]{2}{*}{ EXTRINSECA } & TEXTO & 215 & CEXTR & 158 \\
\hline & & & & & IMAGEN & 131 & CEXTOP & 23 \\
\hline
\end{tabular}




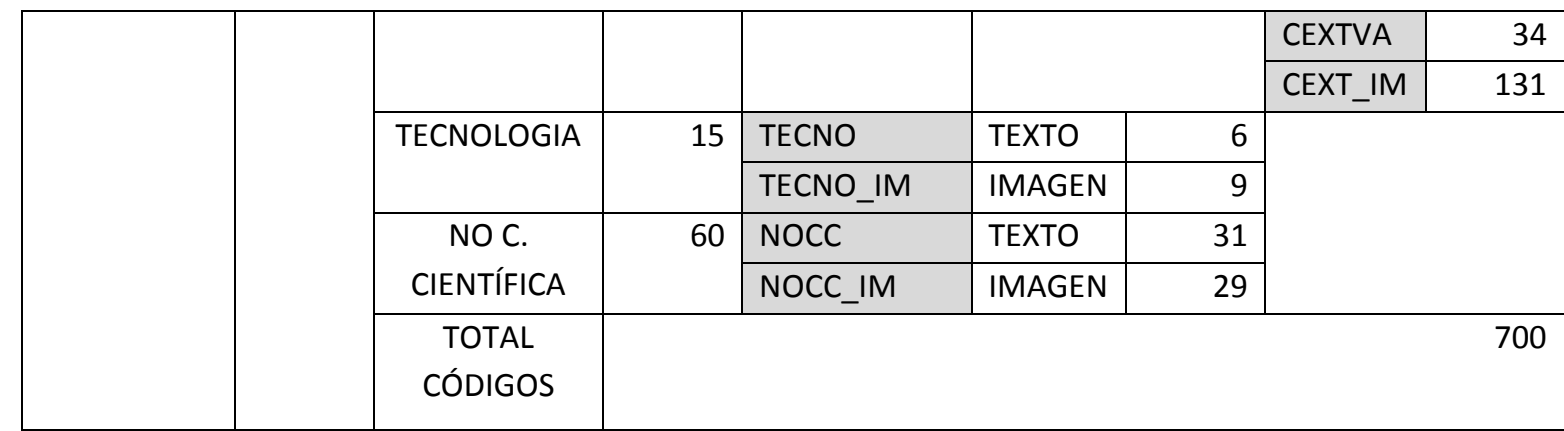

Tabla 7.5. Sumario de las categorías de la codificación manual por MCC. COREA DEL SUR

Los 341 artículos coreanos seleccionados tienen 700 códigos. Los detalles específicos de los códigos de estas tres tablas se describirán de forma gradual.

La siguiente tabla muestra el resultado de la codificación de los artículos periodísticos a través de MCC.

\begin{tabular}{|c|c|c|c|c|c|c|c|c|c|c|c|c|}
\hline & \multicolumn{4}{|c|}{ AÑO 2008} & \multicolumn{4}{|c|}{ AÑO 2009} & \multicolumn{4}{|c|}{ AÑO 2010} \\
\hline & \multicolumn{2}{|c|}{ ESPAÑA } & \multicolumn{2}{|c|}{ COREA } & \multicolumn{2}{|c|}{ ESPAÑA } & \multicolumn{2}{|c|}{ COREA } & \multicolumn{2}{|c|}{ ESPAÑA } & \multicolumn{2}{|c|}{ COREA } \\
\hline & MUN $^{34}$ & PAI & HAN & JOO & MUN & PAI & HAN & JOO & MUN & PAI & HAN & JOO \\
\hline CINTR & 15 & 0 & 26 & 15 & 41 & 20 & 38 & 29 & 16 & 9 & 23 & 10 \\
\hline CINTOP & 8 & 0 & 2 & 1 & 2 & 1 & 1 & 0 & 0 & 1 & 1 & 1 \\
\hline CINTVA & 4 & 0 & 6 & 4 & 2 & 1 & 2 & 0 & 0 & 1 & 0 & 0 \\
\hline CEXTR & 17 & 5 & 13 & 15 & 25 & 12 & 46 & 43 & 15 & 6 & 26 & 15 \\
\hline CEXTOP & 10 & 2 & 3 & 2 & 34 & 15 & 7 & 7 & 9 & 4 & 1 & 3 \\
\hline CEXTVA & 4 & 6 & 16 & 9 & 14 & 7 & 4 & 3 & 2 & 1 & 0 & 2 \\
\hline TECNO & 2 & 3 & 2 & 0 & 1 & 4 & 0 & 2 & 0 & 1 & 0 & 2 \\
\hline NoCC & 2 & 3 & 2 & 2 & 8 & 7 & 5 & 8 & 9 & 11 & 7 & 7 \\
\hline № artículos & 34 & 13 & 52 & 35 & 99 & 51 & 83 & 85 & 45 & 29 & 50 & 36 \\
\hline
\end{tabular}

Tabla 7.6. № de artículo por código de MCC, periódico y año

\begin{tabular}{|l|r|r|}
\hline & ESPAÑA & COREA \\
\hline CINTR & 101 & 141 \\
\hline CINTOP & 12 & 6 \\
\hline CINTVA & 8 & 12 \\
\hline CEXTR & 80 & 158 \\
\hline CEXTOP & 74 & 23 \\
\hline CEXTVA & 34 & 34 \\
\hline TECNO & 11 & 6 \\
\hline NoCC & 40 & 31 \\
\hline
\end{tabular}

34 En las tablas, utilizamos los nombres de periódicos en abreviatura. EL MUNDO: MUN, EL PAÍS: PAI, HANKYOREH: HAN y JOONGANG: JOO. 


\begin{tabular}{|l|l|l|}
\hline № artículos & 271 & 341 \\
\hline
\end{tabular}

Tabla 7.7. № de artículo por país. MCC

Ahora convertimos los datos de la tabla 7.7 a porcentaje y expresamos como gráfico.

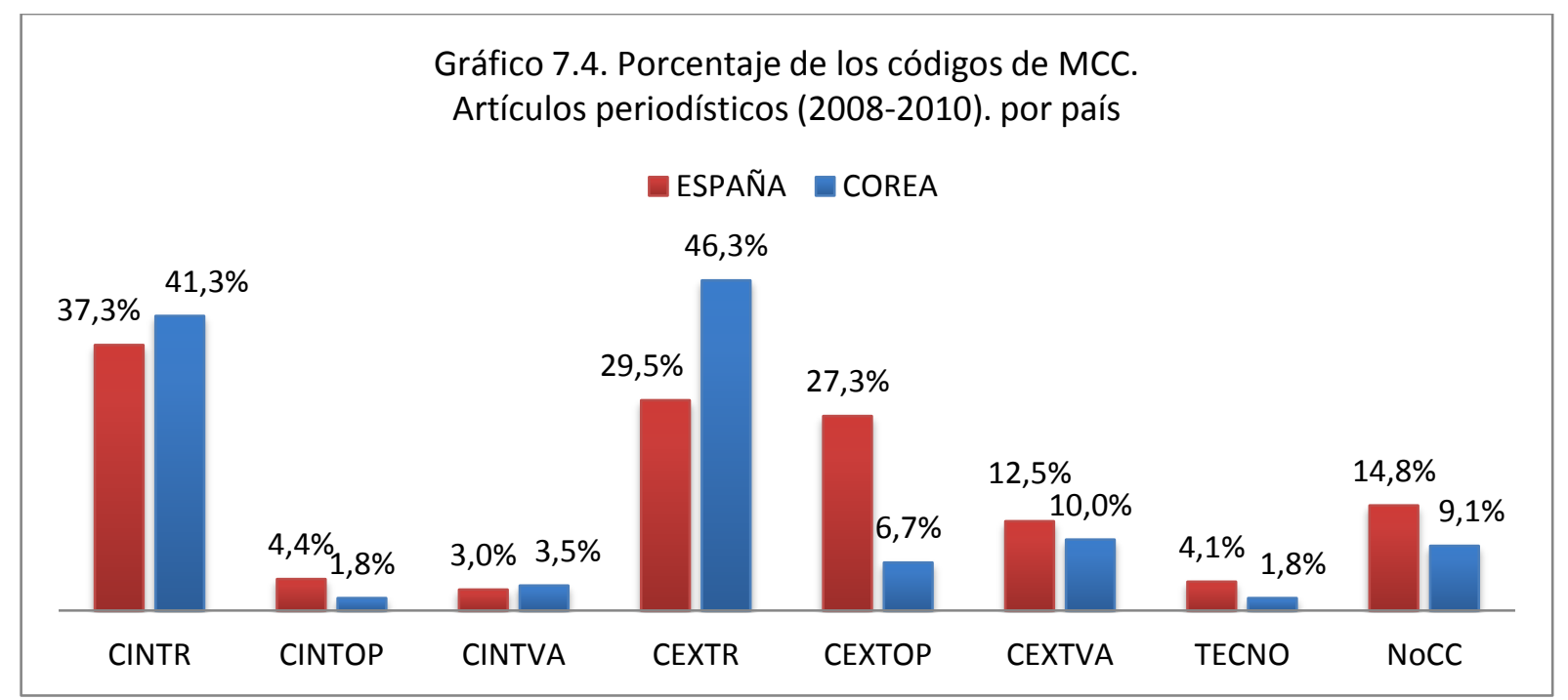

Podemos interpretar este gráfico:

- Entre los artículos españoles, el código que tiene más artículos es CINTR (37,3\%), el segundo es CEXTR $(29,5 \%)$ y el tercero es CEXTOP $(27,3 \%)$.

- Entre los artículos coreanos, el código que posee más artículos es CEXTR (46,3\%), el segundo es CINTR (41,3\%) y el tercero es CEXTVA (10.0\%).

- La proporción del CEXTR de Corea es más de 1,5 veces que la de España.

- El porcentaje de CEXTOP de España es casi 4 veces que el coreano. Hay artículos que presentan actividades científicas como exposiciones conmemorativas, apertura de museos, eventos divulgativos, etc.

- En los dos países aparecen varios artículos que incluyen informaciones valorativas, especialmente la proporción del CEXTVA es bastante alta (España: 12,5\%, Corea del Sur: $10,0 \%)$

El gráfico 7.5 expresa el resultado por la cultura científica intrínseca y la extrínseca. 


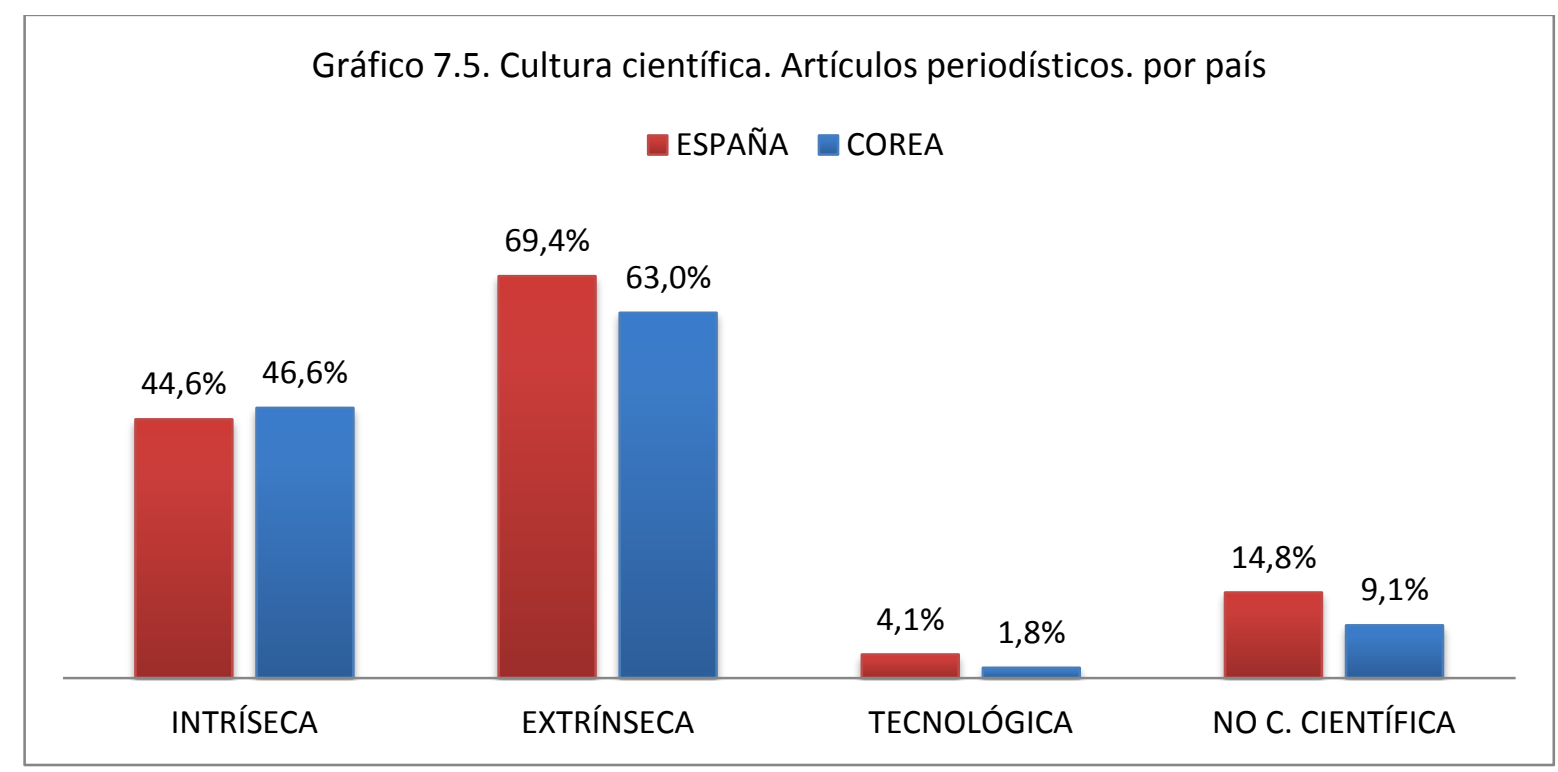

La proporción de la información intrínseca es considerablemente baja en comparación a los libros de texto (Libros de texto: España 93,3\%, Corea 94,1\% | Prensa: España 44,6\%, Corea 46,6\%) y la extrínseca es mucho más alta (Libros de texto: España 8,7\%, Corea 9,8\% | Prensa: España 69,4\%, Corea 63,0\%) en los dos países. Los datos demuestran que hay una gran diferencia en función de tipo de texto. Enseñar ciencia y transmitir noticias sobre ciencia son bastante diferentes y éste depende más de la sociedad. Además, la actualidad periodística podría influir en la proporción entre la cultura científica intrínseca y extrínseca, ya que se han seleccionado los tres años por la conmemoración de Darwin de 2009, que es periodísticamente importante pero académicamente no tanto y eso podría producir el alto porcentaje de la cultura científica extrínseca.

Once artículos españoles $(4,1 \%)$ y seis coreanos $(1,8 \%)$ son tecnológicos. Entre los españoles, siete artículos se refieren a digitalizar contenido científico (especialmente, lo darwiniano) para divulgar. Otros tres hacen referencia a videojuegos que utilizan conceptos darwinianos y el último es sobre una exposición de tecnología. Entre los coreanos, dos se refieren a videojuegos y cuatro hablan del mercado tecnológico. Entre los últimos cuatro sobre el mercado, tres mencionan el "efecto Galápagos" para explicar el aislamiento de un mercado.

Por otra parte, 40 artículos españoles $(14,8 \%)$ y 31 coreanos $(9,1 \%)$ no son científicos pero mencionan a Darwin o su teoría. En estos artículos podremos detectar cómo tratan los periódicos de España y Corea del Sur el darwinismo en contexto no científico sino social. 


\section{Informaciones de Cultura Científica Intrínseca}

Como hemos observado en el gráfico $7.5,44,6 \%$ de los artículos españoles y $46,6 \%$ de los coreanos incluyen informaciones intrínsecas. Entre los dos países no hay gran diferencia.

La información intrínseca se puede clasificar entre la representacional, la operacional y la valorativa.

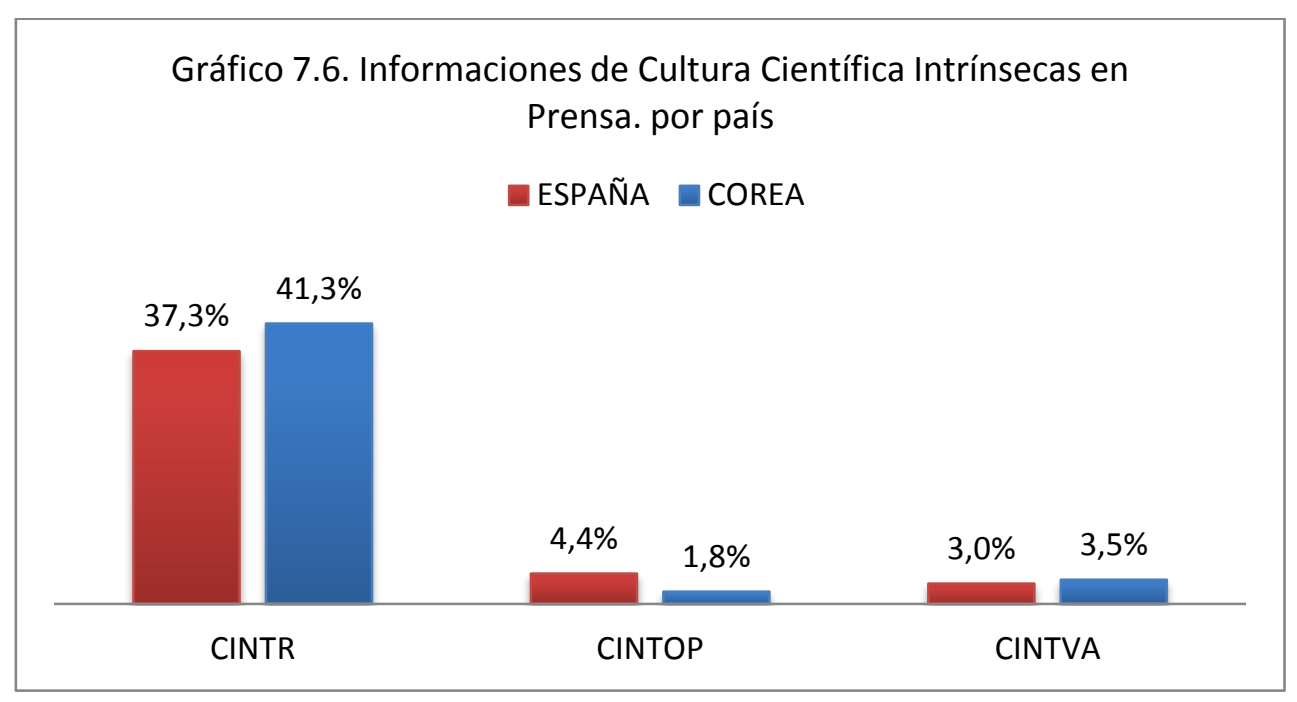

CINTR, Cultura Científica Intrínseca Representacional ocupa el 37,3 de España y el 41,3\% de Corea del Sur. Corea tiene $4 \%$ más. Las informaciones de CINTR podemos encontrar en artículos que explica la propia teoría de la evolución o presenta nuevos estudios científicos. Los contenidos que podemos percibir en los párrafos siguientes codificamos como el CINTR. 


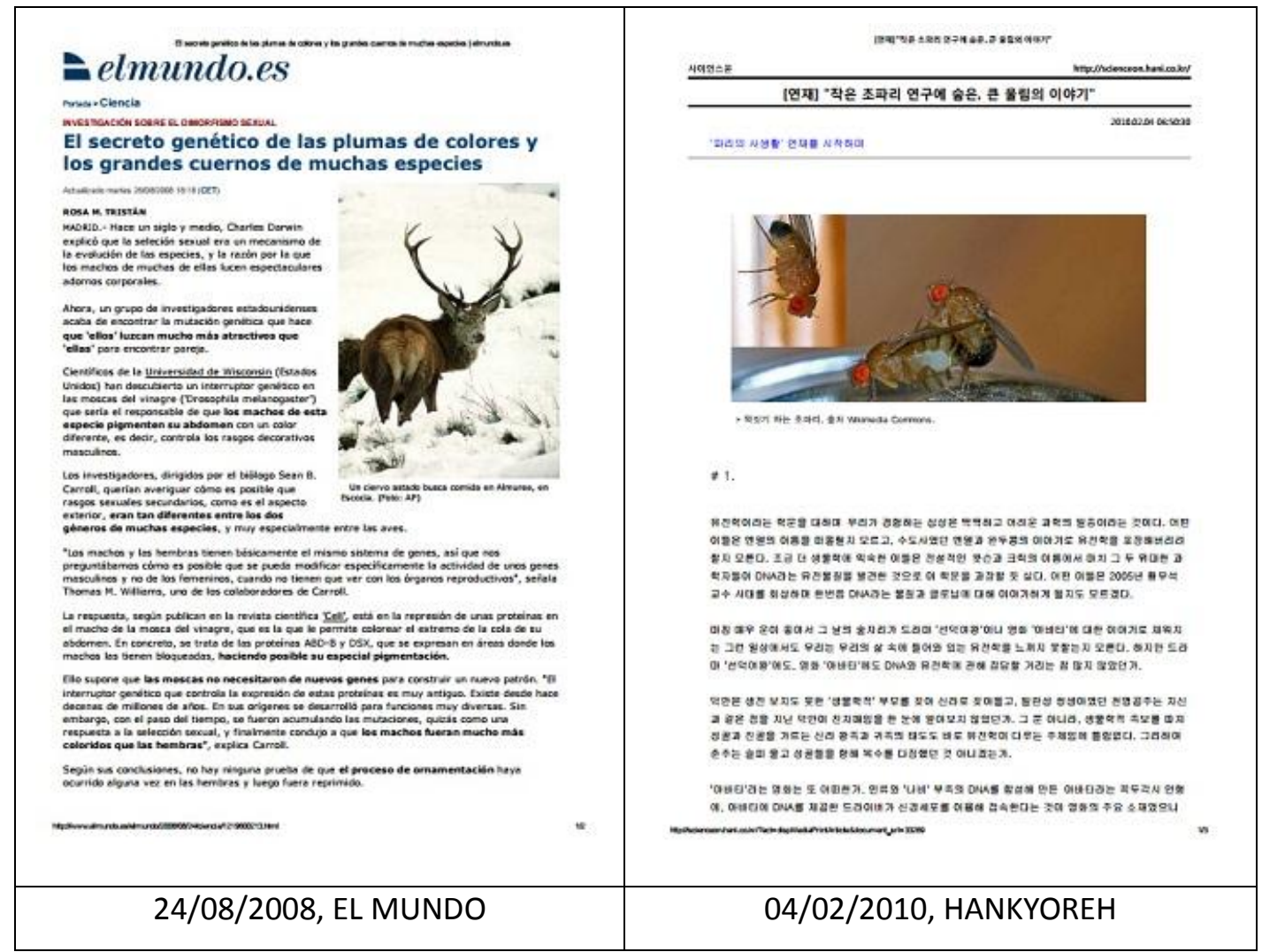

Ilustración 7.1. Ejemplos de artículos de CINTR

Ahora, la aparición en un yacimiento de Wyoming del fósil de una nueva especie de murciélago, bautizada como 'Onychonycteris finneyi', acaba de proporcionar la respuesta: primero aprendieron a volar, después desarrollaron su peculiar sentido de radar. (Ángel Díaz, "El eslabón perdido de los murciélagos", 13/03/2008, EL MUNDO)

Esto significa que el patrón evolutivo darwiniano es universalmente activo. En los virus, la mutación está ligada a los cambios en la secuencia del ácido nucleico que lleva a la resistencia a los tratamientos farmacológicos. Ahora, esta adaptabilidad ha bajado al nivel de los priones y al plegamiento de la proteína: "Está claro que no es necesario el ácido nucleico para el proceso de la evolución", añade el científico. (Joan Carles Ambrojo, "Los priones siguen la ley de Darwin", 05/01/2010, EL PAÍS)

뉴호프 교수는 이러 결과에 대해 "진화론에서 볼 때 닥치는 위험을 예측해서 서둘러 반응하는 행동은 적은 투입으로도 포식자로부터 도망칠 시간 여유를 얻는 이점이 있 다"고 설명했다. [El profesor Neuhoff explica sobre el resultado, "Desde el punto de vista evolutivo, una respuesta precipitada a anticipar el peligro plantea la ventaja de permitir el tiempo para escapar del depredador con menos aporte."] (Hongsub Cho, “사람은 토끼에 가까 울까 호랑이에 가까울까 (¿Eㅣ ser humano está cercano al conejo o al tigre?)”, 01/05/2009, 
HANKYOREH)

공개된 화석 유골은 나무 위 생활이 가능한 싳체구조를 가졌다는 점에서는 오스트랄 로피테쿠스와 우사하다. 동시에 직립보행이 특징인 호모 에렉투스와 유사한 하반신 골격을 갖췇다. [Los huesos fósiles presentados son similares a Australopithecus en su estructura corporal. Al mismo tiempo, tiene un esqueleto inferior del cuerpo similar al Homo Erectus, que presenta un paso vertical.] (Sangeon Lee, "원인 인류 중간존재? ... 남아공서 새 화석유골 발견 (¿Un ser intermedio entre el primitivo y el ser humano? ... Nuevos huesos fósiles en República Sudafricana", 10/04/2010, JOONGANG)

No se destaca gran diferencia en las informaciones de CINTR, debido a que son para transmitir o divulgar conocimientos científicos.

A continuación, véase ejemplos de los artículos de Cultura Científica Intrínseca Operacional, CINTOP.

En efecto, las moscas presentaron cambios regresivos hacia sus orígenes... pero sólo hasta cierto punto. "Estimamos que la convergencia a las frecuencias de alelos ancestrales durante 50 generaciones de evolución reversible es de un 50\%, y que esto es independiente a la historia evolutiva", escriben los autores en el estudio. "La evolución 'reversible' parece detenerse cuando las poblaciones de moscas se adaptan al ambiente ancestral, lo cual puede no coincidir con el estado original. A nivel genético, la convergencia hacia el estado ancestral es del 50\%. La evolución es contingente a la historia también a nivel genético", dice Henrique Teotónio. (Tana Oshima, “¿Volverían las especies a evolucionar igual si se les diese la oportunidad?”, 15/01/2009, EL MUNDO)

과학자 사고과정 따라해봐요: 개정되는 초등 5, 6학년 과학교과서의 주된 교육 방향 은 '과학자처럼 생각하기'다. 평균 10 차시로 구성된 한 단원 내에서 '실'험탐구 $\rightarrow$ 개념 획득 $\rightarrow$ 과학적 글쓰기 $\rightarrow$ 새로운 문제제기'를 하도록 내용을 구성한다. [Seguir el proceso de pensamiento del científico: La dirección primaria de los libros de texto revisados de la ciencia de 5 ㅇ y 60 curso de la escuela primaria es 'pensar como científico'. En una unidad compuesta por 10 horas, el contenido se compone de 'Explorar y experimentar $\rightarrow$ Adquirir el concepto $\rightarrow$ Escritura científica $\rightarrow$ Plantear cuestiones'.] (Jieun Lee, "개정되는 초5.6학년 과학교과서 대 비하려면(“Esperar los libros de texto reformados de ciencias de quinto y sexto grado de Primaria", 15/12/2010, JOONGANG) 
En los párrafos, podemos observar ejemplos de 'hacer ciencia'. El primer artículo del periódico EL MUNDO explicó el proceso de la investigación recién presentada. Y el segundo informa sobre la reforma educativa que quiere enseñar la manera de pensar como científico a los alumnos de Primaria.

Ahora vamos a ver contenidos de artículos de Cultura Científica Intrínseca Valorativa, CINTVA.

El misterio que rodea la evolución de los peces que tienen los dos ojos en el mismo lateral, los peces planos (o pleuronectiformes), una incógnita que se debate desde la época de Charles Darwin, ha sido resuelto por un estudiante postdoctoral de la Universidad de Chicago (Estados Unidos). (Rosa M. Tristán, “El 'eslabón perdido' de los lenguados”, 09/07/2008, EL MUNDO)

"최근 다윈은 회춘했다." 디엔에이(DNA)의 발견과 고고학의 발굴 성과, 인간 게놈 프 로젝트의 추진 등에 힘입은 바 크다. 하지만 일반 독자의 처지에서 진화론의 가치는 다른 데 있을 수 있다. "과학은 늘 과학적 탐구의 범위 내에서 답할 수 없는 문제를 제기"하며 “과학은 우연, 미래, 극대와 극미, 가까운 것과 먼 것에 관한 질문을 던진 ㄷ.." [Gracias al descubrimiento de ADN, los hallazgos paleontológicos, el proyecto de genoma humano, etc., "últimamente Darwin se ha rejuvenecido." Sin embargo, el valor del darwinismo puede ser diferente para los lectores generales. "La ciencia siempre cuestiona algo que no se puede responder en investigación científica" y "La ciencia lanza preguntas sobre el azar, el futuro, el máximo y el mínimo, algo cercano y algo lejano."] (Jinsik Chun, “과학과 문학 사이 진화론 (El Darwinismo entre la ciencia y la literatura)", 09/05/2008, HANKYOREH)

Estos dos ejemplos mencionan la evaluación científica sobre el darwinismo y un estudio darwiniano. El primer artículo español pone énfasis en la importancia de la investigación que ha resuelto un viejo problema de la biología evolutiva. El segundo artículo coreano enfatiza que la teoría de Darwin ha sido complementada por estudios posteriores y sigue siendo importante. El párrafo también agrega la evaluación de la ciencia.

\section{Informaciones de Cultura Científica Extrínseca}

Ahora veamos los artículos que incluyen informaciones de Cultura Científica Extrínseca. Estos contenidos dependen más de la sociedad en la que el texto se publicó. Entre los textos periodísticos, Cultura Científica Extrínseca ocupa la proporción más grande que la de 
Intrínseca en ambos países. $69,4 \%$ de los artículos españoles y $63,0 \%$ de los coreanos tienen informaciones de Cultura Científica Extrínseca.

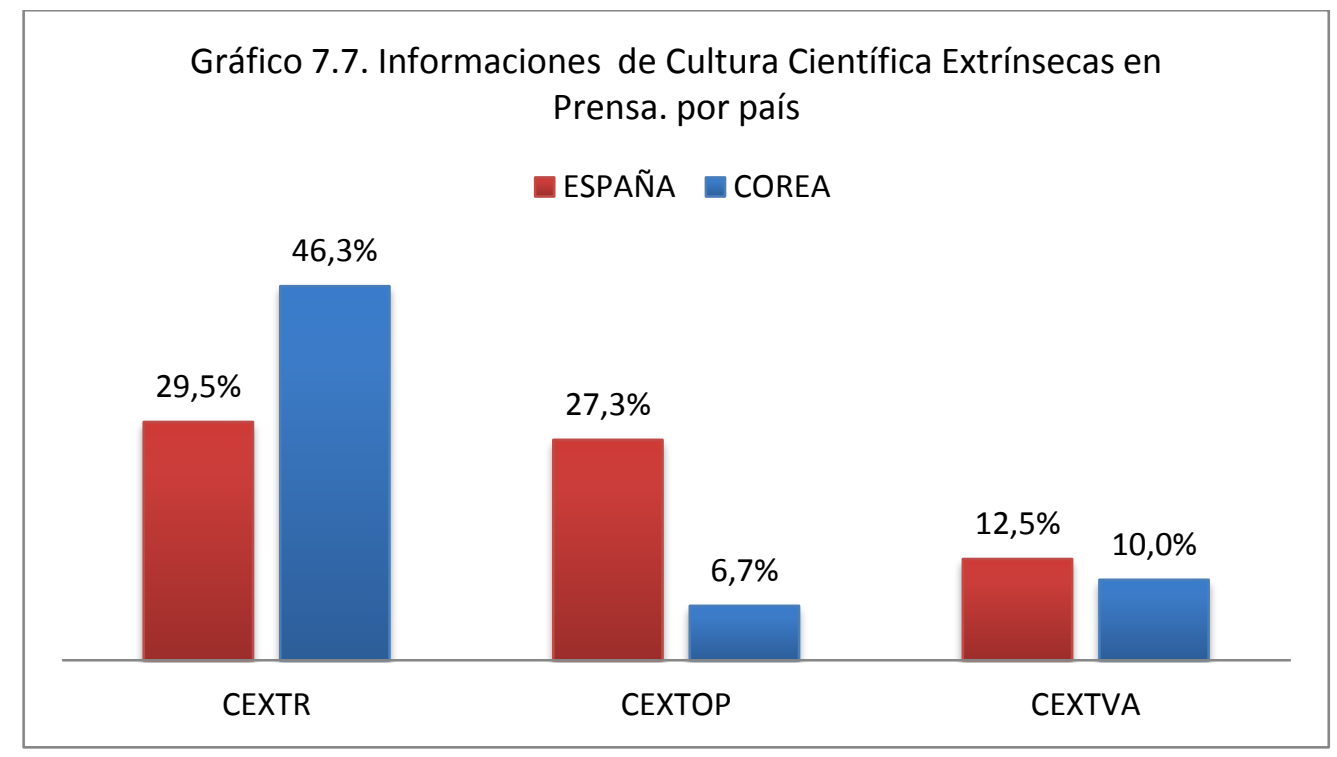

En primer lugar, recordemos ejemplos de Cultura Científica Extrínseca Representacional, CEXTR. Son informaciones representacionales y no son propiamente científicas pero están relacionadas con la ciencia. El código CEXTR ocupa $46,3 \%$ de los textos coreanos y $29,5 \%$ de los españoles. Explican la vida de Darwin y otros científicos evolucionistas. También hablan de la teoría de la evolución social que aplica la teoría evolutiva a los fenómenos sociales o analizan la sociedad a través de la teoría de la evolución social.

2 월 12 일은 찰스 다윈(1809 82)의 생일입니다. '종의 기원'을 밝히는 인류의 여정이 200년 전 이날, 평생 병치레를 했던 병약한 갓난아이로부터 시작됐죠. 다윈은 일생 동안 2000 여 명의 인물과 1 만 5000 여 통의 편지를 주고받았다는군요. [El 12 de febrero es el cumpleaños de Charles Darwin (1809-1882). La trayectoria del ser humano para descubrir 'el origen de las especies', empezó hoy hace 200 años por un niño débil recién nacido que fue enfermizo toda la vida. A lo largo de su vida, Darwin intercambió más de 15.000 cartas con más de 2.000 personas.] (Ilwoo Joo, "다윈의 일기 (1) 딱정벌레에 미친 청년 (El diario de Darwin (1) Un joven loco por escarabajo", 12/02/2009, JOONGANG)

그는 이 책에서 다원의 진화론을 사회현상에 확대적용하여 '적자생존'을 주장했던 허 버트 스펜서류의 사회진화론에 반격을 가했다. "만인에 대한 만인의 투쟁이 자연의 유일 법칙은 아니다. 상호 투쟁만큼이나 상호부조 역시 자연의 법칙이다." [É contraataca al darwinismo social spenceriano que aplicó el darwinismo a la sociedad e insistió 
en 'supervivencia de lo más apto'. "La lucha de todos contra todos no es la única ley de Naturaleza. Como la lucha mutua, la ayuda mutua también es ley de Naturaleza."] (Jungwoo Lee, “경쟁이냐 협력이냐 (¿Competencia o Cooperación?)”, 01/03/2009, HANKYOREH)

El investigador británico se conoce infinidad de detalles de su vida. Por ejemplo que hablaba español, aunque con mal acento. "En otro caso, era imposible que conociera tantos detalles de especies locales de Latinoamérica, que le transmitían los guías y las gentes de los lugares". O que los gauchos le llamaban Don Carlos, el naturalista. Y si alguien preguntaba qué era eso, puntualizaban: "Es la persona que sabe de todo». (Rosa M. Tristán, "Don 'Carlos' Darwin, el naturalista chistoso que hablaba español", 07/05/2008, EL MUNDO)

Aprovechando el 200 aniversario del nacimiento de Charles Darwin, así como el 150 aniversario de la publicación de El origen de las especies, decidimos a finales de 2009 hacer un viaje en barco por las Galápagos. Creo que nunca olvidaremos la experiencia. Comprendimos lo que Darwin vivió durante aquellos días de 1835 y cómo lo plasmó en su obra. En el archipiélago ecuatoriano -formado por 13 islas grandes, 6 más pequeñas y decenas de islotes y rocas- se multiplican las especies animales y vegetales, tanto en tierra como bajo agua. (Ángel Borja y Celia Aparicio, “Emulando a Darwin", 03/04/2010, EL PAíS)

Aunque no trasmiten directamente conocimientos científicos, presentar algo relacionado al darwinismo con la teoría o el científico puede atraer la atención de lectores.

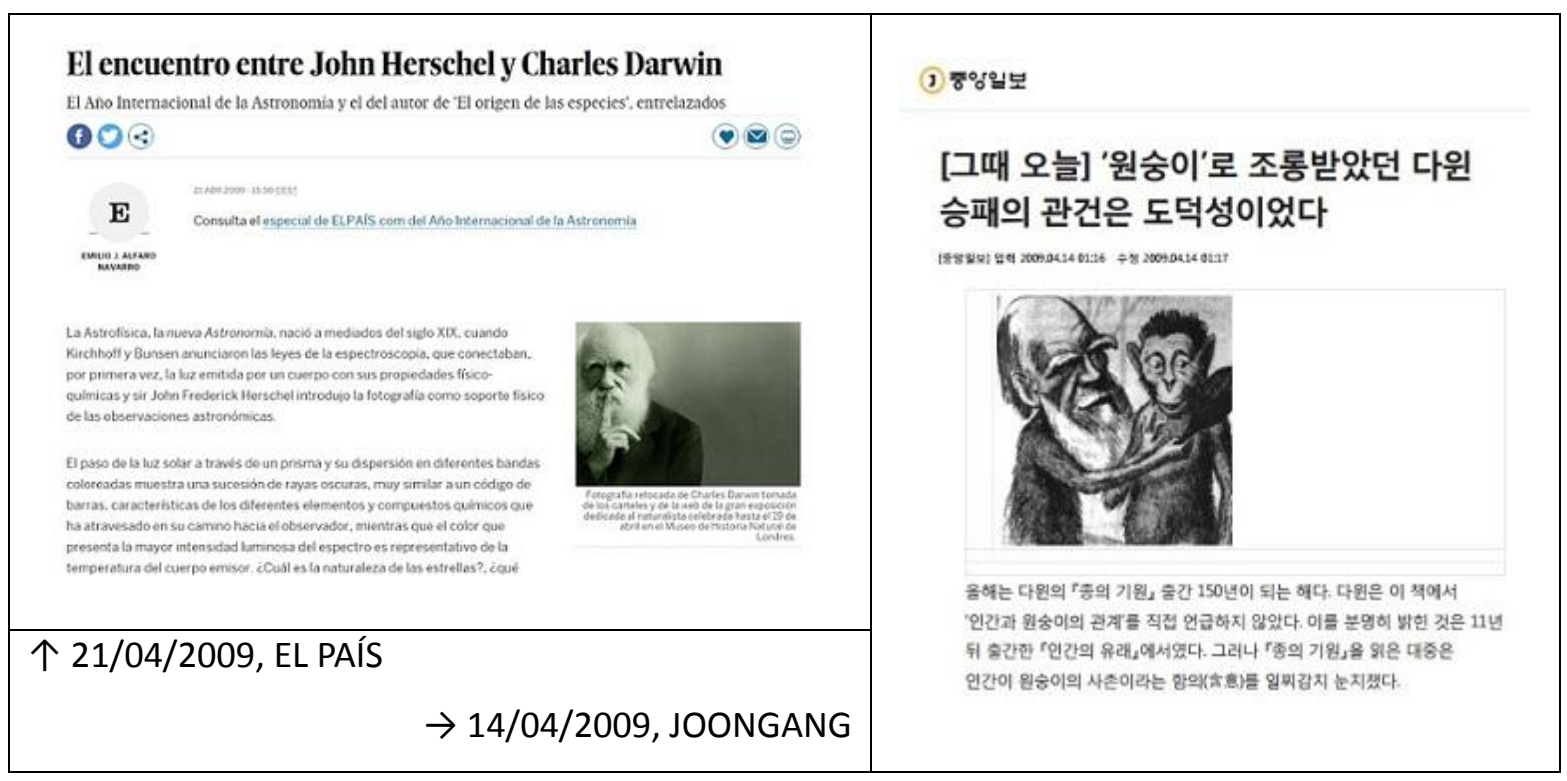

Ilustración 7.2. Ejemplos de artículos de CEXTR

A continuación, veamos los contenidos de Cultura Científica Extrínseca Operacional, CEXTOP. 
Este código ocupa el 27,3\% de los artículos españoles y el 6,7\% de los coreanos. Corea tiene más artículos de CEXTR y España tiene de CEXTOP. Clasificamos los contenidos que incluyen 'el interés en la ciencia' y 'las normas relacionadas con la ciencia', como CEXTOP. El alto porcentaje de CEXTOP de España proviene de las actividades conmemorativas que tuvieron lugar en los tres años, debido a que España celebró muchas actividades científicas relacionada con el darwinismo e inauguró el Museo de la Evolución Humana en Burgos en el año 2010.

다윈 탄생 200년을 맞아 국내 10 개 학회가 모여 연합학술대회를 연다. 경기도 국립과 천과학관에서 다음달 2 일부터 이틀 간 12 개 주제에 걸쳐 논문 발표와 강연.토론이 펼 쳐진다. (...) '다윈'을 매개로 인문-과학 분야의 학제적 연구가 확산되는 것이다. [Con motivo del bicentenario del nacimiento de Darwin, diez sociedades académicas se reúnen para celebrar conferencias unidas. Se presentarán ponencias, conferencias y discusiones sobre 12 temas durante los dos días a partir del 2 del próximo mes en el Museo Nacional de la Ciencia de Gwacheon, Gyeoung-gui-do. (...) La investigación interdisciplinaria entre humanidades y ciencias se está extendiendo a través de Darwin.] (Nopil Bae, “다윈이 가져다 준 '통섭', 탄생 200년 연합학술대회('Consiliencia' que nos trajo Darwin. Conferencias conmemorativas por el bicentenario de su nacimiento", 30/06/2009, JOONGANG)

Un mes después de la inauguración ya han pasado más de 50.000 visitantes. Sin duda, un éxito para los que hemos promocionado este gran proyecto des del Equipo de Investigación de Atapuerca (EIA), para la Junta de Castilla y León y para el propio Ayuntamiento. Es un buen ejemplo de colaboración entre administraciones y equipo científico. (Eudald Carbonell, "Un mes de Museo de la Evolución Humana", 31/08/2010, EL MUNDO)

Por último, véase artículos de Cultura Científica Extrínseca Valorativa, CETXVA. El código ocupa el $12,5 \%$ en el caso de España y un $10,0 \%$ en el de Corea del Sur.

Las diferentes posturas entre los expertos y la sociedad en general se manifiestan, por ejemplo, en temas clave y controvertidos -sobre todo en EEUU- como el cambio climático o la evolución de las especies. El $87 \%$ de los científicos y $32 \%$ de la población estadounidense general afirma que los humanos y todas las especies vivas han evolucionado en el tiempo y que la evolución es el resultado de la selección natural. En cuanto al cambio climático, el $84 \%$ de los científicos y sólo el $49 \%$ de la sociedad consideran que el planeta se está calentando debido a las actividades humanas. (EL PAÍS, "Los estadounidenses valoran alto la ciencia, pero menos que hace una 
década", 09/07/2009, EL PAís)

그러ㄷㅔㅔ 당신과 생각이 다른 사람들이 있다. 이른바 창조론자 혹은 지적설계론자들이 다. (...) 2005년 실시된 한 여론조사에 따르면 이같은 이들이 미국인의 42\%나 된다. '과 학대국을 자처하는 나라치곤 웃기는 현상이다. 기독교라 종교 때문이다우리나라도 개신교인 중 $70.2 \%$ 가 이렇게 생각한다고 한다). [Sin embargo, hay personas que tienen diferentes pensamientos de usted. Los llamados creacionistas o seguidores del diseño inteligente. (...) Según una encuesta que se realizó en el 2005, son $42 \%$ de los estadounidenses. Es un fenómeno ridículo para un país que afirma ser una 'nación gigante de la ciencia'. Es por una religión, el protestantismo (En nuestro país también, 70,2\% de los protestantes piensa así.)] (Manhoon Lee, "창조론 허점 파헤친 진화론의 반격 (El contraataque del darwinismo que expone la debilidad del creacionismo)", 09/06/2008, JOONGANG)

Los dos ejemplos presentan una encuesta sobre la valoración del público hacia la ciencia. El artículo español explica el resultado de la encuesta estadounidense y el coreano también, pero en este caso el autor añadió su propia valoración sobre el resultado de la encuesta.

\section{Información de Cultura Tecnológica y No Cultura Científica}

El código siguiente es Cultura Tecnológica, TECNO. Los artículos presentan páginas web que ofrecen contenidos del darwinismo, programas de medios o videojuegos cuyo tema es la evolución biológica.

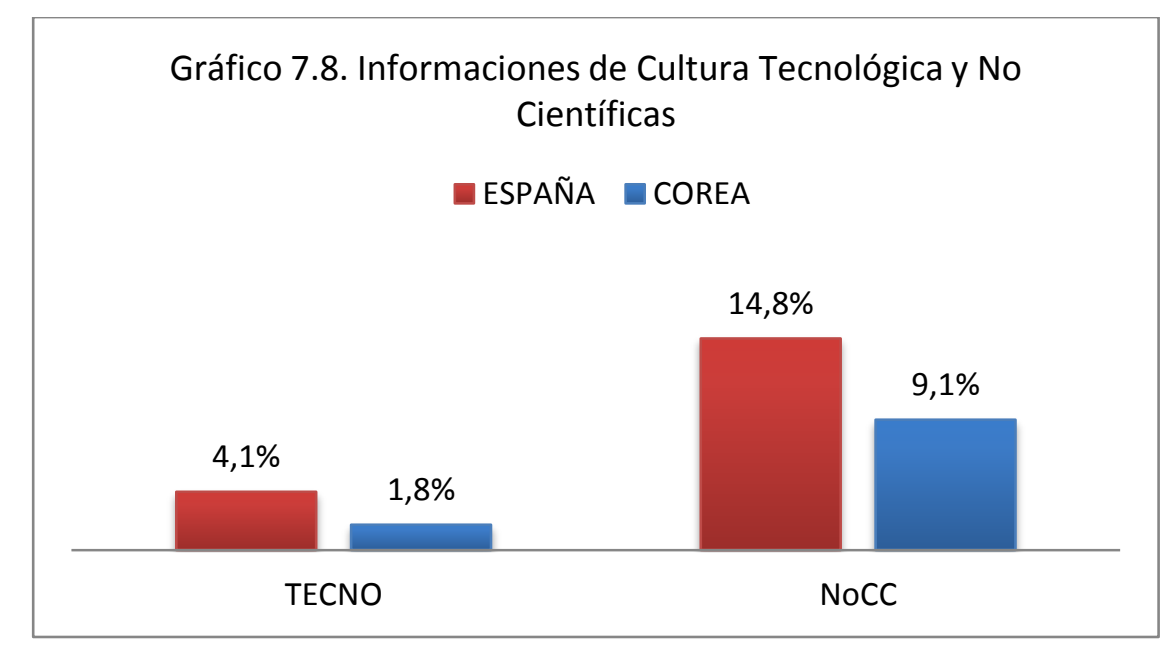

4,1\% de los artículos españoles y 1,8\% de los coreanos se codificaron como TECNO. 
La cadena británica $B B C$ y la Open University mantienen esta solvente 'web' que ofrece conferencias de reputados investigadores, recrea experimentos sobre evolución, permite acceder a un póster del 'árbol de la vida' y explica cómo han influido las ideas de Darwin más allá de los círculos de científicos evolucionista. (Antonio Fraguas, “El 'Beagle' navega en la Red”, 14/06/2009, EL PAÍS)

다윈은 '강한 것이 살아남는 것이 아니라 적응한 것이 살아남았다'고 했습니다. 변화 를 받아들인 자만이 패권을 유지할 수 있습니다. 미국도 패권 유지를 위해 하드파워 에 소프트파워를 더한 '스마트 파워'를 새로운 지배전략으로 고민하고 있습니다. 정치 도 패권을 유지하려면 '스마트 정치’로 전환해야 합니다. 바로 지금 말입니다. [Darwin dijo, "No es la especie más fuerte la que sobrevive, sino la que mejor se adapta al cambio". Sólo aquellos que aceptan el cambio pueden mantener su supremacía. Estados Unidos también está considerando el 'poder inteligente', que es una combinación de poder duro y poder suave, como una nueva estrategia dominante. Si quiere mantener su supremacía política, tiene que cambiar a la "política inteligente". Ahora mismo.] (Sungmin Park, "의원님들, 살 길은 “스마트 정치’입 니다(Señorías, la forma de sobrevivir es 'política inteligente'.)", 30/10/2010, JOONGANG)

El último ejemplo no relaciona el darwinismo con la tecnología directamente, sino que conecta la tecnología a la política aplicando el darwinismo a la sociedad.

A continuación, presentaremos ejemplos de No Cultura Científica, NoCC que los artículos cuyo tema no es de la cultura científica intrínseca, extrínseca ni tecnológica pero se refieren al darwinismo. Entre los artículos españoles NoCC ocupa 14,8\% y entre los coreanos 9,1\%.

Un libro que contiene las recetas de cocina de la esposa de Charles Darwin (1809-1882) se ha publicado en el Reino Unido, ofreciendo un fascinante testimonio sobre la comida que degustó el famoso naturalista. Según informa hoy la cadena pública BBC, la obra se basa en las notas personales de Emma Darwin e incluye pistas para cocinar más de cuarenta platos victorianos, como los champiñones a la parrilla y el hojaldre de queso. (EFE Londres, "El libro de cocina de la esposa de Darwin se publica en Reino Unido", 25/12/2008, EL PAÍs)

A juicio de 'Paris Match', ese beso es la prueba de que "Letizia, la divorciada, la plebeya, la ex presentadora es un triunfo para el futuro de la monarquía española". Así, la revista destaca que mientras aumentan los ataques contra la Monarquía (con los nacionalistas catalanes quemando fotos del Rey Juan Carlos), los futuros soberanos siguen las leyes de Darwin: si quieren sobrevivir, se tienen que adaptar. (elmundo.es, "Los Príncipes de Asturias, en la portada de 'Paris Match'”, 
12/11/2009, EL MUNDO)

작품에 등장한 거북이 '헤리엇'은 진화론 창시자 찰스 다윈이 1835년 연구를 위해 갈라파고스 섬에서 데려왔던 거북 세 마리 중 한 마리다. 스페인 극작가 후안 마요르 가(44)는 2006년 오스트레일리아의 한 동물원에서 '헤리엇'이 175 살로 숨졌다는 소식' 을 신문에서 일고 “헤리엇이 인간으로 진화했다”는 설정을 바탕으로 이 희곡을 썼다. [La tortuga 'Harriet' en la obra de teatro es una de tres tortugas que Darwin trajo de las islas Galápagos en 1835. El dramaturgo español Juan Mayorga (44) leyó la noticia que anunció la muerte de Harriet en un zoo australiano en 2006 y escribió esta obra de teatro basándose la idea, “Harriet se evolucionó a un ser humano”] (Sangyoung Jung, "진화한 거북이, 인간한테 '퇴화' 를 배우다 (La tortuga evolucionada aprende a "degenerar" de los seres humanos)", 26/10/2009, HANKYOREH)

다윈의 진화론처럼 기업도 진화한다. 위험에 직면했을 때 가장 잘 적응하는 기업만이 살아남는다. [Como el evolucionismo de Darwin, la empresa también evoluciona. Cuando se enfrentan al peligro, sólo sobreviven las compañías que se adaptan bien.] (Byoungjoo Moon, “판 사 출신 경영인 '클린 SK' 이미지 가꾸다 (Ex juez se hace director profesional. Crea la imagen de 'Clean SK')", 28/05/2009, JOONGANG)

Se presentan obras de arte (poesía, teatro, etc.) inspiradas por Darwin. Y la actitud evolutiva social se encuentra constantemente. 


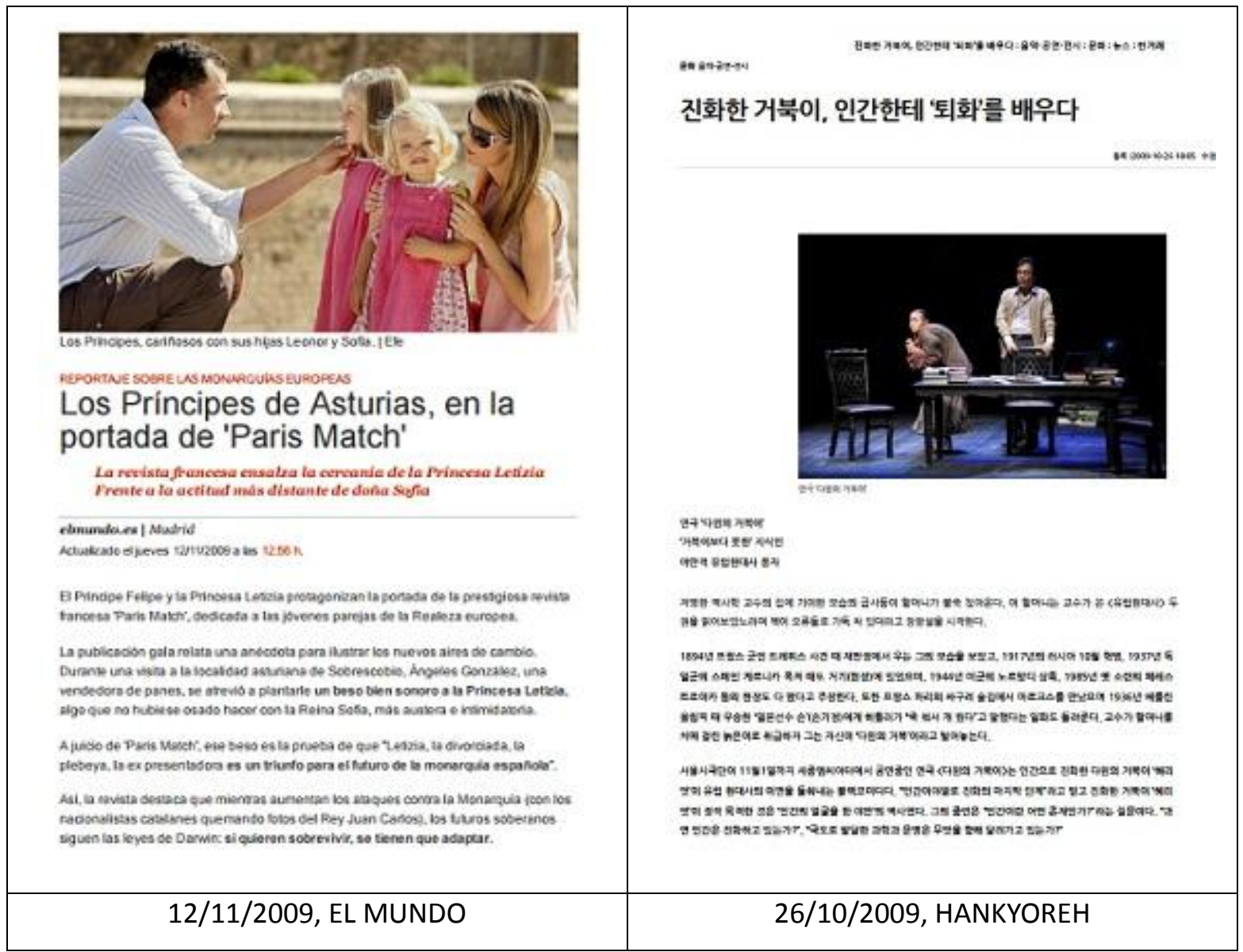

Ilustración 7.3. Ejemplos de artículos de NoCC

Ahora véase cómo cambió la distribución de los códigos por año.

\begin{tabular}{|l|r|r|r|r|r|r|}
\hline \multirow{2}{*}{ MODELO } & \multicolumn{3}{|c|}{ ESPAÑA } & \multicolumn{3}{c|}{ COREA DEL SUR } \\
\cline { 2 - 8 } & AÑO2008 & AÑO2009 & AÑO2010 & AÑO2008 & AÑO2009 & AÑO2010 \\
\hline CINTR & 15 & 61 & 25 & 41 & 67 & 33 \\
\hline CINTOP & 8 & 3 & 1 & 3 & 1 & 2 \\
\hline CINTVA & 4 & 3 & 1 & 10 & 2 & 0 \\
\hline CEXTR & 22 & 37 & 21 & 28 & 89 & 41 \\
\hline CEXTOP & 12 & 49 & 13 & 5 & 14 & 4 \\
\hline CEXTVA & 10 & 21 & 3 & 25 & 7 & 2 \\
\hline TECNO & 5 & 5 & 1 & 2 & 2 & 2 \\
\hline NoCC & 5 & 15 & 20 & 4 & 13 & 14 \\
\hline No artículos & 47 & 150 & 74 & 87 & 168 & 86 \\
\hline
\end{tabular}

Tabla 7.8. № de artículos por código de MCC por año

Primeramente, veamos el cambio de los porcentajes durante los tres años en España.

Convertimos los datos españoles a porcentaje y expresamos como el gráfico siguiente. 


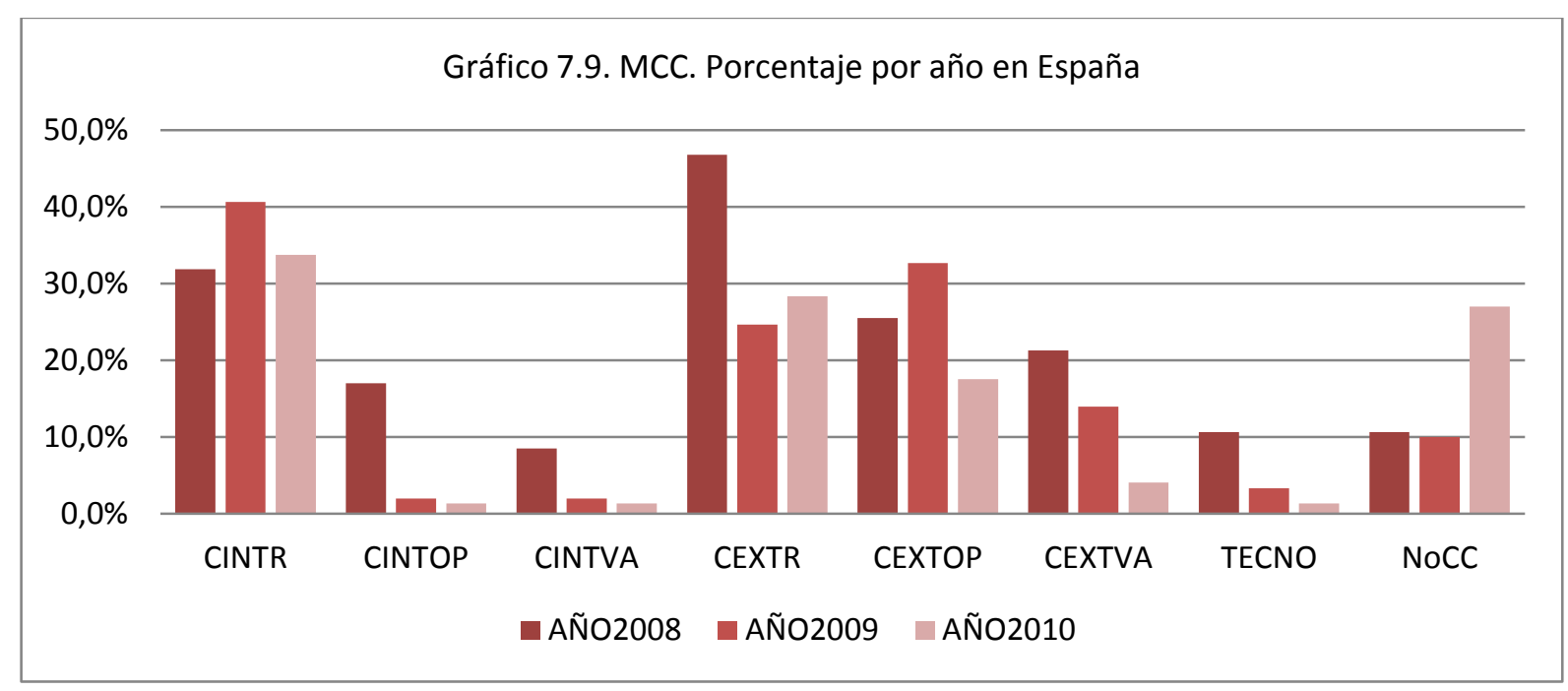

En España, el porcentaje de CINTR aumenta en 2009 pero disminuye en 2010. CINTOP y CINTVA tenían más artículos en 2008 que en 2009 y 2010. CEXTR también en 2008 tiene 46,8\% de los artículos españoles. En el año conmemorativo 2009, aumento el porcentaje de CEXTOP ya que se celebraron muchas actividades científicas. TECNO ocupa 10,6\% de 2008 pero también disminuye cada año, en cambio, NoCC en 2010 aumenta visiblemente y llega a $27 \%$.

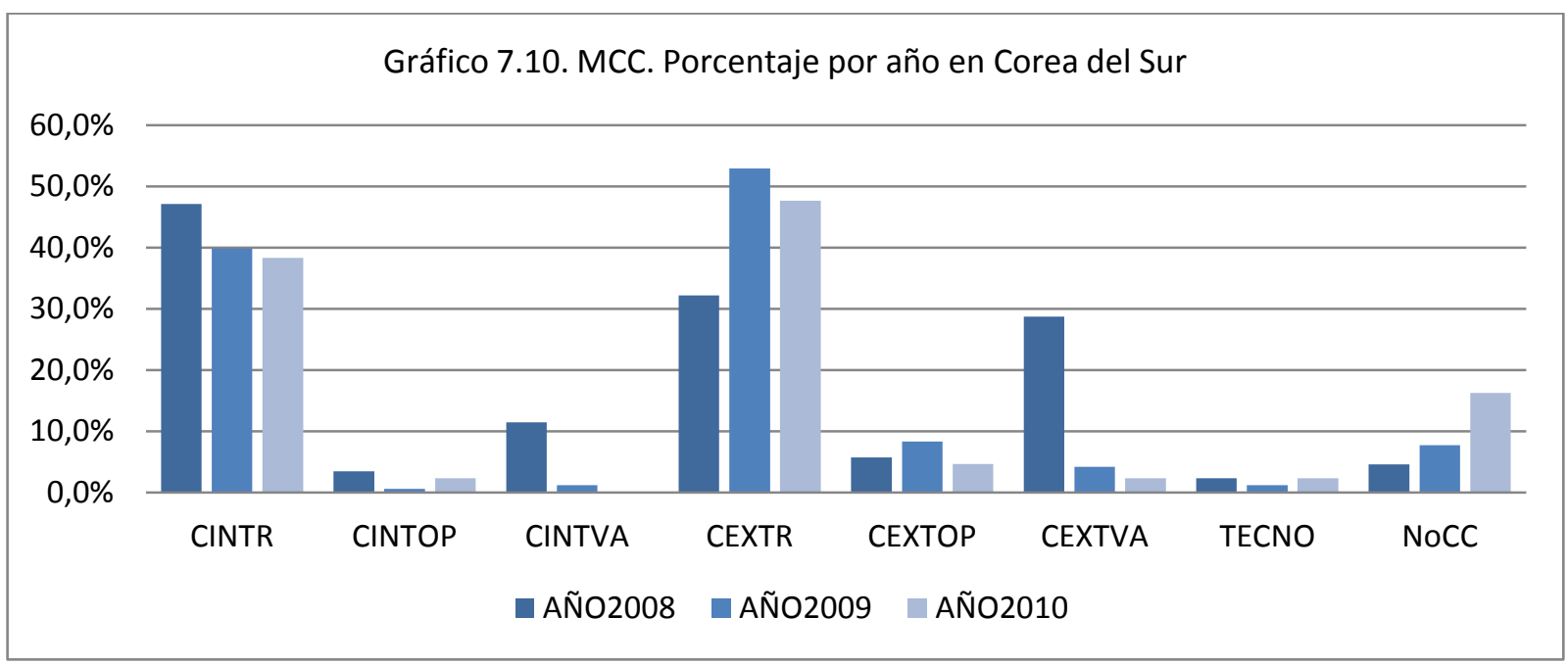

En Corea del Sur, CINTR ocupa un 47,1\% en 2008 y disminuye cada año. CEXTR aumenta considerablemente en 2009 y disminuye en 2010 pero sigue manteniendo un porcentaje alto $(47,7 \%)$. En 2008 , CEXTVA tiene el $28,7 \%$ de los artículos coreanos. TECNO no ofrece muchos artículos en los tres años. NoCC aumenta cada año como lo de España. 


\section{Análisis de imágenes en artículos}

A continuación, averiguaremos el análisis de las imágenes en los artículos periodísticos seleccionados. Una imagen se codifica por su contexto o texto asociado, debido a que los artículos periodísticos incluyen las imágenes generalmente para ayudar la comprensión o atraer la atención. Codificamos en cuatro categorías, Imagen de Cultura Científica Intrínseca (CINT_IM), de Cultura Científica Extrínseca (CEXT_IM), de Cultura Tecnológica (TECNO_IM) y de No Cultura Científica (NoCC_IM) como hemos realizado en las imágenes en los libros de texto. No clasificamos en la representacional, la operacional y la valorativa, porque a menudo las imágenes no transmiten informaciones suficientes para aplicarlas.

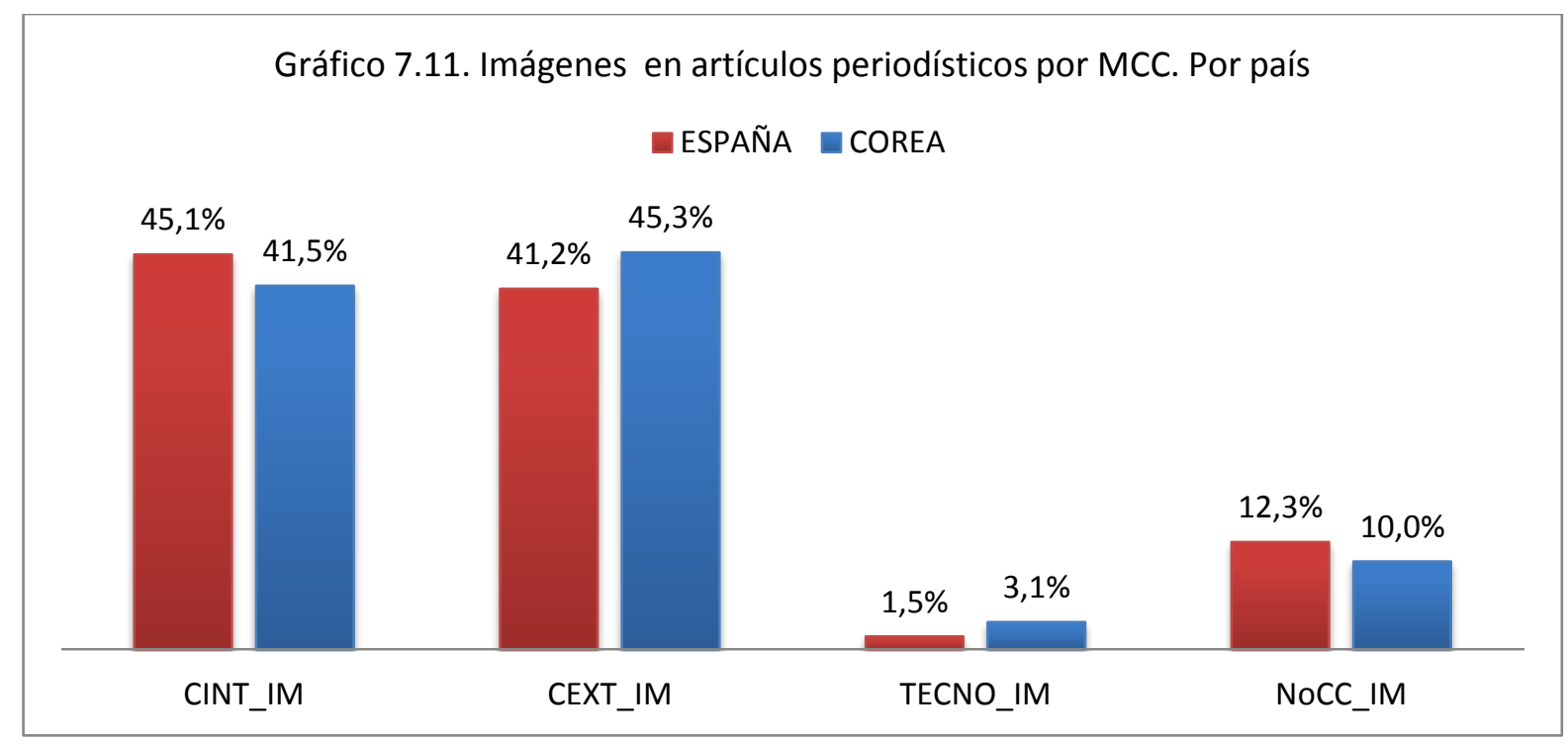

No hay gran diferencia entre el porcentaje de imágenes intrínsecas (CINT_IM) y extrínsecas (CEXT_IM) de cultura científica en cada país. Entre los dos países tampoco se destaca algún contraste solamente Corea acompaña más imágenes con textos extrínsecos. En el análisis de libros de texto, imágenes intrínsecas (CINT_IM) era la mayoritaria (España: 95,4\%, Corea: $96,8 \%)$.

\begin{tabular}{|l|r|r|r|r|r|r|}
\hline \multirow{2}{*}{ MODELO } & \multicolumn{3}{|c|}{ ESPAÑA } & \multicolumn{3}{|c|}{ COREA DEL SUR } \\
\cline { 2 - 7 } & AÑO2008 & AÑO2009 & AÑO2010 & AÑO2008 & AÑO2009 & AÑO2010 \\
\hline CINT_IM & 15 & 63 & 14 & 44 & 51 & 25 \\
\hline CEXT_IM & 16 & 53 & 15 & 39 & 46 & 46 \\
\hline TECNO_IM & 3 & 0 & 0 & 1 & 5 & 3 \\
\hline NoCC_IM & 6 & 10 & 9 & 6 & 13 & 10 \\
\hline
\end{tabular}




\begin{tabular}{|l|r|r|r|r|r|r|}
\hline № imágenes & 40 & 126 & 38 & 90 & 115 & 84 \\
\hline
\end{tabular}

Tabla 7.9. Número de imágenes en los artículos periodísticos

Convertimos los datos españoles a porcentaje y los expresamos como gráfico.

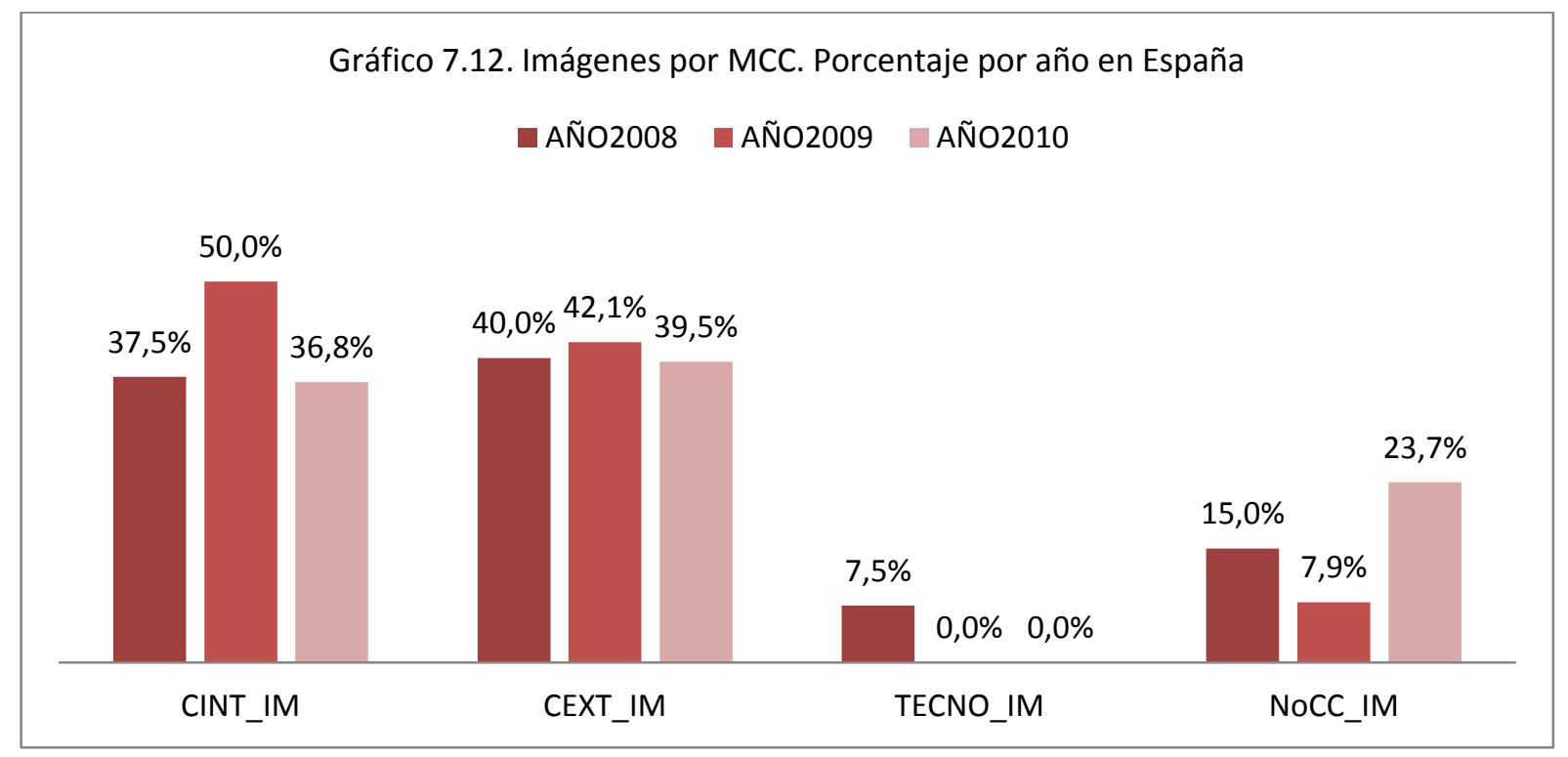

En España, durante los tres años el porcentaje de las imágenes de cultura científica extrínseca no ha variado mucho. El número de las imágenes de cultura científica intrínseca aumentó en 2009 pero en 2010 volvió a ser como antes. En 2009 y 2010 los artículos españoles no tienen ninguna imagen de cultura científica. Imágenes no relacionadas con la ciencia ni con la tecnología en 2010 llegó a ocupar 23,7\%.

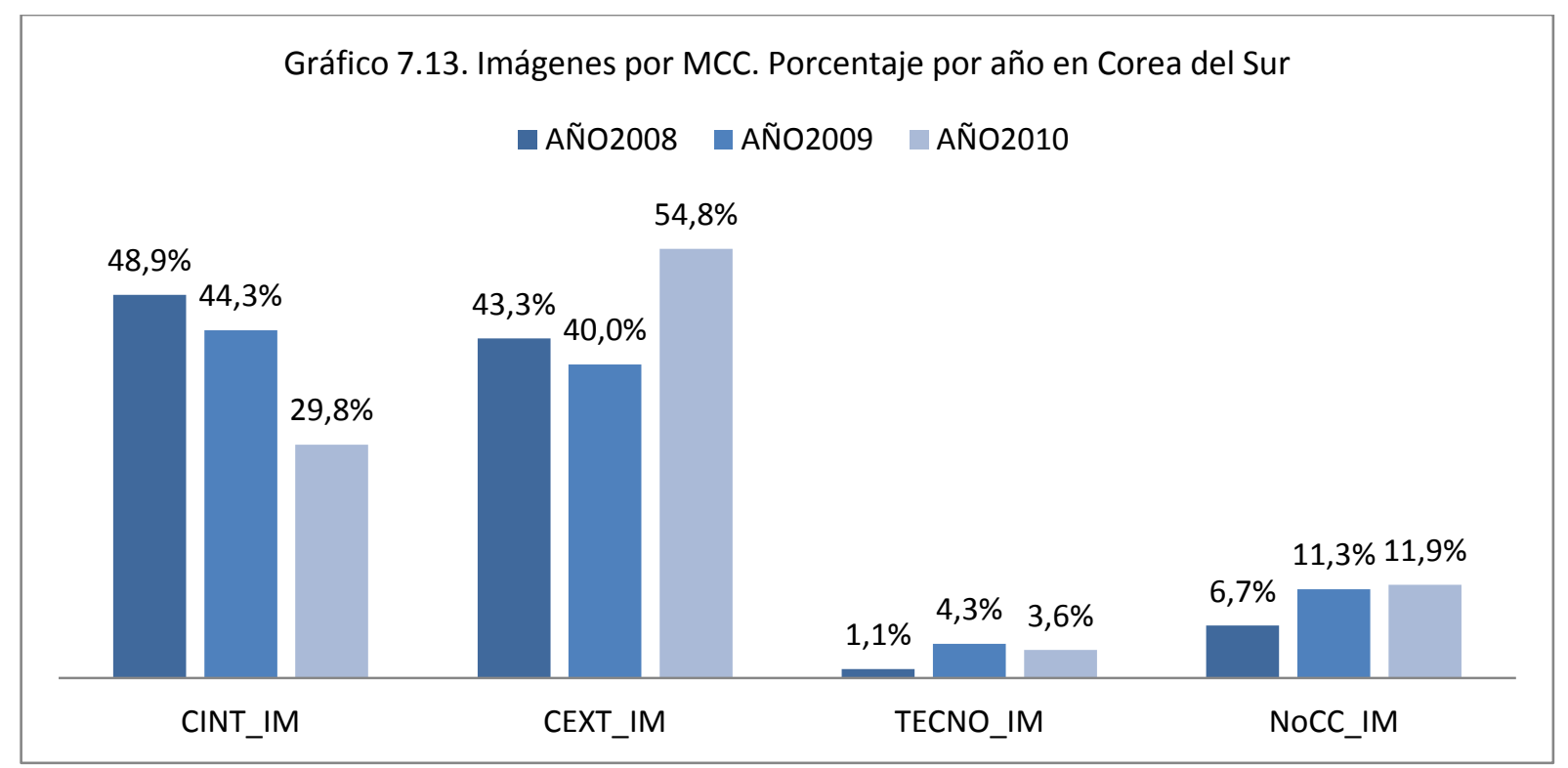


En Corea, cada año reduce el porcentaje de las imágenes de cultura científica intrínseca. Las imágenes de cultura científica extrínseca llegan a 54,8 en 2010.

7.3. Darwinismo en la Prensa. ¿Cómo y qué transmiten los medios de comunicación de España y Corea del Sur?

En este subcapítulo, para complementar el análisis realizado con MCC se han utilizado técnica de análisis de contenido de los artículos periodísticos. Como hemos anotado en el capítulo 5, los criterios provienen del estudio La Biotecnología Española: Impacto Económico, Evolución y Perspectivas (Quintanilla, et al., 2005)

Los textos obtenidos se han clasificado según los siguientes criterios:

- Sección

- Géneros Periodísticos

- Autoría

- Fuente

- Encuadre

- Temas: Novedades Científicas e Ideas Religiosas

Detectaremos primero en qué secciones se coloca cada artículo. Normalmente un periódico general tiene diversas secciones como Ciencia, sociedad, cultura, internacional, etc., podemos detectar en qué secciones están los artículos que se refieren a Darwin y el darwinismo.

En segundo lugar, analizaremos los géneros periodísticos de los textos obtenidos. Los géneros de artículos periodísticos incluyen noticias, reportaje, entrevistas, reseñas de libros y más. A través de la distribución de los géneros, se puede indagar qué género trata con Darwin. 
A continuación, se han clasificado los artículos por su autor, fuente y encuadre respectivamente. Quién escribió el artículo, dónde se originó el contenido, y con qué motivo se publicó son elementos importantes en el análisis del artículo. Estos tres criterios muestran el proceso de la publicación de un artículo periodístico, por eso podemos averiguar en ellos cómo transmiten los medios de las dos sociedades el darwinismo a la población. Por consiguiente, prestaremos atención a la relación con el análisis de MCC que avanzamos en el último subcapítulo.

Por último, analizamos los dos temas concretos, presencia de novedades científicas e ideas religiosas. Primero, se han clasificado los artículos que informan nuevas investigaciones relacionadas con el darwinismo. Ya habíamos observado en el análisis de MCC la transmisión de los conocimientos científicos generales por las informaciones de cultura científica intrínseca. Aquí solamente contamos las novedades científicas porque su presencia puede ser un criterio de interés social en el darwinismo como una teoría puramente científica.

El segundo tema, la presencia de ideas religiosas es un criterio importante que permite observar la incorporación del darwinismo en el contexto social. Todos los textos seleccionados para este estudio incluyen contenido darwiniano, así que la presencia de ideas religiosas significa que el darwinismo y la religión aparecen en un mismo artículo. Analizar estos artículos puede mostrar la perspectiva de las dos sociedades hacia el darwinismo.

\subsubsection{Sección}

Se han clasificado por sección de periódico. Las categorías son Ciencia, Cultura, Economía, Internacional, Opinión, Regional, Salud, Sociedad, Tecnología u Otras secciones.

\begin{tabular}{|c|c|c|c|c|c|c|c|c|c|c|c|c|}
\hline \multirow{3}{*}{ SECCIÓN } & \multicolumn{4}{|c|}{ AÑO 2008} & \multicolumn{4}{|c|}{ AÑO 2009} & \multicolumn{4}{|c|}{ AÑO 2010} \\
\hline & \multicolumn{2}{|c|}{ ESPAÑA } & \multicolumn{2}{|c|}{ COREA } & \multicolumn{2}{|c|}{ ESPAÑA } & \multicolumn{2}{|c|}{ COREA } & \multicolumn{2}{|c|}{ ESPAÑA } & \multicolumn{2}{|c|}{ COREA } \\
\hline & MUN & PAI & HAN & JOO & MUN & PAI & HAN & JOO & MUN & PAI & HAN & $\mathrm{JOO}$ \\
\hline Ciencia & 30 & 0 & 10 & 0 & 54 & 0 & 18 & 4 & 15 & 0 & 4 & 7 \\
\hline Cultura & 0 & 4 & 23 & 22 & 13 & 4 & 37 & 56 & 8 & 4 & 30 & 13 \\
\hline Economía & 0 & 0 & 2 & 0 & 1 & 0 & 2 & 3 & 0 & 1 & 0 & 1 \\
\hline Internacional & 1 & 1 & 0 & 4 & 4 & 0 & 2 & 4 & 5 & 1 & 2 & 0 \\
\hline Opinión & 0 & 0 & 7 & 0 & 1 & 0 & 8 & 0 & 0 & 0 & 4 & 5 \\
\hline
\end{tabular}




\begin{tabular}{|c|r|r|r|r|r|r|r|r|r|r|r|r|r|}
\hline Regional & 0 & 0 & 0 & 0 & 22 & 0 & 1 & 0 & 5 & 0 & 0 & 0 \\
\hline Salud & 0 & 0 & 0 & 0 & 1 & 0 & 0 & 0 & 2 & 0 & 0 & 0 \\
\hline Sociedad & 0 & 4 & 9 & 3 & 0 & 32 & 14 & 2 & 0 & 15 & 8 & 6 \\
\hline Tecnología & 2 & 0 & 0 & 0 & 0 & 2 & 0 & 0 & 0 & 1 & 0 & 1 \\
\hline Otras & 1 & 4 & 1 & 6 & 3 & 13 & 1 & 16 & 10 & 7 & 2 & 3 \\
\hline № Total & 34 & 13 & 52 & 35 & 99 & 51 & 83 & 85 & 45 & 29 & 50 & 36 \\
\hline
\end{tabular}

Tabla 7.10. Sección. Por periódico y por año.

\begin{tabular}{|c|r|r|}
\hline SECCIÓN & ESPAÑA & COREA \\
\hline Ciencia & 99 & 43 \\
\hline Cultura & 33 & 181 \\
\hline Economía & 2 & 8 \\
\hline Internacional & 12 & 12 \\
\hline Opinión & 1 & 24 \\
\hline Regional & 27 & 1 \\
\hline Salud & 3 & 0 \\
\hline Sociedad & 51 & 42 \\
\hline Tecnología & 5 & 1 \\
\hline Otras & 38 & 29 \\
\hline No Total & 271 & 341 \\
\hline
\end{tabular}

Tabla 7.11. Sección. Por país.

Convertimos los datos a porcentaje y lo expresamos en un gráfico:

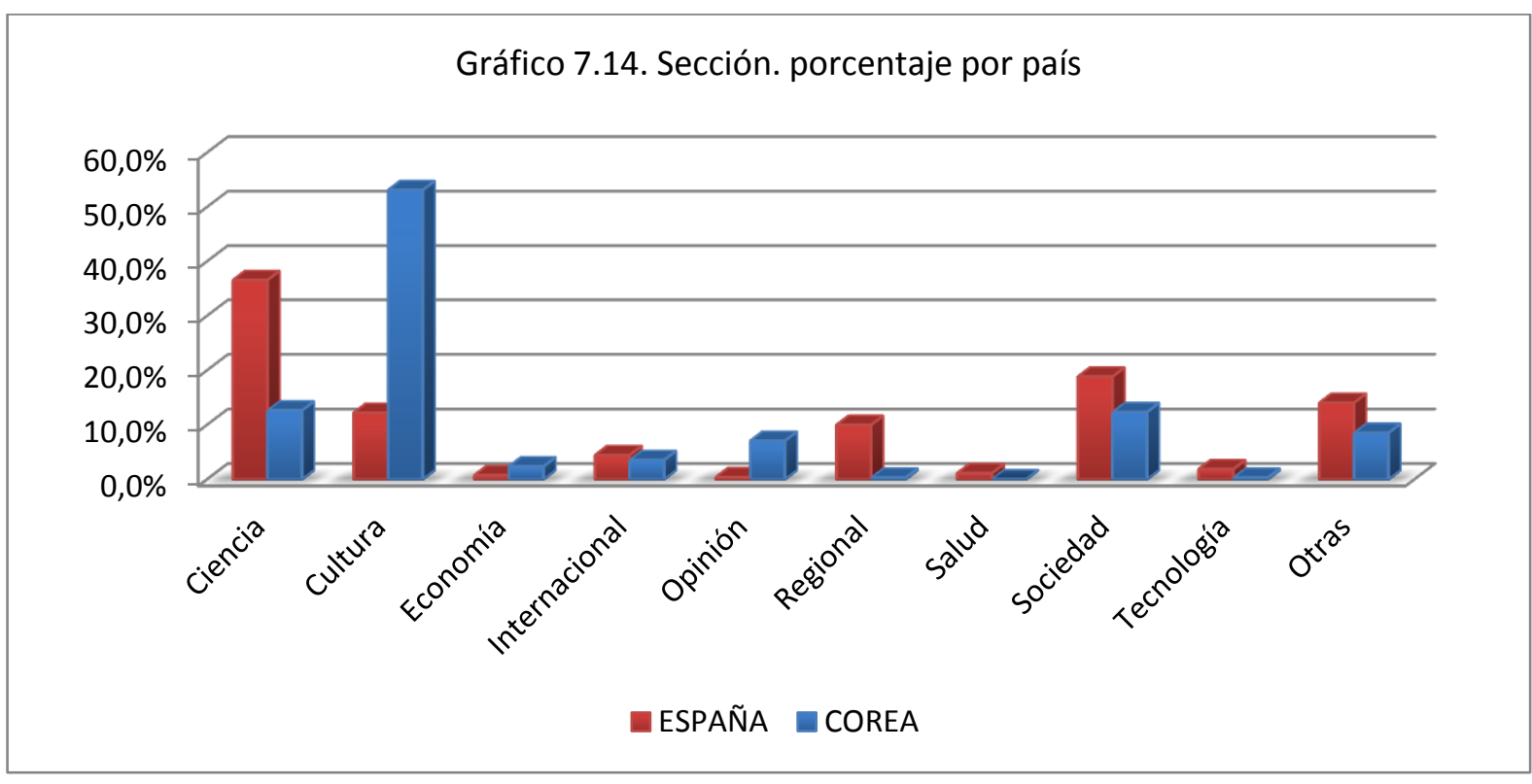

Entre los artículos españoles, la sección que tiene más artículos es 'Ciencia' (36,5\%), la segunda es 'Sociedad' (18,8\%) y la tercera es 'Cultura' (12,4\%). Las proporciones de 'Ciencia' no son tan altas. En el caso de España, el periódico EL PAís no clasificó ningún artículo en la sección 'Ciencia'. Sin embargo, el porcentaje español (36,5\%) de la sección 'Ciencia' es 
mucho más alto que el de Corea (12,6\%).

La razón por la que estudiamos la clasificación de secciones es percibir en qué contexto se transmiten los artículos que incluyen el darwinismo. Sin embargo, en los tres años que estudiamos (2008, 2009 y 2010) entre los dos periódicos españoles solamente EL MUNDO tenía la sección de 'Ciencia'35. En ese momento, EL PAís no parecía haber dirigido una sección separada de 'Ciencia'. Los artículos susceptibles de encajar en la sección de 'Ciencia' parecen haber sido colocados principalmente en la sección de 'Sociedad' o de 'Cultura'. Si calculamos el porcentaje en los artículos de EL MUNDO, 55,6\% están colocadas en la sección 'Ciencia'. Podemos saber que más de la mitad de los artículos relacionados con el darwinismo de EL MUNDO aparecieron en el contexto científico.

Entre los artículos coreanos, la sección que tiene más artículos es 'Cultura' (53,1\%), la segunda es 'Ciencia' (12,6\%) y la tercera es 'Sociedad' (12,3\%). Aun cuando existe la sección de 'Ciencia', la sección de 'Cultura' tiene mucho más artículos relacionados con el darwinismo. Los periódicos coreanos han publicado más de la mitad de sus artículos en la sección de 'Cultura', a pesar de tener la sección separada de 'Ciencia'. De hecho, se menciona a menudo en el contexto cultural.

En suma, a pesar de que solo uno de dos periódicos españoles tenía la sección de 'Ciencia', el hecho de que la proporción de artículos en la sección de 'Ciencia' es mucho mayor y el número de artículos es más del doble que en Corea. Eso muestra que el país asiático no tiene muchos artículos del darwinismo que aparecen en contexto puramente científico y en la sección de 'Ciencia'.

Corea únicamente ofrece un artículo en la sección 'Regional' (España 27 artículos, el 10\%). España tiene solo un artículo en la sección ‘Opinión' (Corea 24 artículos, el 7\%)

\begin{tabular}{|c|r|r|r|r|r|r|}
\hline \multirow{2}{*}{ SECCIÓN } & \multicolumn{3}{|c|}{ ESPAÑA } & \multicolumn{3}{c|}{ COREA DEL SUR } \\
\cline { 2 - 7 } & AÑO2008 & AÑO2009 & AÑO2010 & AÑO2008 & AÑO2009 & AÑO2010 \\
\hline Ciencia & 30 & 54 & 15 & 10 & 22 & 11 \\
\hline
\end{tabular}

\footnotetext{
35 En el estudio que investigó los artículos periodísticos de biotecnología en 7 periodísticos (EL MUNDO y EL PAís incluidos), en 2003 solamente EL MUNDO tenía la sección de 'Ciencia' (Quintanilla, et al., 2005: 43). Sin embargo, en la actualidad (en 2016) EL PAís tiene las secciones de 'Ciencia' y 'Tecnología' separadamente y EL MUNDO cuenta con una sección de 'Ciencia y Salud' y otra 'Tecnología'.
} 


\begin{tabular}{|c|r|r|r|r|r|r|}
\hline Cultura & 4 & 17 & 12 & 45 & 93 & 43 \\
\hline Economía & 0 & 1 & 1 & 2 & 5 & 1 \\
\hline Internacional & 2 & 4 & 6 & 4 & 6 & 2 \\
\hline Opinión & 0 & 1 & 0 & 7 & 8 & 9 \\
\hline Regional & 0 & 22 & 5 & 0 & 1 & 0 \\
\hline Salud & 0 & 1 & 2 & 0 & 0 & 0 \\
\hline Sociedad & 4 & 32 & 15 & 12 & 16 & 14 \\
\hline Tecnología & 2 & 2 & 1 & 0 & 0 & 1 \\
\hline Otras & 5 & 16 & 17 & 7 & 17 & 5 \\
\hline No Total & 47 & 150 & 74 & 87 & 168 & 86 \\
\hline
\end{tabular}

Tabla 7.12. Sección. Por país y por año

Convertimos los datos a porcentaje y expresamos como un gráfico:

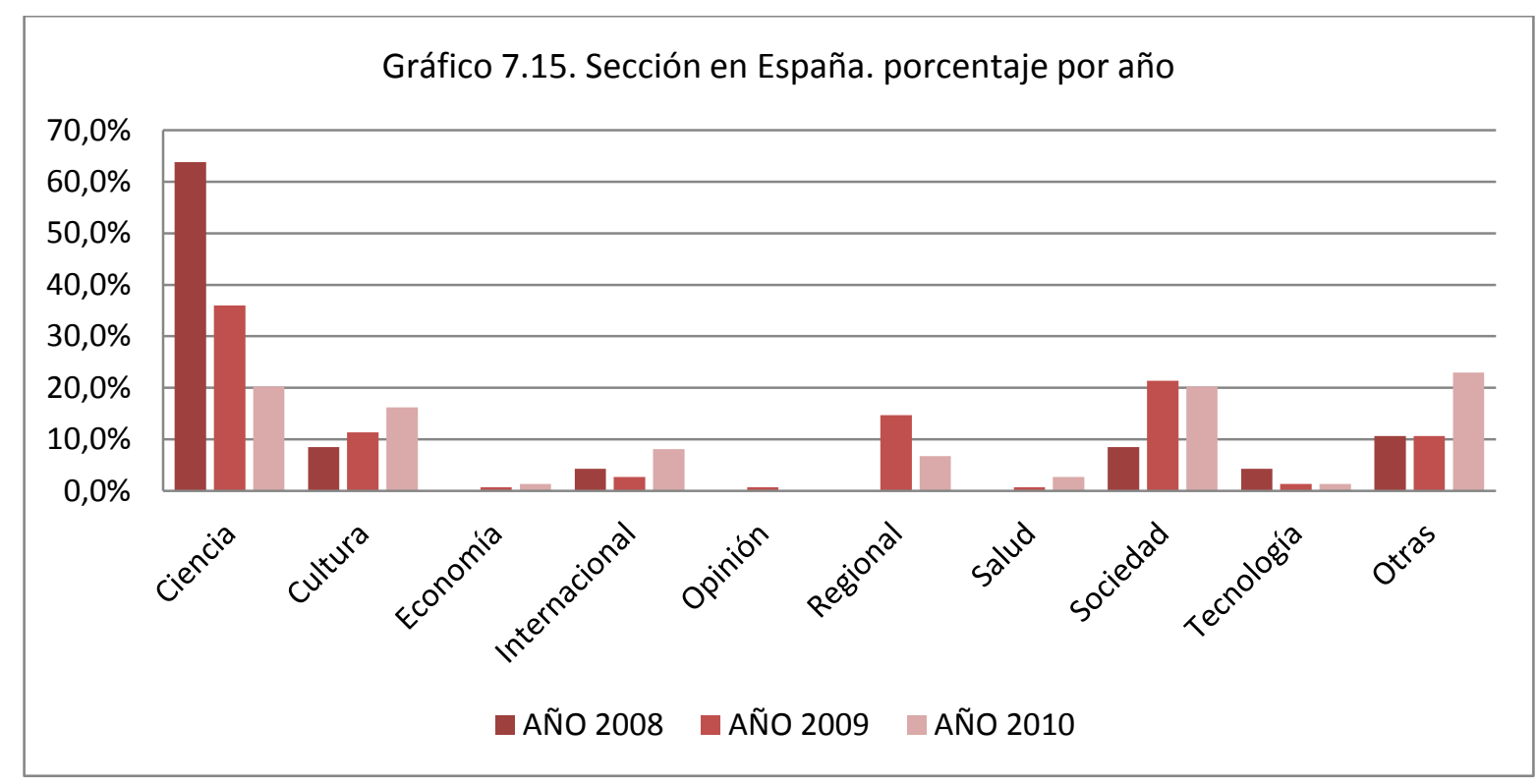

El porcentaje de la sección disminuye cada año. El porcentaje de la sección 'Cultura' aumenta cada año. El porcentaje de la sección 'Sociedad' aumenta en 2009 y no varió mucho en 2010. 


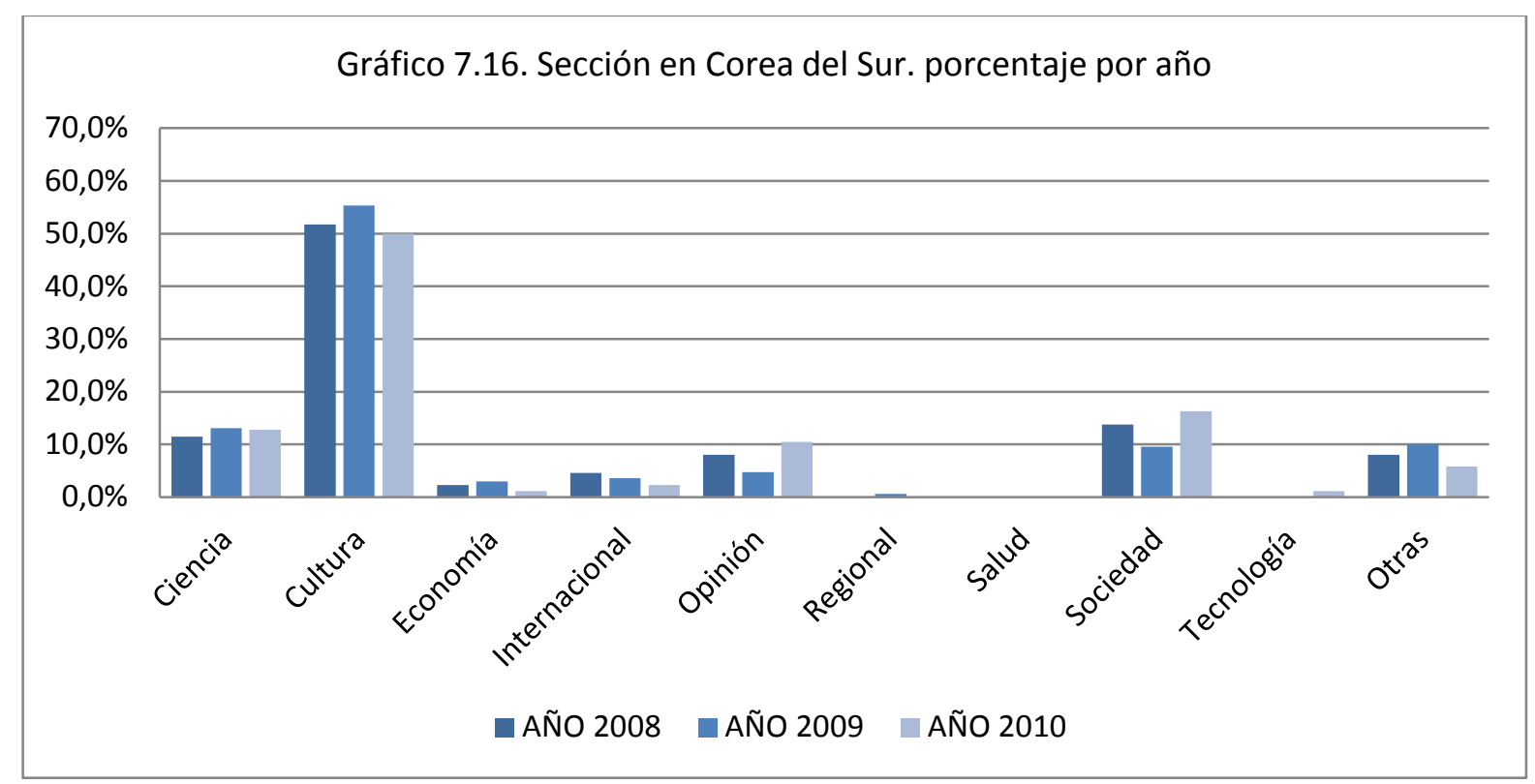

Los porcentajes de la sección 'Ciencia' y 'Cultura' no cambian mucho por año. Las proporciones de ‘Opinión' y 'Sociedad' disminuyen en 2009 pero en 2010 recuperan el nivel de 2008.

\subsubsection{Géneros Periodísticos}

El material estudiado también se ha clasificado por géneros periodísticos. A pesar de que 'Reseña (de libros)' no se considera normalmente como un género periodístico, se ha añadido en este estudio porque su presencia es visible, especialmente en Corea. Esto se refiere a un artículo que introduce un libro recién publicado y se refiere a las teorías de Darwin y Darwin en su contenido.

- Artículo (de opinión): Artículos de opinión escritos por periodista en redacción.

- Columna: Artículo de opinión escritos por colaborador/a externo/a.

- Entrevista

- Nota breve

- Noticia

- Reportaje

- Reseña (de libros) 


\begin{tabular}{|c|c|c|c|c|c|c|c|c|c|c|c|c|}
\hline \multirow{3}{*}{ GÉNERO } & \multicolumn{4}{|c|}{ AÑO 2008} & \multicolumn{4}{|c|}{ AÑO 2009} & \multicolumn{4}{|c|}{ AÑO 2010} \\
\hline & \multicolumn{2}{|c|}{ ESPAÑA } & \multicolumn{2}{|c|}{ COREA } & \multicolumn{2}{|c|}{ ESPAÑA } & \multicolumn{2}{|c|}{ COREA } & \multicolumn{2}{|c|}{ ESPAÑA } & \multicolumn{2}{|c|}{ COREA } \\
\hline & MUN & PAI & HAN & JOO & MUN & PAI & HAN & JOO & MUN & PAI & HAN & $\mathrm{JOO}$ \\
\hline Artículo & 1 & 0 & 0 & 1 & 5 & 0 & 1 & 2 & 0 & 0 & 1 & 3 \\
\hline Columna & 6 & 3 & 18 & 3 & 12 & 6 & 24 & 16 & 9 & 6 & 9 & 11 \\
\hline Entrevista & 2 & 0 & 2 & 3 & 7 & 0 & 1 & 6 & 3 & 2 & 4 & 3 \\
\hline Nota breve & 2 & 4 & 2 & 3 & 5 & 2 & 3 & 4 & 0 & 0 & 1 & 0 \\
\hline Noticia & 23 & 3 & 8 & 6 & 54 & 31 & 20 & 7 & 32 & 18 & 5 & 3 \\
\hline Reportaje & 0 & 1 & 0 & 1 & 11 & 11 & 2 & 23 & 0 & 3 & 1 & 2 \\
\hline Reseña & 0 & 2 & 22 & 18 & 5 & 1 & 32 & 27 & 1 & 0 & 30 & 15 \\
\hline № Total & 34 & 13 & 52 & 35 & 99 & 51 & 83 & 85 & 45 & 29 & 50 & 36 \\
\hline
\end{tabular}

Tabla 7.13. Géneros Periodísticos. Por periódico y por año

\begin{tabular}{|l|r|r|}
\hline GÉNERO & ESPAÑA & \multicolumn{1}{l|}{ COREA } \\
\hline Artículo & 6 & 8 \\
\hline Columna & 42 & 81 \\
\hline Entrevista & 14 & 19 \\
\hline Nota breve & 13 & 13 \\
\hline Noticia & 161 & 49 \\
\hline Reportaje & 26 & 29 \\
\hline Reseña & 9 & 144 \\
\hline No Total & 271 & 341 \\
\hline
\end{tabular}

Tabla 7.14. Géneros Periodísticos. Por país

Convertimos los datos a porcentaje y expresamos como un gráfico:

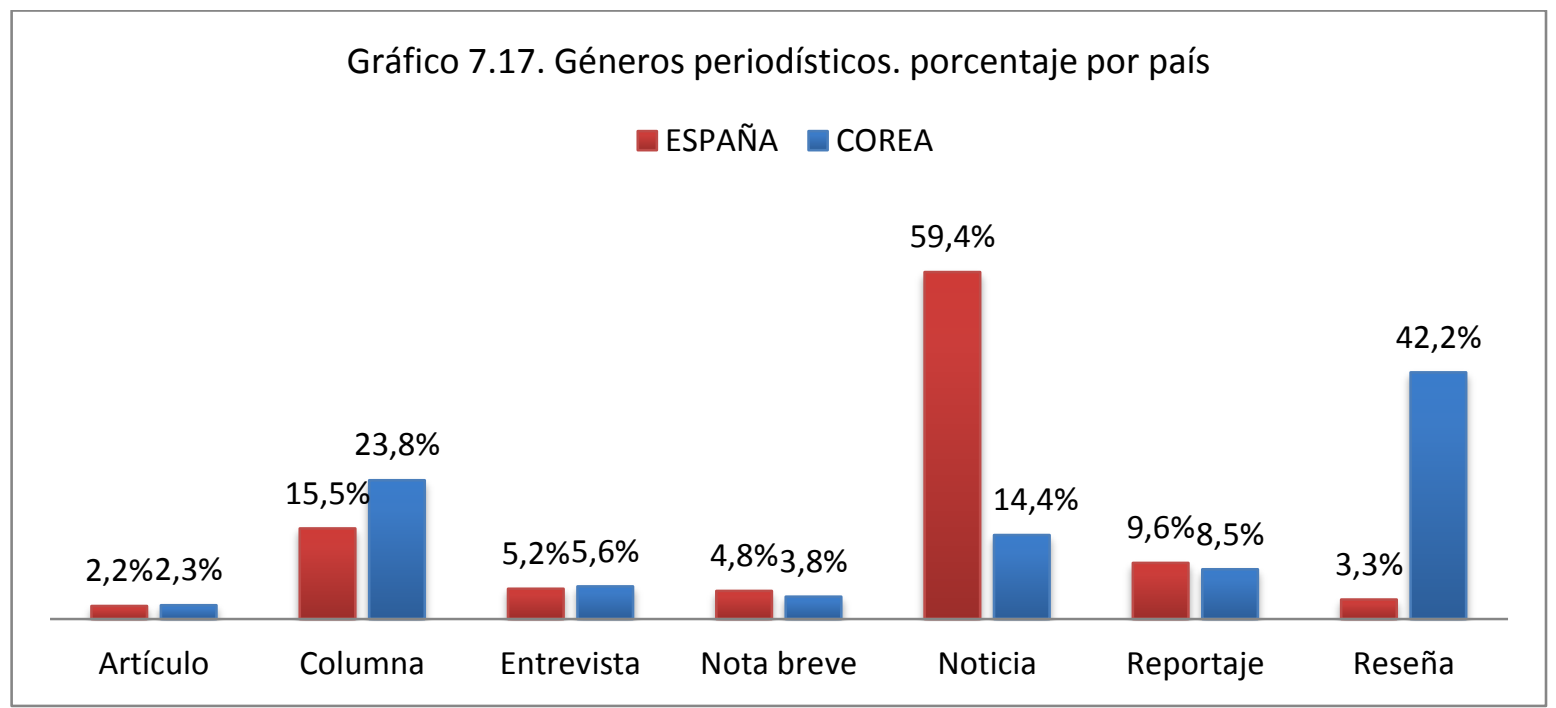

El género que ocupa más porcentaje es 'Noticia' en España y 'Reseña' en Corea. Y el segundo género es 'Columna' en los dos países.

La proporción de 'Noticia' de España es $59,4 \%$ y la de Corea es solo $14,4 \%$. La diferencia 
entre los dos países es bastante notable. 'Noticia' indica un artículo que transmite un hecho nuevo. En estos artículos se trasmiten nuevas noticias relacionadas con el darwinismo. El hecho de que el $59,4 \%$ de los artículos españoles sean 'Noticia' muestra que el darwinismo se considera como un tema actual. En cambio, el porcentaje de 'Noticia' en Corea del Sur solamente en del $14,4 \%$.

Por otra parte, 'Reseña' ocupa el 42,2\% (144 artículos) en Corea y un 3,3\% (9 artículos) en España. 'Reseña' es un género bastante minoritario en España y normalmente no se considera un género periodístico, pero es el género más frecuente entre los artículos seleccionados de Corea del Sur. Introducir libros recién publicados es una práctica semanal de los periodísticos coreanos y es una sección muy familiar para los coreanos. Además, alrededor de 2009 se dio un auge en la publicación de libros relacionados con el darwinismo y la mayoría de los libros fueron libros traducidos. Puede ser una prueba de que libros importantes sobre el darwinismo no fueron traducidos hasta entonces. Por el motivo de la conmemoración, surgieron varios proyectos de traducción y publicación sobre el científico y su teoría. Gran parte de estos libros eran para el público, no profesionales. Si pensamos con el bajo porcentaje de 'Noticia' de Corea, el género 'Reseña' no trata informaciones muy recientes, porque se presenta al público en forma de libro después de que algunos logros de investigación han madurado.

Corea tiene 7\% más que España en cuanto a los artículos de 'Columna'. Los porcentajes de artículo, entrevista, nota breve y reportaje son similares entre los dos países.

\begin{tabular}{|l|r|r|r|r|r|r|}
\hline \multirow{2}{*}{ GÉNERO } & \multicolumn{3}{|c|}{ ESPAÑA } & \multicolumn{3}{|c|}{ COREA DEL SUR } \\
\cline { 2 - 7 } & AÑO2008 & AÑO2009 & AÑO2010 & AÑO2008 & AÑO2009 & AÑO2010 \\
\hline Artículo & 1 & 5 & 0 & 1 & 3 & 4 \\
\hline Columna & 9 & 18 & 15 & 21 & 40 & 20 \\
\hline Entrevista & 2 & 7 & 5 & 5 & 7 & 7 \\
\hline Nota breve & 6 & 7 & 0 & 5 & 7 & 1 \\
\hline Noticia & 26 & 85 & 50 & 14 & 27 & 8 \\
\hline Reportaje & 1 & 22 & 3 & 1 & 25 & 3 \\
\hline Reseña & 2 & 6 & 1 & 40 & 59 & 45 \\
\hline № Total & 47 & 150 & 74 & 87 & 168 & 86 \\
\hline
\end{tabular}

Tabla 7.15. Géneros Periodísticos. Por año y por país.

Convertimos los datos a porcentaje y expresamos como un gráfico: 


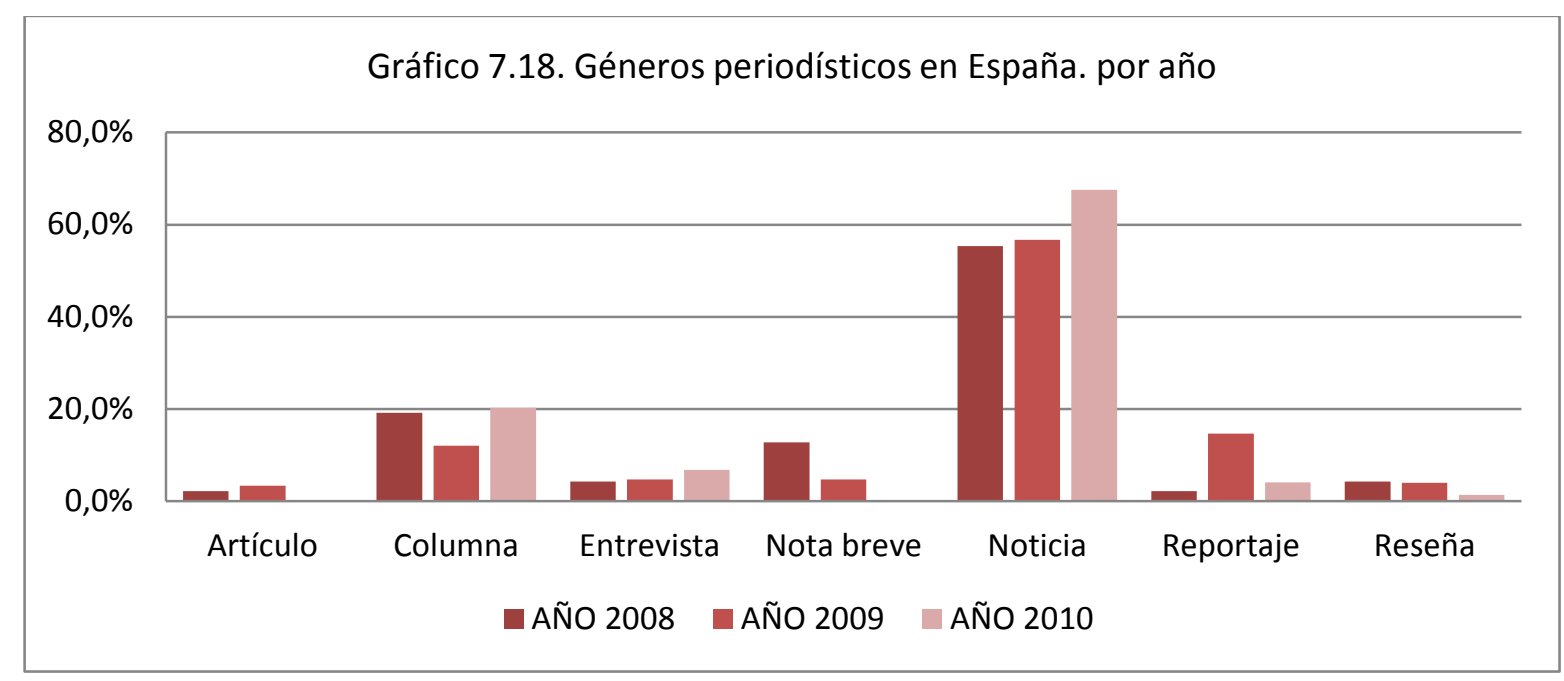

Entre los artículos españoles, en 2009 disminuye 'Columna' y aumenta 'Reportaje'. El porcentaje de 'Noticia' en España aumenta en 2010.

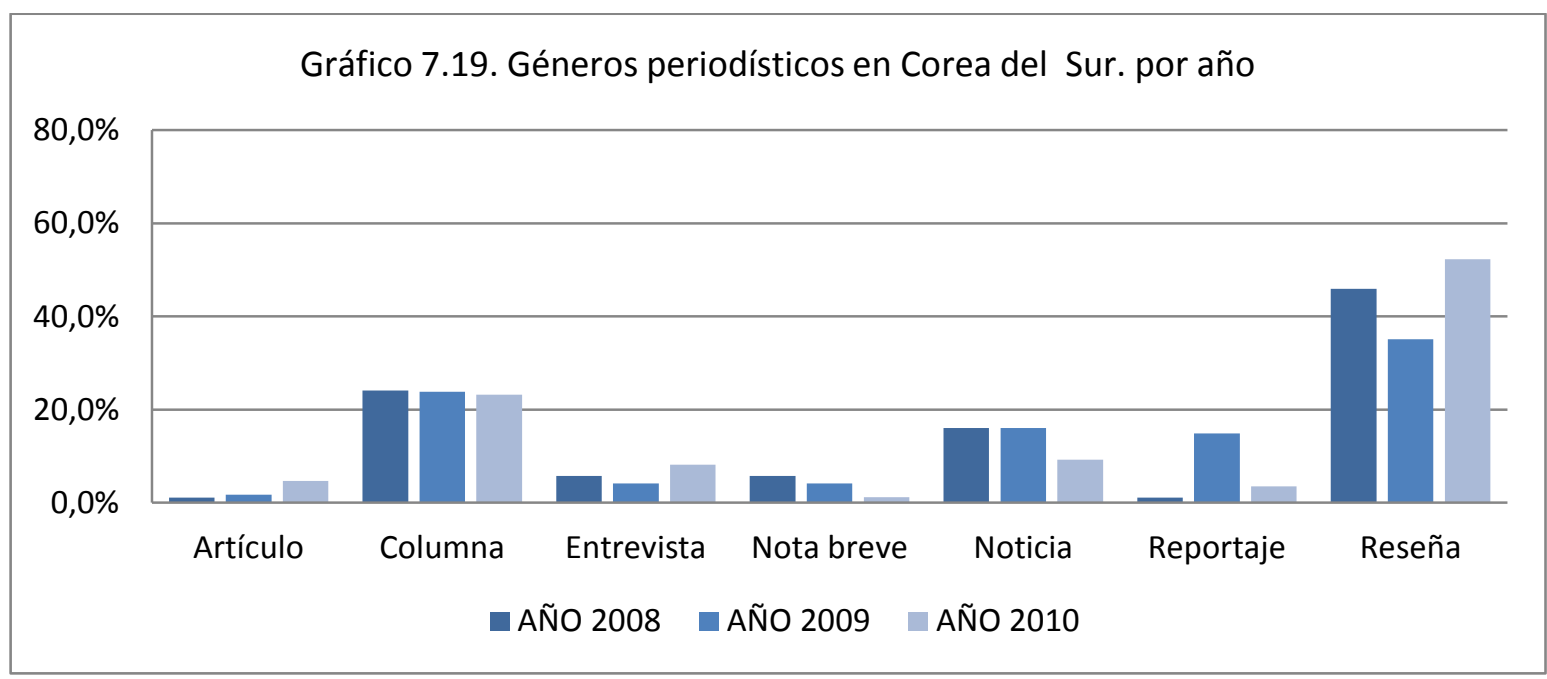

En Corea el porcentaje de 'Columna' se mantiene sin gran cambio en los tres años. Sin embargo, el número de artículos de 'Columna' en 2009 es doble (en 2008: 21 artículos $\rightarrow$ 2009: $40 \rightarrow$ 2010: 20) de 2008 y 2010, ya que en 2009 aumenta el número total de artículos.

En 2009 disminuye el porcentaje de 'Reseña', pero el número de artículos es más alto (en 2008:40 artículos $\rightarrow$ 2009: $59 \rightarrow$ 2010: 45).

En 2009, 'Reportaje' aumenta mucho (2008: 1 artículo $\rightarrow$ 2009: 25). Se entiende que por la conmemoración aumentan los reportajes sobre la vida de Darwin y su teoría. En 2010 disminuye de nuevo (2009: 25 artículos $\rightarrow$ 2010: 3). 


\subsubsection{Autoría}

Se han clasificado los artículos en función del tipo de autor. La distribución de escritores de los artículos seleccionados es una referencia para saber la tendencia del interés sobre la teoría. Se han añadido la categoría 'Científico' ya que hay varios artículos redactados por profesionales de la ciencia.

- Agencia: Agencia de noticias.

- Científico: Científicos profesionales. Colaboradores externos.

- Columnista: Colaboradores externos excepto científicos.

- Redacción: Sin nombre de periodista. Escrito por la redacción.

- Periodista: Periodistas en redacción.

Entre las categorías, 'Agencia', 'Redacción' y 'periodista' son de gente que se dedica al periodismo. Si un científico se refiere al darwinismo en su artículo periodístico, podemos clasificarlo como divulgación científica.

La mayoría de los columnistas que escribieron artículos mencionando el darwinismo pertenecen al ámbito intelectual. La presencia del darwinismo en sus artículos muestra la influencia del darwinismo fuera de la comunidad científica en la sociedad.

\begin{tabular}{|c|c|c|c|c|c|c|c|c|c|c|c|c|}
\hline \multirow{3}{*}{ AUTORÍA } & \multicolumn{4}{|c|}{ AÑO 2008} & \multicolumn{4}{|c|}{ AÑO 2009} & \multicolumn{4}{|c|}{ AÑO 2010} \\
\hline & \multicolumn{2}{|c|}{ ESPAÑA } & \multicolumn{2}{|c|}{ COREA } & \multicolumn{2}{|c|}{ ESPAÑA } & \multicolumn{2}{|c|}{ COREA } & \multicolumn{2}{|c|}{ ESPAÑA } & \multicolumn{2}{|c|}{ COREA } \\
\hline & MUN & PAI & HAN & $\mathrm{JOO}$ & MUN & PAI & HAN & $\mathrm{JOO}$ & MUN & PAI & HAN & $\mathrm{JOO}$ \\
\hline Agencia & 9 & 7 & 2 & 0 & 27 & 12 & 2 & 3 & 17 & 5 & 1 & 0 \\
\hline Científico & 3 & 0 & 1 & 0 & 4 & 7 & 2 & 4 & 1 & 1 & 2 & 1 \\
\hline Columnista & 2 & 1 & 16 & 8 & 9 & 2 & 24 & 33 & 6 & 2 & 9 & 10 \\
\hline Redacción & 2 & 4 & 15 & 8 & 12 & 12 & 7 & 16 & 2 & 2 & 12 & 8 \\
\hline Periodista & 18 & 2 & 18 & 19 & 47 & 20 & 48 & 29 & 19 & 19 & 27 & 17 \\
\hline № Total & 34 & 13 & 52 & 35 & 99 & 51 & 83 & 85 & 45 & 29 & 50 & 36 \\
\hline
\end{tabular}

Tabla 7.16. Autoría. Por periódico.

\begin{tabular}{|l|r|r|}
\hline AUTORÍA & ESPAÑA & COREA \\
\hline Agencia & 77 & 8 \\
\hline Científico & 16 & 10 \\
\hline Columnista & 22 & 100 \\
\hline Redacción & 34 & 66 \\
\hline
\end{tabular}




\begin{tabular}{|l|l|l|}
\hline Periodista & 125 & 158 \\
\hline № Total & 271 & 341 \\
\hline
\end{tabular}

Tabla 7.17. Autoría. Por país.

Convertimos los datos a porcentaje y expresamos como un gráfico:

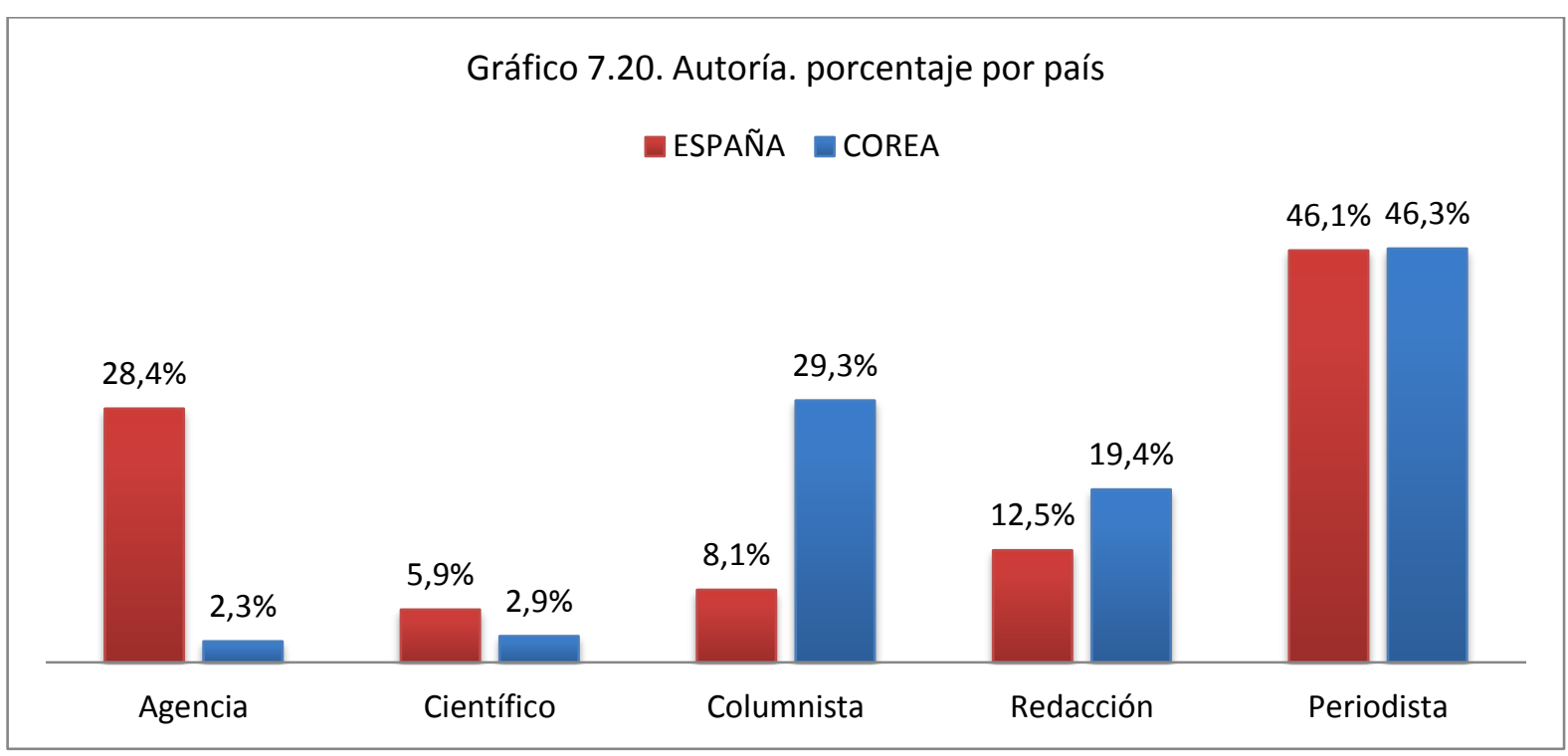

'Periodistas' de España y Corea del Sur han redactado $46 \%$ de los artículos sobre el darwinismo (España 46,1\% y Corea 46,3\%). La segunda categoría más destacada es 'Agencia' en España y 'Columnista' en Corea del Sur.

El porcentaje de los artículos españoles redactados por Agencia es considerablemente mayor que el de Corea (España 28,4\%, Corea 2,3\%). El número de artículos es 77 (España) vs. 8 (Corea). Es la categoría que muestra más diferencia entre los dos países. En Corea, parece que suelen publicar artículos con nombre de un periodista de redacción en vez de con nombre de agencia, aunque la modificación del contenido sea pequeña. Se puede relacionar el alto porcentaje de autoría 'Agencia' con el de género 'Noticia'. La mayoría de los artículos redactados por agencia de noticias transmiten nuevas informaciones y los periódicos españoles parecen haber publicado sin intervención. En cambio, Corea no tiene muchos artículos de 'Noticia' y tampoco de autor 'Agencia'.

Columnistas coreanos redactaron un $29,3 \%$ de los artículos del darwinismo y es mucho más que en España (8,1\%). Son colaboradores externos del periódico y no son profesionales de la ciencia, ya que en este estudio lo codificamos aparte bajo la subcategoría de autoría, 
'Científico'. El hecho de que el 29,3\% de los artículos fueron escritos por intelectuales externos, no por científicos ni por periodistas, muestra que es más probable que se refiera al darwinismo en un contexto social que en un contexto científico.

Ahora veamos la distribución de los códigos de MCC (Modelo de Cultura Científica) entre los artículos redactados por Periodistas.

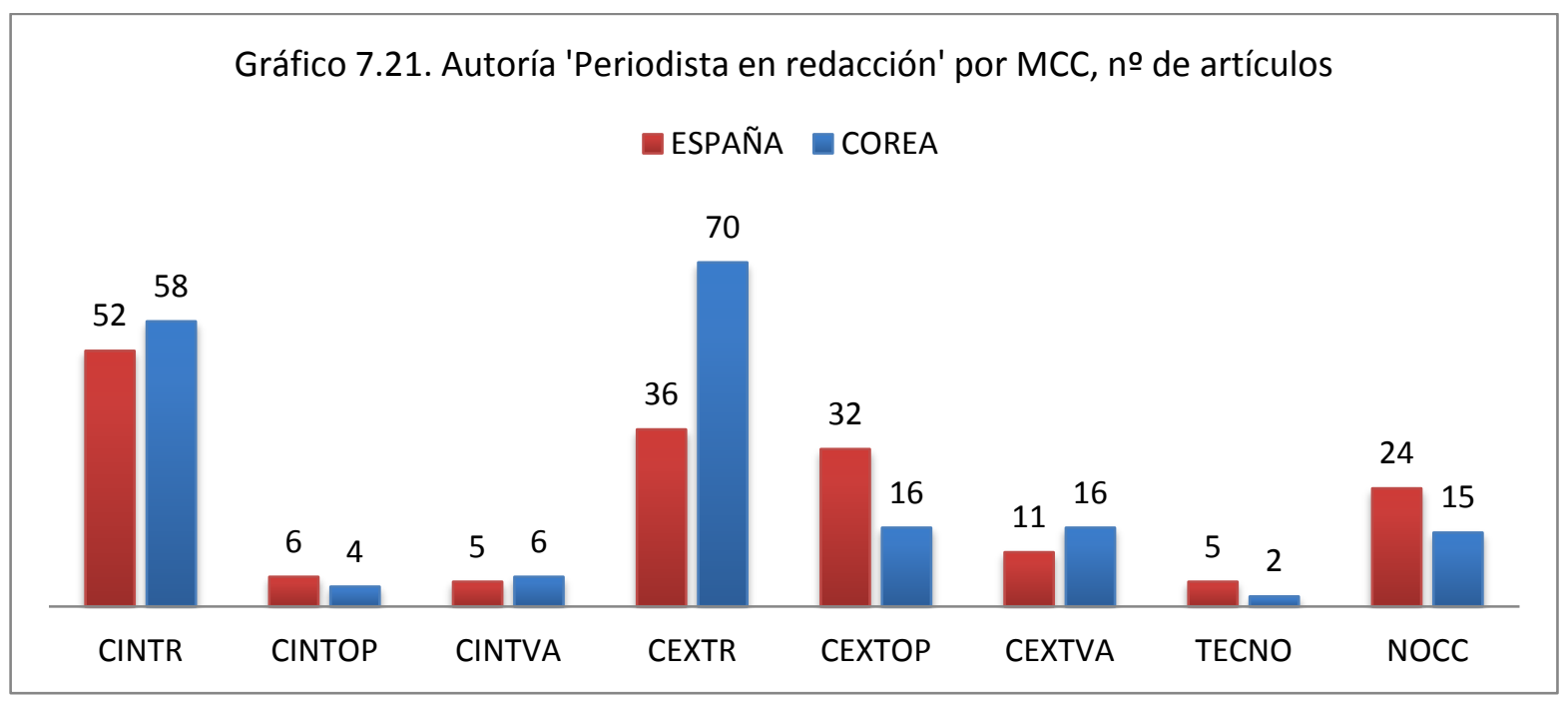

Periodistas coreanos escribieron 70 artículos de CEXTR. La segunda categoría es CINTR (58 artículos). Los artículos de Cultura Científica Representacional son 128 de 158 artículos coreanos redactados por periodistas (81.0\%). Periodistas españoles también escribieron más de 50 artículos de CINTR (52), pero el número de CEXTR (36) es casi mitad del coreano (70). 32 artículos españoles son de CEXTOP y es doble de los coreanos (16). Además, periodistas españoles mencionaron más a Darwin o el darwinismo en los artículos no científicos (NoCC).

El gráfico 7.22 muestra la distribución de los códigos de MCC entre los artículos redactados por Agencias. 


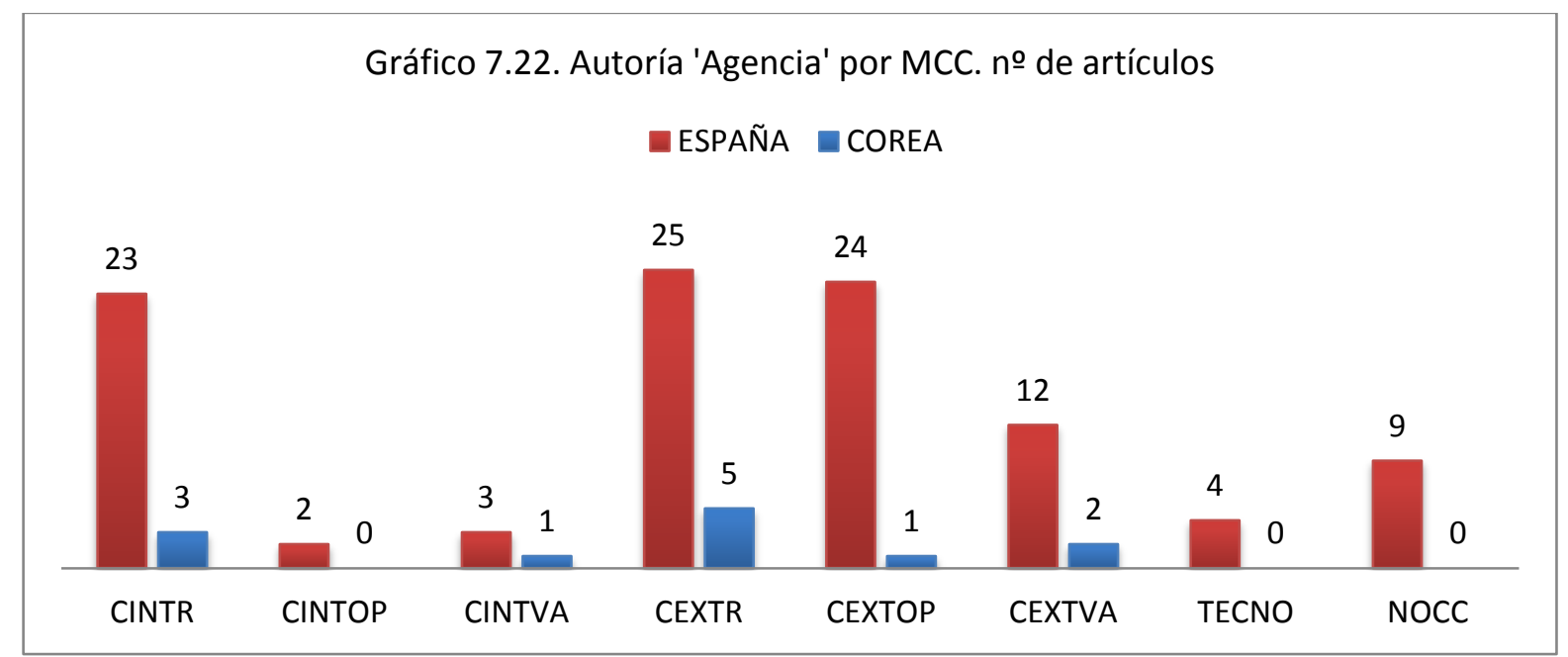

Entre los artículos españoles publicados con nombre de Agencias, se puede encontrar artículos de CINTR (23 artículos), CEXTR (25) y CEXTOP (24) de número similar respectivamente y 12 artículos de CEXTVA. Además, en 9 artículos de NoCC se refieren a Darwin. El número de artículos coreanos es muy pequeño y la cultura científica extrínseca es la mayoría (CINT (4) < CEXT (8)).

En Corea hay más artículos escritos por la redacción (España 12,5\% y Corea 19,4\%). El número de Corea (66 artículos) es casi el doble que el de España (34). El gráfico 7.23 muestra la distribución de los códigos de MCC en los artículos de la redacción. La mayoría de los artículos coreanos incluyen informaciones representacionales de cultura científica intrínseca y extrínseca (CINTR y CEXTR. 58 de 66 artículos (88\%)). Los artículos españoles se distribuyen centrando a CINTR, CEXTR, CEXTOP y CEXTVA.

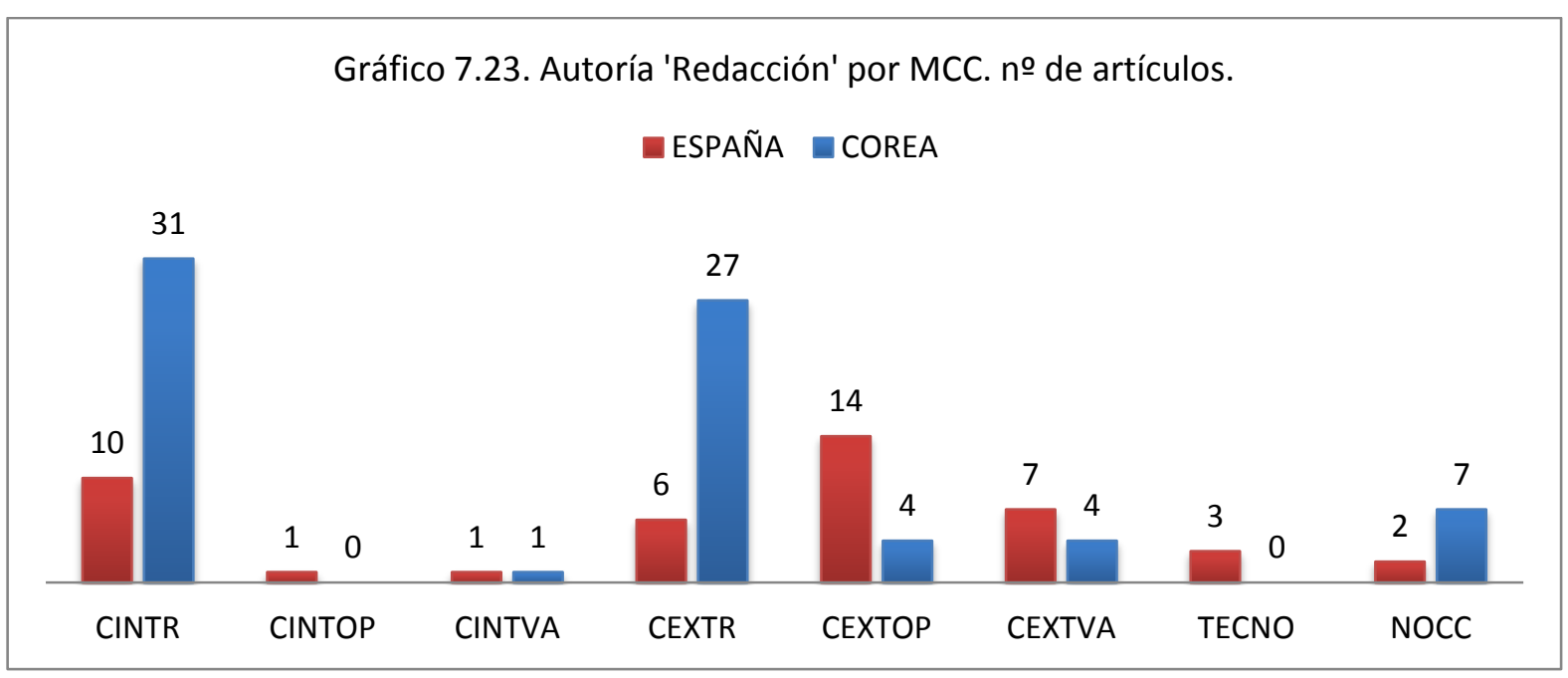


87\% de los artículos españoles se redactaron en el ámbito del periodismo (Agencia, Redacción y Periodista), el porcentaje coreano es $68 \%$.

Los artículos redactados por científicos/as son 16 de España y 10 de Corea. El porcentaje de España $(5,9 \%)$ es 2 veces más alto que el de Corea $(2,9 \%)$.

En el gráfico 7.24 podemos apreciar la distribución de los códigos de MCC de los artículos redactados por científicos. 8 de 10 artículos coreanos redactados por científicos son de CINTR. España tiene 11 artículos de CINTR, 4 de CEXTR y CEXTOP respectivamente.

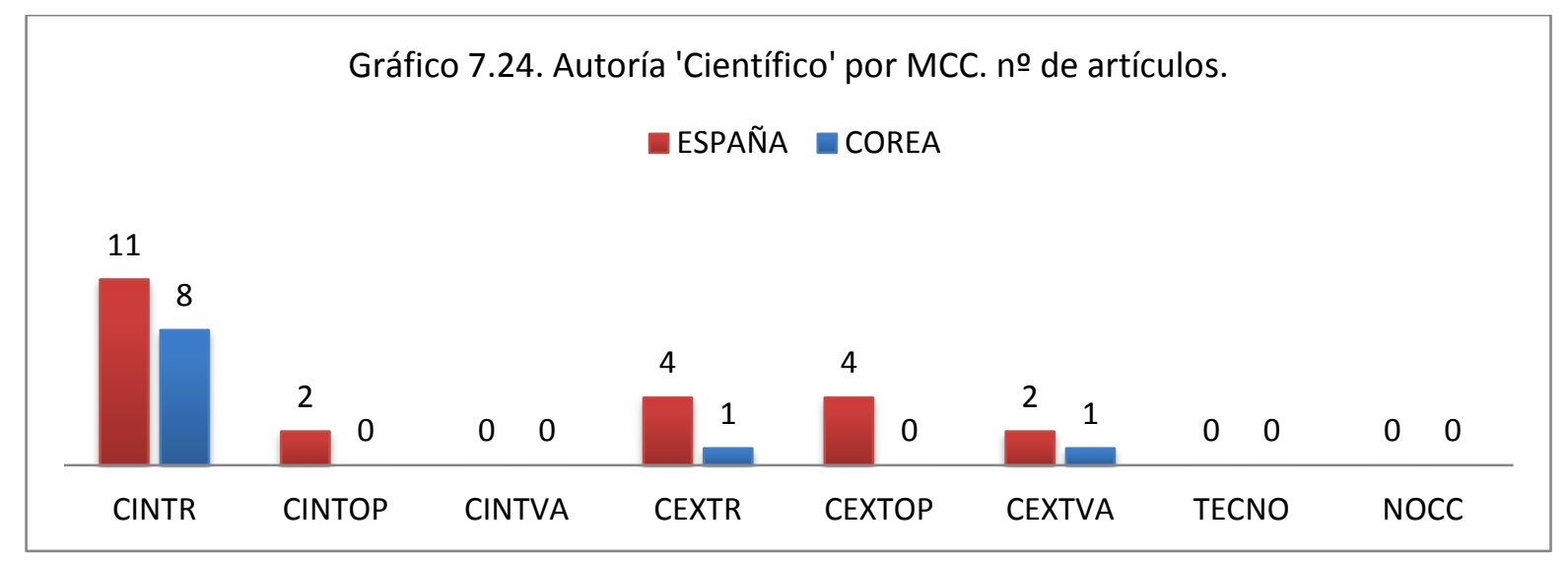

En el caso de Corea, columnistas han redactado el $29,3 \%$ de los artículos. En la sociedad coreana, colaborar con prensa es bastante común en ambientes intelectuales. Los estudiosos coreanos mencionan más a menudo el darwinismo en su columna que los españoles (España 22 artículos y Corea del Sur 100). Podemos decir que la diferencia muestra que el darwinismo está más visible en contexto social en Corea del Sur.

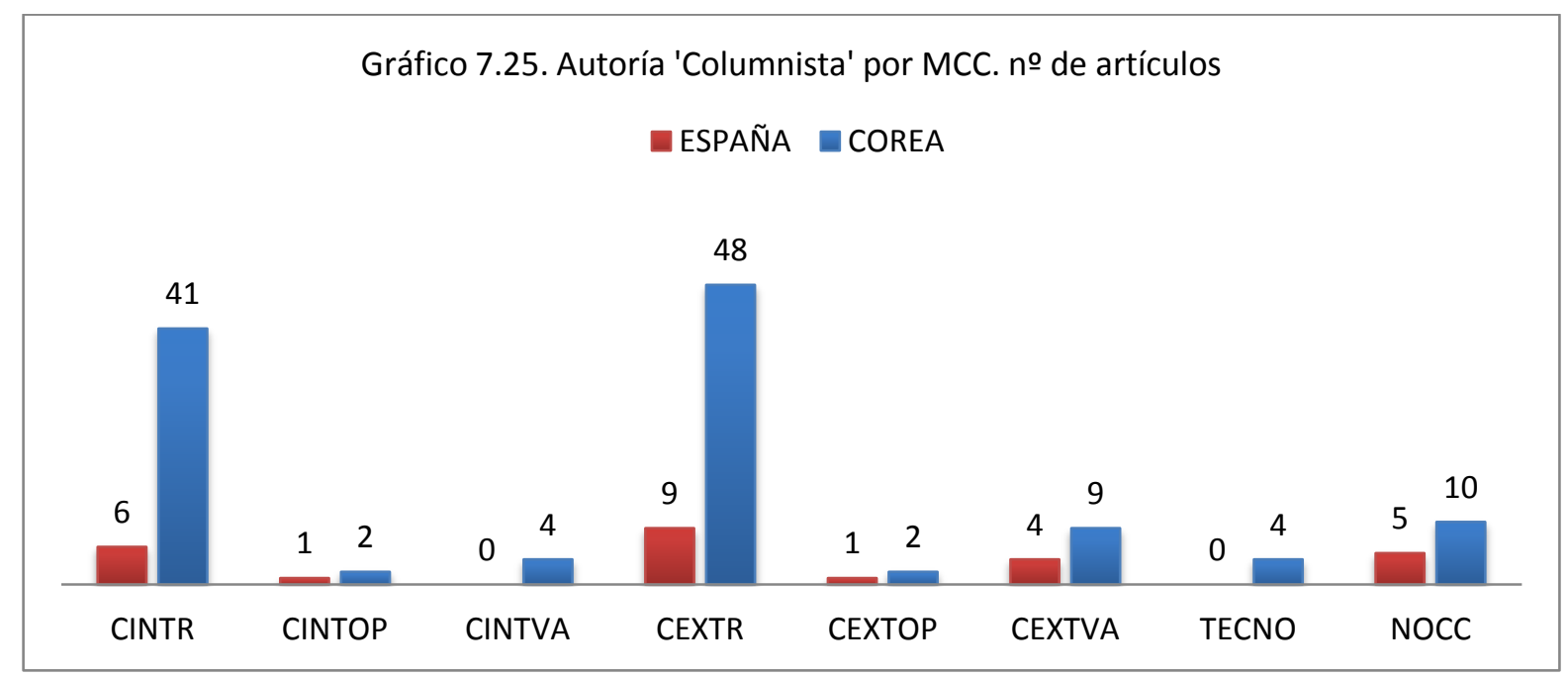


En la distribución por MCC de los artículos redactados por columnistas en Corea del Sur, se destacan los números grandes de las informaciones representacionales de cultura científica intrínseca y extrínseca (CINTR (41) y CEXTR (48), 89\%). España también tiene 15 de 22 artículos (68\%) representacionales. Los columnistas coreanos no son científicos pero incluyeron bastantes informaciones intrínsecas en sus artículos (48\%). Entre los artículos españoles la proporción de la cultura intrínseca es 32\%.

Si se suman el porcentaje de 'Científico' y 'Columnista' (colaboradores externos) en cada país, el de España es 14,0\% y el de Corea es 32,2\%. Es decir, en Corea casi un tercio de los artículos que mencionan el darwinismo son escritos por colaboradores externos.

Ahora veamos la distribución de los autores por año.

\begin{tabular}{|l|r|r|r|r|r|r|}
\hline \multirow{2}{*}{ AUtORÍA } & \multicolumn{3}{|c|}{ ESPAÑA } & \multicolumn{3}{|c|}{ COREA DEL SUR } \\
\cline { 2 - 8 } & AÑO2008 & AÑO2009 & AÑO2010 & AÑO2008 & AÑO2009 & AÑO2010 \\
\hline Agencia & 16 & 39 & 22 & 2 & 5 & 1 \\
\hline Científico & 3 & 11 & 2 & 1 & 6 & 3 \\
\hline Columnista & 3 & 11 & 8 & 24 & 57 & 19 \\
\hline Redacción & 6 & 24 & 4 & 23 & 23 & 20 \\
\hline Periodista & 20 & 67 & 38 & 37 & 77 & 44 \\
\hline No Total & 47 & 150 & 74 & 87 & 168 & 86 \\
\hline
\end{tabular}

Tabla 7.18. Autoría. Por año y país

Convertimos los datos a porcentaje y expresamos como gráfico:

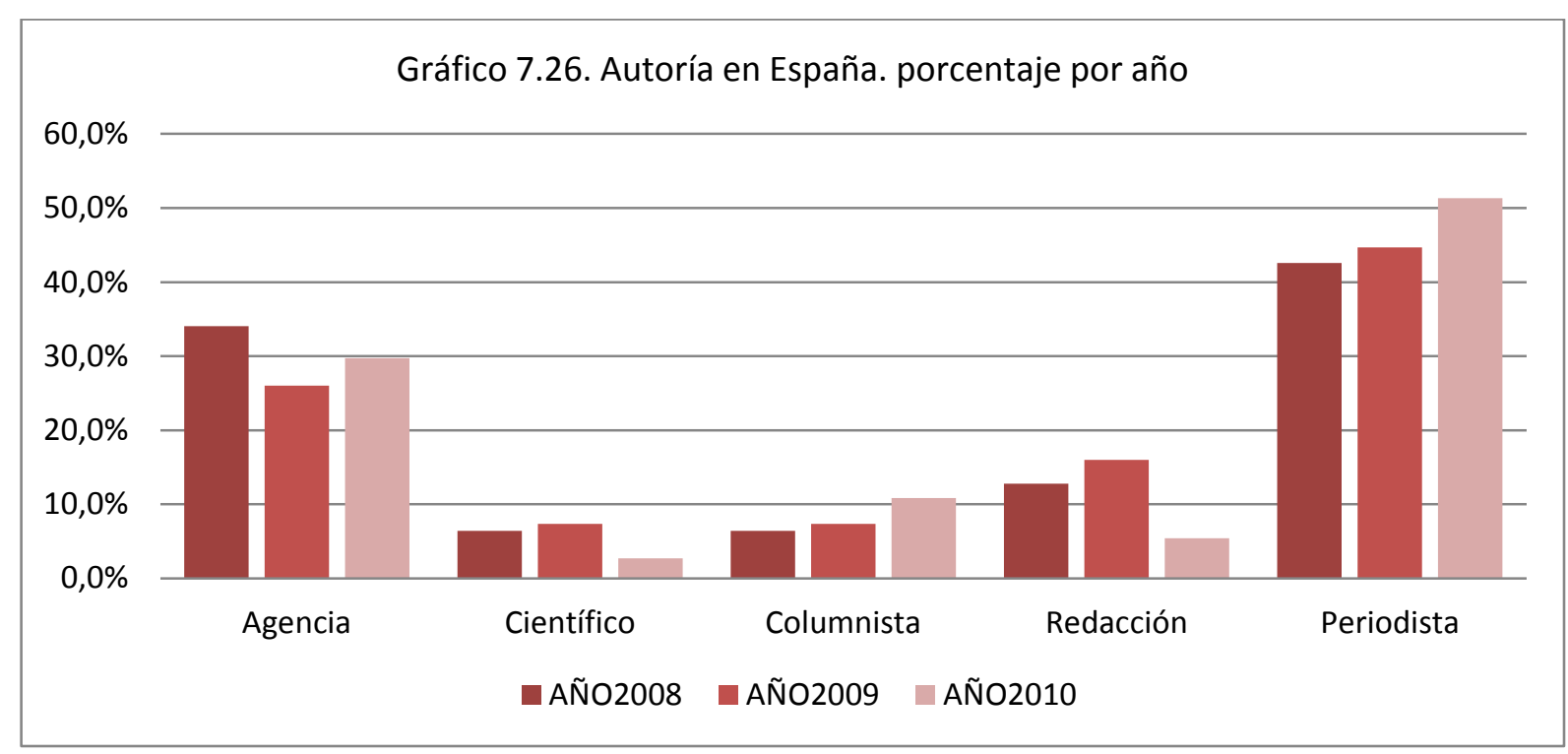

En el caso de España, cada año aumenta el porcentaje de 'Periodista' y 'Columnista' en los 
artículos españoles. En 2010, disminuye la proporción de 'Científico’ y ‘Redacción'.

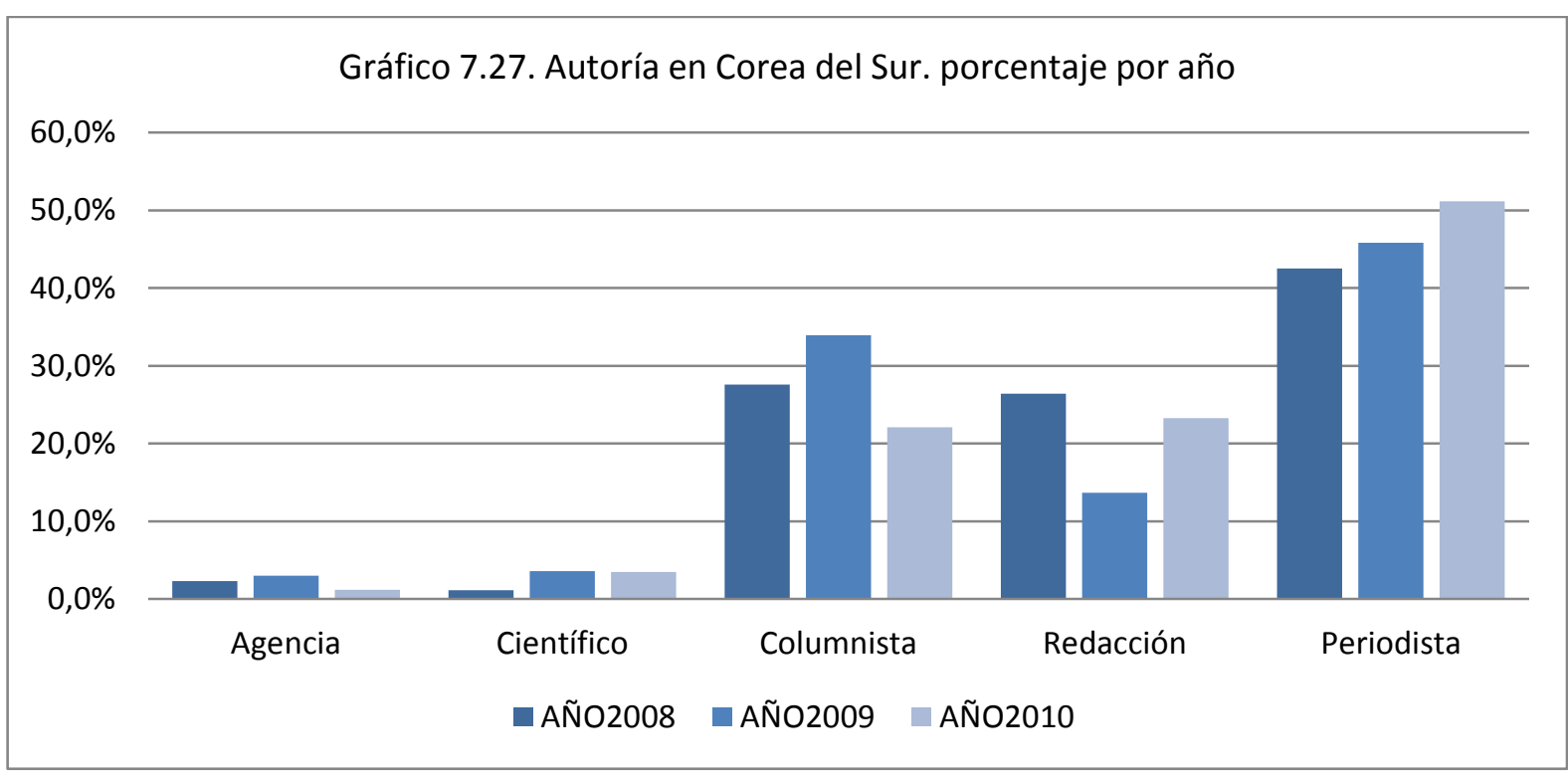

En el caso de Corea del Sur, cada año aumenta el porcentaje de 'Periodista' en los artículos coreanos. En 2009, el año de Darwin, aumenta el porcentaje de 'Columnista' en Corea. Colaboradores externos mencionan el darwinismo más que en años normales (2008 y 2010). La proporción de 'Redacción' redujo en 2009, pero el número de artículos se mantenían. (2008: 23 artículos $\rightarrow$ 2009: $23 \rightarrow$ 2010: 20). 'Columnista' aumentó en 2009 visiblemente (2008: 24 artículos $\rightarrow$ 2009: $57 \rightarrow$ 2010: 19).

\subsubsection{Fuente}

A continuación, veamos los orígenes de las informaciones transmitidas en los artículos seleccionados. La fuente es uno de los factores más importantes para analizar artículos periodísticos. Dependiendo de dónde vino la información, podemos saber en qué contexto se refiere al darwinismo en cada sociedad.

Se han clasificado la fuente de los artículos por las siguientes categorías. Cada texto puede contener varias fuentes de diferentes tipos.

- Centros e Institutos de investigación.

- Entidades gubernamentales (Gobierno). 
- Entidades Religiosas.

- Empresa.

- Museos.

- Publicaciones (Artículos académicos y Libros).

- Científicos y Sociedades Científicas.

- Universidades.

- Otras (congresos, organizaciones no gubernamentales, organismos internacionales, etc.).

- Sin Fuentes declaradas.

Se ha añadido 'Entidades Religiosas' como una de las fuentes de los artículos, ya que surgen a veces temas religiosos enfrentados al darwinismo y desde las entidades religiosas se manifiestan voces contrarias a él.

La categoría de 'Museo' se ha incluido también porque los museos informan de exposiciones y otras actividades científicas. Aun cuando a veces los museos tienen proyectos científicos, es difícil clasificarlos como instituto de investigación. Por eso los clasificamos aparte.

\begin{tabular}{|c|c|c|c|c|c|c|c|c|c|c|c|c|}
\hline \multirow{3}{*}{ FUENTE } & \multicolumn{4}{|c|}{ AÑO 2008} & \multicolumn{4}{|c|}{ AÑO 2009} & \multicolumn{4}{|c|}{ AÑO 2010} \\
\hline & \multicolumn{2}{|c|}{ ESPAÑA } & \multicolumn{2}{|c|}{ COREA } & \multicolumn{2}{|c|}{ ESPAÑA } & \multicolumn{2}{|c|}{ COREA } & \multicolumn{2}{|c|}{ ESPAÑA } & \multicolumn{2}{|c|}{ COREA } \\
\hline & MUN & PAI & HAN & JOO & MUN & PAI & HAN & $\mathrm{JOO}$ & MUN & PAI & HAN & $\mathrm{JOO}$ \\
\hline $\begin{array}{l}\text { Centros e } \\
\text { Institutos }\end{array}$ & 5 & 0 & 5 & 2 & 24 & 13 & 12 & 0 & 13 & 7 & 1 & 0 \\
\hline Gobierno & 2 & 1 & 2 & 0 & 8 & 2 & 1 & 0 & 3 & 2 & 0 & 0 \\
\hline $\begin{array}{l}\text { Entidades } \\
\text { Religiosas }\end{array}$ & 6 & 3 & 4 & 1 & 0 & 0 & 2 & 4 & 1 & 2 & 0 & 0 \\
\hline Empresa & 2 & 1 & 0 & 1 & 2 & 1 & 1 & 1 & 0 & 1 & 0 & 0 \\
\hline Museos & 3 & 1 & 1 & 1 & 13 & 7 & 1 & 0 & 7 & 3 & 0 & 1 \\
\hline Publicaciones & 6 & 3 & 31 & 23 & 21 & 11 & 39 & 52 & 12 & 5 & 35 & 22 \\
\hline $\begin{array}{l}\text { Sociedad } \\
\text { Científica }\end{array}$ & 5 & 0 & 0 & 1 & 6 & 6 & 0 & 2 & 0 & 4 & 1 & 1 \\
\hline Universidades & 6 & 1 & 1 & 4 & 19 & 12 & 5 & 4 & 11 & 3 & 1 & 5 \\
\hline Otras & 4 & 4 & 11 & 5 & 23 & 14 & 24 & 26 & 15 & 14 & 11 & 12 \\
\hline Sin Fuente & 0 & 0 & 0 & 0 & 6 & 1 & 1 & 1 & 1 & 1 & 2 & 1 \\
\hline № Total & 34 & 13 & 52 & 35 & 99 & 51 & 83 & 85 & 45 & 29 & 50 & 36 \\
\hline
\end{tabular}

Tabla 7.19. Fuente. Por periódico y por año

\begin{tabular}{|c|r|r|}
\hline FUENTE & ESPAÑA & COREA \\
\hline Centros e Institutos & 62 & 20 \\
\hline
\end{tabular}




\begin{tabular}{|c|r|r|}
\hline Gobierno & 18 & 3 \\
\hline Entidades Religiosas & 12 & 11 \\
\hline Empresa & 7 & 3 \\
\hline Museos & 34 & 4 \\
\hline Publicaciones & 58 & 202 \\
\hline Sociedad Científica & 21 & 5 \\
\hline Universidades & 52 & 20 \\
\hline Otras & 74 & 89 \\
\hline Sin Fuente & 9 & 5 \\
\hline № Total & 271 & 341 \\
\hline
\end{tabular}

Tabla 7.20. Fuente. Por país

Convertimos los datos a porcentaje y expresamos como gráfico:

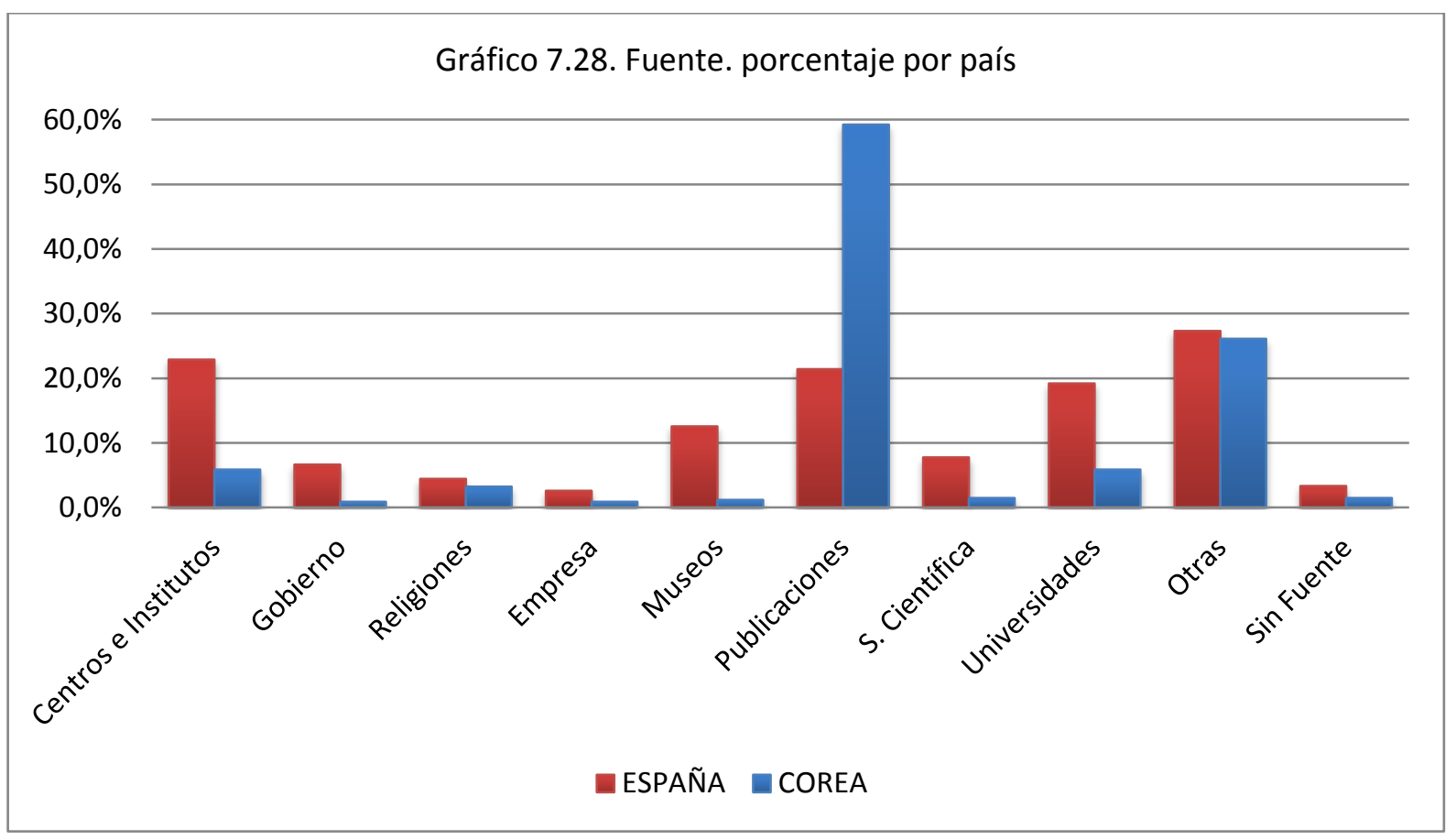

En el caso de Corea, 'Publicación' es la fuente más importante y su porcentaje representa un $59,2 \%$. La mayoría de estos artículos son presentaciones de los libros recién publicados, no sobre artículos académicos. Con el motivo del bicentenario de Darwin, se han escrito y traducido muchos libros del darwinismo como hemos mencionado en 7.3.2.

Anteriormente, no había tantas traducciones de libros profesionales y populares relacionadas con el darwinismo en Corea del Sur. El interés por la industria editorial se planteó en torno al año de Darwin, y muchos libros se publicaron con los esfuerzos de científicos y traductores. 
En cambio, 21,4\% de los artículos españoles proviene de 'Publicaciones'. Entre los artículos españoles, la categoría que alcanza un porcentaje más alto es 'Otras (27,3\%)'. Eso significa que existen varios tipos de fuentes. Las siguientes son 'Centros e Institutos (22,9\%)', 'Publicaciones (21,4\%)' y 'Universidades (19,2\%)'.

Ahora veamos la distribución de los artículos de fuente de 'Publicaciones' por MCC. En el gráfico 7.29 podemos apreciar que la mayoría de los artículos tiene informaciones representacionales (CINTR y CEXTR).

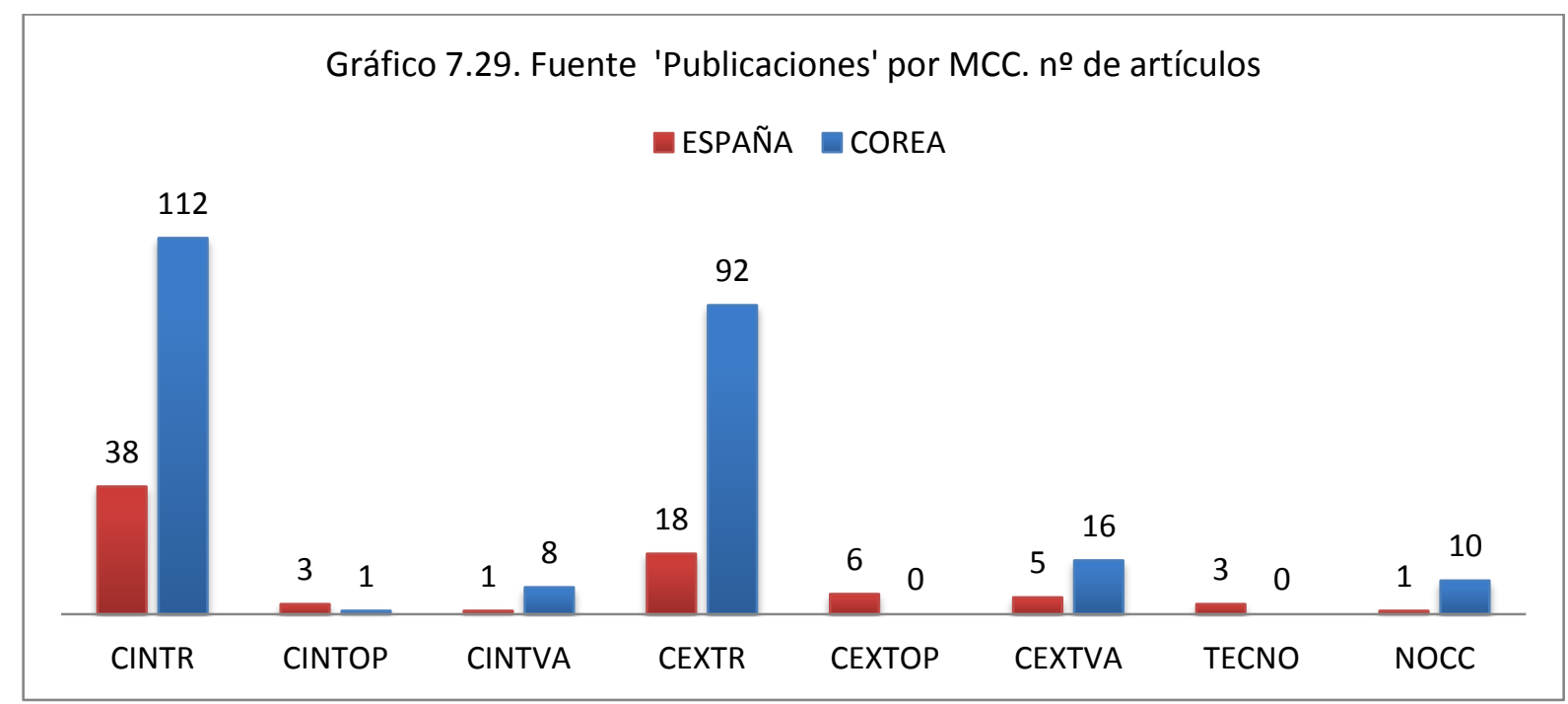

Si se suman artículos españoles de 'Centros e Institutos' y 'Universidades', que representan instituciones de investigación, la proporción es de un $42,1 \%$ y la de Corea, es de $11,8 \%$. Se suman artículos españoles de 'Centros e Institutos', 'Universidades' y 'Sociedad Científica', que pertenecen a la comunidad científica, la proporción alcanza casi la mitad $(49,8 \%)$, pero la de Corea es solo 13,2\%. La diferencia resulta notoria. 


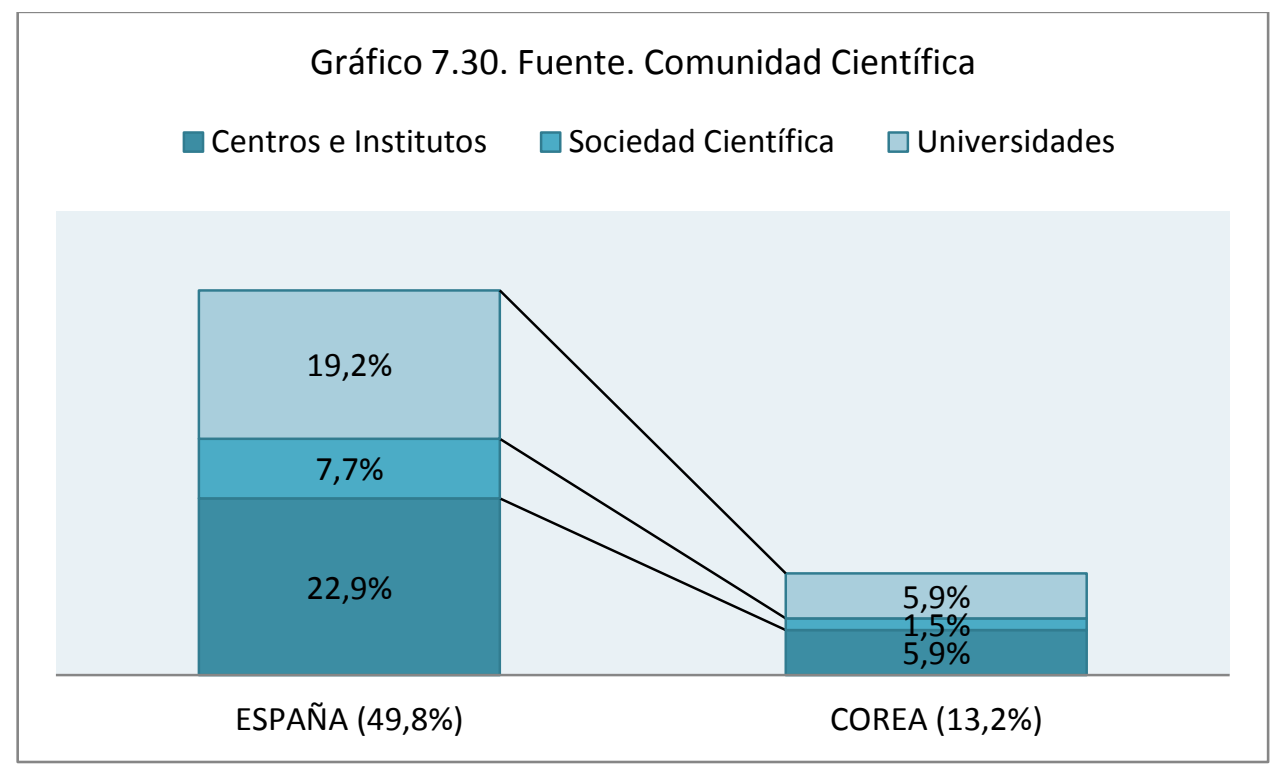

En España, casi la mitad de los artículos que se refieren a Darwin proviene de la comunidad científica, pero en Corea del Sur, solamente un 13,2\% tiene origen científico. Es un resultado interesante, porque el $86,8 \%$ de los artículos coreanos que hablan de una teoría científica, el darwinismo, no han obtenido contenidos desde la comunidad científica.

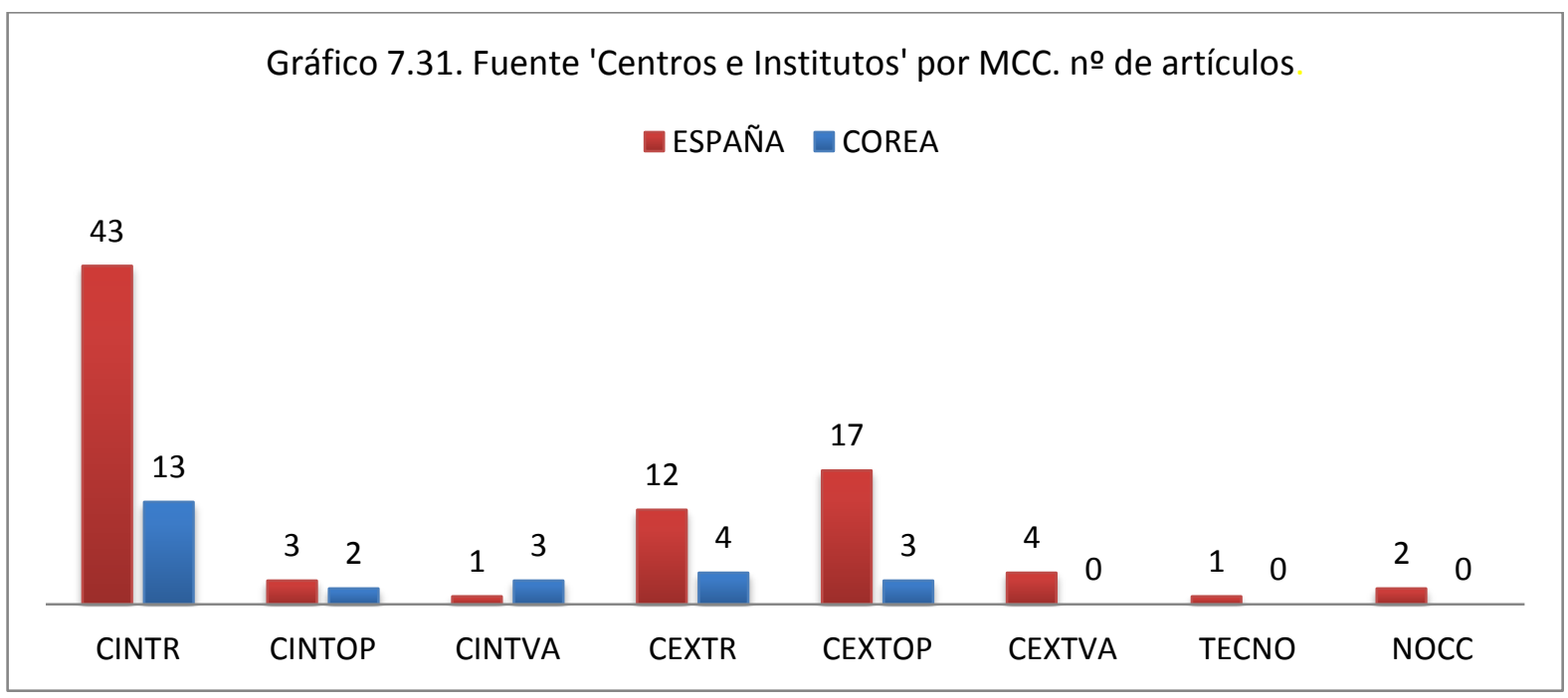

Entre los artículos cuya fuente es Centros e Institutos, CINTR representa la primera categoría en el número de artículos en los dos países ya que su fuente es entidad científica. España también tiene 12 artículos de CEXTR y 17 de CEXTOP. Corea no posee muchos artículos y tiene 13 de CINTR. 


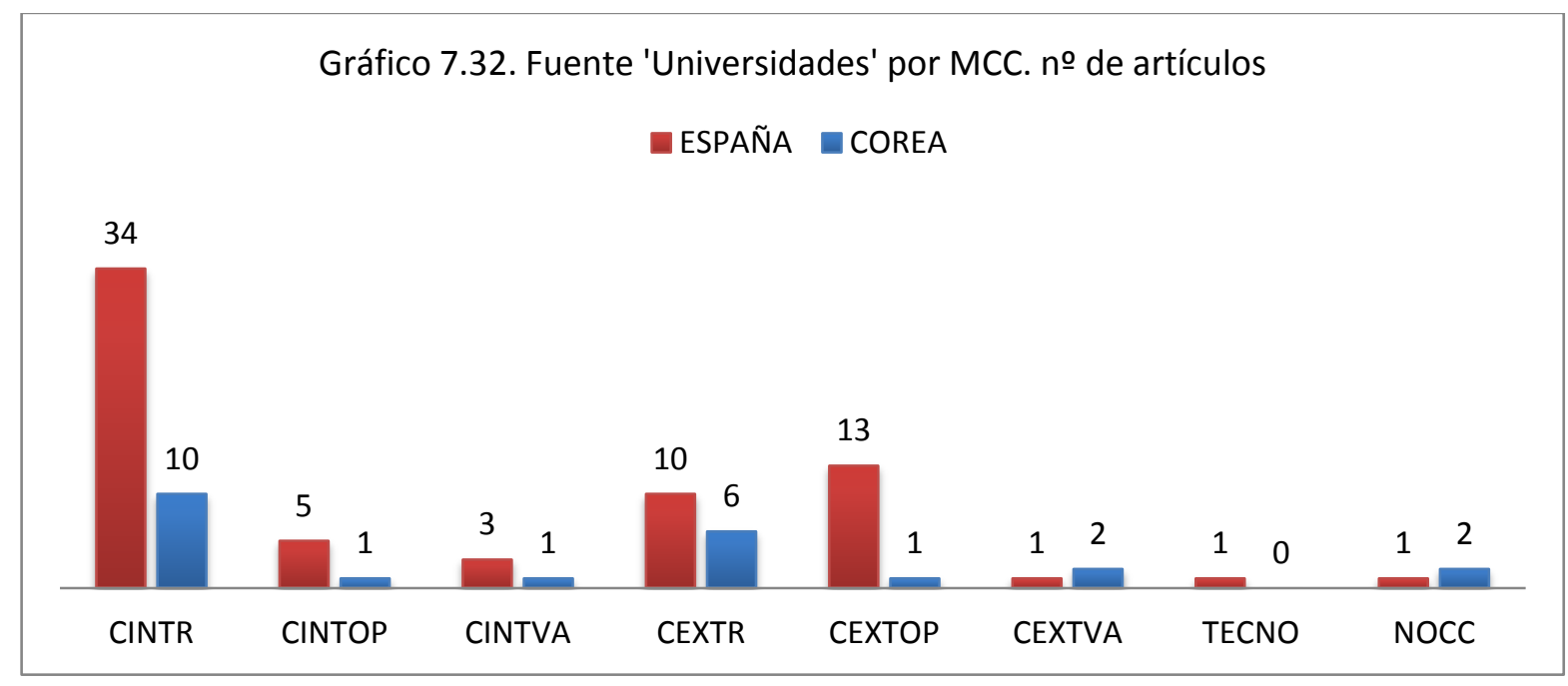

Podemos clasificar la fuente 'Universidades' también como entidades de investigación; mientras que CINTR ocupa una gran parte de los artículos de la fuente. La distribución de los códigos de MCC es similar a la fuente 'Centros e Institutos'.

'Museo' ha sido fuente de 34 artículos españoles (12,5\%) y de 4 de coreanos (1,2\%). Hay una clara diferencia entre los dos países. La prensa española informó más actividades conmemorativas. Además, en 2010 el Museo de la Evolución Humana inauguró y produjo varias noticias. No existen muchos museos de ciencias en Corea del Sur y las actividades científicas para el público general no son muy activas. A menudo, se piensan que los eventos científicos son solo para los niños.

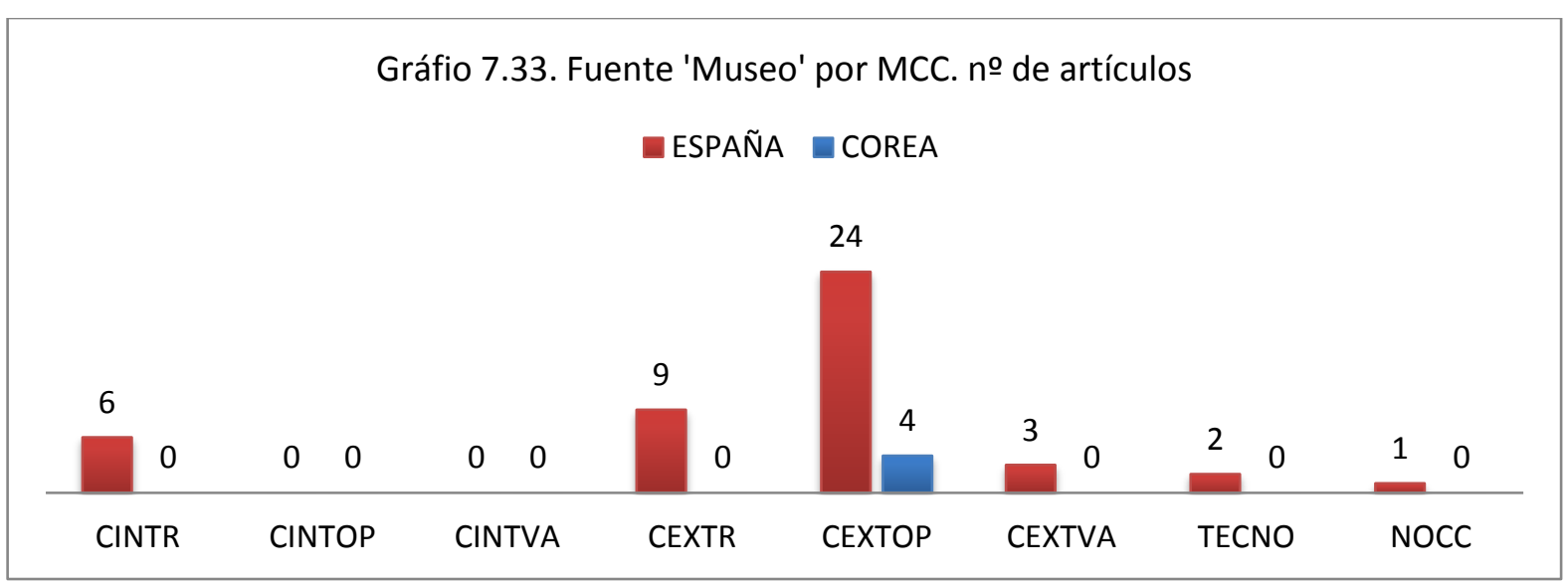

Los cuatro artículos coreanos informan sobre actividades científicas de museos, así que se han clasificado como CEXTOP. 24 artículos españoles de la fuente también son de CEXTOP, pero también hay 9 de CEXTR y 6 de CINTR. 
12 artículos españoles (4,3\%) y 11 coreanos (3.2\%) incluyen informaciones derivadas de entidades religiosas. España tiene 18 artículos cuya fuente es el Gobierno y Corea posee solo tres.

\begin{tabular}{|c|r|r|r|r|r|r|}
\hline \multirow{2}{*}{ FUENTE } & \multicolumn{3}{|c|}{ ESPAÑA } & \multicolumn{3}{|c|}{ COREA DEL SUR } \\
\cline { 2 - 8 } & AÑO2008 & AÑO2009 & AÑO2010 & AÑO2008 & AÑO2009 & AÑO2010 \\
\hline Centros e Institutos & 5 & 37 & 20 & 7 & 12 & 1 \\
\hline Gobierno & 3 & 10 & 5 & 2 & 1 & 0 \\
\hline Entidades Religiosas & 9 & 0 & 3 & 5 & 6 & 0 \\
\hline Empresa & 3 & 3 & 1 & 1 & 2 & 0 \\
\hline Museos & 4 & 20 & 10 & 2 & 1 & 1 \\
\hline Publicaciones & 9 & 32 & 17 & 54 & 91 & 57 \\
\hline Sociedad Científica & 5 & 12 & 4 & 1 & 2 & 2 \\
\hline Universidades & 7 & 31 & 14 & 5 & 9 & 6 \\
\hline Otras & 8 & 37 & 29 & 16 & 50 & 23 \\
\hline Sin Fuente & 0 & 7 & 2 & 0 & 2 & 3 \\
\hline No Total & 47 & 150 & 74 & 87 & 168 & 86 \\
\hline
\end{tabular}

Tabla 7.21. Fuente. Por año y por país

Convertimos los datos a porcentaje y expresamos como gráfico:

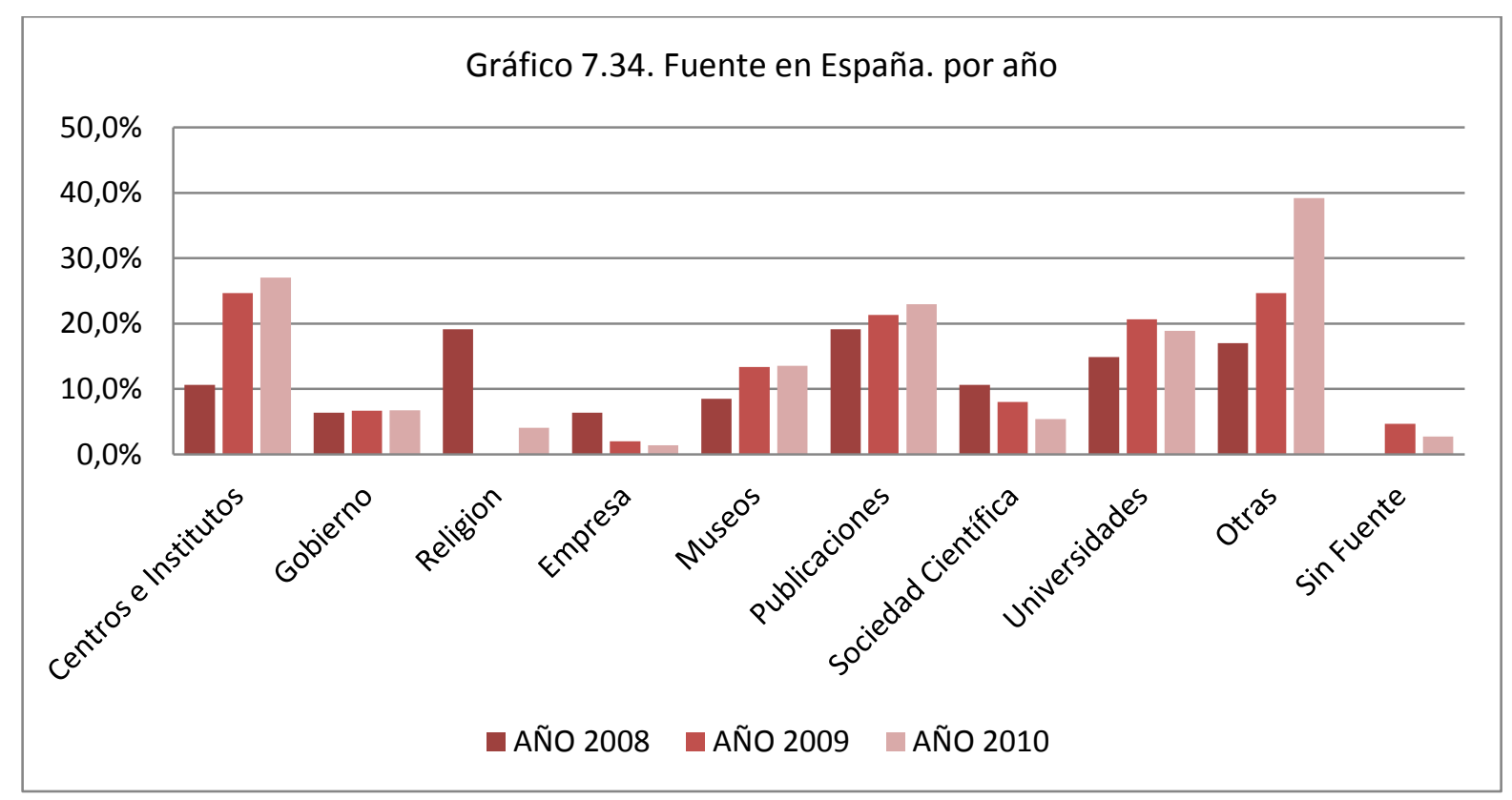

Entidades Religiosas ha sido fuente de 9 artículos españoles (19,1\%) en 2008, en 2009 de ningún artículo y en 2010 de 3.

Los porcentajes de 'Centros e Institutos', 'Museos', 'Publicaciones' y 'Otras' aumentan cada año y los porcentajes de 'Empresas' y 'Sociedad Científica' disminuyen cada año. 


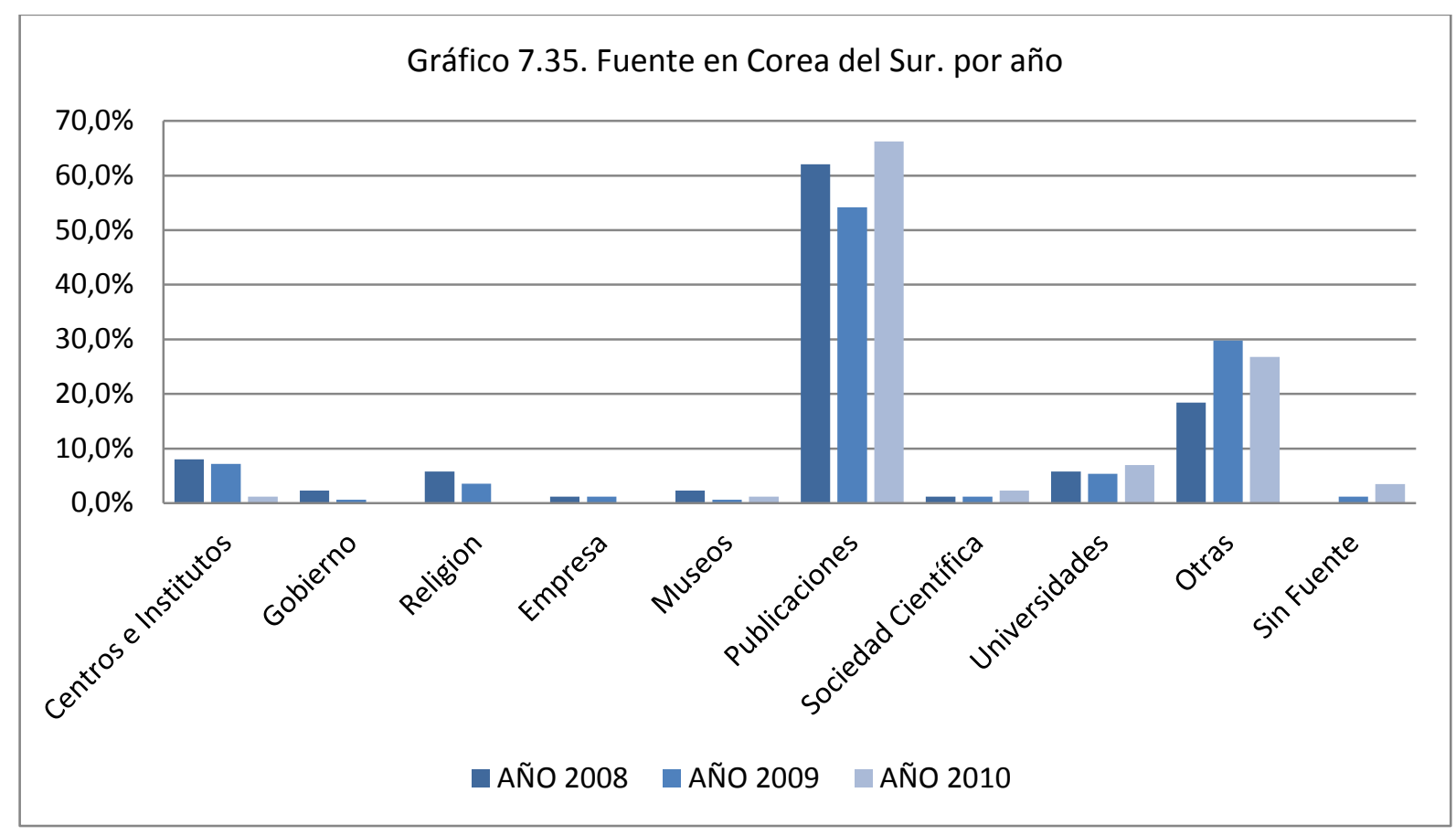

Se nota la alta proporción de 'Publicaciones' en las fuentes de los artículos coreanos. El porcentaje de 2009 bajó un poco, pero el número de artículos eran más (2008: $52 \rightarrow$ 2009: $91 \rightarrow$ 2010: 57). En 2009, aumentó el porcentaje de la fuente 'Otras (congresos, organizaciones no gubernamental, organismo internacional, etc.)'. Excepto 'Publicaciones' y 'Otras', otros tipos de fuente tiene menos de $10 \%$.

\subsubsection{Encuadre}

Los artículos periodísticos se publican en diversos encuadres o marcos de referencia que determinan el motivo o significado del texto (Quintanilla, et al., 2005). Se han modificado las categorías para ajustar en este estudio. Con el motivo del bicentenario del nacimiento de Charles Darwin, se ha añadido la categoría 'Actividades Conmemorativas'. Si el artículo transmite información científica, se clasifica en 'Divulgación Científica'. Si el artículo muestra la incorporación del darwinismo en la sociedad, se clasifica en 'Darwinismo en la Sociedad'. Por otra parte, hay artículos de 'Política Científica' y otros cuyo tema no es científico que se clasifican en 'Menciones Simples'. Un artículo puede clasificarse en más de un encuadre.

- Actividades Conmemorativas: Artículos sobre actividades conmemorativas respecto al bicentenario de Charles Darwin. 
- Darwinismo en la Sociedad: Artículos que hablan o muestran cómo la sociedad apropia el darwinismo.

- Divulgación Científica: Artículos que divulgan conocimientos científicos, especialmente sobre el darwinismo.

- Política Científica: Artículos que incluyen decisiones legales y políticas sobre la ciencia, especialmente sobre el darwinismo.

- Menciones Simples: El tema de artículos no es el darwinismo y lo mencionan simplemente como un contenido complementario.

\begin{tabular}{|c|c|c|c|c|c|c|c|c|c|c|c|c|}
\hline \multirow{3}{*}{ ENCUADRE } & \multicolumn{4}{|c|}{ AÑO 2008} & \multicolumn{4}{|c|}{ AÑO 2009} & \multicolumn{4}{|c|}{ AÑO 2010} \\
\hline & \multicolumn{2}{|c|}{ ESPAÑA } & \multicolumn{2}{|c|}{ COREA } & \multicolumn{2}{|c|}{ ESPAÑA } & \multicolumn{2}{|c|}{ COREA } & \multicolumn{2}{|c|}{ ESPAÑA } & \multicolumn{2}{|c|}{ COREA } \\
\hline & MUN & PAI & HAN & JOO & MUN & PAI & HAN & JOO & MUN & PAI & HAN & JOO \\
\hline $\begin{array}{c}\text { Actividades } \\
\text { Conmemorativas }\end{array}$ & 7 & 1 & 3 & 1 & 19 & 8 & 6 & 2 & 8 & 2 & 1 & 0 \\
\hline $\begin{array}{c}\text { Darwinismo } \\
\text { en la Sociedad }\end{array}$ & 8 & 4 & 11 & 3 & 12 & 4 & 28 & 20 & 6 & 5 & 19 & 13 \\
\hline $\begin{array}{c}\text { Divulgación } \\
\text { Científica }\end{array}$ & 17 & 1 & 24 & 18 & 52 & 29 & 44 & 49 & 17 & 12 & 25 & 17 \\
\hline $\begin{array}{c}\text { Política } \\
\text { Científica }\end{array}$ & 0 & 0 & 1 & 0 & 4 & 1 & 0 & 0 & 0 & 2 & 0 & 1 \\
\hline $\begin{array}{l}\text { Menciones } \\
\text { Simples }\end{array}$ & 10 & 8 & 14 & 13 & 13 & 12 & 7 & 15 & 15 & 11 & 9 & 7 \\
\hline № Total & 34 & 13 & 52 & 35 & 99 & 51 & 83 & 85 & 45 & 29 & 50 & 36 \\
\hline
\end{tabular}

Tabla 7.22. Encuadre. Por periódico y año

Se suman los datos en la tabla 7.22 por país, podemos obtener la tabla 7.23.

\begin{tabular}{|c|c|c|}
\hline ENCUADRE & ESPAÑA & COREA \\
\hline Actividades Conmemorativas & 45 & 13 \\
\hline Darwinismo en la Sociedad & 39 & 94 \\
\hline Divulgación Científica & 128 & 177 \\
\hline Política Científica & 7 & 2 \\
\hline Menciones Simples & 69 & 65 \\
\hline № Total & 271 & 341 \\
\hline
\end{tabular}

Tabla 7.23. Encuadre. Por país

Convertimos los datos a porcentaje y expresamos como gráfico: 


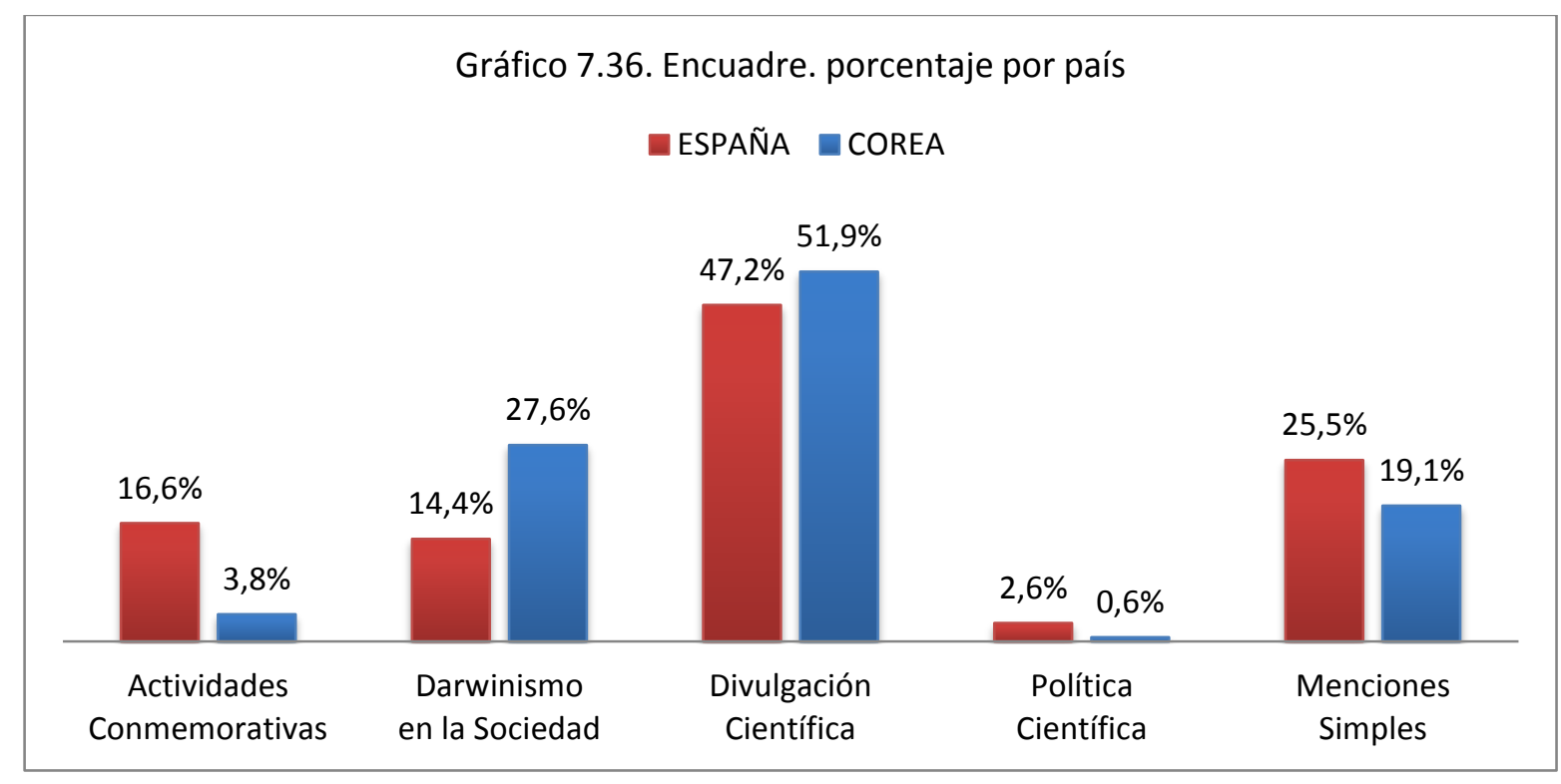

Como podemos apreciar en el gráfico 7.36, la proporción de 'Actividades Conmemorativas' de España es superior a la de Corea, y la proporción de 'Darwinismo en la Sociedad' de Corea resulta mucho mayor que la de España. El resultado de los dos encuadres es recíproco entre ellos, o sea, si se agrega la proporción de estos dos encuadres por país, en los dos países sale 31\% aproximadamente (España: 31\%, Corea: 31,4\%).

En el encuadre 'Actividades Conmemorativas', España tiene 45 artículos y Corea 13. Como se mencionó anteriormente, en Corea del Sur las actividades científicas para el público son en su mayoría reconocidas para los estudiantes de primaria y los eventos para los adultos son difíciles de encontrar. Puede encontrarse en la percepción general de la sociedad coreana de que la ciencia es difícil y solo es un campo para los profesionales de la ciencia. En 2009, el año de Darwin se celebró con varias actividades pero no tuvo un gran impacto social.

Más de un cuarto de los artículos coreanos se refieren al darwinismo en un contexto social. Como hemos mencionado en la Parte I de esta tesis, el darwinismo se incorporó como una teoría sociológica en su primera época en Corea. Pensamos que todavía se puede encontrar la huella sociológica en la incorporación del darwinismo en la sociedad surcoreana. La alta proporción de 'Darwinismo en la Sociedad' en Corea se puede explicar en este contexto. Se refieren al propio concepto de "lucha (competencia)" o su variación como "selección y extinción a través de la lucha" en algún contexto social, no científico. Se utilizó el año de Darwin para volver a mencionar la lucha en una sociedad no tan darwiniana. 
El encuadre que tiene más artículos es 'Divulgación Científica' en los dos países. Son artículos para difundir conocimientos científicos. Casi la mitad de los artículos (España: 128/271, Corea del Sur: 177/341) que mencionan el darwinismo trasmiten informaciones científicas. Los artículos en este encuadre son para divulgar conocimientos científicos especialmente, del darwinismo.

Le han bautizado como 'Darwinopterus' (ala de Darwin). Tenía los dientes puntiagudos y el cuello flexible, y era uno de los muchos tipos de pterosaurios que abundaban en la era Mesozoica, hace unos 220 millones de años. Éstas son las principales características del nuevo reptil volador de la era de los dinosaurios que ha descubierto en China un equipo de científicos del Reino Unido y del propio gigante asiático. (elmundo.es, "Darwinopterus': el nuevo reptil volador de China", 15/10/2009, EL MUNDO)

"곹 나의 시대가 온다." 다윈의 진화론으로 인해 세상이 떠들썩할 때, 유전법칙을 발 견한 멘델이 한 말이다. 멘델은 이미 자신이 얼마나 대단한 일을 해냈는지 간파하고 있었던 것 같다. 그렇게 자신감에 차 있을 정도였으니.... 그러나 진정한 천재는 생전 에 그 천재성을 인정받을 수 없다고 했던가. 그는 곹 차가운 주검이 되었다. [“Mi día vendrá pronto." dijo Mendel que descubrió la ley de la genética, cuando la teoría de la evolución de Darwin estaba animada. Mendel parece haber comprendido ya lo grande que lo hizo. Tenía tanta confianza... Sin embargo, ¿̇un genio genuino no puede ser reconocido en la vida? Pronto dio su último respiro.] (Hyungja Kim, "DNA 이중나선에 얽힌 드라마틱한 이야기(Un cuento dramático enredado de la doble hélice de ADN", 15/10/2008, HANKYOREH)

Entonces, ¿qué información de cultura científica tienen estos artículos? Véase la distribución por MCC dentro de los artículos para la divulgación científica. 


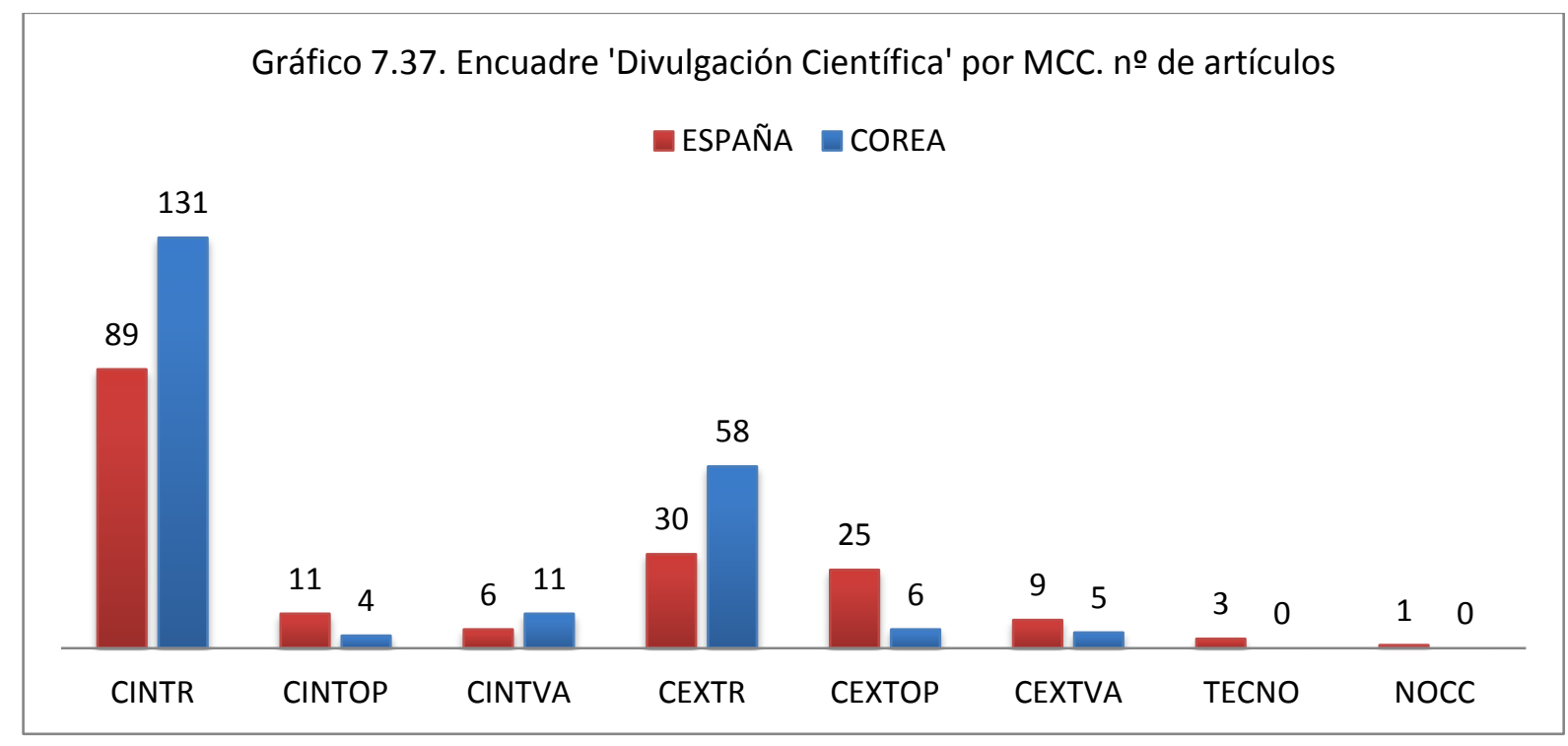

La información que tiene el mayor porcentaje en los dos países (España: 69,5\%, Corea: 74,0\%) en este encuadre es CINTR. Resulta natural porque se han clasificado los artículos que divulgan la ciencia. CEXTR también posee bastantes artículos. En el caso de España CEXTOP tiene 25 artículos.

El porcentaje español de 'Actividades Conmemorativas' (16,6\%) es mucho más alto que el de Corea $(3,8 \%)$. El número de artículos españoles representa una cifra tres veces superior (España 45 y Corea 13). Se entiende que había más actividades conmemorativas en España. España celebró el año de Darwin con diversas actividades conmemorativas y en el año siguiente (2010) inauguró el Museo de la Evolución Humana en Burgos que es bien conocida por los yacimientos de Atapuerca. La prensa española puso atención e informó estas actividades. En cambio, Corea tiene menos artículos que informan actividades científicas del darwinismo. Podemos ver unos ejemplos de este encuadre.

La historia de la Teoría de la Evolución, la biografía de su autor, Charles Darwin, así como los contextos científicos anterior y posterior, se muestran en una exposición que se abrió ayer en Madrid, en el Museo Nacional de Ciencias Naturales (MNCN), con ocasión del 200 aniversario del nacimiento del gran científico británico. También en 2009 se conmemoran los 150 años de la publicación de su libro El origen de las especies, que revolucionó la ciencia. (EL PAÍS, "Darwin, en el Museo Nacional de Ciencias Naturales", 11/07/2009, EL PAís)

La Reina doña Sofía, apenas un día después de aterrizar de Sudáfrica, ha asistido a la inauguración del Museo de la Evolución Humana (MEH) en Burgos, una institución que quiere 
convertirse en una referencia para aquellos interesados en el pasado de la especie. El Museo, cuyo edificio es obra del arquitecto Juan Navarrio Baldeweg, consta de 12.000 metros cuadrados, la mitad de los cuales están dedicados a la exposición sobre esa larga historia humana que comenzó hace más de seis millones de años, cuando un ancestro se fue separando de otros grandes primates, como los chimpancés, los gorilas o los orangutanes. (Rosa M. Tristán, “El Museo de la Evolución Humana abre sus puertas", 12/07/2010, EL MUNDO)

생물진화 이론을 제창한 영국 과학자 찰스 다윈(1809 1882.사진)의 탄생 200 돌과 <종 의 기원> 출간 150 돌인 올해를 기념해, 국내에서도 인문학자와 자연과학자들이 '다윈 과 진화론”을 주제로 한자리에 모이는 최대 규모의 학술대회가 열린다. [Para celebrar el bicentenario del nacimiento del científico británico Charles Darwin (1809 1882·foto) que presentó el evolucionismo de los seres vivos y el 150 aniversario de la publicación de su obra <El Origen de las Especies>, en nuestro país también tiene lugar una gran conferencia de 'Darwin y el darwinismo' en la que se reúnen humanistas y científicos.] (Chulwoo Oh, “인문학-자연과학 소통하는 '진화론' (El darwinismo comunica el humanismo y la ciencia)", 30/06/2009, HANKYOREH)

España tiene mucho más artículos (España: 45 artículos, Corea: 13). El gráfico 7.27 muestra los artículos de 'Actividades Conmemorativas' por MCC.

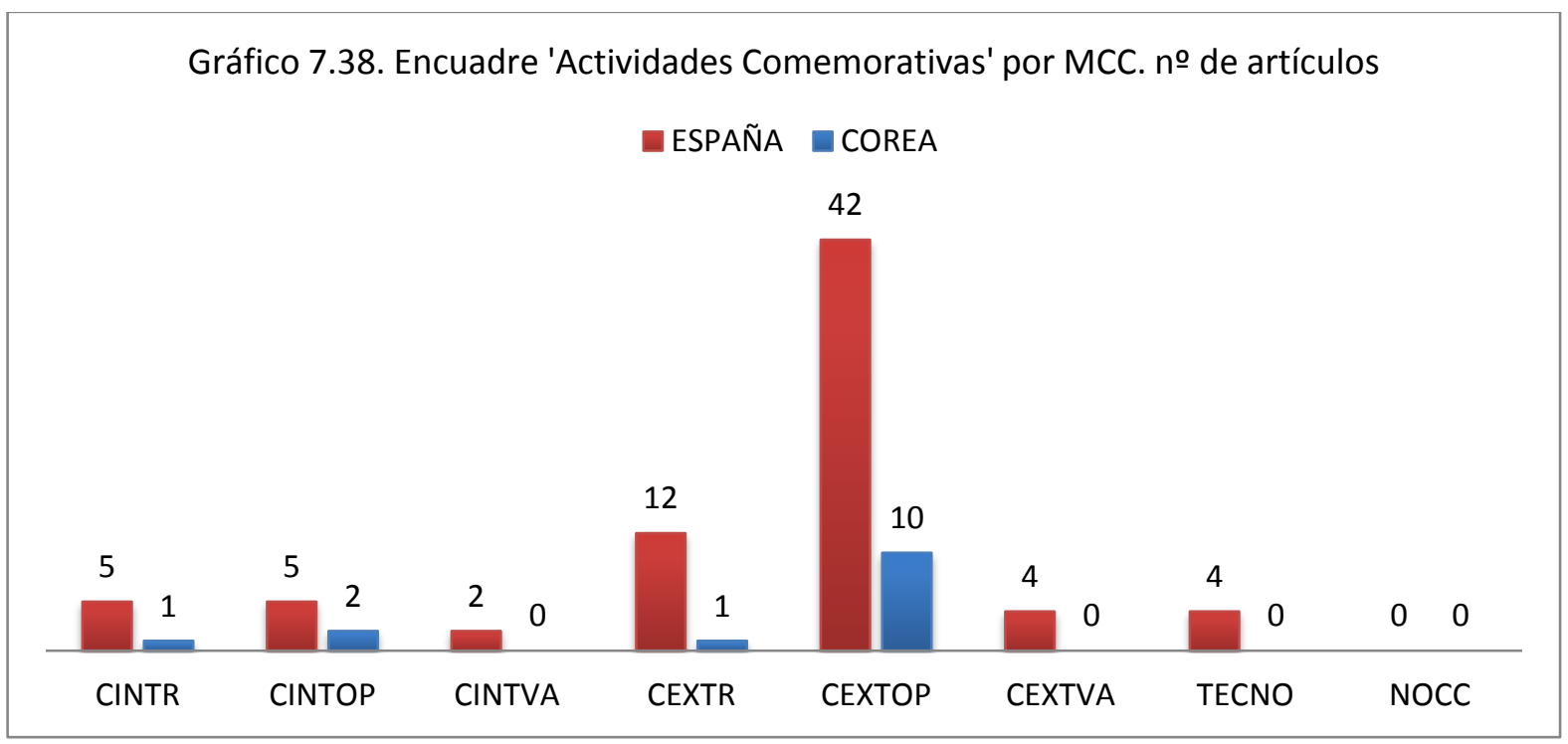

Como los eventos preparados para el público en la comunidad científica están incluidos en CEXTOP, CEXTOP es el más grande en ambos países. En España, 12 artículos son de CEXTR, y CINTR, CINTOP, CEXTVA, y TECNO, tienen 4-5 artículos respectivamente. 10 en Corea son 


\section{CEXTOP.}

Entre los artículos coreanos, el marco de 'Darwinismo en la sociedad' ocupa 27,6\% (94 artículos). En el caso de España es 14,4\% (39 artículos). Este encuadre cubre artículos que mencionan el darwinismo no en contexto científico sino social, por ejemplo, hablando de 'lucha por supervivencia'.

이 책은 대성공이었다. 다윈에게 경도된 스펜서는 사회다윈주의를 부르짖을 정도였 다. 적자생존이 진화의 동력으로 작용하듯, 약육강식에 따른 우승열패야말로 사회 발 전의 토대라는 위험한 주장이었다. 따지고 보면, 오늘날 세계경제를 파탄으로 몰고 간 신자유주의도 진화론의 산물이다. 무한경쟁과 지속 가능한 성장이란 신자유주의 의 구호에는 적자생존의 원칙과 진화에 대한 신념이 엿보인다. [El libro logró gran éxito. Spencer se fascinó por la idea de Darwin y propuso el evolucionismo social. Fue pensamiento peligroso que insiste en que el triunfo de los superiores es el fundamento del desarrollo social. De hecho, el neoliberalismo que llevó la economía mundial a la quiebra es fruto del evolucionismo. En lemas del neoliberalismo como 'competencia infinita' y 'desarrollo sostenible' podemos detectar convicciones del principio de 'supervivencia de lo más apto' y la evolución.] (Seungjong Baik, "[백승종의 역설], 찰스 다윈 ([La paradoja de Seungjong Baik] Chales Darwin)", 03/04/2009, 한겨레)

"Charles Darwin: 200 años después de tu nacimiento, la Iglesia de Inglaterra te debe una disculpa por malinterpretarte y por, además de tener una reacción equivocada, haber animado a otros a no comprenderte tampoco. Tratamos de practicar la antigua virtud de 'fe buscando la comprensión' y confiamos en que esto suponga una reparación". (Servimedia Londres, "La iglesia anglicana pedirá perdón a Charles Darwin", 14/09/2008, EL PAís)

El biólogo británico Charles Darwin, de quien este año se celebra el 150 aniversario de la publicación de su obra 'El origen de las especies', es muy conocido en el planeta (un 70\% ha oído hablar de él en alguna ocasión). No obstante, en algunos sitios se sabe más de él que en otros, y son mayoría quienes piensan que su teoría de la evolución de las especies por la selección natural es compatible con la creencia en un Dios. (Rosa M. Tristán, "El 45\% de los españoles cree en Dios y en Darwin", 07/07/2009, EL MUNDO)

Podemos detectar la distribución de los artículos por MCC en el gráfico 7.38: 


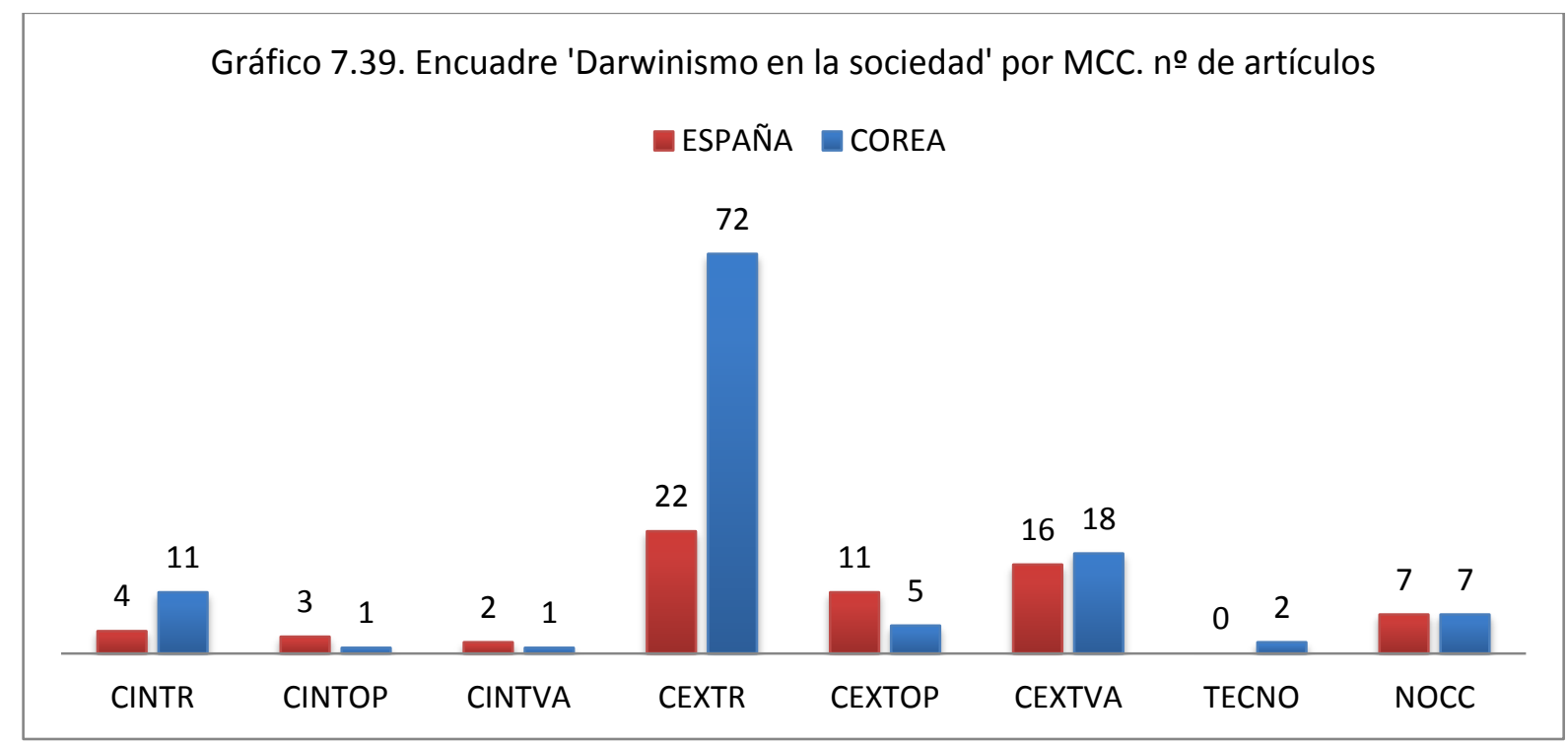

Se nota la alta proporción de CEXTR $(76,5 \%)$ entre los artículos coreanos. Las informaciones representacionales que interpretan el darwinismo socialmente ocupan más de 3/4. 11 artículos coreanos y 4 españoles incluyen informaciones de CINTR explicando el darwinismo en la sociedad.

No hay muchos artículos de 'Política Científica'. 7 artículos de España y 2 de Corea mencionan el contexto político.

El Govern tratará de convertir el Parc Bit en el lugar de convergencia entre la investigación y la empresa privada, para incentivar la participación de los empresarios en la creación de nuevos conocimientos y, para ello, el Plan de Ciencia será básico. La ciencia también estará presente en numerosos actos que se desarrollarán en las islas, coincidiendo con la celebración del Año Darwin que, en Palma, evocará la figura del cartógrafo mallorquín Felipe Bauzá, según han presentado hoy Antich y el comisario de esta iniciativa, el catedrático Camilo José Cela Conde. (Efe, “El Govern aprobará el Plan Ciencia 2009-2012 en las próximas semanas", 22/01/2009, EL MUNDO)

En España, apenas el $40 \%$ de los recursos que se invierten en $1+D$ provienen de fondos privados. En países como Dinamarca o Japón, el $80 \%$ de las inversiones provienen de capital privado. Lo mismo ocurre en cuanto al personal investigador: en estos países, el 70\% trabajaen el sector privado y el 30\% en el público. En España, los porcentajes se invierten. Son datos presentados hoy por Carlos Martínez Alonso, secretario de Estado de Investigación. "El gran origen de la falta de recursos para investigación está en la falta de implicación de la iniciativa privada", ha dicho 
en la Universidad Menéndez y Pelayo en Santander, durante la conferencia de clausura del curso Las fronteras de la biología, 200 años después del nacimiento de Darwin, organizada por la Escuela de Periodismo de EL PAÍS, con la colaboración de la Fundación BBVA. (Mónica L. Ferrado, "La I+D necesita más inversiones privadas, según el secretario de Estado de Investigación", 17/07/2009, EL PAÍs)

동.식물 종을 가리는 분류학은 자연 연구의 기초이자 다윈 이래 오랜 전통을 지닌 학문 분야이다. (...) 정부도 생물자원이 국가경쟁력 향상의 초석이라고 인식해 야생 동.식물보호 기본계획을 마련하기도 했다. [La taxonomía, que es una disciplina científica que clasifica las especies, es un fundamento de estudios de la Naturaleza y tiene una larga tradición desde Darwin. (...) El gobierno reconoce la importancia de los recursos biológicos como un base de mejora de la capacidad competitiva internacional y estructuró un plan básico para proteger nuestra fauna y flora.] (Hongsub Cho, “봄 야생화 150종 가릴 수 있어야 관문 통 과 (Para aprobar, deben distinguir 150 especies de flores silvestres)", 16/04/2008, HANKYOREH)

부총리제도까지 두었던 과학기술부가 교육부에 병합될 때 아무런 저항도 없는 것을 보면서 선배 과학자에게 경의를 표할 후배는 없다. [El ministro de Ciencia y Tecnología fue al nivel de vice primer ministro. Sin embargo, cuando el Ministerio de Ciencia y Tecnología fue incorporado al Ministerio de Educación, no hubo ninguna protesta desde la comunidad científica.] (Hyeonggeun Kim, “로켓공학의 아버지 베르너 폰 브라운 (Padre de la tecnología de Cohete, Wernher von Braun", 23/11/2009, JOONGANG)

$25,5 \%$ de los artículos españoles y 19,1\% de los coreanos son de 'Mención Simple'. No se pueden incluir en las categorías anteriores y mencionan el darwinismo en otro contexto. Estos artículos ocupan más de un cuarto de los artículos españoles y los coreanos representan casi el $1 / 5$. Con ello, podemos decir que Darwin es ampliamente mencionado en artículos no específicamente relacionados con la ciencia.

\begin{tabular}{|l|r|r|r|r|r|r|}
\hline \multirow{2}{*}{ ENCUADRE } & \multicolumn{3}{|c|}{ ESPAÑA } & \multicolumn{3}{c|}{ COREA DEL SUR } \\
\cline { 2 - 7 } & AÑO2008 & AÑO2009 & AÑO2010 & AÑO2008 & AÑO2009 & AÑO2010 \\
\hline Actividades Conmemorativas & 8 & 27 & 10 & 4 & 8 & 1 \\
\hline Darwinismo en la Sociedad & 12 & 16 & 11 & 14 & 48 & 32 \\
\hline Divulgación Científica & 18 & 81 & 29 & 42 & 93 & 42 \\
\hline Política Científica & 0 & 5 & 2 & 1 & 0 & 1 \\
\hline Menciones Simples & 18 & 25 & 26 & 27 & 22 & 16 \\
\hline No Total & 47 & 150 & 74 & 87 & 168 & 86 \\
\hline
\end{tabular}

Tabla 7.24. Encuadre. Por año y por país 
Convertimos los datos a porcentaje y expresamos como gráfico:

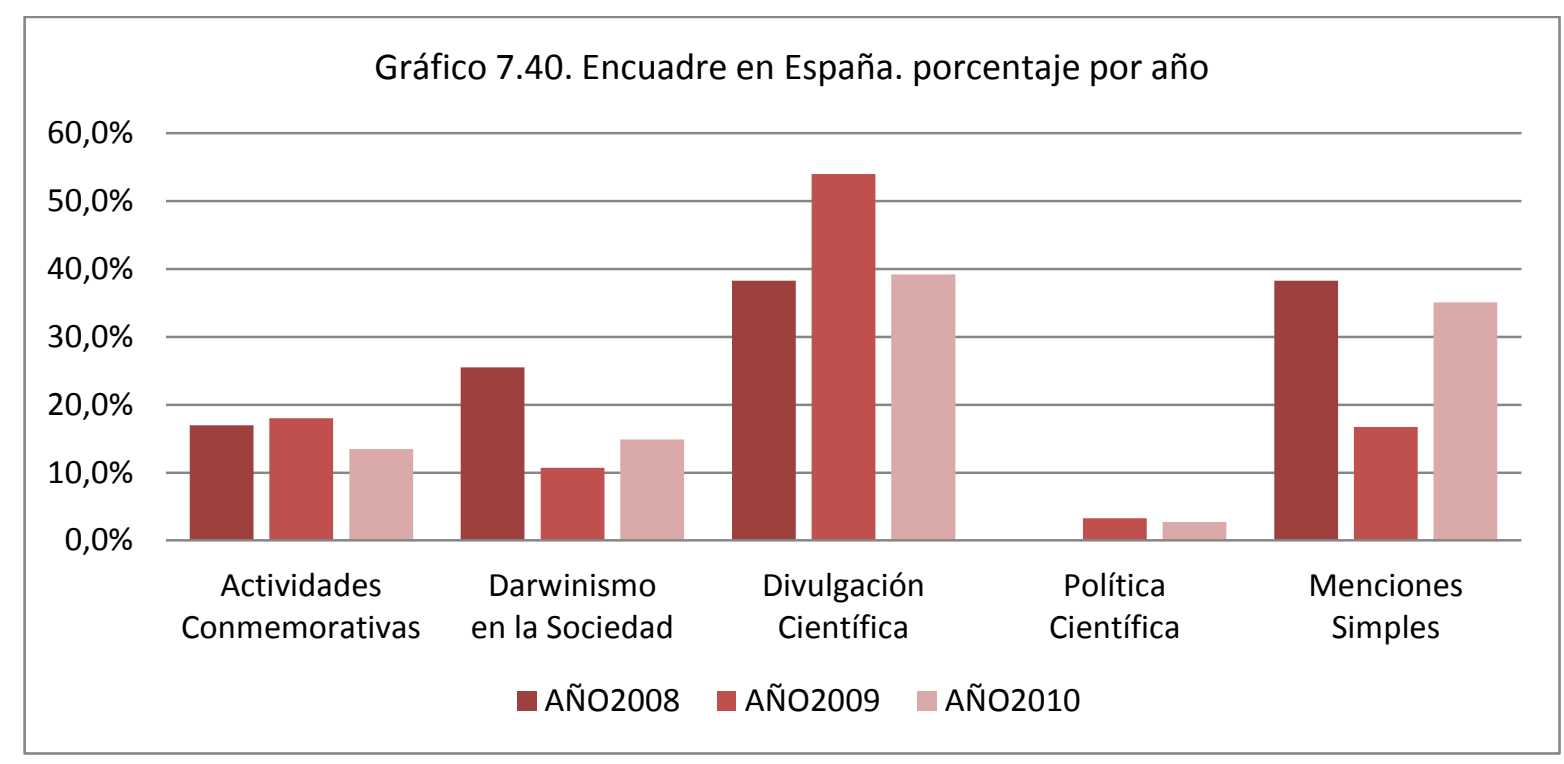

Si comparamos la distribución de los encuadres por año, en el caso de España en 2009 aumenta el porcentaje de 'Divulgación Científica' y disminuyen 'Mención Simple' y 'Darwinismo en la Sociedad'. Es decir, en el año de Darwin se publicaron más artículos periodísticos con el motivo de difundir conocimientos científicos. Entre los números de artículos se da una diferencia más grande (2008: 18 artículos $\rightarrow$ 2009: $81 \rightarrow$ 2010: 29), porque en 2009 aumenta el número total. En 2010 volvió al porcentaje de 2008, pero el número de artículos aumentó.

Los porcentajes de los artículos de 'Actividades conmemorativas' en los tres años son similares, pero en 2009 había 27, en 2008 se dieron ocho y en 2010 diez artículos. Aunque son menos que en 2009, también había actividades conmemorativas y artículos que las informan. 


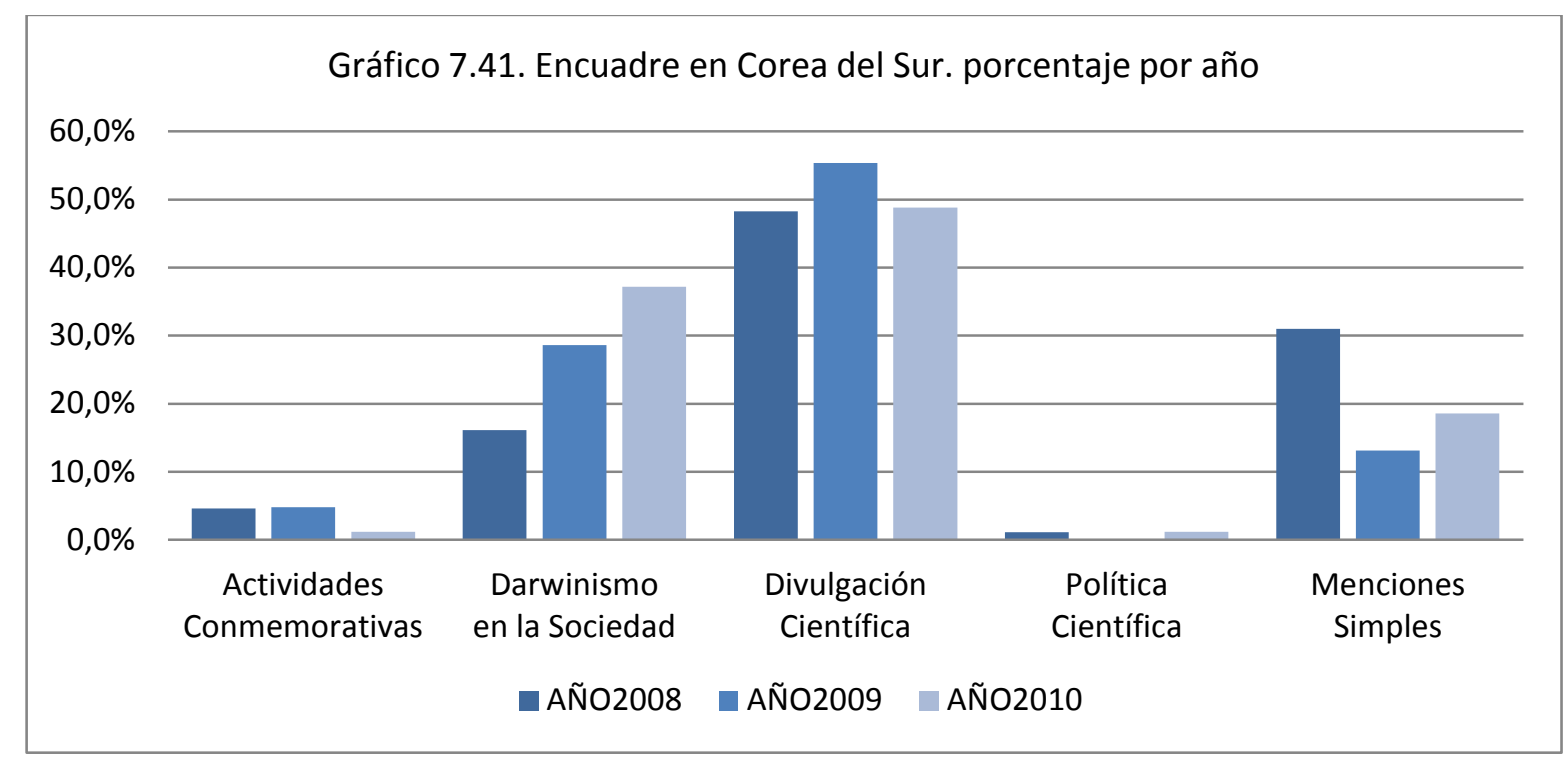

En el caso de Corea, también en 2009 aumenta el porcentaje de 'Divulgación Científica'. El número de los artículos es casi doble (2008:42 $\rightarrow$ 2009: $93 \rightarrow$ 2010: 42). Por otra parte, en el mismo año disminuye el de 'Mención simple'. El aumento de la proporción de 'Darwinismo en la Sociedad' llama la atención. Generalmente tiene alto porcentaje que España y cada año ocupa más terreno.

\subsubsection{Temas. Novedades Científicas e Ideas Religiosas}

Dado que el contenido del artículo ha sido estudiado hasta cierto punto a través del análisis por MCC y por su encuadre de difusión, esta sección discutirá dos temas específicos que no pudieron ser identificados en el estudio anterior. En las dos etapas de análisis, añadimos un pequeño análisis adicional sobre temas específicos para precisar mejor la incidencia del contexto entre la cultura científica intrínseca y extrínseca de MCC.

Para analizar aparte, se ha elegido "Novedades Científicas" como la subcategoría bajo la cultura científica intrínseca e "Ideas Religiosas" bajo la extrínseca.

La presencia de "Novedades científicas" relacionadas con el darwinismo puede ser un barómetro que muestra el interés social del darwinismo como teoría científica actual. Como se mencionó anteriormente, es porque los medios han valorado que la investigación superó el 'umbral' del interés del público y debe ser reportado en los medios generales, no solo en 
las revistas científicas. Estos artículos naturalmente tienen informaciones de cultura científica intrínseca, así que este tema es una subcategoría adecuada para percibir más detalladamente la cultura científica intrínseca (CINT) de MCC.

Por otra parte, "Ideas Religiosas" es el tema analizado como un subcategoría de las informaciones extrínsecas. La presencia de "Ideas Religiosas" en la colección de artículos darwinistas significa que los conceptos darwinianos y conceptos religiosos coexisten en el mismo artículo. Esto está profundamente relacionado con el contexto social. Es notorio que el darwinismo es una de las pocas teorías científicas que tienen grupos opuestos, generalmente religiosos. Por lo tanto, puede ser un tema adecuado para analizar como una subcategoría de la cultura científica extrínseca (CEXT) de MCC.

\subsubsection{Novedades Científicas}

Entre los artículos seleccionados, se separaron los artículos que transmitían nuevas noticias científicas relacionadas con el darwinismo. Veamos ejemplos que informan las novedades científicas.

El misterio que rodea la evolución de los peces que tienen los dos ojos en el mismo lateral, los peces planos (o pleuronectiformes), una incógnita que se debate desde la época de Charles Darwin, ha sido resuelto por un estudiante postdoctoral de la Universidad de Chicago (Estados Unidos). Matt Friedman ha localizado el fósil de una platija de hace casi 50 millones de años, que confirma el proceso evolutivo que siguieron estas especies de peces planos. Se trata de un eslabón perdido entre los que tienen un ojo a cada lado del cráneo y los que los tienen en el mismo. (Rosa M. Tristán, “El 'eslabón perdido' de los lenguados”, 09/07/2008, EL MUNDO)

Desde hace una década la comunidad científica viene aceptando la hipótesis de que existe una diferencia mínima, cifrada en un 1,24\%, entre el ADN de los humanos y el de los chimpancés. Un estudio realizado por un equipo internacional de investigadores, entre ellos dos españoles, asegura que esa estimación es incorrecta y que las diferencias entre ambos genomas pueden ser hasta diez veces superiores, ha informado ayer el Consejo Superior de Investigaciones Científicas (CSIC) en un comunicado. (EL PAís.com, "Las diferencias entre el genoma humano y del chimpancé son diez veces mayores de lo que se creía", 11/02/2009, EL PAís) 
"실험은 너무도 단순했지만 20년 동안 쌓인 데이터는 생물 진화에 관해 너무도 흥미 로운 결과를 보여줍니다." (...)최근 과학 전문지 <네이처> 온라인판에 발표된 이 연구 는 대장균을 20년 동안 쉼없이 배양하며 적응도를 분석해온 미국.프랑스 연구팀과 대장균의 게놈 진화를 추적해온 한국 연구팀의 합작품이다. [A pesar de que el experimento era tan simple, los datos acumulados durante 20 años nos muestran resultado muy interesante sobre la evolución de los seres vivos. El estudio, publicado en línea en la revista Nature, es una colaboración entre un equipo de investigación en los EE.UU. y Francia que han estado cultivando Escherichia coli durante 20 años sin detenerlo, y un equipo de investigación coreano que ha seguido la evolución del genoma de Escherichia coli] (Chulwoo Oh, "대장 균 20 년 동안 배양해보니... (Cultivar Escherichia coli durante 20 años...)", 20/10/2009, HANKYOREH)

La tabla 7.25 muestra el resultado de la clasificación de los artículos por año y por periódico.

\begin{tabular}{|c|c|c|c|c|c|c|c|c|c|c|c|c|}
\hline & \multicolumn{4}{|c|}{ AÑO 2008} & \multicolumn{4}{|c|}{ AÑO 2009} & \multicolumn{4}{|c|}{ AÑO 2010} \\
\hline & \multicolumn{2}{|c|}{ ESPAÑA } & \multicolumn{2}{|c|}{ COREA } & \multicolumn{2}{|c|}{ ESPAÑA } & \multicolumn{2}{|c|}{ COREA } & \multicolumn{2}{|c|}{ ESPAÑA } & \multicolumn{2}{|c|}{ COREA } \\
\hline & MUN & PAI & HAN & JOO & MUN & PAI & HAN & JOO & MUN & PAI & HAN & JOO \\
\hline Novedades Científicas & 10 & 0 & 3 & 1 & 19 & 14 & 8 & 0 & 9 & 7 & 1 & 1 \\
\hline № Total & 34 & 13 & 52 & 35 & 99 & 51 & 83 & 85 & 45 & 29 & 50 & 36 \\
\hline
\end{tabular}

Tabla 7.25. Novedades Científicas. Por periódico y por año

Se suman los artículos por país:

\begin{tabular}{|l|l|r|r|}
\hline & & ESPAÑA & COREA \\
\hline \multirow{2}{*}{ Novedades Científicas } & No Total & 59 & 14 \\
\cline { 2 - 4 } & Porcentaje & $21,8 \%$ & $4,1 \%$ \\
\hline \multicolumn{2}{|c|}{ № Total } & 271 & 341 \\
\hline
\end{tabular}

Tabla 7.26. Novedades Científicas. Por país

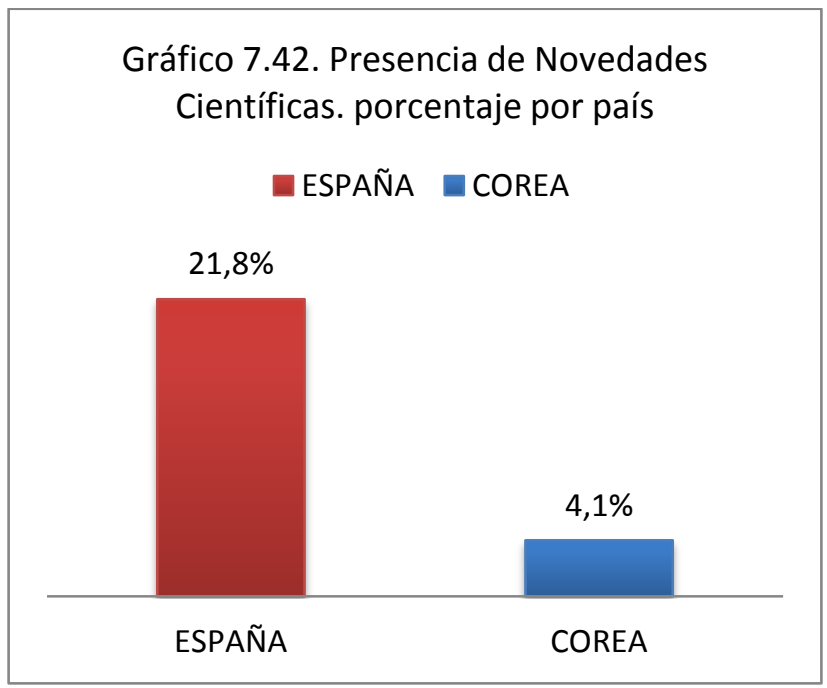


La diferencia de los dos países es significativa. Entre los artículos españoles, $21,8 \%$ (59 artículos) son de resultados científicos recién publicados. La prensa española se fija en el darwinismo como una teoría científica 'actual' y a menudo trata las investigaciones relacionadas a la teoría. Sin embargo, entre los coreanos, solo el 4,1\% (14 artículos) son de las novedades científicas.

Además, aun cuando se han seleccionado artículos de los mismos tres años (2008, 2009 y 2010) en los dos países, solo un estudio científico sale en ambos países y no es reciente. Se trata de un estudio sobre medusas que realizó Charles Darwin (nieto del fundador del darwinismo) en los años cincuenta y no es el tema de los artículos sino un estudio antecedente de las investigaciones recientes. El tema principal del artículo español es un estudio realizado por CALTECH.

Hace ya cincuenta años, Charles Darwin, nieto del famoso científico, fue el primero en afirmar la influencia de los animales en el océano. "En el mecanismo darwiniano, un organismo arrastra el agua a su alrededor a medida que avanza", explica Daibiri. Esta teoría abrió un gran debate en la comunidad científica. Partiendo de esta idea, los investigadores realizaron simulaciones matemáticas de lo que ocurriría si muchos animales se mueven a un tiempo en la misma dirección. Cada día miles de millones de diminuto kril y copépodos emigran miles de metros desde el fondo a la superficie. Según el mecanismo de Darwin, arrastrarían con el los parte de las aguas más frías y pesadas hacia arriba, lo que crearía inestabilidad en algún momento, se mezclarían. (elmundo.es, "La cara más amable de las medusas" 31/07/2009, EL MUNDO).

El artículo coreano es un estudio de Instituto Nacional de Ciencias de la Pesca de Corea del Sur.

최근 국립 수산과학원은 '유해 해양생물 해파리 피해예방 기획연구'라는 보고서를 통 해 해파리로 인해 연간 1,521 3,048억 원 정도의 피해를 받은 것으로 추정된다고 밖 혔다. (...) 하지만 해파리가 이런 악역만 맡고 있는 건 아니다. 바닷속을 분주히 움직 이며 물을 순환시키는데 크게 일조하고 있다. 과학자 찰스 다원 ('종의 기원'을 지은 찰스 다윈의 손자)은 1950년대 중반 해양 생물이 움직이며 일으키는 작은 물살이 바 닷물의 순환을 돕는다고 주장했다. [Recientemente, el Instituto Nacional de Investigaciones Pesqueras dijo que se estima que las medusas damnifica la industria pesquera de 1.521 a 304.800 millones de wones al año a través del informe de "Prevención de la especie dañina de 
vida marina "las medusas'". (...) Pero las medusas no son siempre malas. Está contribuyendo grandemente a la circulación del agua moviendo diligentemente en el mar. El científico Charles Darwin (el nieto de Charles Darwin, quien publicó 'El Origen de las Especies') afirmó en los años cincuenta que una pequeña corriente por el movimiento de vida marina ayuda a la circulación del agua de mar.] (“해파리도 좋은 일을 한다 (Las medusas también hacen cosas buenas)", 12/08/2009, HANKYOREH).

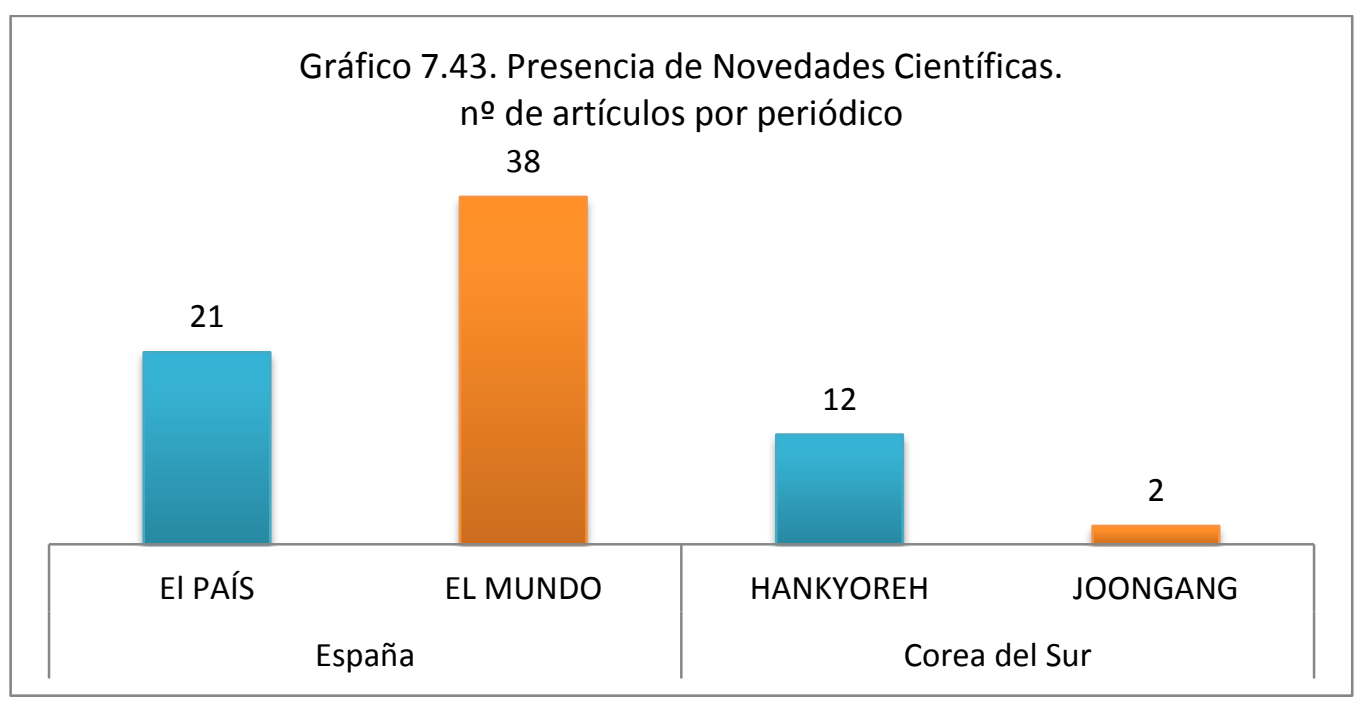

En España, el periódico centro-derecha EL MUNDO informó más novedades científicas que EL PAÍS de centro-izquierda, pero en Corea del Sur es al contrario. HANKYOREH tiene 12 artículos de novedades científicas y JOONGANG posee solo dos artículos durante los tres años.

Ahora véase los porcentajes de los artículos por año:

\begin{tabular}{|l|r|r|r|r|r|r|}
\hline & \multicolumn{3}{|c|}{ ESPAÑA } & \multicolumn{3}{c|}{ COREA DEL SUR } \\
\cline { 2 - 7 } & AÑO2008 & AÑO2009 & AÑO2010 & AÑO2008 & AÑO2009 & AÑO2010 \\
\hline Novedad Científica & $21,3 \%$ & $22,0 \%$ & $21,6 \%$ & $4,6 \%$ & $4,8 \%$ & $2,3 \%$ \\
\hline № total Artículos & 47 & 150 & 74 & 87 & 168 & 86 \\
\hline
\end{tabular}

Tabla 7.27. Novedades Científicas. Por año y por país 


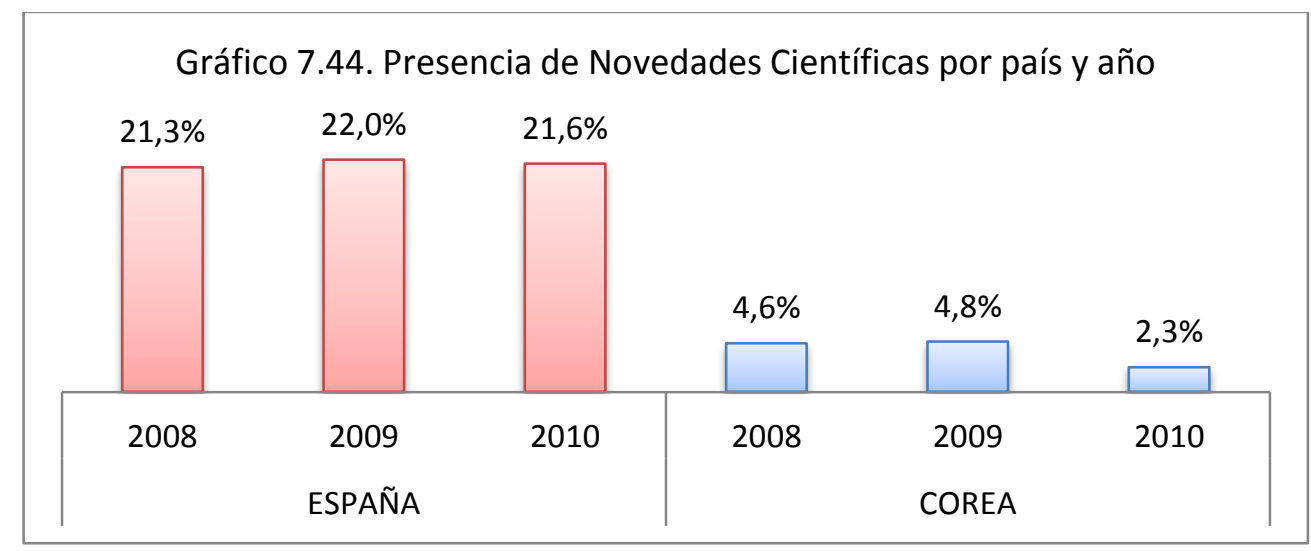

Entre los artículos españoles, en los tres años 'Novedades Científicas' se mantienen ocupando más del 20\%. Entre los artículos coreanos el porcentaje disminuye en 2010.

Además, se han clasificado las investigaciones que se han tratado en los artículos.

\begin{tabular}{|l|r|r|}
\hline Novedades Científicas & ESPAÑA & COREA \\
\hline Hallazgo de Nuevas Especies & 9 & 1 \\
\hline Hallazgo de Fósiles & 6 & 2 \\
\hline Nuevas Explicaciones de la Evolución & 37 & 11 \\
\hline Otro & 7 & 0 \\
\hline TOTAL (Novedades Científicas) & 59 & 14 \\
\hline
\end{tabular}

Tabla 7.28. Contenidos de los artículos de Novedades Científicas

Si clasificamos las Novedades Científicas como hallazgo de nuevas especies, hallazgo de fósiles, explicaciones de la evolución recién añadidas, etc., en toda la categoría, España tiene más artículos que Corea del Sur.

\subsubsection{Ideas Religiosas}

Por último, vamos a mirar la presencia de las ideas religiosas con el darwinismo.

\begin{tabular}{|c|c|c|c|c|c|c|c|c|c|c|c|c|}
\hline & \multicolumn{4}{|c|}{ AÑO 2008} & \multicolumn{4}{|c|}{ AÑO 2009} & \multicolumn{4}{|c|}{ AÑO 2010} \\
\hline & \multicolumn{2}{|c|}{ ESPAÑA } & \multicolumn{2}{|c|}{ COREA } & \multicolumn{2}{|c|}{ ESPAÑA } & \multicolumn{2}{|c|}{ COREA } & \multicolumn{2}{|c|}{ ESPAÑA } & \multicolumn{2}{|c|}{ COREA } \\
\hline & MUN & PAI & HAN & $\mathrm{JOO}$ & MUN & PAI & HAN & $\mathrm{JOO}$ & MUN & PAI & HAN & JOO \\
\hline Ideas Religiosas & 5 & 1 & 2 & 3 & 4 & 4 & 3 & 4 & 3 & 0 & 4 & 0 \\
\hline № Total & 34 & 13 & 52 & 35 & 99 & 51 & 83 & 85 & 45 & 29 & 50 & 36 \\
\hline
\end{tabular}

Tabla 7.29. Ideas Religiosas. Por periódico y por año 
Se suman los datos de la tabla 7.29 por país:

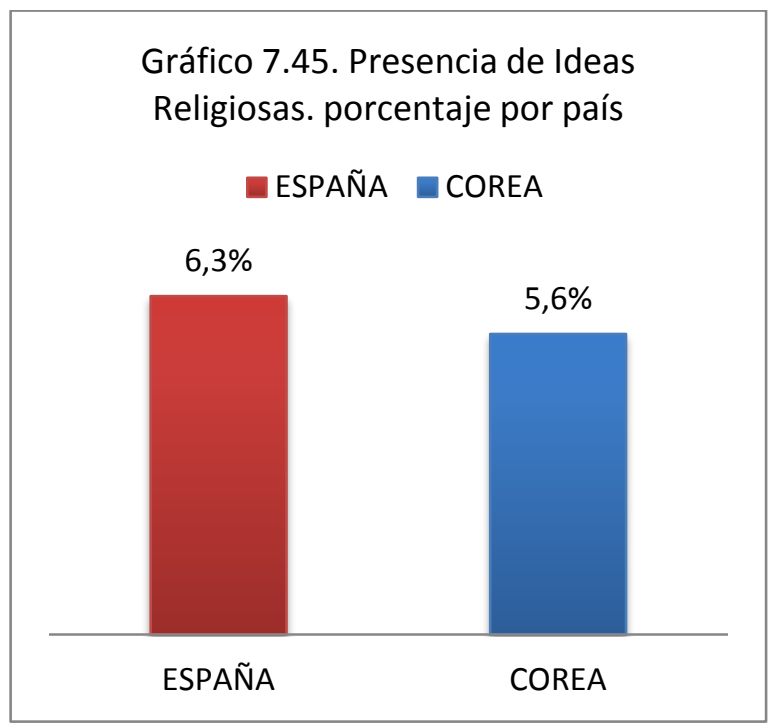

\begin{tabular}{|l|l|r|r|}
\hline & & ESPAÑA & COREA \\
\hline \multirow{2}{*}{ Ideas Religiosas } & No Total & 17 & 16 \\
\cline { 2 - 4 } & Porcentaje & $6,3 \%$ & $5,6 \%$ \\
\hline \multicolumn{2}{|c|}{ № Total } & 271 & 341 \\
\hline
\end{tabular}

Tabla 7.30. Ideas Religiosas. por país

17 artículos españoles y 16 coreanos hablan de ideas religiosas y el darwinismo a la vez. Entre los dos países no existe una diferencia notoria entre el número de artículos y su porcentaje.

Ahora veamos el número de artículos por periódico.

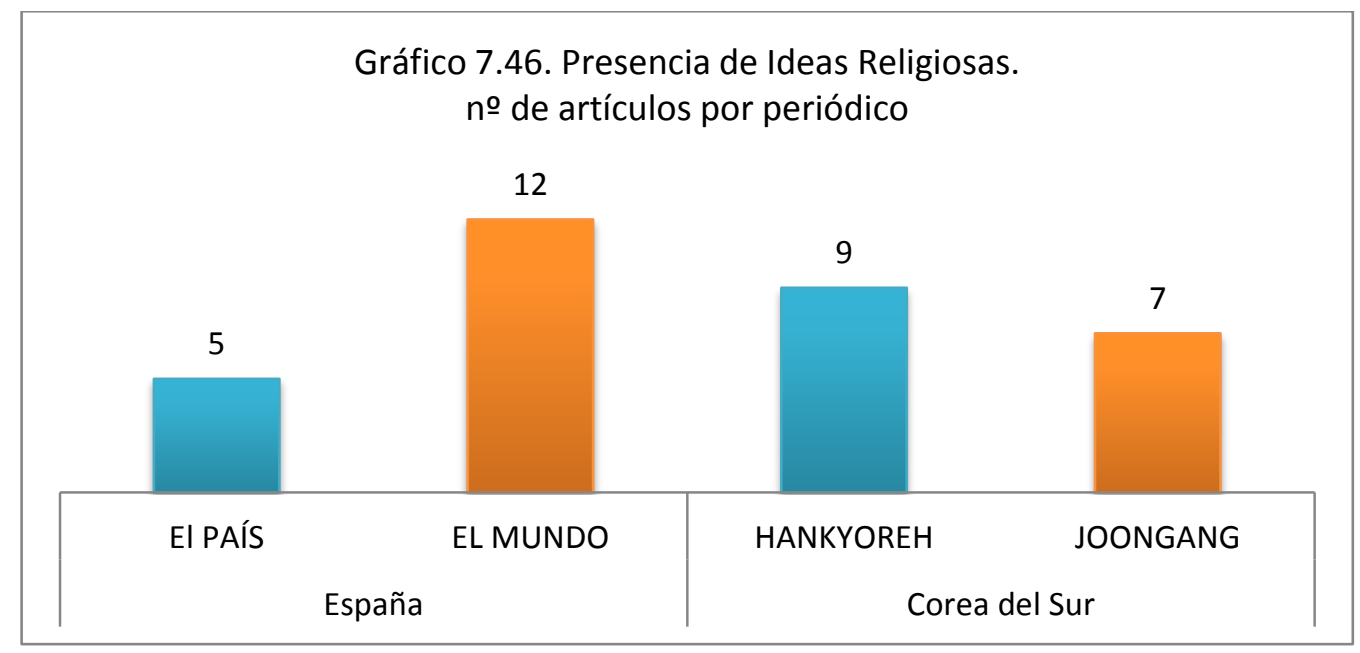

Los dos periódicos coreanos tienen 9 y 7 artículos respectivamente y no hay gran diferencia entre ellos. En España, EL MUNDO publicó 12 artículos y EL PAís 5. 


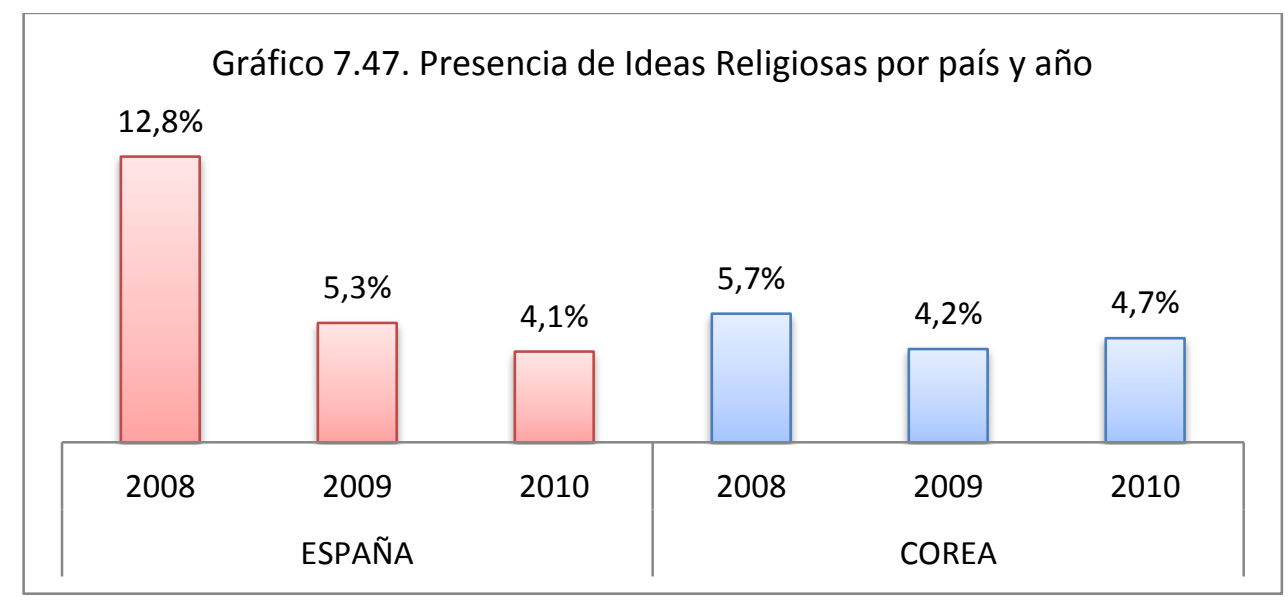

En España, el porcentaje disminuye en 2009, pero el número de artículos aumenta. En 2008, 6 artículos hablan de pensamientos religiosos, se publican 8 artículos en 2009 y 3 en 2010.

En Corea, no cambia tanto el porcentaje. Tiene 5 artículos en 2008, 7 en 2009 y 4 en 2010 incluyen ideas religiosas respecto al darwinismo.

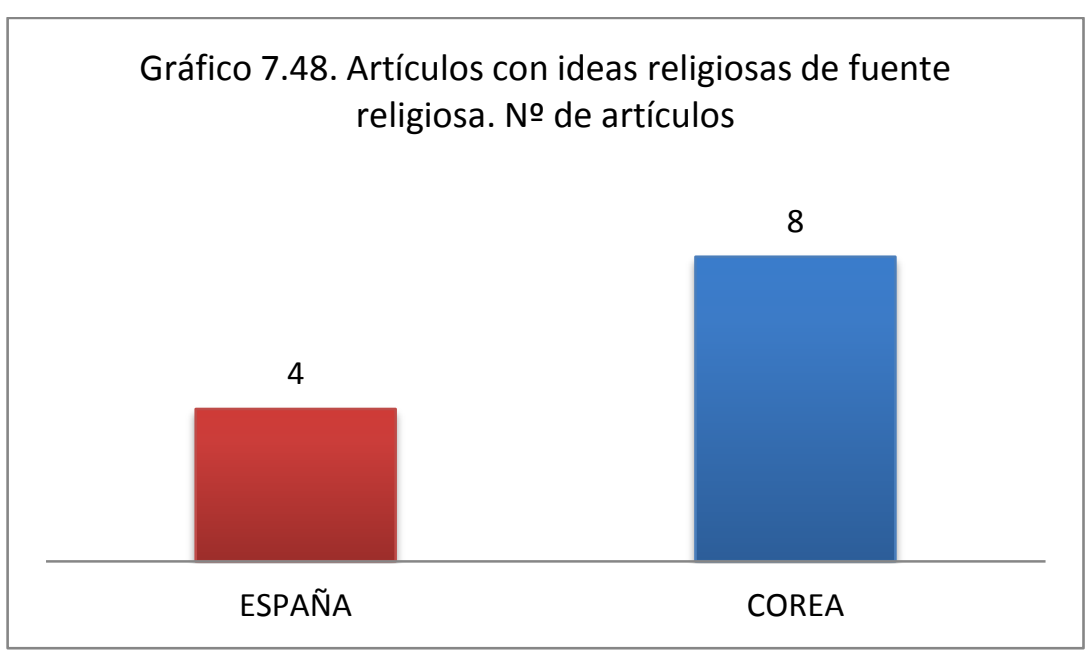

Entre estos artículos, 8 de los 16 coreanos proceden de una fuente religiosa. En España es un poco menos de un cuarto (4 de 17). La mitad de los artículos coreanos que manifiestan ideas religiosas incluyeron por consiguiente, contenidos de origen religioso. 


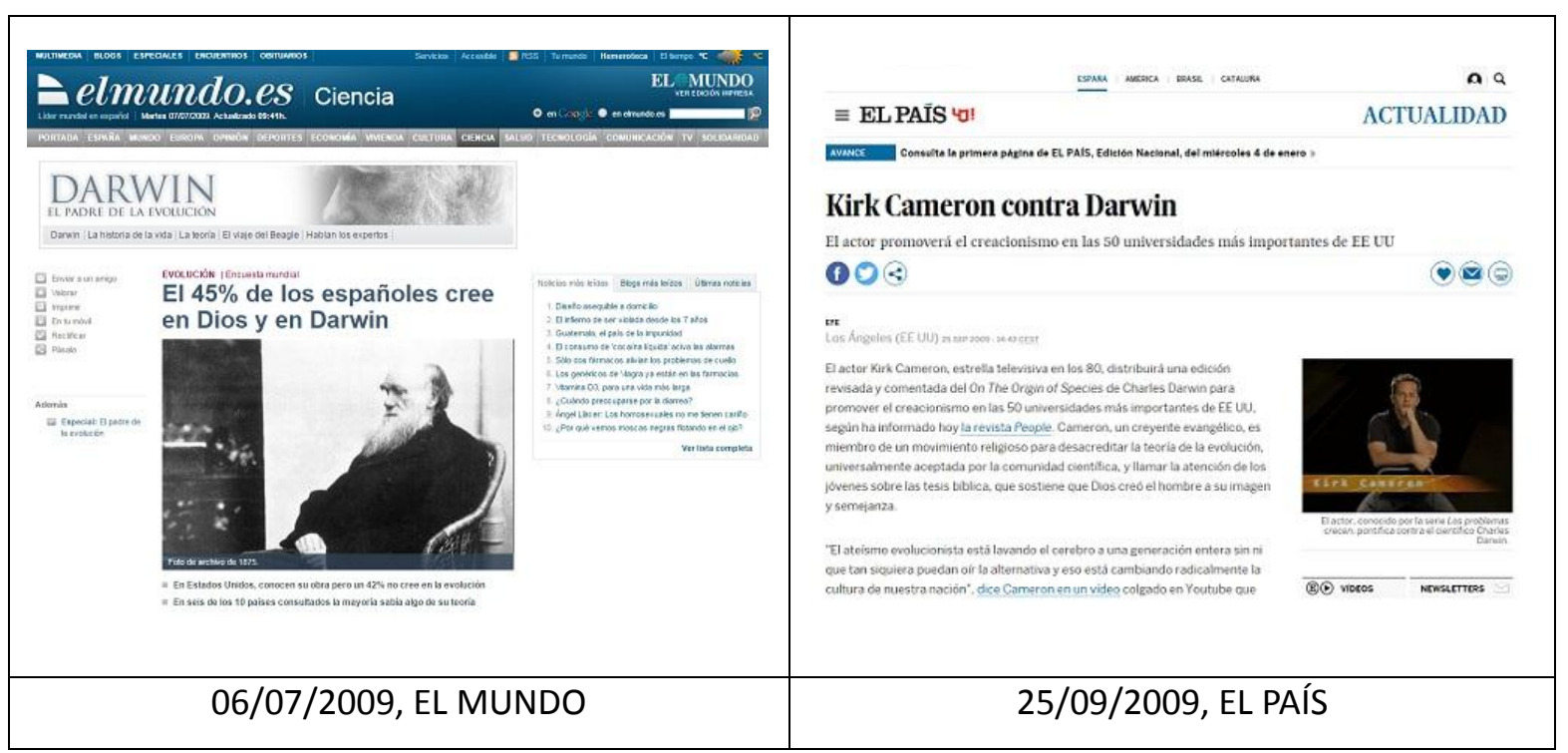

Ilustración 7.4. Ejemplos de artículos que tienen ideas religiosas. España

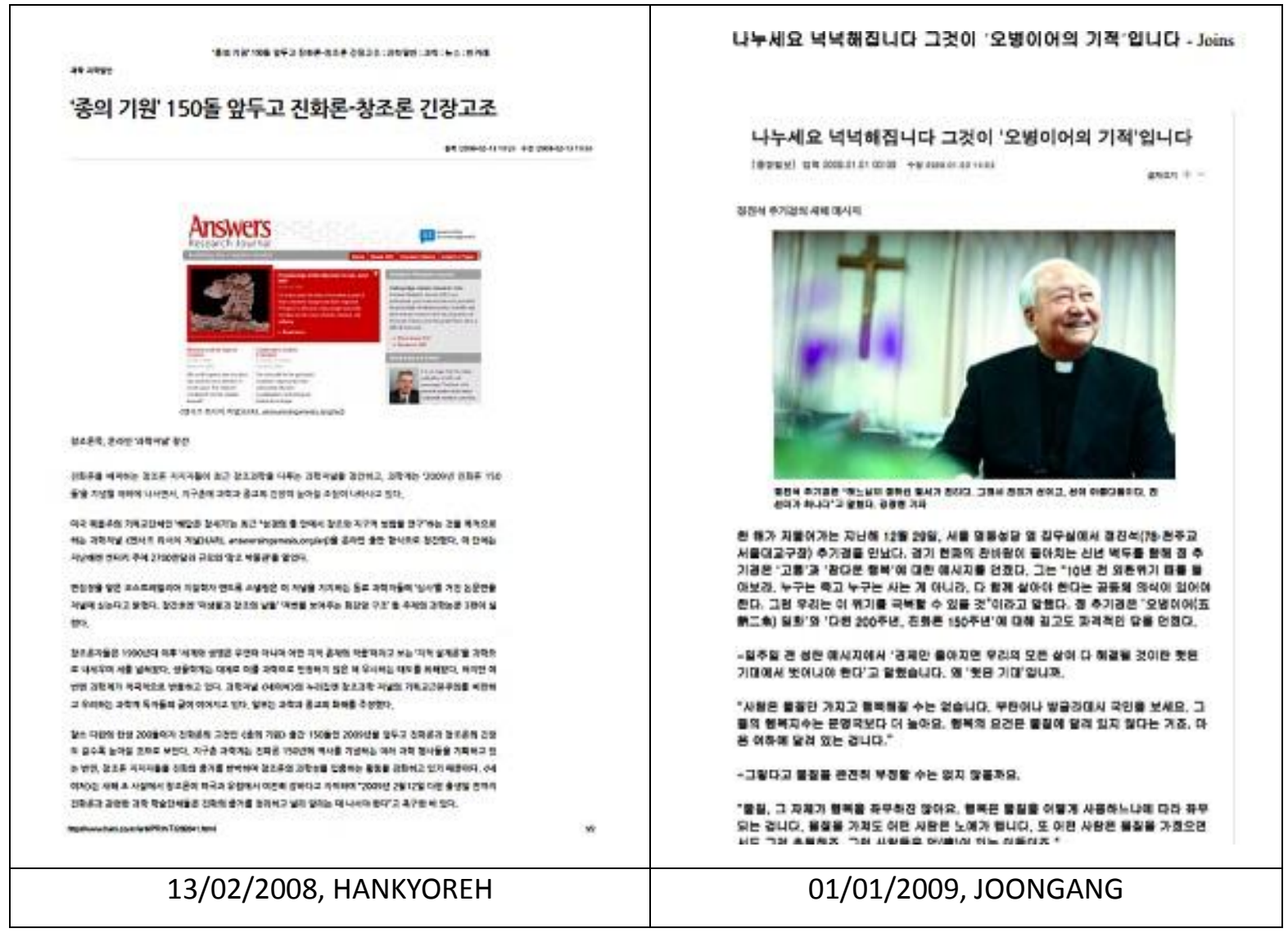

Ilustración 7.5. Ejemplos de artículos que tienen ideas religiosas. Corea del Sur 


\section{Compatibilidad entre la Fe y el Darwinismo}

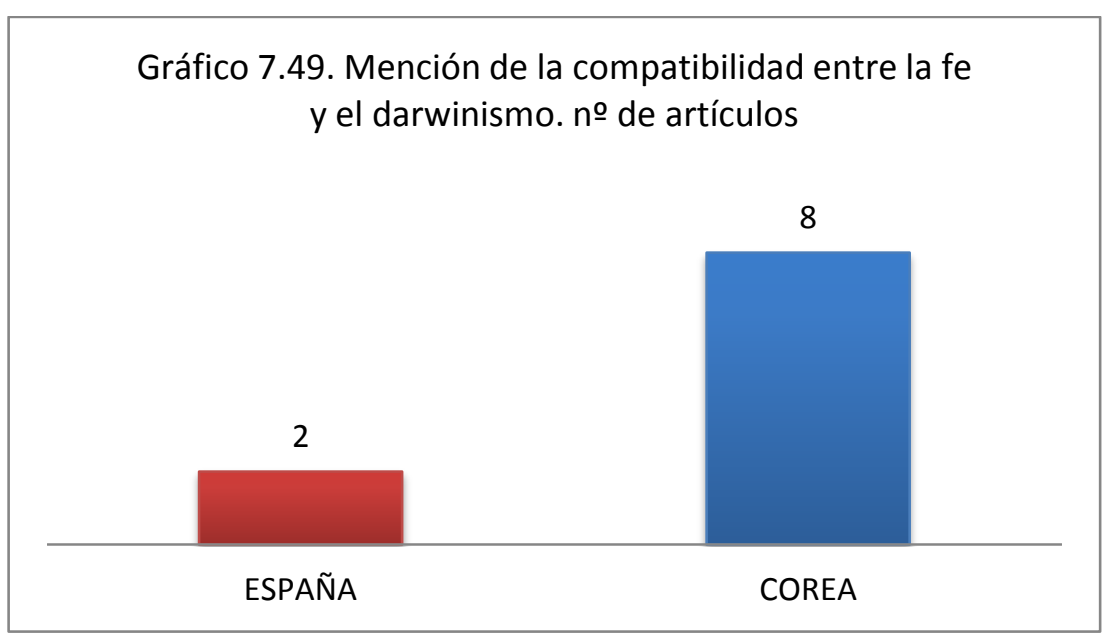

Además, Corea posee un 50\%, 8 artículos que mencionan la compatibilidad entre la fe y el darwinismo. España solo tiene 2 artículos.

¿Se puede conciliar la ciencia con la religión? ¿Es compatible el Big Bang con pensar que Dios creó el mundo en siete días? Benedicto XVI piensa que sí. "No existe ninguna oposición entre la comprensión de la fe respecto a la creación y la evidencia de las ciencias empíricas", subrayaba esta mañana el Papa, destacando que todo en el Universo y en la naturaleza sigue un guión preestablecido escrito por Dios. El Pontífice hacía esa afirmación durante la inauguración en el Vaticano de un congreso, organizado por la Pontificia Academia de las Ciencias, en el que hasta el próximo martes reputados científicos (incluido el físico Stephen Hawking) analizarán el nacimiento del Universo, la evolución de las especies y las teorías de Darwin. (Irene Hernández Velasco, "El Vaticano celebra un Congreso sobre las relaciones entre la ciencia y la religión", 01/11/2008, EL MUNDO)

Uno de los científicos que más ha hecho por conciliar ciencia y religión es el experto español en evolución genética de las especies, Francisco Ayala. El investigador de la Universidad de California en Irvine, EEUU, declaró a elmundo.es que "la fe y la ciencia no son incompatibles porque tratan cuestiones diferentes", (...) "La investigación científica debe encargarse de explicar el origen del mundo (el cómo) y la religión, de los valores morales y las relaciones entre las personas (el porqué)", afirmó el jueves Ayala desde la Universidad de California, en EEUU. (Ana Luz Díaz, “Hawking reabre la polémica entre Ciencia y Religión”, 02/09/2010, EL MUNDO)

El primer artículo presenta la opinión de un pontífice y el segundo transmite pensamientos de Francisco Ayala que es un biólogo bien conocido en España e insiste en la compatibilidad 
de la fe cristiana y el darwinismo.

푸네스 신부는 과학과 종교의 관계에 대해서도 언급했다. 그는 “과학과 종교는 서로 필요하다"며 “많은 천문학자가 신의 존재를 믿는다”고 주장했다. 교황청은 과학계와 교류를 강화하기 위해 '진화론'의 창시자인 찰스 다윈 탄생 200 주년을 맞는 내년에 학술회의를 개최홀 예정이다. [El sacerdote Funes también mencionó la relación entre la ciencia y la religión. "La ciencia y la religión necesitan uno a otro.", dijo. "Muchos astrónomos creen en Dios". El Vaticano celebrará una conferencia académica el próximo año para conmemorar el 200 aniversario del nacimiento de Charles Darwin, el fundador de la teoría de la evolución.] (Nakyeon Won, “교황청 천문대 신부 “외계인도 형제자매”(El sacerdote del observatorio del Vaticano, "Los extraterrestres también son nuestros hermanos")", 15/05/ 2008, JOONGANG)

2009 년은 '진화론의 해'다. 찰스 다윈 타생ㅇ 200 주년, 진화론의 고전인 『종의 기원』 출간 150 주년이 되는 해다. 한때 발명가의 뀜을 꿨던 공학도(서울대 화학공학과) 출 신답게 정 추기경은 "우리 인간이 아는 것은 우주 전체의 한 부분에 불과하다. 인간 의 과학이 발전하는 과정은 결국 신의 섭리를 알아가는 과정”이라며 '진화론'에 대해 서도 정면으로 답했다. "창조론과 진화론은 대치되는 개념이 아닙니다." [2009 es el año del darwinismo. Se conmemora el bicentenario del nacimiento de Charles Darwin y el 150 aniversarios de la publicación del clásico del evolucionismo, $\ulcorner$ El Origen de las Especies. El cardenal Jung, que es ingeniero que aspirar ser inventor (ingeniería química de Universidad Nacional de Seúl), "Lo que conocemos es solo una parte del universo entero. El proceso de desarrollo científico es un proceso de conocer la Divina Providencia." También respondió directamente sobre el darwinismo. "El creacionismo y el darwinismo no son conceptos que confrontan.”] (Sungho Paik, “나누세요 넉넉해집니다 그것이 '오병이어의 기적'입니다 (Compartan. Será abundante. Es el milagro de 'Multiplicación de los panes y los peces')", 01/01/2009, JOONGANG)

Estos dos ejemplos de los artículos coreanos transmiten voces de sacerdotes católicos. En Corea solamente el catolicismo menciona la compatibilidad entre la fe y el darwinismo, ya que el protestantismo coreano tiene actitud hostil hacia el darwinismo. 


\section{Diseño Inteligente}

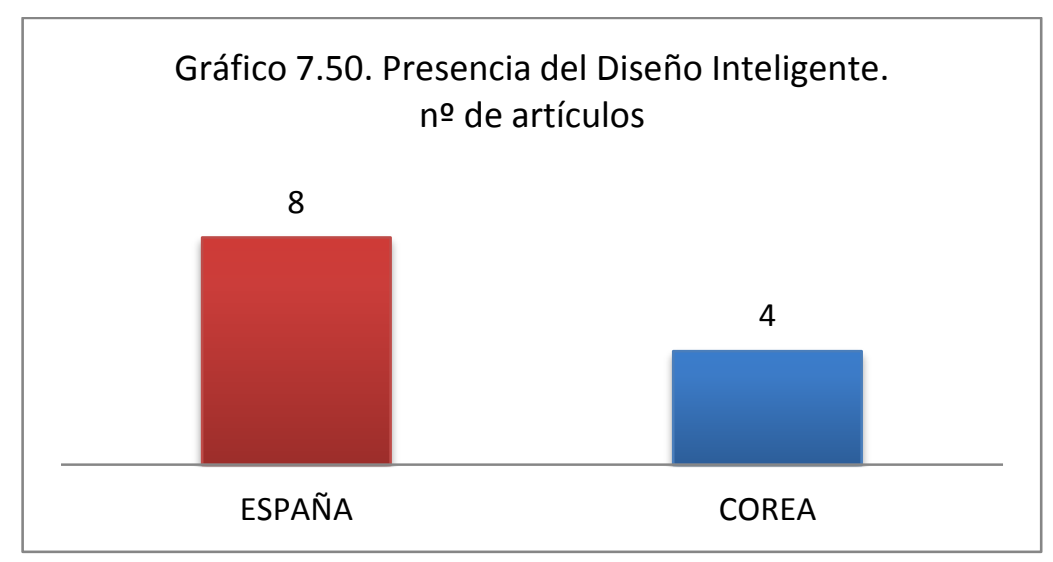

En lo que se refiere a los artículos que hablan del Diseño Inteligente (en adelante DI) son 8 de España y 4 de Corea. 3 de los 8 artículos españoles critican el DI y 5 tienen actitud neutral. Entre los coreanos, 3 son neutros y solo 1 muestra una actitud crítica.

Resulta increíble que en el Aula Magna de la Facultad de Biología de la Universidad de León se vaya a celebrar precisamente un acto de promoción del ID, que es estrictamente opuesto a lo que esa facultad enseña a diario. ¿Por qué ceder el recinto a quien menosprecia el trabajo de los científicos? (...) No es la primera vez, ni será la última, me temo, que en recintos universitarios se celebran actos de carácter anticientífico, lo que dice muy poco de la forma en que se programan las actividades en estos centros. (Javier Armentia, "Diseño no demasiado inteligente", 08/01/2008, EL MUNDO)

Contra la sinrazón, sonrisas. Esta parece ser la consigna de la III Muestra de Humor Gráfico que se inagura este jueves en 'La Llotgeta', el espacio cultural de la Caja de Ahorros del Mediterráneo (CAM) de Valencia, y cuyo tema es 'Evolución y Creacionismo'. La exposición, que coincide con la celebración del segundo centenario del nacimiento de Charles Darwin ly los 150 años de la publicación de 'El Origen de la Especies') reúne 189 obras de autores de 44 países seleccionadas de un total de 459 propuestas. (Javier Cavanilles, "Humor contra el 'diseño inteligente'", 23/04/2009, EL MUNDO)

Estos dos artículos muestran una actitud crítica sobre el DI. Especialmente el primer ejemplo criticó tajantemente lo que ocurrió en la Universidad de León y el autor del artículo era el director de Planetario de Pamplona de entonces. El segundo artículo llama el creacionismo como 'sinrazón' explicando la exposición de ‘Evolución y Creacionismo'. 
En las décadas siguientes, el darwinismo tomó fuerza, y también los opositores a las nuevas teorías. Aún siglo y medio después, hay grupos, sobre todo en Estados Unidos, que arropados por religiosos ultraconservadores, siguen defendiendo que un ser superior diseñó la vida en el planeta. Incluso se ha abierto un Museo de la Creación en Kentucky (EEUU) en el que se explica que los dinosaurios y los humanos compartieron la Tierra, en contra de todas las evidencias científicas. (Rosa M. Tristán, "Darwin, una polémica que dura siglo y medio", 20/06/2008, EL MUNDO)

Un destacado miembro de la Royal Society <http://royalsociety.org/>del Reino Unido, la academia nacional de la ciencia en este país, ha instado a los profesores británicos a explicar el creacionismo en clases y a presentarlo como una "idea sobre el mundo" no aceptada por la comunidad científica y no como una "teoría errónea". (...) Las palabras de Reiss tuvieron una respuesta inmediata por parte de destacados miembros de la comunidad científica. "El creacionismo se basa en la fe y no tiene nada que ver con la ciencia, por lo que no tiene cabida en las clases de ciencia", criticó el profesor Lewis Wolpert, biólogo del University College, de Londres. (Elmundo.es, "Un científico británico defiende la enseñanza del creacionismo en las escuelas", 12/09/2008, EL MUNDO)

La teoría de la evolución, de Darwin, y su forzada contrapartida, la teoría del "diseño inteligente", han sido por más de dos años los símbolos del debate que adelanta el Consejo de Educación de Texas para cambiar el actual plan de estudios que siguen 4,7 millones de estudiantes, desde preescolar hasta el final de la secundaria. Con diez miembros republicanos y cinco demócratas, todos elegidos en las urnas por períodos de cuatro años, el SBOE -por sus siglas en inglésmantiene en Austin, desde el miércoles y hasta el viernes, la que será la penúltima discusión antes de cerrar, en mayo, el perfil de lo que a partir del ciclo 2011-2012 las escuelas texanas van a enseñar durante los próximos diez o quince años. (Rubén Correa, "La política domina el debate por el nuevo plan de estudios de Texas", 11/03/2010, EL MUNDO)

Estos tres artículos explican asuntos anti-darwinistas que acontecieron EE.UU. y Reino Unido y su actitud es relativamente neutral porque principalmente presentan el progreso de los sucesos.

Ahora veamos ejemplos coreanos.

$$
\begin{aligned}
& \text { 저자는 지적설계론들을 “낡은 턱시도를 걸친 창조론자"라며 그들이 과학을 흥내내 } \\
& \text { 내세우는 주장들을 각종 “진짜 과확"을 동원해 조목조목 부순다. "신은 없다"며 돌진 }
\end{aligned}
$$


하는 도킨스보다 박력은 덜하지만 반박자료의 다양성이나 논리적 설득에선 더 나은 느낌이다. 흥미로 쳐도 지금까지 소개된 창조론비판서 중 단연 돋보인다. [El autor del libro dijo que el DI es "creacionista vestido un esmoquin viejo" y rompió sus alegaciones pseudocientíficas una por una con la 'ciencia auténtica'. Es menos vigoroso que Dawkins que se lanza diciendo "Dios no existe", pero parece mejor que él en la diversidad de los datos y la convicción lógica. Se destaca entre los libros críticos del darwinismo para entretener.] (Manhoon Lee, “창조론 허점 파헤친 진화론의 반격(El contraataque del darwinismo que revela la debilidad del creacionismo)", 06/09/2008, JOONGANG)

Este artículos generalmente mantiene una actitud crítica sobre el creacionismo y explica el libro que opina del DI desde el punto de vista evolucionista.

최근 진화론을 비판하는 논의는 '지적설계론'이다. 1990년대 초 등장한 이 이론은 생
명이 초월적이 조재에 의해 설계되었음을 과하적이 어어로 주잫하려는 이론이다. 프 로그램은 진화론과 종교 사이의 대화를 위해 '만들어진 신'의 저자로 알려진 진화학 자 리처드 도킨스와 사회생물학의 창시자이자 '통섭'을 주창하는 생물학자 에드워드 윌슨을 직접 만나 그들의 주장을 들어보고, 복음주의 신학자 알리 맥그라스와 종교 철학자 알빈 플라팅가의 반박도 살펴본다. [EI debate que recientemente critica la evolución es la «teoría del diseño inteligente». Esta teoría, surgida a principios de los noventa, es una teoría que pretende insistir en el diseño de los seres vivos por un ser trascendente con un lenguaje científico. Para el diálogo entre la evolución y la religión, el programa entrevistó a Richard Dawkins, un estudioso de la evolución conocido como el autor del "El Espejismo de Dios" y a Edward Wilson, un biólogo que propuso la "consiliencia". También entrevistó al fundador de la biología social, McGrath y el filósofo de la religión Alvin Plantinga.] (Youngjeon Kwon, "진화론과 종교 150년 동안의 논쟁(El debate durante 150 años entre el darwinismo y la religión)", 13/12/2009, HANKYOREH)

El artículo introdujo un programa de televisión que pronto estrenaría e informa que el programa entrevistó a dos biólogos evolucionistas y dos estudiosos pro-DI. Es decir, presenta informaciones con una actitud neutral.

다음달 12 일 찰스 다윈 탄생 200 주년이 다가오고 있지만 지금까지도 미국에서 진화 론과 창조론에 대한 뜨거운 논쟁은 계속되고 있다고 미 언론사인 맥클래치 신문이 26 일 보도했다. 다윈의 이론이 맞는 것인지, 어린 학생들에게 서로 대립되는 이론들 을 가르쳐도 되는 것인지에 대한 논쟁이 이어지는 이유는 부분적으로 찬반 양측의 
주장이 막상막하로 맞서고 있기 때문이다. [El día 26 el periódico estadounidense McClatchy Informó que el bicentenario del nacimiento de Charles Darwin se acerca, pero el debate caliente entre la evolución y el creacionismo continúa en Estados Unidos. El debate sobre si la teoría de Darwin es correcta, o si puede enseñar a los estudiantes jóvenes las teorías que se enfrentan entre sí es porque en parte los argumentos están confrontados igualmente.] (Yonhap, “다윈 탄생 200주년...계속되는 진화론 논쟁(El bicentenario del nacimiento de Darwin... Debates continuos del darwinismo )", 27/01/2009, HANKYOREH)

Este artículo dice que el debate entre el darwinismo y el creacionismo es parcialmente igual. Podemos considerar que es una actitud inclinada por el creacionismo. El artículo se publicó con el nombre de Yonhap, que es la principal agencia de noticias financiada por fondos públicos. Estos artículos coreanos a menudo incluyen expresiones como 'sigue el debate entre el darwinismo y el creacionismo' como si hubiera conflictos significativos entre ellos.

Hemos investigado los artículos de España y Corea del Sur que incluyen el darwinismo durante tres años (2008-2010), mediante MCC y otras herramientas de análisis de artículos de periódico. Según el resultado del análisis con MCC, las proporciones de la cultura científica intrínseca y extrínseca de España y Corea del Sur fueron similares. Después de investigar los contenidos de los artículos, captamos una diferencia general entre los dos países, que el darwinismo como una teoría puramente científica está bastante presente en la prensa española, pero no de la misma forma en la coreana donde se trata la evolución más en el contexto social.

Los resultados de la investigación en este capítulo se valorarán en detalle en el capítulo 8, que es la conclusión de esta parte, con el análisis de los libros de texto en el capítulo 6. 


\section{Capítulo 8. Conclusiones de la Segunda Parte}

En esta parte II, hemos investigado los contenidos darwinianos de España y Corea del Sur en libros de texto y artículos periodísticos, que son las principales vías que transmiten el darwinismo al público. Hemos analizado los contenidos a través de modelo de Cultura Científica (MCC) y otros criterios complementarios.

En el capítulo 5, hemos propuesto la metodología para realizar el análisis de contenido del este estudio. MCC es una herramienta para clasificar los contenidos de la cultura científica en información incorporada en el sistema científico (cultura científica intrínseca) y la información relacionada con la ciencia pero no incorporada en el sistema científico (cultura científica extrínseca), y también divide cada uno de ellas en información representativa, práctica y valorativa. Este modelo puede utilizarse para examinar si los factores culturales de España y Corea del Sur influyen en la estructura de los contenidos didácticos y periodísticos. Además, para analizar cómo se trata específicamente el darwinismo, hemos comparado la presencia de los conceptos concretos de éste en los libros de texto y varios caracteres de los artículos periodísticos de España y Corea del Sur. En el capítulo 6 analizamos el contenido de los libros de texto y en el capítulo 7 analizamos los artículos periodísticos que incluyen el darwinismo.

En el capítulo 6 investigamos el contenido de libros de texto que enseñan el darwinismo. Se seleccionaron cuatro libros de texto para 10 curso escolar en cada país y se añadieron 2 libros coreanos de 12 a curso para equilibrar el contenido de los dos países (total 10 libros: España 4, Corea 6).

En primer lugar, consideramos el currículo de España y Corea del Sur comparando con el de Estados Unidos e Inglaterra. En el currículo español no se destaca alguna característica. El currículo de Corea es similar, pero no incluye pruebas de la evolución pero sí una actividad que propone pensar el impacto del darwinismo sobre la sociedad. 
Las informaciones recogidas de libros de texto son 1107 unidades en España y 1179 en Corea (párrafos e imágenes). Estos contenidos se codificaron con MCC usando Atlas.ti.

El resultado de la codificación por MCC no muestra gran diferencia entre España y Corea del Sur. En España, 93,3\% del contenido darwiniano era de cultura científica intrínseca y solo 8,4\% era de cultura extrínseca. En Corea, 94,1\% era de cultura científica intrínseca y la extrínseca ocupaba $9,8 \%$.

Incluso si las informaciones se clasifican en representacional, operacional y valorativa en detalle, la diferencia no resulta notable. CINTR es 70,6\% del total en España, 73,3\% en Corea, CINTOP es 22,3\% en España, 20,2\% en Corea, CINTVA 0,4\% en España y 0,6\% en Corea. No muestra gran diferencia. En la cultura científica extrínseca, CEXTR es 5,9\% en España, 3,3\% en Corea, CEXTOP en España 1,9\%, Corea 4,8\%, CEXTVA en España 0,9\% y Corea 1,6\%, tampoco hay gran diferencia.

Es natural que la cultura científica ocupe más del $93 \%$ en los textos analizados en los dos países, ya que son informaciones recopiladas de libros de texto de ciencias que enseñan formalmente el darwinismo a los alumnos. Un 95,4\% de las imágenes españolas y el 96,8\% de las coreanas son de cultura científica intrínseca, porque en libros de texto normalmente las imágenes se añaden para ayudar la comprensión del texto.

Si resumimos el resultado de la codificación de los libros de texto mediante MCC:

- La proporción entre la cultura científica intrínseca y extrínseca en los libros de texto del darwinismo en España es similar a la proporción de Corea del Sur.

- La proporción entre la información representacional, operacional y valorativa (tipos de la información) en la cultura científica intrínseca en los libros de texto del darwinismo en España es similar a la proporción de Corea del Sur.

- La proporción entre los tres tipos de la información en la cultura científica extrínseca en España es un poco diferente de la proporción de Corea del Sur, pero no es una diferencia significativa. 
A partir de estos resultados, podemos pensar que los factores culturales no influyen mucho en la proporción entre la cultura científica intrínseca y extrínseca en libros de texto que enseñan el darwinismo.

Después de la investigación con MCC, estudiamos las informaciones más en detalle concentrando los conceptos del darwinismo.

Lo más notable es que los cuatro libros de texto españoles mencionan el creacionismo en el contexto de la 'historia de la ciencia'. Es cierto que el fijismo, que era una forma de explicar la vida antes de la evolución, está asociado con el creacionismo, pero parece que adquieren una importancia exagerada en los libros. En particular, los libros de texto de las editoriales SM y Edelvives, que tienen origen religioso, muestran su religiosidad poniendo obras maestras de Miguel Ángel, frases de Génesis o discurso de Papa en cuanto al creacionismo. Además, al explicar a Darwin, ambos libros incluyen que Darwin era una persona religiosa.

En cambio, entre los seis libros de Corea del Sur, dos mencionan el creacionismo solo una vez respectivamente, pero era para explicar el ambiente de la época darwiniana y no incluyen ningún contenido religioso.

En las informaciones intrínsecas que explican el darwinismo, hemos podido encontrar diferencias en detalle entre España y Corea del Sur:

- Los cuatro libros de texto españoles explican en detalle las pruebas de la evolución en un subcapítulo separado, pero los cuatro libros de texto coreanos para 10ำ curso no explican aparte. Los dos libros coreanos para $12 \circ$ curso las explican y significa que consideran 'las pruebas de la evolución' como un contenido avanzado del darwinismo.

- Los libros de texto españoles definen el darwinismo en manera darwiniana (cambio de los seres vivos con el tiempo), pero los libros de texto coreanos lo definen genéticamente (cambio de la frecuencia alélica en el acervo genético).

- Generalmente los libros españoles prestan más atención a la historia de la ciencia que los coreanos. Los españoles incluyen más informaciones sobre teorías anteriores 
y posteriores a Darwin. Especialmente, hace hincapié a la teoría de equilibrio puntuado.

- Generalmente los libros coreanos prestan más atención a las informaciones genéticas. El concepto de 'acervo genético' está presente en todos los libros coreanos (6 libros), pero en ninguno de los españoles.

Si simplificamos estas observaciones, los libros españoles dan importancia a la teoría científica en la historia de la ciencia y el significado del propio darwinismo y los libros coreanos muestran su interés en la genética y la biotecnología. Por supuesto, la genética es una teoría posterior a Darwin, pero en los libros coreanos no se tratan en el contexto de la historia de la ciencia, sino de una ciencia aplicada.

Esta característica de los libros coreanos parece derivarse de la cultura científica de Corea del Sur, que ha desarrollado solamente las ciencias aplicadas que pueden producir 'beneficios' en poco tiempo sin una tradición de la ciencia pura, a diferencia de España, donde ha convivido la historia de la ciencia.

Después de este análisis, para ampliar la investigación sobre el contexto social, hemos revisado brevemente cómo se trató el darwinismo en los libros de texto pasados de Corea y España de los años cuarenta a los noventa del siglo XX.

Como hemos anotado en la parte I, en la primera mitad de la dictadura franquista en España, Darwin no se encontraba en los libros de texto. A veces el concepto de la evolución estaba presente, pero no con Darwin sino con Lamarck o Mendel. Darwin y su teoría de la evolución comenzaron a regresar a los libros de texto a finales de los años sesenta. Con el regreso del darwinismo en los libros de texto, el creacionismo también apareció en ellos para insistir en su compatibilidad con el darwinismo. Si un libro de texto no incluye el darwinismo, el creacionismo tampoco estaba incluido. Es decir, la presencia del creacionismo en los libros de texto dependía de la del darwinismo.

En Corea del Sur el darwinismo nunca ha sido censurado. Desde el primer plan de estudios del país que se fundó en 1945 hasta ahora, la teoría nunca ha sido excluida. Hasta la década de 1960, el creacionismo apareció en algunos libros de texto coreanos, surgió como un 
concepto de 'historia de la ciencia'. Se puede imaginar que fue la influencia de los libros de texto extranjeros. A partir de mediados de los años setenta, el creacionismo desapareció en la explicación del darwinismo.

En el capítulo 7, analizamos cómo el darwinismo fue reportado en dos periódicos de España (El Mundo y El País) y Corea del Sur (Hankyoreh y Joongang) respectivamente. Los artículos son de tres años centrado en 2009 (2008, 2009 y 2010), cuando se celebró el bicentenario del nacimiento de Darwin.

En estos tres años, los dos periódicos españoles mencionaron a Darwin o el darwinismo en 271 artículos (2008: 47, 2009: 150, 2010: 74) y los dos periódicos coreanos en 341 artículos (2008: 87, 2009: 168, 2010: 86). En España el número de artículos triplicó en el año de Darwin (2009) en comparación con 2008; en 2010 también se publicaron más artículos que en 2008. En Corea del Sur, de igual forma aumentó el número de artículos en 2009 en comparación con 2008, pero no alcanzó a doble de 2008 y en 2010 volvió al número de 2008. En otras palabras, se puede decir que en Corea del Sur la influencia del "Año de Darwin" en el número de artículos periodísticos es menor que la de España.

Se codificaron los artículos mediante MCC con Atlas.ti. La proporción entre la cultura científica intrínseca y extrínseca en los artículos periodísticos de España es similar a la de Corea del Sur. En España, 44,6\% de los artículos incluyeron informaciones intrínsecas y 69,4\% tenían las extrínsecas. En Corea, el 46,6\% provenían de las informaciones intrínsecas y las extrínsecas representaban un 63\%. No se destaca la diferencia entre España y Corea.

Sin embargo, como hemos visto en el capítulo 6, en el análisis MCC de los libros de texto 93,3\% de España y 94,1\% de Corea eran de cultura científica intrínseca. La cultura extrínseca ocupaba un 8,3\% en España y un 9,4\% en el caso de Corea. Esto demuestra que la naturaleza de texto tienen una mayor influencia en la proporción entre la cultura científica intrínsecaextrínseca que los factores culturales.

Los artículos se clasifican en representacional, operacional y valorativa en detalle, en el caso de la cultura científica intrínseca, la diferencia entre los dos países no es notable. CINTR es 
37,3\% del total en España, 41,3\% en Corea, CINTOP es 4,4\% en España, 1,8\% en Corea, CINTVA 3,0\% en España y 3,5\% en Corea. No se aprecia gran diferencia.

Sin embargo, en la proporción entre tres tipos de texto en la cultura científica extrínseca, se puede detectar la diferencia entre los dos países. CEXTR ocupa el 29,5\% en España y el 46,3\% en Corea. Los artículos coreanos tenían mucho más CEXTR. Puede interpretarse que la referencia al darwinismo en el contexto social es mucho más frecuente que la de España. En cambio, CEXTOP es 27,3\% en España y Corea posee sólo 6,7\%. La alta proporción de los artículos con CEXTOP en España se puede explicar con la celebración del año Darwin y la apertura de Museo de la Evolución Humana en Burgos. En Corea, había menos actividades conmemorativas y por tanto se introdujeron relativamente en pocos artículos. España tiene 12,5\% de CEXTVA y Corea 10,0\% y la diferencia es pequeña. Entre las imágenes incluidas en los artículos, las imágenes de la cultura intrínseca son 45,1\% en España y 41,5\% en Corea. Las imágenes extrínsecas son 41,2\% en España y 45,3\% en Corea.

Si resumimos el resultado de la codificación de los artículos periodísticos mediante MCC:

- La proporción entre la cultura científica intrínseca y extrínseca en los artículos periodísticos que incluyen el darwinismo en España es similar a la proporción de Corea del Sur.

- La proporción entre la información representacional, operacional y valorativa (tipos de la información) en la cultura científica intrínseca en los artículos periodísticos que incluyen el darwinismo en España es similar a la proporción de Corea del Sur.

- Corea tiene más artículos que incluyen informaciones representacionales de la cultura científica extrínseca que España. España tiene más artículos que incluyen informaciones operacionales de la cultura científica extrínseca que Corea del Sur.

Entre España y Corea, no había gran diferencia en la proporción de cultura intrínsecaextrínseca en el análisis de los libros de texto y en el análisis de los artículos periodísticos tampoco. Significa que en la proporción influye más la característica del texto que la cultura científica de la sociedad. 
Después del análisis con MCC, estudiamos los artículos más en detalle con varios criterios para textos periodísticos. Los artículos periodísticos fueron clasificados según secciones, géneros, autores, fuentes y encuadres, y se analizaron por separado dos temas específicos (Novedades Científicas e Ideas Religiosas) obtenidos en este proceso.

Tomando estos análisis junto con el de MCC, podemos llegar a un resultado general en la investigación de los artículos periodísticos: En los artículos coreanos, 'el darwinismo en el contexto social (simbolizando la competencia en la sociedad)' es más visible que 'el darwinismo como teoría científica'. En los artículos españoles, 'el darwinismo como teoría científica' es mucho más claro que Corea. Las razones de tal síntesis son las siguientes:

- 59,4\% de los artículos españoles eran 'Noticias'. El porcentaje de Corea es sólo 14,4\%. Los periódicos coreanos no estaban activos en la comunicación de nuevos hechos relacionados con el darwinismo.

- 29,3\% de los artículos coreanos fueron escritos por 'Columnistas Externos' no científicos. Por lo general, mencionaron el darwinismo en artículos en contexto social.

- $\quad 49,8 \%$ de los artículos españoles tienen la 'Comunidad Científica' como su fuente del contenido. Sin embargo, sólo $13,2 \%$ de los artículos coreanos la tienen como su fuente.

- 27,6\% de los artículos coreanos abordan el 'Darwinismo en la sociedad'. En España, el peso del artículo es de $14,4 \%$.

- $\quad$ 16,6\% de los artículos españoles introdujeron 'Actividades Conmemorativas' del año Darwin, pero entre los coreanos solamente 3,8\% las mencionaron.

- 21,8\% de los artículos españoles transmiten 'Novedades Científicas' relacionadas con el darwinismo, pero Corea tiene sólo 4,1\%.

- La prensa coreana adopta una posición neutral en comparación con España en los artículos sobre el conflicto entre darwinismo y religión.

Este resultado puede expresar como el dibujo siguiente: 


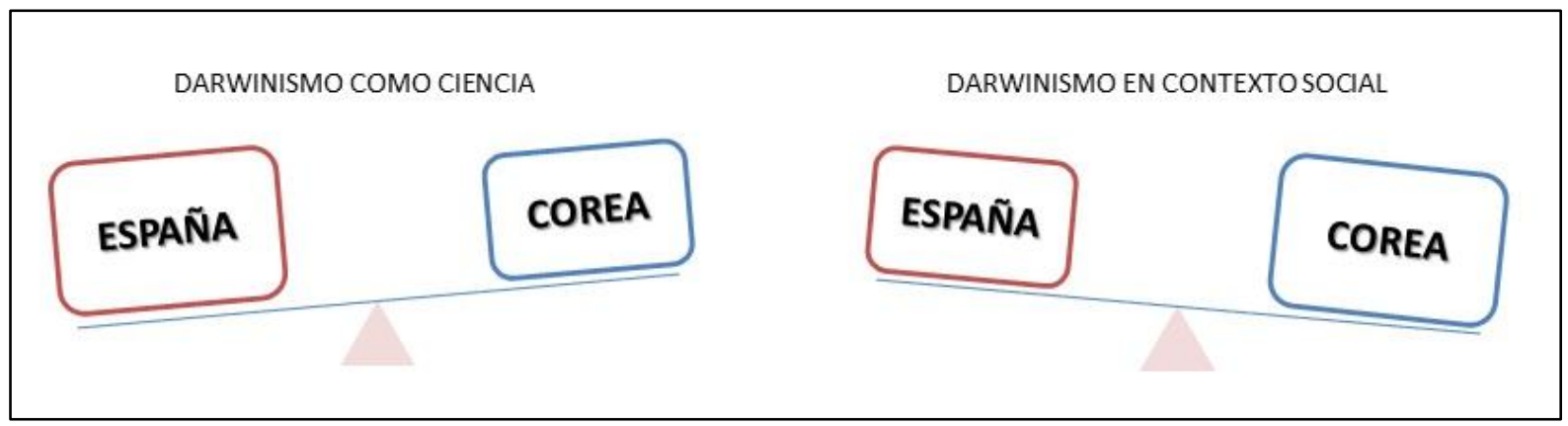

Ilustración 1. Darwinismo en España y Corea del Sur. Contexto científico y social

En los artículos de periódicos españoles, el darwinismo se muestra en detalle y se trata como una teoría científica. Sin embargo, los artículos de periódicos coreanos tratan más del 'darwinismo en el contexto social' y el 'darwinismo como teoría científica' no está muy visible. Entre los artículos de prensa españoles, hay mucho menos artículos sobre el darwinismo en el contexto social que en Corea. Los artículos españoles tienen una perspectiva mucho más 'científica' hacia el darwinismo.

En esta parte II, hemos analizado los aspectos actuales de la incorporación del darwinismo en España y Corea a través de libros de texto y artículos periodísticos, dos grandes vías del darwinismo para llegar al público. En el análisis con MCC, no había diferencias significativas entre los dos países en la relación entre la cultura científica intrínseca y extrínseca.

Las diferencias más destacadas en el análisis de los libros de texto fueron la presencia del 'Creacionismo' en los libros españoles y el énfasis en la 'Genética' de los libros coreanos. Podemos encontrar el motivo de la diferencia en la cultura y el proceso de la incorporación de la teoría, que investigamos en la parte I de esta tesis.

El sistema educativo español, creado en una cultura española con una clara tradición católica, no estaba libre de la influencia de la Iglesia Católica. El darwinismo, que se había eliminado en los libros de texto en la dictadura franquista, regresó a la educación en la segunda mitad de la dictadura, pero acompañado con el creacionismo para defenderse contra algún conflicto. Con el tiempo, el creacionismo en los libros de texto de ciencias se ha reducido a una parte de la historia de la ciencia, pero todavía aparece en los libros de texto que describen el darwinismo. 
Los libros de texto coreanos ponen énfasis en la genética. Definen la evolución genéticamente e incluyen abundantes informaciones genéticas pero no los conceptos básicos como las pruebas de la evolución. Pensamos que puede encontrarse la causa en la cultura coreana. En Corea, donde no existe una tradición de ciencia pura en sentido occidental, tampoco existe mucho interés en 'hacer ciencia'. Parece que se revela en los libros de texto de interés de la ciencia aplicada. Muestran las preferencias culturales sobre cómo la ciencia y la alta tecnología que pueden generar 'beneficio'.

La diferencia más destacada en el análisis de los artículos periodísticos entre España y Corea del Sur fue la cientificidad del darwinismo en la prensa. En los artículos españoles, 'el darwinismo como teoría científica' tenía más peso, mientras que los artículos coreanos mencionan 'el darwinismo en contexto social' con más frecuencia.

A través del análisis de los artículos periodísticos, podemos ver que en la cultura científica española que ha convivido con las tradiciones occidentales de la ciencia, el darwinismo está incorporado como una teoría científica sin lugar de duda aunque pasó una época de polémica. En la celebración del 'Año de Darwin', se prepararon varias actividades conmemorativas y se publicaron muchas noticias periodísticas. Se puede considerar que el año conmemorativo atrajo la atención social porque afectó el número de artículos hasta el año siguiente. A diferencia de los libros de texto, que no pueden independizarse de la tradición del sistema educativo y las políticas del gobierno, en los artículos periodísticos fue difícil encontrar la religiosidad de la sociedad española.

Por otra parte, en Corea, que ha aceptado el darwinismo en un contexto social sin tradición científica en el sentido occidental, se pueden encontrar rastros de su apropiación sociológica en sus artículos periódicos incluso después de más de 100 años.

El darwinismo se utilizó como herramienta para explicar la 'competencia' en el contexto social en lugar de como una 'teoría científica' fundamental de la biología moderna. La celebración del bicentenario de Darwin fue también mucho menor que en España. Aunque el número de artículos aumentó, se publicaron diversos libros conmemorativos y columnistas externos escribieron más artículos para honrar a Darwin, la influencia no duró mucho. 
En resumen, en el análisis mediante el modelo de Cultura Científica (MCC), la naturaleza del texto (libro de texto o artículo periodístico) influye más que los factores culturales de la sociedad en la proporción entre la cultura intrínseca y extrínseca.

Los análisis complementarios mostraron las diferencias entre los dos países más claramente. El motivo de las diferencias se puede encontrar en el contexto cultural que hemos visto en la parte I. La religiosidad de la cultura española influyó en los libros de texto, pero en los artículos de prensa es difícil encontrar su influencia hoy en día. Y el contexto 'sociológico' del primer encuentro entre el darwinismo y la sociedad coreana sigue influyendo en los artículos periodísticos. La cultura científica coreana, que prefiere las ciencias aplicadas que pueden generar beneficios a las ciencias puras, puede ser el motivo de la importancia de la genética en los libros de texto. 
CONCLUSIONES GENERALES 
Este estudio se construye a partir de la hipótesis de que los factores culturales influirán en el proceso de la incorporación de una determinada teoría científica a la sociedad. El darwinismo puede ser una teoría adecuada para investigar esta cuestión, ya que provocó muchos debates sociales debido a la inclusión de una nueva visión de los seres vivos. De hecho, el propio Darwin también estaba interesado en las distintas reacciones a su teoría en cada país. Estudiamos la incorporación del darwinismo en España y Corea como ejemplos de la cultura occidental y oriental respectivamente para obtener una perspectiva más global.

La investigación comenzó comparando los trasfondos filosóficos de las dos culturas con las implicaciones filosóficas del darwinismo. Y se examinó la transmisión del darwinismo a España y Corea y su transcurso, y su incorporación hoy en día en la sociedad española y coreana. Luego, a través del análisis de libros de texto y artículos periodísticos del darwinismo, que son las principales vías del darwinismo para llegar al público, estudiamos más en detalle la incorporación en los dos países.

\section{El Darwinismo y la Filosofía Occidental y Oriental}

El darwinismo, como se sabe, explica la diversidad de todos los seres vivos en la Tierra, incluido el ser humano, con una manera totalmente diferente de la que dominaba Occidente en el momento de su presentación.

Según el pensamiento occidental de entonces, el Dios Creador creó todos los seres vivos y cada especie poseía su esencia inmutable. El mundo tenía una causa final y el ser humano era la cumbre de la Creación Divina.

Sin embargo, Darwin explicó los fenómenos biológicos sin Dios. Según el naturalista británico, sin ninguna intervención de Ser Supremo, las especies cambian gradualmente y se ramifican. La selección natural y sexual fue su mecanismo.

El pensamiento de Darwin parecía incompatible con el tradicional, especialmente con la fe cristiana. La oposición de la Iglesia era natural. En el mundo académico, que todavía no estaba libre de la influencia de la religión, también era difícil de aceptar el darwinismo de inmediato. De ahí que surgieran debates no solo religiosos y sino también académicos. 
Sin embargo, el darwinismo no era una teoría impactante para la filosofía oriental, sino era un pensamiento compatible con su tradición. El 'cambio' es uno de los conceptos básicos y principales de la filosofía y en ella no existe Dios Creador. En la filosofía, que ve al mundo como una gran armonía, el ser humano sólo es un miembro de esta armonía con otros animales. Es diferente del ser humano en la filosofía occidental que domina la naturaleza con la autoridad dada por Dios.

El darwinismo tiene más puntos semejantes con pensamientos orientales, que se basan en el cambio, la armonía y el equilibrio, que los occidentales del teocentrismo, el esencialismo y el finalismo.

Por supuesto, no significa que toda la filosofía oriental encaje perfectamente con el darwinismo. Pero al menos, entre las filosofías principales de Oriente, no existe filosofía que pueda ser incompatible con el darwinismo e impida la incorporación de la teoría en la sociedad.

\section{La Transmisión del Darwinismo}

En el primer encuentro entre el darwinismo y la sociedad española, el factor social más importante fue la religión. Casi inmediatamente la teoría se incluyó en la lista de censura de Iglesia Católica. Académicamente la influencia de Francia y Alemania fue notoria.

La teoría de Darwin no tardó mucho en llegar a España. Sin embargo, la transmisión fue parcial, solamente alguna parte de ésta se introdujo. En aquellos días en el campo académico de España, la filosofía y la religión ocupaban la cosmovisión y la ciencia no tenía mucho poder de tratarla. España aceptó el darwinismo poco a poco, normalmente en la forma más moderada como el evolucionismo teísta y finalista de origen francés y alemán, debido a que eran más 'cómodos' en el ambiente intelectual de entonces.

Durante los seis años de democracia, con la libertad de publicación y el aumento de estudios científicos, comenzó a publicarse libros relacionados de la teoría de la evolución en España. Sin embargo, con la Restauración Borbónica cambió el ambiente. La Iglesia Católica definió el darwinismo como una teoría 'ateísta-materialista'; desde entonces, cada vez que 
la Iglesia tomaba el poder político, el darwinismo sufría censura y se descartaba en los libros de texto de Ciencia.

En la primera mitad del Franquismo, el darwinismo desapareció totalmente en el plan de estudio de la Secundaria y el Bachillerato bajo la censura estricta; en el ámbito universitario también se redujo el número de investigadores del darwinismo y muchos se exiliaron en el extranjero. En la segunda mitad de la dictadura el darwinismo poco a poco recuperó su campo en la enseñanza pública y en universidades.

En la época de Darwin, Corea era un país hermético. A finales del siglo XIX, tuvo que abrir forzadamente su puerto al exterior. De este modo, la cultura occidental se introdujo de golpe en Corea; por consiguiente, las teorías científicas también entraron en aquel momento, pero los coreanos no estaban preparados para entenderlas, debido a que la forma de pensar era diferente. Precisamente, dicha situación no facilitaba el que pudieran surgir debates científicos sobre ciertas teorías.

El darwinismo llegó a Corea a través de diversos países y algunos conceptos llamaron la atención. Intelectuales que se preocupaban el futuro del país introdujeron el darwinismo social, que utilizaba la selección natural para explicar la sociedad como si fuera un organismo. En la época no se daba ningún conflicto entre el darwinismo y la religión. Las religiones orientales eran compatibles con el darwinismo y el cristianismo apenas se estaba adaptando al país y no prestó atención a la teoría.

Algunos estudiosos que habían estudiado en el extranjero lideraron la primera apropiación del darwinismo en Corea. Como el país estaba sufriendo fuertes invasiones japonesas, 'fortalecer el país y sobrevivir' era inminente y persuasivo para ser un lema, y así se incorporó el darwinismo social en la sociedad. El darwinismo biológico se aceptó sin examen como si fuera una parte del darwinismo social.

Después de recuperar la soberanía con el fin de la Segunda Guerra Mundial, el darwinismo se incorporó inmediatamente en el primer sistema educativo de Corea del Sur y nunca ha sido censurado hasta ahora; de hecho, sigue siendo uno de los temas más importantes de la asignatura de Biología. El gobierno dictatorial de Corea censuró numerosos libros, pero el darwinismo no fue incluido en la lista. 


\section{El Darwinismo Actual}

El darwinismo se enfrentó a la oposición religiosa en España en los primeros años de su aceptación, pero Corea recientemente ha experimentado una situación similar. En 2012, hubo un intento para debilitar los contenidos del darwinismo en libros de texto cuyo eje principal era un grupo protestante.

Lo interesante es que el oponente en los conflictos entre el darwinismo y la religión siempre ha sido el 'cristianismo' en España y Corea del Sur, aunque se dieran en diferentes siglos. En España era la iglesia católica y en Corea del Sur el protestantismo de estilo estadounidense. Las religiones orientales nunca han mostrado algún movimiento contra el darwinismo.

Aparentemente la sociedad española se ve mucho más religiosa que la coreana. Corea del Sur afirma claramente en la Constitución la separación entre la religión y la política y no apoya el presupuesto nacional para ninguna entidad religiosa. Sin embargo, la Constitución Española menciona la Iglesia católica aparte y ofrece una parte del presupuesto nacional a la Iglesia. Podríamos afirmar que es un país católico y prácticamente $70 \%$ de los españoles son católicos.

Sin embargo, curiosamente entre los españoles que viven en una 'sociedad religiosa', $83,7 \%$ piensan que "el ser humano proviene de otros animales anteriores" (FECYT, 2015). Entre los coreanos que viven en una 'sociedad laica' relativamente, solamente $45 \%$ están de acuerdo con la frase (Gallup Korea, 2012).

El motivo de la diferencia se puede encontrar en la situación actual de las religiones occidentales en ambos países. Hoy en España, el catolicismo pertenece al ámbito cultural y no se presenta como una religión que se practique por mucha gente en su vida cotidiana. La iglesia no parece tener un impacto significativo en la cosmovisión de un creyente. Por otro lado, en Corea del Sur, las religiones occidentales, especialmente el protestantismo, influyen en la cosmovisión de creyente y la incorporación del darwinismo. Por lo tanto, podemos afirmar que hoy en día la creencia de un individuo es más influyente en la incorporación 
personal del darwinismo que el trasfondo filosófico y cultural de la sociedad en la que vive la persona.

En la primera parte de esta tesis, hemos examinado el trasfondo filosófico, la aceptación inicial y la incorporación actual del darwinismo en la sociedad española y la surcoreana. A continuación, con el fin de estudiar cómo se revelan estos factores culturales en los textos divulgativos del darwinismo hoy en día, hemos analizado en detalle cómo se muestra la teoría en los libros de texto y la prensa, que son los principales canales de las teorías científicas para llegar al público.

\section{Herramientas para analizar los Textos Divulgativos sobre el Darwinismo}

En este estudio aplicamos el modelo de Cultura Científica (Quintanilla, 2012) a los textos divulgativos del darwinismo en España y Corea del Sur para averiguar si se da una diferencia cultural en el 'carácter científico' de las informaciones. Y añadimos otros criterios complementarios para investigar más concretamente las informaciones del darwinismo considerando las características de texto didáctico y periodístico.

De acuerdo con el modelo, si una información es científica y está incorporada en el sistema científico de la sociedad, se la clasifica como 'cultura científica intrínseca' y si una información no es propiamente científica pero tiene relación con la ciencia, se la clasifica como 'cultura científica extrínseca'. Las informaciones intrínsecas en los textos divulgativos se pueden explicar con el 'modelo de déficit' de la comunicación de la ciencia, que la comunidad científica produce y transmite informaciones científicas al público unidireccionalmente. Las informaciones extrínsecas se pueden explicar con el 'modelo contextual' que da importancia a la relación ciencia-público. (Marcos, 2010; Montañés, 2010; Gross, 1994). Analizamos los textos divulgativos de España y Corea del Sur mediante el modelo y comparamos los dos países

Después del análisis con el modelo que averigua la cientificidad de las informaciones, realizamos investigaciones más detalladas sobre los contenidos de libros de texto y artículos 
periodísticos respectivamente, para obtener la diferencia y la semejanza en las informaciones darwinianas entre España y Corea del Sur.

Estudiamos la presencia e importancia de los conceptos concretos del darwinismo para observar cómo los libros de texto coreanos y españoles enseñan el darwinismo. En los artículos periodísticos, clasificamos por varios factores de prensa como autor, fuente de la información y género periodístico para detectar cómo y qué transmite la prensa española y coreana sobre el darwinismo.

\section{El Darwinismo en Libros de Texto}

Analizamos los contenidos sobre el darwinismo en libros de texto a través del modelo de Cultura Científica (MCC). En el resultado, no había gran diferencia en la proporción de la cultura intrínseca y extrínseca entre los dos países. El 93,3\% de los contenidos españoles y un $94,1 \%$ de los coreanos fueron informaciones intrínsecas. Las informaciones extrínsecas ocuparon el 8,4\% en España y un 9,8\% en Corea. Podíamos esperar el alto porcentaje de la cultura intrínseca debido a que los contenidos son para enseñar una teoría científica en libros de texto de ciencias, pero es significativo que las proporciones de los dos países sean bastante similares. Parece que las diferencias culturales entre Corea y España no influyen en la proporción entre la cultura intrínseca y extrínseca en un mismo tipo de texto.

Aunque no existen grandes diferencias en los contenidos principales de los libros de texto de España y Corea, los libros de texto españoles están más estructurados en general. Los libros de texto coreanos para el primer curso de bachillerato presentan el darwinismo brevemente y no incluían ciertos contenidos esenciales, como pueden ser las pruebas de la evolución.

Las diferencias más destacadas entre España y Corea del Sur en sus libros de texto son la presencia del 'creacionismo' en todos los libros españoles y la importancia de la 'genética' en los libros coreanos.

Los cuatros libros españoles incluyeron el creacionismo, como el origen del fijismo y una teoría antecedente al darwinismo para explicar la vida en el contexto histórico de la ciencia. 
Sin embargo, en dos de los cuatro libros el creacionismo se presentó con un encuadre religioso acompañando un discurso del Papa y pinturas célebres sobre la Creación.

Esto se debe a que el sistema educativo en España ha sido tradicionalmente influenciado por la Iglesia Católica, y varias editoriales de libros de texto tienen raíces religiosas. En los libros de texto coreanos, es difícil encontrar el creacionismo, si está presente en ellos, es sólo para explicar el conflicto que sufrió el darwinismo contra la religión.

Los libros de texto coreanos se caracterizan por tener más información genética que los libros de texto españoles. Los libros españoles definen la evolución como 'cambio de las especies con el tiempo', pero los libros coreanos la definen genéticamente, como 'cambio de la frecuencia alélica en el acervo genético'. Esto puede explicarse como la influencia de la cultura coreana que admira los estudios prácticos y recientes, así como un contenido intrínseco más estricto.

Después de los libros actuales de texto, investigamos brevemente libros antiguos de texto que enseñaban el darwinismo de los años cuarenta a los noventa, para percibir el cambio de los contenidos sobre el darwinismo. En los libros de texto españoles, el darwinismo a veces desapareció y volvió por la influencia de la censura. En la época afectada, explicaron la teoría de la evolución con Lamarck y Mendel, sin mencionar a Darwin. Cuando el darwinismo volvió a los libros de texto en la segunda mitad de la dictadura, la teoría estaba acompañada con el creacionismo para generar una impresión sobre ella que fuera compatible con la fe cristiana. Por otra parte, en Corea del Sur el darwinismo siempre ha sido una de las teorías más importantes en los libros de texto de ciencias y nunca ha sido censurado. El darwinismo en los libros de texto coreanos nunca fue influido por la situación socio-política.

\section{El Darwinismo en Artículos Periodísticos}

Al igual que el resultado ofrecido por el estudio de los libros de texto, la diferencia entre España y Corea no tampoco fue tan notoria al analizar los artículos periodísticos con el MCC. Un $44,6 \%$ de los artículos españoles y un $46,6 \%$ de los coreanos tenían informaciones 
intrínsecas. Las informaciones extrínsecas ocuparon el 69,4\% en España y el 63\% en Corea. La diferencia entre los dos países es un poco mayor que la de libros de texto, pero aún es difícil anotar que sea algo significativo. Como el formato de los artículos periódicos es mucho más libre que los libros de texto, podíamos afirmar que la diferencia entre los dos países resulta mínima. A diferencia de los libros de texto que tienen más del $90 \%$ de las informaciones intrínsecas, los artículos periodísticos muestran mucho más informaciones extrínsecas que las intrínsecas tanto en España como en Corea. Esto también puede ser debido a la influencia del género de texto. Se puede detectar que las características del texto poseen una influencia más decisiva en la proporción entre la información intrínseca y extrínseca que la diferencia cultural en el análisis con el MCC.

El análisis más detallado de los artículos de prensa revela que en España el darwinismo ya está incorporado en la sociedad como una teoría científica, pero en Corea del Sur todavía destaca más el contexto social que el científico.

Casi la mitad de los artículos españoles tiene la comunidad científica como su fuente de la información, mientras que entre los artículos coreanos, solamente fue un $13,2 \%$. Los artículos españoles que informan sobre las novedades científicas del darwinismo fueron más de un $20 \%$. Sin embargo, entre los coreanos, solo fue del $4,1 \%$. La prensa española informó de varias actividades conmemorativas del Año Darwin, pero la coreana no informó mucho sobre ellas. Corea tiene más artículos que incluyeron la teoría en el contexto social.

A diferencia de los libros de texto, que están bajo la influencia de la política educativa, los artículos periodísticos son libres en cuanto a su contenido. La diferencia, que se advierte en los artículos periodísticos, muestra cómo está apropiado el darwinismo en la sociedad española y la coreana.

El darwinismo en España enfrentó a debates religiosos y científicos en los primeros años de su incorporación y a la repetida censura por situaciones políticas, pero recientemente las huellas de tales debates han desaparecido y los medios los tratan como una teoría científica importante. Por otro lado, en Corea, el darwinismo fue aceptado sin ninguna controversia en los primeros días, pero su aceptación fue casi exclusivamente sociológica. Y todavía en el 
ámbito de prensa se queda la imagen de la 'competencia social' en el darwinismo. El darwinismo como una teoría puramente científica aún no está presente con suficiencia en la prensa coreana.

\section{Balance de las Conclusiones}

El darwinismo es una teoría científica con una cosmovisión que se parece más a la filosofía oriental que a la filosofía occidental. Cuando el darwinismo fue presentado y llegó a España y a Corea, las primeras reacciones de los dos países se relacionaron con el trasfondo filosófico de la sociedad respectivamente.

En España, surgieron debates religiosos y académicos. Hubo esfuerzos para defender la filosofía tradicional y el papel de Dios en la naturaleza contra la teoría.

En Corea, por otra parte, se aceptó el darwinismo sin un claro argumento religioso o filosófico. Sin embargo, la teoría fue entendida como una teoría sociológica, debido a la situación socio-política de la época y a la carencia del campo académico en sentido moderno que podría discutir la teoría científicamente.

Durante el paso de la guerra y la dictadura, el darwinismo se incorporó gradualmente en la sociedad española, sufriendo las correspondientes censuras. En la sociedad coreana el darwinismo nunca ha sido censurado.

Sin embargo, según encuestas recientes, la proporción de los evolucionistas entre los españoles es mucho más alta que la de los coreanos. Aunque viven en una sociedad católica, hoy en día los españoles no practican mucho la religión. La sociedad coreana es oficialmente laica, pero los coreanos que creen en la religión occidental son creyentes fieles y muchos creen que Dios creó el mundo. El trasfondo filosófico de la sociedad ya no tiene una influencia decisiva en la aceptación del darwinismo de un individuo, sino que su religión parece mucho más poderosa.

No existe una diferencia significativa en la proporción entre las informaciones intrínsecas y extrínsecas en los textos divulgativos del darwinismo entre España y Corea, que hoy poseen 
un nivel de vida similar y garantizan la libertad de pensamiento. Los dos países tienen proporciones similares dependiendo del género del texto.

En los contenidos se encontraron algunas diferencias. La presencia del creacionismo en los libros de texto de biología de España muestra la religiosidad de la sociedad. La importancia de la genética en los libros de texto de Corea del Sur muestra su cultura que prefiere las ciencias aplicadas. Por otra parte, ya es difícil encontrar la religiosidad de la sociedad española en sus artículos periodísticos. Los artículos coreanos todavía mencionan más a menudo el darwinismo en el contexto social.

El darwinismo en los libros de texto de España todavía muestra cierta marca religiosa. Sin embargo, los artículos periodísticos del país no muestran la religiosidad de la sociedad, sino tratan el darwinismo como un hecho científico. En Corea del Sur, parece que su cultura práctica influyó en los libros de texto que enseñan el darwinismo y no se encuentra alguna huella del trasfondo filosófico de la sociedad en ellos. En la prensa coreana todavía queda la influencia de la aceptación inicial sociológica y hay más artículos que mencionan el darwinismo en el contexto social que en España.

Hoy en día, que la mayor parte del mundo comparte el sistema global de la ciencia y disfruta la comunicación libre entre países, el trasfondo filosófico de cada sociedad ya no parece influir mucho en la aceptación del darwinismo de la gente.

Sin embargo, como en España, algunas informaciones culturales se trasmiten al público en el aula escolar. En Corea, que aceptó la teoría científica como una teoría sociológica cuando no tenía un campo científico para aceptarla, todavía en los medios de comunicación se refiere al darwinismo más sociológicamente. La menor tasa de la aceptación de la evolución biológica por los coreanos en comparación con los españoles se puede deber al color sociológico del darwinismo en Corea y la influencia del protestantismo estadounidense. 


\section{REFERENCIAS BIBLIOGRÁFICAS}


AERTS, D. et al. (2007) World Views. From fragmentation to integration. Bruselas: VUB press.

AGAZZI, E. (2009) La evolución entre ciencia e ideología. ArtefaCTos, 2 (1), pp. 38-63.

$\mathrm{AHN}$, S. D. (2010) 진화론과 불교가 만나는 곳과 만나지 못하는 곳은 어디인가 [¿¿ónde se pueden encontrar el darwinismo y el budismo y dónde no?]. En: AHN, S. D. et al. 붓다와 다윈이 만난다면 [Si Buda se encuentra a Darwin]. Seúl: Seoul National University Press.

AIBAR, E. y QUINTANILLA, M. Á. (2002) Cultura tecnológica estudios de ciencia, tecnología y sociedad. Barcelona: ICE Universidad de Barcelona.

ALLPORT, G. W. Y ROSS, J. M. (1967) Personal Religious Orientation and Prejudice. Journal of Personality and Social Psychology, 5, pp. 432-443.

AYALA, F. J. (1994) La naturaleza inacabada. Ensayos en torno a la evolución. Barcelona: Salvat Editores S.A.

AYALA, F. J. (2007) Darwin y el Diseño Inteligente. Madrid: Alianza.

BENAVIDES, M. (1988) De la ameba al monstruo propicio. Raíces naturalistas del pensamiento de Ortega y Gasset. Madrid: Ediciones de la Universidad Autónoma de Madrid.

BLÁZQUEZ, F. (2007) Notas sobre el debate evolucionista en España (1900-1936). Revista de Hispanismo Filosófico, 12, pp. 23-44.

BLÁZQUEZ, F. (2009) La recepción del darwinismo en la universidad española (1939-1999). Anuario de Historia de la Iglesia, XVIII, pp. 55-68.

BLÁZQUEZ, F. (2013) Breve historia del darwinismo en España. Ambiociencia - Revista de Divulgación Científica, 11, pp. 23-28.

BOURDIEU, P. (1991) Language and Symbolic Power. Cambridge: Polity Press.

BRITISH COUNCIL (2009) Results of British Council Darwin International Survey. [En línea]. Disponible en: www.britishcouncil.org/darwin [Accesado 27/10/2012]

BRUMME, J. (2013) La transmisión del saber Darwin vía Francia. En: SINNER, C. (ed.) Comunicación y transmisión del saber entre lenguas y culturas. Múnich: Peniope.

CANNON, W. F. (1961) The Impact of Uniformitarianism. Two Letters from John Herschel to Charles Lyell, 1836-1837. Proceedings of the American Philosophical Society, 105 (3), pp. 301-314.

CENTRO DE INVESTIGACIONES SOCIOLÓGICAS (2016) Barómetro de abril 2016 Estudio número 3134. [En línea]. Disponible en: 
http://www.cis.es/cis/opencm/ES/1_encuestas/estudios/ver.jsp?estudio=14277, [Accesado 08/06/2016]

CLARAMONTE, V. (2010) Darwin: De dónde y adónde. Antecedentes y consecuencias del pensamiento evolucionista. Éndoxa: Series Filosóficas, 24, pp. 21-45.

CHO, K. H. (1992) 장자의 '우주’ 개념과 그 철학적 의미 [El concepto de 'Cosmos' de Zhuāngzĩ y su significado filosófico]. En: 중국철학연구회 [THE SOCIETY OF CHINESE PHILOSOPHY] (ed.), 동양의 자연과 종교의 이해 [Comprensión de la naturaleza y la religión en Oriente]. Seúl: Hyungsul.

CHO, K. I. (2007) 고등학교 과학과 교육 과정의 변천에 관한 연구 생물과 중심으로 [Estudio sobre el cambio de la enseñanza de Ciencias de la Naturaleza en bachillerato enfocando a la biología]. Tesis de Máster Oficial, Chungnam University.

CHOE, J. C. (2002) 다윈의 진화론: 철학 논의를 위한 기본 개념 [El evolucionismo de Darwin: Principios para debates filosóficos]. En: 철학연구회 [SOCIEDAD DE INVESTIGACIÓN FILOSÓFICA] (ed.) 진화론과 철학 [El Evolucionismo y la Filosofía]. Seúl: Filosofía y Realidad.

CHOE, J. C. (2010) '진화론적 해탈'은 가능한가 - 불교와 진화론의 지적 통섭 [¿¿Es posible el nirvana evolucionista? - La Consiliencia del Budismo y el Evolucionismo]. En: AHN, S. D. et al. 붓다와 다윈이 만난다면 [Si Buda se encuentra a Darwin]. Seúl: Seoul National University Press.

CHOE, J. C. (2012) 다원 지능: 공감의 시대를 위한 다윈의 지혜 [Inteligencia Darwinista: sabiduría de Darwin para la época de simpatía]. Seúl: Science Books.

DARWIN, C. (1859) On the Origin of Species by Means of Natural Selection, or the Preservation of Favoured Races in the Struggle for Life. Londres: John Murray.

DARWIN, C. (1870) To Armand de Quatrefages 28 May [1870]. En: DARWIN, F. y SEWARD, A. C. (eds.), More Letters of Charles Darwin. Londres: John Murray.

DARWIN, C. (1871) The Descent of Man, and Selection in Relation to Sex. Londres: John Murray. DARWIN, C. (1872) The Expression of the Emotions in Man and Animals. Londres: John Murray. DAWKINS, R. (1986) The Blind Watchmaker. Londres: Longman.

DAWKINS, R. (2009) The Greatest Show on Earth. The evidence for evolution. Londres: Transworld publisher.

DUPRÉ, J. (2006) El legado de Darwin. Qué significa hoy la evolución. Buenos Aires: Katz.

ENGELS, E. M. y GLICK, T. F. (2006) The Reception of Charles Darwin in Europe (The Reception of 
British and Irish Authors in Europe). Londres: Continuumbooks.

ESCOBAR, M. et al. (2014) Indicadores de cultura científica por comunidades autónomas. En: FECYT (ed.) Percepción Social de la Ciencia y la Tecnología 2014. Madrid: pp. 190-215.

FROMM, E. (1970) Phychoanalisis and Zen Buddism. En: FROMM, E. et al. (eds.), Zen Buddhism and Psychoanalisys. Nueva York: Haper \& Row.

FUNDACIÓN ESPAÑOLA PARA LA CIENCIA Y LA TECNOLOGÍA (ed.) (2015) Percepción Social de la Ciencia y la Tecnología 2014. Madrid: FECYT.

GALLUP KOREA (2012) 창조론과 진화론에 대한 여론조사 [Encuesta sobre el creacionismo y el evolucionismo]. [En línea]. Disponible en http//www.gallup.co.kr/gallupdb/reportContent.asp?seqNo=310\&pagePos=1, [Accesado 04/10/2012]

GALLUP KOREA (2015) 한국인의 조ㅇㅛㅛ 1984-2014 [The Religion of Koreans 1984-2014]. Seúl: Gallup Korea.

GERNET, J. (1982) Chine et Christianisme, action et reaction. París: Gallimard.

GERNET, J. (1999) El Mundo Chino. Barcelona: Crítica Barcelona.

GIRÓN, Á. (2008) Darwinismo y Política. Boletín de la Institución Libre de Enseñanza, 70-71, pp. 141160.

GLICK, T. F. y HENDERSON, M. G. (2001) The Scientific and Popular Receptions of Darwin, Freud, and Einstein. Toward an Analytical History of the Diffusion of Scientific Ideas. En: RUIZ, R. y PUIGSAMPER, M. A. (eds.) The Reception of Darwinism in the Iberian World. Londres: Kluwer Academic Publisher.

GLICK, T. F. y SHAFFER, E. (2014) The literary and Cultural Reception of Charles Darwin in Europe. Londres: Bloomsbury.

GLICK, T. F. (ed.) (1974) The Comparative Reception of Darwinism. Chicago: The University of Chicago Press.

GLICK, T. F. et al. (eds.) (1999) El darwinismo en España e Iberoamérica. Madrid: CSIC.

GODIN, B. y GINGRAS, Y. (2000) What is scientific and technological culture and how is it measured? A multidimensional model. Public Understanding of Science, 9, pp. 43-58.

GOMIS BLANCO, A. y JOSA LLORCA, J. (2009) Los primeros traductores de Darwin en España. 
Vizcarrondo, Bartrina y Godínez. Revista de la Asociación de Hispanismo Filosófico, 14, pp. 43 60.

GONZÁLEZ, W. J. (ed.) (2009) Evolucionismo: Darwin y los enfoques actuales. A Coruña: Netbiblo.

GONZÁLEZ, W. J. (2011) Darwinian Influence beyond Biology. The Cultural Impact of Evolutionism as Philosophical Conception. En: AGAZZI, E. y MINAZZI, F. (eds.) Evolutionism and Religion. Milan: Mimesis.

GRASA, R. (1987) El Evolucionismo de Darwin a la Sociobiología. Madrid: Cincel.

GREGORY, J. y MILLER, S. (1998) Science in Public Communication, Culture, and Credibility. Estados Unidos: Basic Books.

GROSS, A. G. (1994) The roles of rhetoric in the public understanding of science. Public Understanding of Science, 3 (1), pp. 3-23.

GROVES, T. et al. (2016) Ten years of science news: A longitudinal analysis of scientific culture in the Spanish digital press. Public Understanding of Science, 25 (6), pp. 691-705.

HAN, J. K. (2001) 동서양의 인간 이해 [Pensamientos sobre el ser humano de Oriente y Occidente]. Seúl: Seokwangsa.

HONG, S. W. (2010) 진화론과 기독교의 역사는 불교에 무엇을 말하는가 [¿¿Qué muestra la historia entre el darwinismo y el cristianismo al budismo?]. En: AHN, S. D. et al. 붓다와 다원이 만난다면 [Si Buda se encuentra a Darwin]. Seúl: Seoul National University Press.

HUH, D. H. (2004) 개화기 (1883-1905) 미국 유학생과 민족운동 [Estudiantes coreanos en el Estados Unidos y los movimientos nacionalistas en la época de aperture (1883-1905)]. 한국민족운동사연구 [Estudios de la historia de los movimientos nacionalistas de Corea], 38, pp. $39-63$

HULL, D. L. (1974) Darwinism and Historiography. En: GLICK, T. F. (ed.) The Comparative Reception of Darwinism. Chicago: The University of Chicago Press, pp. 388-402.

IM, C. H. y CHOI, J. D. (2010) 역사의 지평에서 찰스 다윈을 만나다 [Nos encontramos a Charles Darwin desde una perspectiva histórica]. En: $\mathrm{CHOI}$, J. D. (ed.) 찰스 다원, 한국의 학자를 만나다 [Charles Darwin encuentra a los investigadores coreanos]. Seúl: Humanist.

JEONG, H. K. (2002) 국가별 스타일로 바라본 다윈 진화론의 수용과 발전 [Acceptance and development of Darwinian evolution from country-style perspective]. 과학사상 [Revista de Pensamientos Científicos], 43, pp. 196-221. 
JEONG, Y. K. (2002) 진화생물학과 윤리학의 자연화 [La Biología Evolutiva y la Naturalización de la Ética]. En: 철학연구회 [Sociedad de Investigación Filosófica] (ed.) 진화론과 철학 [El Evolucionismo y la Filosofía]. Seúl: Filosofía y Realidad.

JUNG, E. S. et al. (2010) 신과 다원의 시대 [Época de Dios y Darwin]. Seúl: Segyesa.

KIM, D. C. (2015) 대한민국은 왜?: 1945-2015 [¿ंPor qué Corea del Sur es así?: 1945-2015]. Seúl: Sagyejeol.

KIM, D. I. (2016) 피에르 부르디외 [Pierre Bourdieu]. Seúl: Comunication Books.

KIM, H. K. (1992) 『주역』에 나타난 '도'의 의미 [El significado de 'Tao' en『IChing』]. En: THE SOCIETY OF CHINESE PHILOSOPHY (ed.) 동양의 자연과 종교의 이해 [Comprensión de la naturaleza y la religión en Oriente]. Seúl: Hyungsul.

KIM, H. C. (1995) 인물성동이논쟁 [Debate de la semejanza y la diferencia entre el ser humano y todas las cosas]. En: 한국철학사상연구회 [KOREAN ASSOCIATION FOR STUDIES OF PHILOSOPHICAL THOUGHT] (ed.) 논쟁으로 보는 한국철학 [Debates de la Filosofía Coreana]. Seúl: Yeomun.

KIM, H. Y. (2009) 미국에서의 사회다윈주의와 우생학: 도덕주의자들의 실패한 기획 [El darwinismo social y la eugenesia en EE.UU. el proyecto fracasado de moralistas]. 한국과학사학회지 [Revista de la Sociedad Coreana de la Historia de la Ciencia], 2 (31), pp. 303-324.

$\mathrm{KIM}$, S. C. y CHOI, J. D. (2010) 진화론적 사유가 동아시아의 사유와 만나다 [Pensamientos evolucionistas encuentran con pensamientos de Asia Oriental]. En: CHOI, J. D. (ed.) 찰스 다원, 한국의 학자를 만나다 [Charles Darwin encuentra a los investigadores coreanos]. Seúl: Humanist.

KIM, S. C. (2007) 다윈이 맹자와 만났을 때 - 고전적 유가 수양론의 진화론적 사유구조 [Cuando Darwin se encuentra a Mencio - Estructura evolutiva del pensamiento de la cultura moral en confucianismo clásico]. 의철학연구 [Revista de Estudios de la filosofía de la medicina], 4, pp. 69-84.

KIM, W. D. (2010) 번역과 한국의 근대 [La traducción y la modernidad coreana]. Seúl: Somyong.

KOH, O. E. (2013) El encuentro entre el darwinismo y la sociedad. Un estudio comparado de España y Corea del Sur. ArtefaCToS, 6 (1), pp. 81-107.

LAMARCK, J. B. (1809) Philosophie zoologique ou exposition des considerations relatives à l'histoire naturelle des animaux. París: Museum d'Histoire Naturelle.

LEE, H. G. (2002) 진화론의 관점에서 본 철학 [La filosofía desde el punto de vista evolucionista]. En: 철학연구회 [SOCIEDAD DE INVESTIGACIÓN FILOSÓFICA] (ed.) 진화론과 철학 [El Evolucionismo y 
la Filosofía]. Seúl: Filosofía y Realidad.

LEE, H. G. (2010) 진화론은 철학을 어떻게 변화시켰는가 [Cómo el evolucionismo cambió la filosofía]. En: AHN, S. D. et al. 붓다와 다윈이 만난다면 [Si Buda se encuentra a Darwin]. Seúl: Seoul National University Press.

LEE, J. W. (2014) 한국철학사 - 외래 사상과 토착 사상의 갈등과 융합 [Historia de la Filosofía Coreana Conflicto y Fusión entre Pensamiento Extranjero e autóctono]. Seúl: Idambooks.

LEE, S. K. (1992) 19세기말, 20세기초의 한국과 일본의 진화론 수용 [La apropiación del evolucionismo de Corea y Japón a finales del siglo XIX y al comienzo del siglo XX]. 한국과학사학회지 [Revista de la Sociedad Coreana de la Historia de la Ciencia], 1 (14), pp. 123-126.

LEE, S. K. (2001) 연구노트: 진화론 논쟁에서의 신라마르크주의 [Research Notes : Neo-lamarckism in the Debate of Evolution]. 한국과학사학회지 [Revista de la Sociedad Coreana de la Historia de la Ciencia], 2 (23), pp. 144-156.

MARCOS, A. (2010) Ciencia y Acción. Una filosofía práctica de la ciencia. México D. F.: Fondo de Cultura Económica.

MAYR, E. (1982) The Growth of Biological Thought: Diversity, Evolution, and Inheritance. Cambridge y Massachusetts: The Belknap Press of Harvard University Press.

MAYR, E. (1992) Una larga controversia. Darwin y el darwinismo. Barcelona: Crítica.

MAYR, E. (2001) What evolution is. Nueva York: Basic Books.

MAYR, E. (2004) Por qué es única la biología. Buenos Aires: Katz.

MILLER, J. D. et al. (2006) Public Acceptance of Evolution. Science, 313. Disponible en: www.sciencemag.org/cgi/content/full/313/5789/765/DC1, [Accesado 01/03/2014]

MONTAÑÉS, O. (2010) La cultura científica como fundamento epistemológico de la comunicación pública de la ciencia. ArtefaCToS, 3 (1), pp. 187-229.

MOSTERÍN, J. (1993) Filosofía de la cultura. Madrid: Alianza.

NEEDHAM, J. (1977) La Gran Titulación. Ciencia y Sociedad en Oriente y Occidente. Madrid: Alianza. NISBETT, R. E. (2003) The Geography of Thought. How Asians and Westerners Think Differently...and Why. Nueva York: The Free Press.

NORTHROP, F. S. C. (1946) The Meeting of East and West. Nueva York: The Macmillan.

NUMBERS, R. L. (2009) Galileo Goes to Jail and Other Myths about Science and Religion. 
Massachusetts: Harvard University Press.

NUMBERS, R. L. y STENHOUSE, J. (1999) Disseminationg Darwinism. The role of place, race, religion and gender. Cambridge: Cambridge University Press.

NUMBERS, R. L. (1998) Darwin comes to America. Boston: Harvard University Press.

NÚÑEZ, D. (1997) El darwinismo en España: un test significativo de nuestra situación cultural. Revista de Hispanismo Filosófico, 2, pp. 31-36.

ORELLANA, A. (2007) Cultura Científico-Tecnológica y Grupos Minoritarios. El caso de las Personas con Discapacidad. Tesis doctoral, Universidad de Salamanca.

PARÍS, C. (1968) Unamuno. Estructura de su mundo intelectual. Barcelona: Península.

PARK, I. M. (2007) 나비의 꼼이 세계를 만든다 [El sueño de mariposa crea el Mundo]. Seúl: Woongjin Munhak.

PARK, R. J. (2005) 우승열패의 신화 [La leyenda de 'Los fuertes ganan y los débiles pierden']. Seúl: Hankyoreh.

PARK, S. R. (1982) 중국에서의 진화론 - 양계초를 중심으로 [El evolucionismo en China - enfocando a Liang Qichao]. 한국과학사학회지 [Revista de la Sociedad Coreana de la Historia de la Ciencia]. 1(4), pp. 141-145.

PARK, S. Y. (1982) 한국에서의 다윈주의의 수용 [La incorporación del darwinismo en Corea]. 한국과학사학회지 [Revista de la Sociedad Coreana de la Historia de la Ciencia], 1 (4), 1982, pp. 145-146.

PARK, Y. H. (1995) The Natural and the Cultural. En: TIMIENIECKA, A. T. (ed.) Heaven, Earth, and InBetween in the Harmony of Life. Massachusetts: Kluwer Academic Publisher.

PELAYO, F. (1996) Creacionismo y evolucionismo en el siglo XIX: las repercusiones del Darwinismo en la comunidad científica española. Anales del Seminario de Historia de la Filosofía, 13, pp. 263284.

PELAYO, F. (2009a) Debatiendo sobre Darwin en España: Antidarwinismo, Teorías evolucionistas alternativas y Síntesis moderna. Revista de Historia de la Medicina y de la Ciencia, LXI (2), Juliodiciembre de 2009, pp. 101-128.

PELAYO, F. (2009b) Darwin en España. Las Controversias sobre la Teoría de la Evolución en la Comunidad Científica Española. Apuntes de Ciencia y Tecnología, 33, pp. 27-33.

PUELLES, M. y HERNÁNDEZ, M. (2009) El darwinismo en los manuales escolares de ciencias naturales 
de segunda enseñanza desde la publicación del "Origen de las especies" en España hasta finales del siglo XIX. Anuario de Historia de la Iglesia, XVIII, pp. 69-83.

QUINTANILLA, M. Á. (2005) Tecnología: Un enfoque filosófico. Y otros ensayos de filosofía de la tecnología. México D. F.: Fondo de Cultura Económica.

QUINTANILLA, M. Á. (2010) La ciencia y la cultura científica. ArtefaCToS, 3 (1), pp.31-48.

QUINTANILLA, M. Á. (1998) Técnica y cultura. Teorema, XVII (3), pp. 49-69.

QUINTANILLA, M. Á. (2002) Tecnología y cultura. En: AIBAR, E. y QUINTANILLA, M. Á. Cultura tecnológica estudios de ciencia, tecnología y sociedad. Barcelona: ICE Universidad de Barcelona, pp.15-38.

QUINTANILLA, M. Á. et al. (2011) Scientific and technological culture in ESO textbooks. [En Línea] Universidad de Salamanca. Disponible en: http://gredos.usal.es/jspui/handle/10366/122700 [Accesado 15/01/2016]

QUINTANILLA, M. Á. et al. (2005) Cultura Biotecnológica en España Análisis e Interpretación de Datos. Salamanca: Genoma España.

RUSE, M. (1988) Philosophy of Biology Today. Nueva York: State University of New York Press.

RUSSELL, B. (1972) A History of Western Philosophy. Nueva York: Simon \& Schuster.

SANDÍN, M. (2000) Sobre una redundancia: el darwinismo social. ASCLEPIO, LII (2), Madrid: CSIC.

SEONG, T. Y. (2001) 주역과 21세기 [I Ching y el siglo XXI]. Seúl: EBS.

SIMÓ, J. (2004) La Naturphilosophie en España. La Recepción del Evolucionismo en el entorno de la Tradición Krausista. Revista de Historia de la Medicina y de la Ciencia, LVI (2), pp. 197-222.

SKOOG, G. y BILICA, K. (2002) The Emphasis Given to Evolution in State Science Standards: A Lever for Change in Evolution Education? Science Education, 86 (4), pp. 445-462.

SOBER, E. (2000) Philosophy of Biology. Colorado: Westview press.

SONG, Y. B. (1994) 제자백가의 사상 [Estudios de Cien escuelas del Pensamiento]. Seúl: Hyuneumsa.

SONG, Y. B. (2012) 동서 철학의 충돌과 융합 [Choque y Fusión de la filosofía oriental y occidental]. Seúl: Sahoepyeongnon inc.

THE PALEONTOLOGICAL SOCIETY OF KOREA (2012) 교진추(교과서진화론개정추진위원회)의 청원서에 대한 공식 반론문 [Refutación oficial a la petición de la sociedad para revisión del evolucionismo en libro de texto]. 한국고생물학회지 [Journal of the Paleontological Society of 
Korea], 28 (1-2), pp. 153-159.

THE ROYAL SOCIETY (1985) The Public Understanding of Science. Londres: The Council of the Royal Society.

VIDAL, C. (2008) What is a worldwiew? En: VAN BELLE, H. y VAN DER VEKEN, J. (eds.) Thinking novelty. The sciences and the creative aspect of reality. Leuven: Acco.

WOO, H. J. (2010) 불교적 진화는 우리의 삶 속에서 어떻게 구현될 것인가 [¿Cómo se encarnará la evolución budista en nuestras vidas?]. En: AHN, S. D. et al. 붓다와 다윈이 만난다면 [Si Buda se encuentra a Darwin]. Seúl: Seoul National University Press.

WOO, N. S. (1999) 한국근대사에서의 사회 진화론 수용 양식 [El evolucionsimo social en la historia moderna coreana]. 한국정치외교사논총 [Journal of Korean Political and Diplomatic History], 7 (21), pp. 27-59.

WOO, N. S. (2010) 유길준과 에드워드 모스 연구 - 사상적 교류를 중심으로 [Research on Yu Kil-chun and Edward Morse : focusing on the exchange of their ideas]. 동양정치사상사 [Revista de Historia de los pensamientos políticos asiáticos], 2 (9), pp. 157-185.

WOO, N.S. (2011) 사회진화론의 동아시아 수용에 관한 연구: 역사적 경로와 이론적 원형을 중심으로 [Study on East Asian Acceptance of the Theory of Social Evolution: Focused on Acceptance Historical Path and Original Type]. 동양정치사상사 [Revista de Historia de los pensamientos políticos asiáticos], 2 (10), pp. 117-141.

YANG, I. M. (2008) 옌푸: 중국의 근대성과 서양사상 [Yan Fu La modernidad de China y los pensamientos occidentales]. Seúl: Taehaksa.

YANG, I. M. (2013) 동아시아의 사회 진화론 재고 - 중국과 한국의 '진화' 개념의 형성 [Reconsideración de evolucionismo social en Asia oriental - Formación del concepto de la 'evolución' en China y Corea]. En: HALLIM INSTITUTE OF SCIENCE (ed.), 두 시점의 개념사 - 현지성과 동시성으로 보는 동아시아근대 [Historia de conceptos desde dos puntos de vista - la modernidad de Asia Oriental a través del character local y la contemporaneidad]. Seúl: Purun Yeoksa, pp.69-97.

YOON, I. J. y YANG, D. Y. (2013) 한국인의 종교성과 종교적 배타성 [La religiosidad de los coreanos y su exclusividad religiosa], 아세아연구 [Revista de Estudios Asiáticos], 2 (56), Korea University, pp. 226-259.

YOON, S. S. (1986)한국유학사상론 [Pensamientos Confucianistas Coreanas]. Seúl: Yeolumsa. 


\section{Artículos Periodísticos}

BAE, M. K. (2015) 2016년 실제 공휴일 66일...4일 연휴는 설날 [66 días de festivos en 2016... 4 días para Año Nuevo]. Kyunghyang, 25 Feb. Disponible en:

http://news.khan.co.kr/kh_news/khan_art_view.html?artid=201502251126431 [Accesado $12 / 12 / 2015]$.

EL PAÍS (2015) Festivos nacionales: Calendario laboral para 2016. El País, 18 Oct. Disponible en: http://elpais.com/elpais/2015/10/18/media/1445183631_801101.html [Accesado $12 / 12 / 2015]$.

LEE, G. Y. (2012) 교과서에서 '시조새’ 뺀다고? 한국 실망이야 [¿¿Excluye el 'Archaeopteryx' en el libro de texto? Qúe decepción, Corea]. Hankyoreh, 14 Jul. Disponible en: http://www.hani.co.kr/arti/science/science_general/537861.html [Accesado 02/02/2015].

MOK, S. M. y SONG, H. S. (2012) 학회 시조새, 교과서 삭제 안된다... 기독교계·과학계 충돌 [La sociedad científica No se puede eliminar el 'Archaeopteryx' en el libro de texto... Conflicto entre la ciencia y el protestantismo]. Kyunghayng, 21 Jun. Disponible en: http://news.khan.co.kr/kh_news/khan_art_view.html?artid=201206212132495 [Accesado 02/02/2015].

PARK, S. B. (2012a) South Korea surrenders to creationist demands. Nature, 7 Jun. Disponible en: http://www.nature.com/news/south-korea-surrenders-to-creationist-demands-1.10773 [Accesado 02/02/2015].

PARK, S. B. (2012b) Science wins over creationism in South Korea. Nature, 6 Sep. Disponible en: http://www.nature.com/news/science-wins-over-creationism-in-south-korea-1.11377 [Accesado 02/02/2015].

TRAYWICK, C. (2012) South Korean Textbooks Reject Evolution. Time, 12 Jun. Disponible en: http://newsfeed.time.com/2012/06/12/south-korean-textbooks-embrace-creationism/ [Accesado 02/02/2015].

EUROPA PRESS (2015) La Iglesia recibirá cada mes 13,2 millones de euros en 2016. El Mundo, 4 Ago. Disponible en: http://www.elmundo.es/espana/2015/08/04/55c09aeb22601dc7018b4576.html [Accesado 10/08/2015].

\section{Constituciones}


Constitución Española 1978. Madrid: Cortes Generales de España.

대한민국 헌법 1987 [Constitución de República de Corea] . Seúl: Ministerio de Legislación de Corea del Sur.

\section{Datos en línea}

MINISTRY OF STRATEGY AND FINANCE OF KOREA (2015) Summary of Budget for FY2016. [En Línea].

Disponible en:

http://mosf.go.kr/com/synap/synapView.do?atchFileld=ATCH_000000000001017\&fileSn=1

[Accesado 03/10/2016].

KNOEMA (2016) World GDP Ranking 2015. [En Línea]. Disponible en:

http://knoema.es/nwnfkne/world-gdp-ranking-2015-data-and-charts [Accesado 15/12/2016].

STATISTIC KOREA (2014) 취학률과 진학률 [Ratio de inscripciones]. [En Línea]. Disponible en:

http://www.index.go.kr/potal/main/EachDtlPageDetail.do?idx_cd=1520 [Accesado 15/06/2015].

WORLDMETERS (2016) Countries in the world by population (2016). [En Línea]. Disponible en: http://www.worldometers.info/world-population/population-by-country [Accesado 15/12 2016]. 


\section{ANEXOS}


ANEXO I: LISTA DE MATERIALES DEL ANÁLISIS DE CONTENIDO

1. LIBROS DE TEXTO

1.1 Libros de texto actuales

1.1.1 España

1.1.2 Corea del Sur

1.2 Libros de texto antiguos

1.2.1 España

1.2.2 Corea del Sur

2. ARTÍCULOS PERIODÍSTICOS

2.1 Año 2008: El Mundo, El País, Hankyoreh y Joongang

2.2 Año 2009: El Mundo, El País, Hankyoreh y Joongang

2.3 Año 2010: El Mundo, El País, Hankyoreh y Joongang 


\section{LIBROS DE TEXTO}

\subsection{Libros de texto actuales}

\subsubsection{ESPAÑA}

\begin{tabular}{|l|l|l|l|}
\hline Asignatura & Editorial & Autores & Año \\
\hline $\begin{array}{l}\text { Biología y Geología } \\
\text { 4ESO }\end{array}$ & Anaya & $\begin{array}{l}\text { Salvador Balibrea, Antonio Álvarez, Alfredo Sáez, } \\
\text { Manuel Reyes y José Miguel Vílchez }\end{array}$ & 2008 \\
\cline { 2 - 4 } & Edelvives & $\begin{array}{l}\text { Francisco José Ortega Nieto, Francisco Marquez } \\
\text { Alvarez y Antonio Mora Pizarro }\end{array}$ & 2008 \\
\cline { 2 - 5 } & Santanilla & $\begin{array}{l}\text { Miguel Ángel Madrid Rangel, Ignacio Meléndez } \\
\text { Hevia, Marcos Blanco Kroeger y Eduardo Vidal- } \\
\text { Abarca }\end{array}$ & 2008 \\
& S.M. & Emilio Pedrinaci y Concho Gil & 2009 \\
\hline
\end{tabular}

\subsubsection{COREA DEL SUR}

\begin{tabular}{|l|l|l|l|}
\hline Asigantura & Editorial & Autores & Año \\
\hline $\begin{array}{l}\text { 고등학교 과학 } \\
\text { [Ciencias Bachillerato] }\end{array}$ & Chunjae & $\begin{array}{l}\text { Oh, P. S., Yoo, S. W., Lee, S. Y., Bae, M. J., Son, J. } \\
\text { W., So, Y. M., Lee, B. W., Choi, S. Y. y Choi, S. K. }\end{array}$ & 2011 \\
\cline { 2 - 4 } & Kumsung & $\begin{array}{l}\text { An, T. I., Lee, M. W., Lee, S. Y., An, J. S., Kwon, } \\
\text { S. M., Kim, M. H., Han, I. S., Shin, S. J., Ha, Y. K., } \\
\text { Kim, D. J., Chae, K. P. y Kim, Y. H. }\end{array}$ & 2011 \\
\cline { 2 - 5 } & Sangsang & $\begin{array}{l}\text { Kim, H. J., Kang, J. H., Kwon, Y. S., Kim, S. K., } \\
\text { Lee, M. K., Lee, Y. K., Lee, J. S. y Cheon, B. H. }\end{array}$ & 2013 \\
\cline { 2 - 5 } & The Text & $\begin{array}{l}\text { Kwak, Y. J., Park, J. I., Kang, S. C., Woo, M. S., } \\
\text { Kim, J. W., Roh, K. J., Park, M. A. y Park, K. S. }\end{array}$ & 2011 \\
\hline $\begin{array}{l}\text { 고등학교 생명과학 II } \\
\text { [Biología II Bachillerato] }\end{array}$ & Bisang & $\begin{array}{l}\text { Shim, K. C., Yeo, S. H., Kim, Y. J., Hwang, E. W., } \\
\text { An, P. H. y Lee, I. K. }\end{array}$ & 2012 \\
\cline { 2 - 5 } & Chunjae & $\begin{array}{l}\text { Lee. J. K., Lee, B. R., Koo, H. M., Oh, H. S., Yoo, } \\
\text { H. M. y Kang, H. J. }\end{array}$ & 2011 \\
\hline
\end{tabular}

\subsection{Libros de texto antiguos}

\subsubsection{ESPAÑA}

\begin{tabular}{|l|l|l|l|}
\hline Año & Asigantura & Editorial & Autores \\
\hline 1940 & Biología & Instituto de Enseñanza Media & Salustio Alvarado \\
\hline 1958 & Biología General & Instituto de Enseñanza Media & Salustio Alvarado \\
\hline 1964 & Biología General & Instituto de Enseñanza Media & Salustio Alvarado \\
\hline 1966 & Biología Preuni & Instituto de Enseñanza Media & $\begin{array}{l}\text { Carrato Ibañez, A., Fernandez-Galiano, } \\
\text { D., Alvira Alvira, T. y Vives Codina, J. }\end{array}$ \\
\hline 1967 & CC. Naturales & Instituto de Enseñanza Media & Salustio Alvarado \\
\hline 1971 & Biología COU & Instituto de Enseñanza Media & Salustio Alvarado \\
\hline
\end{tabular}




\begin{tabular}{|l|l|l|l|}
\hline 1975 & CC. Naturales & Editorial Librería General & $\begin{array}{l}\text { Luis García-Amorena Sánchez y Agustín } \\
\text { Sanmiguel Mateo }\end{array}$ \\
\hline 1979 & Biología COU & ECIR & Dualde, V. \\
\hline 1983 & Biología COU & ECIR & Dualde, V. \\
\hline 1985 & CC. Naturales & ECIR & Dualde, Vy Lillo, J. \\
\hline 1992 & Biología COU & Edelvives & $\begin{array}{l}\text { Bonilla Mangas, I., Díaz Miguel, E. y } \\
\text { Sanz Esteban, M. }\end{array}$ \\
\hline 1995 & Biología COU & CIDEAD & $\begin{array}{l}\text { Fernandez, M. A., Martínez, M. J., } \\
\text { Rodríguez, R., de la Rubia, M. E. y } \\
\text { Torres, M. D. }\end{array}$ \\
\hline
\end{tabular}

\subsubsection{COREA DEL SUR}

\begin{tabular}{|l|l|l|l|}
\hline Año & Asigantura & Editorial & Autores \\
\hline 1949 & 고등생물 [Biología Avanzada] & Donga Munhwasa & Park, M. K. \\
\hline 1950 & 생물 하 [Biología II] & Paikyongsa & Kang, Y. S. \\
\hline 1956 & 고등생물 [Biología Avanzada] & Yongji Munhwasa & Choi, K. C. y Kim, J. M. \\
\hline 1960 & 고등생물 [Biología Avanzada] & Hankook Guminjung & Lee, H. J. y Na, Y. S. \\
\hline 1968 & 새로이 생물 [Nueva Biología] & Kwahak Jinheungsa & Yang, W. Y. y Kim, J. H. \\
\hline 1974 & 생물 II [Biología II] & Dongkook Munhwasa & $\begin{array}{l}\text { Shin, Y. W., Kim, K. H., Lee, S. } \\
\text { S., Kim, W. K. y Kim, H. S. }\end{array}$ \\
\hline 1981 & 생물 [Biología] & Moonhosa & Lee, I. K., Lim, H. B. y Kim, D. M. \\
\hline 1983 & 생물 I, II [Biología I, II ] & Kyohaksa & Kang, M. S. y Lee, I. K. \\
\hline 1991 & 생물 [Biología] & Neungryuk Gaebal & Ha, D. B., Park, Y. C. y Kim, S. K. \\
\hline 1993 & 생물 [Biología] & Kyohaksa & Kang, M. S. y Lee, I. K. \\
\hline 1995 & 생물 I [Biología I] & Kumsung & $\begin{array}{l}\text { Kim, J. H., Nam, S. Y., Lee, H. D., } \\
\text { Jeong, W. H. y Kim, C. E. }\end{array}$ \\
\hline 1998 & 생물 II [Biología II] & Jihaksa & Jeong, H. M. y Yoon, K. I. \\
\hline
\end{tabular}




\section{ARTÍCULOS PERIODÍSTICOS}

\subsection{AÑO 2008}

\begin{tabular}{|c|c|c|}
\hline Fecha & Periódico & Títular \\
\hline 04/01/2008 & El Mundo & Hallan tres nuevas especies de salamandras en Costa Rica \\
\hline 06/01/2008 & El Mundo & Las grandes rectificaciones de los científicos más prestigiosos \\
\hline 08/01/2008 & El Mundo & Diseño no demasiado inteligente. \\
\hline 29/01/2008 & El Mundo & Matanza a golpes de 53 leones marinos en una playa de las islas Galápagos \\
\hline $29 / 01 / 2008$ & El Mundo & Mis héroes de la conservación en España \\
\hline $12 / 02 / 2008$ & El Mundo & Celebrando a Darwin \\
\hline $13 / 02 / 2008$ & El Mundo & El eslabón perdido de los murciélagos \\
\hline $14 / 02 / 2008$ & El Mundo & 'Puedes ser el Dios del Universo' \\
\hline 19/04/2008 & El Mundo & El Darwin original, en Internet \\
\hline 07/05/2008 & El Mundo & Don 'Carlos' Darwin, el naturalista chistoso que hablaba español \\
\hline $15 / 05 / 2008$ & El Mundo & Subastada en Londres una carta en la que Einstein calificó la religión como 'infantil' \\
\hline 05/06/2008 & El Mundo & Los gestos faciales regulan los sentidos \\
\hline 30/06/2008 & El Mundo & Darwin, una polémica que dura siglo y medio \\
\hline 09/07/2008 & El Mundo & El 'eslabón perdido' de los lenguados \\
\hline $26 / 08 / 2008$ & El Mundo & El secreto genético de las plumas de colores y los grandes cuernos de muchas especies \\
\hline 03/09/2008 & El Mundo & $\begin{array}{l}\text { Presentan el 'caparazón de cristal', una nueva ala del Museo de Historia Natural de } \\
\text { Londres }\end{array}$ \\
\hline 09/09/2008 & El Mundo & 'iPerfora, nena, perfora!' \\
\hline $12 / 09 / 2008$ & El Mundo & Un científico británico defiende la enseñanza del creacionismo en las escuelas \\
\hline $15 / 09 / 2008$ & El Mundo & 'Charles Darwin: la iglesia anglicana te debe una disculpa por malinterpretarte' \\
\hline 16/09/2008 & El Mundo & Las acciones Take Two caen un 25\% después de que Electronic Arts retirara su oferta \\
\hline $16 / 09 / 2008$ & El Mundo & Perdones eclesiales \\
\hline $27 / 09 / 2008$ & El Mundo & Premio Prisma de divulgación científica a la sección de Ciencia de EL MUNDO \\
\hline 20/10/2008 & El Mundo & Los volcanes originaron la vida en la Tierra \\
\hline $21 / 10 / 2008$ & El Mundo & España y Colombia celebran el bicentenario de un pionero de la botánica y la razón \\
\hline 01/11/2008 & El Mundo & El Vaticano celebra un Congreso sobre las relaciones entre la ciencia y la religión \\
\hline 02/11/2008 & El Mundo & La amenaza del cambio climático llega al Museo de Historia Natural de Nueva York \\
\hline $12 / 11 / 2008$ & El Mundo & El último ejemplar de tortuga Pinta de Galápagos no tendrá descendencia \\
\hline 20/11/2008 & El Mundo & Descubren cómo funcionan los ojos más primitivos en el mundo animal \\
\hline 04/12/2008 & El Mundo & Darwin más que nunca \\
\hline $10 / 12 / 2008$ & El Mundo & Los terremotos fuertes pueden desencadenar erupciones volcánicas \\
\hline $17 / 12 / 2008$ & El Mundo & El Hard Rock Madrid se reinventa de la mano de El Canto del Loco \\
\hline $22 / 12 / 2008$ & El Mundo & Sobre la diversidad \\
\hline $22 / 12 / 2008$ & El Mundo & La salud de los hijos de primos hermanos \\
\hline $30 / 12 / 2008$ & El Mundo & 2009: el año del 'padre' de la evolución \\
\hline
\end{tabular}

\begin{tabular}{|c|c|l|}
\hline Fecha & Periódicos & \multicolumn{1}{c|}{ Títular } \\
\hline $12 / 01 / 2008$ & El País & Los grandes hallazgos científicos, a sólo un 'click' \\
\hline $05 / 04 / 2008$ & El País & El mono luminoso \\
\hline $17 / 04 / 2008$ & El País & La obra completa de Darwin, en una página web \\
\hline $09 / 05 / 2008$ & El País & Leonardo Da Vinci, personaje más influyente de la cultura europea \\
\hline $03 / 06 / 2008$ & El País & Un juez rechaza la petición de Yoko Ono de prohibir usar 'Imagine' en una película \\
\hline $01 / 07 / 2008$ & El País & RNE lanza por primera vez un programa en Internet antes de emitirlo en las ondas \\
\hline $09 / 08 / 2008$ & El País & Tortugas gigantes en la isla del rey Perro \\
\hline $23 / 08 / 2008$ & El País & Desfile apasionante en el gran teatro urbano \\
\hline $01 / 09 / 2008$ & El País & La hija de 17 años de Sarah Palin, embarazada \\
\hline
\end{tabular}




\begin{tabular}{|l|l|l|}
\hline $14 / 09 / 2008$ & El País & La iglesia anglicana pedirá perdón a Charles Darwin \\
\hline $29 / 09 / 2008$ & El País & Seis billones de euros a quien demuestre la Teoría de la Evolución \\
\hline $06 / 12 / 2008$ & El País & La isla de las tierras coloreadas \\
\hline $25 / 12 / 2008$ & El País & El libro de cocina de la esposa de Darwin se publica en Reino Unido \\
\hline
\end{tabular}

\begin{tabular}{|c|c|c|}
\hline Fecha & Periódicos & Títular \\
\hline $15 / 01 / 2008$ & Hankyoreh & [시민편집인칼럼] ‘한겨레 공동체’를 꿈꾸며 \\
\hline $16 / 01 / 2008$ & Hankyoreh & "여성의 매력은 허리와 엉덩이 비율에 있다" \\
\hline $27 / 01 / 2008$ & Hankyoreh & 딱딱함 벗고 쉽게 풀어쓴 고전 \\
\hline $27 / 01 / 2008$ & Hankyoreh & 기술지향주의로 생태계 파괴 심각 \\
\hline $13 / 02 / 2008$ & Hankyoreh & '종의 기원' 150 돌 앞두고 진화론-창조론 긴장고조 \\
\hline 02/03/2008 & Hankyoreh & 인간 본성도 진화한다? \\
\hline 09/03/2008 & Hankyoreh & 닭다리 색깔이 노랗게 된 이유는? \\
\hline $10 / 03 / 2008$ & Hankyoreh & [종교계 짧은 소식] ‘붓다의 생애와 가르침’ 강좌...외 \\
\hline $28 / 03 / 2008$ & Hankyoreh & 3 월 29 일 교양 새 책 \\
\hline $11 / 04 / 2008$ & Hankyoreh & 연재중단 '옷 벗은' 검사의 못다한 0 애기 \\
\hline $13 / 04 / 2008$ & Hankyoreh & [세상읽기] '일벌레’ 권하는 한국사회 / 김영환 \\
\hline $16 / 04 / 2008$ & Hankyoreh & 봄 야생화 150 종 가릴 수 있어야 관문 통과 \\
\hline $18 / 04 / 2008$ & Hankyoreh & 도살은 인종차별이나 마찬가지다 \\
\hline 09/05/2008 & Hankyoreh & 과학과 문학사이 진화론 \\
\hline $16 / 05 / 2008$ & Hankyoreh & 소고기 등급기준 ‘마블링’은 자본의 음모 \\
\hline 19/05/2008 & Hankyoreh & [블로그] 우리아이의 모델은 레오나르도 다빈치 \\
\hline $01 / 06 / 2008$ & Hankyoreh & 다니엘 리 "나는 인간인 척하는 동물이다" \\
\hline 06/06/2008 & Hankyoreh & 지구를 생명체로 간주임박한 위기극복 꾀해 \\
\hline $11 / 06 / 2008$ & Hankyoreh & 170 여년전 다윈의 항해길 한국 과학자 되짚어간다 \\
\hline $22 / 06 / 2008$ & Hankyoreh & 인용문과 결론의 정합성 따지라 \\
\hline $27 / 06 / 2008$ & Hankyoreh & 6 월 28 일 잠깐 독서 \\
\hline $27 / 06 / 2008$ & Hankyoreh & 복잡계 경제학, 대안이론 될까 \\
\hline $13 / 07 / 2008$ & Hankyoreh & 공통논지 추출 뒤 논거를 정리하라 \\
\hline $18 / 07 / 2008$ & Hankyoreh & ‘다윈의 권위' 상식으로 맞서다 \\
\hline $25 / 07 / 2008$ & Hankyoreh & [기고] 껍질을 벗어 버려라 / 배태영 \\
\hline 04/09/2008 & Hankyoreh & [세상읽기] 한 번 해병은 영원한 해병? / 김형경 \\
\hline 05/09/2008 & Hankyoreh & 9 월 6 일 잠깐 독서 \\
\hline $26 / 09 / 2008$ & Hankyoreh & [삶의창] 창조 이야기 / 박기호 \\
\hline $29 / 09 / 2008$ & Hankyoreh & ‘미생물이 우주로 진화하기까지' 교육효과 탁월 \\
\hline $01 / 10 / 2008$ & Hankyoreh & 미안해하되, 당신 갈 길 가 \\
\hline $10 / 10 / 2008$ & Hankyoreh & 과학자들의 진실게임 - 그 법칙은 내꺼야! \\
\hline $15 / 10 / 2008$ & Hankyoreh & 10 월 16 일 학술 새책 \\
\hline $15 / 10 / 2008$ & Hankyoreh & DNA 이중나선에 얽힌 드라마틱한 이야기 \\
\hline $17 / 10 / 2008$ & Hankyoreh & 10 월 18 일 교양 새 책 \\
\hline $17 / 10 / 2008$ & Hankyoreh & 인류의 조상찾기, 그 행복한 괴로움 \\
\hline $20 / 10 / 2008$ & Hankyoreh & 뇌도 격렬한 운동 중에는 (근육처럼) 젓산을 사용한다 \\
\hline $24 / 10 / 2008$ & Hankyoreh & 10 월 25 일 지성 새 책 \\
\hline $24 / 10 / 2008$ & Hankyoreh & 불안을 먹고 사는 보험 \\
\hline $03 / 11 / 2008$ & Hankyoreh & '일 군국주의.나치' 한국.독일서 발 못붙여 \\
\hline $07 / 11 / 2008$ & Hankyoreh & '동물의 왕국' 시청자의 은밀한 심리 \\
\hline $12 / 11 / 2008$ & Hankyoreh & 과학관도 '베토벤 바이러스’? \\
\hline $14 / 11 / 2008$ & Hankyoreh & 11 월 15 일 지성 새 책 \\
\hline $14 / 11 / 2008$ & Hankyoreh & 위기는 자유의지의 힘 보여줄 기회 \\
\hline $20 / 11 / 2008$ & Hankyoreh & 돌·흙과 지구 생명체 함께 진화했다 \\
\hline $23 / 11 / 2008$ & Hankyoreh & [유레카] 진화와 민주주의 / 김지석 \\
\hline $28 / 11 / 2008$ & Hankyoreh & 마음의 작동원리?‘신’도 ‘다윈’도 틀렸어 \\
\hline $12 / 12 / 2008$ & Hankyoreh & 세계 최고 진화론자들의 '끝장논쟁' \\
\hline
\end{tabular}




\begin{tabular}{|l|l|l|}
\hline $12 / 12 / 2008$ & Hankyoreh & 다윈도 괴테도 카프카도 않았던 그것 \\
\hline $19 / 12 / 2008$ & Hankyoreh & '어둡고 험한 시대' 격랑 건너는 법 \\
\hline $19 / 12 / 2008$ & Hankyoreh & [삼의창] 성탄 등을 달면서 / 박기호 \\
\hline $26 / 12 / 2008$ & Hankyoreh & 12 월 27 일 잠깐 독서 \\
\hline $30 / 12 / 2008$ & Hankyoreh & 천문·진화론의 해...날아라 '한국형 위성발사체' \\
\hline
\end{tabular}

\begin{tabular}{|c|c|c|}
\hline Fecha & Periódico & Títular \\
\hline $08 / 01 / 2008$ & Joongang & 가족과 함께보는 특별한 체/험/전 \\
\hline $17 / 01 / 2008$ & Joongang & [김영희칼럼] 실용주의 과잉을 경계한다 \\
\hline $18 / 01 / 2008$ & Joongang & [BOOK 북카페] ‘수컷사냥’ 보바리 부인의 DNA 는 ... \\
\hline $18 / 01 / 2008$ & Joongang & [BOOK 책갈피] 종교라는 이름 뒤에 감춰진 ‘잔인한 폭력' \\
\hline $02 / 02 / 2008$ & Joongang & [행복한책읽기 Review] 읽은 책 권수 늘어나면서 잘난 사람 앞에서 '기살아' \\
\hline $06 / 02 / 2008$ & Joongang & $\begin{array}{l}\text { 세계적 철학자 } 7 \text { 명 릴레이 인터뷰 (6) 비토리오 회슬레 미 노틀댐대 } \\
\text { 석좌교수 }\end{array}$ \\
\hline $22 / 02 / 2008$ & Joongang & [과학칼럼] 웃으면 즐거워지는 뇌 \\
\hline $04 / 03 / 2008$ & Joongang & 세계적 철학자 7명 릴레이 인터뷰 (8).끝 김재권 미 브라운대 석좌교수 \\
\hline $28 / 03 / 2008$ & Joongang & [혁이삼촌의꽃따라기] 풍도는 '한국의 갈라파고스' \\
\hline $29 / 03 / 2008$ & Joongang & [글로벌책읽기] 꼬리를 무는 폭력 ... 피로 물든 라틴아메리카 \\
\hline $29 / 03 / 2008$ & Joongang & [BOOK 책갈피] “진화론은 현재 진행형 ... 창조론은 이제 접으시죠" \\
\hline $26 / 04 / 2008$ & Joongang & [BOOK 책갈피] 냉혹하다는 편견 버려라 과학은 따뜻하고 아름답다 \\
\hline $07 / 05 / 2008$ & Joongang & [MBA 스타강사들] "기업 현장이 최고 교과서" \\
\hline $10 / 05 / 2008$ & Joongang & [BOOK 책갈피] 교외로 나가야만 자연 느낀다? \\
\hline $15 / 05 / 2008$ & Joongang & 교황청 천문대 신부 “외계인도 형제자매” \\
\hline $17 / 05 / 2008$ & Joongang & [행복한책읽기 Review] ‘형에 치인 아우’가 역사를 바꿨다 \\
\hline $19 / 05 / 2008$ & Joongang & 4 억원 낙찰 아인슈타인 편지 속엔 ... \\
\hline $22 / 05 / 2008$ & Joongang & [노트북을 열며] 공짜가 없는 세상 \\
\hline $28 / 05 / 2008$ & Joongang & 미 "인문·자연과학 담을 넘어서" \\
\hline $30 / 06 / 2008$ & Joongang & 방학캠프 ‘바이오스피어 W 프로젝트’ 에 오세요 \\
\hline $04 / 07 / 2008$ & Joongang & [행복한책읽기 Review] 진화론으로 본 남녀관계 어제와 오늘 \\
\hline $21 / 07 / 2008$ & Joongang & "언어학은 진정한 통섭의 학문" \\
\hline $26 / 07 / 2008$ & Joongang & [새로 나온 책] 라틴아메리카의 근대를 말하다 外 \\
\hline $06 / 09 / 2008$ & Joongang & [BOOK 책갈피] 창조론 허점 파헤친 진화론의 반격 \\
\hline $30 / 09 / 2008$ & Joongang & 아이를 않이 낳으면 가난해진다고? \\
\hline $11 / 10 / 2008$ & Joongang & 언어 .... 자유 ...34 가지 질문 \\
\hline $13 / 10 / 2008$ & Joongang & 영국 명문대를 가다 (4) \\
\hline $18 / 10 / 2008$ & Joongang & [BOOK 책갈피] 진화론 확실하게 믿게 해 줄게 \\
\hline $18 / 10 / 2008$ & Joongang & [BOOK 북카페] 고독 ... 절망 ... 세기의 전환 그림으로 위안받은 뭉크 \\
\hline $25 / 10 / 2008$ & Joongang & [이 책과 주말을] 다양한 학문들의 짝짓기 '지적 이종교배' 현주소 \\
\hline $25 / 10 / 2008$ & Joongang & [새로 나온 책] 체계론으로 보는 세계사 外 \\
\hline $30 / 10 / 2008$ & Joongang & 여친이 바람 피우는 것 남자들은 다 안다 \\
\hline $29 / 11 / 2008$ & Joongang & [BOOK 책갈피] 자연선택 vs 다수준선택, 현대 진화론 맞짱 토론 \\
\hline $06 / 12 / 2008$ & Joongang & [BOOK 책갈피] 도구를 만드는 생명체 인간 말고도 또 있네 \\
\hline $27 / 12 / 2008$ & Joongang & [새로나온책] 서구의 자멸 外 \\
\hline
\end{tabular}

\subsection{AÑO 2009}

\begin{tabular}{|c|l|l|}
\hline Fecha & Periódico & \multicolumn{1}{c|}{ Títular } \\
\hline $05 / 01 / 2009$ & El Mundo & La iguana rosada que dio esquinazo a Darwin \\
\hline $14 / 01 / 2009$ & El Mundo & La expansión del 'Homo sapiens' \\
\hline $15 / 01 / 2009$ & El Mundo & ¿Volverían las especies a evolucionar igual si se les diese la oportunidad \\
\hline $16 / 01 / 2009$ & El Mundo & Atapuerca, tras el rastro de los primeros europeos \\
\hline $16 / 01 / 2009$ & El Mundo & Los monos capuchinos eligen su cascanueces \\
\hline
\end{tabular}




\begin{tabular}{|c|c|c|}
\hline $22 / 01 / 2009$ & El Mundo & ¡Eureka!'_Galileo y Darwin \\
\hline $22 / 01 / 2009$ & El Mundo & El Govern aprobará el Plan Ciencia 2009-2012 en las próximas semanas \\
\hline 30/01/2009 & El Mundo & Nace en la red la gran enciclopedia virtual de la biodiversidad ibérica \\
\hline 01/02/2009 & El Mundo & Más del $50 \%$ de la población británica no acepta la teoría de la Evolución de Darwin \\
\hline 05/02/2009 & El Mundo & Canales fueguinos \\
\hline 06/02/2009 & El Mundo & El museo más 'verde' del mundo abre en San Francisco \\
\hline 06/02/2009 & El Mundo & Las opiniónes religiosas de un presentador le cuestan dinero a su televisión \\
\hline 07/02/2009 & El Mundo & Desde Darwin, no se sostiene que un ser superior haya creado el mundo' \\
\hline 09/02/2009 & El Mundo & El ‘GPS’ mallorquín con el que navegó la expedición de Charles Darwin \\
\hline $10 / 02 / 2009$ & El Mundo & Charles Darwin, 200 años y un día \\
\hline $12 / 02 / 2009$ & El Mundo & Humanos y chimpancés, parientes no tan cercanos \\
\hline 12/02/2009 & El Mundo & La calle Darwin está en el Coll \\
\hline 13/02/2009 & El Mundo & El diario de un sabio viajero de sólo 22 años \\
\hline $13 / 02 / 2009$ & El Mundo & Presentado el primer borrador del genoma del neandertal \\
\hline $14 / 02 / 2009$ & El Mundo & Reflexiónes a partir de Darwin \\
\hline $16 / 02 / 2009$ & El Mundo & Inés Rodríguez afronta el reto de dirigir el Museo de la Ciencia \\
\hline 19/02/2009 & El Mundo & Darwin, protagonista en la Ciudad de las Artes \\
\hline 19/02/2009 & El Mundo & Paseando por ahí con Darwin \\
\hline $25 / 02 / 2009$ & El Mundo & El escribano palustre, 'Ave del Año 2009' \\
\hline $25 / 02 / 2009$ & El Mundo & La rápida evolución geográfica del VIH \\
\hline $28 / 02 / 2009$ & El Mundo & El 'gran pacto final' y la 'miopía' de la oposición \\
\hline 02/03/2009 & El Mundo & La Feria del Libro de Madrid mira a Francia en su 68a edición \\
\hline 07/03/2009 & El Mundo & CCOO y UGT desean seguir dando 'una oportunidad' a la negociación colectiva \\
\hline $12 / 03 / 2009$ & El Mundo & El Consejo Científico de Turquía censura un reportaje sobre Charles Darwin \\
\hline $15 / 03 / 2009$ & El Mundo & El presidente de Ecuador no recibirá al principe Carlos \\
\hline $16 / 03 / 2009$ & El Mundo & El 'Hombre de Pekín' envejece 200.000 años \\
\hline 24/03/2009 & El Mundo & Menorca capital de la ciencia \\
\hline $31 / 03 / 2009$ & El Mundo & De Galileo a Darwin, las mil y una odiseas de la Ciencia \\
\hline 01/04/2009 & El Mundo & Gorriónes negros \\
\hline 03/04/2009 & El Mundo & Presentan el primer tebeo infantil editado en España que aborda los viajes de Darwin \\
\hline 07/04/2009 & El Mundo & Culta, romántica y asequible \\
\hline 23/04/2009 & El Mundo & Diez lecturas para saber de ciencia \\
\hline $23 / 04 / 2009$ & El Mundo & El eslabón perdido del origen de las focas \\
\hline $23 / 04 / 2009$ & El Mundo & Humor contra el 'diseño inteligente' \\
\hline 05/05/2009 & El Mundo & La UMA inaugura en Teatinos el nuevo edificio del Jardin Botánico \\
\hline $14 / 05 / 2009$ & El Mundo & Un $12 \%$ de las aves, en peligro de extinción \\
\hline 20/05/2009 & El Mundo & El PUMA contra el Hummer \\
\hline 20/05/2009 & El Mundo & La UMA ofrecerá más de 30 cursos de verano basados en la 'calidad' \\
\hline 20/05/2009 & El Mundo & Mirando los confines del Universo \\
\hline $22 / 05 / 2009$ & El Mundo & 1796. Laplace expone 'el sistema del mundo' \\
\hline $22 / 05 / 2009$ & El Mundo & Descubierto el antepasado humano más primitivo \\
\hline $23 / 05 / 2009$ & El Mundo & Darwin y el colibrí \\
\hline 05/06/2009 & El Mundo & Sir' Naturaleza \\
\hline 08/06/2009 & El Mundo & El 'reloj' evolutivo de Darwin \\
\hline 08/06/2009 & El Mundo & Encuentro digital con Juan Luis Arsuaga \\
\hline 08/06/2009 & El Mundo & Uno de los 'pinzones de Darwin', en peligro crítico \\
\hline 09/06/2009 & El Mundo & Saramago_ 'La corrupción no le importa a nadie' \\
\hline 09/06/2009 & El Mundo & Siete lenguas, para seguir soñando \\
\hline $17 / 06 / 2009$ & El Mundo & Tarzán, de la selva al museo \\
\hline $17 / 06 / 2009$ & El Mundo & Un museo viejo y cercenado \\
\hline $18 / 06 / 2009$ & El Mundo & Lo caro es no hacer nada contra el cambio climatico' \\
\hline 19/06/2009 & El Mundo & Los escarabajos de las Islas \\
\hline 26/06/2009 & El Mundo & Una exposición recoge treinta años de excavaciónes en Atapuerca \\
\hline $27 / 06 / 2009$ & El Mundo & Memoria de un naturalista ejemplar \\
\hline
\end{tabular}




\begin{tabular}{|c|c|c|}
\hline $03 / 07 / 2009$ & El Mundo & El secreto regenerativo de las salamandras \\
\hline 06/07/2009 & El Mundo & Arrancan los cursos de El Escorial con un Matías Prats emociónado \\
\hline 06/07/2009 & El Mundo & Las ovejas menguantes \\
\hline $07 / 07 / 2009$ & El Mundo & El $45 \%$ de los españoles cree en Dios y en Darwin \\
\hline $07 / 07 / 2009$ & El Mundo & La Reina Doña Sofía inaugura la sede de la Fundación Atapuerca \\
\hline 08/07/2009 & El Mundo & La mujer, vencedora de la guerra de los sexos \\
\hline $10 / 07 / 2009$ & El Mundo & El padre de la evolución 'desembarca' en Madrid \\
\hline $10 / 07 / 2009$ & El Mundo & Los origenes de nuestra especie \\
\hline $23 / 07 / 2009$ & El Mundo & Un retrato de Darwin abrirá la próxima exposición de Eduardo Arroyo en París \\
\hline $27 / 07 / 2009$ & El Mundo & El Antecessor se cita con Darwin \\
\hline $31 / 07 / 2009$ & El Mundo & La cara más amable de las medusas \\
\hline 03/08/2009 & El Mundo & La selección natural y su utilización con fines ideológicos \\
\hline $12 / 08 / 2009$ & El Mundo & Los humanos nunca anduvieron sobre las cuatro patas \\
\hline $12 / 08 / 2009$ & El Mundo & Los turistas y los mosquitos abocan a las Galápagos a un desastre ecológico \\
\hline $29 / 09 / 2009$ & El Mundo & Cruceros en la ruta de Darwin \\
\hline $02 / 10 / 2009$ & El Mundo & El gran amigo de los anfibios y de los reptiles \\
\hline $10 / 10 / 2009$ & El Mundo & Spacey se atreve con Darwin \\
\hline $15 / 10 / 2009$ & El Mundo & Darwinopterus'_el nuevo reptil volador de China \\
\hline $16 / 10 / 2009$ & El Mundo & La metáfora del rock de pintura y hojalata \\
\hline $21 / 10 / 2009$ & El Mundo & Viaje con Darwin a bordo del Beagle \\
\hline $22 / 10 / 2009$ & El Mundo & Es nuestro deber moral evitar la extinción de las especies' \\
\hline $26 / 10 / 2009$ & El Mundo & La 'r-evolución' de un hombre tranquilo, en la muestra sobre Darwin \\
\hline $26 / 10 / 2009$ & El Mundo & Más de la mitad de los adultos quiere que el 'creacionismo' se enseñe en las escuelas \\
\hline $05 / 11 / 2009$ & El Mundo & Darwin estaría horrorizado por el estado actual de conservación de la naturaleza' \\
\hline $07 / 11 / 2009$ & El Mundo & Una exposición reúne restos de organismos de hace 500 millones de años \\
\hline $10 / 11 / 2009$ & El Mundo & Una iniciativa para humanizar la Ciencia y hacerla cercana \\
\hline $12 / 11 / 2009$ & El Mundo & Los Príncipes de Asturias, en la portada de 'Paris Match' \\
\hline $19 / 11 / 2009$ & El Mundo & Personajes mecánicos pueblan el Parque de las Ciencias de Granada \\
\hline $22 / 11 / 2009$ & El Mundo & El libro de... Llibres Fiol \\
\hline $25 / 11 / 2009$ & El Mundo & La primera edición de 'El Origen de las Especies', a subasta en Londres \\
\hline $28 / 11 / 2009$ & El Mundo & Algunas variedades de tomates de la Península se venden como 'ramellet' \\
\hline $01 / 12 / 2009$ & El Mundo & Galápagos, una maravilla natural en peligro \\
\hline 09/12/2009 & El Mundo & Ada Yonath_'El Real Madrid interesa más que cualquier descubrimiento' \\
\hline $11 / 12 / 2009$ & El Mundo & Uno de cada diez pájaros, condenados a la 'soltería' por 'feos' \\
\hline $21 / 12 / 2009$ & El Mundo & Herrera inaugura el edificio Darwin de la ULE \\
\hline $21 / 12 / 2009$ & El Mundo & Kurt Vonnegut_sobre hombres, iguanas y focas \\
\hline $23 / 12 / 2009$ & El Mundo & El 'instinto' de la religión \\
\hline $24 / 12 / 2009$ & El Mundo & La Ruta Quetzal BBVA termina este año durante la Navidad en Chile \\
\hline $28 / 12 / 2009$ & El Mundo & Un tesoro de 290 especies 'rescatado' en un año \\
\hline $29 / 12 / 2009$ & El Mundo & Una cosecha histórica en la exploración del Cosmos \\
\hline
\end{tabular}

\begin{tabular}{|c|c|l|}
\hline Fecha & Periódicos & \multicolumn{1}{c|}{ Títular } \\
\hline $06 / 01 / 2009$ & El País & Una nueva especie de reptil arroja pistas sobre la teoría de la evloución \\
\hline $13 / 01 / 2009$ & El País & Los escarabajos pueden contar \\
\hline $24 / 01 / 2009$ & El País & Alpiste viajero para terrícolas \\
\hline $01 / 02 / 2009$ & El País & Hacia la defensa intelectual de la Fiesta \\
\hline $02 / 02 / 2009$ & El País & El Sol_a ocho minutos luz \\
\hline $09 / 02 / 2009$ & El País & Darwin, sin censura \\
\hline $11 / 02 / 2009$ & El País & $\begin{array}{l}\text { Las diferencias entre el genoma humano y del chimpancé son diez veces mayores de lo que } \\
\text { se creía }\end{array}$ \\
\hline $12 / 02 / 2009$ & El País & El darwinismo no está en crisis \\
\hline $14 / 02 / 2009$ & El País & Carlos de Inglaterra, un ecologista en 'jet' privado \\
\hline $21 / 02 / 2009$ & El País & Encuentros en la tercera fase y abuelos nudistas \\
\hline
\end{tabular}




\begin{tabular}{|c|c|c|}
\hline $23 / 02 / 2009$ & El País & Un lugar en el Pacífico en el que las medusas no pican \\
\hline $28 / 02 / 2009$ & El País & Niños gratis y otras ofertas contra la crisis \\
\hline $02 / 03 / 2009$ & El País & Francia protagonizará la próxima Feria del Libro de Madrid \\
\hline 07/03/2009 & El País & Orgasmo. Qué, cómo, por qué \\
\hline $10 / 03 / 2009$ & El País & Cometas en el cielo \\
\hline $14 / 03 / 2009$ & El País & Las pasiones de la pandilla \\
\hline $23 / 03 / 2009$ & El País & Darwin, un 'gentleman' que hacia novillos \\
\hline 09/04/2009 & El País & Mil actividades en tres meses del Año de la Astronomía en España \\
\hline $14 / 04 / 2009$ & El País & El alquimista galáctico \\
\hline $21 / 04 / 2009$ & El País & El encuentro entre John Herschel y Charles Darwin \\
\hline $25 / 04 / 2009$ & El País & Verde o no verde, ésa es la cuestión \\
\hline 06/05/2009 & El País & Un pie y unos hipopótamos ayudan a interpretar el 'Hobbit' \\
\hline $20 / 05 / 2009$ & El País & Un primate de hace 47 millones de años \\
\hline 04/06/2009 & El País & Attenborough, premio Principe de Asturias de Ciencias Sociales por su defensa de la vida \\
\hline 08/06/2009 & El País & Hitchens firma su antología del pensamiento ateo \\
\hline $10 / 06 / 2009$ & El País & La Luna, un recurso por descubrir \\
\hline $14 / 06 / 2009$ & El País & El 'Beagle' navega en la Red \\
\hline 03/07/2009 & El País & Ciencia lúdica en el Observatorio Fabra \\
\hline 08/07/2009 & El País & Las herramientas de jardín de Darwin \\
\hline 09/07/2009 & El País & Los estadounidenses valoran alto la ciencia, pero menos que hace una década \\
\hline $11 / 07 / 2009$ & El País & Darwin, en el Museo Nacional de Ciencias Naturales \\
\hline $14 / 07 / 2009$ & El País & Galileo, Darwin y Armstrong \\
\hline $16 / 07 / 2009$ & El País & La población de neandertales era de sólo 7.000 personas \\
\hline $17 / 07 / 2009$ & El País & La I+D necesita mas inversiones privadas, según el secretario de Estado de Investigación \\
\hline $24 / 07 / 2009$ & El País & El pico refrigerante del tucán \\
\hline $25 / 07 / 2009$ & El País & Dragones con buen rollito \\
\hline $11 / 08 / 2009$ & El País & Darwin en viñetas \\
\hline $19 / 08 / 2009$ & El País & Frenar la nueva gripe a golpe de ratón \\
\hline $25 / 09 / 2009$ & El País & Kirk Cameron contra Darwin \\
\hline $28 / 09 / 2009$ & El País & Descubiertas 850 nuevas especies subterráneas en Australia \\
\hline $01 / 10 / 2009$ & El País & El antepasado más antiguo del hombre no era como los monos actuales \\
\hline 09/10/2009 & El País & Un grupo norteamericano propone depurar la Biblia de conceptos liberales \\
\hline $14 / 10 / 2009$ & El País & Carlos Boyero__Me dan grima los curas y los contratiempos de Iberia \\
\hline 03/11/2009 & El País & Vuelve la Semana de la Ciencia \\
\hline $13 / 11 / 2009$ & El País & Prehistóricos sí, pero no tan primitivos \\
\hline $23 / 11 / 2009$ & El País & Los australopitecos comían frutos, semillas, raíces y cortezas \\
\hline $25 / 11 / 2009$ & El País & Palabra de Darwin \\
\hline 05/12/2009 & El País & Largo adiós al negacionismo \\
\hline $08 / 12 / 2009$ & El País & Descrita la aparición de una nueva especie de pinzones en las Galapagos \\
\hline $22 / 12 / 2009$ & El País & La estructura molecular de la teoría de la evloución \\
\hline $29 / 12 / 2009$ & El País & Agenda \\
\hline
\end{tabular}

\begin{tabular}{|c|c|c|}
\hline Fecha & Periódicos & Títular \\
\hline 05/01/2009 & Hankyoreh & 역사 속 1 월 과학사엔 어떤 일이 \\
\hline 07/01/2009 & Hankyoreh & 겨울은 과학의 계절 \\
\hline 09/01/2009 & Hankyoreh & 1 월 10 일 잠깐 독서 다윈은 ‘진화’를 말하지 않았다? \\
\hline 09/01/2009 & Hankyoreh & [과학칼럼] 위험한 발상, 좋은 생각, 다시 장엄함 - 장대익 칼럼 \\
\hline $16 / 01 / 2009$ & Hankyoreh & 1 월 17 일 지성 새 책 \\
\hline $23 / 01 / 2009$ & Hankyoreh & ‘인간생명의 비밀’ 미토콘드리아가 쥐고 있다 \\
\hline $27 / 01 / 2009$ & Hankyoreh & 다윈 탄생 200 주년...계속되는 진화론 논쟁 \\
\hline 03/02/2009 & Hankyoreh & 2 월이 물드네...울긋불긋 춤으로 물드네 \\
\hline 03/02/2009 & Hankyoreh & [세상읽기] 다윈, 케플러, 갈릴레오 - 2009 - 송상용 칼럼 \\
\hline 09/02/2009 & Hankyoreh & 2 월 10 일 영남 동네방네 \\
\hline
\end{tabular}




\begin{tabular}{|c|c|c|}
\hline $10 / 02 / 2009$ & Hankyoreh & 진화론의 본질은 자유다 \\
\hline $11 / 02 / 2009$ & Hankyoreh & 3.1 운동, 민족주의 너머 '다층적 의미' 조명한다 \\
\hline $11 / 02 / 2009$ & Hankyoreh & 교황청, 다윈의 진화론 수용적 입장 \\
\hline $13 / 02 / 2009$ & Hankyoreh & 2 월 14 일 교양 새 책 \\
\hline $13 / 02 / 2009$ & Hankyoreh & 글쓰기 '오바마처럼' 해볼까 \\
\hline $15 / 02 / 2009$ & Hankyoreh & 2 월 16 일 이번주 아하! 한겨레에는... \\
\hline $20 / 02 / 2009$ & Hankyoreh & 2 월 21 일 어린이 새 책 \\
\hline $20 / 02 / 2009$ & Hankyoreh & 2 월 21 일 잠깐 독서 \\
\hline $20 / 02 / 2009$ & Hankyoreh & 인간이성 죽였다 다시 살린 프로이트 \\
\hline $22 / 02 / 2009$ & Hankyoreh & [유레카] ‘진화’ 담론 \\
\hline $01 / 03 / 2009$ & Hankyoreh & 경쟁이냐 협력이냐 \\
\hline $03 / 03 / 2009$ & Hankyoreh & [블로그] 진보의 진보 \\
\hline $06 / 03 / 2009$ & Hankyoreh & 다윈의 책은 어려울 거란 편견 \\
\hline $08 / 03 / 2009$ & Hankyoreh & 진화론을 믿으십니까 \\
\hline $10 / 03 / 2009$ & Hankyoreh & “환경적응 결과인 획득형질도 유전 가능” \\
\hline $13 / 03 / 2009$ & Hankyoreh & “잭 런던 걸작선' 미국 사회주의 싣고 오다 \\
\hline $30 / 03 / 2009$ & Hankyoreh & 탄생 200 주년 - 다시 보는 다윈 \\
\hline $03 / 04 / 2009$ & Hankyoreh & [백승종의역설] 찰스 다윈 \\
\hline $03 / 04 / 2009$ & Hankyoreh & 검열된 '함석헌의 외침' 21 년 만에 되찾다 \\
\hline $13 / 04 / 2009$ & Hankyoreh & ‘도덕'이 문제일까 \\
\hline $13 / 04 / 2009$ & Hankyoreh & 용서받을 수 없는 과학자, 멩겔레 \\
\hline $14 / 04 / 2009$ & Hankyoreh & 나이 2400 살 무게는 $605 t$ '괴물' 땅속에 산다 \\
\hline $01 / 05 / 2009$ & Hankyoreh & 사람은 토끼에 가까울까 호랑이에 가까울까 \\
\hline $04 / 05 / 2009$ & Hankyoreh & [이사람] 어머니 루시의 평등 메시지 들어라 \\
\hline $04 / 05 / 2009$ & Hankyoreh & 역사 속 5 월 과학사엔 어떤 일이 \\
\hline $17 / 05 / 2009$ & Hankyoreh & 동아시아의 가부장적 가족문화 \\
\hline $19 / 05 / 2009$ & Hankyoreh & 다윈 탄생 200 돌 기념강좌 \\
\hline $07 / 06 / 2009$ & Hankyoreh & 한국쓰리엠 ‘청소년 무료 과학캠프’ 참가자 모집 \\
\hline $12 / 06 / 2009$ & Hankyoreh & “보이지 않는 손’보이는 손’ 둘 다 고쳐라 \\
\hline $18 / 06 / 2009$ & Hankyoreh & [길을찾아서] 한국전과 월남전...미국 분할통치의 '쌍생아' - 정경모 \\
\hline $19 / 06 / 2009$ & Hankyoreh & 6 월 20 일 지성 새 책 \\
\hline 19/06/2009 & Hankyoreh & "개신교 창조과학·지적설계론은 사이비" \\
\hline $21 / 06 / 2009$ & Hankyoreh & 물고기가 팔굽혀펴기를 했었다 \\
\hline $21 / 06 / 2009$ & Hankyoreh & 사회현실 고민하는 ‘자아성찰’ \\
\hline $30 / 06 / 2009$ & Hankyoreh & 인문학-자연과학 소통하는 '진화론' \\
\hline $19 / 07 / 2009$ & Hankyoreh & 과학글쓰기, 소설처럼 '쉽고 즐겁게' \\
\hline $24 / 07 / 2009$ & Hankyoreh & 인간 중심 편견 넘어선 ‘우주 생물학’ \\
\hline $07 / 08 / 2009$ & Hankyoreh & 하느님과 진화론같이 믿으면 안되나요 \\
\hline 09/08/2009 & Hankyoreh & 신자유주의 속 경제 민족주의 대두 \\
\hline $12 / 08 / 2009$ & Hankyoreh & 해파리도 좋은 일을 한다 \\
\hline $14 / 08 / 2009$ & Hankyoreh & "다윈은 틀렸다...인간의 조상은 돌연변이" \\
\hline $16 / 08 / 2009$ & Hankyoreh & 일제강점기 문학의 주제의식 \\
\hline $21 / 08 / 2009$ & Hankyoreh & 진화론 제대로 즐기는 방법 \\
\hline $04 / 09 / 2009$ & Hankyoreh & 9 월 5 일 잠깐독서 \\
\hline $17 / 09 / 2009$ & Hankyoreh & 진보주의의 시선에 비친 진화론은 \\
\hline $18 / 09 / 2009$ & Hankyoreh & 세계 생물 1500 만 종, 더불어 함께 산다 \\
\hline $21 / 09 / 2009$ & Hankyoreh & [유레카] 시인과 과학자 \\
\hline $25 / 09 / 2009$ & Hankyoreh & 호랑이가 사자보다 똑똑하다 \\
\hline $13 / 10 / 2009$ & Hankyoreh & [한겨레프리즘] 지혜로운 복수 \\
\hline $16 / 10 / 2009$ & Hankyoreh & 다윈주의자 ‘자유의지'를 품다 \\
\hline $18 / 10 / 2009$ & Hankyoreh & [왜냐면] 신문 유가부수 완화는 합당한 조처인가 - 이성민 왜냐면 \\
\hline $20 / 10 / 2009$ & Hankyoreh & 대장균 20 년 동안 배양해보니... \\
\hline $26 / 10 / 2009$ & Hankyoreh & 진화한 거북이, 인간한테 ‘퇴화’를 배우다 \\
\hline $30 / 10 / 2009$ & Hankyoreh & 드라마 작가도 울고갈 '이야기'의 재발견 \\
\hline
\end{tabular}




\begin{tabular}{|c|c|c|}
\hline $03 / 11 / 2009$ & Hankyoreh & “다윈’ 주제로 7일 자연-사회과학 통섭 토론회 \\
\hline $06 / 11 / 2009$ & Hankyoreh & 11 월 7 일 잠깐독서 ‘만들어진 신’에 대한 신학자의 논박 \\
\hline $11 / 11 / 2009$ & Hankyoreh & [블로그] 하이힐 경쟁의 산물은 킬힐 \\
\hline $11 / 11 / 2009$ & Hankyoreh & 교황청, ‘에이리언’ 연구 본격화 \\
\hline $13 / 11 / 2009$ & Hankyoreh & 11 월 14 일 잠깐독서 \\
\hline $19 / 11 / 2009$ & Hankyoreh & [한겨레프리즘] 고고학과 밥줄 - 노형석 칼럼 \\
\hline $20 / 11 / 2009$ & Hankyoreh & 진화론 품은 다윈의 고뇌 낱낱이 \\
\hline $22 / 11 / 2009$ & Hankyoreh & ‘구술면접 준비’ 도서관이 답이다 \\
\hline $23 / 11 / 2009$ & Hankyoreh & 진화론, 어디까지 진화했나 \\
\hline $30 / 11 / 2009$ & Hankyoreh & 외모가 매력적일수록 실력도 좋다 \\
\hline $04 / 12 / 2009$ & Hankyoreh & 12 월 5 일 잠깐독서 ‘좋은 성격' 절반은 유전자 덕분 \\
\hline $11 / 12 / 2009$ & Hankyoreh & 창조론을 흉보는 절묘한 방법 \\
\hline $13 / 12 / 2009$ & Hankyoreh & 진화론과 종교 150 년 동안의 논쟁 \\
\hline $18 / 12 / 2009$ & Hankyoreh & [과학칼럼] 다윈과 '슈퍼지구', 그리고 진화 - 김지현 칼럼 \\
\hline $18 / 12 / 2009$ & Hankyoreh & ‘길잡이'와 ‘동지'가 있는 과학책 읽기 \\
\hline $18 / 12 / 2009$ & Hankyoreh & 제 3 세계 음악 '동병상련의 끌림' \\
\hline $25 / 12 / 2009$ & Hankyoreh & 어두움 더듬어 등불 하나 켜라 하네 \\
\hline $25 / 12 / 2009$ & Hankyoreh & 한 뻠을 걸어도 주저앉지 말라 하네 \\
\hline $27 / 12 / 2009$ & Hankyoreh & 기부의 계절, 기부의 경제학 \\
\hline
\end{tabular}

\begin{tabular}{|c|c|c|}
\hline Fecha & Periódico & Títular \\
\hline $01 / 01 / 2009$ & Joongang & [Art] 2009 문화지도, 올해의 키워드 \\
\hline $01 / 01 / 2009$ & Joongang & 나누세요 넉넉해집니다 그것이 '오병이어의 기적'입니다 \\
\hline $02 / 01 / 2009$ & Joongang & 2009 년은 다윈 · 링컨 · 하이든 · 멘델스존 · 캘빈의 해 \\
\hline $04 / 01 / 2009$ & Joongang & [6시 중앙뉴스] 5 년 만에 매출 10 배로 '껑충'...'절대 경쟁력’이 성공 비결 \\
\hline $08 / 01 / 2009$ & Joongang & 백성호 기자의 현문우답 54 추기경의 '오병이어' 재해석 \\
\hline $10 / 01 / 2009$ & Joongang & [BOOK Briefing] 『다윈 이후』 外 \\
\hline $10 / 01 / 2009$ & Joongang & $\mathrm{S}$ 자형 몸매가 아이를 잘 낳는다고 \\
\hline $17 / 01 / 2009$ & Joongang & [BOOK 책갈피] 다윈·아인슈타인에겐 ‘소통의 기술’이 있었네 \\
\hline $05 / 02 / 2009$ & Joongang & 다윈 탄생 200 주년, 『종의 기원』 150 돌...물리학자·신부의 ‘열린 대화’ 상 \\
\hline $07 / 02 / 2009$ & Joongang & [조우석 칼럼 책에 길을 욷다] 인간, 그거 참 별것 아니군 \\
\hline $08 / 02 / 2009$ & Joongang & [6시 중앙뉴스] 마케팅 고수 3명이 말하는 '불황 탈출법' \\
\hline $08 / 02 / 2009$ & Joongang & 배우자의 '바람' \\
\hline $09 / 02 / 2009$ & Joongang & 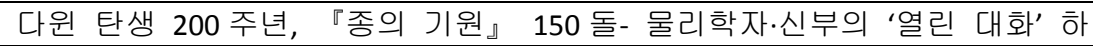 \\
\hline $12 / 02 / 2009$ & Joongang & 2009 기획 - 다윈의 편지 (1) 딱정벌레에 미친 청년 \\
\hline $14 / 02 / 2009$ & Joongang & [BOOK Briefing] 『갈라파고스』 外 \\
\hline $14 / 02 / 2009$ & Joongang & [분수대] 다윈 상 \\
\hline $16 / 02 / 2009$ & Joongang & '폐쇄성 = 경제엔 독' 알면서도 다시 고개드는 보호무역 \\
\hline $19 / 02 / 2009$ & Joongang & [사진] 유쾌한 상상력의 김선이 현대무용 '괴짜섬' \\
\hline $19 / 02 / 2009$ & Joongang & '다윈의 편지' (2) 노예제에 맞서다 \\
\hline $19 / 02 / 2009$ & Joongang & "찰스 다윈 창의성과 천재성의 비밀은 자폐증" \\
\hline $21 / 02 / 2009$ & Joongang & [BOOK 북카페] 임신부 입덧도 '자연의 선택'이다 \\
\hline $26 / 02 / 2009$ & Joongang & '다윈의 편지' (3) 비글호 항해 \\
\hline $05 / 03 / 2009$ & Joongang & '다윈의 편지' (4) 젠틀맨 다윈 \\
\hline $12 / 03 / 2009$ & Joongang & [week\&쉼표\&느낌표] 공연 外 \\
\hline $12 / 03 / 2009$ & Joongang & '다윈의 편지' (5) 내 사랑 엠마 \\
\hline $13 / 03 / 2009$ & Joongang & [중앙 시평] 한국형 '구텐베르크 프로젝트'를 위하여 \\
\hline $14 / 03 / 2009$ & Joongang & [BOOK 북카페] 스쳐간 만남, 운명적 만남 \\
\hline $14 / 03 / 2009$ & Joongang & [새로나온 책] 식민지 이후를 사유하다 外 \\
\hline $16 / 03 / 2009$ & Joongang & [사설] 다시 다윈의 목소리를 들으며 \\
\hline $17 / 03 / 2009$ & Joongang & [e 칼럼] 스페인 독감 바이러스를 부활시키다-하 \\
\hline $20 / 03 / 2009$ & Joongang & [분수대] 3 월의 진달래 \\
\hline 20/03/2009 & Joongang & [알림] '10 개 키워드'로 읽는 과학책 \\
\hline
\end{tabular}




\begin{tabular}{|c|c|c|}
\hline $20 / 03 / 2009$ & Joongang & 다윈의 편지 (6) 스승 헨슬로 \\
\hline $27 / 03 / 2009$ & Joongang & 다윈의 편지 (7) 부족함 없었던 삶 \\
\hline $28 / 03 / 2009$ & Joongang & [BOOK] 아주 다른 두 소년 '뉴욕 명랑일주' \\
\hline $09 / 04 / 2009$ & Joongang & 이어령의 한국인 이야기 4 탄생의 비밀 (4) 왜 울며 태어났을까 \\
\hline $10 / 04 / 2009$ & Joongang & 다윈의 편지 (8) 딸 애니의 죽음 \\
\hline $11 / 04 / 2009$ & Joongang & [BOOK] ‘맛좋게 품종 개량' 이 나쁜 까닭 \\
\hline $14 / 04 / 2009$ & Joongang & [그때 오늘]'원숭이'로 조롱받았던 다윈 승패의 관건은 도덕성이었다 \\
\hline $14 / 04 / 2009$ & Joongang & 정치부패의 公式 깨기 \\
\hline $17 / 04 / 2009$ & Joongang & 다윈의 편지 (9) 못 이룬 첫사랑 패니 \\
\hline $01 / 05 / 2009$ & Joongang & 다윈의 편지 (10) 지질학자의 ‘외도'? \\
\hline $02 / 05 / 2009$ & Joongang & 디지털 시대의 사랑 방정식 \\
\hline $08 / 05 / 2009$ & Joongang & 다윈의 편지 (11) 평생의 친구 후커 \\
\hline $09 / 05 / 2009$ & Joongang & ‘5월의 책' 30 권 선정 \\
\hline $15 / 05 / 2009$ & Joongang & 다윈의 편지 (12) 과학자 토머스 헉슬리 \\
\hline $28 / 05 / 2009$ & Joongang & [Week \& Biz] 판사 출신 경영인 '클린 SK' 이미지 가꾸다 \\
\hline $28 / 05 / 2009$ & Joongang & EBS '신과 다윈의 시대' 등 4 편 방통심위 3 월의 좋은 프로 선정 \\
\hline $29 / 05 / 2009$ & Joongang & 29 다윈의 편지 (13) ‘종의 기원' 논쟁 \\
\hline $30 / 05 / 2009$ & Joongang & [분수대] 마지막 한마디 \\
\hline 04/06/2009 & Joongang & $\begin{array}{l}\text { [그때 오늘] 다윈 “총리 만나봬 영광” 감격 ... 역사는 “다윈 만난 총리가 } \\
\text { 영광” }\end{array}$ \\
\hline $05 / 06 / 2009$ & Joongang & 다윈의 편지 (14) 2 등 될뻔 하다 \\
\hline $12 / 06 / 2009$ & Joongang & 다윈의 편지 (15) 죽음 \\
\hline $13 / 06 / 2009$ & Joongang & [BOOK 깊이 읽기] ‘잘난’ 인간, 넌 사실 낙오한 물고기거든 \\
\hline $20 / 06 / 2009$ & Joongang & [BOOK 깊이 읽기] 보편 과학의 시대, 종교의 유통기한은 끝났는가 \\
\hline $30 / 06 / 2009$ & Joongang & 다윈이 가져다 준 ‘통섭’ 탄생 200 년 연합학술대회 \\
\hline $01 / 07 / 2009$ & Joongang & [추천도서] 『다윈의 대답』 外 \\
\hline $01 / 07 / 2009$ & Joongang & 10 개 키워드로 읽는 과학책 (4) 인간 \\
\hline $15 / 07 / 2009$ & Joongang & [그때 오늘] “힘없는 자는 늑대 떼 속의 양” 열강 외면 속에 이준 열사 순국 \\
\hline $18 / 07 / 2009$ & Joongang & [새로 나온 책] 아빠가 결혼했다 外 \\
\hline $25 / 07 / 2009$ & Joongang & [깊이읽기 BOOK] 살신성인 원숭이와 무자비한 야만인의 후손, 인간 \\
\hline $06 / 08 / 2009$ & Joongang & [과학칼럼] 에디슨과 파스퇴르 \\
\hline $21 / 08 / 2009$ & Joongang & 남성의 ‘그것’도 진화되고 있다 \\
\hline $25 / 08 / 2009$ & Joongang & [추천도서] 라마찬드란 박사의 두뇌 실험실 外 \\
\hline $27 / 08 / 2009$ & Joongang & 따로 노는 1 억 2000 만 명 시장...글로벌 대박 상품도 안 통해 \\
\hline $29 / 08 / 2009$ & Joongang & [BOOK 브리핑] 가이드 경력 신부님이 소개하는 바티칸 外 \\
\hline $07 / 09 / 2009$ & Joongang & ‘신중국 60 년’ 영향 준 외국인 60 명 뽑는다 \\
\hline $10 / 09 / 2009$ & Joongang & 『It's true! 동물』 \\
\hline $06 / 10 / 2009$ & Joongang & [e 칼럼] 네안데르탈인, 왜 인류 조상이 아닌가 (1) \\
\hline $13 / 10 / 2009$ & Joongang & [e 칼럼] 네안데르탈인, 왜 인류 조상이 아닌가 (2) \\
\hline $14 / 10 / 2009$ & Joongang & 연극 ‘다윈의 거북이' “인간은 무시무시한 괴물” \\
\hline $27 / 10 / 2009$ & Joongang & [e 칼럼] 네안데르탈인, 왜 인류 조상이 아닌가 (3) \\
\hline $10 / 11 / 2009$ & Joongang & [e 칼럼] 네안데르탈인, 왜 인류 조상이 아닌가 (5) \\
\hline $12 / 11 / 2009$ & Joongang & [과학 칼럼] 시인과 과학자 \\
\hline $14 / 11 / 2009$ & Joongang & [새로 나온 책] 다윈은 세상에서 무엇을 보았을까 外 \\
\hline $21 / 11 / 2009$ & Joongang & [깊이읽기 BOOK] 다윈은 왜 진화론을 손에 쥐고도 발표를 꺼렸나 \\
\hline $23 / 11 / 2009$ & Joongang & 화장실에 쳐박혀 있던 책 한권이 1 억 2000 만원 \\
\hline $24 / 11 / 2009$ & Joongang & [추천 도서] 유전자만이 아니다 外 \\
\hline $24 / 11 / 2009$ & Joongang & "아버지는 건강하다, 승계에 관한 한 혼선은 없다" \\
\hline $24 / 11 / 2009$ & Joongang & 10 개 키워드로 읽는 과학책 9- 진화 \\
\hline $30 / 11 / 2009$ & Joongang & [그때 오늘] 을사늑약을 목놓아 호곡한 장지연과 친일논란 \\
\hline $11 / 12 / 2009$ & Joongang & [BOOK 깊이읽기] 첨단과학으로 무장한 진화론, 다시 신의 존재를 묻다 \\
\hline $16 / 12 / 2009$ & Joongang & [추천 도서] 동물 철학 外 \\
\hline $16 / 12 / 2009$ & Joongang & 10 개 키워드로 읽는 과학책 10 끝 운명 \\
\hline $17 / 12 / 2009$ & Joongang & '손안의 $\mathrm{PC}^{\prime}$ 새로운 비즈니스를 연다 \\
\hline
\end{tabular}




\subsection{AÑO 2010}

\begin{tabular}{|c|c|c|}
\hline Fecha & Periódico & Títular \\
\hline $12 / 01 / 2010$ & El Mundo & El grillo que poliniza flores \\
\hline $18 / 01 / 2010$ & El Mundo & El bipedismo hizo posible la construcción de herramientas \\
\hline $30 / 01 / 2010$ & El Mundo & Gillian Beer destapa la sensibilidad artística de Charles Darwin \\
\hline $04 / 02 / 2010$ & El Mundo & Los adolescentes más brillantes tiene más riesgo de sufrir trastorno bipolar \\
\hline $04 / 02 / 2008$ & El Mundo & El origen africano de Darwin \\
\hline $18 / 02 / 2010$ & El Mundo & Unicaja muestra en Arco el arte pop de una quincena de creadores \\
\hline $27 / 02 / 2010$ & El Mundo & Evacuación de pobladores y turistas en la isla Galápagos \\
\hline $03 / 03 / 2010$ & El Mundo & El apoderado de José Tomás: 'He venido a este Parlament a pedir amparo' \\
\hline 06/03/2010 & El Mundo & Apoyo unánime a Griñán del PSOE malagueño \\
\hline 09/03/2010 & El Mundo & 'La científica Margalida Comas fue casi la primera en todo' \\
\hline $11 / 03 / 2010$ & El Mundo & La política domina el debate por el nuevo plan de estudios de Texas \\
\hline $18 / 03 / 2010$ & El Mundo & El legado de Darwin y D'Orbigny sigue vivo en la cuenca del río Paraná \\
\hline $22 / 03 / 2010$ & El Mundo & De Lamark a la Síntesis evolutiva: la evolución de la teoría de la evolución \\
\hline $22 / 03 / 2010$ & El Mundo & Darwin en Granada \\
\hline $21 / 04 / 2010$ & El Mundo & La evolución de la salamandra \\
\hline $22 / 04 / 2010$ & El Mundo & Los principales 'blogueros' de divulgación científica se dan cita en Granada \\
\hline $28 / 04 / 2010$ & El Mundo & Las gaviotas de Mallorca confirman las teorías de Darwin \\
\hline $28 / 04 / 2010$ & El Mundo & Las gaviotas de un vertedero mallorquín prueban la teoría de Darwin \\
\hline $28 / 04 / 2010$ & El Mundo & Aviagra Abascal: Hacia el novius erectus \\
\hline $03 / 05 / 2010$ & El Mundo & La endogamia, posible causa de la alta mortalidad de los hijos de Darwin \\
\hline $14 / 05 / 2010$ & El Mundo & El naturalista que cree en el Yeti \\
\hline $17 / 05 / 2010$ & El Mundo & Retirado alemán busca mujer local para comprar tierras en las Islas Galapagos \\
\hline $18 / 05 / 2010$ & El Mundo & Al mal tiempo... más neurociencia \\
\hline $28 / 05 / 2010$ & El Mundo & ¿Qué pasa cuándo nos enfadamos? \\
\hline $02 / 07 / 2010$ & El Mundo & Los primeros cráneos y fósiles visten el Museo de la Evolución de Burgos \\
\hline $12 / 07 / 2010$ & El Mundo & El Museo de la Evolución Humana abre sus puertas \\
\hline $12 / 07 / 2010$ & El Mundo & La Reina inaugura mañana el Museo de la Evolución Humana \\
\hline $12 / 07 / 2010$ & El Mundo & De libre albedrío, nada \\
\hline $14 / 07 / 2010$ & El Mundo & La enfermedad humana que diagnosticaron Ortega y Gasset, Nietzsche y Hegel \\
\hline $30 / 07 / 2010$ & El Mundo & Vida de château (XIX) \\
\hline 09/08/2010 & El Mundo & Fallece el historiador valenciano José María López Piñero \\
\hline $10 / 08 / 2010$ & El Mundo & Salen a la luz los testamentos de personalidades como Marx, Darwin o Dickens \\
\hline $20 / 08 / 2010$ & El Mundo & Una pareja explosiva \\
\hline $31 / 08 / 2010$ & El Mundo & Un mes de Museo de la Evolución Humana \\
\hline 02/09/2010 & El Mundo & Stephen Hawking descarta la existencia de Dios para explicar el origen del Universo \\
\hline 02/09/2010 & El Mundo & Hawking reabre la polémica entre Ciencia y Religión \\
\hline $03 / 09 / 2010$ & El Mundo & Líderes religiosos critican a Hawking por descartar a Dios como creador del Universo \\
\hline 05/09/2010 & El Mundo & El error de Hawking \\
\hline 09/09/2010 & El Mundo & Subastan 'Aves de América', el libro más caro del mundo \\
\hline $04 / 10 / 2010$ & El Mundo & Así se hizo el Museo de la Evolución Humana \\
\hline $11 / 11 / 2010$ & El Mundo & Machado Núñez, patriarca a la sombra \\
\hline $22 / 11 / 2010$ & El Mundo & La Universidad revisa la figura de Einstein bajo la ' lupa' del físico García Moliner \\
\hline $08 / 12 / 2010$ & El Mundo & El libro más caro del mundo \\
\hline $21 / 12 / 2010$ & El Mundo & Proceso negativo \\
\hline $21 / 12 / 2010$ & El Mundo & Islas Ballestas, las Galápagos de Perú \\
\hline
\end{tabular}

\begin{tabular}{|c|c|c|}
\hline Fecha & Periódicos & Títular \\
\hline $02 / 01 / 2010$ & El País & 200 años y un día \\
\hline
\end{tabular}




\begin{tabular}{|c|c|c|}
\hline $05 / 01 / 2010$ & El País & Los pinzones de las Galápagos combaten parásitos invasores \\
\hline $05 / 01 / 2010$ & El País & Los priones siguen la ley de Darwin \\
\hline $11 / 01 / 2010$ & El País & El inquietante mundo del cuerpo \\
\hline $26 / 01 / 2010$ & El País & Sobre el no-concepto de biodiversidad \\
\hline $05 / 03 / 2010$ & El País & El terremoto de Chile no es una sorpresa para los sismólogos \\
\hline $06 / 03 / 2010$ & El País & Terremotos en Chile \\
\hline $09 / 03 / 2010$ & El País & Una nueva cultura... con ciencia \\
\hline $23 / 03 / 2010$ & El País & Viaje por la historia de la evolución en Granada \\
\hline $03 / 04 / 2010$ & El País & Emulando a Darwin \\
\hline $18 / 05 / 2010$ & El País & Las tortugas gigantes reconquistan las Galápagos \\
\hline $21 / 05 / 2010$ & El País & Obama encarga estudiar las implicaciones bioéticas del hallazgo de Venter \\
\hline $21 / 05 / 2010$ & El País & La célula sintética: un avance científico poderoso e imprevisible \\
\hline $21 / 06 / 2010$ & El País & Nueva mirada al origen de los elementos \\
\hline $26 / 06 / 2010$ & El País & Philly y el agujero del 'donut' \\
\hline $12 / 07 / 2010$ & El País & Darwin se quedó corto \\
\hline $13 / 07 / 2010$ & El País & 200 piezas originales de Atapuerca en un nuevo museo \\
\hline $07 / 08 / 2010$ & El País & Diez saltos por el hielo \\
\hline $11 / 08 / 2010$ & El País & Las herencias de Marx, Darwin y Dickens al descubierto \\
\hline $11 / 08 / 2010$ & El País & Fe en el móvil \\
\hline $16 / 08 / 2010$ & El País & Lapido sale del ángulo muerto \\
\hline $02 / 09 / 2010$ & El País & Dios no creó el Universo, asegura Stephen Hawking \\
\hline $07 / 09 / 2010$ & El País & El sueño de Darwin \\
\hline $12 / 09 / 2010$ & El País & La esposa que no se resignó \\
\hline $27 / 09 / 2010$ & El País & Un pájaro que habitó Tenerife ayuda a comprender la evolución de las aves \\
\hline $06 / 11 / 2010$ & El País & En platos Duralex \\
\hline $16 / 11 / 2010$ & El País & De Guindos: "Si no hay acuerdo políticos en economía, hay que convocar elecciones" \\
\hline $18 / 12 / 2010$ & El País & Malaspina 2010 y la Ciencia Cooperativa \\
\hline $18 / 12 / 2010$ & El País & De charla con los pioneros \\
\hline
\end{tabular}

\begin{tabular}{|c|c|c|}
\hline Fecha & Periódicos & Títular \\
\hline $10 / 01 / 2010$ & Hankyoreh & [이사람] 갈라파고스에 진정한 생태관광 일궈 \\
\hline $22 / 01 / 2010$ & Hankyoreh & 내 '마음의 진화' 읽어라 \\
\hline $22 / 01 / 2010$ & Hankyoreh & 개의 진화 법칙 '귀여워야 산다' \\
\hline $24 / 01 / 2010$ & Hankyoreh & 종교 내치면 평화가 올까 \\
\hline $29 / 01 / 2010$ & Hankyoreh & ‘인류 개량' 우생학의 뿌리깊은 욕망 \\
\hline $31 / 01 / 2010$ & Hankyoreh & 애완동물은 물건인가? \\
\hline $05 / 02 / 2010$ & Hankyoreh & 싹트는 시기심 어떻게 할까 \\
\hline $08 / 02 / 2010$ & Hankyoreh & 새로운 과학, 새로운 서사의 등장 \\
\hline 09/02/2010 & Hankyoreh & [세상읽기] 국가적 증오범죄와 사회의 퇴행 / 우희종 \\
\hline $10 / 02 / 2010$ & Hankyoreh & 아버님댁에 재밌는 이야기 한보따리 놔드리죠 \\
\hline $15 / 02 / 2010$ & Hankyoreh & "작은 초파리 연구에 숨은, 큰 울림의 이야기" \\
\hline $28 / 02 / 2010$ & Hankyoreh & 칠레 강진, 아이티의 500 800 배...피해는 '수백분의 1 ' \\
\hline 05/03/2010 & Hankyoreh & "왜 벌레냐고? 곤충 무게는 인류의 1 만배" \\
\hline $19 / 03 / 2010$ & Hankyoreh & 3 월 20 일 청소년 새 책 \\
\hline 19/03/2010 & Hankyoreh & "창세기의 천지창조는 가치의 창조를 뜻해" \\
\hline $26 / 03 / 2010$ & Hankyoreh & '내숭의 시대' 발가벗긴 킨제이의 모든 것 \\
\hline $02 / 04 / 2010$ & Hankyoreh & 다윈의 후예 ‘다윈의 딜레마’를 풀다 \\
\hline $14 / 04 / 2010$ & Hankyoreh & 기득권 맞서 ‘공동의 삶’ 구축 위한 연대를 \\
\hline $16 / 04 / 2010$ & Hankyoreh & 4 월 17 일 어린이 새 책 \\
\hline $19 / 04 / 2010$ & Hankyoreh & 과학의 날에 좋은 부모되는 법 \\
\hline $30 / 04 / 2010$ & Hankyoreh & 무한진화·인간소멸...'불온한 다윈'을 복권하다 \\
\hline $02 / 05 / 2010$ & Hankyoreh & 박지성·김연아는 신체기능만 좋을까 \\
\hline 05/05/2010 & Hankyoreh & [유레카] 인종 프로파일링 / 정남기 \\
\hline
\end{tabular}




\begin{tabular}{|c|c|c|}
\hline $14 / 05 / 2010$ & Hankyoreh & 350 년 된 런던의 '지식창고' \\
\hline $18 / 05 / 2010$ & Hankyoreh & [한겨레프리즘] ‘진화론’에 비춰본 검찰 / 김의겸 \\
\hline $21 / 05 / 2010$ & Hankyoreh & 만들어진 ‘모성 본능 신화’를 허물다 \\
\hline $21 / 05 / 2010$ & Hankyoreh & 신은 망상이다' 도전적 종교비판 \\
\hline $06 / 06 / 2010$ & Hankyoreh & 인문·자연과학...'학문’은 통한다 \\
\hline $06 / 06 / 2010$ & Hankyoreh & [김형태 칼럼] 목포 뻘낙지와 황금률 \\
\hline $25 / 06 / 2010$ & Hankyoreh & 6 월 26 일 청년 새 책 \\
\hline $02 / 07 / 2010$ & Hankyoreh & 7 월 3 일 어린이 새 책 \\
\hline $09 / 07 / 2010$ & Hankyoreh & 천황을 이용하려 했던 '복합적 사상가' \\
\hline $11 / 07 / 2010$ & Hankyoreh & 정재승 교수 “책 프로그램, 진보적 지식인 많이 등장했다는 이유로 폐지" \\
\hline $12 / 07 / 2010$ & Hankyoreh & 【오늘의 트위터 키워드】 정재승, 새떼 \\
\hline $13 / 07 / 2010$ & Hankyoreh & 괴물인데 매력적이네? \\
\hline $15 / 07 / 2010$ & Hankyoreh & "KBS 교향악단 누가 주인인지 고민할때" \\
\hline $30 / 07 / 2010$ & Hankyoreh & 갈라파고스 ‘위험유산 제외’에 위기감 \\
\hline $06 / 08 / 2010$ & Hankyoreh & 놀라운 영감' 주는 신경생물학 강연 \\
\hline $27 / 08 / 2010$ & Hankyoreh & 8 월 28 일 교양 새 책 \\
\hline $03 / 09 / 2010$ & Hankyoreh & 다윈은 왜 과학의 바다로 떠났나 \\
\hline $18 / 09 / 2010$ & Hankyoreh & 9 월 18 일 교양 새 책 \\
\hline $19 / 09 / 2010$ & Hankyoreh & ‘친서민 중도실용' 강화로 ‘공정사회’ 구현 \\
\hline $15 / 10 / 2010$ & Hankyoreh & 공감하라, 그래야 공존할 것이니 \\
\hline $22 / 10 / 2010$ & Hankyoreh & 10 월 23 일 교양 새 책 \\
\hline $22 / 10 / 2010$ & Hankyoreh & 성적 다양성은 진화 이끄는 힘 \\
\hline $05 / 11 / 2010$ & Hankyoreh & 11 월 6 일 청소년 새 책 \\
\hline $05 / 11 / 2010$ & Hankyoreh & 선사시대 진화는 여성들 덕분 \\
\hline $20 / 11 / 2010$ & Hankyoreh & 11 월 20 일 청소년 새 책 \\
\hline $10 / 12 / 2010$ & Hankyoreh & 만물이 출렁이는 무한한 바다, 그것이 '신' \\
\hline $24 / 12 / 2010$ & Hankyoreh & [한겨레 올해의 책] 먹구름 세상 헤쳐나갈 '힘'을 얻다 \\
\hline
\end{tabular}

\begin{tabular}{|c|c|c|}
\hline Fecha & Periódico & Títular \\
\hline $02 / 01 / 2010$ & Joongang & [BOOK] 대학 새내기들에게 권합니다 \\
\hline $25 / 01 / 2010$ & Joongang & [분수대] 이타적 인간 \\
\hline $06 / 02 / 2010$ & Joongang & [BOOK] 종교와 과학의 제로섬 게임, 이제 그만두시죠 \\
\hline $09 / 02 / 2010$ & Joongang & [그때 오늘] 후세가 잘못 이해한 토머스 칼라일의 <영웅 숭배론> \\
\hline $23 / 02 / 2010$ & Joongang & [e 칼럼] 인류의 조상 '루시'를 찾아서(2) \\
\hline $06 / 03 / 2010$ & Joongang & [분수대] 발파라이소 \\
\hline $21 / 03 / 2010$ & Joongang & [새로 나온 책] 파라다이스 1.2 外 \\
\hline $03 / 04 / 2010$ & Joongang & [BOOK] 나른한 봄 원기 충전, 소설이 묘약이지요 \\
\hline $10 / 04 / 2010$ & Joongang & 원인 인류 중간존재? ... 남아공서 새 화석유골 발견 \\
\hline $17 / 04 / 2010$ & Joongang & [깊이읽기 BOOK] 사랑이 있다고 믿느니 UFO 를 믿으라지 ... \\
\hline $26 / 04 / 2010$ & Joongang & 원로 과학자들 열강에 미래 과학자 눈빛 반짝 \\
\hline $01 / 05 / 2010$ & Joongang & [새로 나온 책] 모반의 연애편지 外 \\
\hline $15 / 05 / 2010$ & Joongang & [깊이읽기 BOOK] 과학사 이끄는 '거인 집단' 영국 왕립학회 350 년 \\
\hline $21 / 05 / 2010$ & Joongang & 주입식 교육, 부족한 자유시간 한국 학생들 창의력 향상 걸림돌 \\
\hline $21 / 05 / 2010$ & Joongang & [BOOK] '암컷은 야망 좇는 기회주의자'...모성 신화에 들이댄 당혹스런 칼날 \\
\hline $22 / 05 / 2010$ & Joongang & [새로 나온 책] 법원과 검찰의 탄생 外 \\
\hline $26 / 05 / 2010$ & Joongang & [그때 오늘] “파괴 없는 개혁은 없다” ... 한용운 『조선불교유신론』 발표 \\
\hline $28 / 05 / 2010$ & Joongang & [스페셜 리포트] 스마트폰 비중 11 배 겅충 ... 무선인터넷 시장도 쑥쑥 \\
\hline $14 / 06 / 2010$ & Joongang & [그때 오늘] $3 \cdot 1$ 운동에 천도교.학생 동원 기획한 현상윤 \\
\hline $14 / 07 / 2010$ & Joongang & 대입 독서능력평가 예상모형 살펴보니 \\
\hline $19 / 07 / 2010$ & Joongang & "청소년 위해 표본 7000 만 점 인터넷 전시" \\
\hline $28 / 08 / 2010$ & Joongang & $\begin{array}{l}\text { 일본의 대표적 종합상사 이토추, 고바야시 회장이 밝히는 } 152 \text { 년 ‘장수’의 } \\
\text { 비결 }\end{array}$ \\
\hline $04 / 09 / 2010$ & Joongang & [새로 나온 책] \\
\hline
\end{tabular}




\begin{tabular}{|l|l|l|}
\hline $06 / 09 / 2010$ & Joongang & [시론] 포츠머스 조약의 교훈 \\
\hline $07 / 09 / 2010$ & Joongang & [김환영의 시시각각] 스티븐 호킹의 ‘창조하지 않는 신’ \\
\hline $13 / 09 / 2010$ & Joongang & [뉴스 클립] 뉴스 인 뉴스 <137> 유네스코 세계유산 \\
\hline $25 / 09 / 2010$ & Joongang & [BOOK] 우성인자가 유전된다는데 어째서 질병도 유전될까 \\
\hline $02 / 10 / 2010$ & Joongang & [이훈범의 세상사 편력] 묵자처럼 레넌도 ‘더불어 사는 세상’ 꿈꿨지요 \\
\hline $23 / 10 / 2010$ & Joongang & [책꽂이] 스마트 코리아로 가는 길 유라시안 네트워크 ⼣ㅏ \\
\hline $30 / 10 / 2010$ & Joongang & 의원님들, 살 길은 '스마트 정치’입니다 \\
\hline $30 / 10 / 2010$ & Joongang & [책꽂이] 전략사전 ⼣ㅏ \\
\hline $01 / 11 / 2010$ & Joongang & [e 칼럼] ‘독가스 과학자’ 프리츠 하버(14) \\
\hline $13 / 11 / 2010$ & Joongang & [jStory] 한국을 이그는 24 명 무슨 책을 읽고 있나 \\
\hline $23 / 11 / 2010$ & Joongang & [e 칼럼] 로켓공학의 아버지 베르너 폰 브라운(3) \\
\hline $15 / 12 / 2010$ & Joongang & 개정되는 초 5·6 학년 과학교과서 대비하려면 \\
\hline $21 / 12 / 2010$ & Joongang & [송호근 칼럼] 무신론자의 크리스마스 \\
\hline
\end{tabular}




\section{ANEXO II: CODIFICACIÓN MANUAL}

\section{GUÍA PARA LA CODIFICACIÓN MANUAL}

1.1 Categorias para la codificación manual

1.2 Criterios para la codificación manual

FUENTE: Quintanilla, M. Á., Escobar, M., Groves, T., Montero, J. A., Palacios, R., Montañés, O. y Orellana, A., (2011) Scientific and technological culture in ESO textbooks, Salamanca, Instituto de Estudios de la ciencia y la Tecnología de Universidad de Salamanca.

(La información en el capítulo 1 de este ANEXO II es del Anexo I de la fuente (Quintanilla, et al., 2011) y ha sido parcialmente modificada para este estudio.)

\section{REVISIÓN DE LA CODIFICACIÓN MANUAL}

2.1. Revisión de la codificación de libros de texto

2.1.1. Primera revisión

2.1.2. Segunda revisión

2.2. Revisión de la codificación de artículos periodísticos

2.2.1. Primera revisión

2.2.2. Segunda revisión 


\title{
1. GUÍA PARA LA CODIFICACIÓN MANUAL
}

\subsection{CATEGORIAS PARA LA CODIFICACIÓN MANUAL}

\author{
CULTURA CIENTÍFICA \\ INTRÍNSECA \\ Representacional \\ Práctica (Operacional) \\ Valorativa \\ EXTRÍNSECA \\ Representacional \\ Práctica (Operacional) \\ Valorativa
}

CULTURA TECNOLÓGICA

NO CULTURA CIENTÍFICA

CUADRO DE CÓDIGOS

\begin{tabular}{|c|c|c|}
\hline $\begin{array}{c}\text { MODELO DE CULTURA } \\
\text { CIENTÍFICA }\end{array}$ & CÓDIGO & DESCRIPCIÓN \\
\hline \multirow{6}{*}{ CULTURA CIENTÍFICA } & CINTR & Cultura científica intrínseca representacional \\
\hline & CINTOP & Cultura científica intrínseca operacional \\
\hline & CINTVA & Cultura científica intrínseca valorativa \\
\hline & CEXTR & Cultura científica extrínseca representacional \\
\hline & CEXTOP & Cultura científica extrínseca operacional \\
\hline & CEXTVA & Cultura científica extrínseca valorativa \\
\hline \multirow{2}{*}{$\begin{array}{c}\text { CULTURA CIENTÍFICA_ } \\
\text { IMÁGENES }\end{array}$} & CINT_IM & Imagen de cultura científica intrínseca \\
\hline & CEXT_IM & Imagen de cultura científica extrínseca \\
\hline \multirow{2}{*}{ CULTURA TECNOLÓGICA } & TECNO & Cultura científica tecnológica \\
\hline & TECNO_IM & Imagen de cultura científica tecnológica \\
\hline \multirow{2}{*}{ NO CULTURA CIENTÍFICA } & NoCC & No cultura científica \\
\hline & NoCC_IM & Imagen de no cultura científica \\
\hline
\end{tabular}




\subsection{CRITERIOS PARA LA CODIFICACIÓN MANUAL}

Cultura: A efectos de esta investigación, los términos "cultura" e "información cultural” son sinónimos. Entendemos por cultura toda información de carácter representacional, práctico o valorativo que se transmite por aprendizaje social entre individuos de la misma especie (Mosterín 1993). Distinguimos tres tipos de información cultural:

I. Información representacional: Incluye representaciones, creencias, y conocimientos. acerca del mundo natural o social. Abarca desde opiniones o percepciones individuales o de sentido común, hasta teorías científicas, o creencias religiosas acerca del mundo, de la vida, la sociedad, la humanidad y la realidad en general.

II. Información práctica/operacional: Incluye reglas o normas de comportamiento y acción. Estas pueden ser de carácter técnico, moral, social, o de cualquier otra índole. Y pueden expresarse como reglas explícitas o como pautas de comportamiento que se consideran adecuadas o inadecuadas aunque no estén explícitamente formuladas como normas de comportamiento. En este componente de la cultura se incluyen por lo tanto desde las reglas de actuación para casos concretos, inspiradas en la práctica o en la costumbre, hasta los grandes sistemas jurídicos o morales.

III. Información valorativa: Incluye los valores y sistemas de preferencias individuales o sociales, de cualquier tipo, tanto si son valores explícitamente formulados e integrados en sistemas ordenados y coherentes, como si son preferencias individuales o de grupos, vinculadas a contextos específicos.

Cultura científica: La cultura científica de un grupo social es la información cultural que comparten los individuos de ese grupo y que se refiere a las actividades científicas, sus métodos, sus resultados y sus relaciones con cualquier otra actividad social. La expresión "cultura científica" se usa en este contexto para referirse no a la cultura profesional de los científicos, sino a aquella parte de la cultura de cualquier individuo o grupo de individuos que tiene que ver con la actividad y el conocimiento científicos. Los cuestionarios de "percepción social de la ciencia", de "alfabetización científica" o de "actitudes científicas" de la población general son instrumentos bastante comunes que intentan medir algunos aspectos de la "cultura científica" de la población. En nuestro proyecto resultará útil distinguir dos tipos o niveles de cultura científica que podemos denominar intrínseca y extrínseca

A. Cultura científica intrínseca: Es la cultura que forma parte de las actividades científicas propiamente dichas. Los conocimientos científicos en cada una de las áreas y campos de investigación, las teorías sometidas a debate entre los científicos, los hechos descubiertos por los científicos, las interpretaciones y explicaciones científicas de los fenómenos naturales o sociales, etc., todo eso forma parte de la cultura científica intrínseca. Lo mismo cabe decir de las normas del método científico, las reglas de actuación en la investigación empírica, en la comunicación científica de los resultados de la investigación, etc., así como de los valores que se supone deben guiar la investigación y la actividad científica en general: la objetividad, la honestidad científica, el amor a la verdad, etc.

B. Cultura científica extrínseca: Se trata de todos aquellos componentes representacionales (creencias), prácticos (normas) y valorativos (valores) que se refieren a actividades, instituciones, personas científicas pero que no son parte de la cultura científica intrínseca. Las imágenes de la ciencia (cómo ve la gente a los científicos), los códigos éticos de la actividad científica, la regulación jurídica de las instituciones científicas, las valoraciones de la ciencia desde el punto de vista cultural, moral, político, religioso, etc.: todo eso forma parte de la cultura científica que llamamos extrínseca. 
Cultura tecnológica: La cultura tecnológica de un grupo social es la información cultural que comparten los miembros de ese grupo y que se refiere a sistemas técnicos, su funcionamiento, su diseño y producción, así como a cualquier actividad relacionada con la tecnología. La expresión "cultura tecnológica" se usa en este contexto para referirse no a la cultura profesional de los tecnólogos o ingenieros, sino a aquella parte de la cultura de cualquier individuo o grupo de individuos que tiene que ver con la tecnología, su invención, producción, difusión y uso. Muchos de los ítems que se contemplan en los cuestionarios de percepción de la ciencia se refieren en realidad a la tecnología, de forma indiscriminada, pero también hay, en otros contextos, investigaciones empíricas que recogen información sobre cultura tecnológica, en especial en los estudios de mercado sobre productos tecnológicos, en los que se indaga la utilización que los usuarios dan a un determinado dispositivo técnico (teléfono móvil, automóvil, etc.).

No cultura científica: No cultura cientítica es la información cultural no pertenecen a la cultura científica intrínseca ni extrínseca.

\begin{tabular}{|c|c|c|c|}
\hline MCC & Tipo de información & Contenidos & CÓDIGO \\
\hline \multirow{4}{*}{$\begin{array}{c}\text { CULTURA } \\
\text { CIENTÍFICA } \\
\text { INTRÍNSECA }\end{array}$} & Representaciones & $\begin{array}{l}\text { Conocimientos } \\
\text { Información científica }\end{array}$ & CINTR \\
\hline & Prácticas/Operacionales & $\begin{array}{l}\text { Reglas del método científico } \\
\text { Hábitos científicos }\end{array}$ & CINTOP \\
\hline & Valores & $\begin{array}{l}\text { Valores científico: objetividad, } \\
\text { universalidad, verdad, precisión }\end{array}$ & CINTVA \\
\hline & Imágenes & $\begin{array}{l}\text { Datos visuales asociados con } \\
\text { texto intrínseco }\end{array}$ & CINT_IM \\
\hline \multirow{4}{*}{$\begin{array}{c}\text { CULTURA } \\
\text { CIENTÍFICA } \\
\text { EXTRÍNSECA }\end{array}$} & Representaciones & Imágenes de la ciencia & CEXTR \\
\hline & Prácticas/Operacionales & $\begin{array}{l}\text { Interés por la ciencia } \\
\text { Normas de comportamiento } \\
\text { (Moral, jurídico, etc.) } \\
\text { Relacionadas con la ciencia }\end{array}$ & CEXTOP \\
\hline & Valores & $\begin{array}{l}\text { Valoraciones y actitudes ante la } \\
\text { ciencia }\end{array}$ & CEXTVA \\
\hline & Imágenes & $\begin{array}{l}\text { Datos visuales asociados con } \\
\text { texto extrínseco }\end{array}$ & CEXT_IM \\
\hline \multirow{2}{*}{$\begin{array}{c}\text { CULTURA } \\
\text { TECNOLÓGICA }\end{array}$} & Informaciones Tecnológica & Informaciones Tecnológica & TECNO \\
\hline & Imágenes & $\begin{array}{l}\text { Datos visuales asociados con } \\
\text { texto tecnológico }\end{array}$ & TECNO_IM \\
\hline \multirow{2}{*}{$\begin{array}{l}\text { NO CULTURA } \\
\text { CIENTÍFICA }\end{array}$} & $\begin{array}{l}\text { Informaciones } \\
\text { no científica ni tecnológica }\end{array}$ & $\begin{array}{l}\text { Informaciones } \\
\text { no científica ni tecnológica }\end{array}$ & NoCC \\
\hline & Imágenes & $\begin{array}{l}\text { Datos visuales asociados con } \\
\text { texto no científico ni tecnológico }\end{array}$ & NoCC_IM \\
\hline
\end{tabular}




\section{REVISIÓN DE LA CODIFICACIÓN MANUAL}

2.1. Revisión de la codificación de libros de texto

- Unidad: párrafo

- Páginas total: 267

- Párrafos total: 2294 (promedio de no de párrafos por página: 8.6)

- Páginas de libros coreanos: 183 (Párrafos: 1176, promedio: 6.43)

- Páginas de libros españoles: 84 (Párrafos: 1118, promedio: 13.3)

Para revisar $10 \%$ de total, 22 páginas (337 párrafos) y $5 \%$ de total, 10 páginas son elegidas (124 párrafos) en libros españoles por generador de números aleatorios.

\subsubsection{Primera revisión}

\begin{tabular}{|r|r|r|r|r|r|r|}
\hline pág. & párrafos & concordancia1 & acuerdo & no acuerdo & \% conc. & \% conc. \\
\hline \hline 1 & 16 & 14 & 2 & 0 & 87,50 & 100,00 \\
\hline 8 & 14 & 14 & 0 & 0 & 100,00 & 100,00 \\
\hline 9 & 19 & 17 & 2 & 0 & 89,47 & 100,00 \\
\hline 17 & 8 & 5 & 3 & 0 & 62,50 & 100,00 \\
\hline 21 & 13 & 12 & 0 & 1 & 92,31 & 92,31 \\
\hline 24 & 22 & 16 & 6 & 0 & 72,73 & 100,00 \\
\hline 31 & 16 & 12 & 4 & 0 & 75,00 & 100,00 \\
\hline 33 & 15 & 12 & 3 & 0 & 80,00 & 100,00 \\
\hline 34 & 13 & 13 & 0 & 0 & 100,00 & 100,00 \\
\hline 38 & 14 & 12 & 2 & 0 & 85,71 & 100,00 \\
\hline 44 & 13 & 2 & 10 & 1 & 15,38 & 92,31 \\
\hline 46 & 15 & 8 & 5 & 2 & 53,33 & 86,67 \\
\hline 52 & 13 & 11 & 2 & 0 & 84,62 & 100,00 \\
\hline 55 & 14 & 12 & 2 & 0 & 85,71 & 100,00 \\
\hline 60 & 18 & 17 & 1 & 0 & 94,44 & 100,00 \\
\hline 66 & 21 & 18 & 3 & 0 & 85,71 & 100,00 \\
\hline 67 & 28 & 25 & 2 & 1 & 89,29 & 96,43 \\
\hline 69 & 7 & 3 & 4 & 0 & 42,86 & 100,00 \\
\hline 73 & 16 & 10 & 6 & 0 & 62,50 & 100,00 \\
\hline 75 & 10 & 10 & 0 & 0 & 100,00 & 100,00 \\
\hline 81 & 10 & 5 & 5 & 0 & 50,00 & 100,00 \\
\hline 83 & 22 & 14 & 8 & 0 & 63,64 & 100,00 \\
\hline \hline total & 337 & 262 & 70 & 5 & 77,74 & 98,52 \\
\hline
\end{tabular}

2.1.2. Segunda revisión 


\begin{tabular}{|r|r|r|r|r|r|r|}
\hline \multicolumn{1}{|r|}{ pág. } & párrafos & concordancia1 & acuerdo & no acuerdo & \% conc. 1 & \% conc.2 \\
\hline \hline 7 & 12 & 10,5 & 1,5 & 0 & $87,50 \%$ & $100,00 \%$ \\
\hline 15 & 12 & 12 & 0 & 0 & $100,00 \%$ & $100,00 \%$ \\
\hline 23 & 12 & 10,5 & 1,5 & 0 & $87,50 \%$ & $100,00 \%$ \\
\hline 35 & 14 & 11 & 3 & 0 & $78,57 \%$ & $100,00 \%$ \\
\hline 39 & 12 & 12 & 0 & 0 & $100,00 \%$ & $100,00 \%$ \\
\hline 54 & 11 & 11 & 0 & 0 & $100,00 \%$ & $100,00 \%$ \\
\hline 61 & 12 & 11 & 1 & 0 & $91,67 \%$ & $100,00 \%$ \\
\hline 70 & 12 & 11,5 & 0,5 & 0 & $95,83 \%$ & $100,00 \%$ \\
\hline 76 & 13 & 12,5 & 0,5 & 0 & $96,15 \%$ & $100,00 \%$ \\
\hline 77 & 14 & 14 & 0 & 0 & $100,00 \%$ & $100,00 \%$ \\
\hline \hline total & 124 & 116 & 8 & 0 & $93,55 \%$ & $100,00 \%$ \\
\hline
\end{tabular}

\subsection{Revisión de la codificación de artículos periodísticos}

- Unidad: Artículo

- Artículos total: 612 (coreanos: 341, españoles: 271)

- $10 \%$ de total, 62 artículos y 5\% de total, 31 artículos son elegidos en los artículos españoles por generador de números aleatorios.

\subsubsection{Primera revisión}

\begin{tabular}{|l|l|l|l|l|l|l|}
\hline Artículo & \multicolumn{2}{|l|}{ Codificadora1 } & \multicolumn{2}{l|}{ Codificadora2 } \\
\hline 2008elmundo_0106.docx & CINTR & CINT_IM & CINT_IM & CINTVA & & \\
\hline 2008elmundo_0212.docx & CEXTR & CEXTOP & CEXT_IM & CINT_IM & & \\
\hline 2008elmundo_0912.docx & CEXTR & CEXT_IM & & CEXTR & CEXT_IM & \\
\hline 2008elmundo_1020.docx & CINTR & CINT_IM & & CINTR & CINT_IM & \\
\hline 2008elmundo_1101.docx & CEXTR & CEXTOP & CEXT_IM & CEXTR & CEXTOP & CEXT_IM \\
\hline 2008elmundo_1112.docx & CINTR & CINT_IM & & CINTOP & & \\
\hline 2008elpais_0417.docx & CEXTR & CEXTOP & TECNO & CEXTR & CEXTOP & TECNO \\
\hline 2008elpais_0901.docx & CEXTR & NoCC & & CEXTR & NoCC & \\
\hline 2008elpais_1206.docx & NoCC & & & NoCC & & \\
\hline 2009elmundo_0212 (2).pdf & CEXTOP & & & CEXTOP & & \\
\hline 2009elmundo_0212.pdf & CINTR & & & CINTR & & \\
\hline 2009elmundo_0225 (2).pdf & CINTR & & & CINTR & & \\
\hline 2009elmundo_0302.pdf & CEXTOP & & & CEXTOP & & \\
\hline 2009elmundo_0331.pdf & CINTR & & & CEXTOP & & \\
\hline 2009elmundo_0423.pdf & CEXTVA & CEXTR & CEXTOP & CEXTVA & CEXTR & CEXTOP \\
\hline 2009elmundo_0609 (2).pdf & CEXTR & & & CEXTR & & \\
\hline 2009elmundo_0618.pdf & CINTVA & & & CEXTVA & CEXTOP & \\
\hline 2009elmundo_0627.pdf & CEXTR & & & CEXTR & CEXTOP & \\
\hline 2009elmundo_0710 (2).pdf & CINTR & CINT_IM & & CINTR & CINT_IM & \\
\hline 2009elmundo_0812 (2).pdf & CEXTOP & CEXT_IM & & CINTR & & \\
\hline 2009elmundo_1002.pdf & CEXTOP & CEXT_IM & & CEXTR & & \\
\hline
\end{tabular}




\begin{tabular}{|c|c|c|c|c|c|c|}
\hline 2009elmundo_1016.pdf & NoCC & NoCC_IM & & NoCC & NoCC_IM & \\
\hline 2009elmundo_1026 (2).pdf & CEXTR & CEXTVA & & CEXTR & & \\
\hline 2009elmundo_1128.pdf & CEXTR & & & CINTR & & \\
\hline 2009elmundo_1209.pdf & CEXTVA & & & CINTR & CINTVA & \\
\hline 2009elmundo_1221.pdf & CEXTVA & & & CEXTOP & & \\
\hline 2009elmundo_1229.pdf & CINTR & CEXTOP & & CINTR & CEXTOP & \\
\hline 2009elpais_0124.pdf & CEXTOP & & & CEXTOP & & \\
\hline 2009elpais_0209.pdf & CEXTR & & & CEXTR & & \\
\hline 2009elpais_0421.pdf & CINTR & & & CINTR & CEXTR & \\
\hline 2009elpais_0425.pdf & NoCC & & & NoCC & CEXTOP & \\
\hline 2009elpais_0608.pdf & CEXTVA & CEXTR & & NoCC & CEXTR & \\
\hline 2009elpais_0610.pdf & CINTR & & & CINTR & & \\
\hline 2009elpais_0716.pdf & CINTR & & & CINTR & & \\
\hline 2009elpais_0717.pdf & CEXTR & CEXTVA & & CEXTOP & & \\
\hline 2009elpais_0819.pdf & TECNO & & & TECNO & & \\
\hline 2009elpais_0928.pdf & CINTR & & & CINTR & & \\
\hline 2009elpais_1009.pdf & CEXTR & TECNO & & $\mathrm{NoCC}$ & CEXTR & TECNO \\
\hline 2009elpais_1208.pdf & CINTR & & & CINTR & & \\
\hline 2010elmundo_0118.pdf & CINTR & & & CINTR & & \\
\hline 2010elmundo_0303.pdf & NoCC & & & NoCC & & \\
\hline 2010elmundo_0309.pdf & CINTR & & & CEXTR & & \\
\hline 2010elmundo_0322 (2).pdf & CEXTOP & & & CEXTR & & \\
\hline 2010elmundo_0428 (2).pdf & CINTR & & & CINTR & & \\
\hline 2010elmundo_0517.pdf & NoCC & NoCC_IM & & CEXTR & & \\
\hline 2010elmundo_0528.pdf & CINTR & CINT_IM & & CINTR & CINT_IM & \\
\hline 2010elmundo_0730.pdf & NoCC & & & $\mathrm{NoCC}$ & & \\
\hline 2010elmundo_0820.pdf & NoCC & & & NoCC & & \\
\hline 2010elmundo_0831.pdf & CEXTR & CEXTOP & CEXT_IM & CEXTR & CEXTOP & CEXT_IM \\
\hline 2010elmundo_0902.pdf & CEXTR & & & CEXTR & & \\
\hline 2010elmundo_0903.pdf & CEXTR & & & CEXTR & & \\
\hline 2010elmundo_0905.pdf & CEXTVA & CEXT_IM & & CEXTR & & \\
\hline 2010elmundo_0909.pdf & NoCC & & & CEXTR & & \\
\hline 2010elmundo_1004 & CEXTOP & & & CEXTOP & & \\
\hline 2010elmundo_1122.pdf & CEXTOP & & & CEXTOP & & \\
\hline 2010elmundo_1208.pdf & NoCC & & & CEXTR & & \\
\hline 2010elpais_0309.pdf & CEXTR & CEXTOP & & CEXTR & CEXTOP & \\
\hline 2010elpais_0521 (2).pdf & CEXTVA & & & CEXTR & CEXTOP & \\
\hline 2010elpais_0713.pdf & CEXTR & CEXTOP & & CEXTR & CEXTOP & \\
\hline 2010elpais_0907.pdf & CINTR & & & CINTR & & \\
\hline 2010elpais_1218.pdf & NoCC & & & NoCC & & \\
\hline Concordancia Total & \multicolumn{3}{|c|}{ \% Concordancia1: 73.5\% } & \multicolumn{3}{|c|}{ \% Concordancia2: 95\% } \\
\hline
\end{tabular}

\subsubsection{Segunda revisión}

\begin{tabular}{|l|l|l|l|l|l|l|l|l|}
\hline Artículos & \multicolumn{2}{|l|}{ Codificadora1 } & \multicolumn{2}{l|}{ Codificador2 } & \multicolumn{2}{l|}{ Conc.1 } & Conc.2 \\
\hline 2008elmundo_0213.docx & CINTR & & & CINTR & & & 1 & 1 \\
\hline 2008elmundo_0419.docx & CEXTOP & CEXTR & & CINTR & CEXTR & & 0,5 & 1 \\
\hline 2008elmundo_0927.docx & CINTOP & CEXTOP & & CINTOP & CEXTOP & & 1 & 1 \\
\hline 2008elmundo_1210.docx & CINTR & & & CINTR & & & 1 & 1 \\
\hline 2008elmundo_1222.docx & CINTR & CEXTR & & CINTR & & & 0,5 & 1 \\
\hline 2009elmundo_0206 (2).pdf & CEXTR & CEXTOP & & NoCC & CEXTOP & CEXTR & 0,67 & 0,67 \\
\hline 2009elmundo_0213.pdf & CINTR & CINTVA & & CINTR & CINTVA & CINTOP & 0,67 & 1 \\
\hline
\end{tabular}




\begin{tabular}{|l|l|l|l|l|l|l|l|l|}
\hline 2009elmundo_0216.pdf & CEXTOP & & CEXTOP & & 1 & 1 \\
\hline 2009elmundo_0315.pdf & NoCC & CEXTR & & NoCC & CEXTOP & & 0,5 & 1 \\
\hline 2009elmundo_0324.pdf & CEXTOP & & & CEXTOP & & & 1 & 1 \\
\hline 2009elmundo_0523.pdf & CEXTR & & & CEXTR & & & 1 & 1 \\
\hline 2009elmundo_0617.pdf & NoCC & CEXTR & & NoCC & CEXTR & & 1 & 1 \\
\hline 2009elmundo_0803.pdf & CEXTR & CINTR & & CINTR & & & 0,5 & 1 \\
\hline 2009elmundo_0812.pdf & CINTR & CINTOP & & CINTR & CINTOP & & 1 & 1 \\
\hline 2009elmundo_1010.pdf & NoCC & CEXTOP & & NoCC & CEXTOP & & 1 & 1 \\
\hline 2009elmundo_1021.pdf & CEXTOP & & & CEXTOP & & & 1 & 1 \\
\hline 2009elmundo_1107.pdf & CEXTOP & & & CEXTOP & & & 1 & 1 \\
\hline 2009elmundo_1201.pdf & CINTR & CEXTR & CEXTOP & CINTR & CEXTOP & CEXTVA & 0,67 & 1 \\
\hline 2009elmundo_1211.pdf & CINTR & & & CINTR & & & 1 & 1 \\
\hline 2009elpais_0113.pdf & CINTR & & & CINTR & & & 1 & 1 \\
\hline 2009elpais_0708.pdf & CEXTOP & CINTOP & & CEXTR & CINTOP & & 0,5 & 1 \\
\hline 2009elpais_0811.pdf & NoCC & CEXTOP & & NoCC & CEXTOP & & 1 & 1 \\
\hline 2009elpais_1205.pdf & CEXTR & CEXTOP & & CEXTR & CEXTOP & & 1 & 1 \\
\hline 2010elmundo_0218.pdf & NoCC & & & NoCC & & & 1 & 1 \\
\hline 2010elmundo_0902 (2).pdf & CINTR & & & CINTR & CEXTR & & 0,5 & 1 \\
\hline 2010elpais_0102.pdf & CEXTR & & & CEXTR & & & 1 & 1 \\
\hline 2010elpais_0305.pdf & CINTR & NoCC & & CINTR & CINTOP & & 0,5 & 0,5 \\
\hline 2010elpais_0712.pdf & NoCC & & & NoCC & CEXTVA & & 0,5 & 1 \\
\hline 2010elpais_0713.pdf & CEXTOP & & & CEXTOP & & & 1 & 1 \\
\hline 2010elpais_0811 (2).pdf & NoCC & CEXTR & NoCC & CEXTR & 1 & 1 \\
\hline 2010elpais_0912.pdf & NoCC & & & NoCC & & & 1 & 1 \\
\hline Concordancia Total (31 artículos) & & & & & 26 & 30,17 \\
\hline \% Concordancia Total & & & & & $83,90 \%$ & $97,32 \%$ \\
\hline
\end{tabular}

